RIOT AND REVOLUTION

IN SIINGAPORE AND MATAYA

$\underline{1945-1963}$

by

RICHARD IEWIS CLUTTERBUCK

Thesis submitted for the degree of Doctor of Philosophy

at the University of Iondon

LONDON

January 1971 
ProQuest Number:11015705

All rights reserved

INFORMATION TO ALL USERS

The quality of this reproduction is dependent upon the quality of the copy submitted.

In the unlikely event that the author did not send a complete manuscript and there are missing pages, these will be noted. Also, if material had to be removed, a note will indicate the deletion.

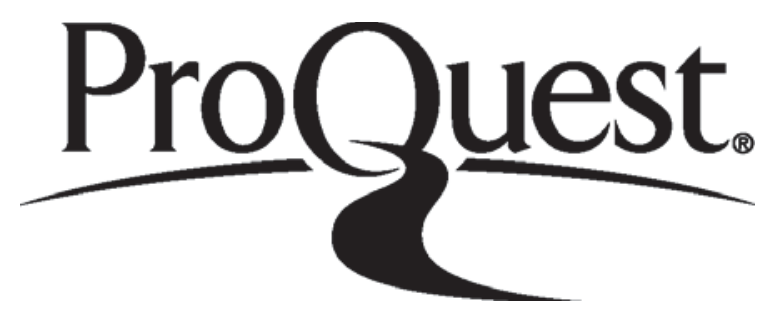

ProQuest 11015705

Published by ProQuest LLC (2018). Copyright of the Dissertation is held by the Author.

All rights reserved.

This work is protected against unauthorized copying under Title 17, United States Code Microform Edition (C) ProQuest LLC.

ProQuest LLC.

789 East Eisenhower Parkway

P.O. Box 1346

Ann Arbor, Ml $48106-1346$ 
Pace

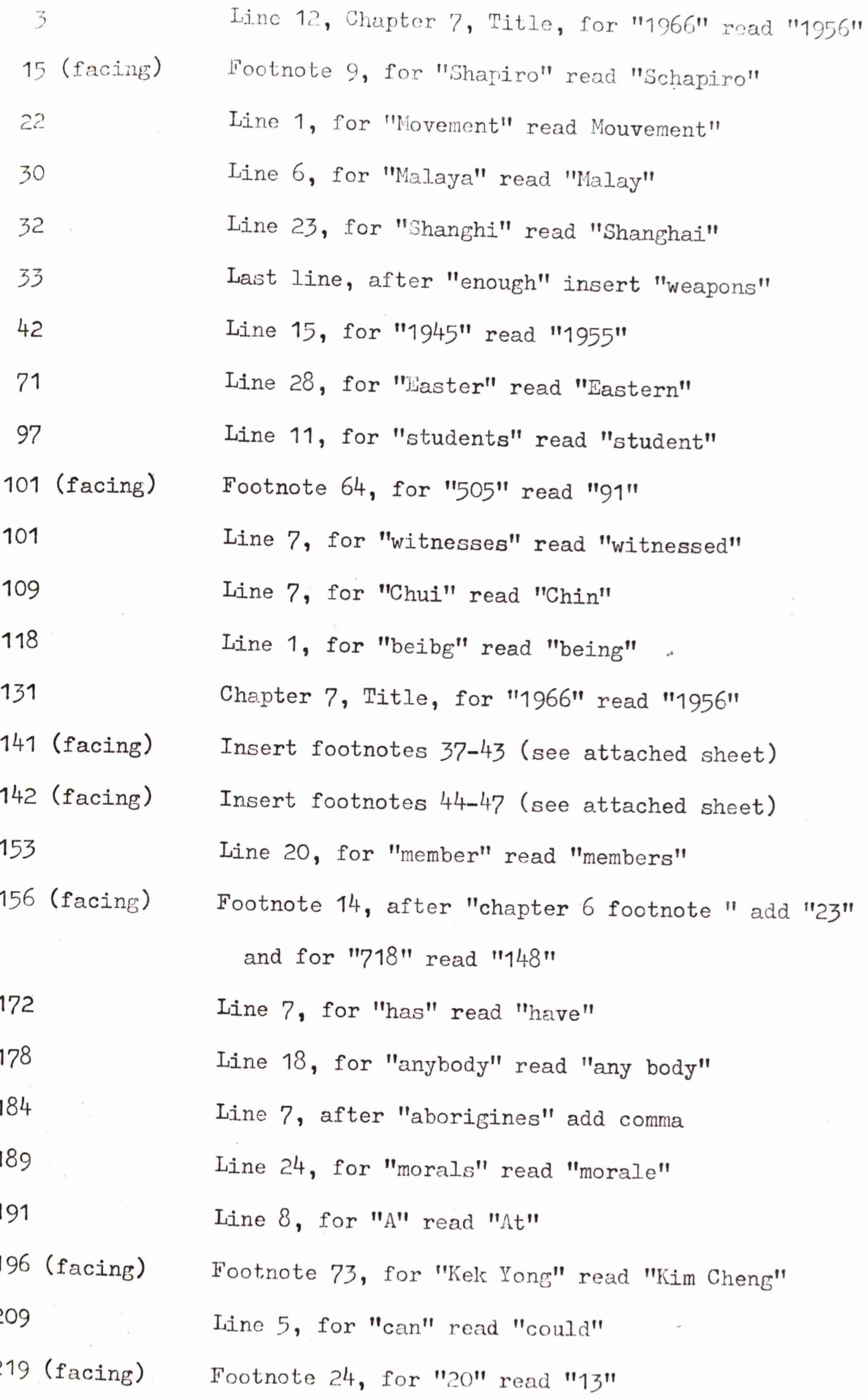


Line 15, after "sometimos" insert "lived"

Line 4, for "than" read "that"

Iine 2, for "doen" read "done"

Iine 2, for "1948" read "1958"

Line 21, after "Base" insert "could"

Line 21, for "fotitude" read "fortitude"

Line 18, for "indoctrinated" read "indoctrinate"

Line 8, for "acivity" read "activity"

Iine 9, for "well-knewn" read "well-known"

Line 23, for "tapper" read "tappers"

Line 14, for "dsperate" read "desperate"

Penultimate item. Underline the words

"Review of the Emergency in". Also, under Abbreviations, underline the word "Review" Fourth item. Under title add "New York 1968" Twelfth item. Underline the word "Malaya" read "Waller, ERs". Also, after the tenth entry add a new entry as follows:-

Author and Title

Waller, PBG, Notes on the Malayan

Emergency: Strategies and

\section{Organisation of the Opposing}

Forces, Stanford Research

Institute, California, USA, 1967
Abbreviation

Waller, Notes 
38. Joint Report p 12.

39. Unauthorized possession of a gun, or even of a round of ammunition, still carried the death penalty, and had done so for the previous 8 years. It is fair to assume that, but for this, the Bukit Timah branch battle would have ended in far more bloodshed, and the same would be true for the riots as a whole.

40. Police Report pp 30-31.

41. $\quad$ ibid Appx J .

42. ibid $\mathrm{p} \mathrm{32.} \mathrm{There} \mathrm{is} \mathrm{no} \mathrm{doubt} \mathrm{that} \mathrm{various}$ gangsters, other than those who were Communist led, did take the opportunity to use violence during the riots, though not on any significant scale. See Joint Report p 9.

43. Police Report Appx J.

Footnotes Facing Page 142

44. Joint Report Appx C.

45. $\quad$ ibid p 16 .

46. Police Report, Appx B

47. Military Report p 26 


\section{RIOT AND REVOLUTION IN SINGAPORE AND MALAYA 1945-63}

\section{Richard Clutterbuck}

\section{ABSTRACT}

This Thesis covers an urban and rural guerilla insurgency carried out simultaneously by the Malayan Communist Party (MCP), and is focussed mainly on the point of contact between the revolutionaries and the people.

In Singapore, the study concentrates on the revolutionary organisations amongst Chinese students and in the trade unions, and later on their attempt to gain control of the political party in power. On the government side particular attention has been paid to police intelligence and riot control.

In the rural insurgency, the main fields of study have been the MCP's "parallel hierarchy" of government which extended through the jungle to the underground organisation amongst the Chinese village population; and the evolution of the government's technique (and especially of its police intelligence system) for identifying and digging out the roots of this underground organisation, thereby finding and destroying a guerilla army and political hierarchy widely dispersed in dense jungle. The early years of the Emergency'have been only briefly sketched. These have been well covered elsewhere, and it was in the later years (1953-58) that both the guerillas' organisation and the government's technique for uprooting it reached their peak of refinement.

The two conflicts, urban and rural, have been analysed in relation to the current controversy amongst revolutionary thinkers between those who support the classical philosophy of Lenin and Mao Tse Tung, with their stress on developing a strong organisation amongst the people before launching a campaign of violence, and writers of the New Left such as Sartre, Fanon and Debray, who reject such delay and commend immediate and continuing confrontation and violence as a better means of rallying popular support. The conclusion supports the classical school, and underlines the indispensability of a viable organisation if a revolutionary movement is to prevail against a determined govermment. 
TABLE OF CONTENTS

\section{IIST OF ABBREVIATIONS}

\section{Ch I INTRODUCTION}

The Aim

Urban and Rural Revolution

How a Revolution Ends

The Developing Pattern of Urban Revolution

Revolutionary Errors Between the World Wars

The Current Reaction Against Leninism

The Pattern of Guerilla Revolution

Popular Support

Escalation

Malaya and Singapore - The Background

The Malayan Communist Party and the Japanese Occupation

Reoccupation by the British

PART I - URBAN REVOLUIION - SINGAPORE

Ch 2 THE FIRST ATTEMPT AT AN URBAN REVOLUTION - 1945-48

The Decision to Adopt an Urban Strategy in 1945

The Difficulties of the MCP as an Open Political Party

The British Military Administration

"Peaceful Agitation"

A Change of Leader

The Government Reacts

Ch 3 THE COMMUNIST PARTY STRUCTURE IN SINGAPORE - 1946-1950

The Open and Secret Organisations of the Party

Recruitment and Advancement

The Student Organisation

1948 - A Drastic Reorganisation

A Tightening of Security in the MCP in Singapore

The Arrest of the Town Committee

The Hertogh Riots

Reorganisation of the Police

Ch 4 THE SURVIVAL OF THE STUDENT ORGANISATION - 1950-54

Resilience

Security - Strengths and Weaknesses

The Schools as a Training Ground for Party Workers for the Jungle War

The Revival of the Urban Campaign in Singapore

Ch 5 SUBVERSION IN THE CHINESE MIDDLE SCHOOLS 1954-56

Formation of the SCMSSU

Party and Open Front Structure in the Schools

The Secret Organisation

Study and Tuition Cells

Self Criticism and Intimidation

The Position of the Teachers

The Baling Truce Talks and the Razak Report 
The"Middle Road" Group of Trade Unions

Self Government

The Peoples' Action Party

The Emergency Regulations

The Hock Lee Bus Strike

David Marshall Faces The Communists

The London Talks of April/May 1956

The PAP Central Executive Committee Election

A New Plan for Internal Security

The Government's UItimatum

Ch 7 THE RIOTS OF OCTOBER 1966

Clearing the Schools

Keeping the Crowds down to Manageable Size

The Special Branch Swoop

The Riots Subside

Summary of Events

The Performance of the Government Forces

Performance of the Revolutionaries

A Comparison with the Hong Kong Riots of 1967

Ch 8 THE STRUGGLE FOR POLITICAL CONTROL

Constitutional Conference in London 1957

Responsibility for Internal Security

The PAP Executive Committee Changes Hands

The Communists send a Plenipotentiary

The 1959 Elections

Lim Chin Siong Released

The Hong Lim By-Election

The Plenipotentiary Identified

The Formation of the Barisan Sosialis

"The British Plot"

The Proposal for Merger

The Referendum on Merger

Indonesian Confrontation and the Renewed Detention of Lim Chin Siong

Independence and the 1963 Elections

The End of the Merger, and Lee Kuan Yew's Consolidation

PART II RURAL GUERTILA REVOLUTION - THE GMERGENCY IN MALAYA

Ch 9 THE FIRST YEARS OF THE EMERGENCY

Launching the Armed Struggle

A State of Emergency

Guerilla Strategy and Tactics 1948

Controversy in the MCP

Sir Harold Briggs

Resettlement

Special Branch

Rewards

Surrendered Enemy Personnel (SEPs) 
Another New Communist Directive - October 1951

Sir Gerald Templer

Village Government

Psychological Warfare and the Information Services

White Areas

Ch 10 ORGANISATION FOR SURVIVAL

The MCP Reorganisation 1952-53

The Parallel Hierarchy

MCP Security

Examples of the Operation of MCP Branches in 1953:-

Case 1. Inner Tenang Road Branch (North Johore)

Case 2. Sabak Estate (Pahang)

Case 3. Tras (Pahang)

Case 4. Ayer Kuning (North Johore)

Case 5. Bidor (Perak)

Target for 1954-56 - A Typical MCP District (Yong Peng)

Ch 11 THE DEVELOPMENT OF A SUCCESSFUL TECHNIQUE

A Difficult Target

Food Denial Operations - Early Attempts

The Latimer Report

Improving the Pattern

Ch 12 THE FINAL PATTERN

Director of Operations Instructions Nos 28 and 36

Selection of the Target

Outlines of Phases

Phase I - Acquiring Agents

Phase II - D Day

Phase II

Phase III

A Strategy to Finish the War

Ch 13 THE CRUMBLE AND THE HARDCORE

A Successful Framework Operation

Hor Iung and the Collapse in Johore

Perak

Kedah - A Different Approach

The Aboriginies

The Thai Border

Ch 14 CONCLUSIONS

City versus Guerilla Revolution

The MCP Organisation in Singapore

Achievements and Failures of the MCP in Singapore

The Singapore Government's Handling of Violence and Coercion

Lee Kuan Yew

The Communists' Balance Sheet in the Village War

The Government's Counter Revolution

Leninism or the New Left? 
APPENDIX A THE 1967 RIOTS IN HONG KONG . . . . . . . . . 293

APPENDIX B OPERATION COBBLE - 1956-57 - An EXample of a Federal Priority Operation based on Food Denial . . . . . 297

Operation COBBLE - The Setting

The Selumpur Branch

The Bukit Siput and Tenang Branches

Operation COBBLE Phase I - Intelligence Activity

Phase I - Operations in Support of Special Branch

Operation COBBLE Phase II

Operation COBBLE - The End of Phase II 


\section{MAPS AND DIAGRAMS}

Fisure

Chapter 1 1A Federation of Malaya, Showing States

1B Federation of Malaya, Showing Main Rubber, Tin and Rice Growing Areas

Chapter 3

3A Singapore Communist Party Organization - 1947

64

3B MCP Cell Organization in Singapore - 1947-1950

3C MCP Organization in Singapore August 1948-1950

3D MCP Communication System from the Jungle to Singapore 1948-1950

3E Security Proceduxe if MCP Cell Member Compromised

Chapter 4 4A MCP Student Organization up to 1953

Chapter 5

5A Parallel Open and Secret Party Organization in the Chinese Middle Schools - 1954-1956

90

Chapter 6

$6 A$

Singapore Police Headquarters Combined Operations Room October 1956

Chapter 7 7A Singapore, General Map

TB Singapore, Main Roads into the City

Chapter 9 9A Malayan Communist Party Organization, Before 1949 and 1949-51

9B Resettlement and Regroupment

9C Monthly Statistics

9D Casualties in the Emergency 1948-1960\}

Chapter 10 10A MCP Political and Logistic Organization and Fighting Units 1951-57

10B Malayan Cormunist Party Organization 1952-1958

10C The Parallel Hierarchy

10D MCP Branch Organization

$10 \mathrm{E}$

Branch Organization - Yong Peng MCP District

$10 \mathrm{~F}$

Map of Yong Peng (Pull out to the right)

208

208

210

211

Chapter 12 12A Federal Priority Operations 1957-1958

Operation COBBLE - Villages and Police Posts? 
$A B L$

ARO

ASP

AWC

AWF

$\mathrm{BCM}$

BCS

BMA

CEP

Com

CP

CPO

CSBO

DCM

DCS

DO

DSP

DWEC

ER

ESI

FTU

GLU

GOC

Gov

$\mathrm{HE}$

HSB

IS

ISC

MCP

MDU

ME

MIO

MPABA

MPAJA

MPABU

MRIAA
Anti-British League

Assistant Resettlement Officer

Assistant Superintendent of Police

Armed Work Cell

Armed Work Force

Branch Committee Member

Branch Committee Secretary

British Military Administration

Captured Enemy Personnel

Person interviewed who was involved with the Communists

Commissioner of Police

Chief Police Officer

Circle Special Branch Officer

District Committee Member

District Committee Secretary

District Officer

Deputy Superintendent of Police

District War Executive Committee

Emergency Regulations

English Speaking Intelligentsia

Federation of Trade Unions

General Labour Union

General Officer Commanding

Person interviewed who was in Government service

His Excellency (The British High Commissioner)

Head, Special Branch

Internal Security

Internal Security Council

Malayan Communist Party

Malayan Democratic Union

Masses Executive

Military Intelligence Officer

Malayan People's Anti-British Army

Malayan People's Anti-Japanese Army

Malayan People's Anti-Japanese Union

Malayan Races' Liberation Army 


\begin{tabular}{|c|c|}
\hline $\begin{array}{l}\text { NDYL } \\
\text { NRIC } \\
\text { NV }\end{array}$ & $\begin{array}{l}\text { New Democratic Youth League } \\
\text { National Registration and Identity Card } \\
\text { New Village }\end{array}$ \\
\hline OSPC & Officer Superintending Police Circle \\
\hline $\begin{array}{l}\text { PAP } \\
\text { PKI } \\
\text { PLEN } \\
\text { PMFTU }\end{array}$ & $\begin{array}{l}\text { People's Action Party } \\
\text { Indonesian Communist Party } \\
\text { Plenipotentiary of the Malayan Communist Party } \\
\text { Pan-Malayan Federation of Trade Unions }\end{array}$ \\
\hline $\begin{array}{l}\text { RCMI } \\
\text { RCS }\end{array}$ & $\begin{array}{l}\text { Regional Committee Member } \\
\text { Regional Committee Secretary }\end{array}$ \\
\hline $\begin{array}{l}\text { SATU } \\
\text { SB } \\
\text { SCMSSU } \\
\text { SCM } \\
\text { SCS } \\
\text { SEAC } \\
\text { SEP } \\
\text { SF } \\
\text { SFSWU } \\
\text { SFTU } \\
\text { SHBEU } \\
\text { SHLU } \\
\text { SLA } \\
\text { SMAA } \\
\text { SMB } \\
\text { SPA } \\
\text { SPC } \\
\text { SWA } \\
\text { SWB } \\
\text { SWES }\end{array}$ & $\begin{array}{l}\text { Singapore Association of Trade Unions } \\
\text { Special Branch } \\
\text { Singapore Chinese Middle Schools Students Union } \\
\text { State Committee Mamber } \\
\text { State Committee Secretary } \\
\text { South East Asia Command } \\
\text { Surrendered Enemy Personnel } \\
\text { Security Forces } \\
\text { Singapore Factory and Shop Workers Union } \\
\text { Singapore Federation of Trade Unions } \\
\text { Singapore Harbour Board Employees Union } \\
\text { Singapore Habour Labourers' Union } \\
\text { Singapore Legislative Assembly } \\
\text { Students Mutual Assistance Association } \\
\text { South Malaya Bureau } \\
\text { Singapore People's Alliance } \\
\text { Self-Protection Corps } \\
\text { Singapore Women's Association } \\
\text { South Wales Borderers } \\
\text { State War Executive Committee }\end{array}$ \\
\hline TUC & Trade Union Congress \\
\hline $\begin{array}{l}\text { UMNO } \\
\text { UPP }\end{array}$ & $\begin{array}{l}\text { United Malay National Organisation } \\
\text { United People's Party }\end{array}$ \\
\hline
\end{tabular}

Malay and Chinese Words Used in Text

Barisan Sosialis

Blukar

Kampong

Kattie

Min Yuen

\author{
Socialist Front \\ Secondary Jungle or Undergrowth \\ Malay Village \\ Measure of Weight ( $1 \frac{1}{3}$ lbs) \\ Peoples' Organisation
}




\section{RIOT AND REVOLUTION \\ IN SINGAPORE AND MALAYA - 1945-1963}

RICHARD CLUTTERBUCK

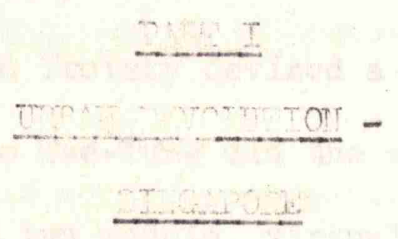

CHAPTEER 1

INTRODUCTION 
1. Robert S McNamara, The Essence of Security London, October 1968

2. J.K. Zawodny, Organisational Problems and Dynamics of Violent Political Movements, presented to the Eighth World Congress of the Intermational Political Science Association, Munich, September 1970, p1 
INTRODUCTION

The Aim

Since 1945, most of the world's conflicts have been internal and not across frontiers. Robert S. McNamara has recorded, for example, that between 1959 and 1966, out of 164 outbreaks of violence of intermational significance, 149 (over 90\%) were internal and only 15 (under 10\%) between states; that the number has steadily increased each year; and that the incidence of conflict has been highest in the poorest countries and lowest in the richest. 1 Professor J.K. Zawodny calculates that from 1958-1970 there were over 500 outbreaks of violence by 50 or more people, and that these involved 93 extra-legal movements in 70 countries. ${ }^{2}$

Internal or revolutionary conflict is nothing new, but since the start of the 20th century there has been a dramatic improvement in its organisation. Lenin and Trotsky devised a technique for urban revolution and proved it in 1917. Mao Tse-Tung did the same for rural or guerilla revolution in 1949. On these two models, virtually all subsequent successful revolutionary attempts (other than "Palace Revolutions" and military coups) have been based. By no means all have been Communist inspired or even Communist supported, but even the non-Communist ones have borrowed much of their organisation and techniques from these two Communist models. No techniques have yet been developed which have proved that they can rival them.

In recent years, writers such as Sartre, Marcuse and Debray have advocated what appears to be a reversion to the passionate but naive revolutionary practices of the late 19th century; they decry Lenin's insistence on organisation, and on waiting until a revolutionary situation arises before launching violent action; instead they counsel violence from the start as a means of bringing on a revolutionary situation more quickly. 
3. Leonard Schapiro "Changing Patterns in the Theory

of Revolution and Insurgency" Royal United

Service Institution Journal, September 1970

4. For example:

G.Z. Hanrahan, The Communist Struggle in Malaya,

New York, 1954

Harry Miller, Menace in Malaya, London, 1954

V. Purcell, Malaya - Communist or Free? London, 1954

M.C.A. Henniker, Red Shadow over Malaya, London, 1955

J.B. Perry Robinson, Transformation in Malaya, London 1956

Kermial Singh Sandhu, "Emergency Resettlement in Malaya" in The Journal of Tropical Geography Vol 18, August 1964, University of Malaya in Singapore 1964

Edgar O'Ballance, Malaya - The Communist Insurgency 1948-60 Iondon 1966.

Richard Clutterbuck, The Long Long War, New York 1966 and Iondon 1967

In addition, a comprehensive History of the Emergency, commissioned by the Malayan Government, has been written by Anthony Short. His manuscript is, unfortunately classified by that govermment and I have not, therefore, been able to use it as a source, but the author has indicated to me in general terms the ground he has covered, and he too has concentrated on the early years. 
Though their disciples have so far nowhere succeeded in overthrowing the established authority, they have achieved considerable erosion of that authority's powers. 3

Much has been written about the causes of unrest and revolution and about the policies of revolutionaries and of the governments they have attacked. A certain amount has been written about revolutionary organisation, but there has been less study of revolutionary techniques.

This thesis aims to fill some of the gaps by examining the attempted urban revolution in Singapore, about which very little research appears to have been done at all, and the later years of "The Emergency" (the Communist guerilla insurgency) in Malaya. The early years of the Emergency (1948-54) were the years of crisis, and they have been well covered by published material. 4 Most of the techniques developed in these years for example, resettlement - are now well known. These early years have therefore been sketched only briefly in this thesis, and the later years dealt with more fully. A further reason for this is that neither side fully developed some of its most important techniques until the later years - for example the Communists' techniques for survival of a guerilla and underground force against overwhelming odds, and the government's techniques for acquiring intelligence with which to hunt down a minute force in intensely difficult country. The surviving Malayan Comranist Party (MCP) branches were, at that time, largely concentrated in the States of Perak and Johore, where the Communists had always been strongest, and their supporters most dedicated. By 1954, after six years of intense government pressure, they had been refined and hardened into a really tough and professional revolutionary organisation. These later years (1954-60) also provide a particularly interesting contrast between the techniques used by the MCP in an urban setting (Singapore) and in a guerilla setting at the same time; and by the government which defeated them in both. 
In the rural areas of Malaya a large proportion of the civil population concerned did not grow food but earned their living from cash crops (such as rubber) and minerals (such as tin). This was perhaps one of the reasons why Mao's techniques did not succeed in Malaya. The question of whether these people should be treated as peasants or as an industrial proletariat was the subject of bitter controvercy in the MCP in 1949 - See Chapter 9. 


\section{Urban and Rural Revolution}

Urban and rural revolution have the same aim - to bring about the overthrow or capitulation of established authority by means outside the law. They have many other features in common, in their organisation, in some of their techniques of terror and coercion, and in their common need to weaken the police and the army by penetration. They are, however, radically different in strategy and in meny other respects. In an urban revolution, the strategy is to seize control of the centres of power and of communications, so that the government in the countryside withers on the vine. In a rural revolution the strategy is to oust the government from the remotest areas first, work inwards and finally isolate the cities so that they fall like ripe plums.

The fears and aspirations of the people who form their raw material are also radically different. City people live from week to week, relying for next week's food on work, wages and a continuing system of wholesale and retail distribution; they also fear the failure of public services, such as water, sewerage, electric power and transport; they therefore have a vested interest in law and order; faced by chaos and a choice between two claimants to power, they will rally to the one which gives them most confidence of a return to normal life - as the Bolsheviks did in Petrograd in 1917.

On the other hand rural people - that is, those of them who live in the under-developed areas where alone Mao Tse Tung's techniques have succeeded - live from season to season; they rely on access to their land and security for their stocks of food until the next harvest; ${ }^{5}$ they fear plunder and abduction; they fear murder, especially in the night or at work in remote places; they usually have little use for government officials or policemen, whom they regard as agents to squeeze taxes or bribes out of them, or to force them to move from their land; they do not want law and order so much as to be left in peace.

Because in every revolution victory depends ultimately on winning 
popular support - with varying degrees of willingness or compulsion these differences in popular fears and aspirations demand that revolutionary leaders must handle urban and remote rural people very differently. If they fail to assess popular reactions correctly they will have little success - and there were examples of this both in Singapore and Malaya.

\section{How a Revolution Ends}

Most revolutionary attempts fail. In those which succeed, the transfer of power can only come in three ways - by cooperation with an invasion from outside, by civil war or by coup d'etat.

In the case of invasion or civil war, a foreign or revolutionary army gains undisputed control of part of the country, from which it advances to drive the government forces from the remainder and places its own leaders in the seats of power. This was Mao Tse Tung's way.

Coups $d^{\prime}$ etat can be subdivided into three types. First is the "Palace Revolution", in which a new team of leaders ousts the old and acquires the practical support of the existing power structure of the country - the civil service, the police, the army etc. Second is the "Military coup" in which significant sections of the power structure are supplanted by a military hierarchy. In a Palace Revolution the power structure is (initially) untouched and in a military coup the military hierarchy already exists, so either of these can happen with little warning, little bloodshed and little disruption of daily life. They may or may not be followed by changes and reforms.

The third form of coup d'etat can be best described as a Party Revolution. This kind of coup is preceded by a prolonged period of dislocation and erosion of authority during which the revolutionary party builds up a parallel hierarchy of government (usually clandestine, but not always) which is ready to replace those sections of the power structure 
6 Edmund Wilson in To The Finland Station New York 1940, gives a masterly account of the evolution of revolutionary philosophy, tracing some of it back to writers who lived - long before the French Revolution, but these . to were theorists, not praçtitioners.

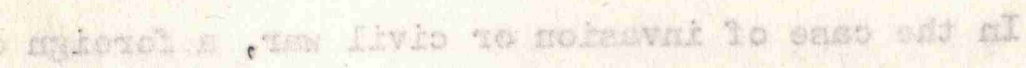

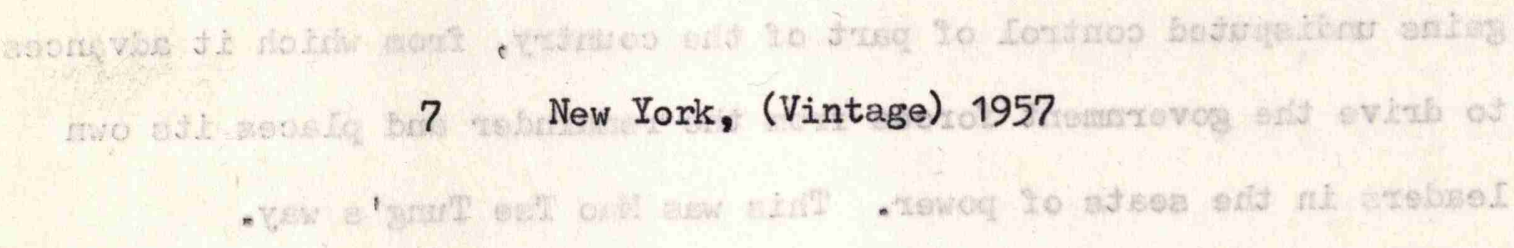

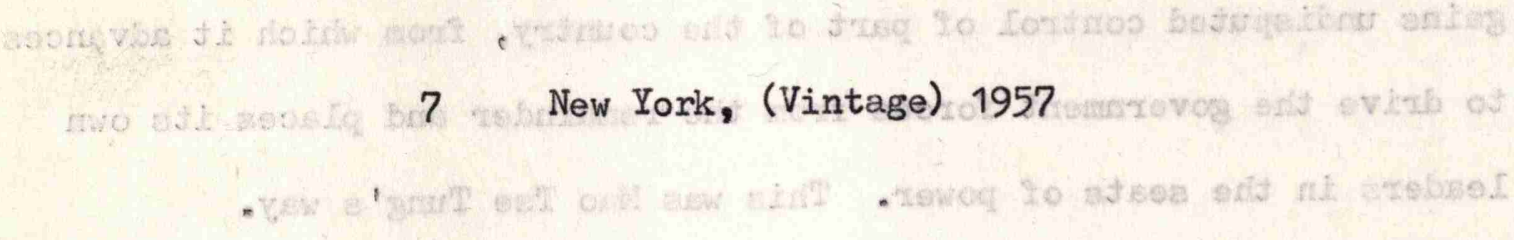

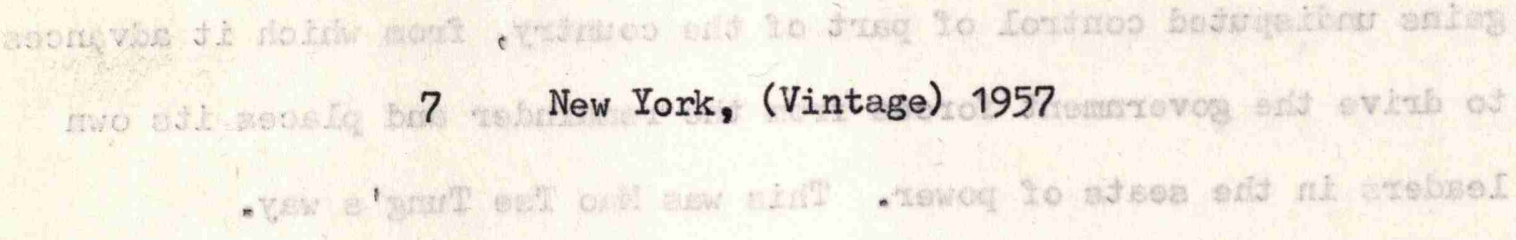


which do not seem likely to cooperate with the revolutionaries. If such replacement is unnecessary, then one of the quicker, simpler methods (a Palace or Military coup) would have been used rather than the more prolonged and disruptive Party Revolution. It therefore follows that a Party Revolution will always be accompanied by considerable changes and reforms.

This was the method used by Lenin and was also the target in both the Singapore and the Malayan insurgencies - though the latter might alternatively have ended in civil war. The evolution of this kind of revolutionary technique has been described in many books, but will be considered briefly here as a historical process in which the Singapore and Malayan attempts have played their part.

\section{The Developing Pattern of Urban Revolution}

Modern urban revolution made its practical debut in the French Revolution 6 which established a pattern of events which has reappeared in many subsequent revolutions. A tyrannical ancien regime was first ousted by moderate politicians who were committed to liberal reforms and to dismantling the suppressive apparatus of the State. Extremists then took advantage of this relaxation to oust the moderates; to hold power they had to resort to terror; terror bred a "Thermidorean Reaction" which carried a powerful and authoritarian ruler (Napolean) to power. This sequence has been lucidly analysed by Crane Brinton in The Anatomy of Revolution. 7

After the defeat of Napolean in 1815, Europe was quiescent for a time, apart from the brief explosion of the July Revolution in France in 1830, but revolutionary theorists and conspirators were hard at work. 1848 saw a series of revolutionary attempts - generally unsuccessful except again in France - which provided much of the material for the theories of Karl Marx, 
8 Captain C.E.S. Dudley, "Insurrection: from the Jacobins to Mao Tse Tung" in The Royal United Service Institution Journal, May 1966 see also Alan.B Spitzen, The Revolutionary: Theories of Louis Auguste Blanqui, New York, - 1957 and Néil Stewart, Blanqui, Iondon 1939.

9 Shapiro, op cit 
but still no successful technique for organising a popular rising had begun to appear. The Jacobin theory of conspiracy was developed by Blanqui (born in Paris in 1805), who based his ideas on the formation of a highly trained elite which would establish barricades from which they could debouch to seize key'points such as arsenals, police stations and centres of government. He was convinced that the workers of Paris would then rise spontaneously and seize the capital. He did not, however, have any organisation to lead them. At his first attempted uprising in 1839, his elitehad immediate success, and he seized the Hotel de Ville and declared a provisional government, but the people, lacking organisation, failed to rise. Worse still, Blanqui had also failed to penetrate or neutralise the army, so it was only a matter of time before the insurgents were defeated. Blanqui made 13 unsuccessful attempts and his theories were finally discredited in the bloody defeat of the Paris Commune in 1871. 8

The focus then shifted to Russia, which Karl Marx considered to be the least suitable place in Europe for this kind of revolution because it was still a predominantly peasant country. Until the end of the century, passionate outbreaks of violence (such as the assassination of Tsar Alexander II in 1881) were not supported by any organisation for a popular rising, so they led simply to decisive reaction and a strengthening of the governments apparatus of power.

Lenin, from the 1880s onwards, began to develop the theories of Tkachev, who followed Blanqui's belief that power could only be seized by a revolutionary elite, but contended that it could only succeed in a situation in which the mass of the people had developed a sense of impunity.9 This sense of impunity was the foundation of the "revolutionary situation" for which Lenin urged his Bolshevik party to strive from 1903 to 1917. He was a brilliant propagandist, and in his writing "his 
10 Edmund Wilson, To the Finland Station,

New York 1940, pp 388-9, cited by

R.N. Carew Hunt, The Theory and Practice

of Communism, London (Pelican) 1963, p 171

11 Schapiro op cit

12 Alan Moorehead, The Russian Revolution,

New York (Bantam Books) 1959, p 231

13 The Bolsheviks were never more than a minority Even in the Constituent Assembly election which was held immediately after the revolution they polled less than $25 \%$ of the votes cast, compared with $58 \%$ by the Social Revolutionary Party. Moorehead p267. 
real aim is not to justify theoretically what he wants done but to make men do it". ${ }^{10}$ He was also an organiser and a tactician, but while he roused the masses, he had no intention of allowing them to influence the power and freedom of action of the party - Tkachev's revolutionary elite.

Lenin also appreciated the importance of the army which Blanqui had not. He realised that the sense of impunity depended above all on confidence that the army would not react effectively against the revolution. In July 1917, he felt that this confidence had not yet developed, so he restrained his Bolshevik colleagues from trying to seize power. $^{11}$ Within less than three months he was convinced that the attitude of the army had radically changed in his favour - thanks largely to the reaction against General Kornilov's attempted military coup and he had become almost hysterical in his messages from his hiding place in Finland urging his comrades to seize the chance..$^{12}$

The pattern of urban revolution which emerged was a series of techniques whereby a minority ${ }^{13}$ cen influence a government or a majority of the public to accept changes which they do not want. This was done to a small extent by an appeal to conscience, but to a far greater extent by sheer exasperation. Also, in the case of the mass of the people, by inducing fear for their livelihood - fear that chaos would result in no work, and therefore no wages next week; no food, no water and (with winter coming on) no fuel. Having no confidence that the Provisional Government could maintain these things they were willing to accept the idea of the Bolsheviks - with their impressive organisation - taking over the reins, even though politically most of them would have preferred it if the leaders of one of the other political parties - especially the Social Revolutionaries - had been forceful enough to take control with similar confidence. 
$\partial \cdot$

Whas

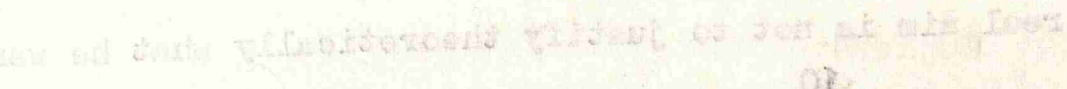

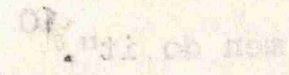

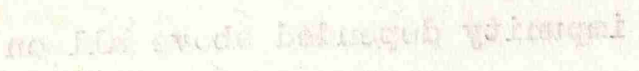

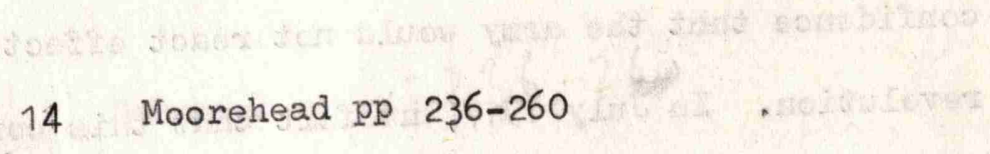

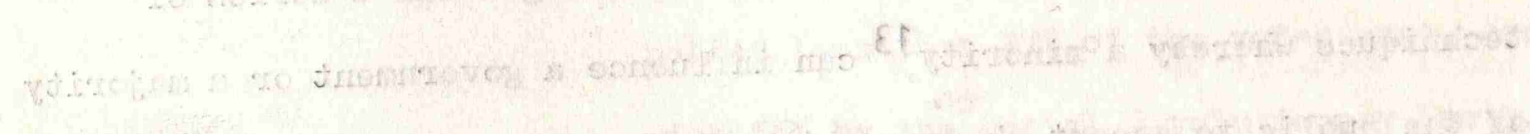

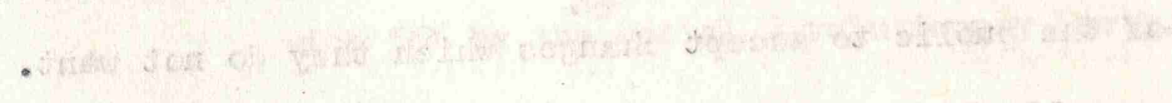

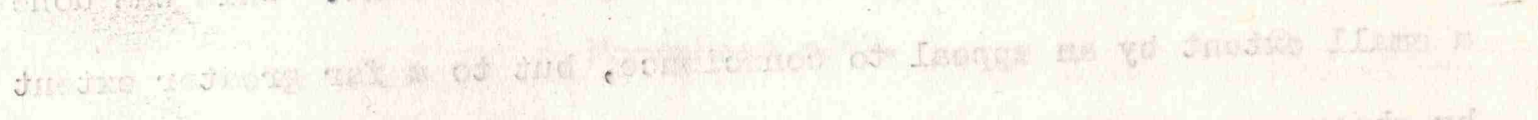

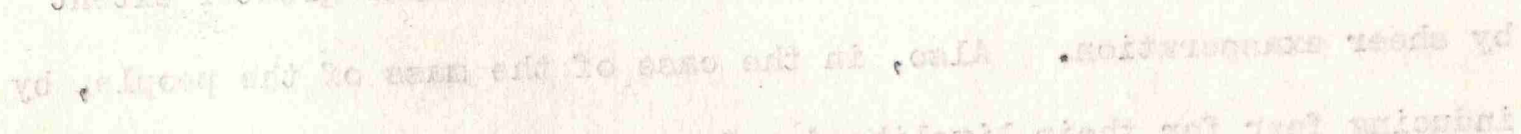

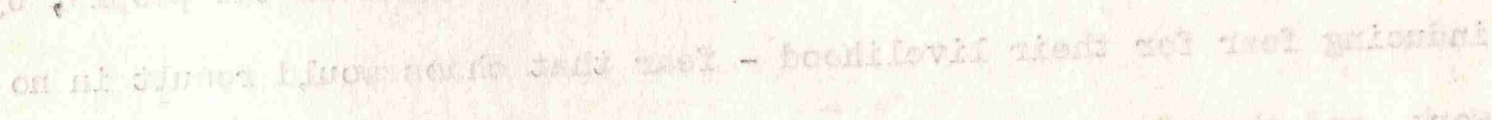

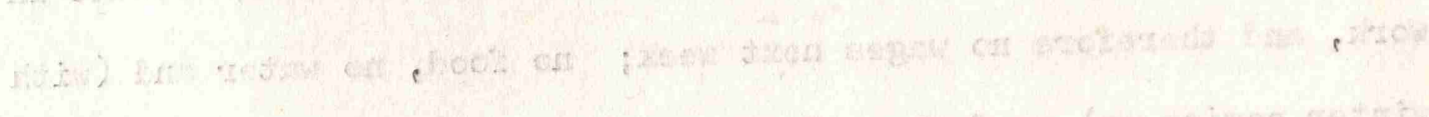

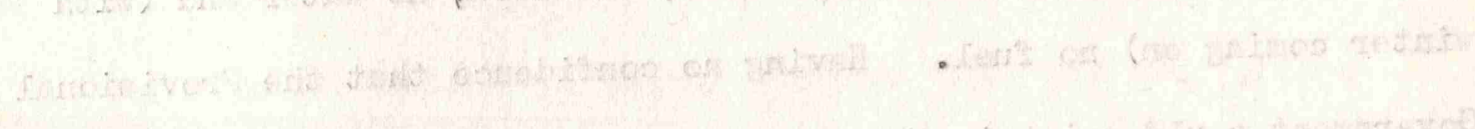

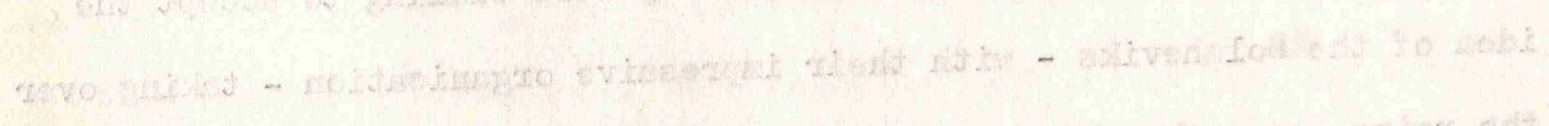

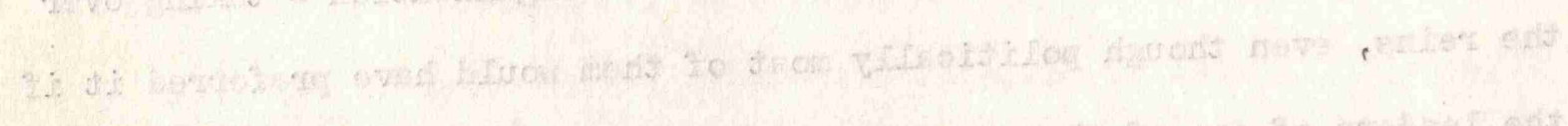

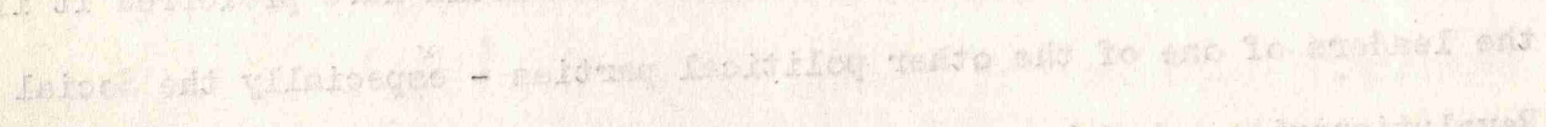

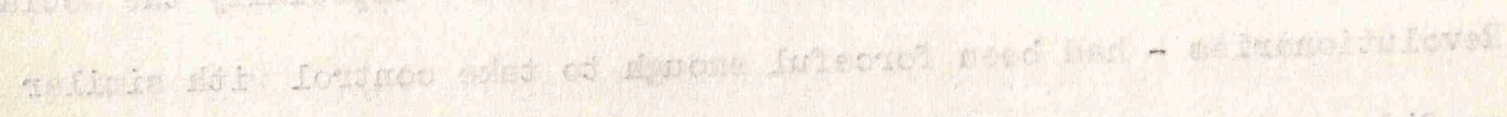

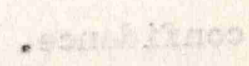


This revolutionary situation had been built up over the previous six months by a calculated erosion of the authority of the Provisional Government, of the civil servants, of army colonels and generals and of factory managements.

Gradually, practical control shifted from the normal power structure 'of the state to' the parallel hierarchy of the Soviets - workers and soldiers committees - which the Provisional Government had agreed should be lawfully constituted. Ultimately it was the control of army regiments by their soviets instead of by their colonels which proved to be the fatal weakness of the Provisional Government. The disease began to gallop when Red Guards in the factories were armed by Trotsky, and in the final stages many of the officials of the government lost heart and waited apathetically to be relieved of their responsibility. The parallel hierarchy - which in this case was the overt structure of Soviets - was already in operation and when Trotsky announced that the Bolsheviks had taken over in Petrograd this was generally greeted with relief. ${ }^{14}$

\section{Revolutionary Errors Between the World Wars}

The 20 depressing years after the first world war - and after the Russian Revolution - might have been expected to be a period of further success for Socialist and Communist revolutionary efforts, but in the event it was one of almost unmitigated failure for them. Perhaps for reasons similar to those for the Thermidorean Reaction to terror and insecurity, people rallied rather to authoritative right-wing leadership, such as that afforded by Mussolini and Hitler.

There were, however, a large number of unsuccessful revolutionary attempts in Europe, by both left and right wing groups. These generally failed because they did not appreciate the resilience of a modern state 
15 The Pocket Oxford Dictionary, Fourth Edition, Oxford 1942

16 Andrew C Janos, The Seizure of Power: A Study of Force and Popular Consent. Princeton University 1964, pp 46-51

17 ibid, pp 62-69 
in resisting a coup de main - and particularly the need to neutralise or control both the civil and the military apparatus of power, and not just one or the other.

Thus there were, in 1919 and the early 1920s, a number of unsuccessful attempts at a putsch (defined as "the seizure of power by a sudden vigorous attack".) 15 In Germany, for example, there was a series of Communist disturbances starting in January 1919 which reached a climax in Hamburg in 1923, when a concerted attempt to seize the post office, railroad stations, and airfields, and to raid all the city's police stations simultaneously was, after some initial success, defeated, because the Communists had failed to shake the control of the trade unions and other mass organisations of the workers by the Social Democrats who supported the government, so that the hoped-for popular rising did not materialize; also because the revolutionaries had failed to neutralise or penetrate the army, or to break the tacit alliance between the General Staff and the Socialist government, which had ensured that the Soldiers' Councils (unlike those in Russia in 1917) were not allowed to prejudice military discipline and the control of units by their officers. 16

Failure to appreciate the power of trade unions and other civil organisations also led to the collapse of a right wing military putsch by the German General Iuttwitz in March 1920. Though Luttwitz successfully seized Berlin on March 13th, he failed to secure the support of the trade unions, the banks, the civil service, or even of the leading right-wing politicians. The combination of a general strike, the refusal of the Finance Ministry to sign cheques and of the National Bank to release money paralysed the new regime. Political and military leaders and the police rallied to the legitimate government, and the insurrection collapsed within four days. 17 
18 Malaparte, Coup d'Etat, cited by Janos, op cit pp 52-57

19 N.N. Sukhanov, The Russian Revolution of 1917 London 1955, p 621, cited by Janos, op cit, p 55

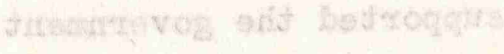


These failures were syritomatic of the fallacy of what could be regarded as a post-1917 version of 19th century Blanquism - the "lifeforce" theory of revolution propounded by Curzio Malaparte, who, like some contemporary revolutionary theorists, rejected the need for organisation and preparation which had been so much insisted upon by Lenin. Malaparte maintained that all that was needed was "a small company, cold-blooded, violent, well-trained in the tactics of insurrection", which could paralyse any state, however strongly organised the policed, by paralysing its "life-force" or nervous system. "The key to the state lies, not in its political and secretarial organisations ...... but in its technical services, such as the electric stations, the telephone and telegraph offices, the post, the gas-works and water mains"。 18

Malaparte, however, like Blanqui, failed to appreciate on the one hand the power of political and civil apparatus (including the trade unions) and the vital importance of the army, as had been so amply demonstrated in Petrograd. "First and foremost" wrote Sukhanov, "the military apparatus had to be liquidated. The telegraphs, bridges, stations and the rest would take care of themselves". 19

The Current Reaction Agáinst Leninism

In view of the success of revolutions which have used Lenin's techniques and organisation, and the almost invariable failure of others, it seems surprising that the need for such organisation is still so much questioned by modern revolutionary theorists. This may just be a symptom of the rejection of Russian Communism, and particularly of the reappearance of an "establishment", in which the once revolutionary party structure appears to lapse back into bourgeois ways.

While the Sino-Soviet dispute arises more from nationalist and doctrinal differences, Mao Tse Tung has certainly made vigorous efforts 
20 See for example, Lin Piao's foreword to the second edition of Quotations from Chairman Mao Tse Tung. Peking, Foreign Language Press, 1966 ("The Little Red Book"), and, on page 40-41 of the same book, Mao's 1963 statement "On Krushchev's Phoney Communism and its Historical Lessons for the World".

21 eg Regis Debray, Revolution in the Revolution?

- London (Pelican) 1968. Debray applies his theories specifically, to Latin America, but some others, such as Leo Huberman and Paul M Sweezy think that they may be applicable elsewhere (see their foreword to the book).

22 See also Frantz Fanon, The Wretched of the Earth London (Penguin) 1967, Chapter 1 had the foreword to the book by Jean-Paul Sartre. 
(in his "Cultural Revolution") to halt this reversion to a bourgeois establishment, but he has been reacting not against Leninism but against what he regards as a Russian betrayal of Leninism. It is true that Mao himself was initially, in the 1920s and 1930s, reviled even in the Chinese Communist Party for his contention that the revolution could have a peasant rather than a proletarian base, but he has always declared and documented his adherence to Leninism, 20 and there is no reason to assume that Lenin, faced with the situation in China, would not have approved of Mao's strategy, for Lenin was always flexible and pragmatic. The essentials of Leninism - the revolutionary elite, the seeking of a revolutionary situation, the weakening of the apparatus of government and of the army, and the imposition of control of all activities of the State by a parallel Communist Party hierarchy both during and after the Revolution - were all reflected in Mao's organisation and technique.

Every subsequent successful party revolution - even those (such as in Algeria) in which the revolutionary party was not Communist - have borrowed these techniques, though it is claimed by some writers that Castro's revolution in Cuba made significant departures from them. 21

These writers are amongst a number of modern revolutionary theorists including Sartre and Marcuse - who contend that the whole pattern of revolution has changed - or should change. They claim that it is wrong to delay the revolutionary process by building up an elaborate organisation, as Lenin did, or to wait for a revolutionary situation; that a revolutionary situation can be created anywhere by urban violence or guerilla activity, and that organisation can follow later; that violence in itself is a proper technique even if it fails in its apparent objective, since violence breeds comradship and commits its participants to the revolutionary cause; ${ }^{22}$ also that, in an orderly society, disorder provokes reaction and suppression which inspires greater revolutionary 
23 Schapiro, op cit. Also Debray, pp 115-127

and Che Guevara, Guerilla Warfare, London 1962, p 0111.

24. Patrick Seale and Maureen McConville,

Red Flag/Black Flag: French Revolution 1968

New York 1968, pp123, 147-149, 187 and

$220-225$ 


\section{. 21}

fervour. 23 This is the technique of continued confrontation with the established power structure, administrative, industrial, social and educational, in order to induce it to modify its powers from fear or from sheer exasperation. The eventual hopesis so to weaken these powers especially those of the police and the army - and so to erode public confidence in the established authority that this authority is induced to cede important functions to revolutionary bodies (under such titles as Workers or 'Students' Councilis) or to abdicate control altogether.

This was the philosophy of the student revolution in Paris in May 1968. It was led by intellectual Trotskyists and anarchists but was not supported by the powerful orthodox Communist Party, which was anxious to avoid provoking the destruction of its organisation. When the French government showed apparent weakness by making concessions to the students (on 11th May) the Communist and Socialist Trade Unions exploited the weakness by building up the biggest strike in French history involving nearly 10 million workers, from which they gained staggering wage increases of $35 \%$ and more. This mattered more to them and to their members than an attempt to change the social order. Some of the left wing intellectual groups in Paris felt that, at this point, de Gaulle might have been overthrown had there been an organised political movement ready to step in. In the event the intellectuals' and the students' revolt collapsed in the face of a firm speech by de Gaulle which rallied the mass or ordinary people who had been shaken by the rioting (which had been greatly magnified by the television cameras). De Gaulle called a snap general election which returned him with a massively increased majority - all the left-wing parties lost over half their seats - less than two months after the rioting had begun. 24

The theory of the use of violence and confrontation as a means of generating popular support is nothing new. First preached in the mid 19 th century, its most famous exposition was in 1906 by Georges Sorel, 
(English translation by T.E. Hulme)

London 1925 p 137

Hannah Arendt, in On Violence, London 1970

(p89) points out that Nechaev and Bukanin

had commended the unifying effect of violence

half a century earlier, and a century ahead of Sartre and Fanon.

26 Sorel, p123

27 ibid p211. Under Sorel's definitions, the State uses "force" while the revolutionaries use "violence" against it. 
in a series of articles in Movement Socialiste, which he later had published collectively in 1908 in his book "Reflections sur la Violence". Sorel tied his philosophy to the syndicalist theory of the destruction of government and the, seizure of control of industry by the workers by means of a general strike.

"Strikes have engendered in the proletariat the noblest and the most moving sentiments they possess; the general strike groups them all in a coordinated picture and, by bringing them altogether, gives to each one of them its maximum of intensity; appealing to their painful memories of particular conflicts, it colours with an intense life all the details of the composition presented to the consciousness". 25

Like Lenin, Sorel was énraged by "social reforms", aimed to lure the workers away from militance and violence.

"When the governing classes, no longer daring to govern, are ashamed of their priviledged situation, are eager to make advances to their enemies, and proclaim their horror of all civil cleavage in society, it becomes much more difficult to maintain in the minds of the proletariat this idea of cleavage without which Socialism cannot fulfil its historical role". 26

He praises the Christian martyrs for provoking the Romans to use force. 27 The Romans, by dealing severely with anyone who showed a tendency to disturb the peace, enabled the Christians - even though their physical martyrdom was in fact rare - to convince people of the superiority of their philosophy, so that Christianity eventually captured the Roman Empire. 
28 ibid p22

29 See Pears Encyclopaedia, London 1967 p J.42

30 Sorel pp 297-8. In his praise of violence, Sorel even commended lynch law in America as preferable to the incompetence and corruption of European judicial systems, pp 206-7.

31 ibid pp 298-9

32. The Economist, 20 June $1970 \mathrm{pp} 11-12$ in a comment on the practice of kidnapping foreign diplomats as hostages to bring about the release of imprisoned revolutionaries. 
To inspire such dedication, Sorel insists that there must be a "myth", believed by its adherents to be certain to prevail in the end, regardless of temporary setbacks. Christianity has for centuries provided one such "myth", 28 and the certainty of the ultimate overthrow of the hated European settlers by the natives is the "myth" expounded by Frantz Fanon in The Wretched of the Earth. Sorels philosophy was much admired later by Mussolini and Hitler, both of whom created their own myths on which to launch their political movements. 29

Sorel's "myth" was the.general strike. Strikes he said, are the means whereby the poletariat asserts itself, and are a phenomenon of war. He compared violent strikes to warfare, saying that, just as war provided most of the ideas of modern culture, so strikes accompanied by violence might engender a socialist society. 31 His writing was understandably diffuse (presumably to avoid giving grounds for arrest) but he leaves no doubt that he considers violence to be the only medium whereby revolutionary fervour can be effectively aroused. 31

Debray is not so diffuse, and is paying for the clarity of his writing by serving a 30 year sentence in a Bolivian prison. There are now regular reflections of Debray's (and Sorel's) philosophy of violence in Latin America - by both urban and rural revolutionaries. For example, a manifesto of a contemporary urban revolutionary organisation in Uruguay the Tupamaros - declares that

"revolutionary action in itself, the simple process of taking up arms, organising supplies and committing acts that violate bourgeois legality will engender a consciousness, a movement, and the conditions for revolution". 32

This has zet to be proved. Where a government or management is weak, the new revolutionaries have proved that its power can be eroded, as was propounded over half a century ago by Sorel. The technique of erosion 
33. It Col Marc Geneste, in an Interview 1963. See also Otto Heilbrunn, "The Algerian Emergency" in The Royal United Service Institution Journal, August 1966

Frantz Fanon (p32), for example, quotes M.. Meyer as saying in the French National Assembly that the French Republic must not be prostituted by allowing the Algerian people to become part of it.

34 Semantically speaking it is wrong to refer to a fighting man as a "guerilia". The Spanish word "guerrilla" means "small war" and the man who fights it.is a guerrillero - the word used throughout By Debray, op cit, and by his translator. Nevertheless in Anglo-American usage the word "guerilla" has come to mean the fighting man himself and the war is usually known as "guerillla warfare". I have used this wording throughout.

35. In an article on the Tupamaros (whom he describes as "urban guerillas") in Uruguay in The Observer on 9th August 1970 the writer commented:

"Unlike Che Guevara, they have learned what every - Latin American General has always known - that power in these parts lies in the city, not in the countrysi The Tupamaros use the city as the Vietcong uses the jungle".

36 J P Morray, The Second Revolution in Cuba, New York, 1 passim. 
by confrontation was used in Russia and in every other country where a party revolution has been attempted, including Singapore and Malaya, but it has not yet led to an actual overthrow of power without the accompaniment of a Leninist or Maoist type of organisation of popular support. A study of the erosive techniques used in these earlier revolutionary attempts may give indications as to the prospects of "violence and confrontation without organisation" achieving its ultimate aim - either in the cities or in the countryside. The Pattern of Guerilla Revolution

Modern guerilla revolutionary technique was born and developed in East and South East Asia. It has been tried elsewhere - for example in Greece - and success for it has been claimed in Algeria and Cuba. Algeria had more of the ingredients of a civil war than of a guerilla revolution, and the French can fairly claim to have won the guerilla war, only to have their victory tossed aside by their own politicians and economists. And in Cuba, despite the folk lore arising from the revolution, thetivities and

revolution, the activities and achievements of the urban revolutionaries had more significance in overthrowing Batista than those of the guerillas 34 in the Sierra Maestra. $35 \quad$ As in the French and Russian revolutions, a moderate liberal regime first ousted the dictatorship and dismantled the apparatus of the police state. This was achieved in Havana in 1958-59. As a part of this revolution, the government army was weakened and its morale collapsed. Castro's guerillas, who were very weak, defeated it because it had withered at the roots, and the rot spread to its branches and twigs in the countryside. Afterwards, when Castro, the charismatic guerilla leader, had been enthroned by the moderates, the Communists thereupon ousted them in classical style - also in Havana. 36

No other radical revolution has succeeded in Latin America in the past 30 years, (though some would put the Bolivian revolution of 1952 in that 
37 For example, apart from Mao's own work, see:J.I.S. Girling, Peoples' War, London 1969

Sir Robert Thompson, Defeating Communist Insurgency, London 1966,

George K Tanham, Communist Revolutionary Warfare:

The Vietminh in Indochina, New York 1961.

Michael Elliott-Bateman, Defeat in the East =

The Mark of Mao Tse Tung on War, London 1967. 
category). There have, however, been a large number of Palace revolutions and military coups.

Thus, with the arguable exception of Cuba and Algeria, the guerilla revolutionary technique developed by Mao Tse Tung has been successful only in East and South East Asia, and has been completed and consolidated only in China itself and in North Vietnam. It failed in the Philippines and in Malaya (though it could revive in either) and it has yet to be seen whether it will succeed or fail in South Vietnam, Laos, Cambodia, Thailand, Burma and Indonesia.

Mao's guerilla revolutionary organisation was no less extensive than Lenin's. In fact, the guerilla army encompassed the party structure. This was also true in Malaya, where the two structures, though in theory separate, were intermingled and shared the jungle.

The pattern of Mao's and Ho Chi Minh's protracted war has been amply described in many books. 37 Briefly, the revblutionary organisations guerillas, village cadres and open front associations - are built up from the bottom. The guerilla army, for example, begins with local village platoons, often part time. From these full time soldiers are selected for regional forces, and from these in turn the main force of regular battalions and regiments are formed and trained. The guerillas dominate the fields, plantations, mines etc. where the people work, so that they have little option but to provide money, supplies and information to the revolutionaries, but dare not betray them to the government. Selective terror is used to deter or punish government informers, to gain popularity by murdering unpopular bosses and administrators, and to intimidate local officials and policemen so that they have to "live and let live" or face death. The village cadres are then able to control the village at least by night, which means that no villager who betrays them can expect to sleep in peace. Eventually, the revolutionaries hope that the government officials will either become totally subservient or will be withdrawn, leaving the cadres in control by day as well. 
38 Mao Tse Tung, On Protracted War (May 1938) cited in his Quotations from Chairman Mae Tse Tung, Peking $1966^{\circ} \mathrm{p} 153$.

39 Mao Tse Tung and Che Guevara Guerilla Warfare London 1962, p113

40 Cited in Richard Clutterbuck The Long Long War, London, 1967 p3

41 Cited in Clutterbuck, op cit p3 
As this control spreads, whole areas are "liberated", and in these the guerilla forces can live openly to be retrained as a conventional army to drive the government forces back, first from the remote areas, and then from the more populated agricultural areas, finally isolating them in the cities. Deprived of food from the countryside, harrassed by urban violence and attacked from the outside, the cities finally succumb and the revolutionaries - in what has by now become civil war - gain complete control. Popular Support

Almost every revolutionary and counter-revolutionary has drawn attention to the need for popular support. Mao Tse Tung, for example, wrote that:

"The army must become one with the people so that they see it as their own army. Such an army will be invincible...." 38

Che Guevara wrote:
"For the individual guerilla warrior, then, wholehearted help from the local population is the basis on which to start. Popular support is indispensable". 39

On the other side, General Templer is quoted as saying:
"The answer lies not in pouring more troops into the jungle, but in the hearts and minds of the people." 40

This thought, however, had already been expressed 134 years earlier by the American John Adams:

\footnotetext{
"The revolution was effected before the war commenced. The revolution was in the minds and hearts of the people". ${ }^{41}$
} 
42 Debray pp ${ }^{41-42}$

43 ibid p 46-47. Debray also cites the "agitprop" patrols used in South Vietnam, - which are well described by Malcolm Browne in The New Face of War, Iondon, $1966 \mathrm{pp}$ 121-135

-44 Debray pp 44-46 and 115-125 11...

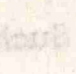


Regis Debray puts a different slant on popular support. Though he does not underestimate the eventual need for the masses to rise, he gives a passionate warning against premature involvement of the population by the guerillas, both because it will invite repressive measures and because of the risk of betrayal. He denounces the "Trotskyist" techniques of dual power, agitation for factory and peasant committees etc, because he says, they invite the destruction of the workers and peasant supporters by the government.

"The revolutionary guerilla force is clandestine .... is independent of the civilian population, in action as well as in military organisation; consequently it need not assume the direct defence of the present population. The protection of the population depends on the destruction of the enemy military potential .... the populace will be completely safe when the opposing forces are completely defeated.

.... This objective requires that the guerilla

foco be independent of the families residing within the zone of operations" 42

While he accepts that the people must be activated and led, he visualizes this being done by small "armed propaganda patrols" - ie by the guerillas rather than by cadres who live in the villages. 43

He sees the guerillas themselves as the nucleus of the party, not vice versa. He scornfully rejects the building up of a revolutionary political organisation which, he says, merely delays the armed struggle, adding that "insurrectional activity is today the number one political activity". His theory is based, not on fixed bases, but on a number of guerilla "focos" or centres of activity, each based on an active and mobile band of guerillas. The impression he gives is of a swarm of bees, sometimes buzzing for a time in the same area, but, when necessary, shifting its focus, still buzzing around. As the enemy swipes, the focus dodges elsewhere. As it buzzes 
45 Clutterbuck, op cit p5

46 T.A. Critchley, in The Conquest of Violence London 1970, gives an impressive historical account of the containment of revolutionary violence in Britain with an astonishingly small loss of life.

istitien veremo of

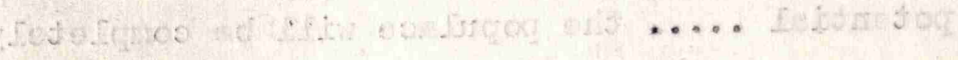

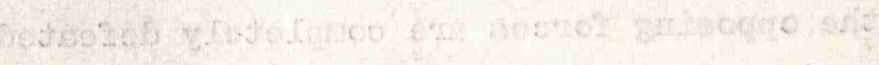

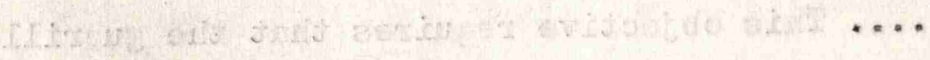

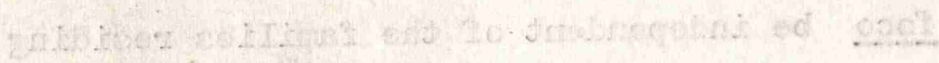

Sit:

(स)

$\sin j \operatorname{sesta}$

(4)

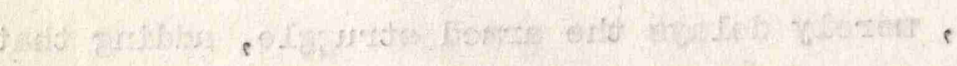

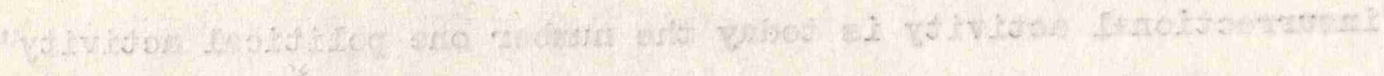

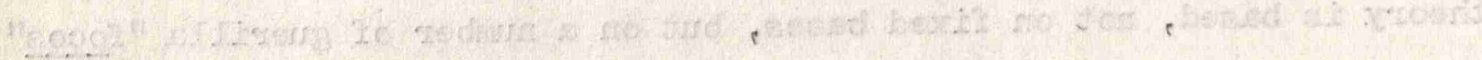

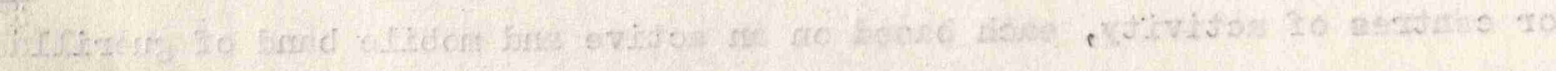

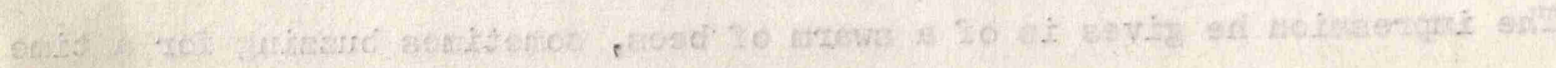

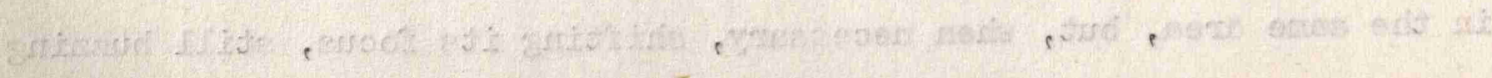


it gathers other insects around it. Soon the whole air is alive with insects everywhere and the enemy swipes in vain until he is stung to death.

Whether the activation of the people is done primarily by guerillas from outside or cadres from inside the villages, it is questionable how widespread the contacts with the population need be. How big a percentage need to be trained and prepared for local leadership, and to provide the support the guerillas need? And is the support of the remainder necessary at all? What is required of the majority is obvious exaggeration, for there will always be some opposition. "Acquiescence" or even "indifference" rather than "support". It is true that neither side can succeed without active support from part of the population, but this part need not be more than about 10\%. If a much larger percentage - say $30 \%$ - gives active support to one side, then this may well prevent the other side from winning. In either case, however, a large proportion - and usually some $80 \%$ - of the population will nearly always be neutral, aiming to keep out of trouble by not giving active support to either side. ${ }^{45}$ This hypothesis was particularly worthy of examination in the Malayan Emergency, and might also repay examination in the current situation in Northern Ireland (1970). Escalation

Since urban violence and guerilla warfare have become prevalent forms of conflict, the prevention of their escalation into something bigger is of some importance to the world. Malaya provided a good example of this prevention. The British can claim a fairly good record in keeping revolutionary conflict from becoming unduly bloody both internally $y^{46}$ and in the decolonization of her Empire. The aftermath, when law and order has been in the hands of a newly independent government, has often been a great deal bloodier, as it was in India and Pakistan, Palestine and Nigeria. Some would say that this aftermath was an inevitable result of a divide-and-rule policy and that Britain was cleverer in abdieating responsibility in time. 


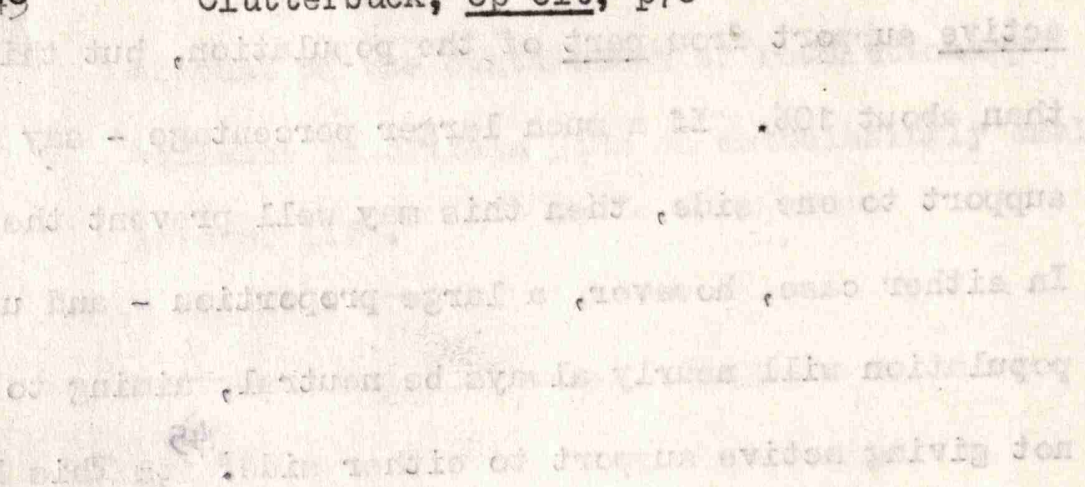


For over 12 years after Independence, it seemed as though the highly explosive racial mixture in Malaya might be kept cooler than the flash point, but the carnage in Kuala Lumpur after the general election in May 1969 may be a portent of worse things to come. The most cursory comparison of Malaya, Cyprus and Kenya with Indochina, Indonesia, Algeria and the Congo suggests, however, that, during the period in which Britain remained responsible for law and order in her emerging colonies, there was much less escalation of violence than in most others.

Sir Robert Thompson contrasts the escalation in Vietnam with that in Malaya. Though there were very marked differences in the situation and in the background, there were also some striking similarities. The insurgents in each had roughly the same plan and used similar techniques. In Malaya in 1949 there were some 4500 guerillas, with about 50,000 supporters. In Vietnam in 1959, there were about 5000 guerillas and 100,000 supporters in a population twice the size. At that time, Thompson suggests that government methods which had succeeded in Malaya could also have succeeded in Vietman, but they were not applied. 47 In any event, the number of civilians killed in Malaya, having risen over these three years 1948-50 $(500,700$ and 1200 respectively) fell away in 1951 to 1000 and continued to fafl; whereas in Vietnam, they'started to rise on a similar scale in relation to the population in the years $1957-59(700,1200,2500)$ but soared in the following year 1960, to 4000 and went on rising 48 until the guerilla war escalated into a conventional war. Malaya and Singapore - The Background

There were, however, very important differences between the settings of the insurgencies in Malaya and in Vietnam: differences in their terrain and in the positions and attitudes of their neighbours; in their ethnic structure, history (including colonial history) and arising from these, in their type of government, and in their relationship with, 


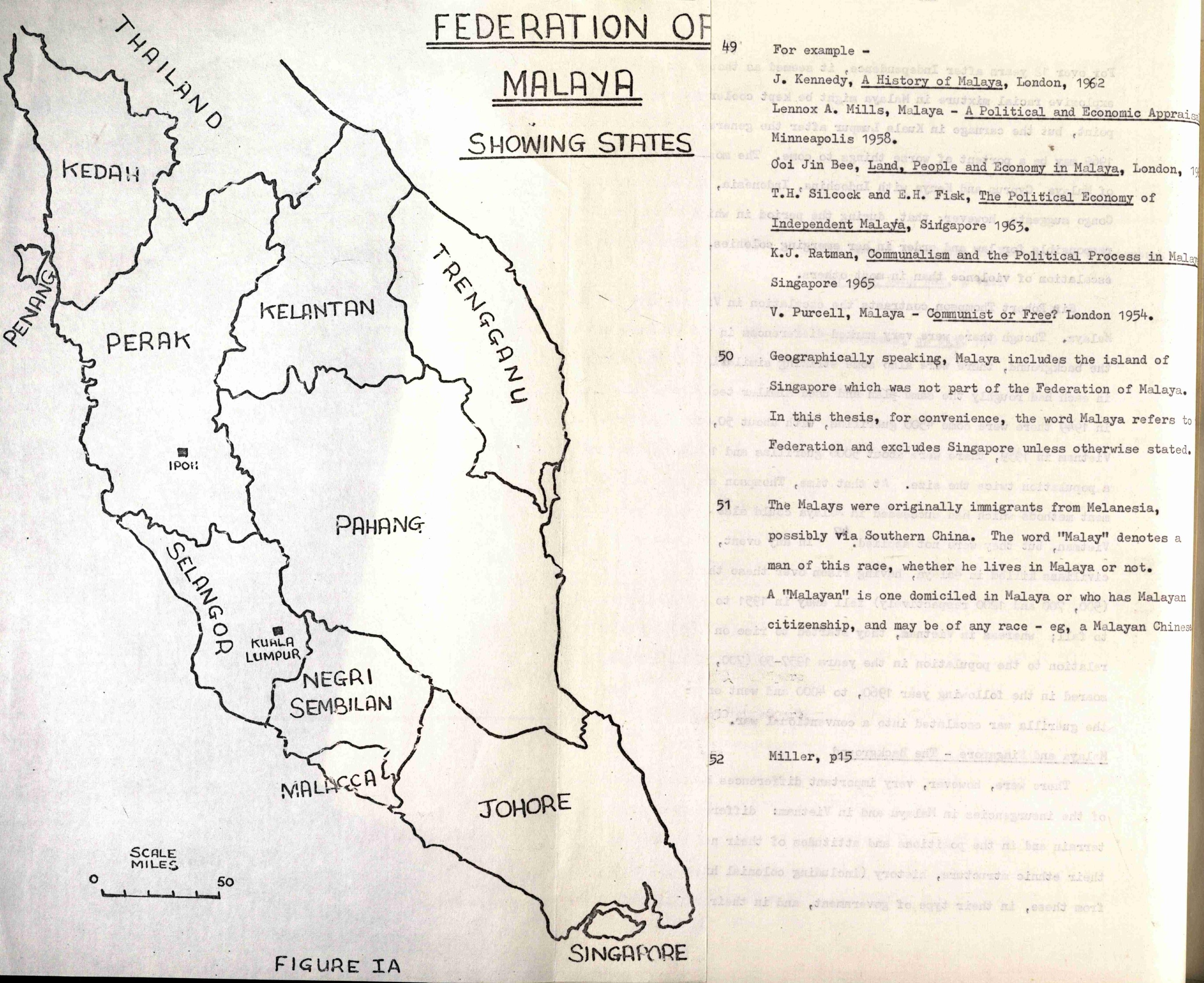


respectively, Britain and the United States. All these things have been described and analysed in several books, 49 so there is no need for more than a brief mention of some of the more important background here. Malaya, ${ }^{50}$ is a peninsula of about 50,000 square miles of which $80 \%$ is uncultivated jungle. Before the Federation of Malaya became independent in 1957, it contained 9 Malaya States ruled by Malay Sultans with British Advisers, and 2 settlements (Penang and Malacca) governed by $\longleftarrow$ British officials (see Figure 1A). Singapore, which was separate, also had a British Governor.

Though a few aborigines remained, the peninsula had been occupied and ruled by Malays ${ }^{51}$ for many centuries. From the 16 th century onwards, Portugese, Dutch and British traders made contact with them, and coastal settlements were established, which eventually became British (Penang, Malacca and Singapore). Treaties were made with the Malay Sultans, who accepted British advice, British officials and British defence, but remained, as they still remain, rulers of their States.

During the late 39 th and early 20th century, the development of the rubber and tin industries led the British to bring in large numbers of Chinese and Indian immigrants, since the Malays never took kindly to working in these industries, preferring their traditional way of life in agriculture and fishing.

By the 1940s, the Malays had ceased to have an overall majority of the population in the Federation though they were the largest single race. Figures were about -

\begin{tabular}{|c|c|}
\hline Malay & $2,600,000-$ \\
\hline Chinese & $2,040,000-$ \\
\hline Indian/Pakistan & $578,000-$ \\
\hline European & 12,000 ) \\
\hline Others & $70,000)$ \\
\hline
\end{tabular}


In Singapore, however, there were over $1 \frac{1}{2}$ million people, of whom 75\% (over 1 million) were Chinese. Had Singapore been joined, like the other Settlements, to the Federation, the Chinese would have had an overall majority. Though at this time very few Chinese had citizenship rights, being regarded as temporary residents from China, this would have been unacceptable to the Malays and their Sultans. That is why Singapore remained separate.

Even so, only two of the Malay States had an overall Malay majority - the two East Coast States of Kelantan and Trengganu, in which rubber and tin had not been appreciably developed.

In the Federation as a whole, and sited mainly astride the main road and railway from Singapore through Kuala Lumpur to Thailand, there were 720 tin mines and 3 million acres of rubber (see Figure 1B). Other crops included pineapple, pil palm and rice, and there were many small peasant farms and market gardens. The rubber estates were worked largely by Indians, with some Chinese, but very few Malays. Tin Mine labour was virtually all Chinese, as were the market gardeners and pig and poultry farmers. The Malays grew most of the rice, but most Malays lived peacefully by fishing and subsistence agriculture in their kampongs (villages). 53 Despite this, however, only half the total rural population of all races was employed in growing food, and the remainder - ie most of the Indians and Chinese - in producing cash crops and tin. 54

Thus, the Chinese and Indians were far more economically effective than the Malays. Average incomes per head in 1947 were: Chinese \$656, Indian \$850 and Malay \$258.55 Even more significant were their contributions to taxation. The only figures available include both the Federation and Singapore. In 1950,

9,624 Europeans paid a total of $, 8136,071,000$ Income Tax

\begin{tabular}{|c|c|c|c|c|c|c|c|c|}
\hline 10,037 Chinese & $"$ & $"$ & $"$ & $"$ & $\$ 117,812,000$ & $"$ & $"$ & \\
\hline 2,610 Indians & $"$ & $"$ & $"$ & $"$ & $\$ 17,569,000$ & $"$ & $"$ & \\
\hline 876 Malays & $"$ & $"$ & $"$ & $"$ & \$ $8,836,000$ & $"$ & $"$ & 56 \\
\hline
\end{tabular}


Thompson, Defeating Communist Insurgency, p19

58

Director of Operations, Review of the Emergency in

Malaya from June 1948 to August 1957 Kuala Lumpur, September 1957

59 Including Miller, pp 19-34 and Clutterbuck, The Long Long War, pp 13-24

60 See Clutterbuck, op cit, p14. Confirmed by Alan Blades, in a letter to the author, 1969. 
Thus, only one Malay in 3000 earned enough to pay any Income Tax at all, compared with 1 in 200 Chinese. But these 1 in 200, that is the 10,000 Chinese merchants landowners, tin miners and industrialists paid, head for head and in all, almost as much as the British.

As a further indication of Chinese economic involvement Donnison records that, out of $\$ 130$ million invested in Malaya before the war, $\$ 50$ million was British and $\$ 40$ million Chinese - again almost equal.

Even so, throughout the Emergency, the British found it hard to convince the bulk of the Chinese working population that they had a stake in Malaya as Malayans. 57 Many remitted money to China, and many returned there, or had planned to do so until China was taken over by Mao Tse Tung.

The bulk of the Federation Army and Police Force were Malay, initially with British officers. At the start of the Emergency there were two Malayan battalions, rising to 8 by 1955, of which 7 were wholly Malay, and the 8 th of mixed race - but still mainly Malay. In the Police Force, almost all the constables were Malay, though its most vital element proved to be the small Special Branch formed during the Emergency, which was largely Chinese with senior posts held by the British. 58

The Malayan Communist Party and the Japanese Occupation

Little need be said about the formation of the Malayan Communist Party (MCP) which has again been described in many books. 59 It had an urban beginning in Singapore where Communist agents from Shanghi started work in 1924, and where the MCP was formed in 1930. The party was, however, set back by a brilliant Special Branch coup in its first year. In 1934, a young Vietnamese communist, Lai Tek, joined the Party and by 1939 had become Secretary General, remaining so throughout the Japanese occupation and thereafter until 1947. It is now generally accepted that he was originally planted by the British Special Branch, though his subsequent loyalties are more doubtful. 60 


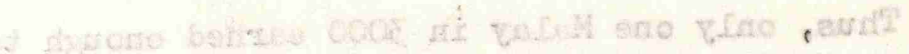

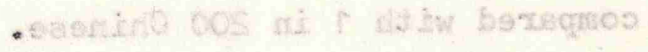

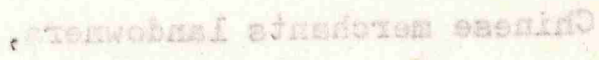

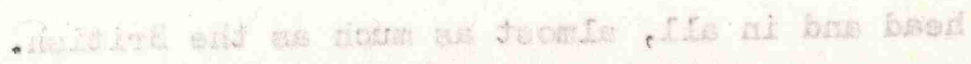

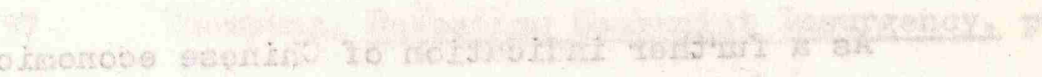

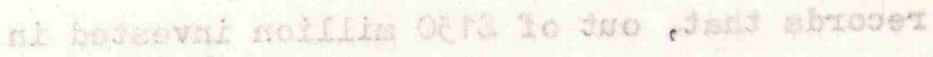

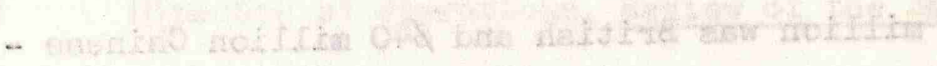
(

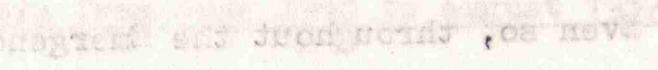

61 Clutterbuck, op cit, pp 15-16. Also 0'Ballance,

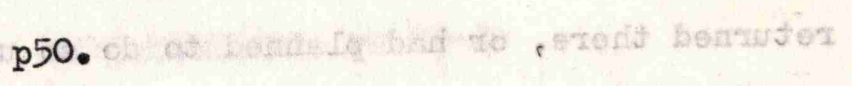

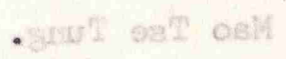

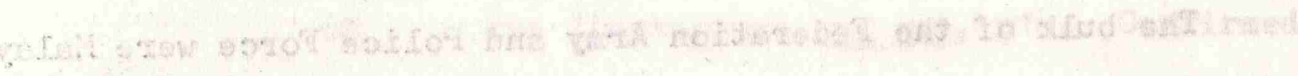

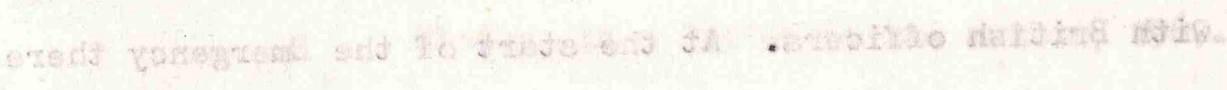

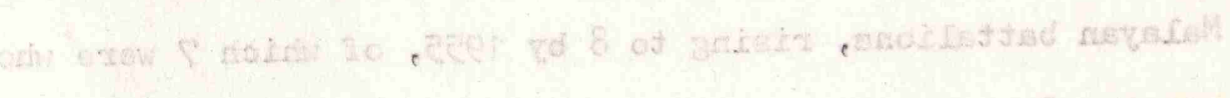

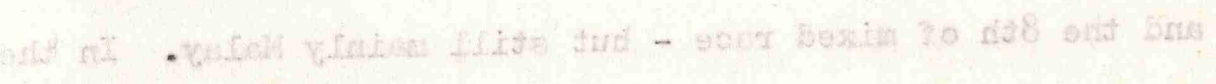

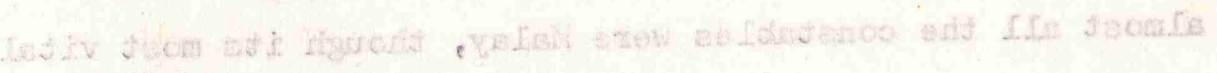

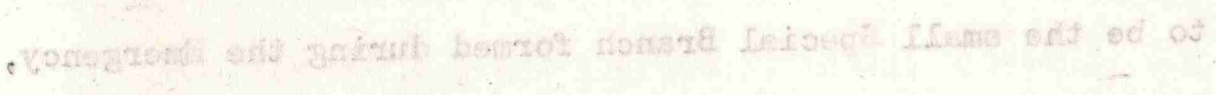

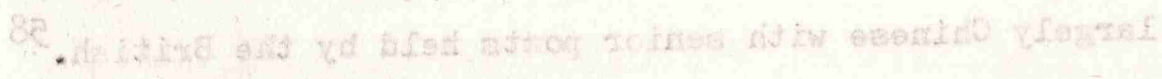
90.

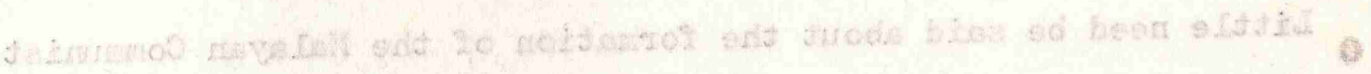

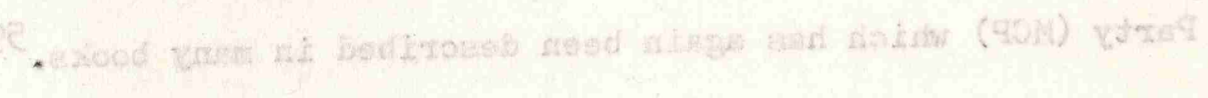

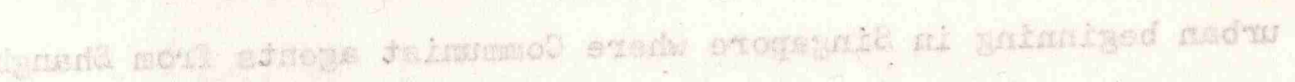

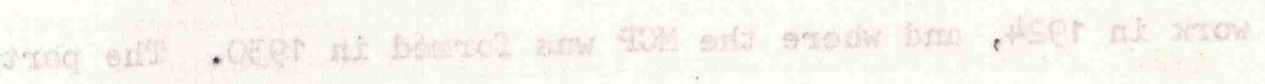

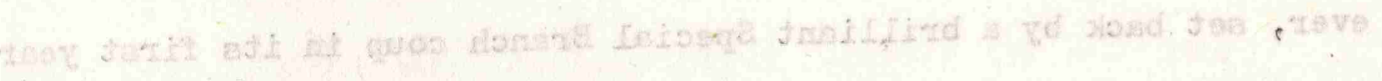

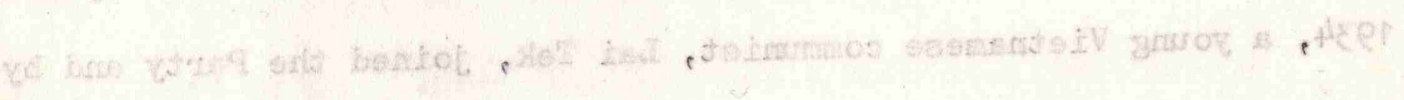

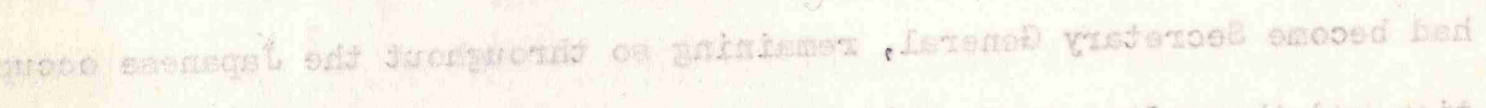

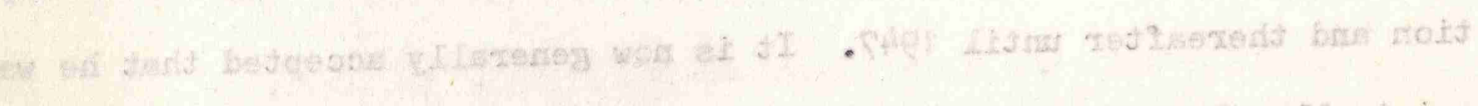

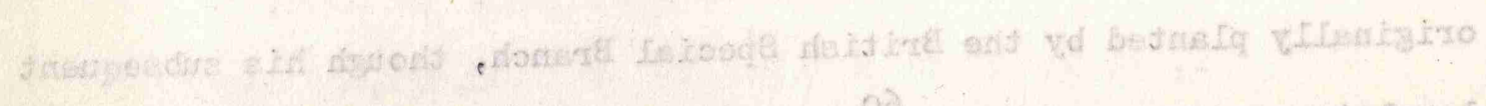


During 1941, the British in Malaya were blissfully sure that the Japanese would not invade Malaya, and that, even if they did, they would not attempt to advance on Singapore from Thailand through the junglecovered Malay peninsula. Though a small irregular warfare training school was started in Singapore early in 1941 by Lieutenant Colonel (now Major General) J.M.L. Gavin, RE, later joined by Major (later Colonel) F. Spencer Chapman, the British High Command in Malaya in October turned down a proposal to train locally enlisted stay-behind parties. Only after Pearl Harbour did they change their minds, and on 20th December 1941 there was a clandestine meeting between British officers and Lai Tek in a back-street room in Singapore. Thereafter, during the four weeks remaining before Singapore fell, under arrangements made with the MCP, $200^{\circ}$ Chinese were trained as guerillas. These took to the jungle behind the advancing Japanese, and during the next three years they grew into a force of 7000 men, under Communist leadership and control, known as the Malayan People's antiJapanese Army (MPAJA). They were supported by a strong, largely spontaneous and loosely organised body of Chinese villagers and squatters on the jungle fringe, known as the Malayan People's anti-Japanese Union (MPAJU)。

The MCP concentrated on building up its organisation, both for use against the Japanese, and eventually for use against the British after the war. Meanwhile, they avoided provoking Japanese interference with this organisation and took little aggressive action. 61 Spencer Chapman remained with them, though virtually a prisoner, until 1945.

The MPAJA operated in patrols of about 100, which included a few girls (who apparently caused no disharmony). Each unit had a Military Commander, but he in turn was a subordinate to a Political Leader who was a Party Member and had absolute power. The army was almost wholly Chinese (Spencer Chapman mentions one Indian in a group or regiment of 216 and no Malays). In addition to the full time guerillas, the MPAJA trained 100\% reserves, who came into the jungle for a 2-months course, and returned to their villages or squatter-huts to await recall when enough had been 
86

62

F. Spencer Chapman, The Jungle is Neutral,

London, 1949 pp 161-175

63 Chapman $\mathrm{p} 317-8$

64 John Davis, Interview, 1966

65 V. Purcell, The Chinese in South East Asia, London 1965, pp 306-311. 
acquired to arm them. 62

Though the MPAJA killed few Japanese, they killed many "traitors". Spencer Chapman found himself for a time with a special Traitor Killing Squad in the jungle near Ipoh, which was credited with killing over 1000 people of all races, mainly by descending on the towns and villages and picking out its victims in houses, coffee' shops or police posts. The killer-squad was never given away to the Japanese by witnesses. 63 Executions such as these were always done by guerillas from the jungle rather than by supporters in the villages who were too vulnerable. 64

On the other side, the Japanese treated the Chinese with extreme ruthlessness, and, for example, slaughtered 5000 in February 1942, mainly picked out by hooded informers. Many Malay officials and police continued in their posts under the Japanese, on the not unreasonable grounds that it was better for them to maintain some semblance of order in their own land rather than abandon it wholly to Japanese officials, but, because of the Japanese butchery of Chinese, the relations between Chinese and Malays, which had been good before the war, were ruined. 65 This resulted in some appalling massacres of Malays by Chinese after the Japanese collapse.

Nevertheless, some of the Chinese did betray their own people to the Japanese - as they were later to do to the British and Malay soldiers and police in the Emergency. The explanation of this surprising attitude is discussed later in Chapter 9.

In May 1943, a new element entered the jungle war in the form of a British army liaison team, Force 136 under Colonel John Davis, which was landed by submarine in August 1943 after an in-and-out reconnaissance in May•

Their function was to contact the guerillas (and rescue Spencer Chapman) to send radio reports to the Allied Command in Calcutta, to arrange the supply of British arms and equipment, and, in due course, to guide the guerillas in cooperating with the Allied reoccupation forces. 
66 Chapman pp 231-240, and Donnison 380-381

67 Davis, Interview, 1966

68 Chapman pp 411-413

69. Davis, Interview, 1966

70. Chapman p371 
Davis made contact with Chin Peng, at that time the MCP leader in Perak, in September 1943, and an agreement was reached with the MCP in December 1943. 66 (Chin Peng was later to become Secretary General of the Party, and remains so to this day, while Davis was to play a major part in running the governments Emergency effort. They never lost their mutual respect, and when Chin Peng emerged for the abortive truce talks in 1955, it was Davis who met him at the jungle fringe and escorted him back there after the talks broke down).67

Thereafter, there was much frustration, largely caused by the failure of the radio and the difficulty of repairing it. The first airdrop of supplies was not received until December 1944. Eventually, between June and December 1945, over 1000 airdrop sorties were made, delivering 510 men and $1 \frac{1}{2}$ million lbs of equipment and supplies, in preparation for the support of the Allied invasion ${ }^{68}$ - which in the event was unopposed due to the Japanese surrender after the dropping of the two atomic bombs.

During the period 1943-45, there were several meetings between Davis and senior MCP representatives including Lai Tek. The MCP was prepared to cooperate in ousting the Japanese but left Force 136 in no doubt that they intended to make Malaya a Communist Republic after the war. ${ }^{69}$ The British, on their side, agreed to pay the MCP 3000 per month, which they said was not to be regarded as wages but as provision for the food and upkeep of the guerillas. 70

\section{Reoccupation by the British}

The British South East Asia Command (SEAC) in Calcutta had been planning to reoccupy Malaya in November 1945, and to assist in planning this operation (code named ZIPPER) Spencer Chapman was taken out of Malaya by submarine on 13th May. The planned date of the landing was then brought forward to mid August 
71 Chapman pp 404-412

72 Donnison pp 384-5

.73 Chapman p 419

74 Donnison p 158 and 385-8

$75 \quad$ ibid 938 
On 6th and 9th of August the atomic bombs were dropped on Hiroshima and Nagasaki. By 11th August it was clear that the Japanese were about to surrender. On the 17th August SEAC ordered Force 136 to cease fire. 71

Meanwhile, there was real concern in SEAC that the MPAJA might usurp the government. Many guerillas entered the towns and villages, and confusion was caused by bandit gangs also doing so and claiming to be MPAJA. The MPAJA seized most of the police stations and barricaded the others. On 22nd August, SEAC authorised Force 136 to reoccupy areas vacated by the Japanese and a few days later to enter Japanese-occupied areas as wel] as to maintain order if the Japanese were not doing so. ${ }^{72}$ Singapore was reoccupied on 8 th September, but it was 28 th September before the Japanese on the East Coast surrendered. 73

During this period and for some months afterwards there was communal violence on an appalling scale. In August, when the MPAJA began to seize control, the Japanese provoked the Malays to kill 400 Chinese in the predominantly Malay Coastal towns of Muar and Batu Pahat, and many Malays, accused of collaboration, were slaughtered by the Chinese. Between September 1945 and 1st April 1946, 600 murders were actually recorded by the police but there were undoubtedly many more. 74

The occupation force commander in Malaya (General Dempsey) decided to keep the guerillas under military control, and to this end they were paid \$30 a month, given clothing and rations, and employed on guard duty. Any who wished were allowed to opt out of this by handing in their weapons and collecting an immediate payment of $\$ 150.75$

Meanwhile, negotiations began for disbandment of the MPAJA. The British were afraid that too high a gratuity would encourage inflation, and decided upon an award of $\$ 350$ at the final disbandment for each guerilla who handed in a weapon. A disbandment ceremony was held at the beginning of December 1945, and 5497 weapons were handed in. This was more than the 


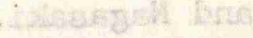

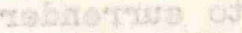

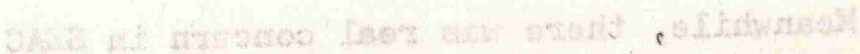

76 ibid, p 386

77 Lam Swee (Com) Interview 1966

78 Chapman p 419

$79 \quad$ ibid p 419

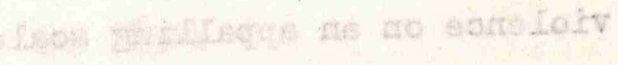

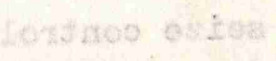

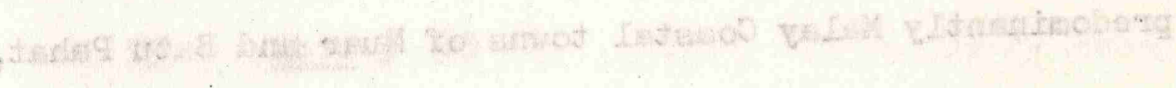

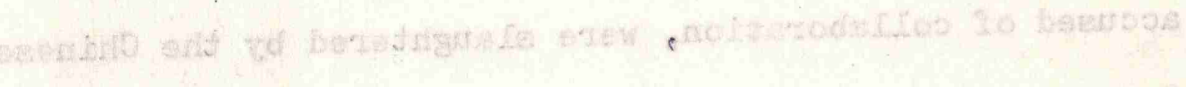

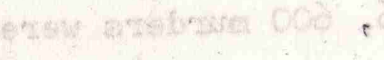


number issued through Force 136 (4765), but certainly not as many as were at large. The MCP already had a substantial clandestine stock of weapons left over from the war in abandoned dumps and taken from dead bodies, and they knew well that they could get more from the same sources. 76

The Party Structure and the Party Branch organisations established in the villages, remained intact. Only the uniformed guerillas handed in their weapons, and registered their names with the MPAJA Old Comrades Association (OCA). Secret members, however, hid their arms and did not register. 77

Nevertheless, the MCP were not as prepared either for the takeover which had been their intention, nor for launching the campaign to oust the new and weakly established British Military Government. The British - all powerful and godlike before the war - had been humiliated by the Japanese, and were no longer regarded by the people as invincible. A concerted take-over bid by the MPAJA might have aroused a response from the Chinese at least, though the Malays might then have rallied to the British as the only hope of preserving their position in the country. As it was, the MPAJA was taken as much by surprise by the atomic bombs and the surrender of the Japanese as was the rest of the world. Hating the Japanese, and relieved of their terror, many of the Chinese "literally wept with joy" when the first British soldiers reappeared. 78

So the British were back. Though the MPAJA had earned great credit for their resistance to the Japanese, there was a slightly hollow ring about their claim to have finally defeated them. Spencer Chapman (writing early in 1948, just before the Emergency began) considered that if only the atomic bomb had come late enough to allow the MPAJA to play their part in driving the Japanese out of Malaya, its resettlement might have proved easier than it did. 79 As it was 
the MCP had to decide all too quickly whether to oust the

British by a guerilla or a city revolution, and started work on it without proper preparation. 
. 39

P A T I

URBA PEVOLUTION

SIII GAPORE 
1. "Seng" (SB) Interview 1966

2. Lucian W. Pye, Guerrilla Communism in Malaya Princeton 1956, p.66 n。

3. Alan Blades, in comments on first draft para. 39, and letter to the author, July 25, 1969. 


\section{CHAPTER 2}

THE FIRST ATTEMPT AT AN URBAN REVOLUTION - 1945-48

\section{The Decision to Adopt an Urban Strategy in 1945}

When the MCP took to the jungle on the arrival of the Japanese in 1942, only a small minority had stayed underground in Singapore, including the secretary General, Lai Tek. Their organisation in the city had then been smashed by the Japanese in August $1942^{2}$; and thereafter it was virtually impossible for the Communists to operate in Singapore for the remainder of the Japanese occupation. 3

In 1945 the Party set its sights on gaining control of Singapore first - i.e., by means of an urban revolution on the Russian model. This may now seem surprising, but in 1945, though Mao Tse Tung's theories had been put on paper, and to some extent practised against the Japanese and the Kuomintang, they had not yet been proved to the world. His victory in China was still 4 years ahead. In any case, the Communists seemed to have a good chance of a quick victory in Singapore in 1945-47. Everything was in their favour at the time of the Japanese surrender. Their prestige was at its peak, and that of the British very low after their humiliation by the Japanese in 1943. Two Communists sat on the Advisory Committee established in 1945 by the British Military Administration. They were the only organised vocal opposition, and there were causes enough for complaint. 
4. G.G.Thomson, in comments on the author's first

- draft, June 1969, para. 3. In a covering letter to these comments he adds that it was the Communists own failings rather than clever policy on the part of the government which brought them to defeat.

5. Pye, p.70. 
The Chinese were an urban people, and urban discontent

was greater because of the difficulty of getting going again quickly in a basically commercial community. 4

Their hope of gaining control by constitutional means was based on a not unreasonable estimate of the British ability and determination to resume effective colonial government. During the war they had hoped that the Japanese army, weakened and overextended by the Americans and the British, would find itself strangled by a popular rising in China enabling the MPAJA to lead a similar rising by the Chinese in Malaya. The sudden ending of the war found them unready everywhere. They expected, however, that the British reoccupation forces would do no more than maintain some kind of order under which the MCP could build up its organization ${ }^{5}$ especially in the urban areas - and it seemed inconceivable to them that the people would not rally to their call for freedom from colonial government, or that the British government would be able to resist the flood of national feeling led by a recognised political party which would quickly prove itself ready to take over. Indeed, there was no other political party which could remotely have stepped in and, although their hopes may now seem to have been naïe, they did not seem so to themselves at the time in the light of the chaos which inevitably followed the collapse of the Japanese administration.

A victory in Singapore would have been followed by others in Kuala Lumpur, Ipoh and Penang, with Communist control thereafter spreading to the mines, estates and rural areas. 


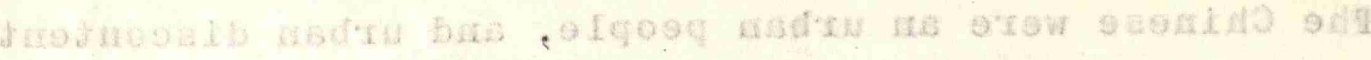

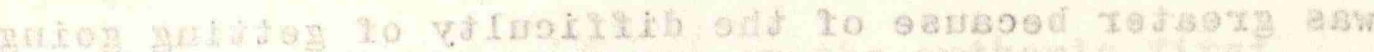

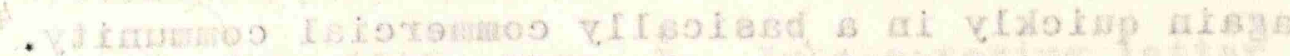

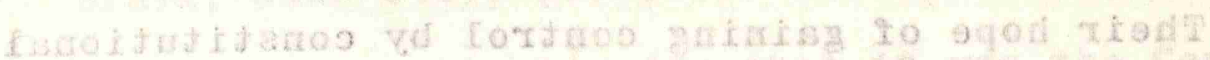

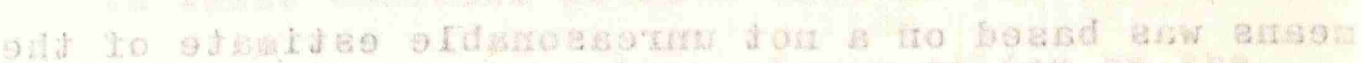

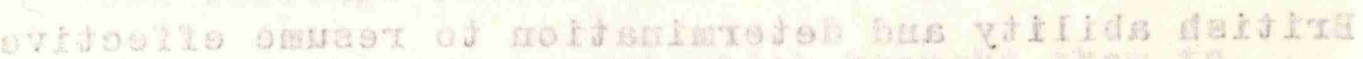

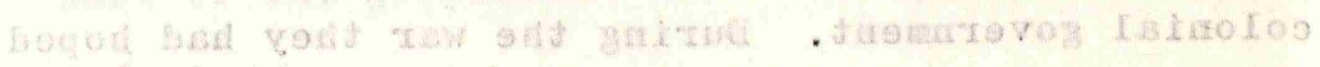

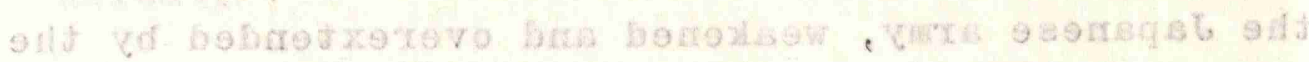

6. "Fu" (SB) Interview 1967 .

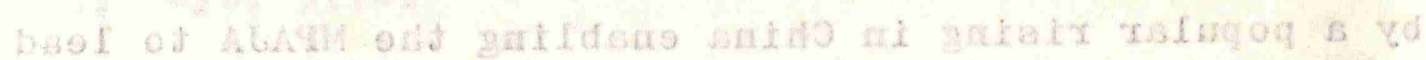

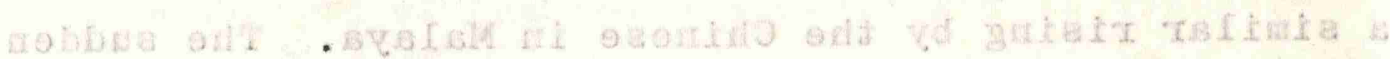

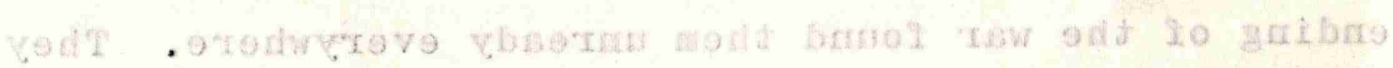

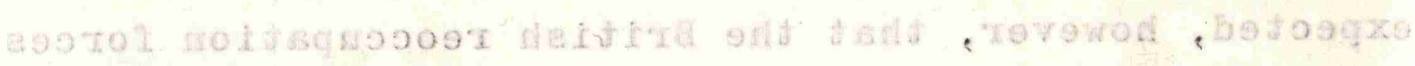

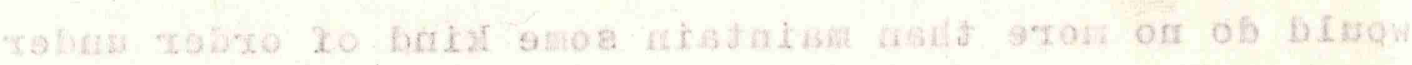

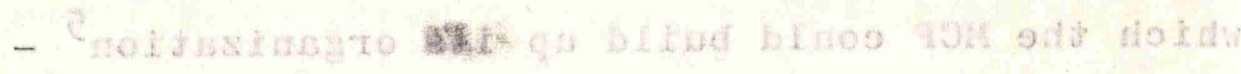

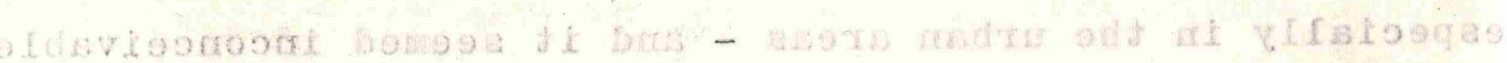

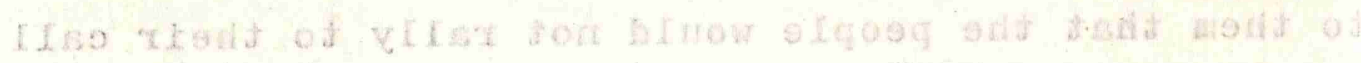

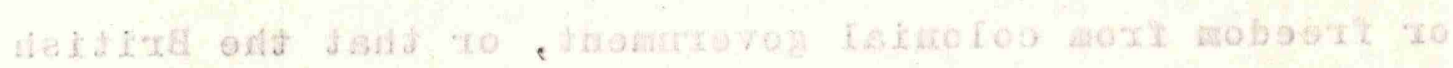

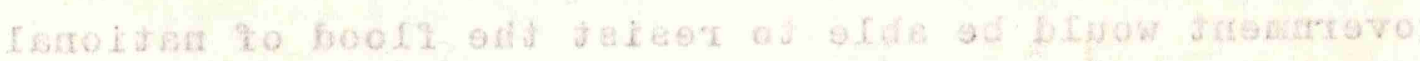

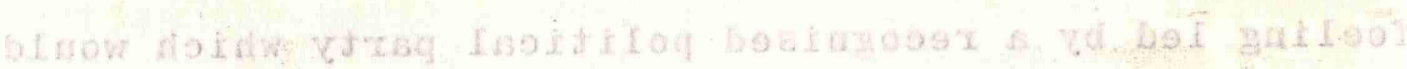

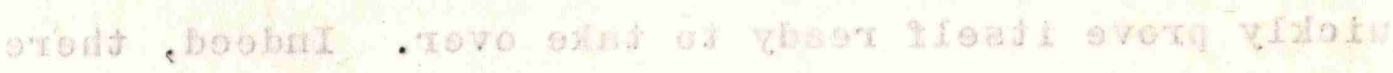

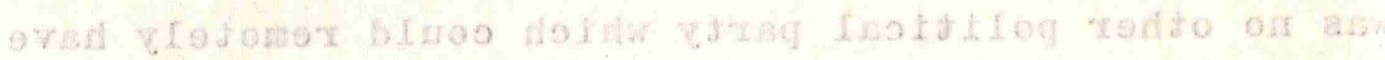

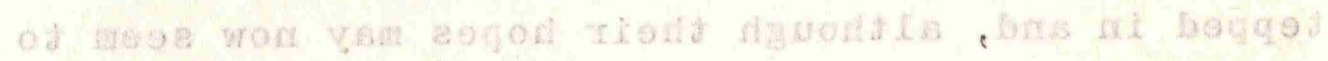

7. "Seng" (SB) Interview 1966 ,

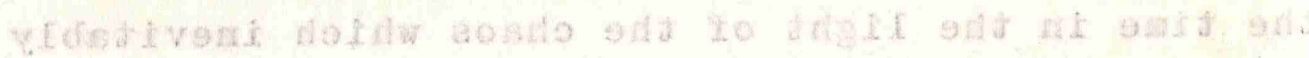

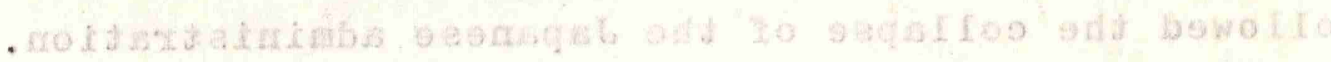

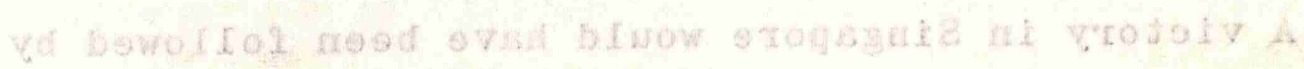

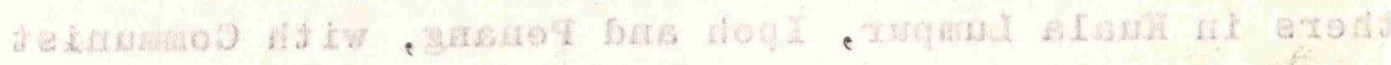

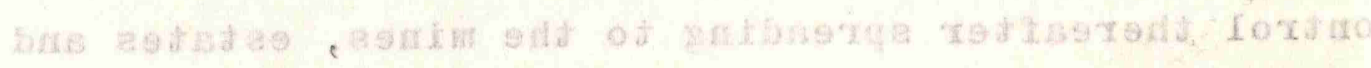


On the other hand it is arguable that, had the MCP maintained its strong guerrilla army in the jungle, supported as it was by a large majority of the rural Chinese on the jungle fringe, the British could never have reestablished control over the rubber estates and tin mines and, with no prospects of profits from these industries, would soon have abandoned both Singapore and the Federation. 6 Perhaps either strategy could have succeeded if the sudden Japanese collapse had not given them so little time.

The urban revolutionary effort in Singapore was doomed to fail in 1948. It was to be resumed with some intensity during the critical years in which Singapore was progressing through the interim phase of self-government aja under British sovereignty to full independence (1945-63), but by that time the party was illegal, while the government and its police force had greater experience and stronger powers with which to deal with it.

In 1945, however, the MCP was legal, and the time seemed ripe for action inthe cities. It therefore sent most of its best men to Singapore and the other big towns to work for the seizure of power. 7 This was an "open front" period - i.e. they worked through a number of legal organisations, especially the Trade Unions which had been revived under the pre-war General Labour Union (GLU) of which the Communists rapidly gained control. Other legal front organisations under MCP control included the New Democratic Youth League (NDYL), The Singapore Women's Association (SWA), the MPAJA 0ld Comrades 
8. G. G. Thomson para. 4

9. C. C. Too (Gov.) - Interview 1968.

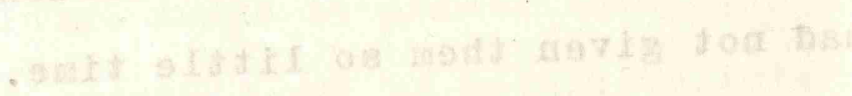

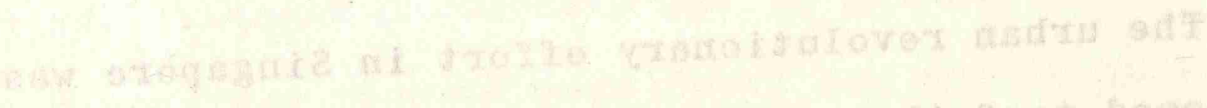

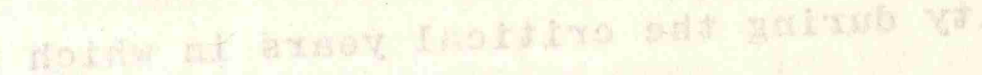

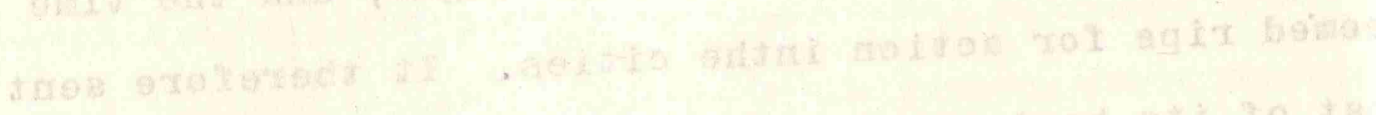

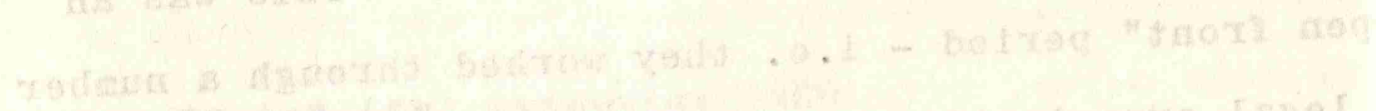

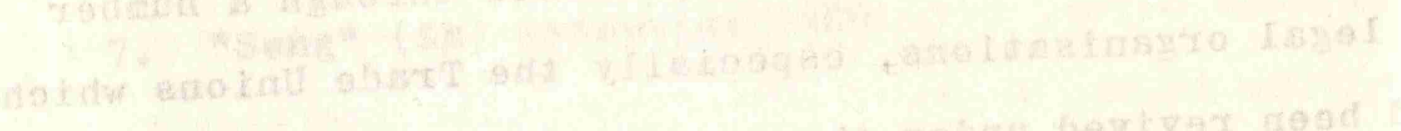

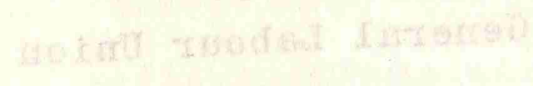

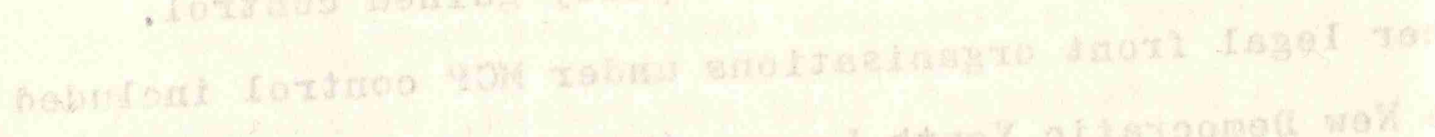

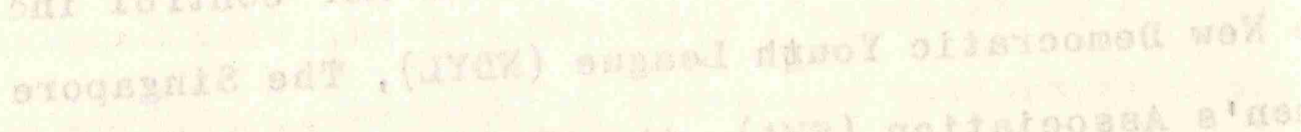

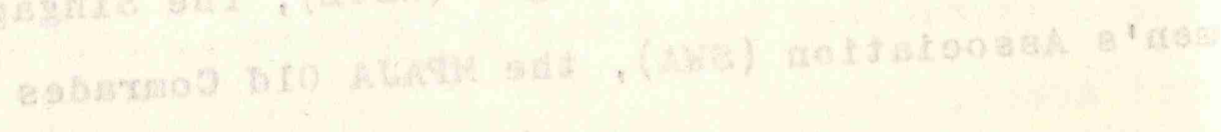


Association (MPAJAOCA) and the Malayan Democratic Union (MDU). 8 All of these were gradually taken under a dual system of open and secret direction as will be described in the next chapter. At the same time, the MCP emerged as a legal Political Party, with a party platform for running the country. The Central Committee itself, led by Lai Tek and including Chin Peng, remained underground, but two senior Party Members, both already well known to the British, established themselves in the Party's Headquarters offices in Kuala Lumpur - Liew Yit Fan at the head of the Political Committee and Lau Yew of the Military Committee. They made speeches, and attended public functions alongside British and other Malayan dignitaries as leaders of a normal political party. 9 The Difficulties of the MCP as an Open Political Party

The MCP was not alone in operating as a legal political party at this time. In 1945 there were many others, for Britain, America and Soviet Russia had emerged as Allies, and Communist Parties were respectable.

In Eastern Europe, under Soviet occupation, "Coalition" governments were formed, but their other member parties were given short shrift by their Communist factions. Czechoslovakia, however, was not occupied by the Soviet Army, and the Coalition lasted until 1948, when the world was given a classic example of the ability of an open and legal Communist political party to seize power through "constitutional" means, even though in a minority. With $38 \%$ of the popular vote in the 1946 elections the Communists secured a number of key ministeries in the Coalition Cabinet, including those of the Interior, Defence, Labour 
10. SORO (Special Operations Research Office of the American University) Casebook on Insurgency and Revolutionary Warfare Washington 1962, p. 597 .

11. SORO, p.593

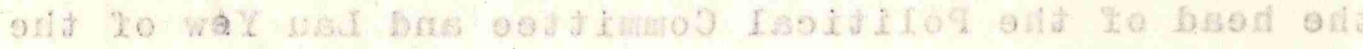

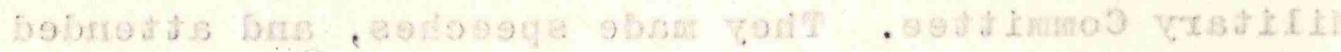

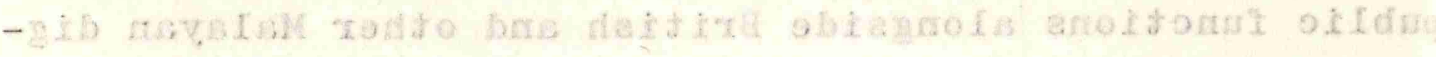

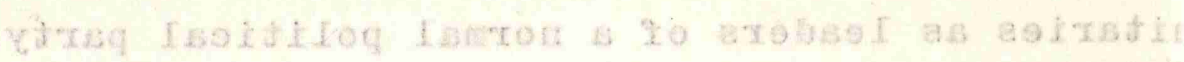

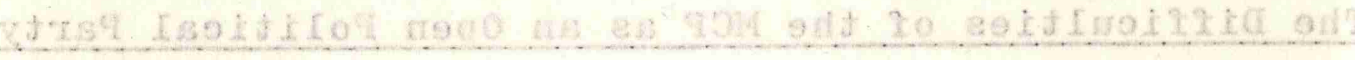

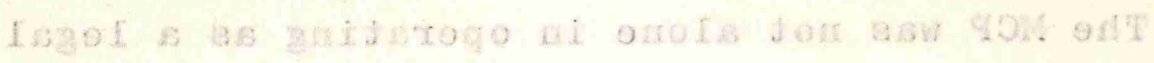

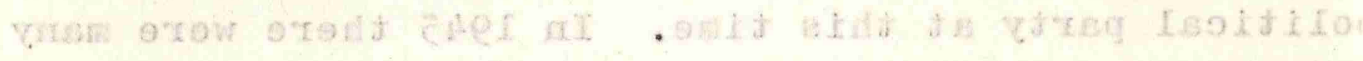

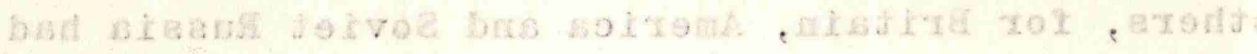

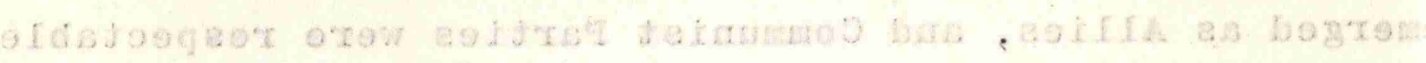

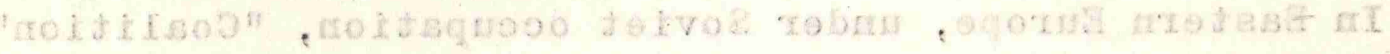

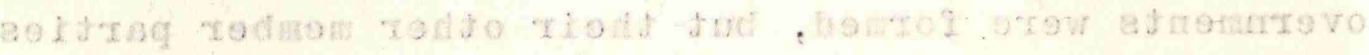

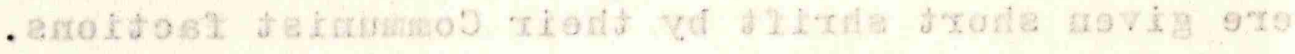

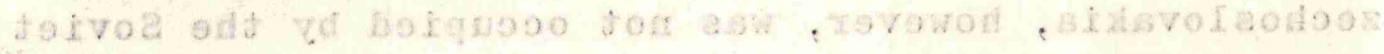

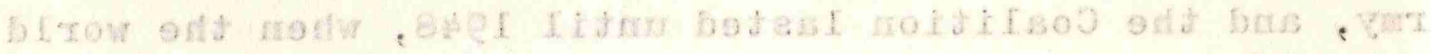

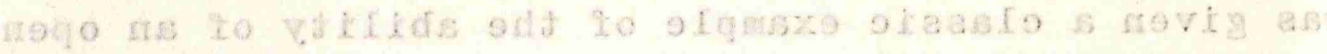

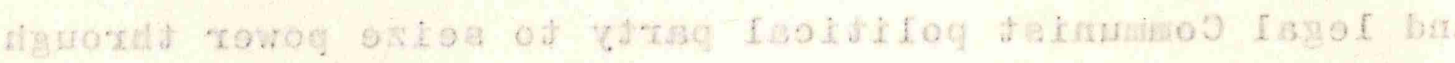

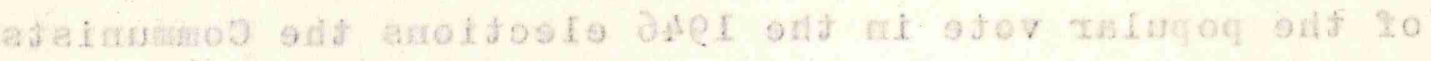

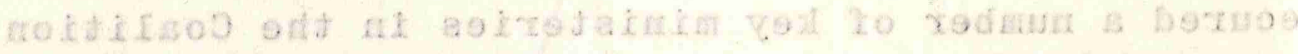

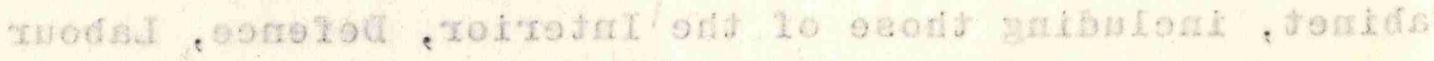


Education and Information. Before long they also had the Premiership, though they held only 9 of the 26 Cabinet posts. 10 By clever and ruthless exploitation of the power of the Ministries; they held, particularly the control of the Police, they manoeuvred 12 anti-Communist ministers into resigning on the tacit understanding that President Benes would ask them to resume their ministriesi. The Party then intimidated the President into replacing them instead with 12 pro-Communists, thereby giving the Communists control of the Cabinet. 11 With any other Party, such control might have been temporary, but the Communists at once disarmed the Constitutional machinery for political change, and have held power ever since. An attempt to liberalize the Party from within was ruthlessly suppressed by a Soviet Army invasion in 1968.

The intimidation of President Benes and of the general public into acquiesence was greatly helped by the Front Organisations, especially the Labour Organisation, and by the Information Services, which created a terrifying prospect of chaos and violence. These organisations were, however, already operating quite openly under Communist control, since there was no need for them to use false colours.

This demonstration of the final stages of a Russianpattern urban takeover gave encouragement to other Communist parties, but was probably more significant in the long run in alerting anti-Communists to this particular Communist technique.

There are many advantages for a Communist Party in having legal status and operating within the nation's constitutional system. Its more respectable image helps it to attract broadlybased support. 


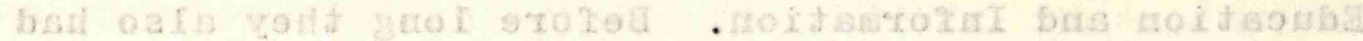

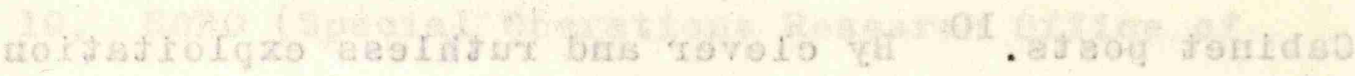

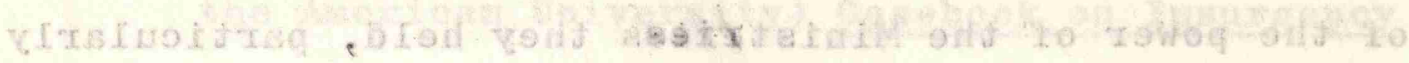

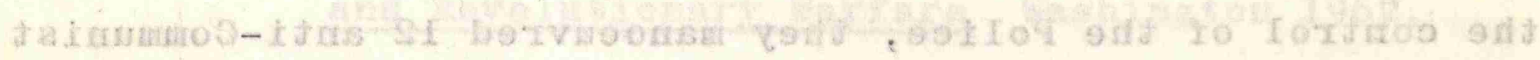

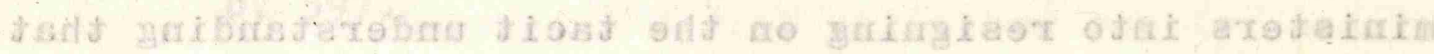

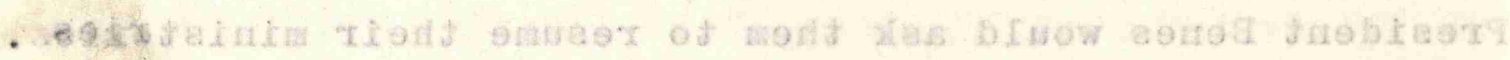

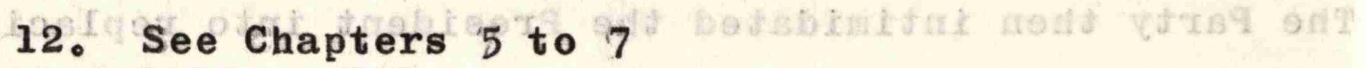

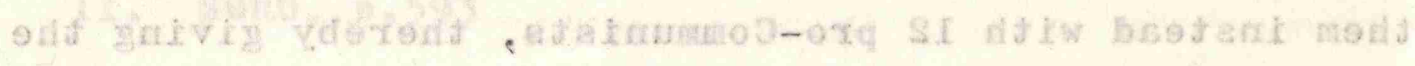

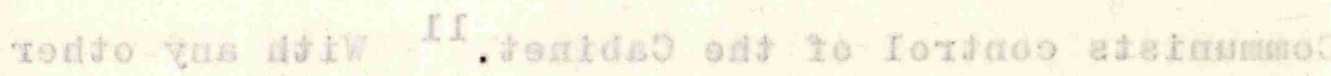

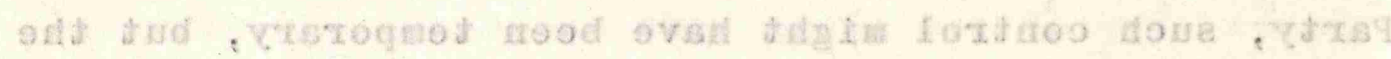

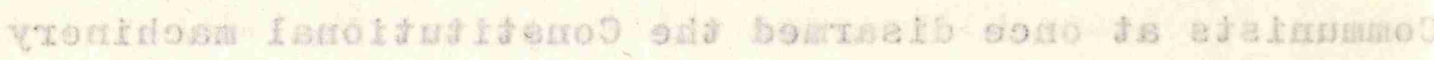

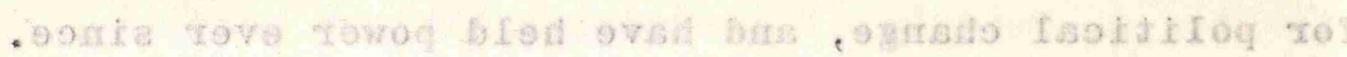

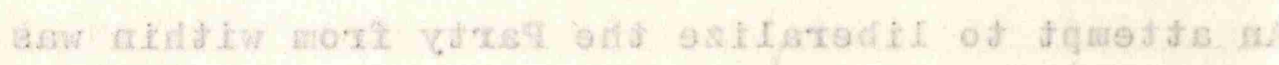

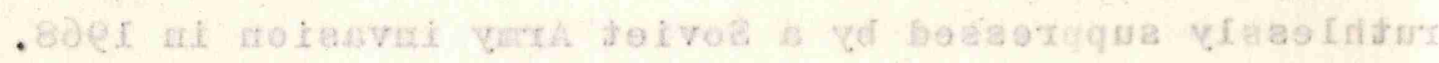

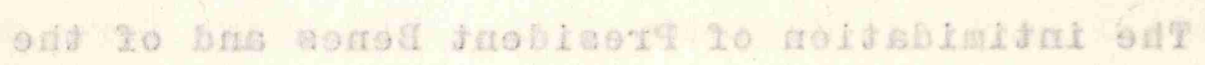

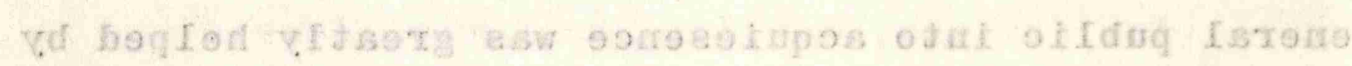

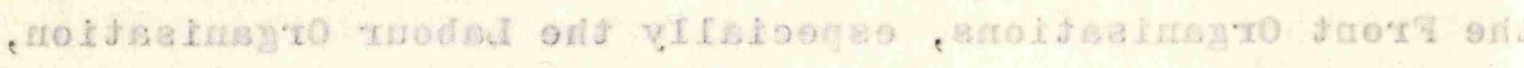

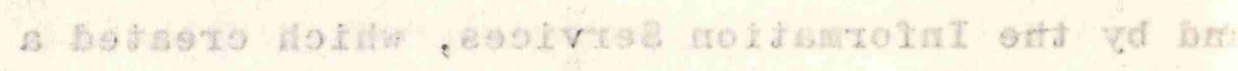

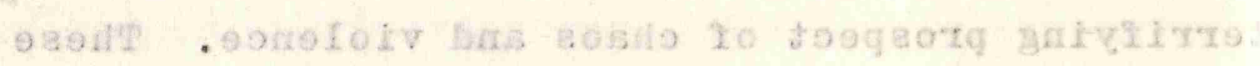

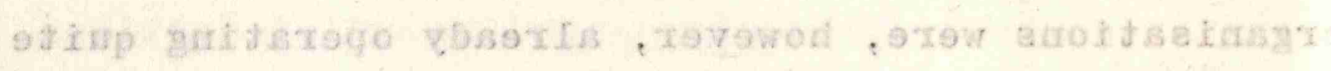

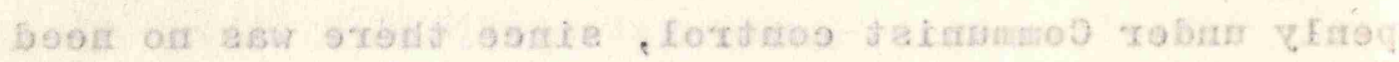
- atroloo gelsi sam od mant zo

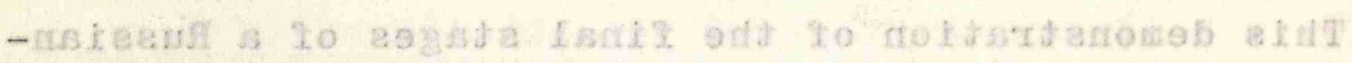

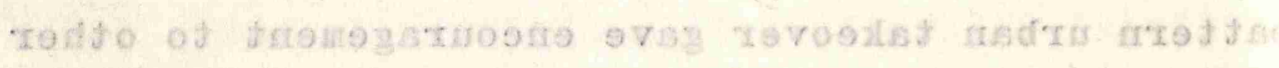

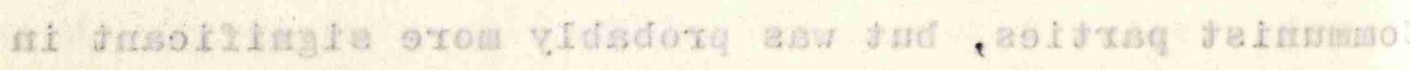

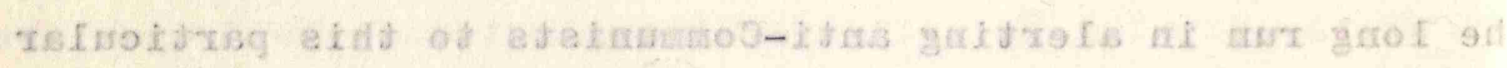

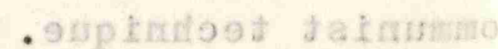

\section{C. C. Too (Gov,) Interview 1968}

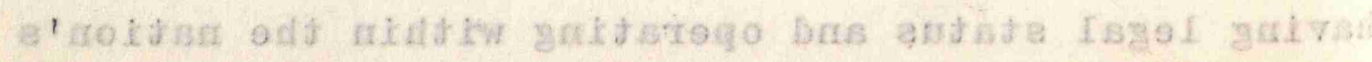

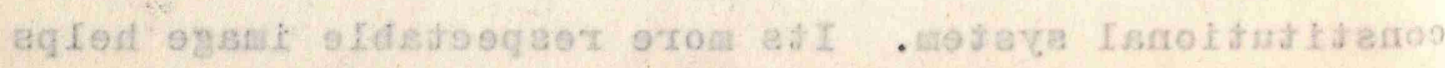


and should result in less shock and reaction if and when it gains power. Meanwhile, the Party has a better platform for propaganda. But there are disadvantages. Although the members of the Open Political Party are in theory quite separate from the secret Party structure, some contact, even though indirect (i.e. thlough couriers and cut-off men) is inevitable. This gives the Police Special Branch more chances of detection and penetration. This also applies if, as happened later in Singapore, 12 the Open Political Party operates under a transparently false name. And if the Party (whether under its own or some other name) is declared illegal, it is difficult for men who have become well-known publicly as politicians to disappear underground. The Party's dilemma is to pick men good enough to attract public support and to govern if power is gained by "constitutional" means but whom it can also afford to lose. Even in states where the Communists have gained full power, the tradition persists that ministers and officials of the government remain subservient to the parallel hierarchy of the Communist Party structure.

Liew Yit Fan and Lau Yew were both, in fact, men of considerable ability, and their "expendability" was presumably partly because both had become well-known to the British. Lau Yew was one of the Party's foremost strategists and military organisers, and had led the MPAJA contingent in the Victory Parade in London. Liew Yit Fan was a Eurasian who looked more European than Chinese - had great charm, and could easily be envisaged emerging as a constitutional prime minister. ${ }^{13}$ 


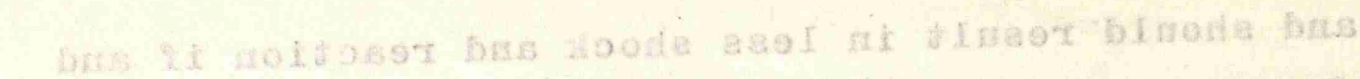
24 is

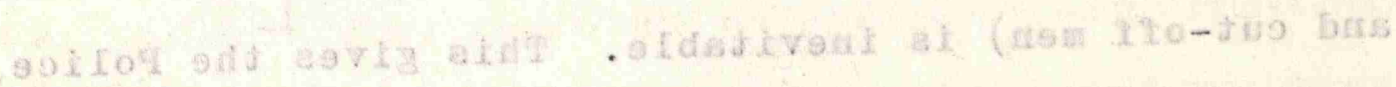

14. Harry Miller, Menace in Malaya, London, 1954, p.94

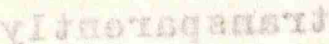

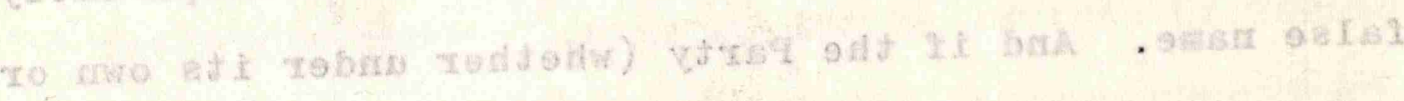

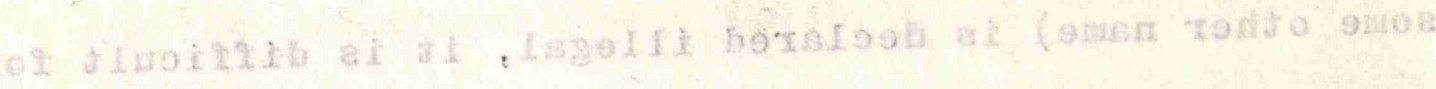

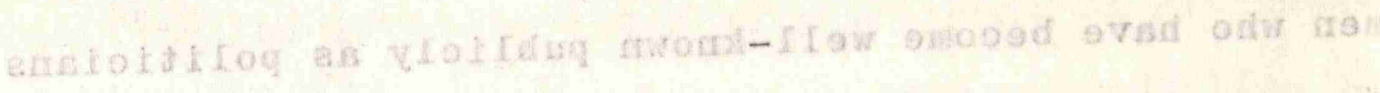
Q d. at sumetib at

15. Pye, p.194

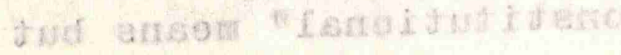

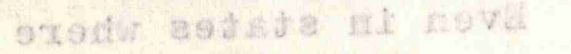

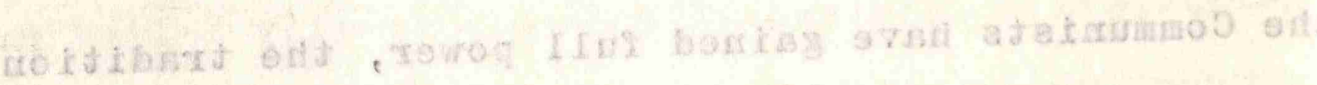

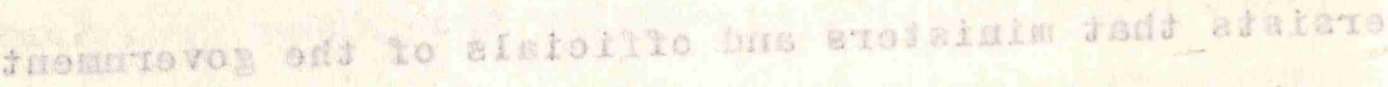

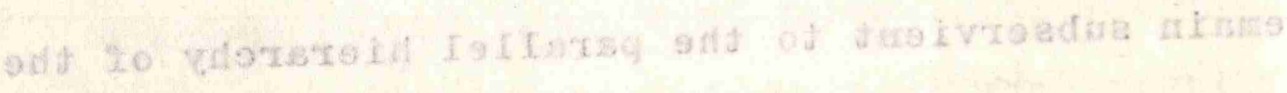

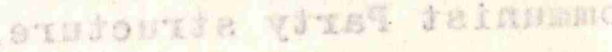

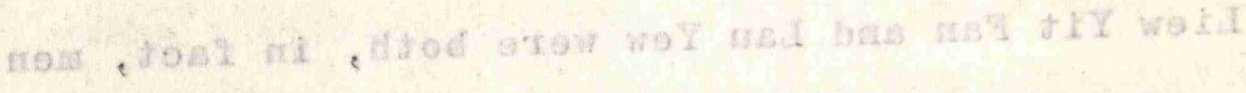

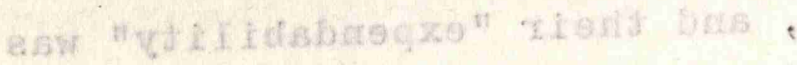

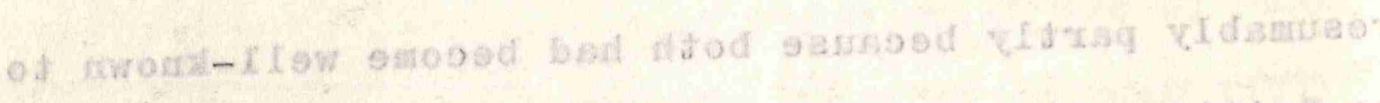

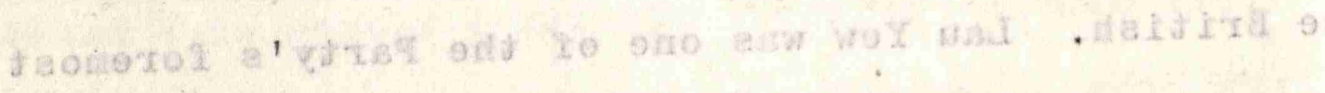

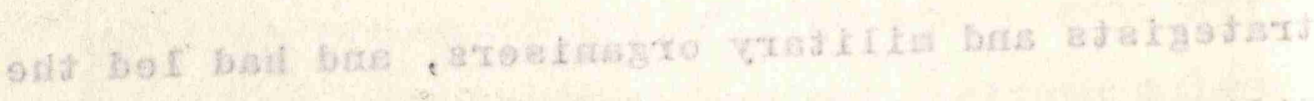

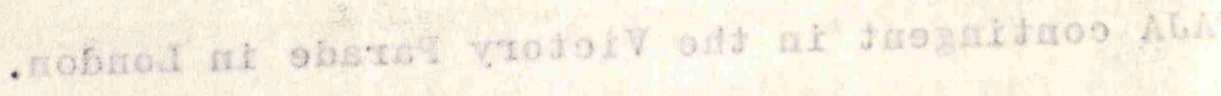

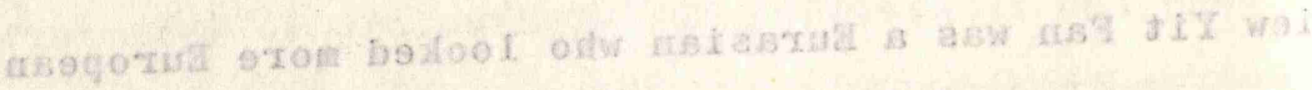

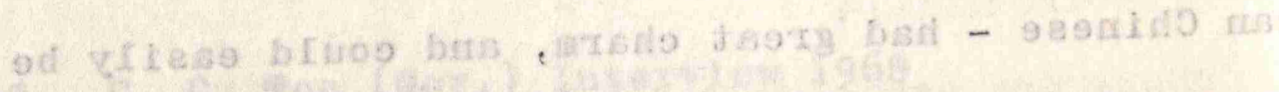

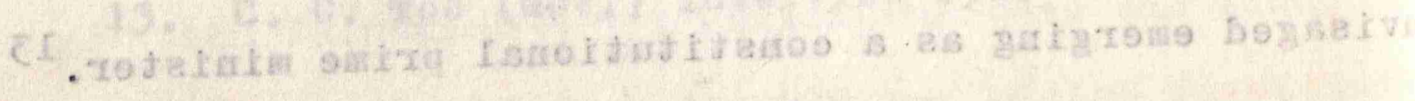


In the event, Liew Yit Fan was arrested on 9th June, 1948, just before the State of Emergency was declared, and later deported to China. Lau Yew went underground and was the first major Communist casualty of the Emergency, being killed on the 16th July, 1948 in a raid by the police (acting on a tip-off) on a hut in the country in which he had set up his military headquarters. 14

During their 3 years as open political leaders they had had few of the opportunities enjoyed by the Party in Czechoslovakia. The reimposition of British Colonial Government meant that there were no ministeries within their grasp. Also, their Front Organisations were not difficult to recognise as Communist, ${ }^{15}$ and it was possible for the Government to frustrate their activities by legislation before they could get the situation out of control.

\section{The British Military Administration}

During the Japanese occupation, the British had not maintained a Government-in-exile for Malaya as they did for Burma. Late in 1943, however, they did form a Malayan Planning Unit, which included-Sir Edward Gent, a Colonial office civil servant who was to become Malaya's first post-war High Commissioner. It was decided that in place of the pre-war mixture of Federated and Unfederated Malay States, a Malayan Union should be formed, in which the immigrant races (mainly Chinese and Indian) would be granted similar citizenship rights to those enjoyed by the Malays, provided that they were born or ordinarily resident in Malaya. 
16. V. Purcell, "Malayan Politics" in Politics in

Southern Asia (Ed. Saul Rose) London 1963.

Mr. Purcell was a member of the Malayan Planning

Unit.

17. G. G. Thomson para. 5

18. For a description of this, see F.S.V. Donnison, British Military Administration in. South East Asia, 1943-46, London 1956, Chapters IX and XX. 
The majority of the Unit also recommended that Singapore should be included in the Union but the Government decided that it should remain separate. 16

The Malayan Union was to have a short, unhappy life from 1946 until 1948. This coincided with the attempted urban revolution which is described hereafter in this chapter, but had little effect on the attitude of the predominantly Chinese population in this attempt except in providing one more issue of dissatisfaction which the MCP could exploit. 17 It did, however, have a disturbing effect on the Malay population, and on Malay government officials, soldiers and policemen, which greatly strained their loyalty to the British, whom they had trusted to defend their rights against the alien Chinese and Indianswhom they (the British) had brought into their country.

For the first 6 months of reoccupation, the Malayan Union was still only a paper plan in London, and the Malay states and Singapore were all under a British Military Administration (BMA) ${ }^{18}$ responsible to the Commander-in-Chief South East Asia Command, Admiral Lord Mountbatten.

The first urban trial of strength was not long in coming, and started not in Singapore but in Kuala Lumpur. On the 29th October, 1945 the General Secretary of the Selangor MPAJU - Soong Kwong - was arrested on a charge of extortion. He was accused of having threatened a Chinese victim and his family with death unless they wrote a promissory note for $\$ 300,000$ as compensation for alleged collaboration with the Japanese. A British 
19. Donnison, p.389

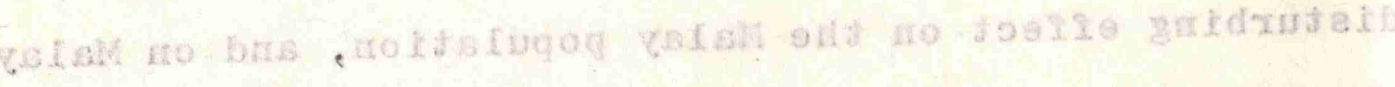

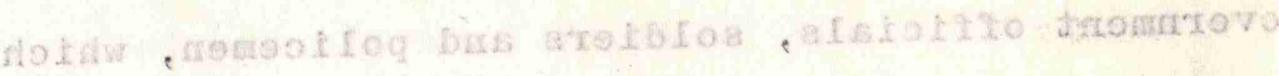

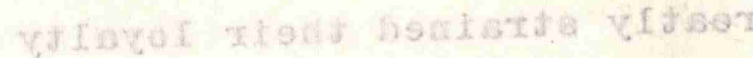

20. Donnison, p. 390. Very few of these 3,500 , however, were Party Members - see Chapter 4.

21. Miller, p.62

22. Straits Times, 5th February, 1946

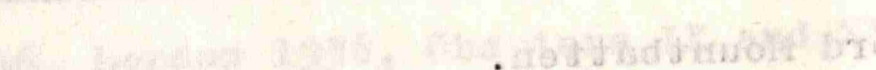

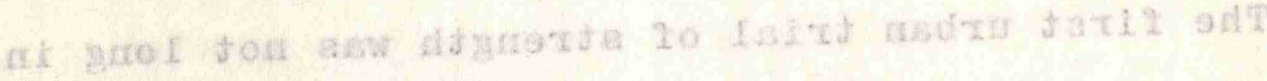

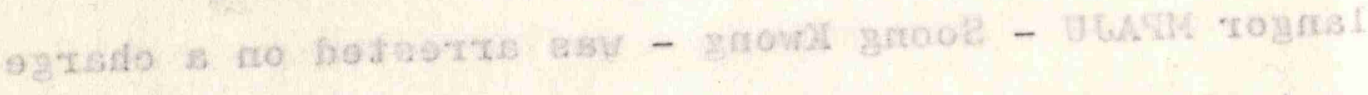

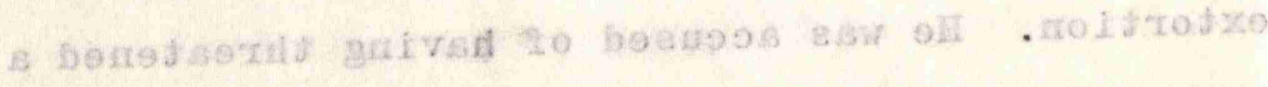

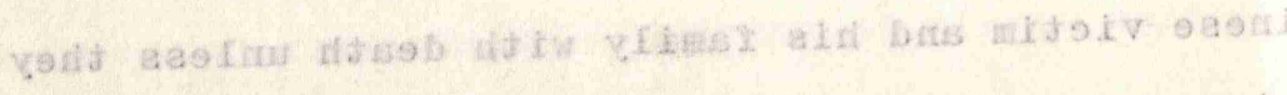

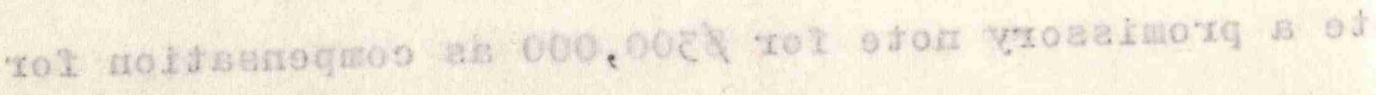

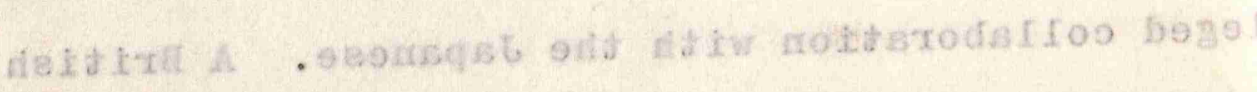


judge presided over the court, with two Malayan assessors. There was a split verdict, the judge finding for conviction and the two assessors for acquittal. A second trial had the same result, and it was deemed that the assessors were intimidated. On 3rd January, 1946, at a third trial (this time all-British) the accused was found guilty and sentenced to 4 years imprisonment 19

There were immediate petitions for his release, and a threat of a general strike. Meanwhile the sentence was reviewed, and it was decided to release the prisoner, but to withhold the announcement of the decision lest it be interpreted as bowing to threats.

On 29th January, the strike began. Over 150,000 took part in Singapore alone, but the great majority did so unwillingly, under intimidation from a well organised cadre of $3,500.20$.

The strike was called off on 30 th January, probably because of the fear of banishment of the leaders, but it had given an awesome warning of the strength and organising capability of the MCP. 21

On 3rd February, the review of Soong Kwong's sentence was published, 22 and he was released on sureties.

The General Labour Union (GLU) thereupon applied for a Public Holiday on 15th February, 1946, avowedly to commemorate the day the MCP had "taken over" in 1943 after the British defeat, 23 but it was blatantly obvious that the real intention was to rejoice over the anniversary of the British defeat on 15th February, 1942. 
24. Donnison, p.392

25. Donnison, pp. $392-3$

26. A fortuitous and particularly dangerous situation arose over one of these - Lim Ah Liang - who was shot and slightly wounded before his arrest. He was named for deportation, and ipnoculated to comply with Hong Kong transit regulations. Unfortunately, between ipnoculation and his sailing dates he fell ill from some quite unrelated cause and died. The MCP at once accused the government of poisoning him, and they marshalled a funeral procession several miles long which became a demonstration to whip up feeling against the police. Blades, para. 7 . 
The Military Government declined to grant a public holiday, commenting that it would be better to hold such a celebration in August, the date of the Japanese defeat. 24

on 13th February, the Government published a warning against applying pressure with a view to using the strike weapon to interfere with the course of law, to endanger the peaceful living of the population by "extortion, intimidation or other illegal means", adding that persons so doing would be "arrested and prosecuted and, if aliens, may in addition be repatriated ...." 25

This was a clear threat that the government intended to use its power of deportation to China, which was greatly feared, since any Chinese accused of Communist activities could expect little mercy from the Kuomintang.

On the morning of 14th February, all Chinese-language newspapers called upon the public to demonstrate. The crowds, armed with sticks, bottles and crowbars, became violent. The police opened fire, killing two and wounding a number of others, including one of the leaders. On the night 14th/15th February, there were a number of arrests, and 9 were named for deportation. 26

The $c-i n-C$, however, refused to approve the deportation orders, on the grounds that the accused had had only 36 hours to heed the warning, and that there had been no judicial proceedings against them.

The case was deferred until the civil government took over one month later. The 9 accused, plus one more, were then deported without legal proceedings and without fuss. It was ruled that the expulsion order was valid provided 
ora

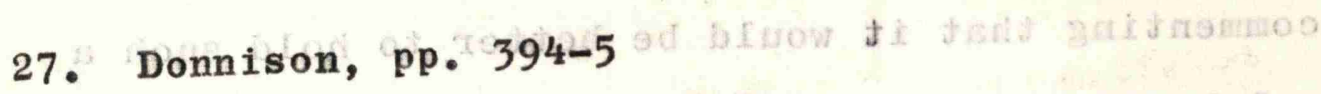

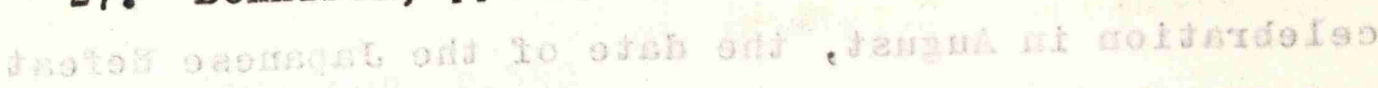

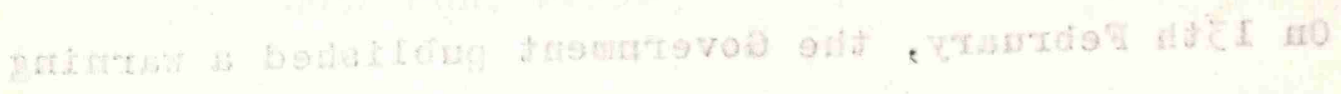

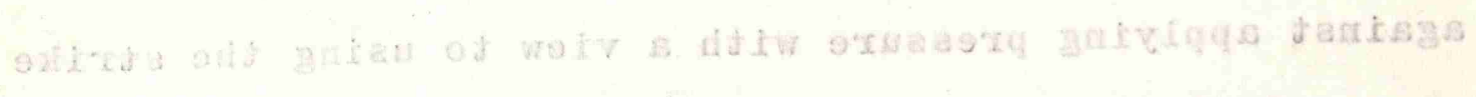

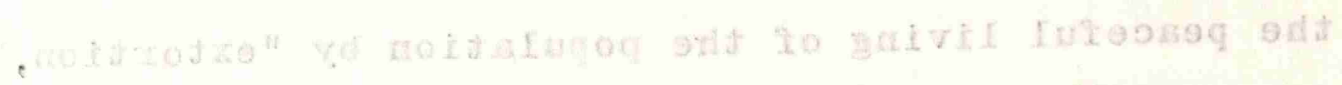

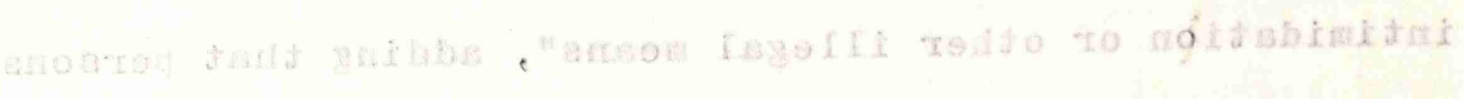

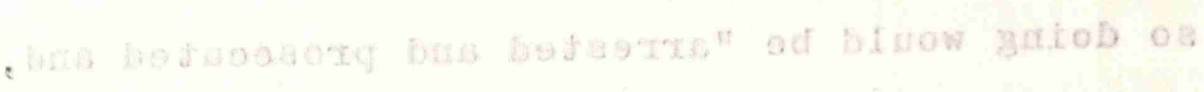

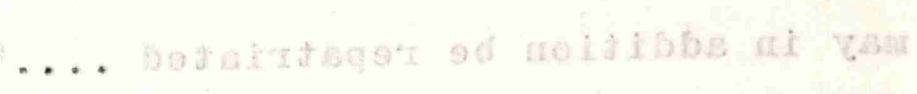

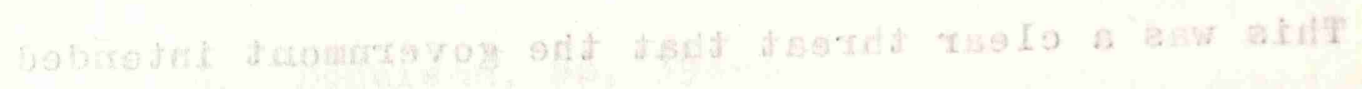

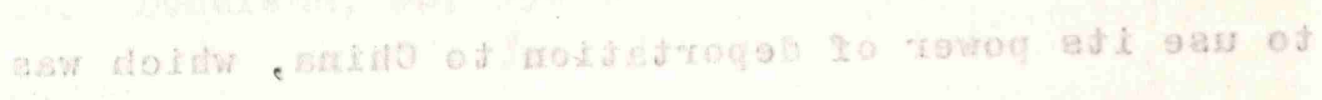

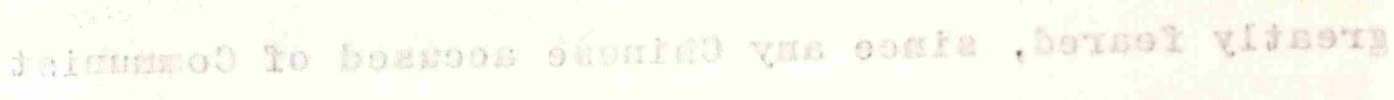

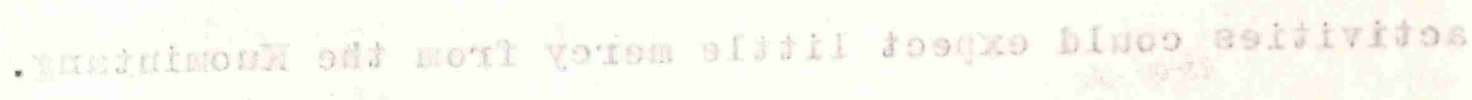

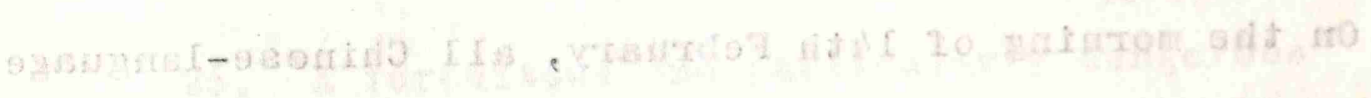

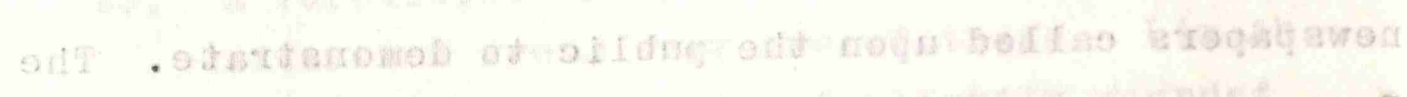

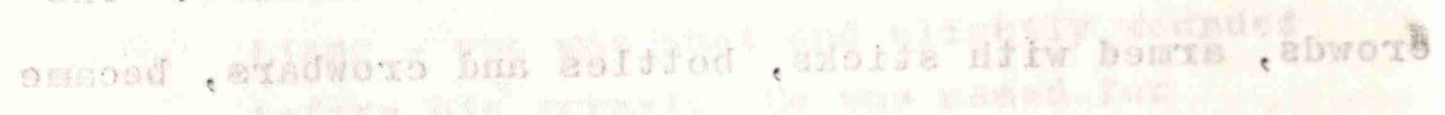

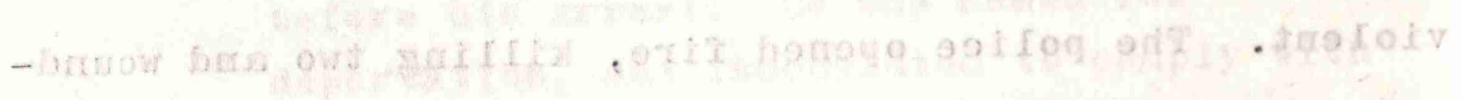

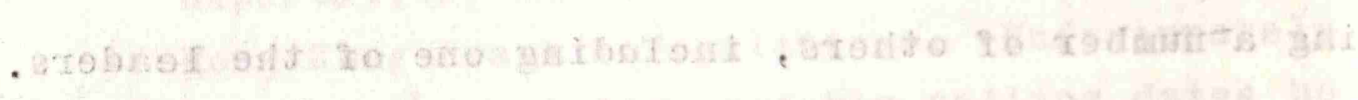

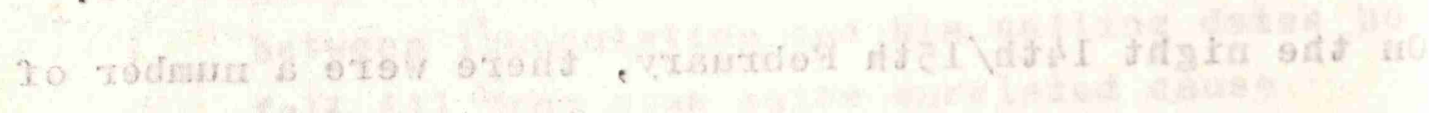
as.

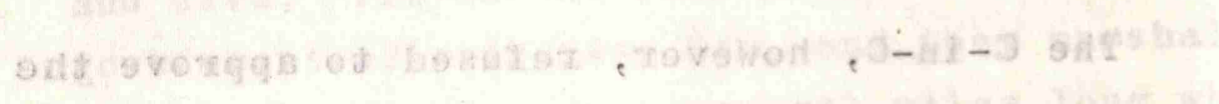

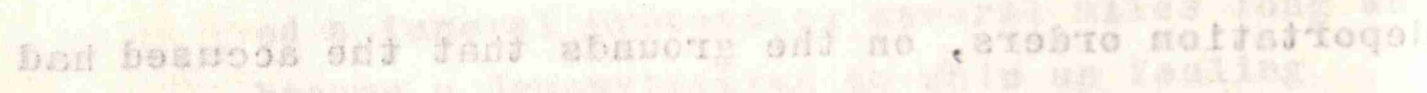

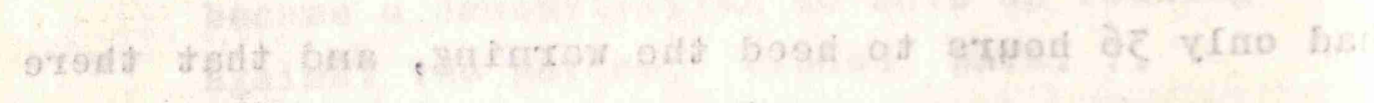
28. Blades, paras. 2 and $3 . \quad$ f lotibut od no pd ban

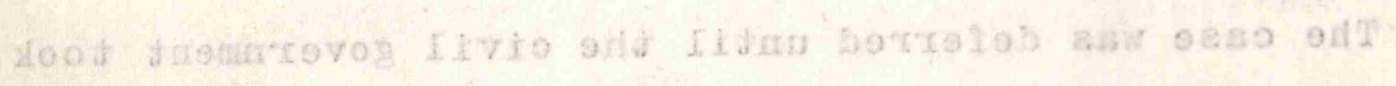

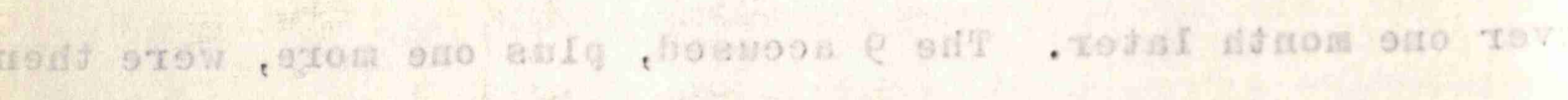

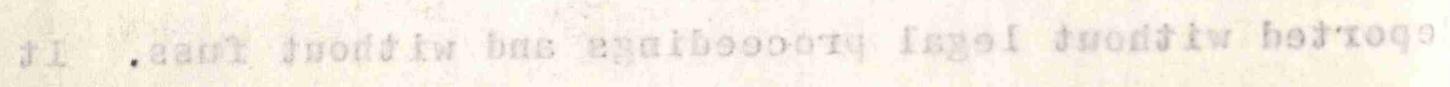

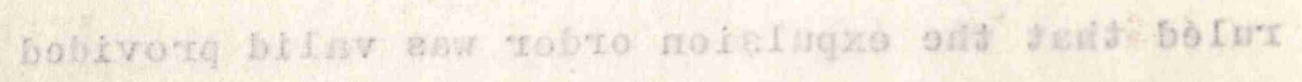


that it was in the public interest, and could be based on evidence of past behaviour (i.e. before the warning). 27 Though somewhat harsh, this was a realistic decision in the circumstances since judicial proceedings would clearly have been impracticable on account of intimidation of witnesses.

\section{"Peaceful Agitation"}

This was the kind of problem which was to plague Singapore and the Federation of Malaya for many years to come, and to some extent does so to this day - how far was it possible to maintain a liberal legal system, with the traditional safeguards of English law for the rights of the individual, in the face of an organised and widespread conspiracy to interfere with the processes of the law? Alan Blades commented in 1969 as follows:-

"There was, however, nothing unusual in banishment without judicial proceed- . ings. This had been the practice for many years before the war in dealing with all kinds of Secret Society pressure tactics, including especially the MCP, which defeated the process of justice through intimidation of witnesses ...... It is salutary to note that detention without trial in open court has been continued and greatly extended as independence has been approached and achieved, and is still in force in 1969." 28 
29. S. S. Awberry and F. W. Dalley, Labour and Trade Union Organisation in the Federation of Malaya and Singapore, Government Press, Kuala Lumpur, 1948, p.26.

30. The following are compiled from 1947 Census figures quoted by Awberry and Dalley (pp. 3 and 4)

$\begin{array}{llllll} & \frac{\text { Federation }}{4} & \text { Singapore } & \text { Total } \\ \text { Chinese } & 1882874(49 \%) & 728523(77 \%) & 2611397(45 \%) \\ \text { Malays... } & 2400441(39 \%) & 116583(12 \%) & 2517024(43 \%) \\ \text { 0thers } & 591923(12 \%) & 86638(11 \%) & 678561 & (12 \%)\end{array}$


A similar problem developed over the Trade Unions. The newly elected British Labour Government was reluctant to inhibit the revival of the Unions, but they were clearly being used by the MCP for purposes much wider than those of labour negotiations. The Party was fully prepared for the task of organising and controlling them. Industry, both urban and agricultural, was disorganised and unemployment was high. Labour tended to move freely, seeking work wherever a new rubber estate or tin mine was restored to operation. By re-establishing the General Labour Union (GLU) the Party was able to offer valuable introductions to itinerant workers. The GLU also incorporated many guilds and labour-contracting gangs, and attracted numerous individual workers, such as trishaw riders, barbers and cabaret girls, 29

The Party was well placed and well prepared to assume the leadership of the whole Chinese community which, in Singapore and the Federation of Malaya added together, was the biggest single racial community, having $45 \%$ of the total compared with $43 \%$ Malays. 30 (The Malays had the majority in the Federation and the Chinese in Singapore.)

In addition to its labour and other activities, the Party sponsored numerous schools. Though most of these were only small elementary schools, they offered Chinese children an opportunity for education to which until the pre-war educational system had been re-established, there was often no alternative. These schools improved the party image, provided a splendid 
31. Pye, p.74

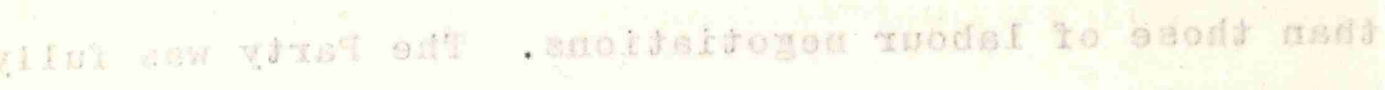

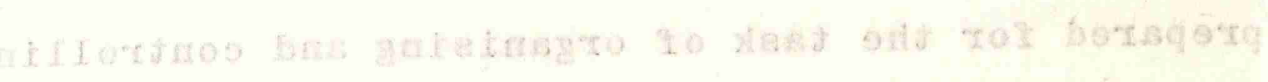

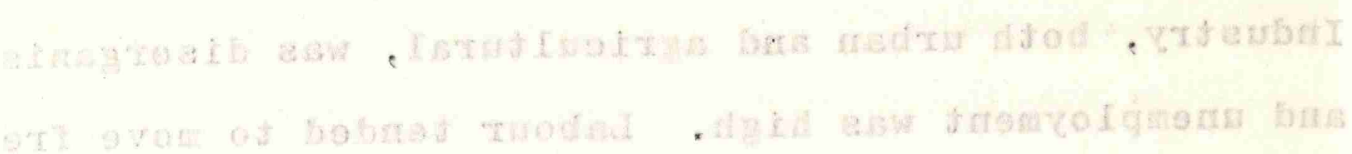

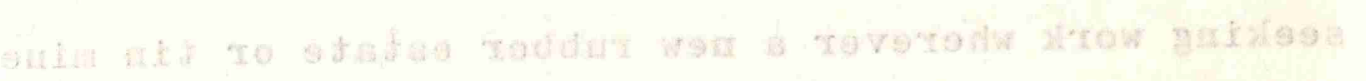

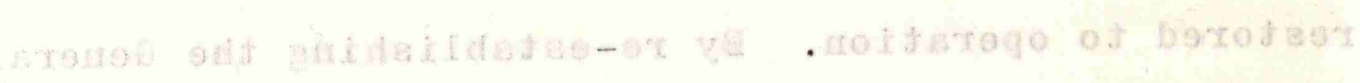

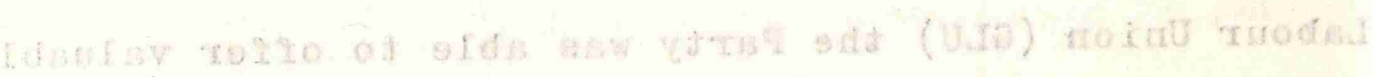

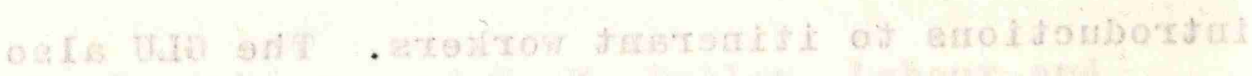

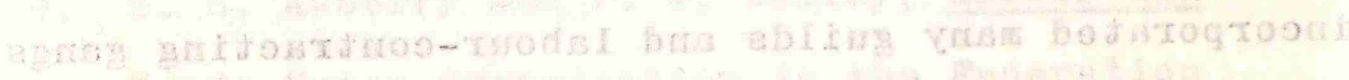

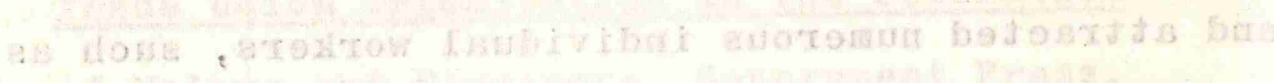

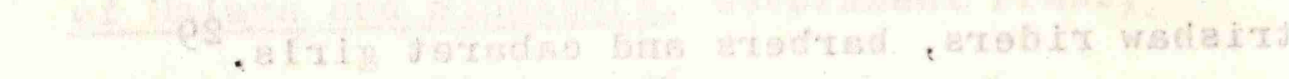

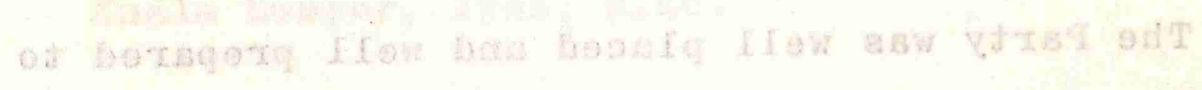

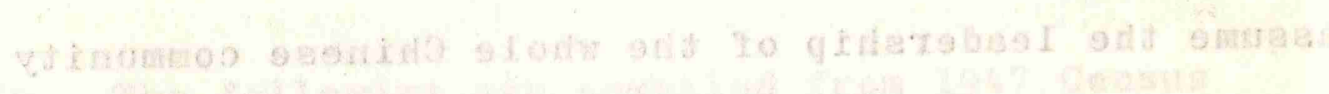

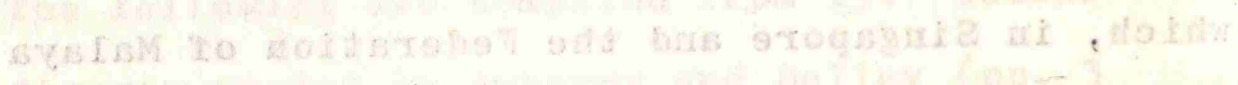

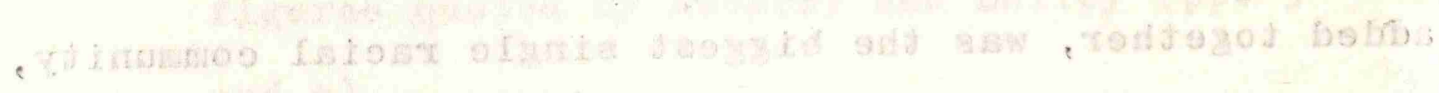

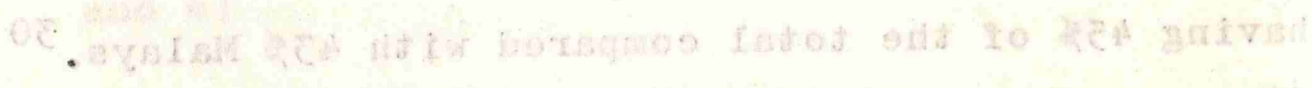

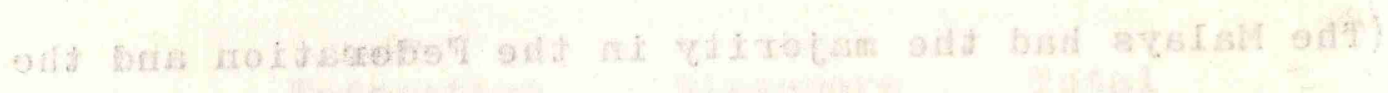

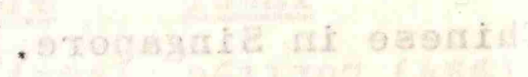

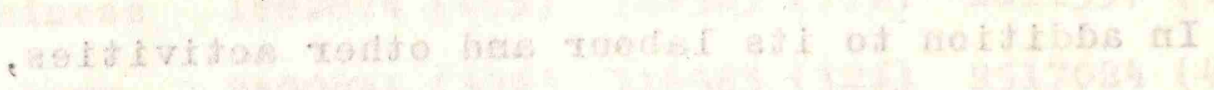

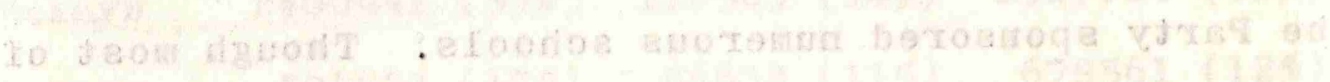

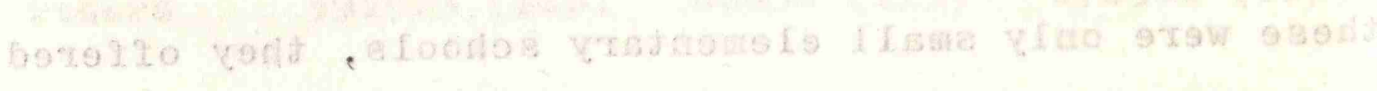

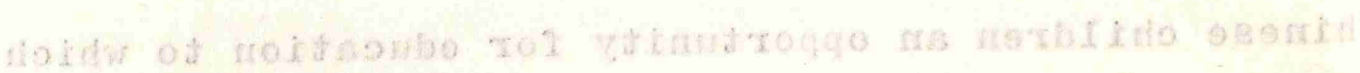

\section{Pye, p.76}

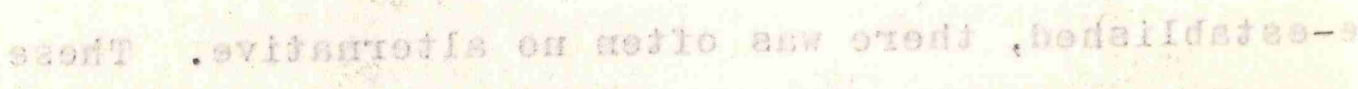

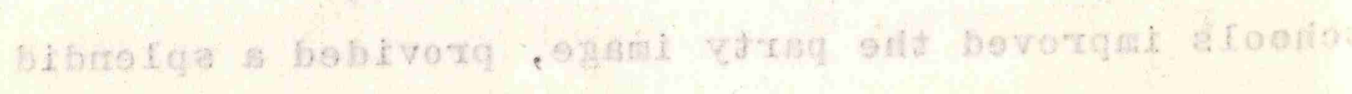


opportunity to influence the young Chinese, and gave employment for Party Members. 31

This last is a point often overlooked by Europeans. Like most Asian Communist Parties, the MCP had expected many of its members to be full-time Party workers, and in the post-war period there were particularly good opportunities for this, not only in the legal party organisation, but in unions, front groups and schools; also in running Communist-sponsored business enterprises such as book-stores, coffee shops and small general stores. The Party membership in the Federation and Singapore was nearly 3000 (as high as it was ever to be throughout the Emergency - remembering that no more than a minority of guerrillas or supporters ever became Party members), and their activities enabled the Party to meet its budgetary needs. By controlling the income of most of its members, the Party was also able to maintain discipline. Indeed, it discouraged its members from finding outside employment.

It soon became clear that the activities of the GLU were too wide to be adjusted to the registration requirements of the Trade Union Ordinances, particularly as the governments of Singapore and the Federation of Malaya were separate. The Party desired at this time that its open activities should have legal status, so the GLU split into two Federations - the Singapore Federation of Trade Unions. (SFTU) and the Pan-Malayan Federation of Trade Unions (PMFTU) both of which were duly registered with their respective governments. 32 
34. See Chapter 1 for an assessment of the theory that Lai Tek was a British agent. It may appear that he was allowed to go too far to be consistent with this theory, but it is worth remembering that the two most notorious police agents in pre-revolutionary Russia - Azev and Malinovsky - were both allowed to go a great deal further than this. In $1904 \mathrm{Azev}$, as head of the Fighting Section of the Social Revolutionary Party, planned and connived in the assassination of his own employer Plehve, the Minister of the Interior. Nevertheless, he continued thereafter as a trusted and highly paid Police agent. Even the Revolutionaries themselves may have been aware of his Police activities and content to accept the risk of betrayal in the belief that they were getting greater dividends from their access through him to Police secrets. Both sides probably regarded him confidently as "their man", and Azev no doubt released to each side only such details of his real activities as would encourage this view. It is significant that, when the Bolsheviks attained access to Police files in 1917, they showed little determination in tracking down agents, presumably because their disclosures might have embarrassed many leading Bolsheviks. Malinovsky returned voluntarily to Russia in 1918, and seems to have been surprised to find himself tried and condemned to death. Lenin's behaviour during his trial suggests that he himself must have been aware of Malinovsky's double game all the time, and he seems to have had a grave struggle with his conscience over approving his execution. See Alan Moorehead, The Russian Revolution, New York (Bantam Books).1959, p.88, and Bertram Wolfe, Three Who Made a Revolution, Boston (Beacon Press) 1955, pp. 266, 479 and 535-557.

35. "Police Socialism" dates back to 1901, in Russia. Its psychology was well expressed by the Chief of the Moscow police at the time: "In order to disarm the agitators, it is necessary to open and point out to the worker a legal solution to his difficulty, for we must bear in mind that the agitator will be followed by the youngest and boldest of the crowd, while the average worker will prefer the less spectacular and quiet legal way. Thus split up, the crowd will lose its power". See Moorehead, p.53. 
They made little secret of their Communist affiliation. Indeed, in Singapore, the SFTU played a more prominent part in running Communist affairs than the Open Party organisation. 33

Their preoccupation with legality, and the desire to attain power by constitutional means - or by nothing more violent than "peaceful agitation" - was a dominating factor in the activities of the MCP during 1946. This is by no means inconsistent with the fact that the Secretary-General, Lai Tek, was (or had been) almost certainly a British Agent. This fact would only have been known to a very small number of Police Special Branch officers and senior government officials, and it would have been normal intelligence practice for them to allow him full rein to organise as much "peaceful agitation" as was necessary to maintain the credibility of his position as Secretary General. 34 Indeed, in the post-war period, some may have been content that he, as a moderate, should lead the MCP into respectable participation in the political life and even the government of the country, rather than have the Party led by a firebrand into its more normal revolutionary opposition. 35

Fong Feng, one of Mao Tse-Tung's Central Committee, may well have been influenced by hopes of British gullibility when, at a meeting in Hong Kong in 1946 he advised Lai Tek not to embark on armed insurrection, but to organise a United Front and work for selfgovernment by constitutional means. 36 
37. Pye; .80 . It is interesting that precisely the same comments arose in Hong Kong in 1967. When there is no need for them to operate underground, Communist Party leaders seem to betray normal bourgeois frailties, claiming that a position of social respectability for them is an asset to the Party.

38. Blades, para. 4 


\section{A Change of Leader}

Nevertheless, Lai Tek did not last for much longer. Within the MCP there was growing dissatisfaction with progress. Although the Party was confident in early 1947 that it had achieved control of labour, this power did not seem to be used to much effect. In the face of economic recovery and social progress in Malaya, the MCP appeared to be losing its position of leading the people towards a better life. Moreover, the rank and file were complaining that too much of the Party's income was going into providing Western-style homes, cars, and other bourgeois comforts for its open leaders, 37

Lai Tek's treacherous dealings with the Japanese, moreover, were now proven beyond doubt in the eyes of the Central Committee. Once his Japanese protection had been removed, and communication between the city and the rural areas had become free, he was bound to be found out. His remaining unexposed for so long is a testimony to his cleverness, and to the legendary reputation he had built up in $1943-45$ amongst the guerrillas - most of whom had never seen him. The problem facing the Central Committee in 1947 was how to expose and dispose of him without doing irreparable damage to party morale. The Party document which finally set out his misdeeds had to be most clearly and convincingly stated as its authors obviously feared that it might be impossible to believe. $38^{\circ}$ 
39. Miller, p.64

40. Miller, p.74

41. Trade Union Registry: Annual Report, 1948

Government Press, Kuala Lumpur, 1948, p.2

Also Charles Gamba, The origins of Trade

Unionism in Malaya, Eastern Universities Press, Singapore 1962, p.155

42. Blades, para. 5 


\section{(}

It was hoped initially, however, not to raise the dangerous issue of his treachery at all, but to oust him on grounds of inefficiency. At a meeting of the Central Committee in February 1947, his leadership was openly attacked. The meeting broke into uproar, and was adjourned until 6th March. Lai Tek never reappeared and was found later to have decamped with the bulk of the Party's funds. 39

Chin Peng was unanimously elected as the new Secretary General, and wasted no time in responding to the desire of the Party for more militant action. 1947 has been described as "The Year of Strikes". There were no less than 300 major strikes involving the loss of 696,036 working days. 40

These strikes continued, with growing use of violence, through into 1948, under the open and militant leadership of the PMFTU and SFTU. Of the 289 Unions in the Federation, only 86 were fully independent. Another 86 were of doubtful allegiance and the other 117 were federated in the PMFTU. 41

Similar domination had been achieved in Singapore by undisguised violence and intimidation. For example, the Singapore Harbour Board Employees Union (SHBEU), an unfederated Union, had in May 1946 successfully negotiated a $20 \%$ wage increase for its men. This kind of success by an unfederated Union was not acceptable to the MCP and feelings ran particularly high because the Kuomintang was behind the SHBEU. ${ }^{42}$ The president of the SHBEU was repeatedly beaten up until in september 1946 he was driven out of Singapore. On 25th 0ctober 
43. Awberry and Dalley, pp. $65-66$

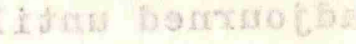

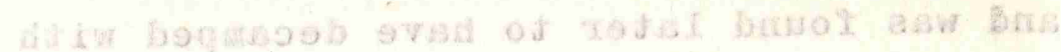

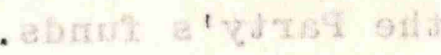

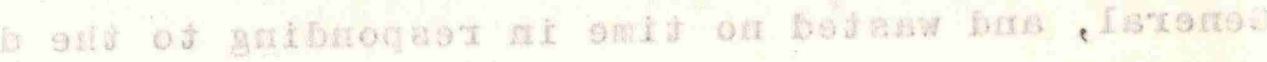

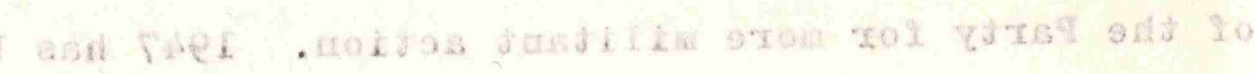

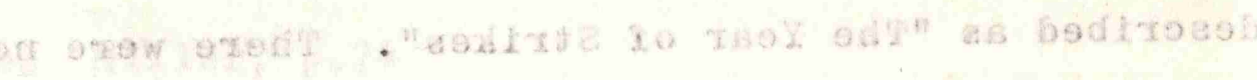

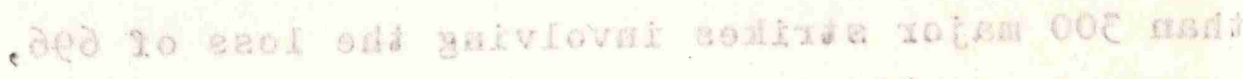

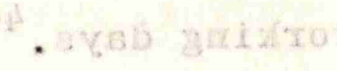

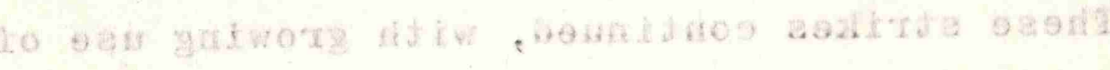

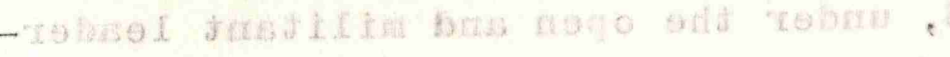

44. Straits Times, 28th Apri1, 1948

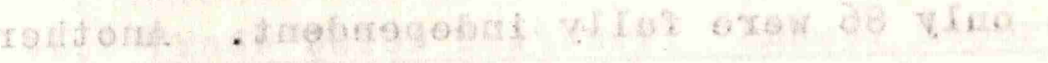

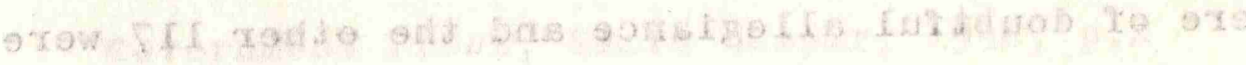
$f_{14}^{4}$

45. Straits Times, 24th April, 1948

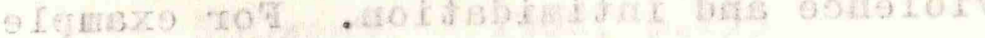

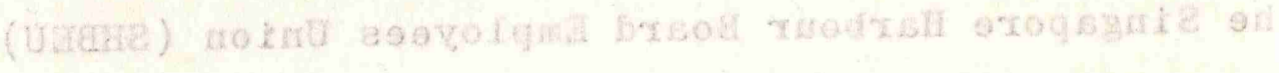

46. G.G. Thomson (Gov.) - Interview 1968.

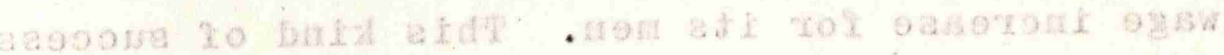

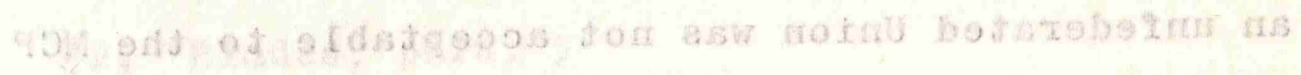

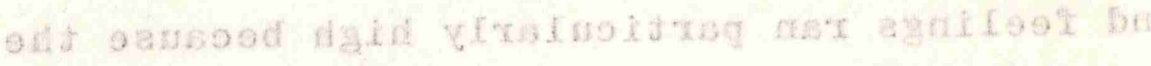

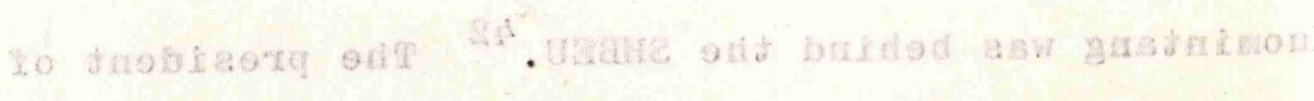


harbour workers were kept out by pickets while the SHBEU offices were destroyed. An unregistered Communistrun body calling itself the Singapore Harbour Labourers Union (SHLU) announced that it had taken over from the SHBEU, which in fact remained out of action until late in 1947. In January 1948, the SHBEU reappeared and, with another unfederated Union, opposed a strike called by the SHLU, and intially succeeded in pexsuading 30-40\% of the total labour force to continue, work for the first night shift. Next day, however, they too, were intimidated into stopping work. 43

The SHLU was again prominent when the SFTU called a general strike on 23rd-24th April, 1948. A police raid on their premises uncovered documents concerning a "Singapore Workers Protection Corps", which gave clear evidence of the use of threats to intimidate people who did not support their activities. Four men were arrested, and at their trial one of these was reprimanded by the judge for giving the clenched fist salute to his supporters in court. 44

Immediately after the General Strike, in which they claimed that 52,000 had participated, the SFTU planned a May Day rally of 100,000, to be followed by a march in procession 5 miles long. 45 , The SFTU demanded that they, and not the police, should be responsible for controlling this procession. Had the government agreed to this, it would have been interpreted as a sign of weakness. 46 The Police, however, while agreeing to the rally, forbade the procession on grounds of interference with traffic. 
47. Straits Times, 29th April, 1948

48. Straits Times, 30th April, 1948

49. G.G. Thoms on (Gov.) Interview 1968. Thomson considers that the SFTU blundered in failing to accept the ban on the procession and to go ahead with the rally only. In the event, a procession would inevitably have formed as the people left the rally. If it had been peaceful, it would have been the demonstration of strength that they wished. If, on the other hand, the police had intervened and violence had ensued it would have given the MCP a propaganda victory in their. policy of a crescendo of opposition and confrontation. The MCP would therefore have gained either way. Thomson thinks that the failure of the 1948 May Day demonstration provoked the MCP to trigger off the violence in the rural areas prematurely, thereby launching into guerrilia warfare before they were ready. G. G. Thomson, para. 6

50. John Davis (Gov.) Interview 1966

51. Miller, p.77

52. Awberry and Dalley, p.26. This had recently been restricted by the government to $10 \%$. 
The SFTU announced that they would defy the ban on the procession, and the government thereupon banned the rally as well, making it clear that this ban would be enforced by the, police, if necessary supported by troops. 47 Next day, the SFTU decided to call off the entire demonstration. 48

There was no doubt that the majority of the people of Singapore were relieved that the Government's firmness had averted a violent demonstration. There was little sign of public resentment at the threatened use of troops, since the Communists had, as on every previous occasion in which there had been use or threat of use of troops, provided ample reason for expecting a breach of the peace, and the people were getting tired of it. 49

The people were also getting tired of the constant interruption of their livelihood by strikes, and with the intimidation of those who failed to support these strikes. They had few financial reserves, and cared more about earning a reasonable living than they did about the wider social and political issues. 50 The Unions, too, were themselves becoming exasperated with the dictatorial attitude of the two Communist Federations, 51 who had demanded that $20 \%$ of the Union contributions be paid into their funds. 52

\section{The Government Reacts}

In June 1948, the Government felt confident enough of these sentiments to introduce some fairly drastic legislation to curb the Communist penetration and manipulation of the Trade Unions. First, no-one was permitted to hold office in a Trade Union, except as Secretary, unless he had had at least three years 
53. Trade Union Registry: Annual Report, 1948

Government Press, Kuala Lumpur, 1949, quoting the Trade Union (Amendments) Ordinance 1948 published on 12th June, 1948, and the Trade Union (Amendments No.2) Ordinance, 1948 published on 19th July, 1948, p.1

54. ibid p.2

55. Pye, pp. $83-84$

56. Douglas Hyde, in The Roots of Guerrilla Warfare, London, 1968, pp. 23-24, suggests that "the delegates from the South-East Asian countries returned home knowing that they had been given the go-ahead to get on with the job of making revolutions" and that, encouraged by Communist successes in China, they were influenced by Chinese experience, but that they still knew the Moscow line on revolution better than Mao Tse Tung's theories of guerrilla warfare. Ruth McVey, in The Calcutta Conférence and the South East Asian Uprisings, Cornell University, New York, 1958, suggests that the influence of the Calcutta conference may have been exaggerated, but both authors note that within a few months an armed struggle had broken out in Burma, Indochina, Malaya, Indonesia and the Philippines. 
experience in the industry or trade concerned. Secondly, anyone convicted of extortion, intimidation and like crimes was prohibited from holding office. Thirdly, no federation of trade unions could be registered except on an industry or occupation basis. 53 These measures, which were introduced only a few days before the declaration of the State of Emergency, proved effective and were accepted with equanimity by the bulk of the working population. Within two weeks, the officers of the two de-registered Federations had taken to the jungle, 54 to join the MPAJA - now renamed the Malayan Peoples Anti-British Army (MPABA) - which had already launched a growing wave of violence in the rural areas of the Federation. (see Chapter 9)

Peaceful agitation had failed. At a meeting of the Asia Youth Conference in Calcutta in February 1948, delegates from all Asian Communist Parties, including the MCP, had meanwhile been urged to seize power "by any means". 55 It is notable that within a few months, armed rebellions had broken out in Burma, Indochina, Malaya, Indonesia and the Philippines. While there were other powerful reasons for their doing so, the Calcutta conference no doubt played some part in prompting the MCP to remobilize the guerrilla army and to go over to the phase of the "armed struggle" in Malaya. 56

The effect of this mobilization was to switch the revolution firmly from the urban to the rural strategy. This rural campaign will be discussed in later chapters. The effect of the decision on Singapore was to reverse the change of 1945, and the Singapore Communist Town 
$2 x+0$

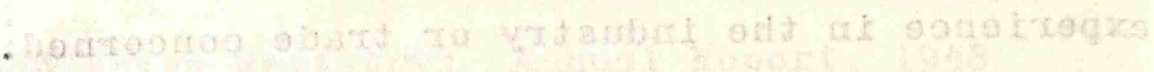

57. "Ah Truk" (Communist Party Town Committee

Secretary, Singapore, in 1948) - Interview, 1966. 
Committee, District and Branch organisation, which had been raised from 50 to $3-400$ in 1945-46, now fell again to about 100,57

This chapter has broadly described the sequence of events during the Communist attempt at an urban revolution in the period 1945-48. The next chapter describes the Communist Party's internal structure in Singapore, and the technique for activating the public which it used during this same period. 
1. Pye, p. 173

2. CC Too (Gov.) Interview 1967

3. "Seng" (Singapore Special Branch) Interview 1968 


\section{The Open and Secret Organisations of the Party}

The Singapore Town Committee of the MCP was responsible directly to the Central Committee of the Party, and ranked equally with any of the dozen or so State and Regional Committees in the Federation.

The Party Structure under the Town Committee was in line with the main Front Organisations - The Trade Unions, The Women's Organisations, The Democratic Youth League and the ex-MPAJA 01d Comrades Association. These provided a machinery for organising and activating working men, women and students - a comprehensive cover. All were open and legal, and not difficult to recognise as Communist - indeed, people joining them had little doubt about the source of their direction. ${ }^{1}$ The SFTU and PMFTU and the Unions they controlled again left no one in any doubt, by their militancy and their methods, that they were Communist organisations, but even they made perfunctory denials of this for the public record, presumably to avoid handing the government a ready-made reason which would be accepted by the public for banning them if the Party itself were banned. ${ }^{2}$

Paradoxically, the secret elements of the Party were far stronger in 1947, when the Party was legal and its front organisations militantly Communist in everything but name, than they were later when the Party was illegal. ${ }^{3}$ This is in fact more sensible than it looks at first sight. Like the leaders of the open political party (see Chapter 2), the semi-secret members were also vulnerable. For example, the legal Committees of the federated Trade Unions, and of the other front organisations, were heavily penetrated by Party members who held many of the key posts on the Committees often including that of Secretary. These Party Groups, as they were known, were supposed to conceal their Party Membership. Apart from 
4. Lee Kuan Yew, in The Battle for Merger, Singapore 1961, p. 18, writes "It is a strange business working in this world. When you meet a Union leader, you will quickly have to decide which side he is on and whether or not he is a Communist. You can find out by the language he uses, and his behaviour, whether or not he is in the inner circle which make the decisions. These are the things from which you determine whether he is an outsider in the Communist underworld."

5. Pye, p. 77 .

6. The main sources for this chapter were discussions in 1966 with "Ah Tuk" (Com.) who in 1947 was a member of the Transport Workers Guidance Committee, and particularly responsible for directing the activities of the Trishaw Riders Union; also with "Seng", of the Singapore Special Branch. In August 1948, after the departure of many leading Communists from Singapore to the jungle, "Ah Tuk" was promoted to the Town Committee, and in November 1948 became Town Committee Secretary - i.e. leader of the Communist Party of Singapore - until his arrest in 1950. "Seng" introduced me to "Ah Tuk", was present throughout my interview with him and continued to help and advise me in 1967 and 1968. As with other ex-Communists, Special Branch officers and some others whose identity is still a delicate matter, they are referred to by pseudonyms throughout.

7. "Ah Tuk" (Com.) and "Seng" (S.B.) Even as Town Committee Secretary, "Ah Tuk" only knew the total number of party members very approximately, because of the strict ban on any personal contacts by any member other than with his own cell, the representative of the superior cell, and the particular subordinate cell which he directed. Subordinates were inclined to inflate their reports to the next man up, and to conceal gaps and defections, so that "Ah Tuk's" estimate is probably high rather than low. Certainly, full party membership was always very small and select, and estimates such as that in O'Ballance op cit, p. 98, that the arrest of the Town Committee in 1950, "left 2,000 Party Members at large in Singapore" bears little relation to those of the primary sources consulted. 
study, they did no underground work and attended no Party meetings, but simply received instructions to influence the decisions of the legal Committees in which they worked to suit the Party's plans. Nevertheless these decisions were often so militant that the Party Groups were not difficult to detect. 4

Within the rank and file of the Unions and other front organisations, therefore, there was an entirely separate structure of Party Workers operating in cells which held regular clandestine meetings but whose members held no overt office in the Unions or Associations concerned. They concealed their Communist affiliation and their links with each other, and their work was wholly secret. The lower their position in the hierarchy the more directly they worked on the masses, and therefore the greater was their risk of compromise. To reduce this risk, however, the members of the Party Group on the legal Union Committee themselves did not know the identity of the underground workers within their own Unions. 5

The control of these two structures in shown in Figure 3A, which also traces as an example the chain of command from Town Committee to one particular Trade Union - the Trishaw Riders Union. 6

The total number of Party Members in Singapore reached a peak of 300$400^{7}$ in 1947. Six of these were members of the Town Committee, each of whom was personally responible for - and the sole contact with - one or more of the Guidance Committees, whose meetings he would attend.

In turn, each member of a Guidance Committee would be resporfible for one of the Unions etc., in his group - e.g. one of the three members of the Transport Workers Guidance Committee was responible for the Bus Workers Union, another for Taxis and miscellaneous workers and the third for the Trishaw Riders Union.

The responibility of this member was exercised through the two separate arms which he controlled - the Party Group which dominated the legal and open Trade Union Committee and the underground Party Workers within that 
8. "Seng" (SB) in an interview in 1968. Lee Kwan Yew, in Battle p. 16, writes that "The ABL relation to the MCP is like that of the volunteer force to the regular professional army."

9. Pye, p. 77 
Union. In the case of the Party Groups, because of the open nature of their work, these contacts would normally be through a courier or cut-off man to protect the Guidance Committee Member.

The underground party workers were organised (See Figure 3B) in party cells, normally only one within each Trade Union. Bach cell member would control the work of one or more "Anti-British League" (ABL) cells, perhaps one in each branch of the Union, each of which/in a number of "sympathiser" cells or Committees. These three grades of cell have been compared with University (Party), High School (ABL) and Primary School (Sympathisers). 8 The sympathiser cells were the most expendable, and would handle as much as possible of the contact with the masses. Their tasks were threefold: first, to detect and report grievances amongst the workers which had potential for exploitation; secondly to activate the workers to demand redress for their grievances; and thirdly to recruit others into the cell system who had leadership potential. Thus the cell system grew downwards, whilst its more successful members graduated upwards through the ABL cells to probationary, and finally to full party membership. The top party cells organising the underground workers reported directly to the responsible member of their Guidance Committee, who would, when appropriate, warn the Party Group on the legal Union Committee to be ready to receive and back the demands activated by the cells as coming from the "grass roots".9 Meanwhile, the Guidance Committee would keep the Town Committee informed, so that they could judge the potential of the grievances and the temper of the workers in particular industries, and decide how and when to provoke and co-ordinate strikes and demonstrations.

This system was particularly effective in the control of transport and the Town Committee was able in 1946 and 1947 to bring the whole trasport system of Singapore to a halt at its command. The total number of full party members involved in the entire transport field was probably less than 25. In the case of the Trishaw Riders Union, the number was seven: the 


$$
\text { 250.20 }
$$

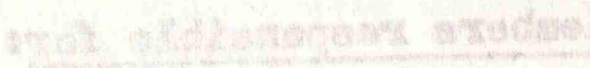

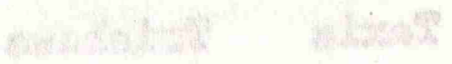

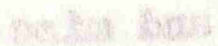

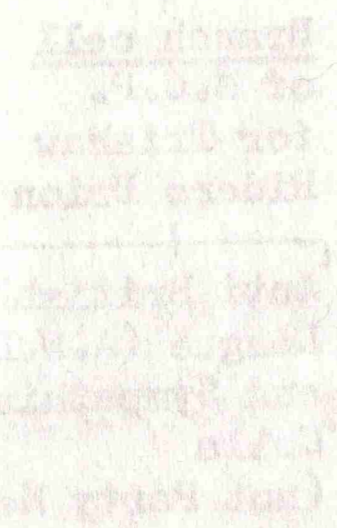

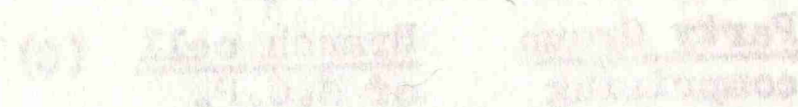


Town Comittee

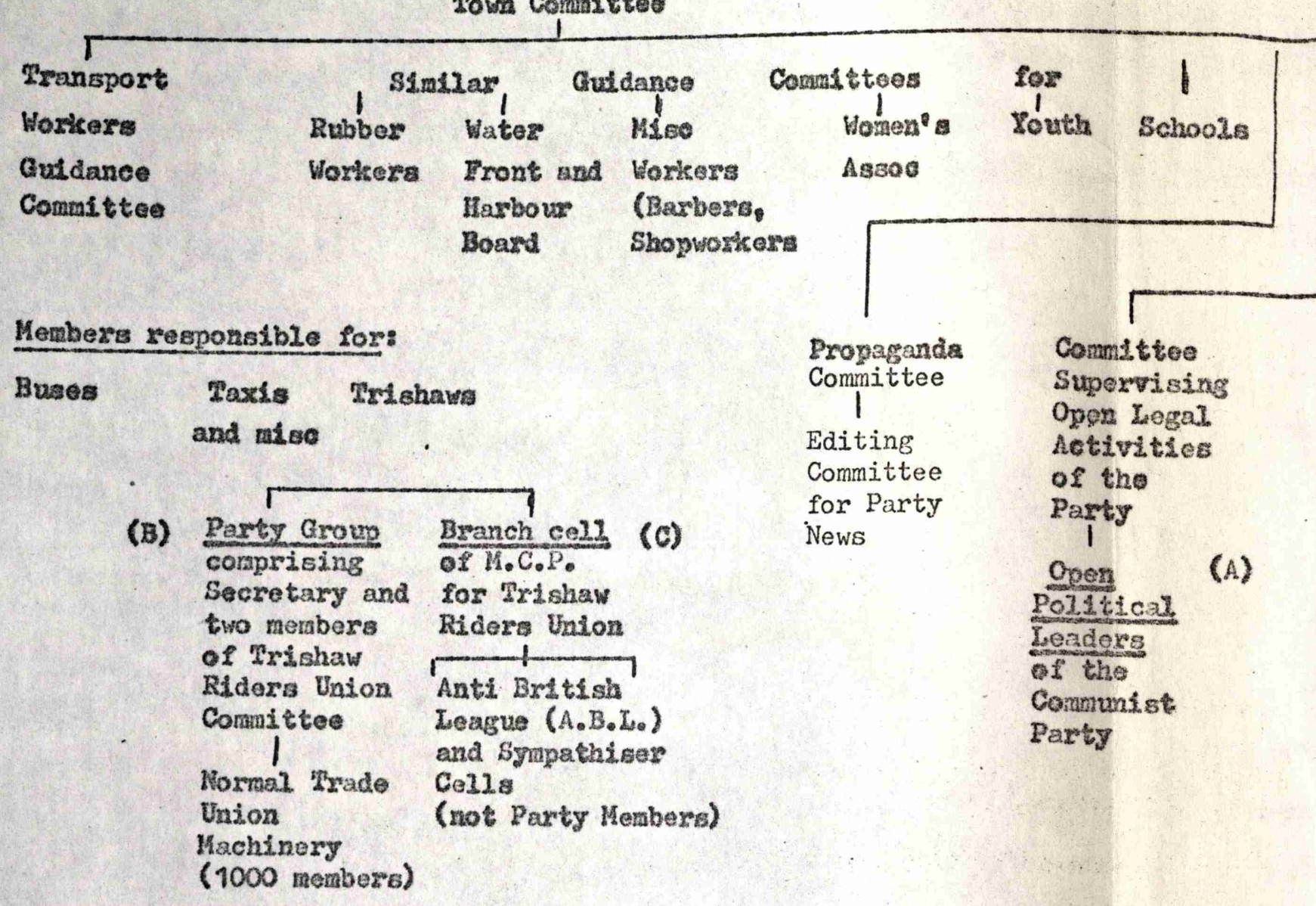
The three rain elenents of the Party organisation at working level are shewa at
$(A),(B)$ and $(C)$.

(A) The Open political leadera (when the Party was legal)

(B) The semi-secret Darty Groups - holding publie offices which they courd menipulato to suit the Party, but concealing theis Party membership.

(c) Tho socret Party cell merbars. Their existence was known, but the ideatity o of sndividual members was not known to $(A)$ ror $(C)$.
10. Pye, p. 78. Dr. Pye also says that the MCP maintained a third chec through the regular party members who were also members of the Union but held no official posts, who reported on Union activities at their own cell meeting and received orders which affected the Union. This was not confirmed by either "Ah Tuk" (Com.) or "Seng" (SB), who knew no cell system other than that described. There may, however, have been cases in which Party Members who were already meeting with some other cell might, by virtue of a change in employment, join a new Unit but continue their party work in their existing cell. The Communist leadership is always ready to have as many independent checks on its members as possible. 
responsible member of the Guidance Committee ("Ah Tuk" - see Note 6); three members of the Trishaw Union cell of the MCP controlling the underground workers (ABL and sympathisers): and the Party Group of three, comprising the Secretary and two other members of the legal Committee of the Trishaw Riders Union (See Figure 3A). Given 14 days' notice by the Guidance Committee, this team was able to bring grievances to a head and bring all the 1,000 Trishaw Riders out on a "bona fide" strike on a prearranged date, together with the bus, taxi and other transport drivers. The underground party workers regarded themselves as more important and more trusted members of the Party than the Party Groups. In the words of one ex-underground party worker, "It was like a pot; the British could arrest union leaders, but they would just be grabbing hold of the lid, and you can't move a pot by holding its lid. We held the pot and all that was in it." 10

There is no doubt an element of Party snobbery here. In the Communist revolutionary tradition secrecy is a status symbol. Nevertheless, the more open elements - the open leadership at the top and the sympathiser cells at the bottom - were the ones which activated the masses and led the strikes, demonstrations and riots which were the main weapons whereby the Party tried to coerce the government into making concessions. As will be seen later, when the Party made its second major attempt at an urban revolution in Singapore in 1954-56 it concentrated almost all its efforts into Party Groups running the Front organisations and spared little effort for an elite Party cell structure barred by its secrecy from any positive leadership of the people. Ideally, the Party has both, but the more open elements should not be too contemptuously dismissed as mere "front.men". It is equally wrong, however, to underestimate the tremendous strength and resilience provided by the secret organisation, which enables it to survive drastic government action against the open organisation, and to go on building up the strength of the Party from below through its clandestine sympathiser cells. 


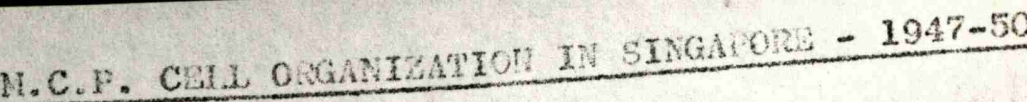

\section{Town Connitteo}

\author{
1 \\ Guiance Comitiees \\ Branch Comaittees
}

(and District Comittees after 1948)

upervised by one nember of Guidance or vistrict comittee Dranch Comittee Secretary (B.C.S.)

2 or 3 Branch Comittee heabers (B.C.2.)

\begin{tabular}{|c|c|c|}
\hline Party $\operatorname{Cell}$ & Party' cell & $\operatorname{paxty}_{1} \operatorname{cel}$ \\
\hline A.B.L. Cell & A.B.L. CeII & A.B.L. \\
\hline $\begin{array}{l}\text { Sympathiser } \\
\text { Cell }\end{array}$ & $\begin{array}{c}\text { Sympathiser } \\
\text { cell }\end{array}$ & $\begin{array}{c}\text { I } \\
\text { Sympatuiser } \\
\text { Celi }\end{array}$ \\
\hline
\end{tabular}

Paxty Nembers

$+$

Anti-British

League -

Future

Party Members

1. B.C.S. and B.C.H.'s each attend and supervise meetincis of oue their subordinate cells. Size of cells normally 3 , wut not rigid.

2. Sinilarly each party Cell Nember and cach A.L.L. Cell ander sumervises one subordinate cell.

3. In theory, the aximu muber of people any menber know wo about 6 - one supervison from above, two fellow ce 11 whis about thee in the coll he supervised.

To ractice, there were larce gaps in tiuls structure, of pathe below were often unaware.

\section{Figure 3B}


Recruitment and Advancement

Recruitment to sympathiser cells was done mainly by encouraging the livelier spirits to join the team of active leaders of generally popular causes; for example, amongst students, the safeguarding of Chinese education and, later, opposition to conscription; for workers, the seeking of better wages and conditions; for rural smallholders, opposition to eviction or, when this failed, obtaining fair compensation; for women, the campaign for equal treatment and pay; and for all, the crusade against colonialism and oppression. See Figure 3B.

Sympathiser cells met for indoctrination and study, also to plan and report on Party work. Their work included the more recognisable and vulnerable activities, such as slogan-painting and (later) the destruction of Identity Cards and the distribution of propoganda. It also included supply work (when necessary) and the acquisition of information about the Security Forces and "Traitors". Cell members who were doing full time paid work for the Party in fact generally lived on the subscriptions collected by their subordinates from party members and sympathisers. (This is also a quite normal method of taxation and payment of government officials in many parts of Asia.) Children and teenagers were also brought in, to carry local messages and acquire information. ${ }^{11}$

The feeling of being members of a secret brotherhood is exciting for anyone young, and particularly for the Chinese, who have always felt the need to join some kind of secret society. To many of them the MCP was a more attractive alternative than the traditional and now largely criminal Chinese Secret Societies. ${ }^{12}$ It would be wrong to picture them as taking part in some dark and destructive conspiracy - at least in their own eyes. There were plenty of things that needed putting right in post-war Singapore and Malaya, and there was much genuine idealism in their attitude. To join a club or society or union was often to fulfil a desire to join an active group of kindred spirits who knew where they were going. To join a sympathiser cell was to join the elite of this group. 
13. In The Battle for Merger, pp. 19,21 and 85.

14. This also became one of the main planks in the platform of Lee Kran Yew's own People's Action Party, and contributed greatly to its success. Blades, para. 7.

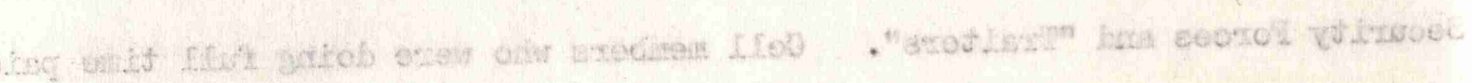

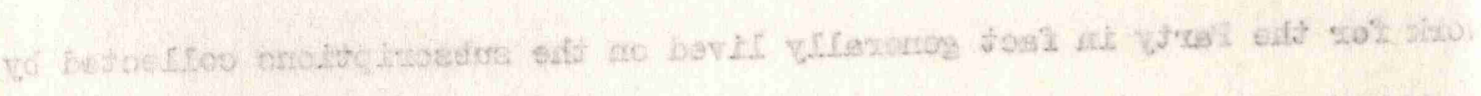

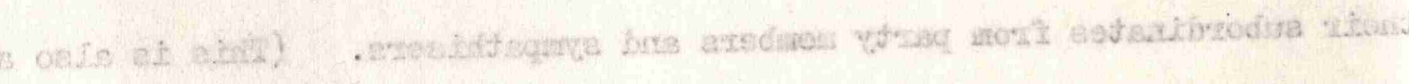

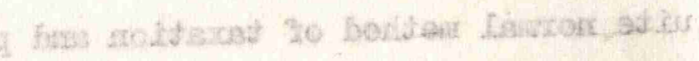

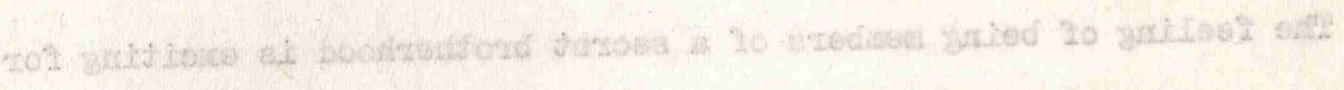

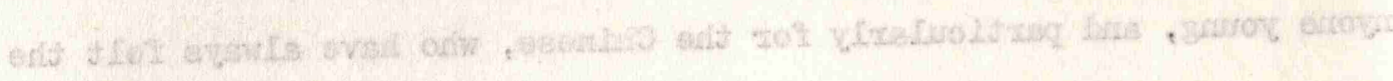

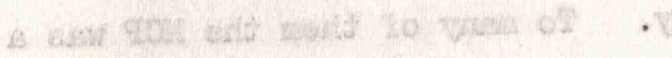

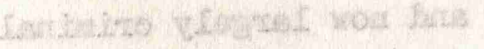

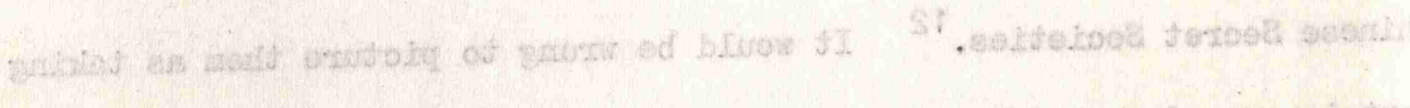

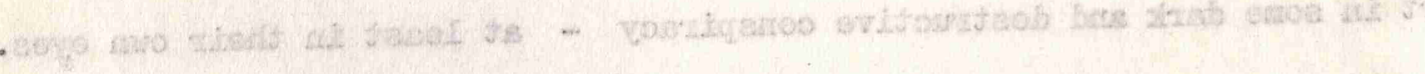

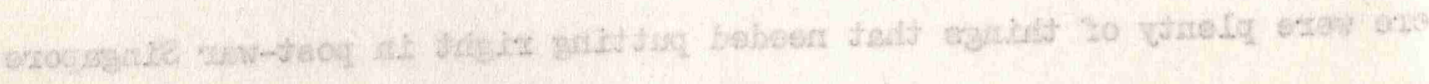
15. Pye, p. 219.

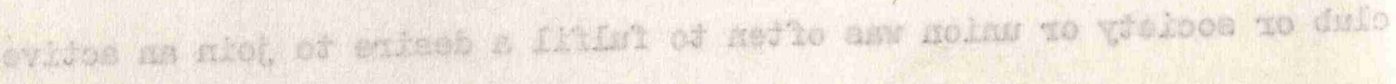

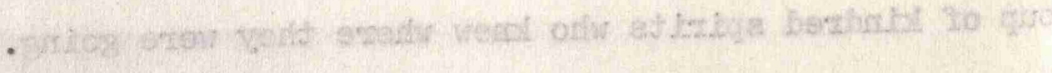


Lee Kwan Yew, ${ }^{13}$ though writing of a later period (1953-56), frankly admits their idealism and their strength.

"The strength of the MCP lies in the propagation of Communist theories and ideals to recruit able and idealistic young men and women to join them in their cause ... "The Communists, though they had only a few hundred active cadres, could muster and rally thousands of people in the unions, cultural organisations and student societies ...

"By working and manifestly appearing to work selflessly and ceaselessly, they won the confidence and regard of the people in the organisations ... 14

"The strength of the Communist Party lies not in their mass as such but in the band of trained and disciplined cadres who lead the masses into Communist causes, of ten . without the masses knowing they are Communist ...

"The Communists always do this. Exploit a real or imaginary grievance through cadres and sympathisers not generally known to be connected with them."

There was also a strong element of reaction against the older generation of Chinese. Many young people despised their parents because they were illiterate, or because their ideas seemed outmoded and subservient. Even children from middle-class homes found the lively political discussions amongst their friends in the Front organisations a great deal more stimulating than conversations at home. Marxism seemed a dynamic and positive philosophy. They gradually became aware that most of the leading spirits, the people they most admired, were Marxists. To find themselves invited to take part in clandestine cell meetings with one of these people was exciting and rewarding. 15

Graduation to a higher cell - of the Anti-British League - was the 
... 16. "Seng" (SB) - Interview 1966.

17. Douglas Hyde (in I Believed, London/ pp. 64-66) describes an interesting parallel from his own experience as a Communist in subverting members of a local branch of the British Labour Party $1930^{\prime} \mathrm{s}$. On arrival in the area he joined the branch, attended meetings, spoke and attracted friends. After a time he was elect to the Bxecutive Committee. Amongst his friends he selected thow whom he considered worth converting to Communism and worked to gei elected to the Committee. Meanwhile, he converted them to Comm secretly, one by one, unknown to the others. At the meetings of Committee these converts formed a "Ginger Group". One day, when judged the time ripe, he assembled the Ginger Group and announced, their surprise, that all present were members of the Communist Par Thereafter they acted as a secret Party Group, retaining their executive positions on the Committee.

He also describes (op cit , pp. 239-240) how similar secret: factions operated within Trade Union Committees, planning strater tactics for meetings, getting members onto Committees, and organis majorities for snap votes on key issues. These factions would af much as nine months before the anmual conference to select resolut to be fostered and plan how to get them through.

18. See Chapters 4 to 6 . 
next stage. This involved more secret indoctrination and training, and after one or two years a promising candidate would be invited to become a probationary member of the Party. After a further six to twelve months, he might be initiated as a full Party Member. ${ }^{16}$

This was a typical pattern of recruitment and graduation, but it would be wrong to visualize it as the standard or sole procedure for getting people involved in Party affairs. The Party Group, for example, also attracted promising members of the ordinary Committees of Trade Unions and other organisations into supporting them at committee meetings. These people became well aware that the "activists" on the committee were Communists, but neither of them would mention this until the Communist felt sure enough of his man to tell him of his affiliation and invite him to join a secret study group. 17

\section{The Student Organisation}

Subversion in the schools had certain differences from that in labour and other front organisations, chiefly because the population was constantly moving - a boy scarcely had time to graduate through the sympathiser and ABL cells before he was in his last year. For this same reason, it was also more difficult for Special Branch to keep track of the cell members so that the student organisation in the event proved the most resilient of all in surviving disruption by the government. The student organisation was not really laid bare until 1956, after a major showdown, and its description will therefore be deferred until that period is discussed. ${ }^{18}$ It was to play a vital part in the survival of an element of the Party structure in Singapore through the very difficult years following the outbreak of the Emergency and the proscription of the MCP in 1948, and really came into its own in 1954, when it provided both the leadership and the organisation for the second attempt at activating an urban revolution in Singapore.

There was a small but very important element of the student organisation amongst the English speaking students at the University of Malaya (which was 


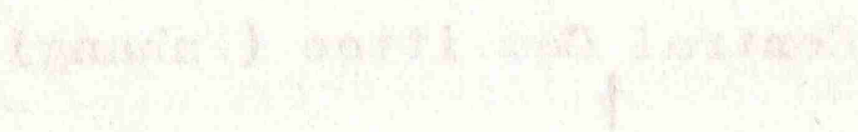

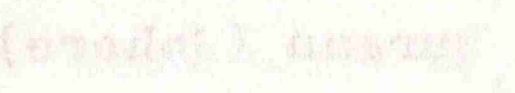

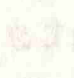

(20.7.0.

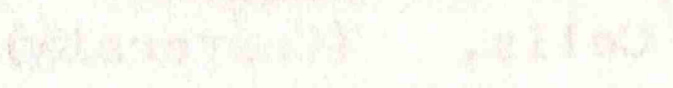

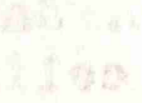

$\leftarrow \frac{\text { Figure } 3 c}{\text { Pull out }}$ 


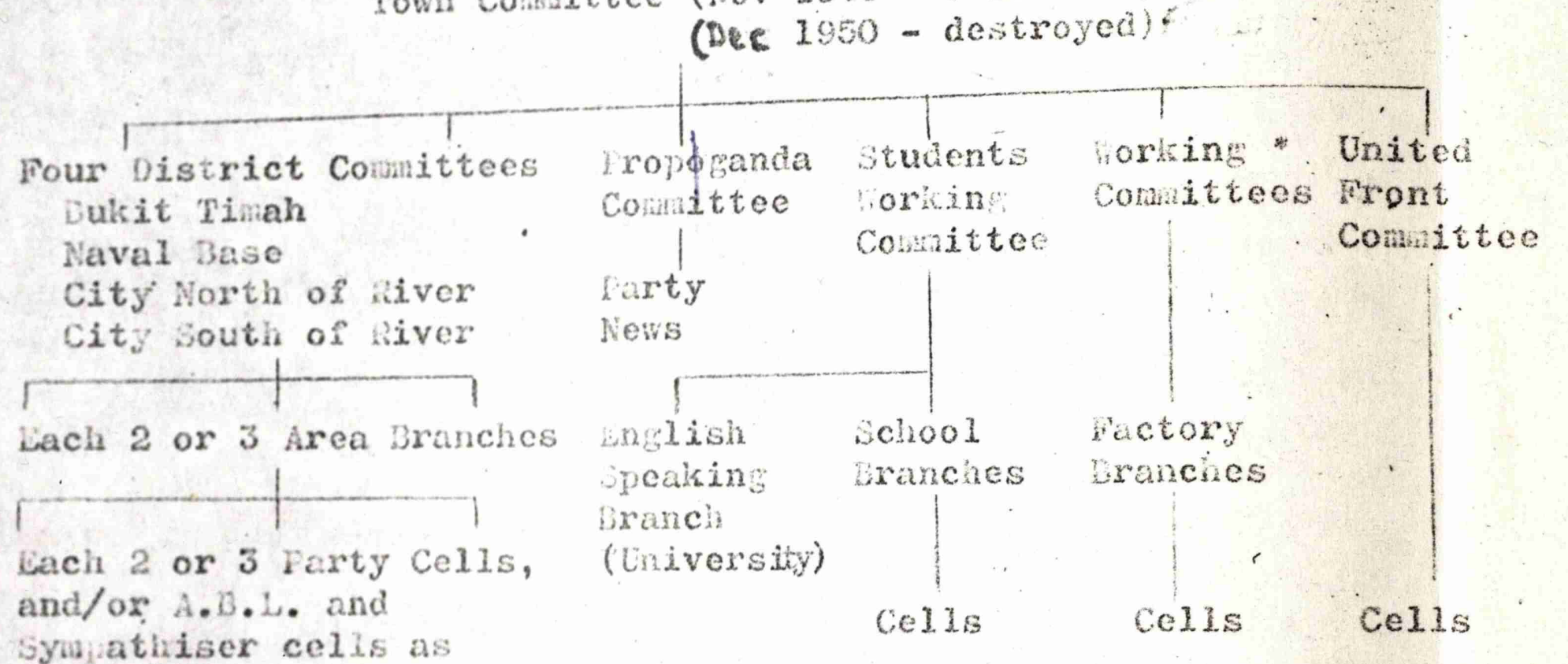

symathiser celis as

in if tire 43 .

* The forkine Comittees had a rathen sporabic oxistence and factory branches often oyerated under the district organization.

Total Iarty strength in singapore

- August 1948 - 40 to 50. Dovonber 1048 - About 100.

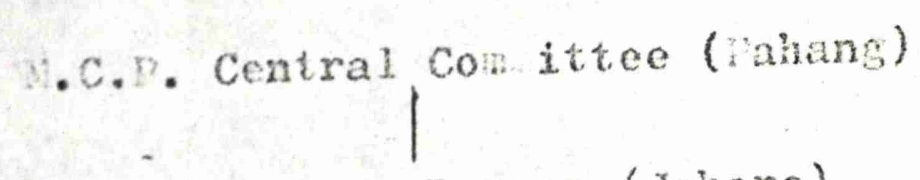

South Yalaya Bureau (Johore)

(Aun 1948 - 5 menuers)

Town Comittce (Nov 3948 - 3 members)

(Der 1950 - destroyed)

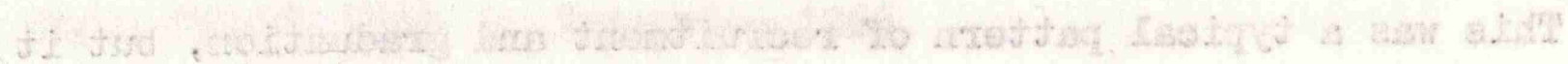

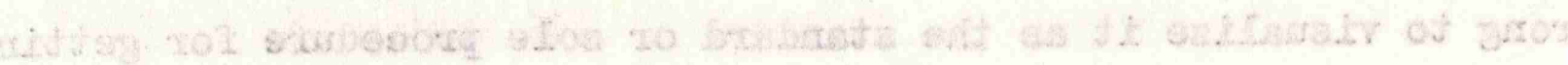

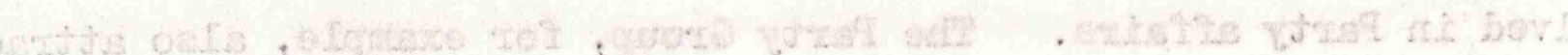

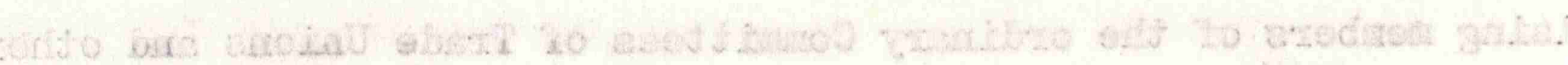

19. Blades, paras. 8 \& 10 . See also Chapters $7 \& 8$

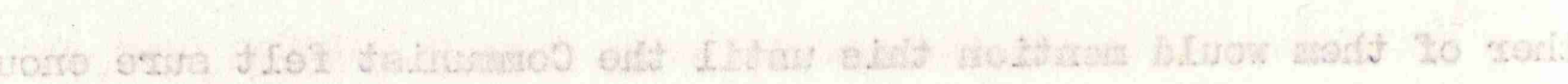

\section{See Chapter 2}
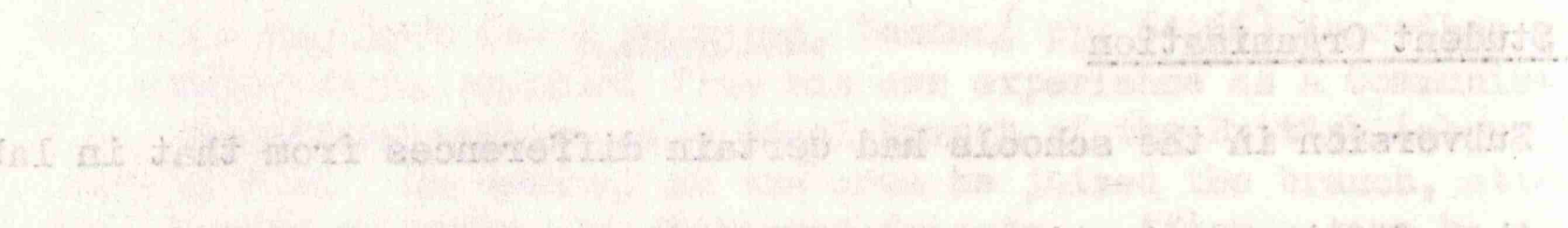

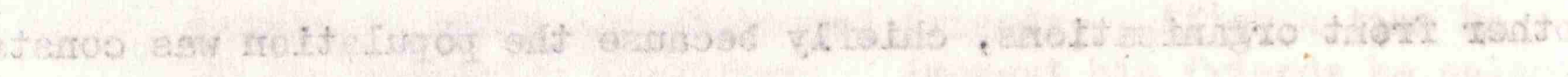

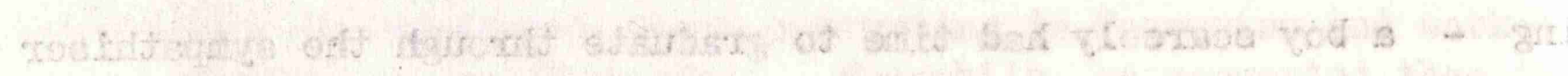

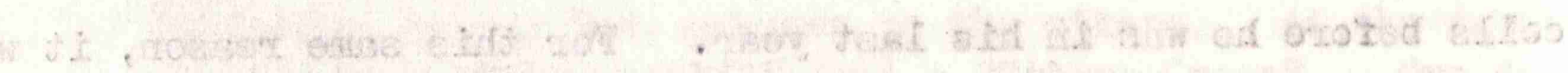

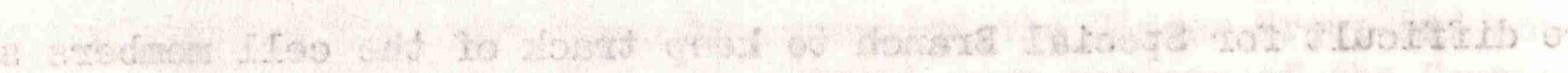
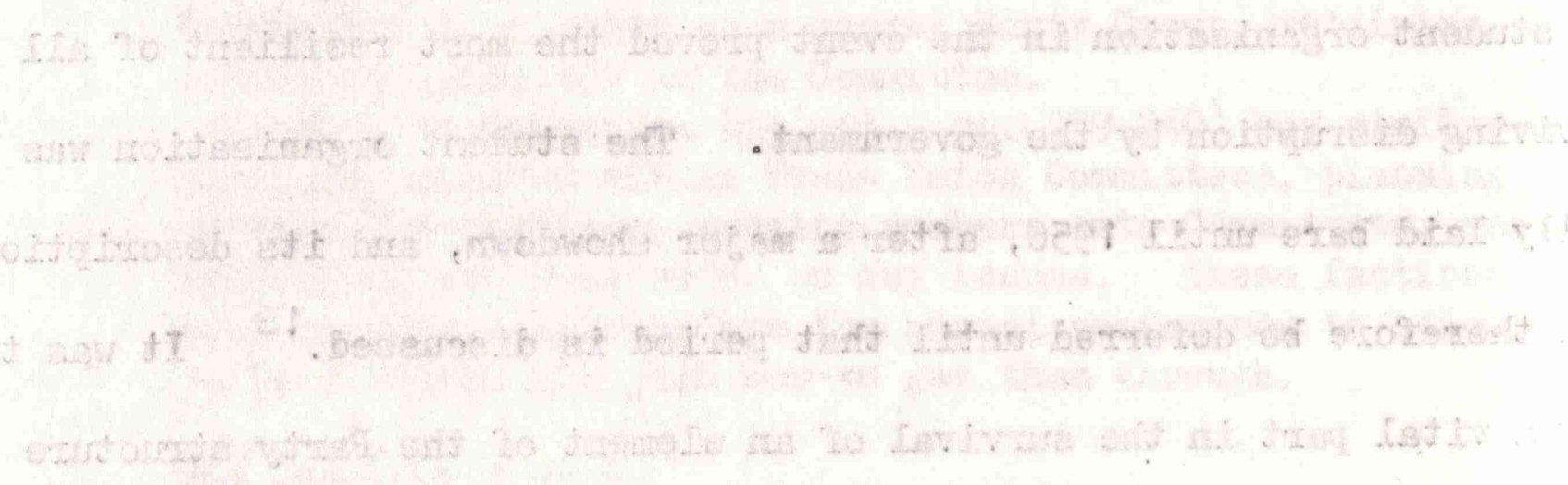

21. "Ah Tuk" (Com.) - Interview 1966

\section{Figure $3 c$}


in Singapore). This had originated from the Malayan Democratic Union which had been formed in 1945, and it attracted a number of very able young lawyers, teachers, etc., - known to the Special Branch as the "English Speaking Intelligentsia" (ESI) - who would undoubtedly have provided a most effective team of open-front political leaders, able to argue with the best and to present their case to the World Press. Though the ESI was successfully unearthed and broken up by the Special Branch in 1951, many of its members reappeared as open-front leaders in 1954, including James Puthucheary, S. Woodhull and Devan Nair. ${ }^{19}$

1948 - A Drastic Reorganisation

In June, 1948, the combined effect of the Government's Trade Union legislation, 20 the MCP's decision to mobilize in the jungle, and the imposition of Emergency Regulations left the Singapore Town Committee with only 40-50 members, and forced it to undertake a drastic reorganisation. Its main structure in the Trade Unions was replaced by a district organisation. There were four District Committees, one District covering the Western part of the Island, and particularly the Bukit Timah factory area, the second covering the Naval Base and the villages and factories in the North part of the Island, and the other two covering the City itself, divided by the Singapore River into North and South, In addition, there were Women's and Student's Committees. The Town Committee was reduced to five and later to three members, each of whom, including the Secretary, supervised the work one or more of the District or other Committees. (See Figure $3 C)^{21}$

A Tightening of Security in the MCP in Singapore

In July, 1948 the Party was declared illegal, and the Police had the power to detain without trial. Most of the known Communists had taken to the jungle, and many others had been arrested. A front organisation leader could no longer enjoy the luxury of letting it be generally known that he was pro-Communist with no more than a perfunctory public denial. He now had to 

JUNGLE TO SINGAPORE, $1948-50$

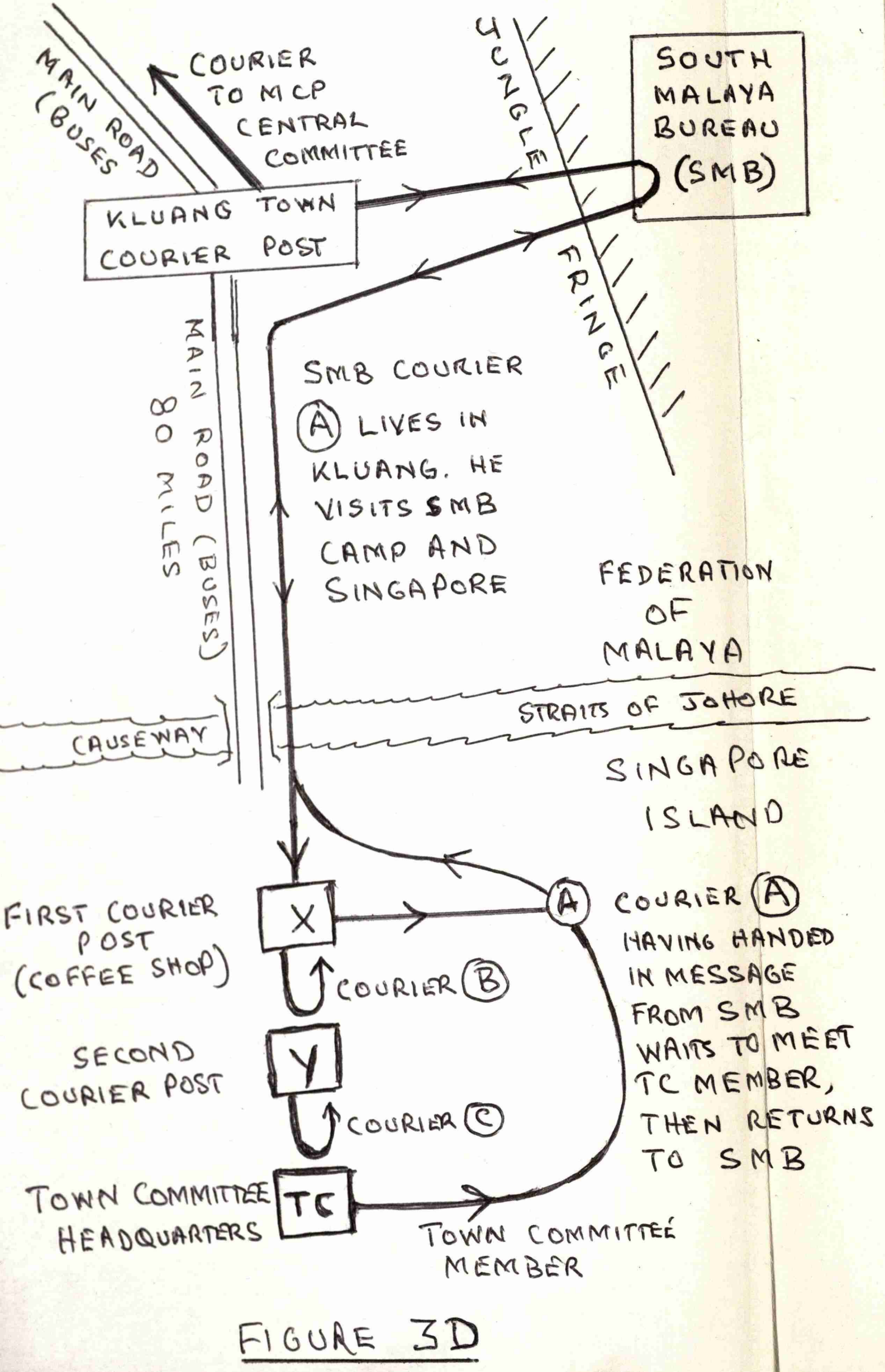

22. This was in 1948. Later, military operations in the Federation me this too dangerous, and people living "outside" seldom knew the lo of camps "inside" the jungle. They would instead be contacted by based couriers at their known places of work in the fields or est or sometimes at pre-arranged rendez-vous near the jungle fringe. and system was part of a rural insurgency/is described in Chapter 10.

23. "Ah Tuk" (Com.) - Interview 1966 , 
conceal it - or go into hiding. A marked increase in security was necessary.

In August, "Ah Tuk" lately "member for trishaw riders" on the Transport Workers Guidance Sub-Committee, was promoted to the Town Committee and in November 1948 he became its Secretary, his predecessor having been appointed Secretary of the South Malaya Bureau (SMB) to which "Ah Tuk" was responsible.

The SMB was located in the jungle near Kluang, about 70 miles North of Singapore. Communications between the SMB and Singapore were by a system of couriers and cut-outs shown in Figure 3D. Nearly all the couriers were women. Only one courier (A) knew the location of the SMB camp and she lived in Kluang town. 22 She would travel by bus to Singapore where she would go to a Courier Post (x) - usually a Coffee Shop. She would wait here while her presence was reported by another courier (B), to a second Courier Post (Y). From this, a third courier (C) would pass the word to the Town Committee (TC).

A member of the Town Committee would then go direct to the first Courier Post (X) to meet the SMB Courier (A) face to face, ${ }^{23}$ to enable her to transmit at least some of the personalities of the respective Bureau and Committee members to each other, and either to develop a little of the theme of the written messages, or give direct verbal messages, thereby avoiding the risk of carrying any written messages at all.

A few years later, these security measures became tighter. Nevertheless, the personal meetings between the Town Committee Members and the SMB Courier did not compromise the complex security barriers imposed by the multiple courier posts as much as they would seem to at first sight. The aim of these barriers was to avoid compromising the base, or headquarters of the Town Committee, where it held meetings every 2 to 4 weeks. A raid on this could wipe out the whole Committee at one blow, unknown to the rest of the party, as did indeed happen later, but the hazarding of a single member was worthwhile to gain the advantages described in the previous paragraph.

In the cell system itself, security was always intense. With the 


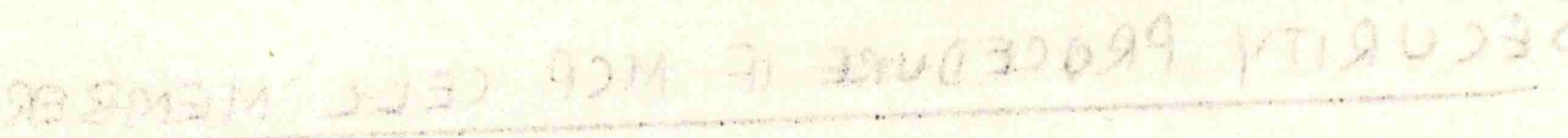

$$
\leftarrow \frac{\text { Figure } 3 \bar{E}}{\text { Pull out }}
$$

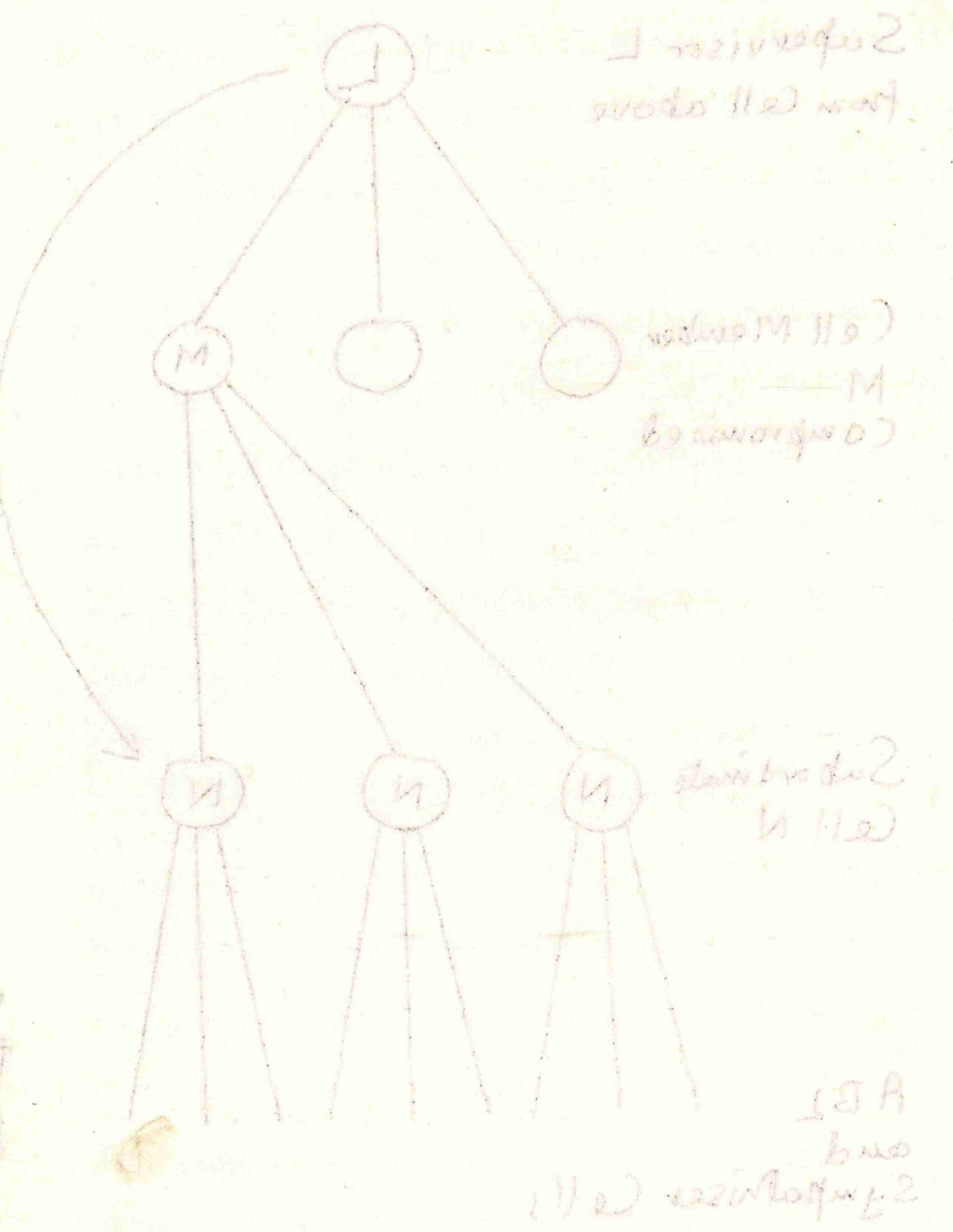


SECURITY PROCEDURE IF MOP CELL MEMBER COMPROMISED

Supervisor $L$ from Cell above

Cell Member Compromised

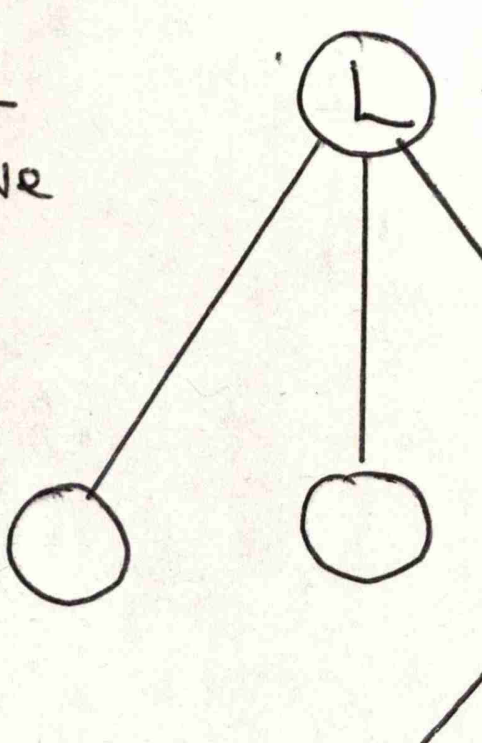

Member of Gall $N$ contacted by Supervisor L who orders Suspension of achiritien for 6 months. L also arranges For fill gaps

$A B L$ by other means and sympathiser Cells

FIGURE $3 E$ 
experience of several generations in clandestine revolutionary activity, the Communist Party always assumes that some amongst its ranks will defect or be captured, and that they will talk. As soon as a cell member (M) made a slip (See Figure 3E), or his supervisor (I) from the cell above suspected that he might be compromised, he (M) would be dropped and never trusted again. The supervisear: would warn the subordinate cells under M's direction (N) to cease operating, usually for about 6 months.

If $M$ then betrayed them to the police, the police would start watching the members of this subordinate cell, but would find them doing nothing, and giving no leads into the ABL or sympathiser cells below them.

Supervisor I would at the same time organise the filling of the gaps, to replace $\mathbb{M}$, and to continue the activities of cell $N$, including the direction of its three subordinate cells. This would not be easy, because I would not know the names of the members of Cell N. He would, however, know their places of work and their party names, and would have other information about them from past reports on their activities by M. With or without M's assistance (depending on the nature of his compromise) I would establish contact with the members of Cell N, and find out enough from them about their subordinate cells for him to arrange for someone else to take over their supervision probably with sufficient alteration to guard against their compromise in the event of members of Cell $\mathrm{N}$ being questioned by the police as a result of betrayal by M. The other various overlapping and cross-checking systems (such as Party Groups, and Party Members who have moved from elsewhere to work in the same factories, etc., as Cell N Members) would also be of some assistance to $\mathrm{I}^{24}$

Nevertheless, the security precautions were so complicated that not only were there large gaps in the MCP cell organisation, but also the leaders at the top and the rank file themselves often unaware of them. People such as I would, if they could, conceal the shortcomings and defections amongst their subordinates, as the image of a solid, loyal, well-recruited structure under them would most impress their superiors. Similarly, the morale of Party 
25. "Seng" (SB) - Interview 1968. Their arrest was part of a police operation following an unsuccessful attempt to assassinate The Gover

of Singapore. G.G. Thomson para. 8.

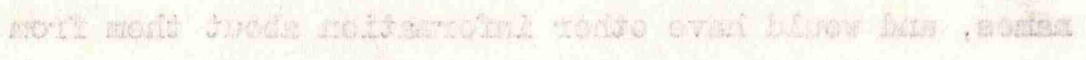

26. Blades, para. 13. 
workers in the cells subordinate to N would be better for not knowing of M's defection or arrest. They too were, therefore, presented with the image of a solid structure above them.

\section{The Arrest of the Town Committee}

The solidity of "Ah Tuk's" organisation, however, was shattered in December 1950 by the arrest of the entire Town Committee. An alert police detective spotted two men at a bus stop exchanging newspapers in a rather suspicious manner, as if there might be messages inside them - which in fact there were. He pursued and arrested them, finding them in possesion of incriminating documents. One was "Ah Tuk", and the documents gave leads to the remainder of the Town Committee. ${ }^{25}$ Their arrest left the MCP in Singapore leaderless through the most critical period of the Malayan Bmergency, and it was not until 1954 that it resumed any significant part in the revolution.

\section{The Hertogh Riots}

In the same month of December occured the most unexpected riots in Singapore during the whole of the period under review - and the most serious in terms of bloodshed. These riots had nothing to do with the Communists. Their significance lay in the weaknesses which they revealed in the Singapore Police Force. The action to remedy these weaknesses produced a Force whose control of the organisation became the envy of visitors from all over the World ${ }^{26}$, and which was to prove itself in the later riots in 1954-56.

The riots in December 1956 arose out of a law suit over the custody of Maria Hertogh, the 13 year old daughter of Dutch-Eurasian parents, who had been born in 1937 and baptized as a Catholic. In 1943, her parents had been arrested in Java by the Japanese, and Maria had been cared for by an Indonesian/Malay family who had subsequently moved to North Easter Malaya and had brought up the girl as a Moslem.

Her parents discovered where she was in 1948, and claimed her back. In 


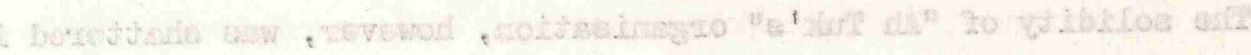

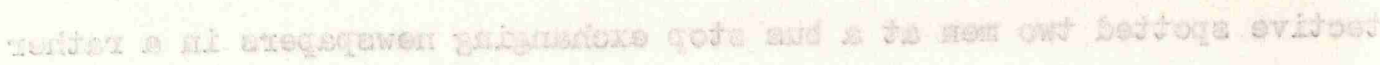

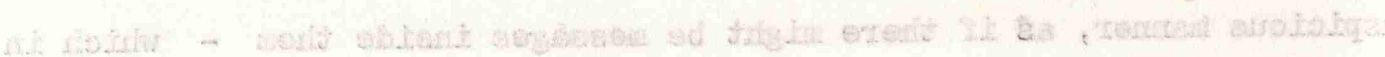

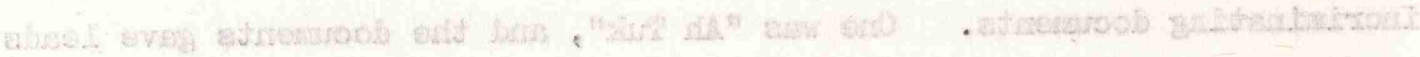

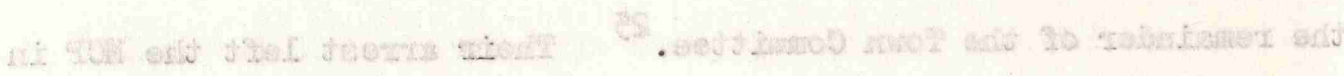

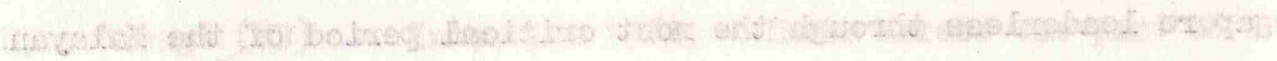

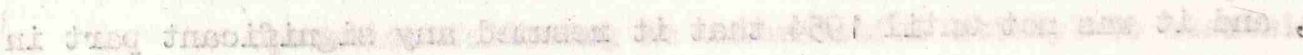
.roojthicones

27. The Singapore Police retain a Gurkha contingent to this day.

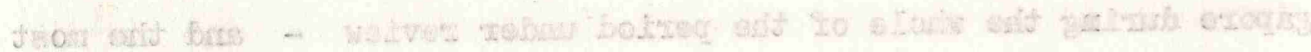

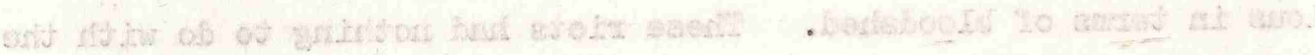

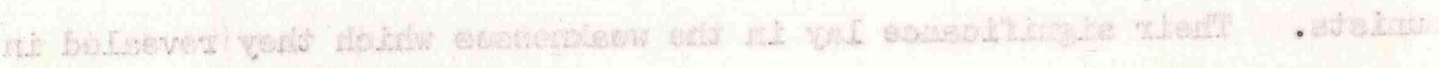

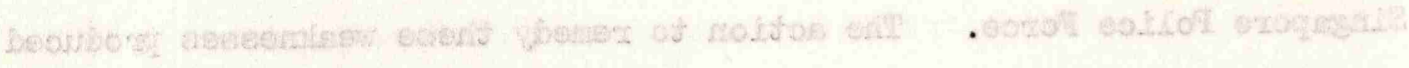

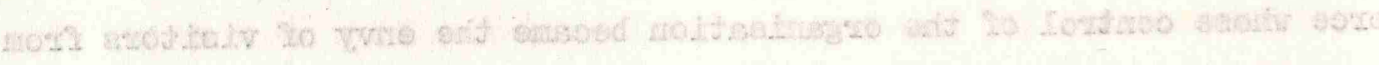

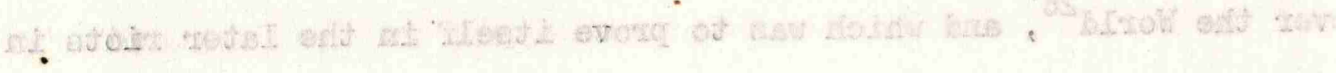

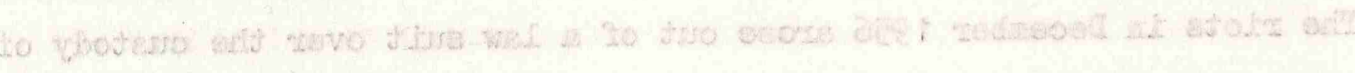

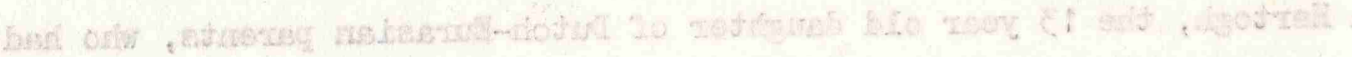

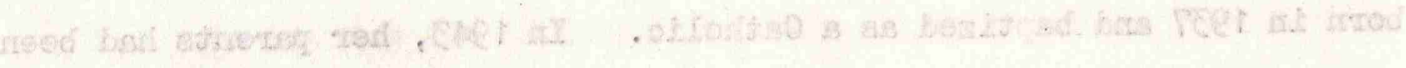

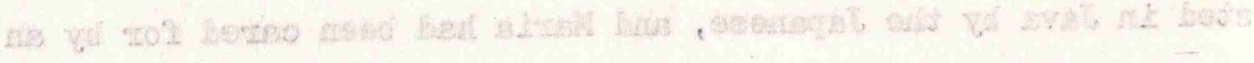

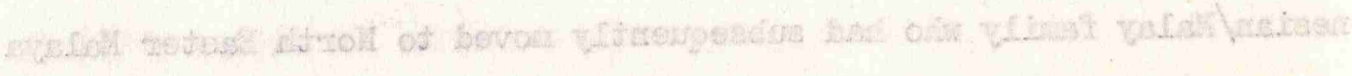

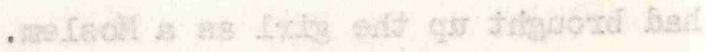


May 1950, The Dutch Consul in Singapore obtained a Court Order for her custody. This order was, however, reversed on a legal technicality in July. Maria returned to her foster parents and was rushed through a marriage ceremony with a Malay, which was within Moslem law, but contrary to Dutch and British law, and aroused great indignation in Holland and amongst many Christians in Singapore. A further Court hearing led to Maria's removal from her Malay "husband" to a Catholic Convent in Singapore. He in turn appealed, and it was the hearing of this appeal at the Singapore Supreme Court which led to the rioting. By this time, the Singapore Moslems (both Malay and Indian/Pakistani) had been aroused to high passion over the issue, and in particular against the Buropean and Euranian communities.

The 70 constables deployed outside the Supreme Court were Malaya. This was both unwise and unnecessary because, although the Singapore Police Force was $90 \%$ Malay, it did include some 400 Indians (some admittedly Moslem) and a contingent of 119 Gurkhas especially trained for dealing with riots - a force of particular value in a multi-racial city. 27

The Malay constables - who had been subjected to considerable propaganda by the Moslem "Action Committee" which led the campaign for Maria Hertogh's custody - allowed a small crowd of demonstrators to pass through their ranks unopposed. The demonstration thereupon gathered momentum, and after $1 \frac{1}{2}$ hours a force of 48 Gurkhas was brought in. A number of the British Police Officers, however, showed the most deplorable indecision and misjudgement, and the Gurkhas were repeatedly moved up and then withdrawn (at the request of the demonstration leaders) in full view of the crowd. As a result, all respect for the Police - Malay and Gurkha - disappeared. By the afternoon, mobs were ranging all over the Island, dragging Europeans and Eurasians from cars and buses. During the evening and the night, they killed 9 people and seriausly injured another 26. The Army was called in just after dark, and next day had to open fire to restore order. In all, 9 people were killed by the Army and the Police, bringing the total death toll 
28. It is a tribute to the nemal efficiency of the Police that, throughout the disturbed years of $1946-63$, this was the highest death-toll of any of the outbreaks of rioting during the whole period. In addition to the $18 \mathrm{killed}, 173$, were injured, 72 vehicles burned and another 119 damaged.

Report of the Singapore Riots Commission, 1951, Singapore 1951, on which the above account is also based.

29. Report of the Singapore Riots Commission in 1951, Singapore 1951.

30. Blades, para. 13. 
to 18.28

\section{Reorganisation of the Police}

It was clear that the demonstrations should never have developed into serious rioting, and the British Government sent out a Commission early in 1951 to investigate the matter. As a result of the Commission's Report, ${ }^{29}$ widespread changes were made in the Police Force. The establishment of junior officers (Inspectors) was trebled, and the increase was rapidly implemented by direct recruiting instead of only by promotion from the ranks. The number of Inspectors thus reached well over 300 during the next few years, many of them younger and better educated than before. In addition, 60 Police Lieutenants were recruited on short contracts. This rank was roughly equivalent to Sergeant-Major in the army, ranking below the Inspectors. Most of them were Europeans or Eurasians, some being British ex-Sergeants from the Palestine Police and from the army. Multi-racial Reserve Units were also formed, especially trained and equipped to reinforce the regular police in riots and other emergencies. The final - and perhaps most significant - improvement was the development of a highly efficient radio patrol system with a central Control Room manned for 24 hours. The Control HQ had space to accomodate an army brigade command post to operate jointly with the Police if needed. Each radio patrol car had a crew of five, often headed by a Police lieutenant. 30 This joint control HQ with its team of 40 patrol cars was to prove a decisive weapon in the ratangerous riots of 1956 (see Chapter 7). 
74 


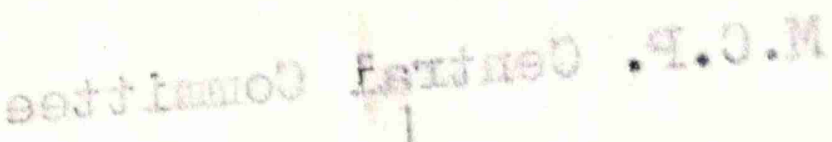

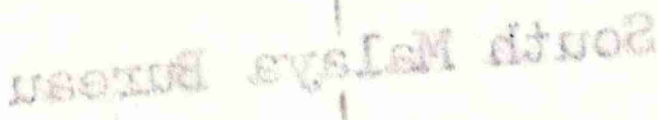

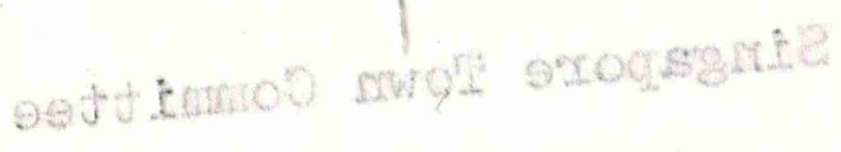

\section{Figue $4 A$}

Tox mal vosteroge

eneteris 20

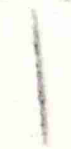

jotinte 2

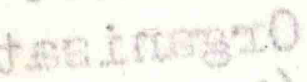

es nexord)

(ced at
202 rod $<$ Poll od atrobute Pall od 
THE SURVIVAL OF THE STUDENT ORGANISATION - 1950-54

\section{Resilience}

At the time of the events described in the last chapter (December 1950) the tempo of the Emergency in the Federation was rising to its peak, and little attempt was made to rebuild the shattered party organisation in Singapore. During the following three years it suffered a further series of disasters, but through all these the student organisation survived, even though the Town Committee Member responsible for students had been captured in 1950. Its structure was as in Figure $4 \mathrm{~A} .{ }^{1}$

The organisation was confined to schools using the Chinese language as the medium of education - i.e. the Chinese Middle Schools ${ }^{2}$ - with the exception of a short-lived but influential English speaking Branch in the University of Malaya, which was broken up in 1951.

The Chinese schools were particularly vulnerable to Communist propaganda. There were no Chinese schools provided by the Government, and they were run with the voluntary support of rich Chinese philanthropists, and by governing bodies whose members were selected more on grounds of prestige than of knowledge of education. Teachers were underpaid and had little security in their jobs. The Chinese boys and girls in turn knew that, by being educated in their own language, their opportunities in Singapore would be less than those of their neighbours' children Who were being educated in English. This caused an obvious feeling of resentment. Since their culture, and many of their teachers, emanated from a land which was now Communist, and whose Communist government enjoyed very high prestige at this time, these boys and girls made excellent material for MCP leadership against the 
3. G.G. Thomson - paragraph 12 and 21

4. "Seng" (SB) Interview 1966

5. Dr. Goh Keng Swee, then Singapore's Defence Minister, reported in the Singapore Sunday Times, 29th January 1967 
the injustices of their situation in Singapore. Little was done to tackle this situation until 1956, when a Commission on Education in Singapore was established, which was to get the Chinese schools within the national education system ${ }^{3}$ - but by this time the Communists had been able to use the Chinese schools as a focus for the most dangerous riots in Singapore's history.

After the destruction of the Town Committee in December 1950, all attempts to revive it were disrupted by Special Branch, but the Students' Committee and the District Committees did manage to resstablish tenuous contact with the Central Committee in the jungle. In 1953 Special Branch managed also to smash the entire District organisation, but the Students' Committee and the Middle School branches still kept alive, ${ }^{4}$ and they continued to survive right through the defeat of the armed revolt in the jungle and the smashing of the second attempt at an urban revolt in Singapore in 1956. Indeed, they remain to this day a most active section of the Party in Singapore. 5

This remarkable resilience was also described much later by tee Kuan Yew, Prime Minister of Singapore :

"For years since the beginning of the Fmergency in 1946, Communism has been painted in terms of violence, terror, brutality and evil. There was violence, there was brutality and there were evil men. But that is not the whole story. For if it was as simple as that, the Communists would have died and perished with the collapse of their armed revolt.

"It is because, together with these weaknesses, they have some strong qualities, that they have been able to survive in spite of the collapse of their armed revolt. 


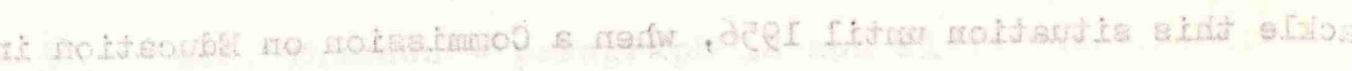

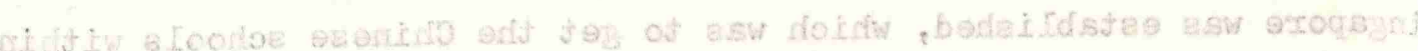

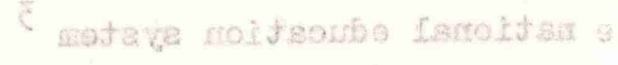

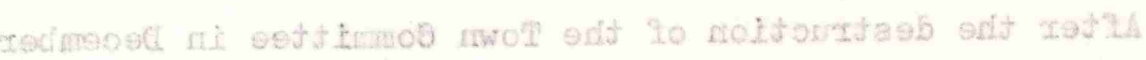

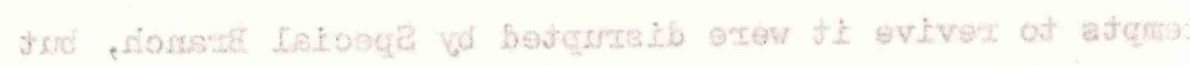

6. Lee Kuan Yew, in a broadcast over Radio Singapore on 15th September 1961, published in The Battle for Merger, Singapore 1961, pp 8-9.

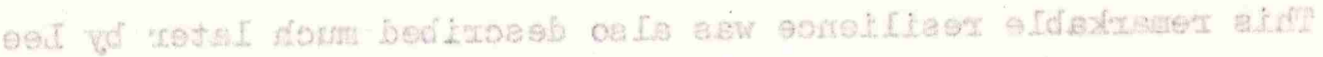

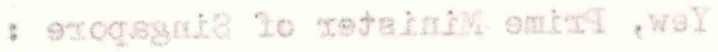

7. "Fu" (SB) Interview 1967.

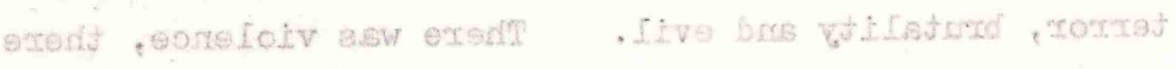

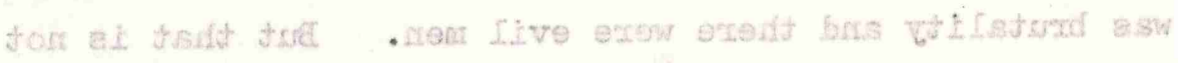

8. "Harris" (SB) Interview 1967. On the other hand Blades, (para.9) considers that the students were generally better at keeping secrets than adults, and were often more fanatical and more difficult to talk round. 
...."New Recruits have been found. These are

idealistic young men and women, largely from the Chinese Middle Schools of Malaya, both the Federation and Singapore ..... Partly by persuasion, mainly by fanaticism and faith that the future belongs to the Communists. These new recruits are continuing the struggle. They press on capturing the leadership of trade unions, cultural organisations and Old Boys' associations. Most important of all they try to capture the power to manipulate the lawful political parties ${ }^{6}$."

Security - Strengths and Weaknesses

Another reason for the survival of the student organisation, both as an activist organisation and as a training ground for future party workers, was that its constant turnover of members made it very difficult for Special Branch to identify its leaders before fresh ones had taken their places, which compensated for the inevitable amateurishness of student Communist activities compared with those outside.?

Security also was much looser amongst schoolboys, not only from lack of experience and restraint, but also because the penalties of discovery were far less - i.e. expulsion or, at worst, detention, whereas those organising supplies or intelligence for the Party outside were liable to the death penalty. 8

Party members inside the schools were rare, since it was almost impossible for a boy to graduate to full membership before leaving. Those who did were invariably over-age students of 20 or more, who were being allowed to make up for missing their schooling in the war. Furthermore, a student would rise out of the cell organisation during his final year, confining his activities to the 
9. "Fa" (SB) Interview 1967.

10. "Young" - a student at the Chinese High School for whom the ABL made a strong bid. See Chapter 5.

11. Another boy who got involved with the MCP whilst at school, and whose identity is safeguarded by a pseudonym. 
supervision of his successor who was in his penultimate year. This made him still harder to catch, and if the cell he supervised was compromised he was available to rebuild it. 9

$A B L$ cell members maintained fairly tight security outside and did not tell their own families - even their wives (unless also members). On the other hand, they were not difficult for those on the fringes of the organisation to recognise within the schools, as they were seen distributing Party News etc. ${ }^{10}$ The Open Front leaders were even more generally known because of their constant exhortations and spouting of propaganda, though they did not openly admit to being Communists. The security of the remainder of the Open organisation was also poor, as will be described later in the chapter.

As outside, a boy who came under suspicion was ostracised by the Party as a matter of security. For example, "Ching"11, after 3 years working up the school front organisation and study cells (see Chapter 5) was found in possession of an incriminating document rolled up in a tiny gramophone needle box. He was held and questioned by Special Branch for a month. On his return to school his friends in the cell system no longer trusted him, and he was also regarded askance by the staff. He therefore switched to an English school before going on to Nanyang University. He is now educated in both cultures and is strongly anti-Communist, so the Communists have been the losers.

The security at the top, however, was excellent, and the Party direction particularly difficult to spot as it came from outside the school. The outside supervisor had contact with a very select number of boys and girls at the top of the structure in the school, and these changed every year. Moreover, since subversive activities, unlike the organisation of supplies or intelligence, could be carried out under general guidance promulgated in Party News, Wall Newspapers 
12. "Harris" (SB) Interview 1967.

13. See Chapter 9 for more details of this change of policy.

14. Extract from MCP Directive of 0ctober 1951, quoted in G.z. Hanrahan, The Communist Struggle in Malaya, New York 1954 .

15. In an interview 1967. 
or even, in guarded terms, in the Left Wing Press, direct contact between the Party supervisor and the cell structure inside the schools needed only to be rare. ${ }^{12}$

The Schools as a Training Ground for Party Workers for the Jungle War

During 1951 the tide in the jungle war began to turn and the Central Committee issued its Directive of October 1951, 13 recognising that unbridled violence was being counter-productive, and ordering a switch of emphasis to building up the popular base outside the jungle. The Middle schools were specifically encouraged to play their part - though still with an eye on the rural rather than the urban campaign:

"Town organisations must train up working personnel to send out to operate in the rural areas. To this end it is very necessary for the Party to be active among Middle School Students ..... ${ }^{14}$."

Mr. "Fu"15 of Johore Special Branch has described an interesting example of this policy in action, which also presents a microcosm of Open Front student subversion in Malaya. In 1951 an over-age student in his twenties - "Hong" - came under suspicion for his Communist activities at the Chinese High School in Penang and decided to move to Singapore. Here his father, who was headmaster of a Primary School in Singapore, bought Hong a false School Certificate, thereby qualifying him to apply for a teaching post himself.

Hong met another Communist whom he had known at school some years previously and who was now headmaster of a Primary School at Ayer Baloi - about 60 miles away in South Johore. Hong, and later also his wife, were taken on as teachers. It was a small school, with only four teachers in all - the Headmaster, Hong, his wife and 
Hong, as well as teaching the primary school children, organised evening classes for Chinese boys of Middle School age. Most of these boys did daytime jobs, so this filled a need that could not be filled for most of them in any other way. Moreover, if they had found time to study at the nearest High School - in the small town of Pontian 8 miles away - it would have cost $\$ 15$ a month, whereas Hong only charged them 20 cents a month for paper etc. He attracted 60 boys from Ayer Baloi alone.

Thus far one could have nothing but praise for the spare-time service he was giving to the young Chinese in his district, but before long, inevitably, their academic studies were supplemented by political instruction, initially innocent enough, but gradually becoming more subversive.

The next step was for Ayer Baloi students to attract brothers, sisters and friends from Pontain to help as part-time instructors. They made a basket ball pitch and invited teams from other schools. A liaison was established with Pontian High School, and likely sympathisers were sought out by asking seemingly innocent questions about social life in the school. Bacon and egg parties at Ayer Baloi and moonlight beach parties soon became the occasion for handing out propaganda publications. The next step was the formation of a secret cell system.

So far, Hong had acted entirely independently in accordance with his Communist training, but in 1952 he met an ex-MPAJA man who offered to put him in contact with the MCP in the jungle. Hong therefore addressed a letter to a member of the South Johore Regional Committee - Lee Hoi Fatt - asking for guidance.

The letter was in fact routed through the Pontian District Committee whose Secretary, Ah Chiau, was a young woman of great 
16. See Chapter 13

17. See Chapter 5 for an account of the function of the "Hsueh Hsin" cells for the study of Party affairs and techniques. 
ability whose District was a model of Communist clandestine administration. 16

She consulted Lee Hoi Fatt, who wanted to hear more. Ah Chiau therefore sent a message to Hong, asking him to park his car at a certain time a mile along the track into a pineapple estate from a certain milestone, and there to await instructions. She sent one of her contacts amongst the estate workers to fetch him, and handed him various Party publications (including, presumably, the appropriate portions of the October 1951 Directive). She congratulated him on what he had achieved, encouraging him particularly to develop the study cells, 17 and the secret side of his activities. There is little doubt that Hong's school thereafter turned out a considerable number of trained party workers well briefed on the strategy and tactics of the jungle war.

Special Branch knew nothing of these activities until the Regional Committee Member, Lee Hoi Fatt, was killed and a letter was found on his body. The handwriting was identified as Hong's by one of his former headmasters. Special Branch arrested Hong, his wife and the Ayer Baloi headmaster, together with 20 or 30 others. They told their story, but opted to be deported to China under the current surrender terms rather than become Special Branch agents to betray their comrades. Hong's wife has since returned to Malaya, and that is why he has been referred to by a pseudonym.

\section{The Revival of the Urban Campaign in Singapore}

By 1953, the war in the jungle was going very badly for the Communists, and the Politburo began to give more thought to the subversive campaign in the cities. Here too, however, they were having their troubles. In that same year the Party in Singapore, still a poor relation whose primary role was the support of the 
18. Douglas Hyde, Interview 1969

19. ibid. Douglas Hyde estimates that Open Front members sometimes had no contact with the secret organisation for 5 or 10 years and acted on their own initiative, guided only by their general knowledge and study of party policy. In some cases they went their own way, using the Party to further their own ideals.

20. ibid. 
jungle war, suffered a series of further blows from Special Branch, who smashed up the entire District Organisation, leaving the resilient Students' organisation as virtually the only functioning element of the Party.

From 1954 onwards, there was a marked revival of positive action towards an urban revolutionary situation in Singapore, though the weakness of the Party organisation in the City necessitated concentrating most of the talent on Open or semi-secret activities rather than on rebuilding a strong secret party cell structure. ${ }^{18}$

It would be misleading to regard this as the result of a conscious appreciation of the situation in the Central Committee in the jungle, resulting in a decision to switch from a rural to an urban strategy, followed by an orderly promulgation of that decision to subordinate units. This would be to credit them with a sophisticated communication system - upwards for information and downwards for orders - such as exists in an established government but not in a clandestine guerilla movement. 19 Nor would this be a normal practice for a Communist revolutionary movement - particularly one on the defensive. The MCP had no "Master Plan", either regarding the emphasis on city or guerilla revolution, or for Singapore itself. The Communists were never fully prepared, and their actions were dictated by events. The Party's policy (if such it can be called) was to expect all of its workers to keep up the pressure in their own particular spheres reacting to "objective conditions". 20 The commonly used analogy of the rising tide creeping up the creeks and lapping at the sea walls does not really apply. The party workers can better be compared to an army of ants surrounded by water, each hunting persistently for a crossing, largely unaware of the activities of his comrades elsewhere on the perimeter. Fven this analogy falls short, because as soon as a crossing is found - or more probably 


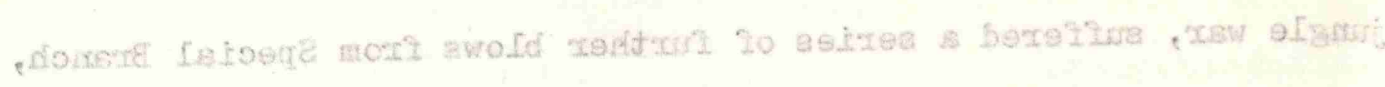

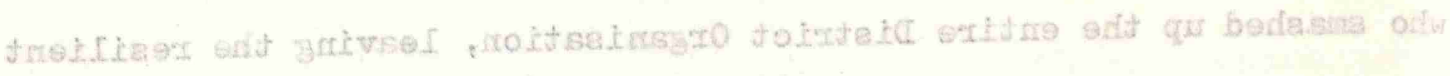

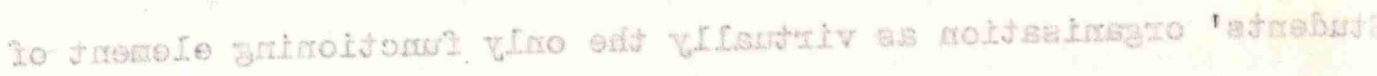

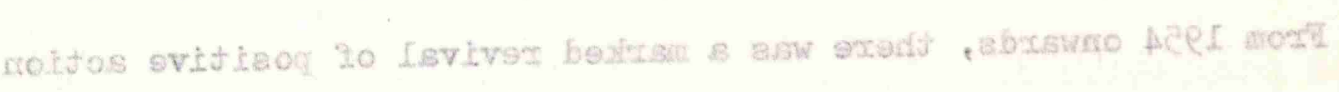

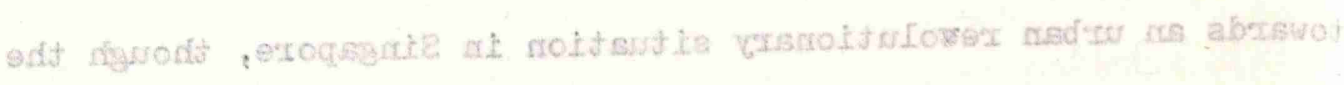

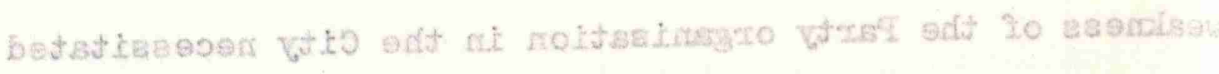

\section{See Chapter 9}

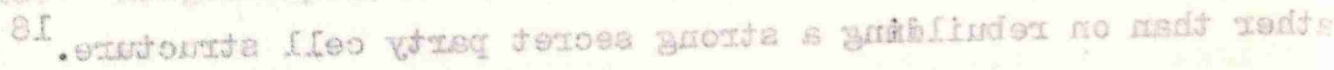

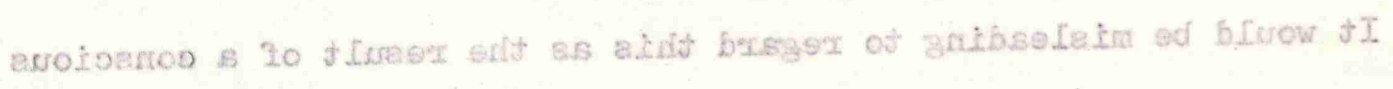

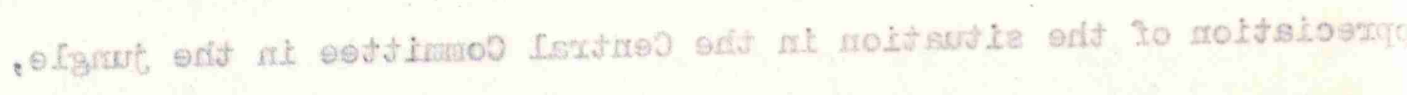

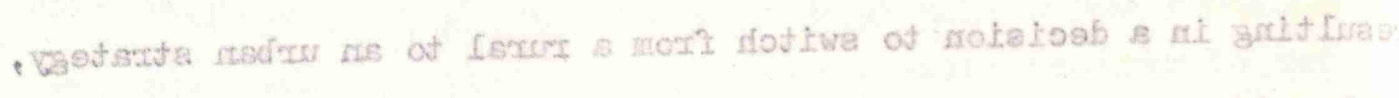

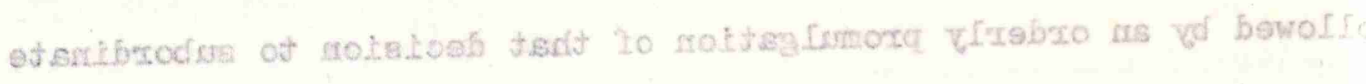

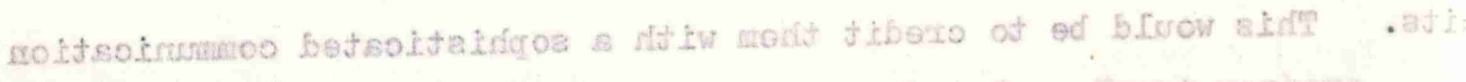

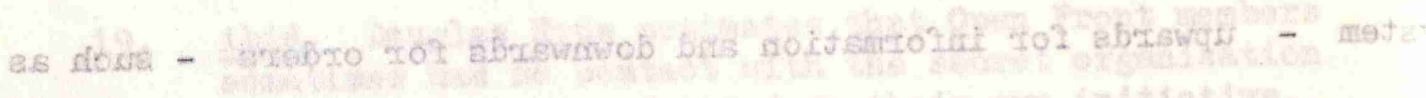

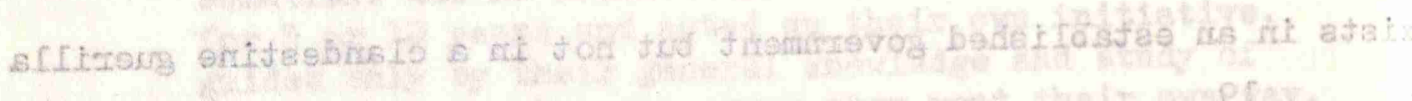

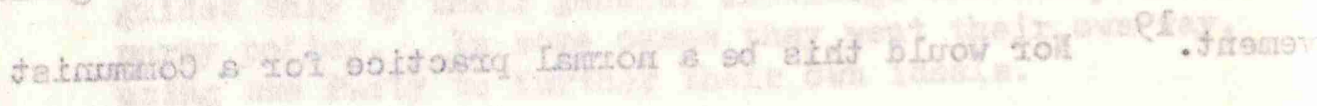

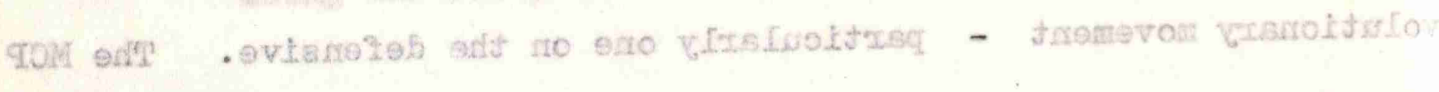

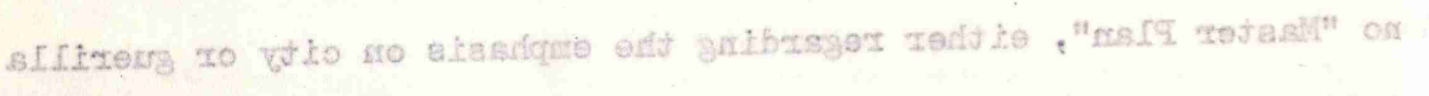

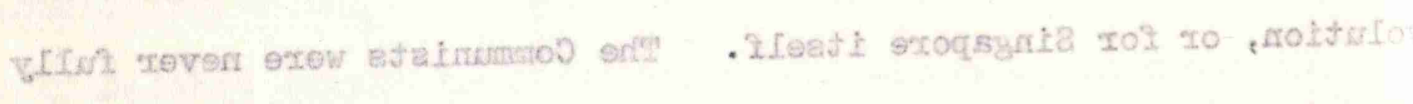

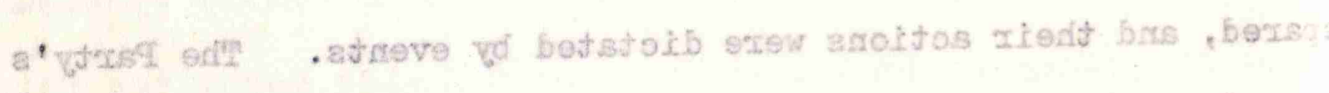

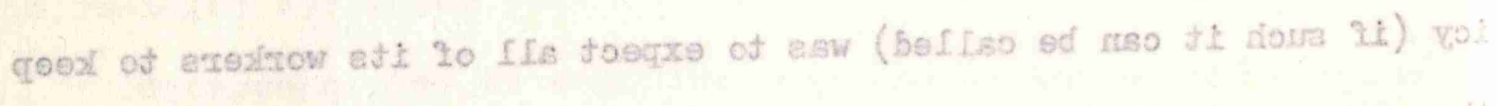

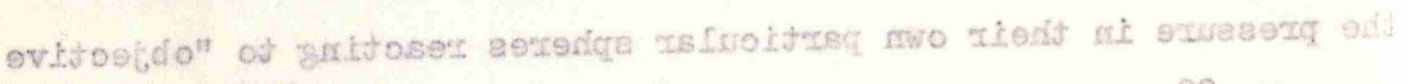

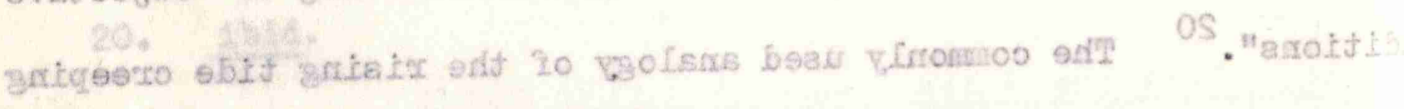

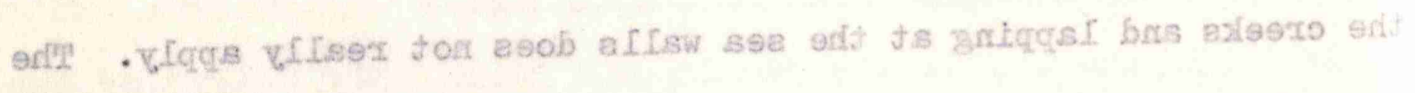

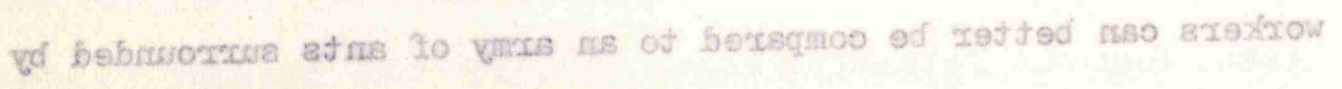

\section{Straits Times, 24th May, 1954.}

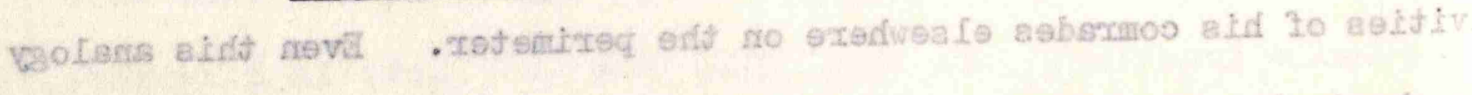

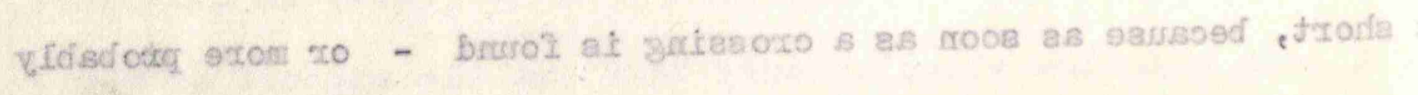


the water pushed back - many other less committed insects join the successful ants and some become ants themselves.

Thus the swing towards an urban strategy should be regarded as a reaction to events and an exploitation of opportunities. Amongst the more important of these events and opportunities were :-

(a) The massive reverses suffered by the Communists in the rural areas between 1951 and 1954, during which they. lost two-thirds of their fighting strength, and support in the Chinese villages fell even more than that. 21 The Central Committee had shown considerable foresight in attempting to forestall this by their October 1951 Directive, but they had failed to do so. In other words, there now seemed little hope of breaking out on the rural flank.

(b) The imminence of self-government, common talk through 1953, and culminating (in the case of Singapore) in the Rendel Constitutional Commission Report on 22nd February, 1954. This gave rise to the hope of the election of a weak liberal government, committed to relaxing irksome security restrictions, and thereby giving the Communists their chance - the "fat bunny" regime which is the historic appetizer for urban revolutionaries.

(c) The relaxation of restrictions on Trade Union activities also announced in the Rendel Report.

(d) The enforcement of the National Service Ordinance, under which Singapore students were required to register for conscription by 22nd May, 1954, at pain of six months in gaol or a fine of $\$ 2,000$ or both. 22 
23. Straits Times, 14 th May 1954

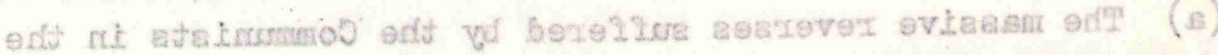

24. Straits Times, 15 th May 1954

25. Legislative Assembly, Singapore, Sessional Paper, No. CMD53 of 1956, Singapore Chinese Middle School Students' Union, Singapore October 1956. (Hereafter known as "White Paper SCMSSU 1956").

26. Chinese High School and the Catholic High School (boys); Chung Cheng (Main and Branch) and Yong Ing High Schools (mixed); Nanyang, Chung Hwa (two branches), Nan Hwa and Nan Chiau Girls' High Schools.

27. Straits Times, 22nd May 1954

28. The psychology of the boys and girls locking themselves into the Chinese Schools lay in the retreat to a congenial environment away from the environment of a society which seemd to them to be alien and anti-Chinese. This group psychology was fully and ably exploited by the Communists. G.G. Thomson, para. 15.

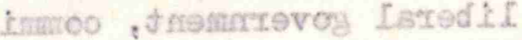

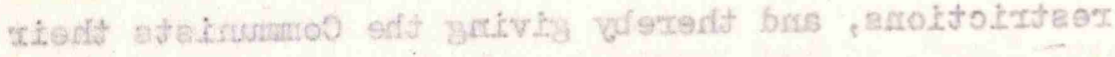

29. Straits Times, 24th May 1954 ts $2^{\prime \prime}$ ed -

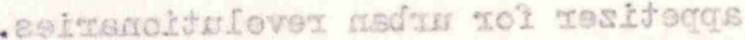

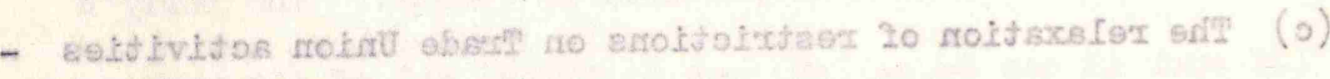

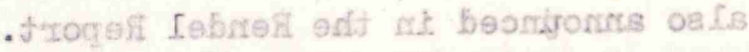

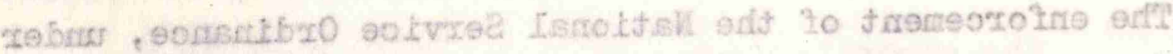

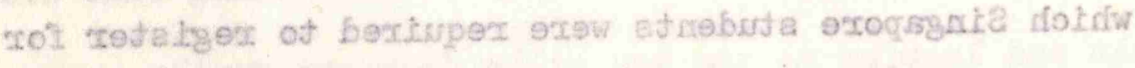

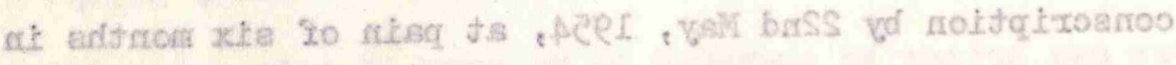

30. G.G. Thomson, para. 13 . 
Only the student organisation was in a position to lead the exploitation of these opportunities. This they did on 13th May 1954, in a violent demonstration against the National Service Ordinance. 500 demonstrated and 26 were injured ( 6 Police and 20 students). 44 boys and one girl were arrested - all over 16.23 All were released next day on bail. Later, 1,000 locked themselves into the Chung Cheng High School, and were forced out next day. 24

On the 18th May, a delegation 55 strong demanded that students be exempted from National Service. Their request was refused. 25

A week later, the threat of further demonstrations led the Directors and Principals of $10^{26}$ boys' and girls' high schools to close them by advancing the summer vacation by two weeks. Over 15,000 Chinese boys and girls were affected. 27

On Saturday, 22nd May - the day after this announcement - 2,500 boys and girls locked themselves into the Chung Cheng High School. 28 At dawn next morning (Sunday) their parents, mainly mothers, came to fetch them out. The student leaders initially tried to prevent the parents from entering the school, but were later persuaded by the police to allow them to pass. The school was cleared without violence by 11 a.m. 29

The National Service issue was a godsend for the MCP. To mobilize boys who, because of their Chinese education, would be given the poorest chances in the alien colonial society which they were being called upon to defend was a gift to Communist slogan writers. Moreover, it offered an anti-colonial issue on which the English educated Chinese would join them. It was in this climate that Lee Kuan Yew's Peoples Action Party (PAP) was founded. 30 The demonstration in May 1954 was hardly a success, but it did much to awaken students' consciousness and 
31. "Seng" (SB) and Ong Ban Chai, both in interviews in 1967.

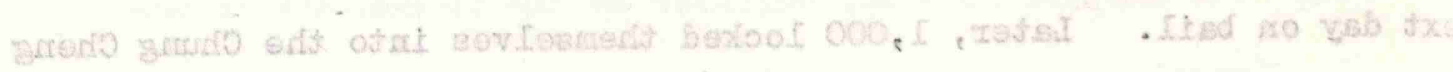

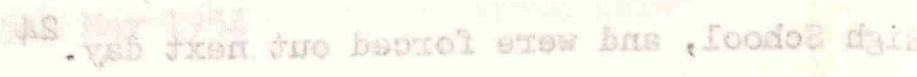

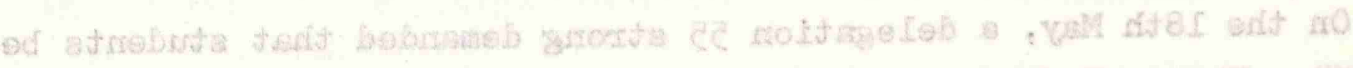

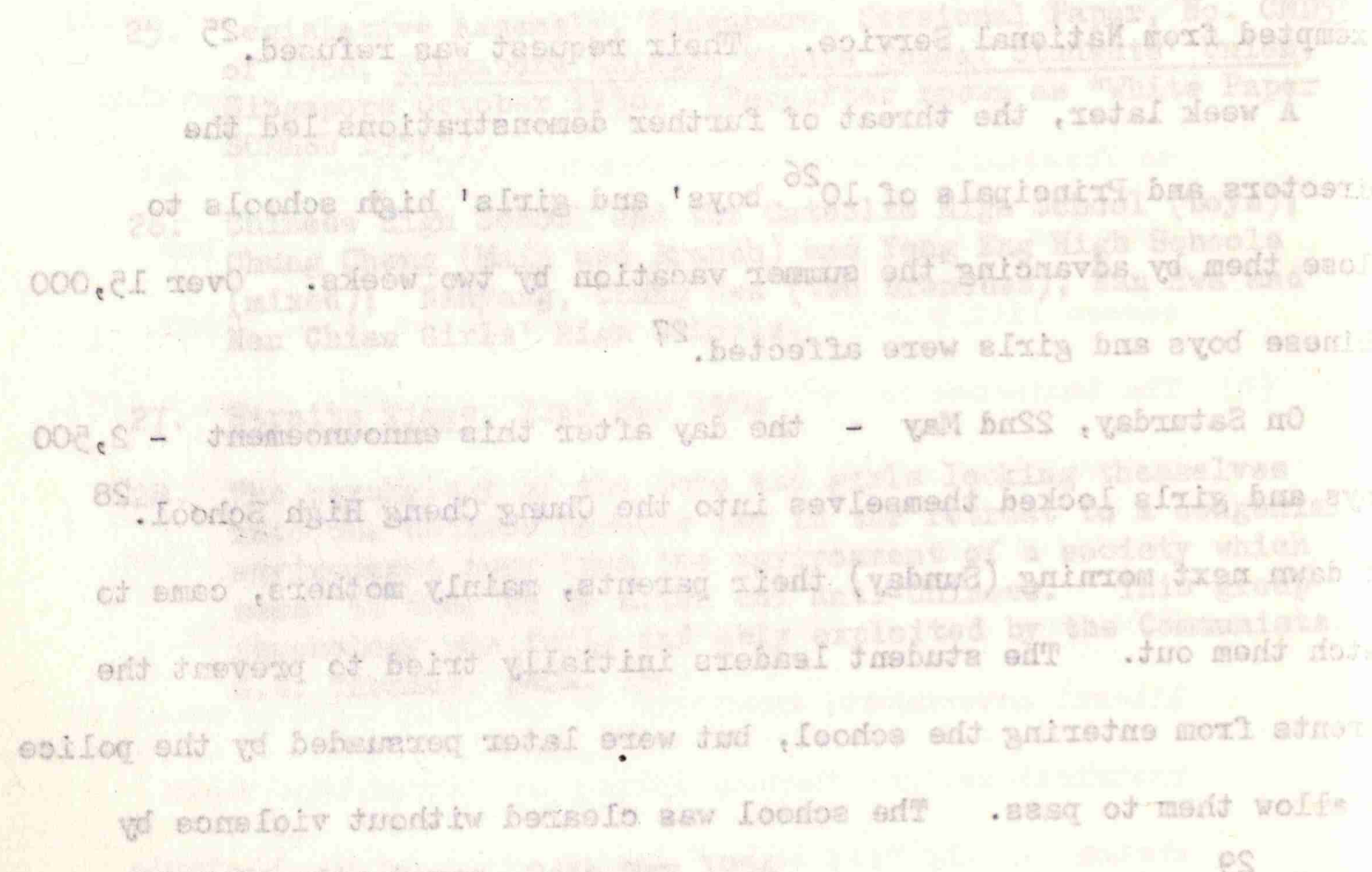

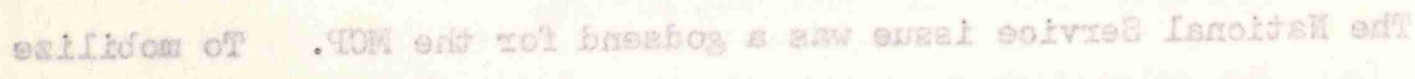

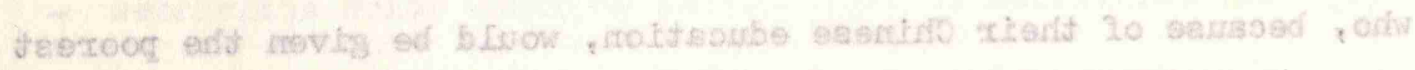

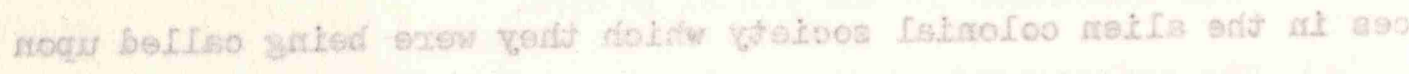

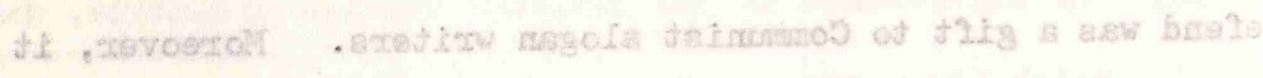

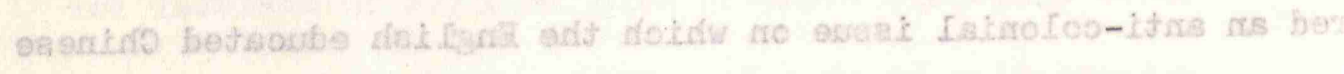
sefegote'

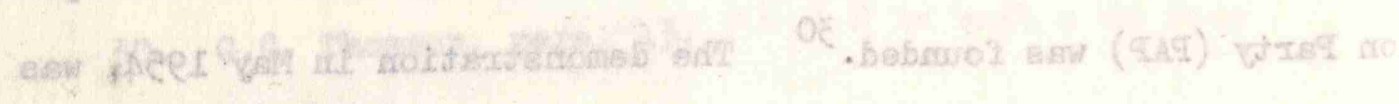

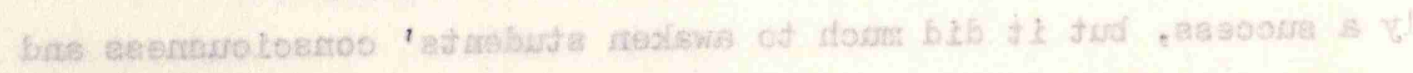


corporate spirit and to strengthen the position of their leaders. Moreover, the Chinese public were always sensitive about any interruption of the process of education in the Chinese schools, and their sympathy was strengthened by the use of violence by the police against schoolchildren. 31 
政

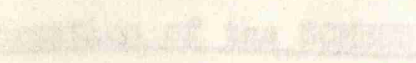

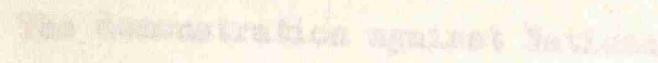

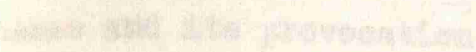

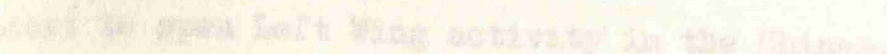

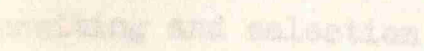

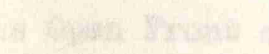

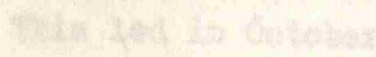

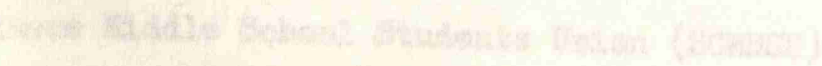

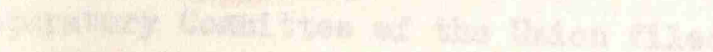

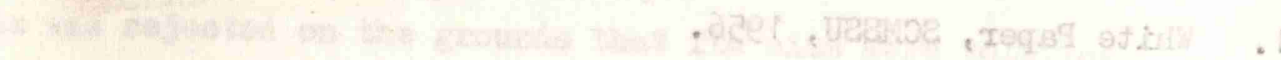

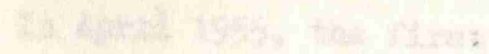

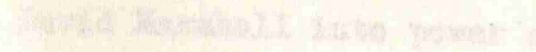

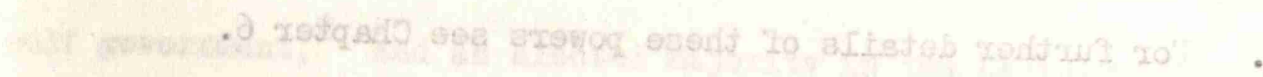

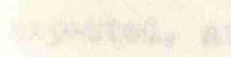

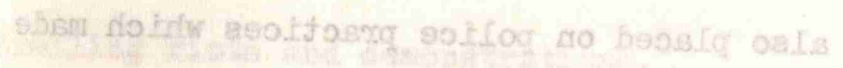

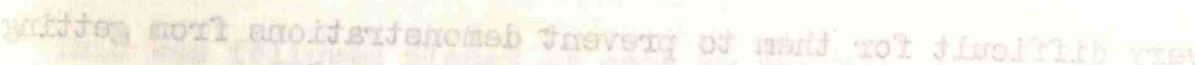

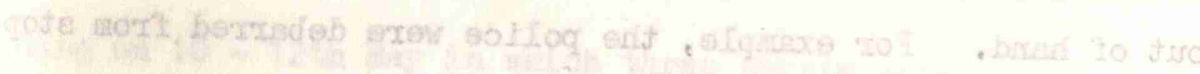

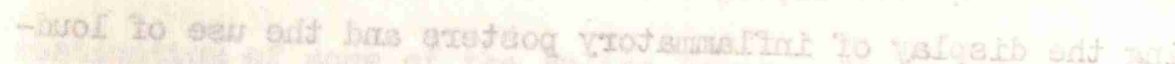

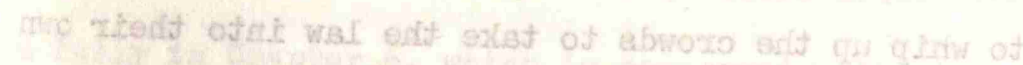

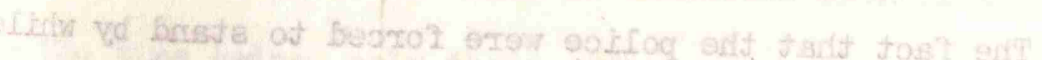

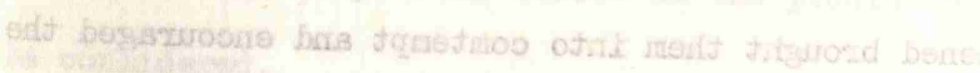

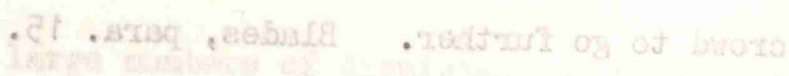


1. White Paper, SCMSSU, 1956.

2. For further details of these powers see Chapter 6.

3. Restrictions were also placed on police practices which made it very difficult for them to prevent demonstrations from getting out of hand. For example, the police were debarred from stopping the display of inflammatory posters and the use of loudspeakers to whip up the crowds to take the law into their own hands. The fact that the police were forced to stand by while this happened brought them into comtempt and encouraged the crowd to go further. Blades, para. 15.

4. Straits Times, 29th April, 1954. 


\section{SUBVERSION IN THE CHINESE MIDDLE SCHOOLS 1954-56}

\section{Formation of the SCMSSU}

The demonstration against National Service in May 1954, with its popular cause and its provocation of the use of force by the police, gave a tremendous boost to open Left Wing activity in the Chinese Middle Schools. The Party recruiting and selection process had drawn many of the most able leaders into this Open Front organisation, and these became popular heroes.

This led in October 1954 to a public proposal to form a Singapore Chinese Middle School Students Union (SCVSSU). On 7 th January, 1955, the Preparatory Committee of the Union filed its application for registration, but this was rejected on the grounds that its aims were political. 1

In April 1955, the first elections under the Rendel Constirutional put Mr. David Marshall into power as the first Chief Minister, with limited power of self government, ${ }^{2}$ and an elected majority in the Legislative Assembly. As expected, at the first meeting of the new Parliament on 22nd April he announced the removal of certain of the powers used by the Police for controlling riots and demonstrations. 3

This was followed almost at once by the Hock Lee Bus Strike, leading to rioting on 10 - 12th May in which three people were killed. These riots, and the restoration of some of the Police Powers afterwards, will be discussed more fully in Chapter 6, which is concerned with rioting and riot control. For the time being, only their effect on the process of student subversion will be considered.

During the strike, large numbers of dismissed bus workers locked themselves into the Hock Lee Garages in Alexandra Road, posting pickets on the gates. From 28th April onwards, thousands of school children brought them food and entertained them with singing and dancing. 4 On 10th May the pickets were removed by the police, and rioting began. On 12th May, twenty lorry 
5. London Times, 13th May, 1954.

6. Michael Gorrie - Interview 1967.

7. London Times, 14th May, 1954.

8. The senior British official in the Singapore Legislative Assembly.

9. London Times, 17th May, 1954.

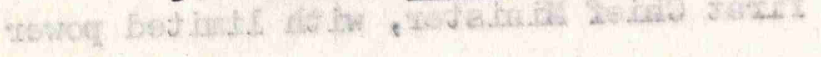

10. Blades, para. 16 .

11. London Times, $23 r d$ May, 1954.

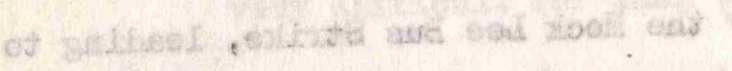

12. London Times, 17th Nay, 1954. It must be noted, however, that the British Governor still retained much of the control over Internal Security measures. See Chapter 6. 
loads of Chinese Middle School Students joined the demonstrating strikers, and seventeen more were intercepted by the police. 5 These lorry loads converged with military precision and timing from schools all over Singapore. $\underline{6}$

On the 13 th May, the Government closed three Chinese schools for a week ${ }^{7}$ and ordered the expulsion of some of the ringleaders.

On the 14th May, the Hock Lee bus strike was settled by government arbitration on terms generally favourable to the strikers.

The focus then shifted to the schools, where the students had locked themselves in to protest against their closure and the expulsion order. The Chief Secretary ${ }^{8}$ Mr. Goode, said in the Legislative Assembly that the part played by the students in the demonstrations was highly organised, and that the School Principals feared assassination. The London Times correspondent reported, however, that the School Management Committees (composed of leading and generally conservative Chinese citizens) refused to take a line at all and seemed to be frightened of the students. ${ }^{9}$ The police who had no legal power to enter the school except at their request, were never asked in until violence had actually begun, so subversion and mass meetings went unchecked. ${ }^{10}$

On 22nd May the stay in strike in the high schools ended when the Govermment withdrew its demands for the expulsion of the student ringleaders. 11

The newly elected government had shown some resistance to mass coercion in its use of the police to break up the riots, and in restoring some of the suspended police powers on 16 th May. ${ }^{12}$ Nevertheless, it har made concessions both to the strikers and to the students, and the students had successfully intimidated many of their school management committees and teachers. The struggle had polarized into the familiar one of the students versus the establishment, and the students rallied to their Open Front leaders. Their blood was up.

Meanwhile, the MCP had instructed the Preparatory Committee of the SCMSSU to reverse their earlier attitude and to seek registration by accepting the governments condition that they undertake not to take part in political 
13. White Paper, SCMSSU, 1956, p. 1.

14. ibid p. 3 .

15. ibid p. 4 .

16. ibid p. 18 .

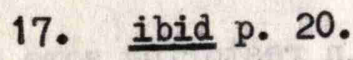

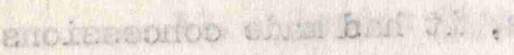

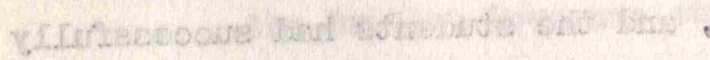

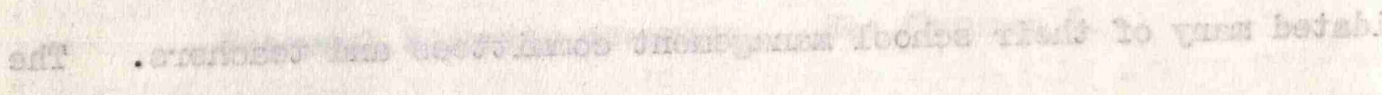

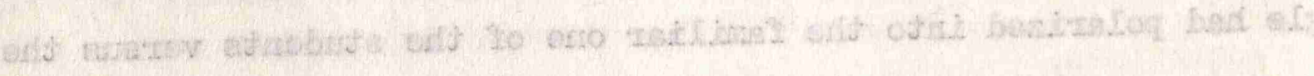

18. HQ Singapore Base District Report on Military Action in Singapore Riots 25 th October, 56 - 2nd November 56, p. 5 (hereafter referred as "Military Report, 1956 Riots"). See also Chapter 4. 
activities or to interfere in labour disputes. They were to give their undertaking without any intention of carrying it out ${ }^{13}$ - a normal .Communist tactic for getting the advantages of legal recognition. This they did on 28 th July, 1955 and on 6 th October their registration was approved. 14

Fourteen days later they launched a campaign against the condition that they had been asked to sign, and at their inaugural meeting on 30th 0ctober they attacked the Public Security Ordinance and government educational policy. On 11 th November, they were warned that they would be dissolved if they continued such political activities, but they rejected this warning at a protest meeting.

On 13th December there was another bus strike - this time against the Singapore Traction Company - and once again the students gave organised support to the strikers.

In March 1956, the SCMSSU leaders became more openly pro-Communist. They protested against the banning of a concert whose programme contained pro-Communist items, and their President, Soon Loh Boon, spoke from the platform at a meeting celebrating the Communist Womens' International Day. ${ }^{15}$ Their flag bore a five-pointed Communist red star on a yellow background, in calculated similarity to the MCP flag - a yellow star on red ground. ${ }^{16}$ In June and July 1956, they held holiday indoctrination classes for over three hundred trade union executives. ${ }^{17}$

The dissolution of the SCMSSU was to be the main pretext for the trial of strength in the October 1956 riots, so this and the events surrounding it will be described in Chapter 6. The current chapter is concerned with the subversive action - open and secret - carried on in the Chinese Middle Schools from the time of its conception after the National Service riots of May 1954 until its dissolution and the arrest of its leaders in October 1956. Party and Open Front Structure in the Schools

The SCMSSU incorporated ten Chinese Middle Schools, with a total student population of nearly 16,000 boys and girls, aged from ten to twentythree, ${ }^{18}$ 
19. White Paper, SCMSSU, 1956, p. 14.

$\frac{\text { PARALIEL OPEN AND SECRET PARTY ORGANIZATIO }}{\text { IN THE CYINESE MTODLLE SCHOOLS, 1954-56 }}$

( $\mathrm{SECR}$ E T

O.PEN FRONT

M.C.P. Outside Supervisor



Figue $5 \mathrm{~A}$

19

Source "Yung" Interview 1967.
20. These were also sometimes known as Senior Middle (SM 3,2 and 1) and Junior Middle (JM 3, 2 and 1)

21. Source "Yung" - Interview 1967.

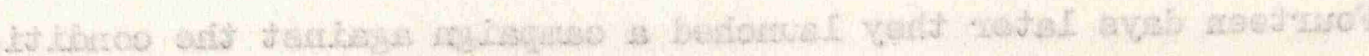

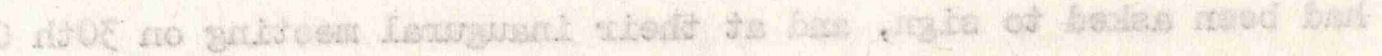

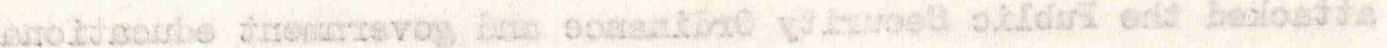

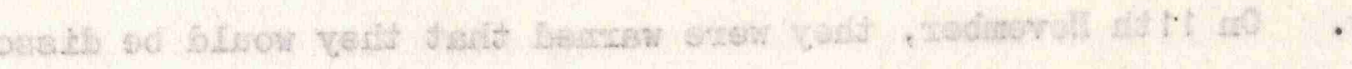

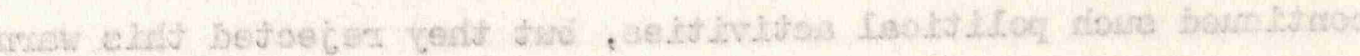

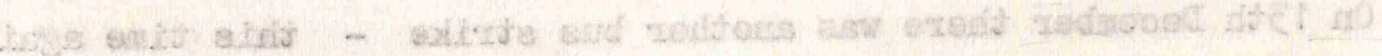

22. "Yung" - Interview, 1967.

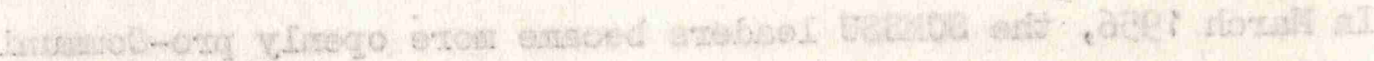

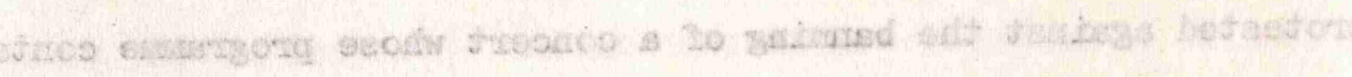

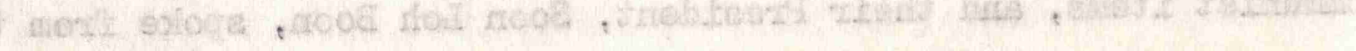

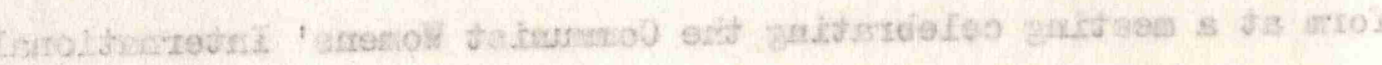

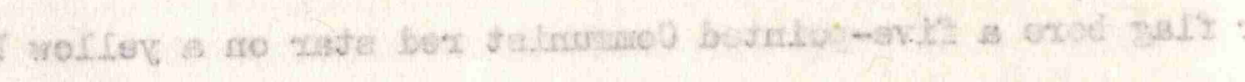

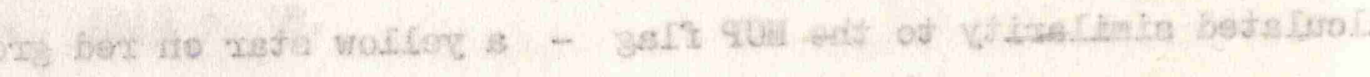

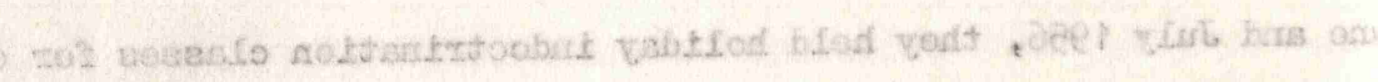

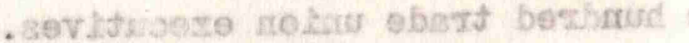

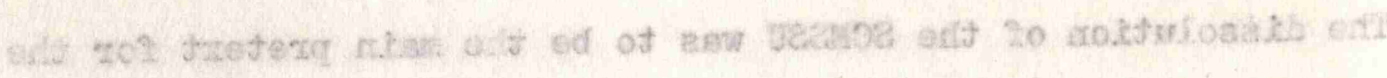

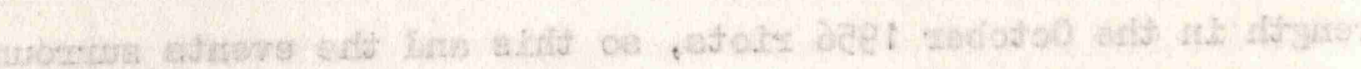

23. "Ching" - Interview, 1967.

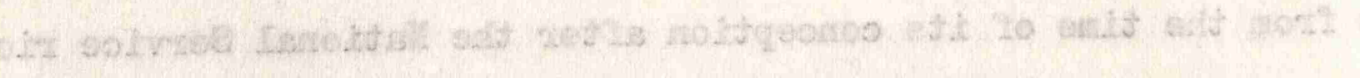

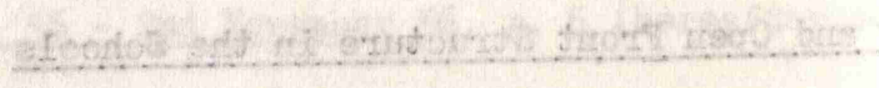

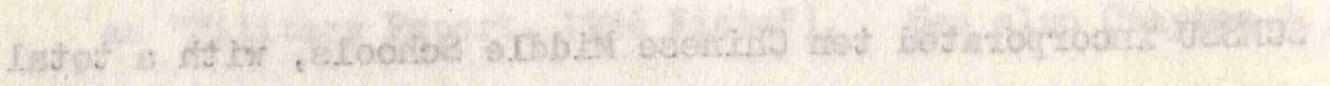

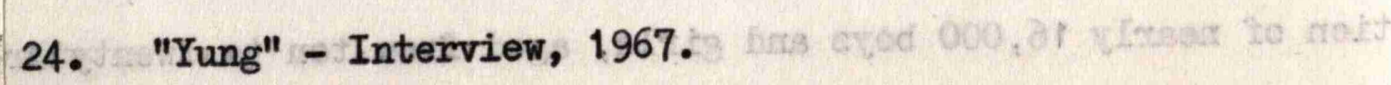


and claimed in 1956 that it had 10,000 members. ${ }^{19}$

Fach school had six standards or grades - Senior 3, 2, and 1 and Junior 3,2 and 1.20 The Open Front Organisation (see Figure 5A) ${ }^{21}$ was run by six Standard Committees, one for each standard. In a large school, a standard might contain several hundred children, mainly of the same age group (though with some over age students amongst them). The Standard Committee normally contained six or seven members from that standard, plus two or three from more senior standards to give guidance and supervision. The Presidents of the six Standard Committees formed the School Committee, which was the "GHQ" of the Open Front in the school, receiving secret guidance from the Party Supervisor outside the school.

In a school of 1,000 boys and girls, there would normally be about six classes in each of the Junior 1, 2, and 3 standards with drop outs narrowing the size to about three classes in the final year. ${ }^{22}$ At the Chinese High School (2,000 boys) there were about 50 classes in all. Each class elected a monitor and an assistant monitor, so there were about 100 of these in all at the Chinese High School and perhaps 150 at Chung Cheng High School, which contained 3,000 boys and girls.

One of the functions of the Standard Committee was to sponsor the election of its own nominees (often over-age students) to be monitors and assistant monitors. This not only gave them a stranglehold on the school's disciplinary structure, but provided them with a structure of their own.

The monitors established their position by genuine welfare work such as the establishment of a Students Mutual Assistance Association (SMAA) to raise funds to aid poor students, though such aid was not always entirely disinterested. 23 They also organised propaganda meetings and published a Wall Newspaper, whose aim was to promote political consciousness. The Wall Newspaper criticised the Government rather than the school staff, since the editors were anxious to avoid prohibition. Many of the staff, certainly at the Chinese High School, knew very well what was going on, but dared not interfere. 24 
25. White Paper, SCMSSU, 1956, p. 15. These are, of course, standard Communist techniques world wide. In "The New Face of War" Iondon 1966, pp. 230-233, Malcolm Browne describes the Vietcong organisation amongst South Vietnamese students in Paris. The $\mathrm{HQ}$ was in a garage, which provided the front for their organisation. Here the students would gather in a happy atmosphere, with guitars, games, food and drink. Senior students acted as waiters, and were addressed neither as "boy" nor "sir" but as "comrade". There were discussion groups and cultural evenings. There was no direct political pressure

- (which would have involved a security risk) but promising students found themselves invited to become waiters or group leaders. They were persuaded that on graduation it would be better not to return to South Vietnam but instead to work in North Vietnam for the liberation of the South. The Vietcong claimed that $90 \%$ of the South Vietnamese in Paris were on their side.

26. White Paper, SCMSSU, 1956, p. 15.

27. See later in this chapter for discussion of the position of the teachers. 
Indoctrination and "agitation of the young masses" was probably the most important task of the School and Standard Committees and of the monitors they controlled. The first thing was to attract the maximum number of students into their sphere of influence. As an example, the Chung Hwa Girls High School Branch of the SCISSU reported that they were using

"Lively and subtle working methods to carry out resolutions on propaganda work, more especially by the various small-scale activities, such as lunches, tea-parties, in acting plays, collective visits to a cinema etc.,

"All these small-scale activities suit the taste of fellow students very much. Consequently the majority of the fellow students were organised in this way." 25

The same branch later described the next stage of its "Programme" in publicising resolutions (of the SCMSSU).

a. Meeting held by the working personnel of the branch. (i.e. the School and Standard Committees) to review and study the resolutions.

b. Issue an "Express News."

c. Meeting of fellow-students (i.e. the "young masses").

d. Meeting of working personnel of the classes, (i.e. of monitors sponsored by the Standard Committees).

e. Issue Wall Newspaper and Blackboard News.

f. The various classes proceeded with small-scale activities and studied the resolutions.

g. Reunion dinner. 26

The Chung Cheng High School reported similarly, and included also visits to tutors as well as to students, and a broadcast to the whole school, of which the script was afterwards distributed. This was with permission of the school authorities. 27 They also reported holding Tests on Current Affairs and "Fill the Blank" games. 
28. White Paper, SCMSSU, 1956, p. 15.

29. ScMSsu Study Outing June 1956, quoted in White Paper, SCMSSU, 1956, p. This is in accordance with a standard technique outlined by Mao Tse-lt and quoted in the same document. 
The questions in these tests were often naive, but made no attempt to conceal their propaganda purpose. For example:-

"Out of the various newspapers in Singapore, which one contains news which is most untrue and with most distortion of facts? (List given, say WHICH).

"The people in the New Villages in the Federation of Malaya are leading a very free life. (YES or NO).

"Malaya is situated in South-East Asia or North-East Africa or South-West Europe. (WHICH)."

The "Fill in Gap" questions were on similar lines - for example:"Malaysia has been ruled by the British Colonialists for ... years. "The tragic incident of May 13th occured in ... (year) at ... Park and ... Road." 28

The SCMSSU also made subtle efforts to represent its views and policies as coming from students:-

"Similarly, after the SCMSSU has collected the numerous but loose and unsystematic views, they will be adjusted into complete systematic common views which will be handed back to the fellow students. The School Committees will lead the fellow students in carrying them out. "Of course before carrying them out, the School Committees should first patiently and carefully make propaganda among the fellow students about the meaning and contents about the resolution passed. The fellow students are then allowed to give the matter consideration and discussion so that thereafter the resolution may be turned into the students' own views and demands and carried out accordingly." 29

The "meetings of working personnel" were the main spring of these activities, and were used to check on their work. Being part of the Open Front, each member of the School Committee knew all the working personnel under his command (i.e. in his own standard) and was kept informed of their statements and answers to questions at their self criticism meetings. He 
30. "Harris" (SB) - Interview 1967.

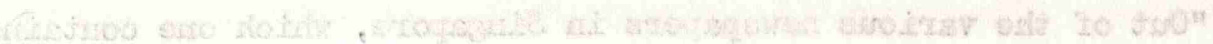

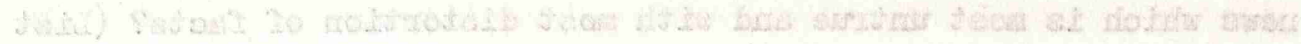

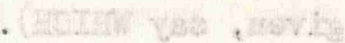

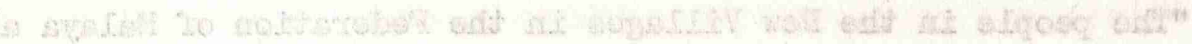

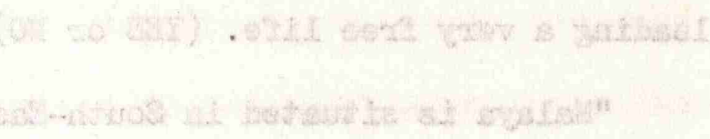

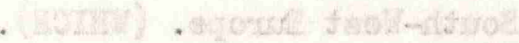

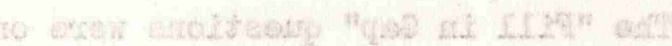

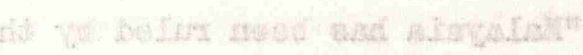

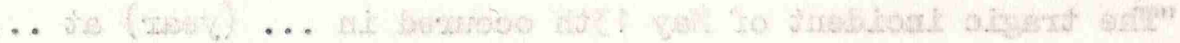

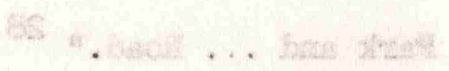

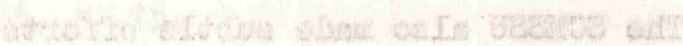

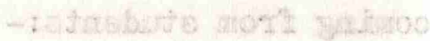

31. "Yung" - Interview 1967.

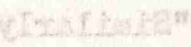


did not, however, know members of other standards, except in so far as their leadership made itself obvious on demonstrations, etc. 30

There was also, however, an element of "strength through joy" in some of the activities of the working personnel - particularly in the joint meetings between equal ranking Standard Committees from brother and sister schools. For this purpose neighbouring schools were affiliated, where possible, to make an added attraction by mixing boys and girls. For example, The Chinese High Schools (2,000 boys) in Bukit Timah Road was affiliated to Nanyang Girls High School (1,000 girls) which was only a few hundred yards away, and with The Chung Hwa/High School (1,200 girls) which, though several miles away, was easily accessible by the ring road. The three Standard Committees of, say, Senior 2. Standard would meet for picnics in the park around the nearby MacRitchie Reservoir - an ideal site with its large surrouding jungle reserve into which the party - some thirty boys and girls in all - could withdraw to complete seclusion if they felt that they were being watched. They would hold discussions on current affairs generally, or on the specific tactics to be adopted in resisting the government education policies or the National Service Ordinance. 31 Unlike those in the secret and earnest $A B L$ cells, these boys and girls did not yet have to endure the dreary catechism of the more theoretical Communist studies, so they generally enjoyed themselves and got great satisfaction out of being members of a lively elite, the thirty of them holding power over about 1,000 of their fellow students, through the monitors, and the study and tuition cells. The three Presidents in particular would look forward to making rather priggish reports of their activities to their School Committees.

\section{The Secret Organisation}

The members of The School Committees, as the Open Front leaders, were, of course, the "ringleaders" whose arrest was threatened in 1955 and carried out in 1956. Nevertheless, many of them were also members of the parallel secret organisation. According to rigid Communist theory, these potential or 
32. "Seng" (SB) - Interview 1968.

33. Lee, Kuan Yew, in The Battle for Merger, Singapore 1961, published some notes which he ascribes to Lim Chin Siong, who, he says, used them for "...a talk he gave in commemmoration of the death of Stalin, to his immediate supporters in the AntiBritish League cell, whose instruction in Marxism-Leninism was his personal responsibility. This talk was given by him in June 1953...." (p.99). There is no doubt about the Communist nature of these notes. For example, "Dear Comrades! We must not forget that we have taken an oath before the Red Flag and Comrade Stalin. We have already become combatants for national liberation! Today, when our most respected and loving leader has left us for ever, and at a time when the enemy has become all the more fanatical in his attacks against us, our duty has clearly become all the greater..." and "... Comrades should take a further step in striving to become glorious Party Members in their work". (p.121) 
probationary party members should not have risked arrest by open activities, but should have concentrated on their theoretical studies of Communist doctrine and revolutionary techniques, and on training themselves to emerge, unsuspected by the police, as party workers for the secret organisation outside. In practice, however, the importance of good leadership and organisation in the schools and in demonstrations, and the weak state of the Party's secret structure as a whole in Singapore, meant that most of the best leaders joined in the 0pen Front Activities. 32

All the same, the secret ABL structure did exist, and in some schools was very strong. These cells were, of course, avowedly Communist, ${ }^{33}$ and members addressed each other as "comrade" whereas in the Open Front organisation (including the semi-secret Study Cells) the members called each other "fellow students". ABL members also used party names, and distributed amongst themselves (and amongst trusted sympathisers whom they hoped to recruit) a clandestine "Free Press" which is not to be confused with the Wall Newpapers, Express News, etc., which were distributed as open propaganda to the whole school.

Recruits for the ABL cells were found, after the usual apprenticeship in a sympathiser cell, by selection from amongst working personnel in the Open Front organisation. As well as ability, power of leadership, popularity, etc., the boys background was also carefully checked.

There was, however an element of Communist snobbery here. It was Party philosophy that a boy of middle class background, however dedicated a Communist, might one day be attracted back to his bourgeois tastes and ambitions, and, if entrusted with the innermost party secrets, might betray them. A boy of proletarian origin, however, should in theory have neither the desire nor opportunity to acquire bourgeois tastes or ambitions, and, if he attained a responsible position in the MCP structure, should feel that he would never have been allowed to attain such a position in a capitalist society, and that he therefore owed everything to the Party, and would have everything to lose 
34. "Yung" - Interview 1967.

35. The Chinese Middle School Students Arts Society, banned in $1,956$.

36. "Yung" - Interview 1967. Also Straits Times 18th and 19th April, $195 \%$

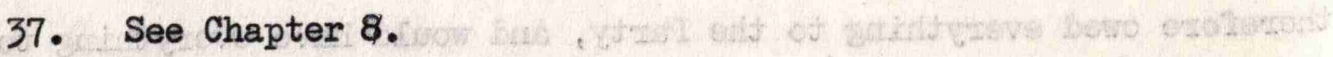


by betraying it. Though there were some notable examples of boys of middle class background joining the ABL and reaching high positions later on, there was at school a definite prejudice against them. 34

So "Ching", son of a contractor, was drawn into the Open Front structure of the Foon Yew High School, and became treasurer of the SWAA, but received no overtures from the secret organisation. On the other hand, "Yung", one of seven childrem of an unemployed father and of a mother who supported the family by working as a hawker for three or four dollars a day, was under constant pressure to join the ABL. He resisted this, though he was a member of his Standard Committee all the way from Junior 1 in 1955 to Senior 3 in 1960, and well knew that these were Communist sponsored. Indeed, one of his supervisors was Cheng Yew Leng, who was arrested in 1956 and deported to China. Many of his friends were $A B L$ members, and gave him copies of their clandestine Free Press, but he did not join, because he realised that it would place him between two grave hazards. If discovered, he would sacrifice his chance of education. If, on the other hand, he were to leave when once he had joined, he would risk being assassinated.

He had experienced a frightening demonstration of Party ruthlessness when he was only twelve or thirteen, before he had left Primary School to join the Chinese High School. On 17th April, 1955 he was attending a rehearsal of a folk dancing performance to be staged by a Front organisation. 35 The conductor of the band was a twentyone year old Chinese High School student, Lee Ta Lim. He was called from the rostrum and shots were heard outside. Lee's body was found in a pool of blood. He was suspected of having betrayed the Party, so there was little expression of sympathy for him, and no-one came forward when the police offered a 20,000 Dollar reward for information. 36

So "Yung" never became a Communist, though, with his strong powers of leadership and working class background, the Party worked hard to get him. Indeed, when he went on to Namyang University, he led the opposition to the Communist attempt to take over the Students Union, 37 and is now a teacher at 
38. Military Report, 1956 Riots, p. 5.

39. Douglas Hyde, Commentsts on first draft, June 1969.

$40 \quad$ "Harris" (SB) - Interview 1967.

41. White Paper, SCMSSU, 1956, p. 8.

42. "Fu" (SB) - Interview 1967. 
the Chung Cheng High School and an active member of Lee Kuan Yew's Peoples Action Party. His experience in the Communist Open Front organisation stands him in good stead, and he has a highly promising future. Study and Tuition Cells

The third sphere of influence of the Party in the Chinese Middle Schools was the twilight world of the "Hsueh Hsih" (Study) Cells, and of the Tuition Cells which fed them.

When the SCMSSU Preparatory Committee drafted its Constitution in 1954, there, were two sinister aspects which were noted by Special. Branch. The first was that membership could be extended one to two years after leaving school which added great strength to the continuity and supervision of Open Front activities. The second was the inclusion of "the betterment of education" amongst its aims, in such a way as to leave no doubt that it planned to use a comprehensive organisation for assisting students in their academic studies as a cloak for political indoctrination, ${ }^{38}$.even though the mutual help.element was none the less real. 39

The nearest translation of Hsueh Hsih is "Study-Action" or "StudyPractice", and it incorporates the Communist idea that study without practical work - the student in an ivory castle - is no good. The Hsueh Hsih cell is in fact an adaption of an old Confucian analect about how the young should educate themselves, and now provides the basis for the lowest cell of Mao-ism ${ }^{40}$, first introduced by Mao Tse-Tung in October 1938. 41 It is a Communist vehicle for assessing and educating the "Grey Masses" (i.e. potential sympathisers) and, though part of the Open Front organisation, its activities are conducted with discretion. 42 These Hsueh Hsih cells will hereafter be referred to as Study Cells.

Prior to being invited to join Study Cells, promising boys were attracted into wholly open Tuition Cells. These were precisely what their name implied. A senior student would offer to form a "seminar" of young students to help them with their studies - in itself a laudable activity. Indeed the SCMSSU 
43. White Paper, SCMSSU, 1956, p. 16.

44. ibid. p. 14. Presumably these particular executives (i.e. monitors) were ones whose posts had not been captured by the Standard Committee's nominees.

45. "Ching" - Interview 1967.

46. "Fu" (SB) - Interview 1967.

47. "Yung" - Interview 1967. For example, the tale of Liew Fu Lan, aged sixteen, who was arrested and killed by the Kuomintang, or one of Mao Tse-Tung's poems. 
claimed that this was their chief function, and used it to inflame public opinion when threatened with dissolution.

These Tuition Cells might be anything from a handful to fifteen strong。 In Chung Cheng High School they were about nine strong, each class being divided into three or four cells as some students were shy of speaking their minds in front of the whole class. 43 Sometimes the Tuition Cells arrogated to themselves wider functions. One school branch, for example, reported the formation of a fifteen man cell to "assist" the class executives elected by the students who were found to be inefficient. 44 Detailed methods varied.

In the Tuition Cells, young students were helped to pass exams, made friends, and gained respect for the senior students who helping them. He, of course, was also a party worker, either in the Open Front or the Secret Party organisation, or both, and it was his duty to discover background data about his students to decide whether they were suitable as recruits for the Study Cells. 45

While he might join a Tuition Cell in his first term, a student would not normally be considered fit to join a Study Cell until he reached Senior 1 Standard - i.e. the age of fifteen or sixteen. He might then become a Study Cell leader in his penultimate year. In his final year (Senior 3), he would rise out of the cell system altogether and act as a supervisor. ${ }^{46}$ This, of course, was without prejudice to his continuing wholly open activities (e.g. on a Standard Committee) or leading a double life as supervisor of an ABL cell.

Indoctrination in the Study Cells would usually begin with Communist folk stories, 47 and an introduction to Chinese literature and history. This would include stories of heroes of past dynasties, and, for example, of the heroic resistance against Japan, and of Communist China's feats of reconstruction. There would also be discussions on the philosophy of life, leading to study of standard works on Communism (Marx, Lenin, Stalin and Mao Tse-Tung). The cell leader would be provided with material from outside 
48. Goh Keng Swee, reported in The Singapore Sunday Times, 29th Jamuary,

49. Central Committee of the Malayan Communist Party, Record of Decisions 13th June, 1940, (quoted in Hanrahan p. 98).

50. In this and the next two quotations, the italics are mine.

51. Liu Shao Shi (then Vice Chairman of the Chinese Communist Party) in a message to the Second National Congress Youth Corps, quoted in White Paper, SCMSSU, 1956, p. 12.

52. Basic Knowledge Textbook of the China New Democratic Youth Corps, quot in White Paper, SCMSSU, 1956, p. 12. 
the school, and would conduct the meetings in a deliberately conspiratorial atmosphere. $^{48}$ In all these activities, criticism and self criticism played an important part.

\section{Self Criticism and Intimidation}

Self criticism is primarily a technique for Party discipline. For example:-

"The functions, feelings, actions, beliefs and speech of a Party member are all of concern to the party ... Party organisations and individuals ... if they uncover the tendency of a comrade which is injurious to the party affairs, must never compromise or keep such a discovery secret." 49

It went wider than that, however, and was used as a weapon to bring pressure to bear on individuals. For example:-

"In order to consolidate their own organisation, the. entire body of members of the Chinese New Democratic Youth Corps must learn how to manipulate ${ }^{50}$ the method of criticism and self criticism so as to carry on a struggle against all the bad phenomena which are harmful to the enterprise of the people and the undertakings of the party. 51

"Criticism and self criticism are the powerful weapons of the Youth Corps when educating its members and the young masses ..." 52

The SCMSSU made use of this weapon in 1954-56 to exert psychological pressure on its members (who comprised a majority of the "young masses" in the Chinese Middle Schools) to swim with the stream. The Secretary-General of the SCMSSU, in his message "Welcome the Year 1956" wrote:-

We must lay stress on the importance of the unity of members (of the SCMSSU) and the development of the union. All members should be able to reach mutual understanding and have a correct hold on the weapon of criticism and self 
53. White Paper, SCMSSU, 1956, p. 12.

54. White Paper, SCMSSU, 1956, p. 12.

55. White Paper, SCMSSU, 1956 pp. 8 and 11.

56. "Yung", - Interview, 1966. 
criticism." 53

Amongst working personnel, the discipline was naturally stricter than amongst the "young masses". The SCMSSU Study Outline for 1956 defined criticism and self criticism as:-

"....just like a searchlight enabling us to check

at once the actual conditions of a certain working

department or section,"

and any who might have the effrontery to fight back were deterred with a threat to which a young Chinese feeling himself entering the elite would be particularly sensitive;

"....everyone can see that standing before them is a weakling who has not the courage to admit his mistakes, a bad worker who is unwilling to rectify his defects ... he is decidedly not a person who possesses the quality of a leader." 54

Thus, public criticism and self. criticism became a subtle form of intimidation, playing on the normal desire of a boy or girl to be accepted as one of a group, "Public" (i.e. in the presence of other members of the group, be it open or secret) was the operative word. Group loyalty was placed above personal loyalty. 55 Carried as far as it was, however, it had something of a backlash in denying boys and girls the normal solace of letting their hair down with their really close friends, and casting a shadow which took a lot of the warmth and humanity away from their lives, ${ }^{56}$ despite the "strength through joy" picnics and the exhilaration of conspiratorial teamwork.

The intimidation of the "young masses" was often direct and brutal, just as it is in schools anywhere in the world in which there is strong and organised leadership against authority. In the Chung Cheng High School, for example, "traitors" were listed on the blackboards, and when a boy in the Chinese High School tore down a poster, he was confronted by a large gang, which announced that it would enforce his immediate ostracism, and hinted 
57. White Paper, SCMSSU, 1956 p. 7.

58. See Page 95.

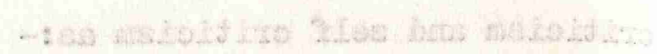

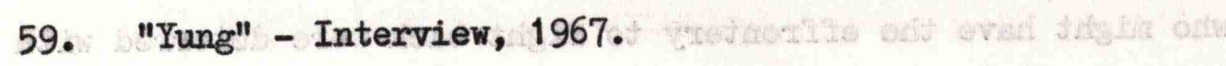

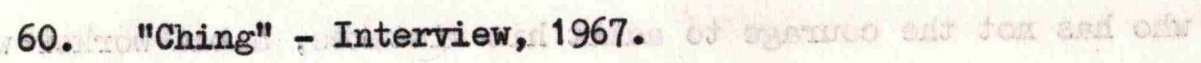

61. "Fu" (SB) - Interview, 1967.

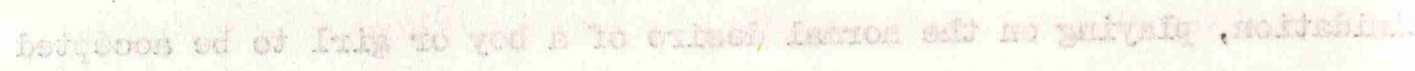

62. White Paper, ScMSSU, 1956, p. 17.

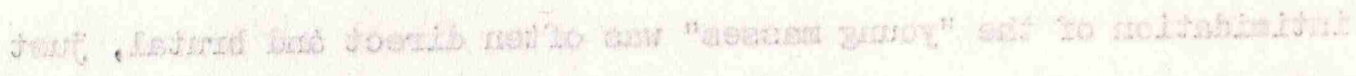

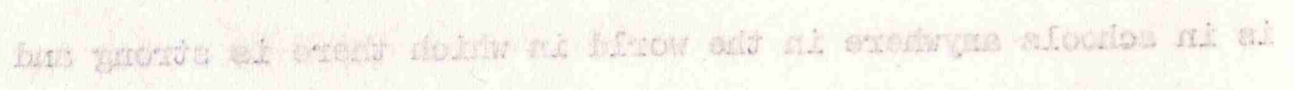

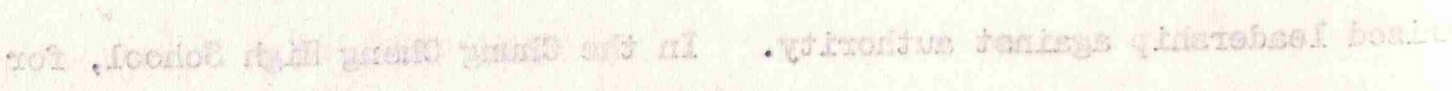

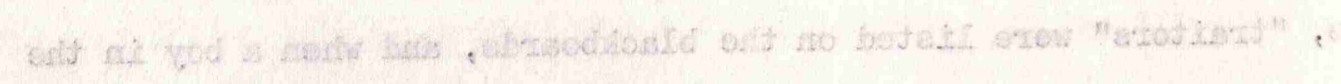

63. See Page 95.

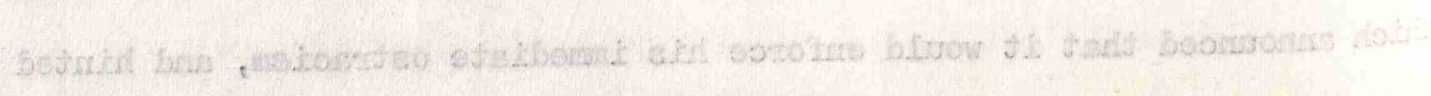


worse to come if he persisted. 57 The murder of Lee Ta Lim in April 1955, 58 and the reluctance of anyone to come forward to give evidence, were an indication of the degree to which this intimidation was sometimes carried though it was seldom necessary to go as far as this.

\section{The Position of the Teachers}

Some of the teachers were openly or discreetly sympathetic to the SCMSSU in the battle for Chinese rights and Chinese culture under the British (and, in the Federation, Malay) domination. 59 Until the foundation of Nanyang University in 1955, there was no Chinese language education available in Singapore or the Federation above middle school level. Thus, most of the Chinese graduates teaching senior classes in the Chinese Middle Schools in 1954-56 had spent three years at University in China. 60 The older ones had done this before or during the Second World War, under the Kuomintang, and were generally anti-Communist, but many of the younger ones had Communist sympathies. 61

The school staffs not unnaturally welcomed the Tuition Cells, and sometimes also welcomed the Study Cells, of whose existence they were generally well aware. In one girls school, the principal suggested the formation of a study section for student teachers to study teaching methods, and offered prizes. This, of course, was accepted with glee by the School Committee. In another school, after some initial opposition to the "Hsueh Hsih" concept, the school authorities changed the extra-curricular programme to enable students to take part in it. ${ }^{62}$

Politics apart, many of the teachers got on well with the students, and particularly with the best amongst them, and it was from amongst the best that the Committee Open Front or secret leaders were recruited. The SCMSSU and the ABL, combining progressive politics with the opportunity for patriotic leadership of the rising generation of Chinese, were particularly attractive to the cream of the students, like "Yung", for example, 63 who was equally popular amongst the staff, his fellow students and the ABL and SCMSSU. The 
64. "Yung" - Interview, 1967. See also page 505 above for a good example of the staff tolerating SCMSSU propaganda activities.

65. "Yung" - Interview, 1967. Another source - "Seng" (SB) states that Song was not present at his trial by the Boys' and girls' "People's Court".

66. White Paper, SCMSSU, 1956, p. 17.

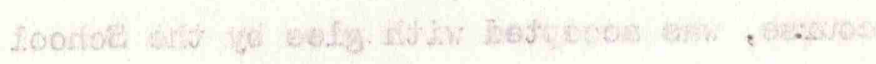

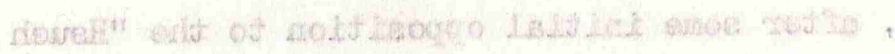

67. "Yung" - Interview, 1967. 
teachers knew about the School and Standard Committees and propaganda indoctrination, but generally - whether from sympathy or intimidation kept out of campus activities, and the ABL and SCMSSU went out of their way to be friendly to them provided that they did not interfere. 64

Those who did not interfere at once became targets for intimidation of a particular vicious kind, since the domination of the "young masses" by the SCYSSU gave it a mob flavour. "Yung" witnesses such an occasion when he was representing the Chinese High School at a mass rally of the Chung Cheng High School branch of the SCMSSU in March 1956. The meeting set itself up as a "Peoples' Court", with over 1000 boys and girls present. One of the teachers, Song Choh Eng, was hauled from his office onto the stage, and students shouted accusations from the floor - "...distributed Kuomintang propaganda!

...spoke against the SCYSSU! ..." etc., The "Peoples' Court" demanded that he be sacked, and the School Management Committee complied. Song went to teach in the Federation. 65

In August 1956, the Nanyang Girls High School went on strike because of the refusal to dismiss their English language teacher, and only returned to work when the Principal promised that the teacher would change her attitude. 66

Personal violence (apart from manhandling) was again relatively rare, but not unknown. In 1954, for example, the Principal of Nanyang Girls High School, Madame Lau Ing Sien, had acid thrown in her face and had to go to UK for treatment. Other teachers were pelted with rotten eggs, but the commonest form of coercion was the mean and impersonal one of damaging the body work of their cars or putting salt or sand in the petrol tanks. 67

Bventually the intimidation of the teachers, principals and management committees was one of the main factors which led the government to take positive action against the student organisation in 0ctober 1956, thereby providing the spark for the riots in that month, which are described later. The Baling Truce Talks and The Razak Report

In June 1955 the MCP in the jungle made overtures for peace talks, and 
68. MCP Directive of 11th June, 1956, quoted in White Paper, SCMSSU,

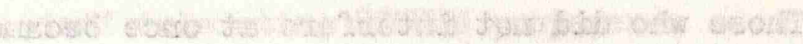

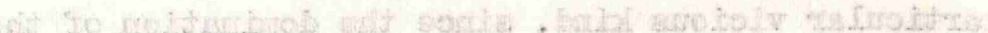

\section{6, p. 1 .}


in December of that year Chin Peng met the Chief Ministers of the newly elected governments of Singapore and the Federation - Mr. David Marshall and Tunku Abdul Rahman. After the breakdown of these talks, the MCP issued a fresh Directive which included the following admissions:-

"Especially in circumstances where the enemy is stronger than we are, the work of winning support from school children and organising them to struggle is more important than military activities." 68

Also in 1955 a new government report on Education was published by Dato Abdul Razak, The Minister of Education in Kuala Lumpur. Although applicable only to the Federation, it raised a tremendous outcry in the Chinese Schools, including those in Singapore. Among other things, it announced that now, eleven years after the end of the war, the time had come to make more room for the rising generation by ceasing to accept overage students. This was, of course, a devastating blow to the MCP, since both their secret and Open Front activities were largely run by over-age students, whose experience and Communist training was indispensable to them. Opposition to the Razak Report provided a fresh focus for the Study Cells and for Open Front propaganda. 69

Thus, coinciding with the Government's reaction to the erosion of the authority of the school staffs, the SCMSSU and the ABL cells intensified their activities in response both to the post-Baling MCP Directive and the Razak Report. By the autumn of 1956 the situation was ripe for a head-on clash.

By the time this clash came, however, Singapore was a self-governing State. Before examining this clash, therefore, we must look back at the development of this self-government which had begun in April 1955, and had proceeded, in conjunction with a sharp rise in strikes and riots, in parallel with the development of the power of the SCMSSU. 
1. "Seng" (SB) - Interview 1968

2. Douglas Hyde - Interview 1969

3. ibid. See also Chapter 8 for Lee Kuan Yew's account of the relationship between Lim Chin Siong and the MCP Underground organisation.

4. Lee Kuan Yew, The Battle for Nerger, p. 1. 


\section{SEHLF GOVERRNIENT}

\section{The "Middle Road" Group of Trade Unions}

Amongst the student organisation in the Chinese High School, one of the leading figures from 1949 to 1951 had been Lim Chin Siong, who was to play a major part in the affairs of Singapore from 1954 to 1962. Expelled from the Chinese High School for organising agitation in 1951 at the age of 18, he had continued his underground work in a supervisory role in the ABL. ${ }^{1}$ He became a paid Trade Union Secretary, was elected to the Assembly in 1955, and played a leading part in the 1956 demonstrations, after which he was in detention until released on Lee Kuan Yew's election to power in June, 1959. During the next four years he made a determined bid to oust Lee Kuan Yew before being placed again into detention in February, 1963. He was eventually released in 1969 and went to England, apparently a broken man in a state of acute depression. ${ }^{2}$

Lim Chin Siong has never publicly admitted to being a Communist. Douglas Hyde, who spent a number of periods of several days in Lim's cell in Changi gaol between 1964 and 1968, is convinced that Lim was never a Party Member, but that his aims did coincide with Communist Party aims. Iim claimed that he used the Party to further his aims, and admitted that he was prepared to fall in with Party plans, but denied that he had any contact with the Party underground. ${ }^{3}$ Lee Kuan Yew, however, has stated categorically that "he is .... what he always has been, a Communist open-front leader", 4 and produces convincing documentary evidence to prove this. At the height of the constitutional battle for power in September 1961, whilst Iim was still a member of the Assembly, Lee Kuan Yew described him in a broadcast over Radio Malaya as follows:

"Lim was the most important open-front leader the MCP had 
5. Lee Kuan Yew, Battle, p. 27.

6. See Chapter 2.

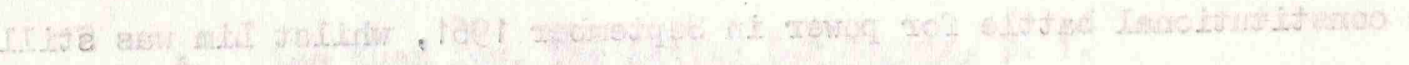

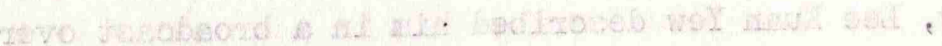

7. Military Report, p. 3. 
built up. By 1955 he knew that I knew this, He is a friendly and quiet person. He is prepared to devote his whole life to working for the creation of a Communist Malaya. But once you resist and fight the Communist cause, then you can expect all that personal friendship to mean nothing in the ruthless and relentless struggle for supremacy." 5

In 1954, Lim was still only 21, but was already emerging as a powerful figure in Singapore. In view of the generally improving Bmergency situation, the British Government was anxious to allow more rein to legitimate organisation of labour and in 1954 the Trade Unions in Singapore recovered some of the freedom of action which they had lost in 1948. The MCP lost no time in establishing control over a number of key unions, enabling them to wield the same power over labour as they had in 1946-48. ${ }^{6}$ In the light of the immediate consequences, the British Government's liberality may seem surprising, but at the time the greatly improved Emergency situation seemed to justify this calculated risk - and in the long run there is little doubt that the policy paid off, both in the Federation and Singapore.

The grouping of Unions in 1954 was much looser than it had been in the Singapore Federation of Trade Unions in 1948. It was simply an informal arrangement whereby the executives of a number of unions met from time to time on the premises of one of them - The Singapore Factory and Shopworkers Union (SFSWU) of which Lim Chin Siong became Secretary-General. The SFSWU head office was in Middle Road, near the centre of the city of Singapore, so this association became known as the "Middle Road Group". Though, as in 1948, there was a more moderate constitutional group of unions (the Singapore TUC) which generally aimed to attain better conditions by some degree of cooperation with management and government, the Middle Road Group controlled the unions in many complete sectors of industry and the public services, including all public transport systems. 7 The control of these unions was closely linked with the Peoples Action Party (PAP) - or rather to its 
8. Singapore Legislative Assembly Debates, Official Report 21 st September, 1955, Column 749.

9. Constitutional Commission, Singapore, Report by Sir George Rendel, 22nd February, 1954, Government Printing Office, Singapore, 1954, pp. 3, 9, 10, 17 and 18. 
militant left wing faction which was led by Lim Chin Siong. Their success can be measured by the fact that, whereas in 1953 and 1954 there was a total of 13 strikes in two years, there were 213 in the five months from April to September, 1955 - 162 of them attributed to the Middle Road Group. 8

\section{Self Government}

Meanwhile, the Constitution for self government proposed in the report of the Rendel Commission was being put into effect. The Assembly contained 32 members of whom 25 were elected. The other 7 consisted of 3 British officials holding Ministerial appointments and 4 unofficial members nominated by the Governor.

The Executive consisted of a Council of Ministers (9) over which the Governor presided. Of the 9 Ministers, 6 were found from the 25 elected members of the Assembly, and the other 3 were the British officials mentioned above. Portfolios were as follows:

Elected Ministers (who included the Chief Minister):-

No. 1 Commerce, Industry, Shipping, Agriculture and Fisheries.

No. 2 Labour, Immigration and Social Welfare.

No. 3 Education.

No. 4 Housing, Lands, Administration of the adjacent Islands, Town and Country Planning and Local Government.

No. 5 Civil Aviation, Communications and Public Works.

No. 6 Health.

British Official Ministers:-

No. 7 Finance Minister

No. 8 Attorney General

No. 9 Chief Secretary, responsible for:

(a) External Affairs.

(b) Internal Security, including Police and Prisons.

(c) Defence.

(d) Public Relations, Broadcasting, Civil Service. ${ }^{9}$ 
10. Blades, para. 17.

11. David Marshall, in a talk on "The Struggle for Nationhood" at St. Andrews Cąthedral, Singapore on 12th July, 1969. 
In the light of subsequent events it is hard to remember that Singapore attained this degree of Constitutional Self Government before the Federation did (in April and May 1955 respectively), because thereafter, whereas the Federation attained full independence from the British in a little over two years (August 1957), Singapore had to wait eight years (September 1963) for hers. Two of the reasons for this were related: first, the MCP in the Federation, though far bigger than in Singapore, was spread about the jungle and had little means of influencing political development in the cities; and secondly, whereas the mon-Communist political factions in the Federation formed an overwhelming Alliance Party holding 51 out of the 52 elected seats, those in Singapore were split in continuous rivalries, which were not resolved until 1963. Which of these, in the long-term, will have proved to be the healthier political apprenticeship will have to be deduced later by historians, who will have many other factors to take into account. Certainly the circumstances mentioned did give Singapore a much more stormy period of transition to full independence than the Federation, though Singapore subsequently attained a remarkable degree of internal political stability.

The 1955 elections in Singapore provided a shock for the British. They had since 1947 been grooming the leaders of the Progressive Party, made up mainly of English-educated commercial Chinese, to take over when the time came for self-government. Unlike the Alliance Party in the Federation, these leaders were decisively rejected at the polls. ${ }^{10}$ Power instead went to a coalition headed by David Marshall, a very successful lawyer who had switched to politics in 1954 after a 6 weeks course in electioneering at Transport House in London. 11 The Coalition supporting him as Chief Minister held only 13 out of the 25 elected seats. Thus, if the 12 opposition members did not support him on any particular measure, he had to rely on the concurrence of the balance of 7 official and nominated members and vice versa. Marshall's 13 were from his own Labour Front (10) and the Alliance Party (3) - while 
12. Straits Times, 23rd April, 1955 and Military Report, p. 3.

13. Report on the Singapore All Party Mission to London April/ May 1956 (Singapore Sessional Paper No. Cmd 31 of 1956), p. 20.

14. SliA Debates, 27th April, 1955 Column 141.

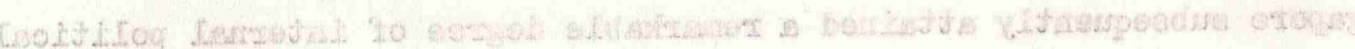

15. David Marshall - Interview 1968.

16. Rendel Report, p. 19 .

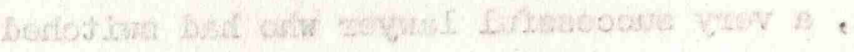


the 'opposition' comprised 4 Progressives, 3 People's Action Party (PAP) and 5 Independents, one of whom in practice always voted with the PAP. The PAP members included Lee Kuan Yew (the party leader) and Lim Chin Siong。 ${ }^{12}$ It is an interesting reflection on the racial complexion of Singapore that the 6 elected ministers included men of 5 different races; Chinese, Malay, Eurasian, Indian and Jewish. ${ }^{13}$

The new Assembly met on 22nd April, 1955. Its mood above all else was anti-colonialist. The 1955 Constitution was a landmark, but it gave them only a limited degree of self-government. In the last resort, for example, responsibility for Internal Security lay with a colonial official - the Chief Secretary - served by a colonial Commissioner of Police and a colonial Head of Special Branch. The three colonial Ministers (all of British race) also retained control of finance, of the judicial system and of the information services, including radio. In practice, as Marshall publicly acknowledged in the Assembly ${ }^{14}$ the 3 British Ministers deferred to the vote of the 6 elected Ministers in the Council, but there was no guarantee legally that they would do this and Marshall resented the fact that he was not always privy to Special Branch secrets and did not have access to their files. ${ }^{15}$ Bven the departments wholly controlled by the elected ministers (such as education and housing) were subject to a budget controlled by a colonial Finance Minister, and the appointment of the ministers themselves was made by the Governor - albeit from amongst the elected members of the Assembly, and on the advice of their majority leader. 16

In the circumstances, with an Assembly containing Open Front Leaders, who might become members of a majority party or coalition, these safeguards were not unreasonable, but of course they were unpalatable to the elected members. While the Assembly did give them a forum from which they could influence public opinion, they did not have real independence and they were not prepared to wait too long for this. They wanted to govern themselves, not to wait for their sons to govern.

In the Assembly, during this transition period, they had individually 


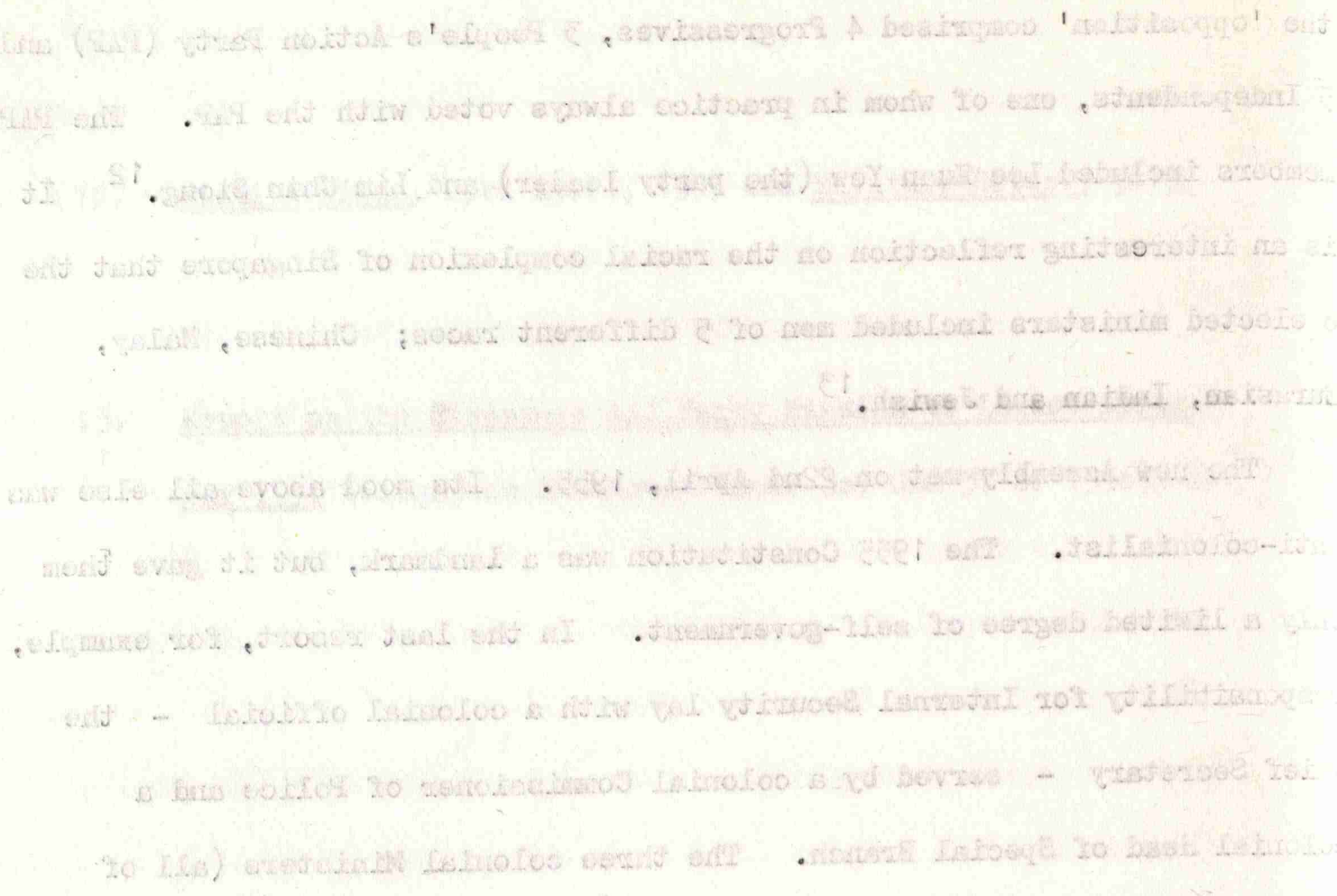

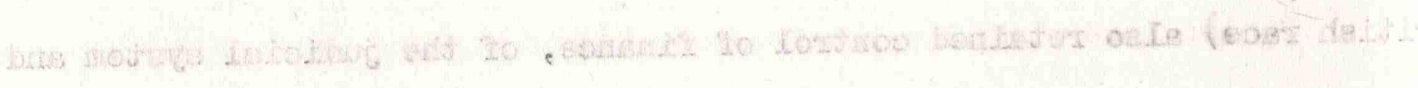

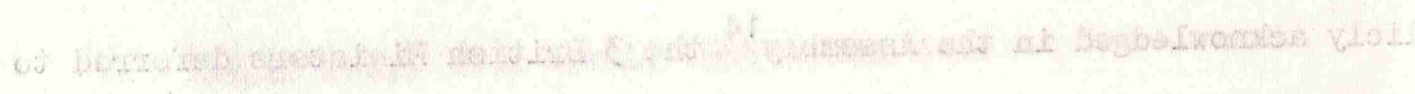

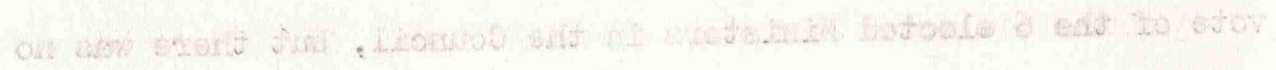

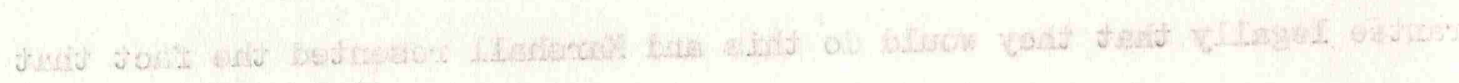

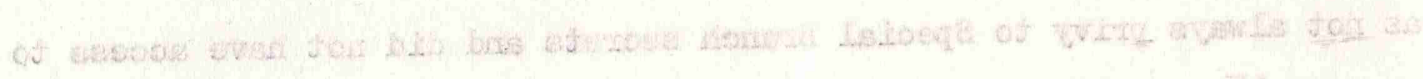

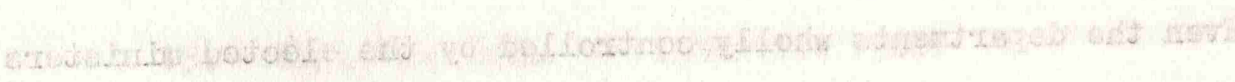

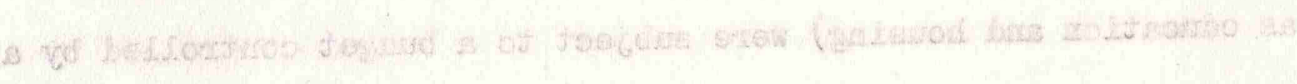

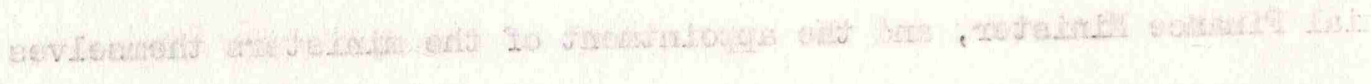

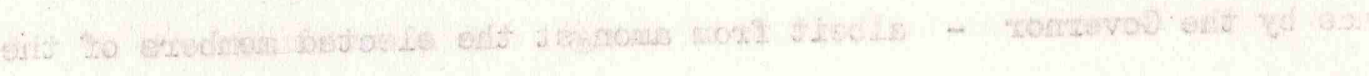
17. Iee Kuan Yew, Battle, p. 19.

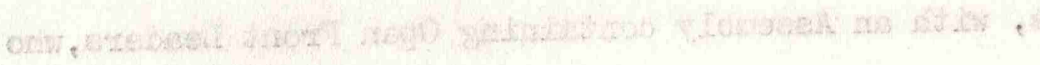

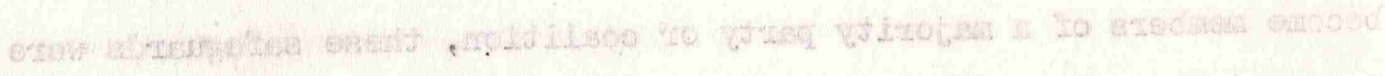

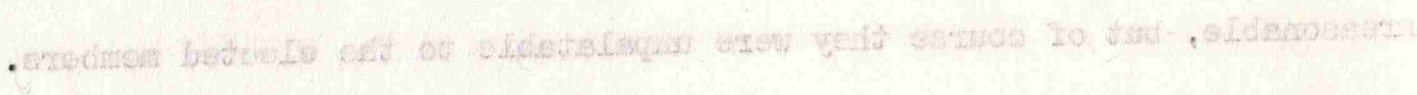

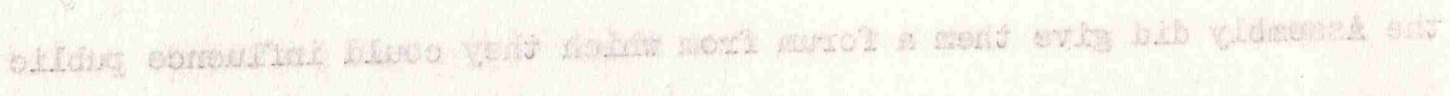

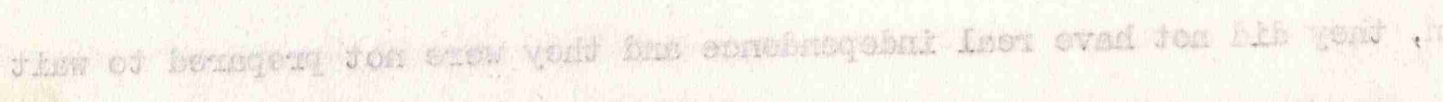

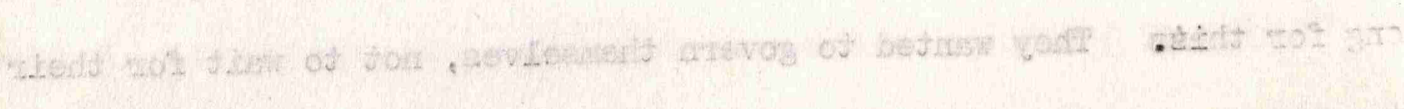
- mevor ou 
to establish themselves as leaders, and this, depended on their presenting a progressive, anti-colonialist image. The most wounding jibe that could be flung across the floor was 'Colonialist stooge'.

Neither Marshall nor his deputy, Lim Yew Hock (who had been a member of the Rendel Commission) seemed to have any illusions about Communism - and Marshall was to give a convincing demonstration of this at the abortive truce talks with Chui Peng at Baling later in the year. Nevertheless, the mood of the Assembly and of the Singapore public was anti-colonialist rather than anti-Communist. Marshall had to ride along a knife edge between appearing to merit the 'stooge' label or allowing the Communists to gather strength and unseat him. He knew that this was the last thing the British wanted, but he was highly critical of the powers they gave him to prevent it. Inevitably, this responsibility cast him as a 'moderate' enabling the PAP to claim the radical leadership, and they exploited this situation to the full. The Peoples' Action Party

The PAP, with only 3 members (or 4 with their Independent supporter) was itself split. Its extreme left wing, represented in the Assembly by Lim Chin Siong, made no secret of its leadership of the militant Middle Road Group of unions, and of the rebellion amongst the Chinese Middle School Students (described in the previous chapter).

The other faction was led by the Party Leader, Lee Kuan Yew, who knew well that the extremists in his party were Communist.

"Some", he said later," "were my personal friends. They knew that I knew they were Communists, for between us there was no pretence. They believed that I should join them."

He was, however, quite convinced that independence from the British required the concerted efforts of all progressive political factions in the Colony, including the Communists. He was confident that he could handle them and in this he proved right. He will go down in history as one of the few democratic leaders who has risen to power astride the Communist tiger 
without ever losing control of it and who has been able to discard it as soon as it seriously challenged his leadership. In 1961, at the height of this challenge, he described his past relations with them in a series of startlingly outspoken broadcasts over Radio Malaya, the published version of which (in The Battle for Merger) now forms a colourful and illuminating reference book on Communist political subversion.

In 1955 he was cooperating with them broadly for three reasons. First, as already mentioned, to accelerate independence from the British; secondly, because he was largely sympathetic with the aspirations of Chinese trade unionists and students; and thirdly because he was determined to bridge the gulf between the Chinese educated in the English speaking schools (such as himself) and those educated in Chinese schools (such as Lim Chin Siong).

Lee Kuan Yew had since 1950 been most active as a barrister in representing the trade unions (he was a brilliant lawyer, with double firstclass honours at Cambridge). In so doing he had made many friends amongst their left-wing leadership. It was, in fact, the court charges arising from the student riots which gave him the chance to bridge the gulf. He describes it thus:

"Then one day, in 1954 we came into contact with the Chinese-educated world. The Chinese Middle School students were in revolt against national service, and they were beaten down. Riots took place, charges were prepared in court. Through devious ways they came into contact with us.

"We bridged the gap to the Chinese-educated world a world teeming with vitality, dynamism and revolution, a world in which the Communists had been working for over the last 30 years with considerable success.

"We, the English-educated revolutionaries ...were considered by the Communists as poaching on their exclusive territory.

"In this world we came to know Lim Chin Siong and Fong 


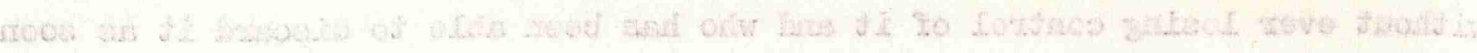

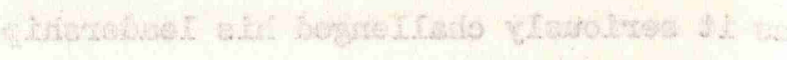

18. Lee Kuan Yew, Battle, pp. 17 and 18.

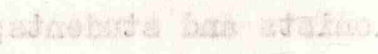

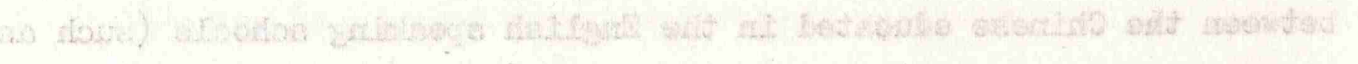

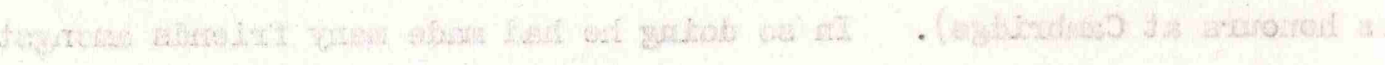

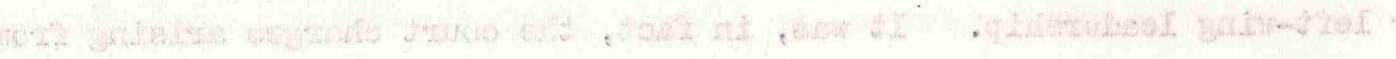

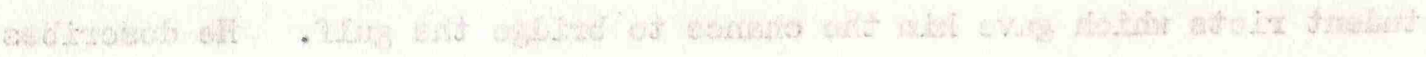

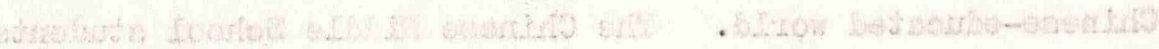

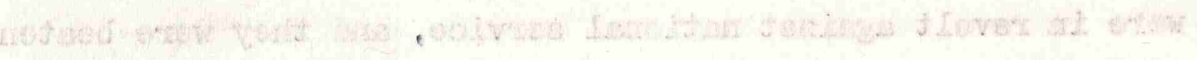

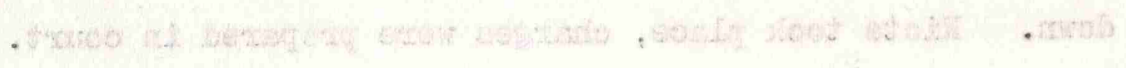

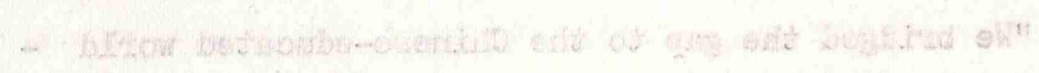

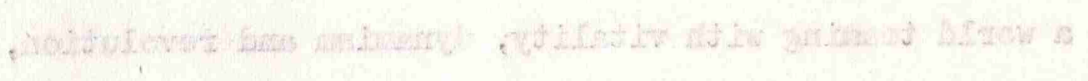

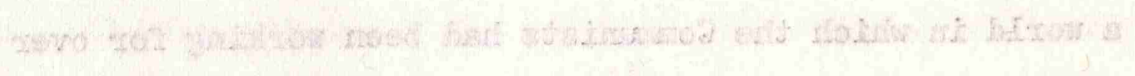

19. Straits Times, 5th May, 1955.

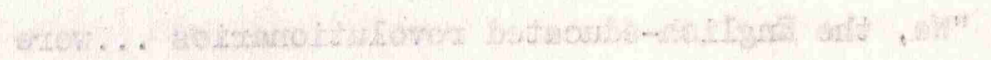


Swee Suan. They joined us in the PAP. In 1955 we contested the elections. Our initiation into the intracies and varifications of the Communist underground organisation had begun.

"It is a strange business working in this world. When you meet a union leader you will quickly have to decide ....whether or not he is a Communist. You can find out by the language he uses and his behaviour, whether or not he is in the inner circle which makes the decisions. These are things from which you determine whether he is an outsider or an insider in the Communist underworld. "I came to know dozens of them. They are not crooks or opportunists. These are men with great resolve, dedicated to the Communist revolution and to the establishment of the Communist state believing that it is the best thing in the world for mankind.

"Many of them are prepared to pay the price for the Communist cause in terms of personal freedom and sacrifice... of ten my colleagues and I disagreed with them and intense fights took place, all concealed from the outside world because they were Communists working in one anti-colonial front with us against the common enemy and it would not do to betray them." 18

In the early stages of the wave of strikes which followed the inauguration of self government (see below) Lee Kuan Yew showed how far he was prepared to go at this stage. Though he repeatedly stressed that he was not a Communist, he was quoted in an interview with the Straits Times on 5 th May, 1955 as saying:

"In Malaya we are sitting on a powder keg... The Communists are certain to win .... Any man in Singapore who wants to carry the Chinese-speaking people with him cannot afford to be anti-Communist .... If I had to choose between Colonialism and Communism, I would vote for Communism, and so would the great majority of the people." 19 This is the most extreme statement attributed to Lee Kuan Yew particularly his alleged remark that "The Communists are certain to win." 
20. ibid, 6th May, 1955.

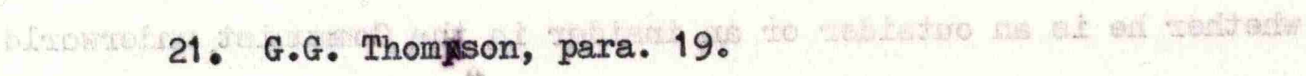

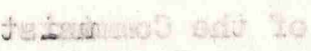

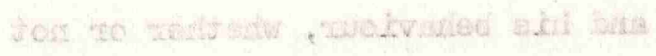

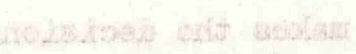

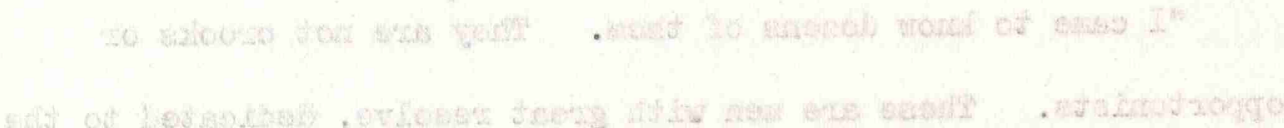

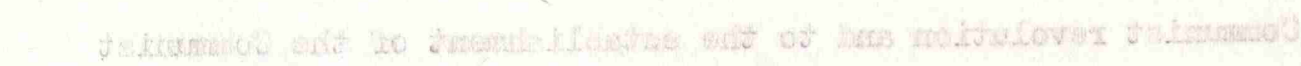
.

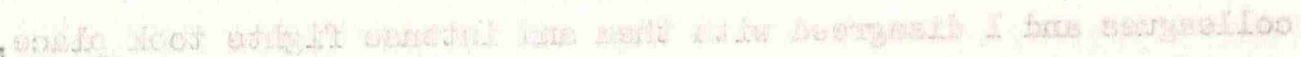

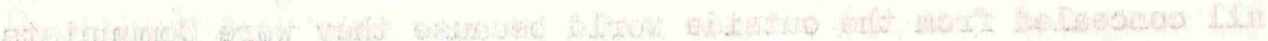

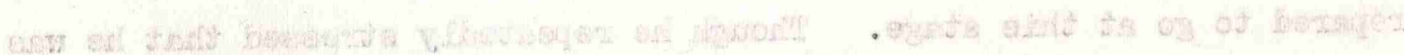

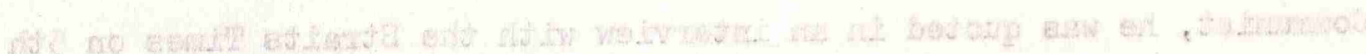

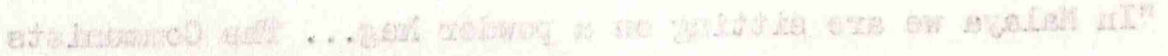

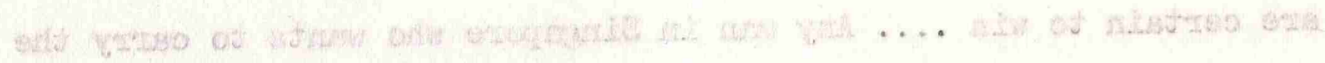

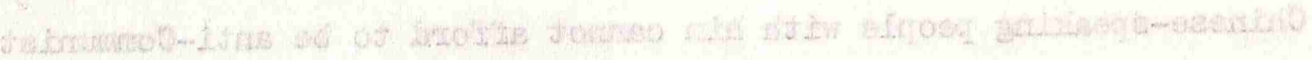

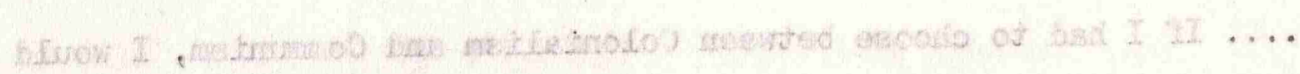

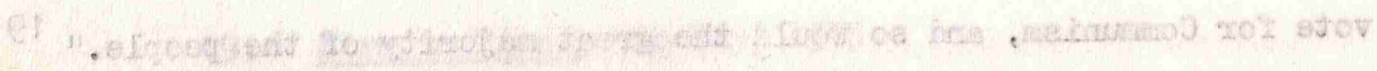
22. Lee Kuan Yew, Battle, pp. 66 and 67.

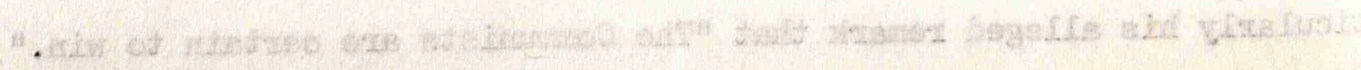


It is in fact at variance with his other public statements, either then or later. A study of his speeches in public debate in the Assembly from 1955 until 1963 shows a general consistency in his attitude towards the Communists.

On the following day he qualified his statement, saying that he would vote for Communism only if it were the only alternative to Colonialism. 20 Nevertheless, this period was the highwater mark of Lee's cooperation with the Communists, though this cooperation was from political necessity rather than from choice. ${ }^{21}$ Six years later (1961), whilst he was at the crisis of his political battle to throw them off, he explained this in one of his broadcasts over Radio Malaya:-

"You may ask: If the Communists are such a danger to our society, why did we work with Lim and his Communist friends in one anti-Colonial united front? This and other questions have to be answered. However uncomfortable the truth may be to me and my colleagues, you must know it...

"We came to the conclusion that we had better forget the differences between our ultimate objectives and work together for our immediate common objective, the destruction of the British. Whether you wanted a democratic Malaya or a Communist Malaya, you had first to get rid of the British...

"But we never forgot that once the British were out of the way, there would be trouble between us and the Communists as to what kind of Malaya we wanted to have in place of the old British colonial Malaya.

"We were quite clear as to what we wanted - an independent, democratic, socialist Malaya, which by democratic means could bring about a more just and equal society. On the other hand, they wanted a Communist Malaya. This is what the Communists mean when they say "seeking concord whilst maintaining differences." 22 
23. Behind the scenes the Governor had shrewdly encouraged Marshall to oppose the extension of Bmergency Regulations, so that the odium of extending them would then fall on the British, using their overriding powers, without damaging Marshall's "progressive" political image. Marshall scorned this offer, preferring not to start his first weeks of power by becoming beholden to his Colonial Governor. David Marshall - Interview 1968.

24. SILA Debates, 27th April, 1955, Column 141.

25. See Chapter 5.

26. SLA Debates, 27th April, 1955, Column 148.

27. Straits Times, 23rd April, 1955. The sections revoked were Nos. $3,6,17,18,19,22,25$, and 32 . In addition to the relaxations mentioned in the text, the police also lost the power to seize transport, arms, foodstuffs, defence materials and printing premises if $/$ judged this to be in the interests of public safety. 


\section{The Bmergency Regulations}

Such was the Assembly which met in Singapore on 22nd April, 1955. David Marshall, with his coalition govermment, determined to evade the 'stooge' label, faced Lee Kuan Yew and Lim Chin Siong, both working for the left-wing vote, but each aware that he would eventually have to fight the other for its leadership.

All three - indeed, all the elected members - demonstrated their rejection of colonial pomposity by wearing open necked shirts.

The government had in fact taken office on 7 th April, and the Council of Ministers had therefore been meeting for two weeks before the Assembly itself met. After an exhaustive examination of the Emergency Regulations, they had agreed to revoke certain of them and to extend the remainder for three months. David Marshall, with some courage, chose himself to move the adoption of the 3 months extension, rather than to leave it to the Chief Secretary ${ }^{23}$, to underline that this was a decision of the Council of Ministers. He said that the 3 British Ministers had shown that they were willing to abide by the majority decision of the Council, no matter how strongly they had expressed their views in arriving at it. ${ }^{24}$

The British Chief Secretary, Mr. Goode, reminded the house during the debate that a young Chinese had been shot dead on Sunday, 17th April, called out from a Club and butchered in a public street. ${ }^{25}$ "Unless the police have some special powers," he said, "these killers are unlikely to be found and locked up, because no-one dares to say what he knows until he is sure that he is safe from retaliation." 26

Nevertheless, it must have been with some misgiving that the British officials had agreed to the removal of certain very important police powers - some of which had before long to be restored. The police were deprived of the power to close roads, to enforce curfews and to search premises, vehicles and persons suspected of having weapons. ${ }^{27}$ But the power of detention without trial remained, and this was strongly attacked by a number 
28. SLA Debates, 27th April, 1955, Column 155. Lee Kuan Yew was willing to accept the Emergency Regulations as such so long as they were necessary during the Emergency in Malaya. G.G. Thomson, para. 20

29. Lee Kuan Yew, in SLA Debates, 16th May, 1955 Column 204.

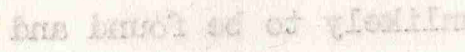

30. Straits Times, 25th April, 1955.

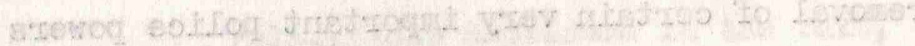


of members, including Lee Kuan Yew, who said that if the government would "remove the Emergency Regulations in so far as they affect arrest and detention without trial in open court, restrictions on freedom of speech, assembly and publication" the PAP would rest content. 28 The Hock Lee Bus Strike

The relaxations of police powers were debated and approved by the Assembly on 27th April, but they had been announced in the Governor's address at the Opening of Parliament (The "Speech from the Throne") on 22nd April. These relaxations, together with greater freedom of action enjoyed by the Trade Unions, gave the Communists their best chance of stirring up trouble in Singapore since 1948, and the Middle Road Group wasted no time in launching a challenge by means of their control of the public transport system. On 23rd April, The Singapore Bus Workers Union (SBWU) served strike notices on the Chinese owned Hock Lee Amalgamated Bus Company, by virtue of a dispute which had been going on for some weeks.

The PAP version of the origin of the dispute was that when the SBWU was formed in February 1955, 250 of the 300 Hock Lee workers had joined it. The company, however, had simultaneously formed a rival union, and had recruited 200 redundant men into a pool of spare drivers, with a retaining fee of $\$ 2$ per day paid on condition that they joined this union. This pool would then be available "to meet any trouble". 29 The dispute came to a head in April over the introduction of new working rosters. The management replied to the strike notice by dismissing a number of workers, who thereupon locked themselves into the company's garages in Alexandra Road and picketed the gate. 30

On the mornings of 25 th and 26th April, the strikers tried to prevent the buses from leaving the garage by sitting on the ground across the gates. On these two days they were persuaded by the police to get up without trouble, but on the 27th April 150 strikers blocking the gate threw stones at the police, who had to remove them physically though "without undue force". 
31. SLA Debates, 16th May, 1955 Columns 176-186.

32. Straits Times, 29-30th April, 1955.

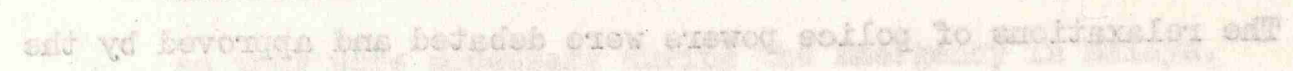

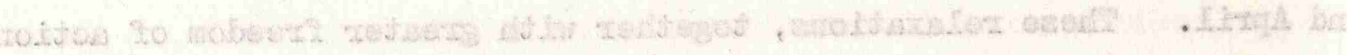

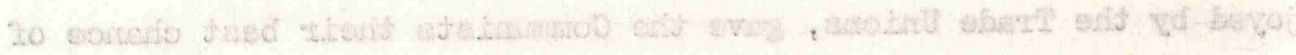

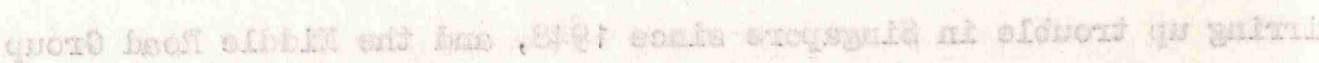

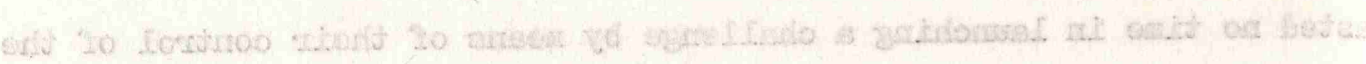

33. SLA Debates, 16th May; 1955 Columns 188-190

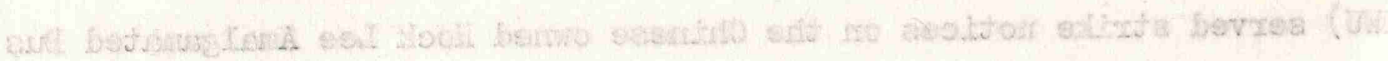

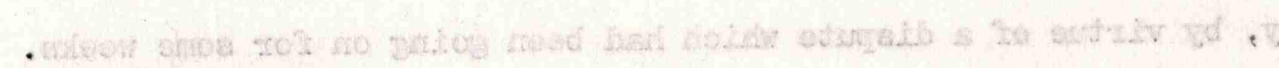

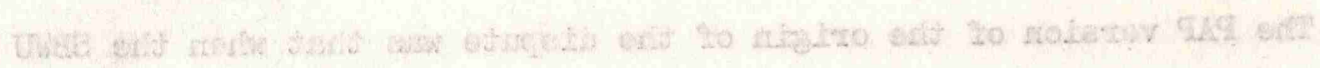

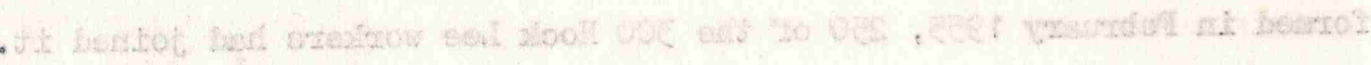

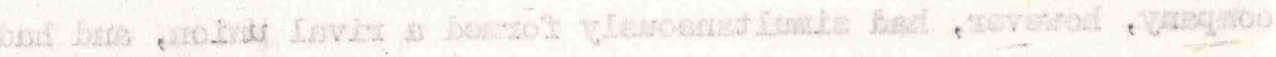

34. ibid, Column 191.

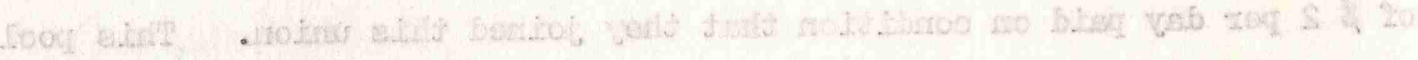

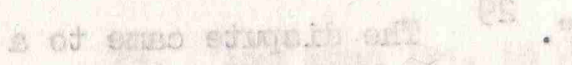

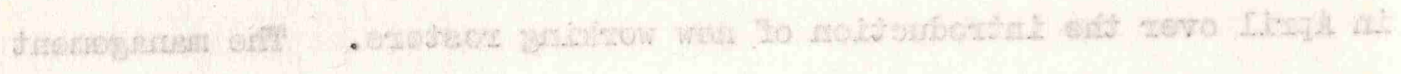

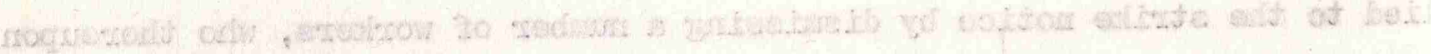

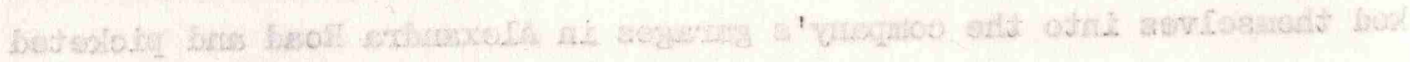

35. ibid, Columns 176-186.

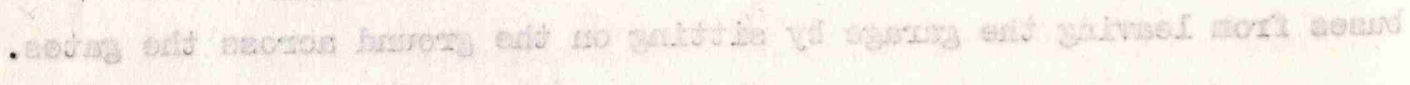

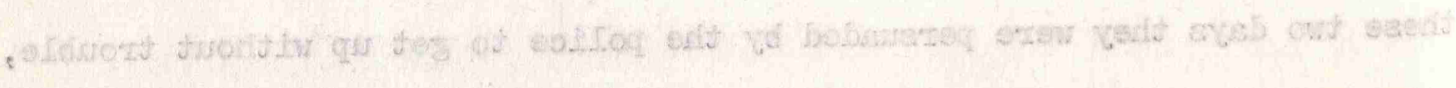

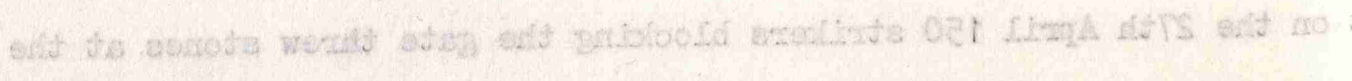

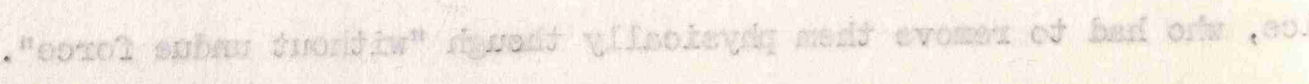


Some strikers feigned injury, but made off when an ambulance was called. 31 On 28th April, the police used batons to clear the gate and 15 people were injured. On the 29th, thousands of students converged from Chinese Middle Schools all over the island, in a highly organised operation, to bring food and to entertain the strikers with singing and dancing. 32

30th April, the eve of May Day, brought a wave of other strikes by unions of the Middle Road Group. These strikes extended to the Docks, on which - with 100 or more ocean going ships lying in the harbour at any one time - the life blood of Singapore depended. The familiar pattern of a widely organised stoppage of the transport of passengers and freight into and within Singapore began to re-emerge. At a May Day Rally Lim Chin Siong and the Secretary of the SBWU Fong Swee Suan both (according to the Chief Secretary) instigated the use of violence. 33

Thereafter large numbers of students from the Chinese High School, Chung Cheng High School and the Chung Hwa, Nanyang and Nan Chiau Girls High Schools arrived day after day in lorries, regimented and organised, gave large sums of money to the workers, danced for their entertainment and sang inflammatory songs. Some students from the two boys schools stayed overnight with the strikers. 34

On Monday, 9th May negotiations between the Company and the SBWU broke down and the police were ordered to take necessary action to ensure the right of passage of buses from the garage. On 10th May the human barrier across the gate was cleared by fire-hoses. Eight strikers were carried to ambulances on stretchers, but on arrival at the hospital one was found to have no injuries whatever, another to be suffering from mild concussion, and the remainder from minor abrasions only. 35

On 11 th May the strikers cleared the gate on arrival of the police, but on 12th May they stoned the police and damaged some of the buses and were again dispersed by hoses. 


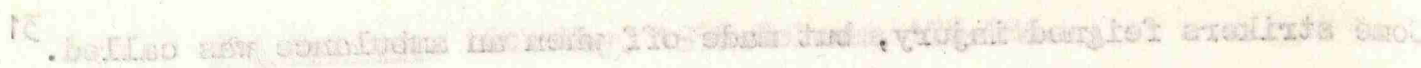

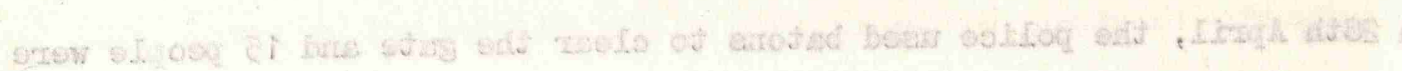

36. London Times, 13th May, 1955.

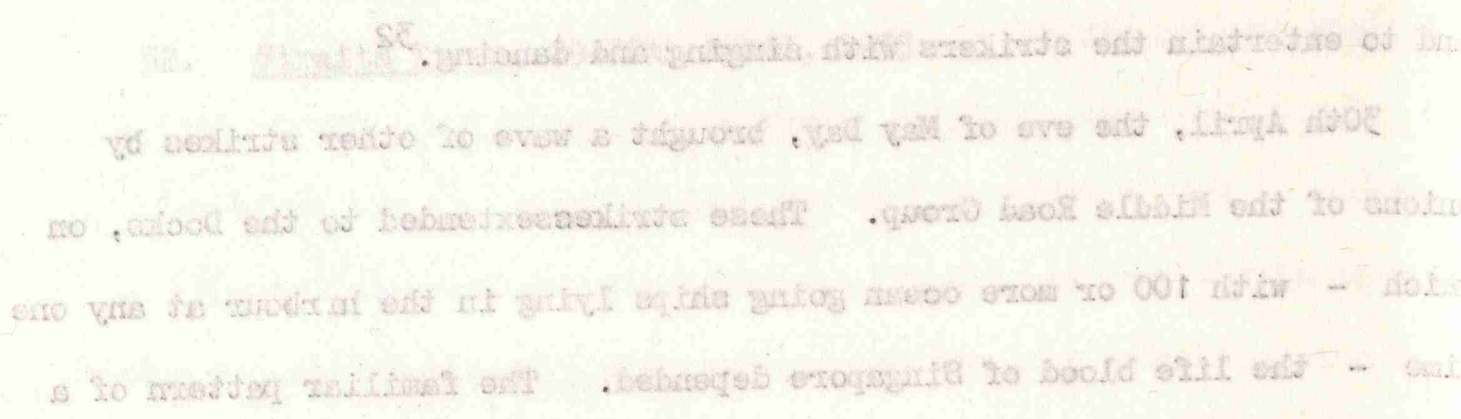

37. G.G. Thomson, para. 14.

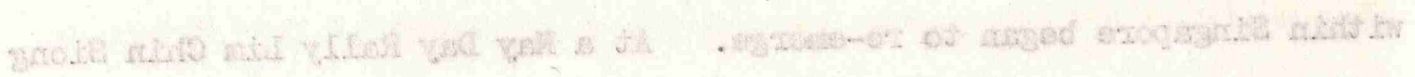

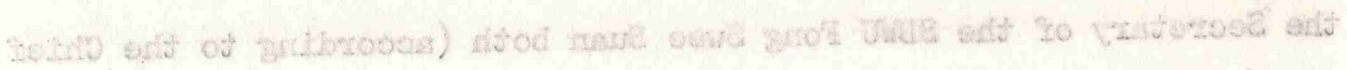

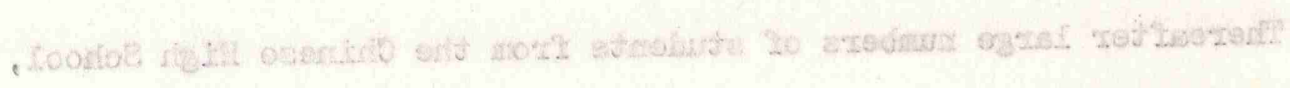

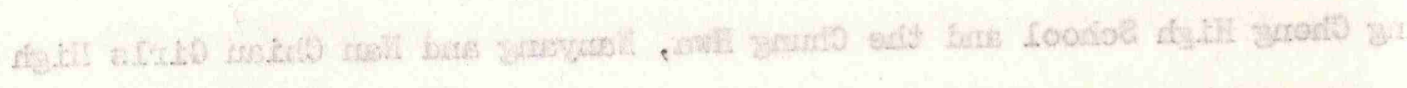

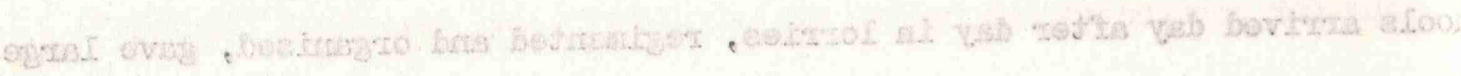

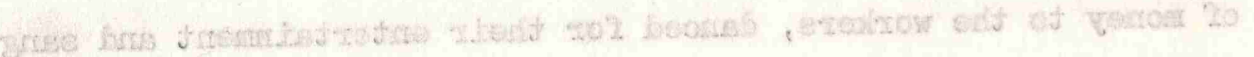

38. SLA Debates, 16th May, 1955 Columns 176-186. 39. Straits Times, 13th May, 1955.

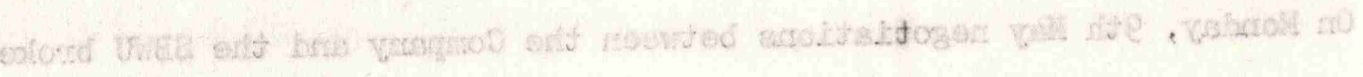

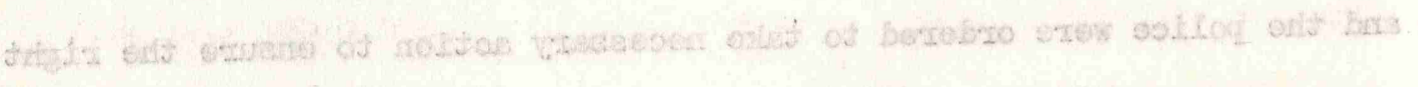

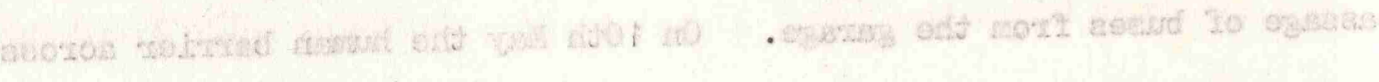

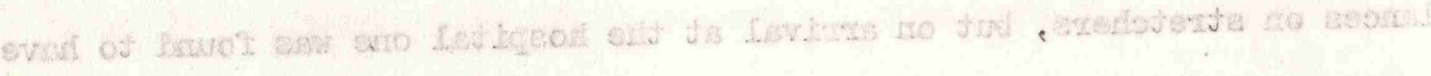

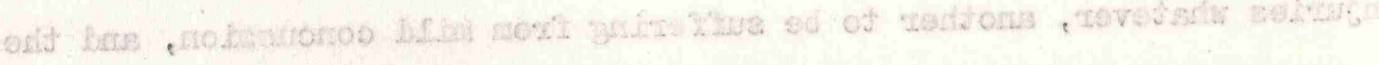

40. Straits Times, 16th May, 1955.

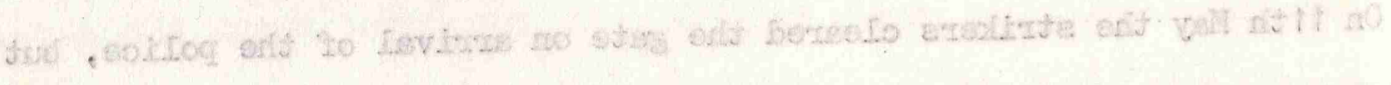

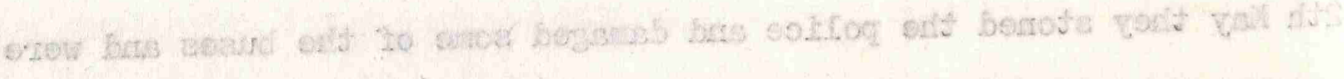


During 12th May the trouble built up. Large numbers of workers and students converged on the Hock Lee garages by lorry and bus. 17 lorry loads were diverted by police, but another 20 got through. Rioting crowds were estimated at 2,000.36 Between 4 and 7 p.m., mobs of up to 1,000 attacked the police and were dispersed by tear gas. During the night, four people were killed in rioting of exceptional viciousness exacerbated by the fact that the SBWU was Communist-oriented, whereas the Chinese owners of the company were regarded as Kuomintang supporters. The bitterness of the feeling can be qujged by incidents such as when the mobs sprayed a Chinese Police officer with petrol and burned him alive. 37 They also beat to death an American Press Correspondent (Gene Symonds) who was covering the strike; and a Chinese volunteer Special Constable, Andrew Teo, was also beaten to death by a mob which set fire to his car, A British police lieutenant in command of another police vehicle opened fire when it was attacked and a 16 year old Chinese student was hit in the lung. The wounded boy was then paraded round by rioters attempting to whip up the crowd, for $2 \frac{1}{2}$ hours before being taken to hospital, where he died. It was stated that if he had been taken there direct he might have lived. 38 In addition to the four dead, 31 were injured. 39

The rioting died by 3 a.m. and the 13th May was generally quiet, though there was an almost complete strike of bus workers throughout Singapore. On Saturday 14th May a government arbitrator gave a ruling which was signed by the Hock Lee Bus Company and the SBWU under which the pre-strike rosters were restored. The Bus Company objected that these rosters were unfair to nonSBWU employees, but stated that they would accept the ruling in the public interest. Bus services were resumed on Monday 16th May. 40

On the face of it, the Middle Road Group won the day in that the employees were directed by the government to meet the strikers' demands. Marshall's problem was that although the SBWU was Communist controlled and was using the dispute for political rather than industrial purposes, the 
41. G.G. Thomson, para. 20.

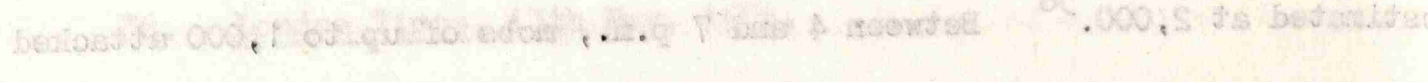

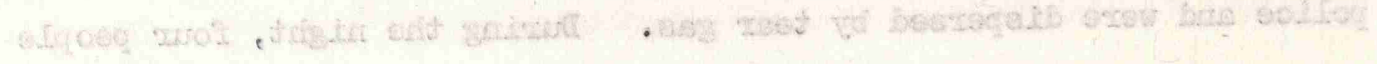

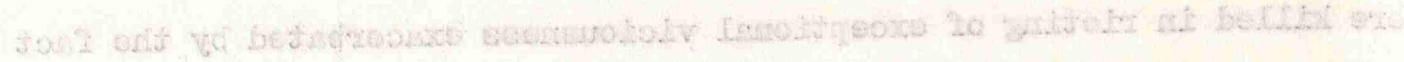
srij :

42. SLA Debates, 16th May, 1955 Column 175.

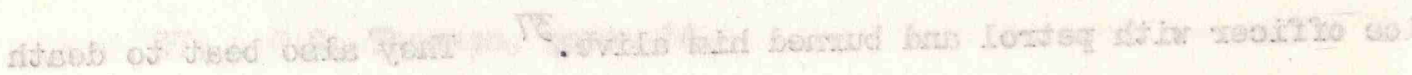

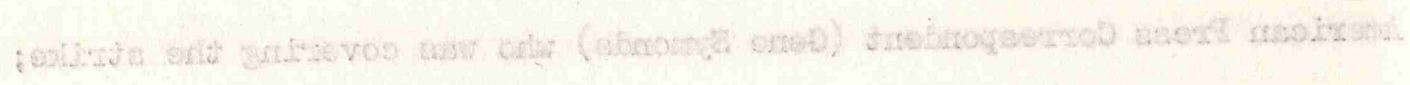

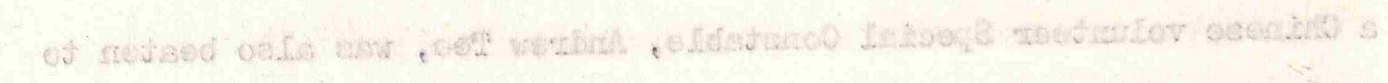

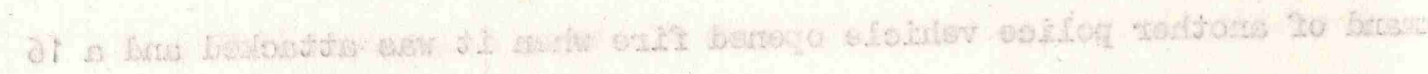

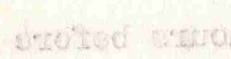

43. ibid, Columns 201-202.

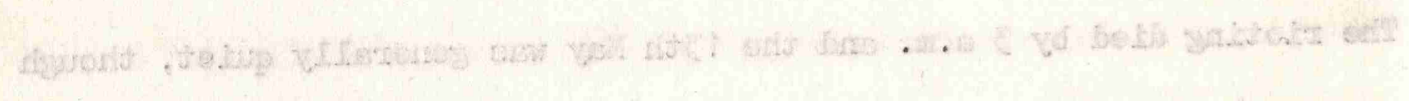

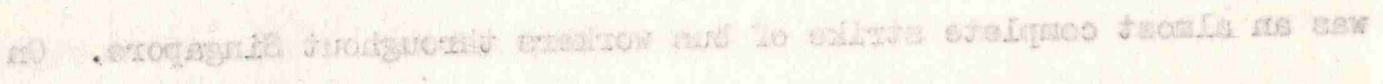

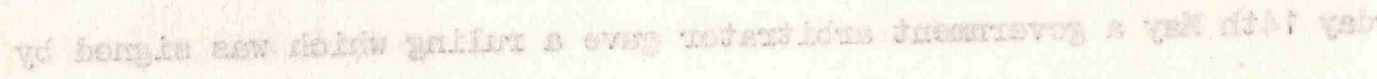
44. ibid, Column 225 .

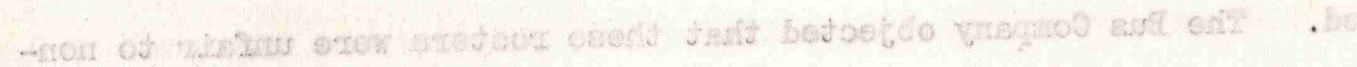

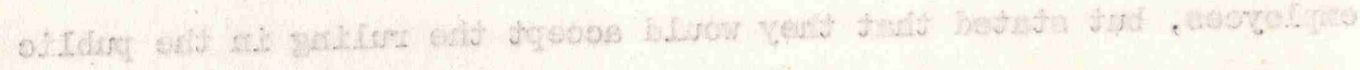

45. SLA Debates, 21 st September, 1955 Column 751.

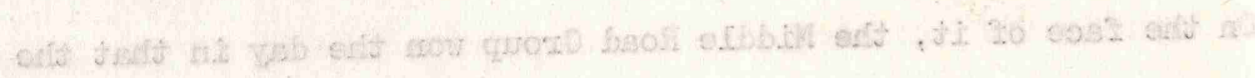

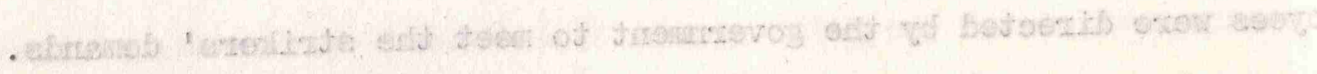

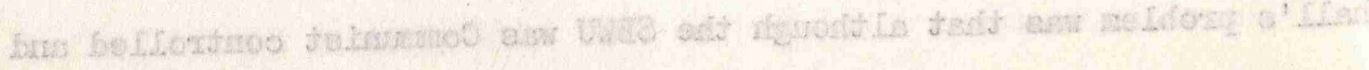

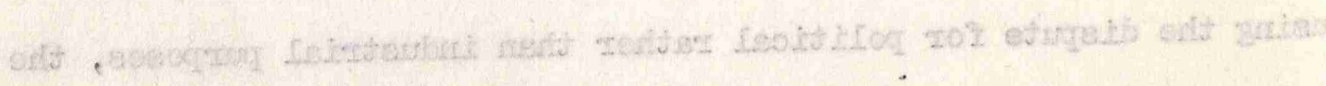


merits of the dispute did appear to put justice on its side, particularly in the eyes of the Chinese-educated public for whose leadership Marshall was competing. 41 On the other hand, the outbreak of violence and the deaths and injuries on the streets shocked the public as a whole and caused a reaction in favour of strengthening the powers of the police in maintaining law and order. There was an immediate reversal (approved by the Assembly) of some of the relaxations of the Bmergency Regulations, and, for example, the power of the Commissioner of Police to impose curfews by administrative order was restored. 42

Lee Kuan Yew's dilemma in reconciling his attempts to cooperate with the Communist Open Front with his disquiet at their methods was plain in the Assembly debate on the riots. He said that the PAP could not be responsible for every single member of the Party. They were working for a democratic non-Communist Malaya, but "would not fight the Communists or the fascists to preserve the colonial system.... we seek to destroy the colonial system and we seek to do so by methods of non-violence... we are opposed to any group or quarter from which violence comes". 43

Lim Chin Siong's contribution to the debate was perfunctory. He said that as an elected representative of the people he was not answerable to a colonial official; that he stood for a free democratic Malaya through peaceful and non-violent methods; that he did not support colonial officials in spreading negative hysteria of anti-Communism; and that otherwise he had nothing to add to what Lee Kuan Yew had said. ${ }^{44}$ He spoke for less than a minute. Both then and later, in the words of David Marshall, Lim. Chin Siong, "ostentatiously refused to answer the question as to where his loyalty lies - whether it is to Singapore or to Communism". 45

David Marshall Faces the Communists

On 24th August, 1955 the government tabled a new bill for the Preservation of Public Security. This was to replace the Emergency Regulations, though these were meanwhile to be extended (for the last time) 
46. SLA Debates, 12th October, 1955 Column 856.

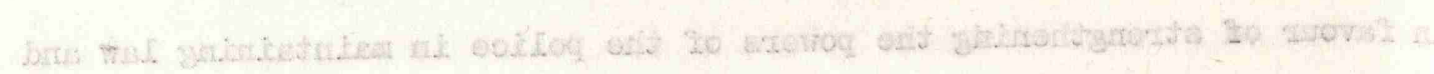

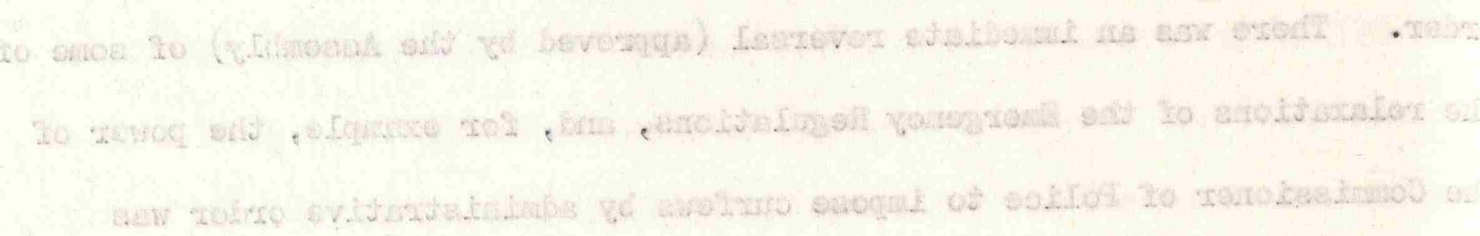
St. 2000

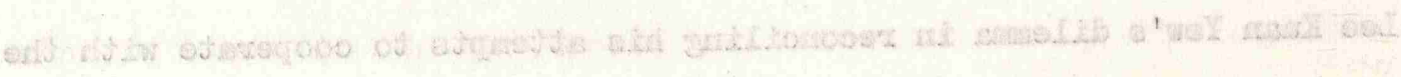

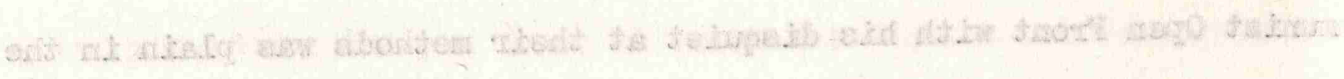

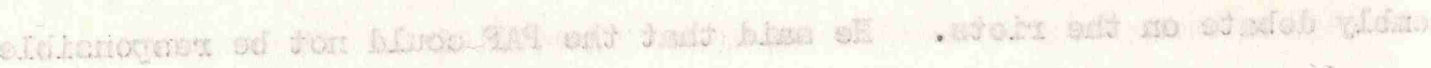

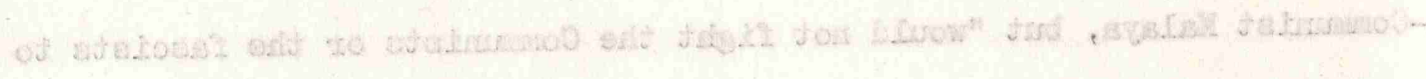

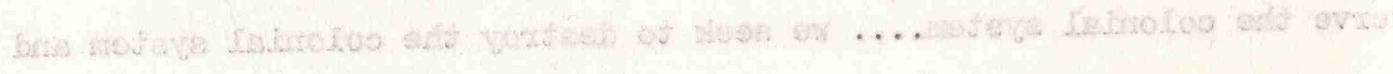

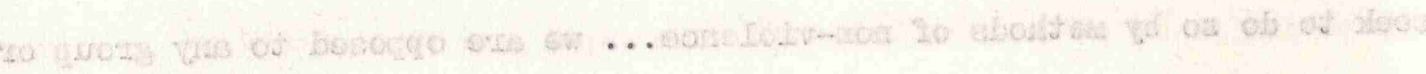

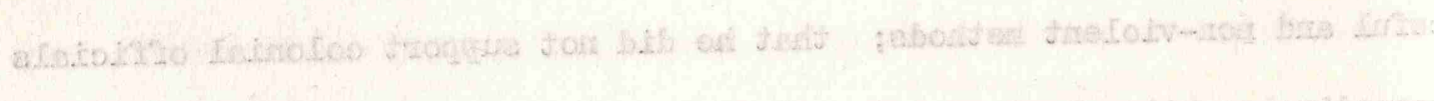

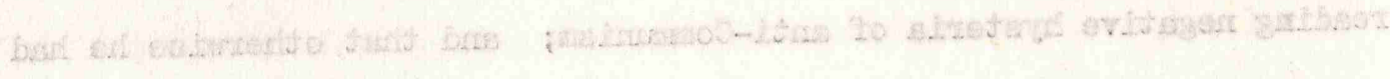

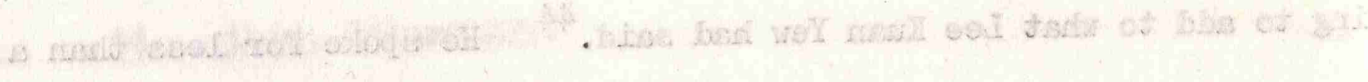

47. Military Report, pp. 4 and 5.

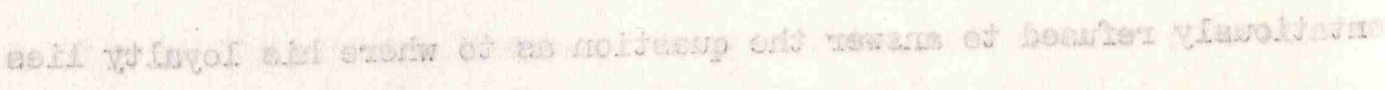

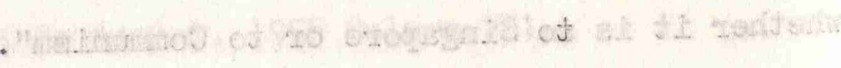

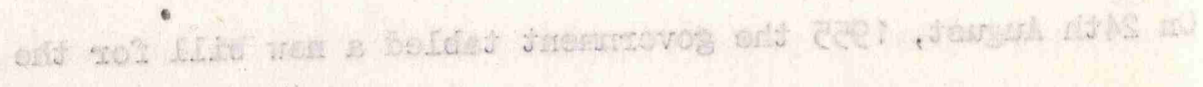

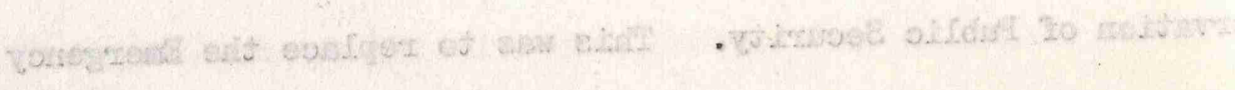

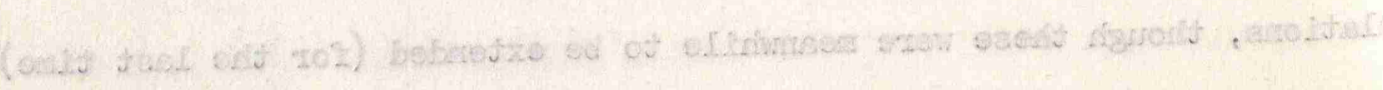


for a further three months while the new Bill was beibg processed by the Assembly. It restored the police powers of search, and of imposing curfews and road blocks, and was finally passed on 12th October, 1955 by 19 votes to 4 (3 PAP and one Independent) with 7 abstentions. 46

There was a strong reaction, predictibly, both from the PAP and from the Middle Road Group of Unions. Workers in all the major hotels went on strike in September, and a strike in the large Singapore Cold Storage Company was defeated only when picketers were arrested for obstruction. The men of the Singapore Traction Company - the only European owned bus company in the Colony - also came out on strike in September, and remained out for five months. The union's adviser during this strike was Devan Nair, who was later to be detained with Lim Chin Siong, but who subsequently came over firmly to the support of Lee Kuan Yew.

In November, the Singapore Bus Workers Union brought out all the rest of the Island's 12 bus companies on strike under the leadership of Fong Swee Suan, who was not only Secretary of the SBWU, but also assistant Secretary General of Lim Chin Siong's SFSWU. Fong, who had already been detained for a few weeks in August, was to go into detention with Lim Chin Siong twice more, the second time being as a staunch opponent of Lee Kuan Yew in the political struggle that was to come to a head in 1963. It is ironical that in November 1955 it was Lee Kuan Yew who saved the SBWU and the Midale Road group from defeat in this strike by proposing that there should be a public examination of the Bus Companies' books. At the prospect of this, the employees capitulated. 47

It was at about this same time (October 1955) that the Singapore Chinese Middle School Students Union, on the instruction of the Malayan Communist Party, gave the required 'undertaking' not to take part in political activities, and so became legally registered, as described in the previous chapter.

After 7 stormy months in office, David Marshall had no illusions about the threat that the Communists' activities, amongst both workers and students, 
48. Military Report, p. 6 .

49. A full account of the Baling Truce Talks will be included in Anthony Short's The Communist Insurrection in Malava, now awaiting release for publication by the Malaysian government.

50. Anthond Short - Interview 1969.

51. "Harris" (SB) - Interview 1966. 
posed to his authority as Chief Minister. In December 1955 he joined the newly elected Chief Minister of the Federation of Malaya, Tunku Abdul Rahman, in the Truce Talks with Chin Peng at Baling. The main point at issue at these talks was the recognition of the Malayan Communist Party, with freedom to act as a legal political party after the end of hostilities. The PAP urged that this recognition should be given. 48 The Tunku and Marshall, however, both stood firm against this and the talks broke down. 49

Chin Peng's Central Committee, who knew that they could now do no more at best than hold onto a bare existence as a political nucleus in the jungle, therefore issued further injunctions to the Party branches, both rural and urban, to concentrate major efforts on subversion - particularly in the Chinese Middle Schools. 50

It should not be imagined that this directive from the Central Committee reached many of the Party branches in time to have much direct bearing on the intensification of the student campaign in the first nine months of 1956. Nevertheless, the normal Communist education and study in party cells will have been enough to lead members to this reaction (particularly in view of the well publicised failure of the truce talks) without further orders. Those responsible for publication of Party News, Wall newspapers etc., also used these media to exhort their followers to intensify their actions in the urban field ${ }^{51}$, with the effect described in the previous chapter.

\section{The London Talks of April/May 1956}

Meanwhile, preparations were building up for constitutional tạlks in London in April, 1956. Marshall took with him an All-Party Delegation which included both Lee Kuan Yew and Lim Chin Siong. The talks opened in a promising atmosphere. The British Secretary of State for the Colonies, the Rt. Hon. Alan Lennox Boyd, paid tribute to the Chief Minister's fight against Communism. He said that he did not intend that Singapore should become an outpost of Communist China "where perhaps for a while the essential defence 
52. Report on the Singapore All-Party Mission to London April/ May 1956 (Singapore Sessional Paper No. Cmd 31 of 1956) p. 18.

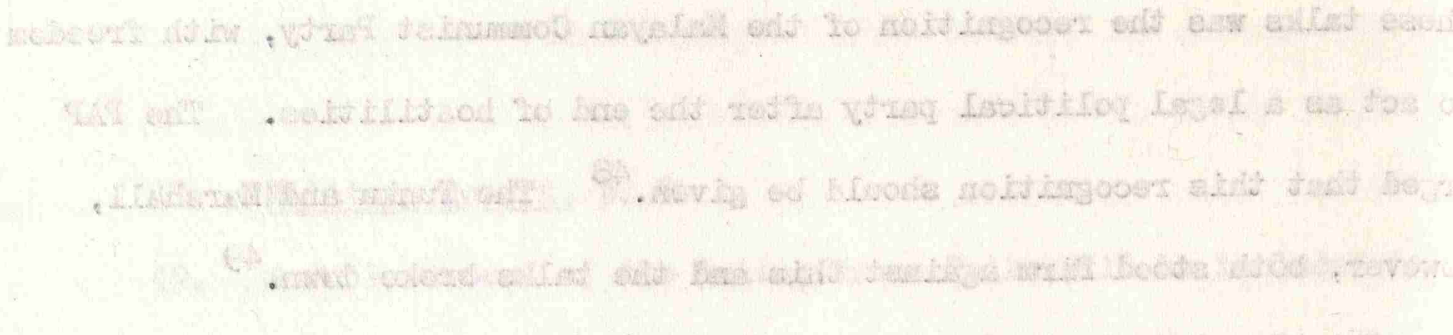

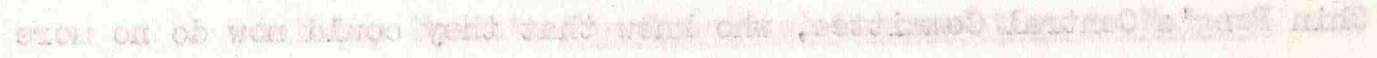

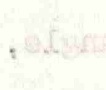

53. ibid, p. 52 .

54. ibid, p. 68 .

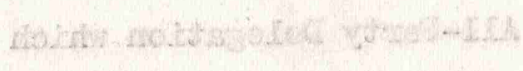

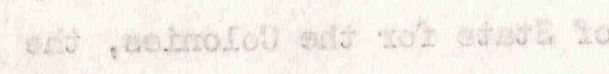

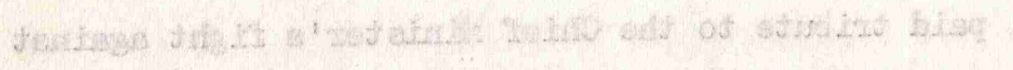

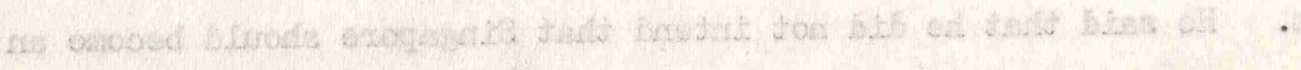
55. ibid, p. 20 . 
bases might be tolerated because they helped to keep down unemployment, but which would assuredly be crippled in times of emergency by strikes or sabotage". 52

The constitution proposed by the British Government provided that exofficio and nominated members of the Assembly would be abolished, and that the Assembly (wholly elected) would be increased to 50 members. The three British official ministers would be replaced by elected members, and the Chief Minister would preside over the Council of Ministers. The British Governor would be replaced by a High Commissioner, who would preside over a Defence and Security Council, which would include two other representatives of the British Government, and two of the Singapore Government. The British High Commissioner would thus have the decisive vote. In addition, the British Government would retain responsibility for external affairs and defence, including the power to make laws by Order in Council and to authorise the High Commissioner to make regulations, both of which would over-ride other laws that might be in force in Singapore. These powers were in relation to external defence and external affairs, but the definition of external defence included "the preservation or restoration of public safety or public order and the maintenance of essential supplies and services" in so far as they related to external defence or external affairs. 53 The United Kingdom also retained the power to suspend the Constitution "if in their opinion the internal security of Singapore has so far deteriorated as to threaten Her Majesty's Government's ability to carry out their responsibility for external defence or extermal affairs; or if the Government of Singapore have acted in contravention of the Constitution as provided in this Order." 54 .

David Marshall applauded the rapid pace at which the Federation of Malaya was advancing to independence despite the continued need for military operations against the Communists; Singapore had no shooting war, and no British troops had had to be used to deal with internal disturbances during the past five years; his Government had now been operating for a full year, and it was their desire to be friends, but their will to cease to be dependents. 55 
56. ibid, p. 15.

57. ibid, p. 7.

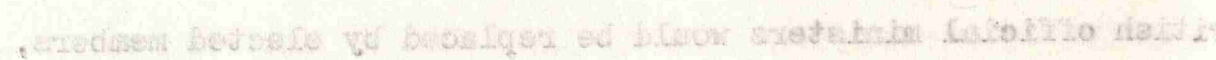

58. ibid, p. 6.

59. David Marshall - Interview 1968.

60. Sing. Cmd No. 31 of 1956, p. 8.

61. ibid, p. 7 .

62. ibid, p. 8.

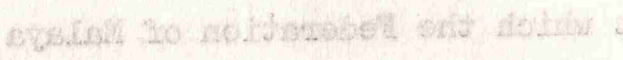

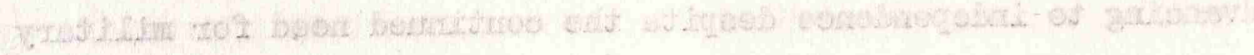

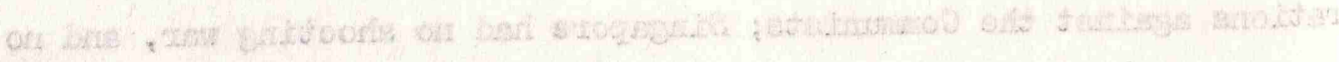

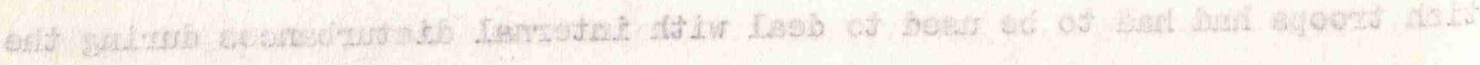

61. 63. ibid, p. 14.

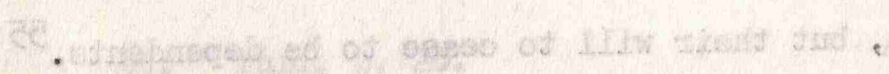


He accepted the provisions of the proposed Constitution but for the UK government's insistence on legislative power to make over-riding orders in Council on matters of internal security, and on a British majority vote on the Defence and Security Council. 56 He demanded that internal security should be the exclusive responsibility of the Singapore Government ${ }^{57}$, and also objected to the British retention of the right to appoint the Commissioner of Police, who was also to have direct access over the heads of elected ministers to the British High Commissioner. 58 (This objection was, of course, primarily concerned with the restrictions on his access to Special Branch secrets. ${ }^{59}$ ) Marshall pointed out that, with his reserve powers, the High Commissioner could, for example, legislate against strikes, processions and student rallies if regarded as prejudicial to external defence, and that, with such powers, the freedom granted by the proposed Constitution was illusory. 60 He said that such powers were unnecessary, since the British Government could always suspend the Constitution even before the eruption of violence if it considered that the deterioration of the internal security situation by subversion affected the efficacy of external defence.

installations. 61

The British Secretary of State replied that it was possible to conceive of many disputes between Her Majesty's Government and the Singapore Government which would not call for so drastic an action as suspension. He insisted that the British Government "must under present circumstance retain an ultimate authority in matters of external defence, internal security and external affairs". 62

On the twelfth and final day of the Conference, the Singapore delegation offered to accept the UK retention of over-riding legislative powers if, and only if, the Defence and Security Council were composed of equal numbers of British and Singaporean representatives, with a Malayan Chairman appointed by the Federation Government. This proposal was rejected. 63 David Marshall's delegation finally asked whether, if they accepted all the proposals in the 
64. ibid, p. 15 .

\section{David Marshall - Interview 1968.}

66. Lee Kuan Yew, Battle, p. 25. He names these as Lim Chin Siong, Devan Nair, Chia Fk Tian and Goh Boon Toh.

67. Military Report, p. 6. 
new Constitution, the over-riding legislative powers could be limited to two years. This too was rejected. The Singapore delegation then took a vote amongst its members, nine voting against acceptance of the proposed Constitution, the other four abstaining. The talks thereupon ended. 64

According to David Marshall, the left wing members of his delegation were anxious to accept the Constitution rather than go back with nothing, presumably confident that they could make faster progress under that than under the present Constitution. At the crucial vote on the final day, however, Marshall insisted that he would vote against it, and that if they accepted it he would be established as more radical than they were. On this they agreed to vote with him. 65

After the failure of the talks, Marshall resigned and his deputy, Lim Yew Hock, bacame Chief Minister.

The PAP Central Executive Committee Elections

Soon after his return from London, Lee Kuan Yew was faced with a determined Communist challenge for control of the PAP. In July 1956, the party held elections for a new Central Executive Committee, which resulted in four of the twelve places being filled by pro-Communists. 66 Indeed, Lim Chin Siong himself received more votes than Lee Kuan Yew, ${ }^{67}$ though Lee's chairmanship was endorsed by the vote of the eight members of the Committee who supported him.

Having failed to secure control of the Central Executive Committee on the popular vote of the PAP branches, the Communists attempted to have the Constitution redrafted so as to allow the branch committee to nominate members to the Central Executive Committee, instead of having them elected by a ballot open to all members of the branch. Lee Kuan Yew resisted this change, considering that it would in effect enable the Communists to capture the party. 68 This is a standard Communist tactic, used to gain control of Trade Unions and other organisations. Routine branch meetings are not usually well attended except by the more militant members, and by counting heads and springing a 


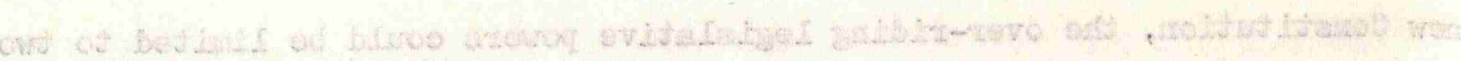

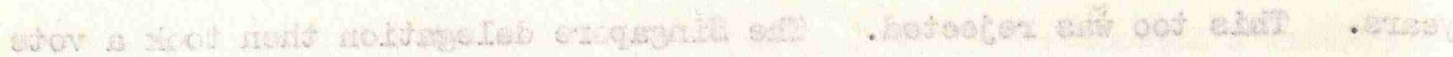

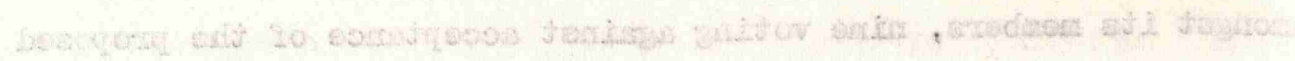

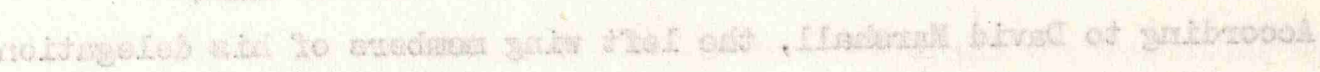

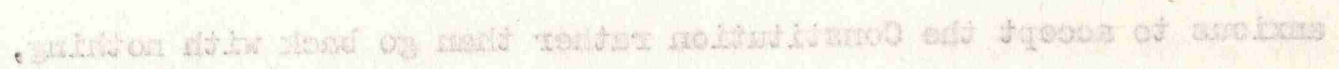

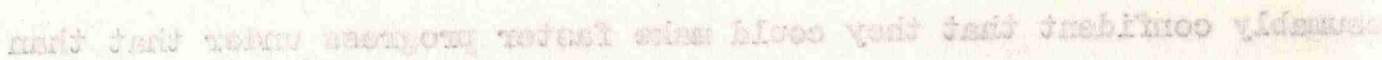

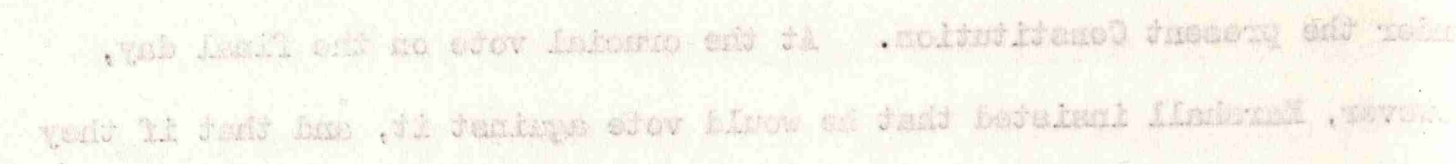

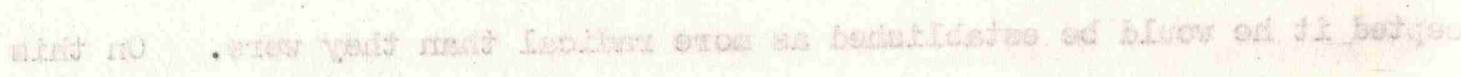

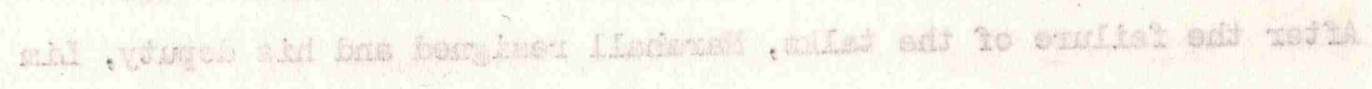

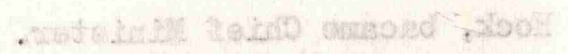

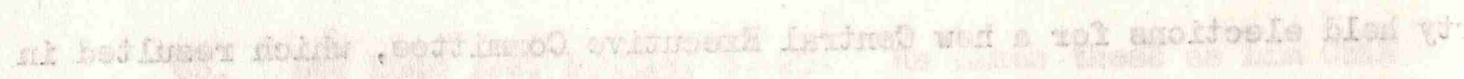

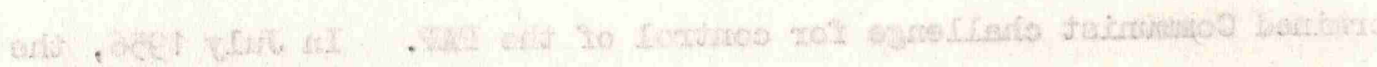

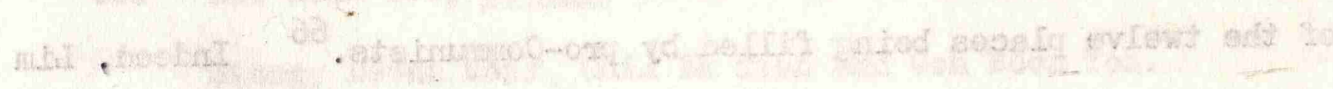

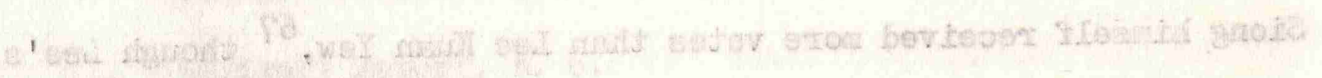

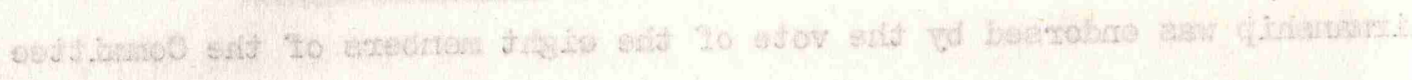

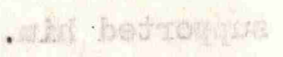

69. Military Report, p. 7.

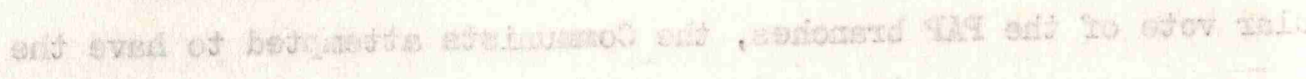

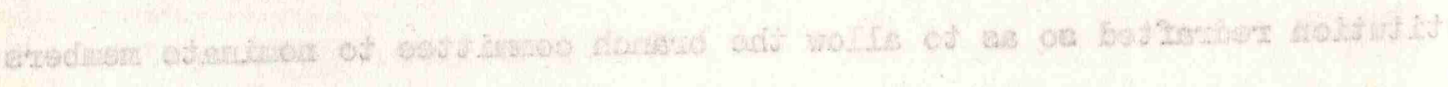

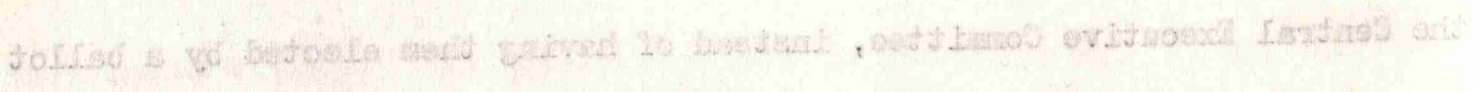
70. Lim Yew Hock - Interview 1965.

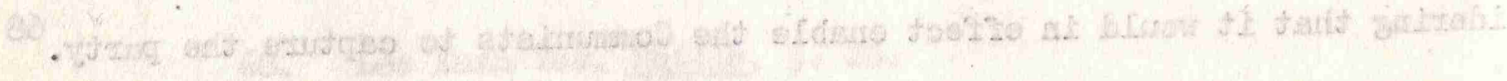

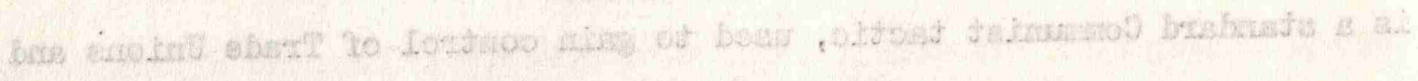

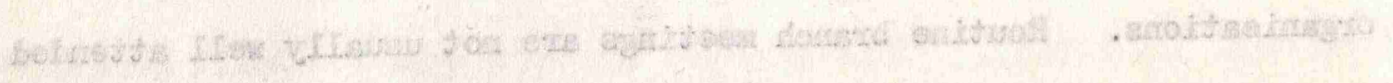

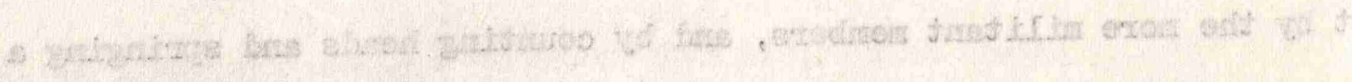


well-timed snap vote, it is easy enough to get left-wing members elected one by one to the Committee until they hold a majority. If thereafter this Committee nominates its representative to the next one up, and so on in a tiered system of nominations to the top, the Communists have only to capture the branch committees to capture in due course all the others including the Central Executive Committee. On the other hand, if each member of the Central Committee is elected by a popular vote of all members of the brancheps, this is far more difficult to manipulate - and more difficult still if the voting is by secret ballot. That is why, from its inception, the Soviet system was based on voting only at the bottom level with a tiered system of nominations above it. In Singapore, the 'Constitutional' Trade Unions (those affiliated to the Trade Union Congress) were generally run on the British system of election of all Committees by popular vote, whereas the Left-Wing Unions were run on the tiered system. But the Left-Wing attempt to extend the tiered system to the PAP was successfully resisted by Lee Kuan Yew.

\section{A New Plan for Internal Security}

The new Chief Minister, Lim Yew Hock, realised that neither the British Government nor the Federation of Malaya would allow Singapore to advance to full independence, or even to the control of their own internal security, so long as there was doubt about the ability of the government forces, whether directed by the British or not, to control the Communist erosion of their power. 69 The Communist intention at this stage was clearly to coerce the government into making concessions which would give them rein to extend and consolidate their control of the students and workers by subversion and intimidation. Unlike Lee Kuan Yew, Lim Yew Hock believed that this could not be achieved by cooperating with them. ${ }^{70}$ He therefore gave his full cooperation to the British Governor and Commissioner of Police.

The Commissioner of Police (CP) anticipated that the failure of the London talks, and the new Chief Minister's firm attitude towards the LeftWing, would lead to bigger disturbances within the next few months. In July 1956 he therefore prepared a new Internal Security Plan, in conjunction with 


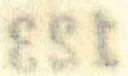

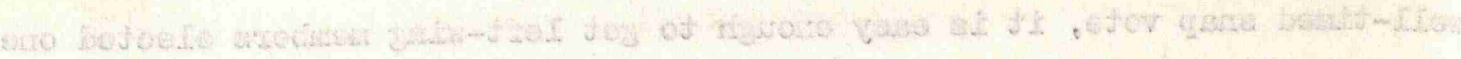

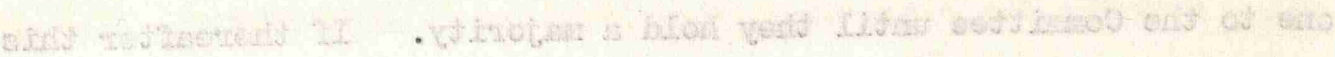

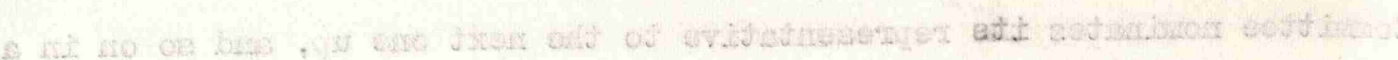

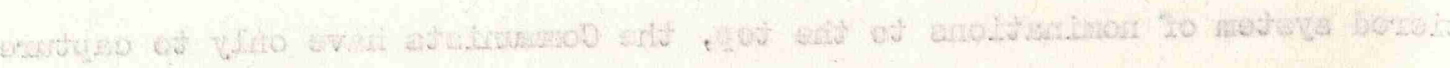
oft.

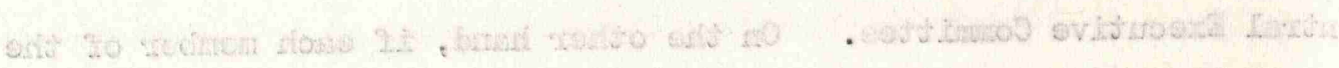

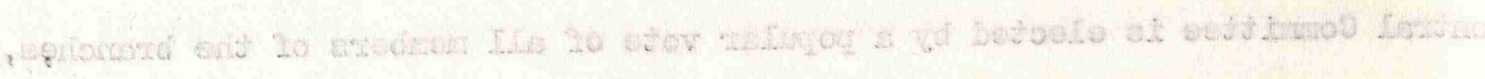

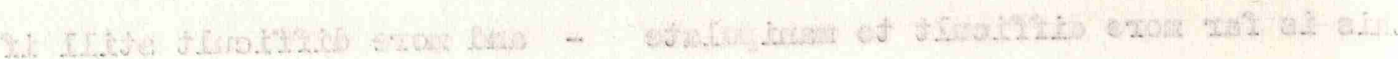

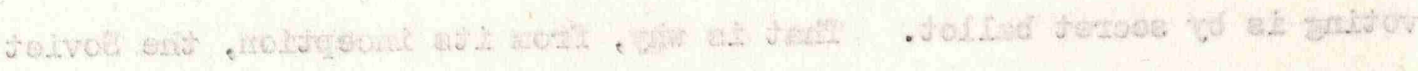

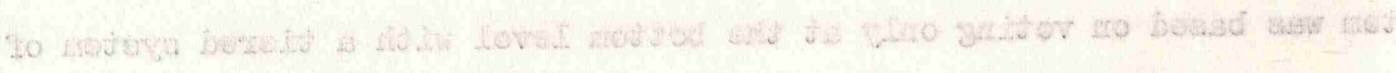

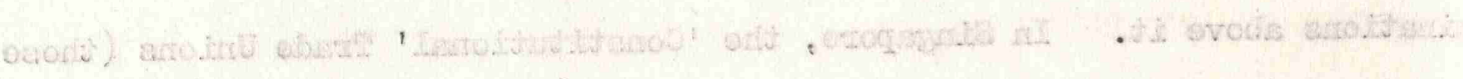

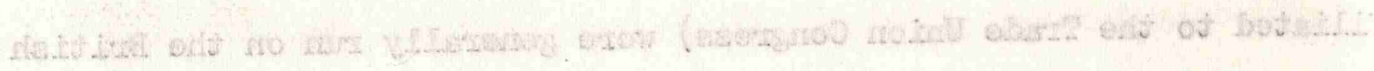

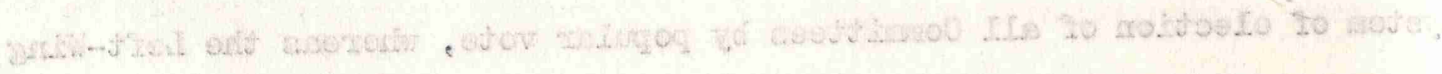

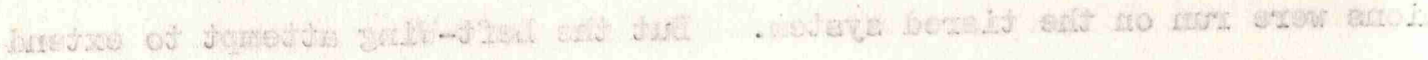

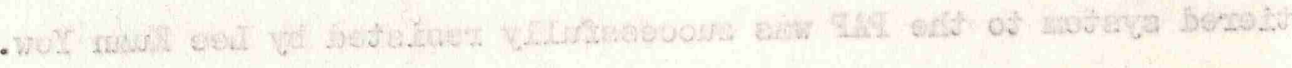

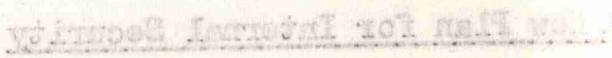

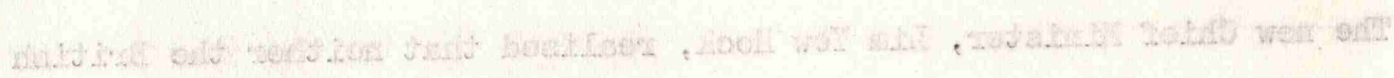

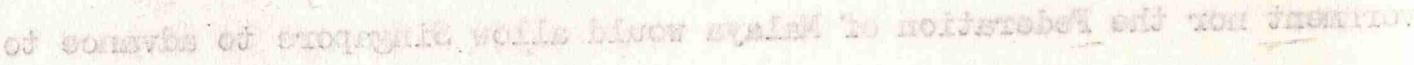

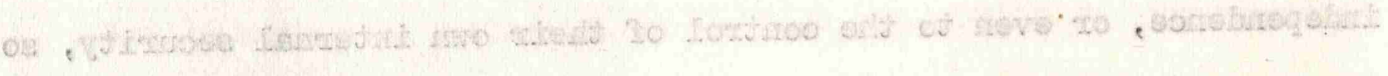

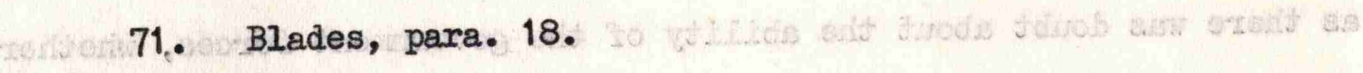

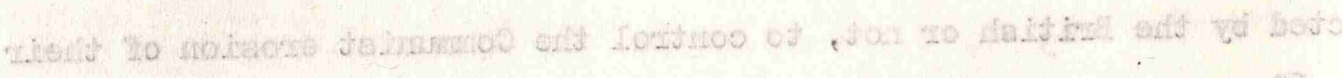

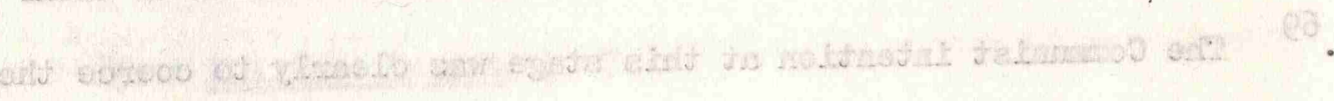

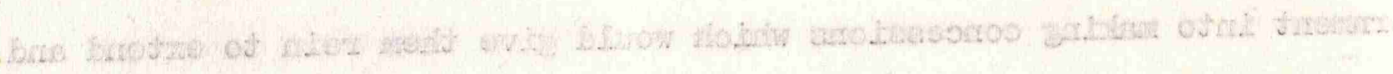

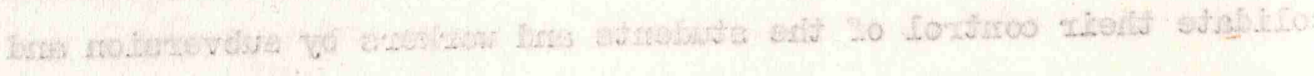

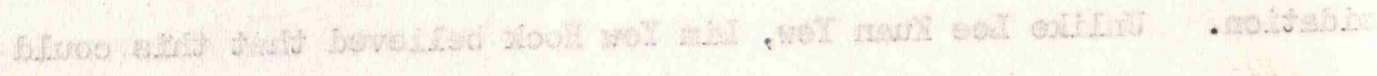

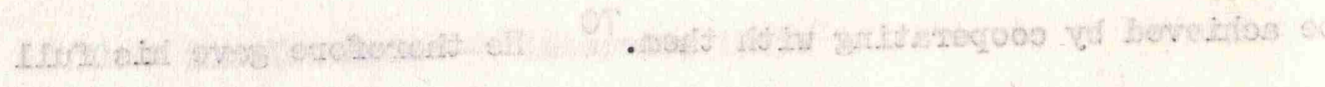

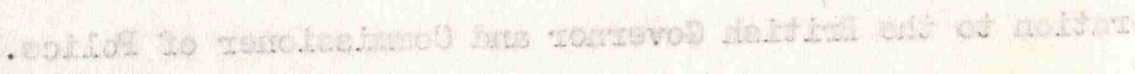

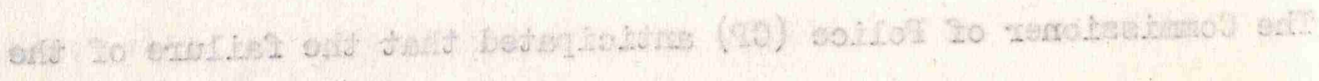

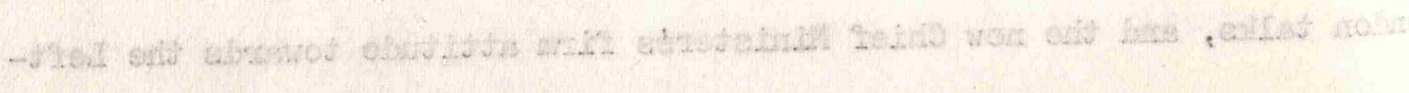

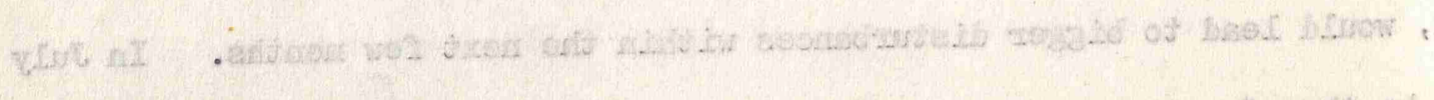

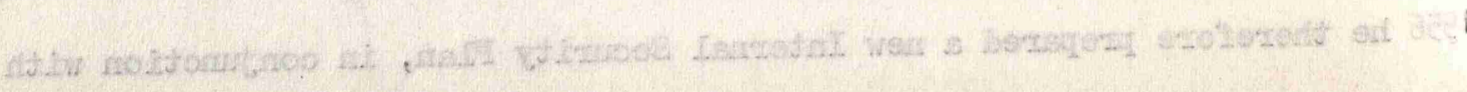


the General Officer Commanding (GOC) Singapore Base District. This plan was known as 'Operation PHOTO' (a pun on FOTO - Failure of Talks Operation).

The plan was besed on maintaining 40 continuous patrols by police radio cars, working in conjunction with Army roadblocks and patrols and supported by 2. RAF helicopters (in the event reinforced to 5). The police car coverage was such that from the time of a call, one car could be on the scene within three minutes, and 2 to 3 more within another five minutes. Bach patrol car had a crew of 6 armed policemen, equipped also with tear gas and dye grenades (to stain the clothes of rioters as an aid to their subsequent identification).

One of the delicacies of this final period of transition from Colonial rule to independence was that a precipitate show of military force, especially by British units, would certainly be politically exploited, and might therefore do more harm than good. An important feature of Operation PHOTO was a discreet stand-by and deployment stage which enabled $a \cdot$ show of force to be made from previously practised vantage points, (normally the Police Divisional HQ Stations) within minutes of a decision by the Governor - a decision to be reached, it was hoped, together with the Chief Minister and the Cabinet, unless they themselves were acting as a defiant opposition. This foresight was to pay good dividends. 71

Working from these vantage points the Army planned to establish 26 (later increased to 29) road blocks, covering all roads entering the city, and all the bridges across the river which splits the centre of the city in half. The army also provided vehicle patrols and night patrols to enforce the curfew.

All of these - the roadblocks, the helicopters and the patrols were designed to prevent small bands of demonstrations from joining up into big crowds. Should they find crowds beyond their power to control, the soldiers could call on riot squads, each 50 strong, from each Police Area Headquarters, and of course, on the rest of the army. 


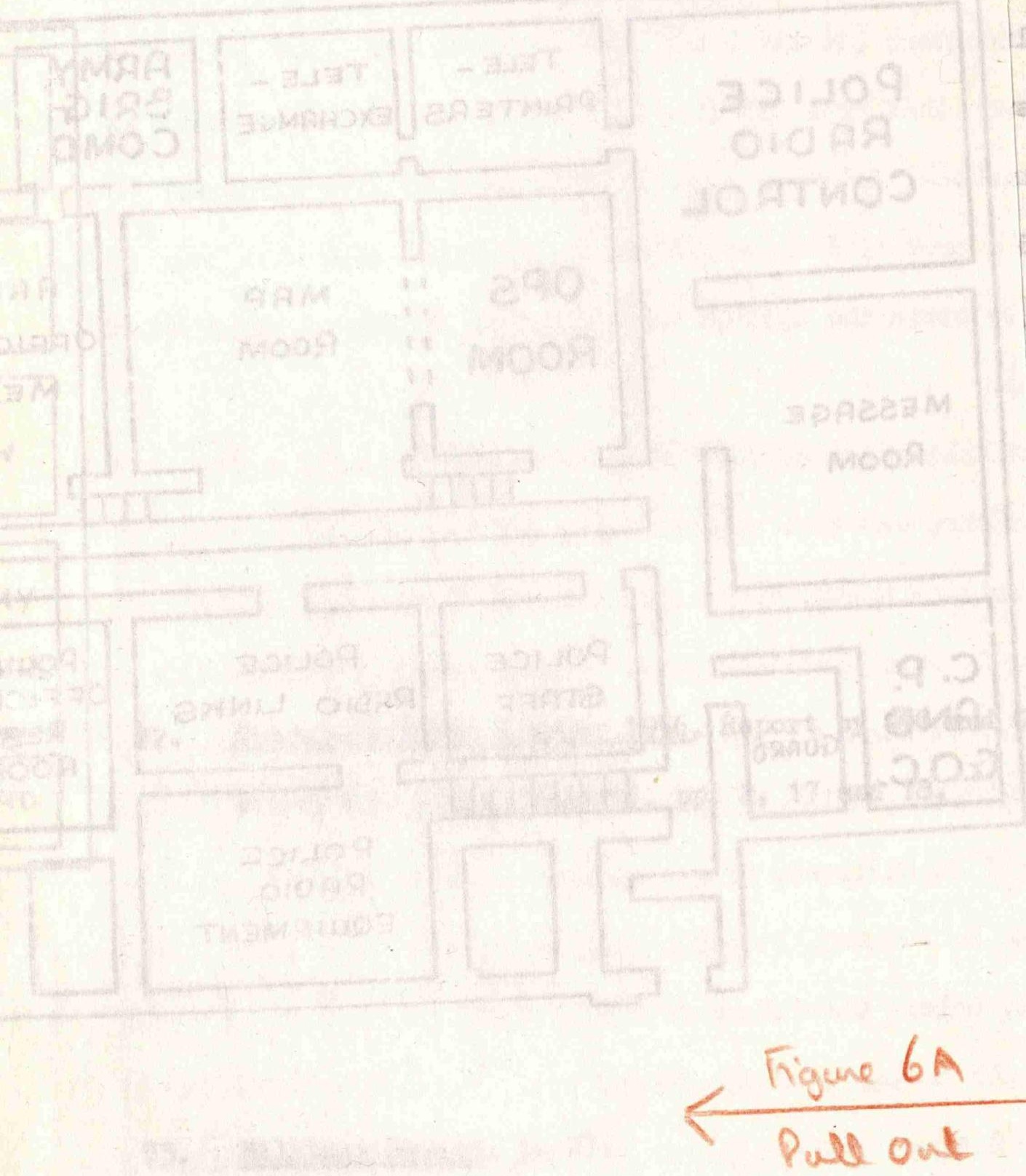

2ko17914 99009

7o. ganorzengho?

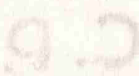

:

$30 \times 2$ Aswe wi. soovint

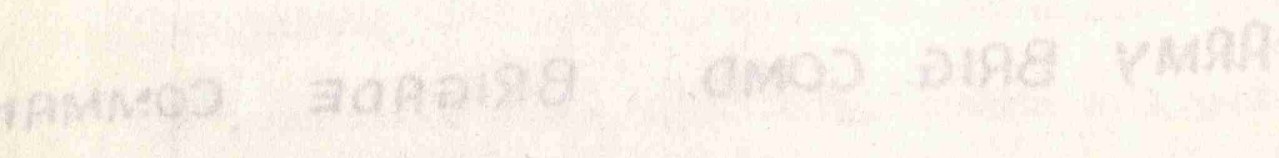
OOA EHOITAM=90 MoO9 290 
SINGAPORE POLICE HEADQUARTERS

COMBINED OPERATIONS ROQM

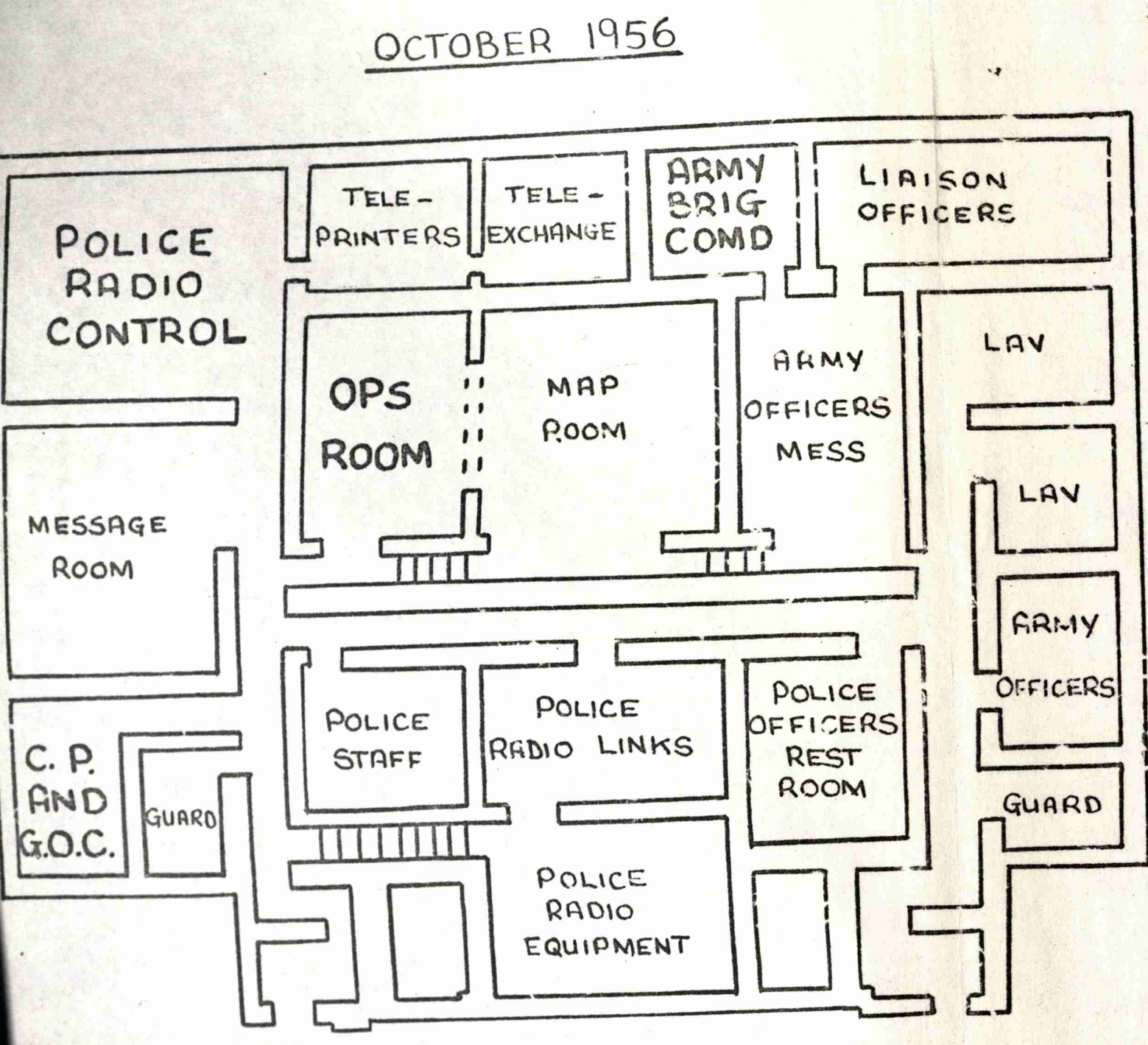

ABBREVIATIONS

C.P.

COMMISSIONER OF POLICE

G.O.C.

GENERAL OFF!CER COMNIANLING TRUOPS, IN SINGAPURE

ARMY BRIG. COMD. BRIGADE COMMANDEP.

OPS ROOM OPERATIONS ROOM
72. Singapore Riots October 1956, Report by GOC and Commissioner of Police, (Joint Report), pp. 2, 17 and 18.

73. Military Report, p. 27.

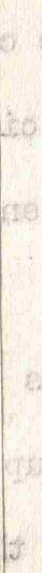

74. Joint Report, p. 4 . 
The army garrison of Singapore contained only one British infantry battalion, (lst QUHEHS), and even this was normally all deployed in the jungle on the mainland except for one company at a time resting. Two further improvised Internal Security battalions were formed from a Malaymanned artillery regiment and from various units in the Base (also mainily Malay). These soldiers were given part-time training in Internal Security Duties and were known as "X" and "Y" I.S. Battalions. They had already proved their worth in the 1950 (Maria Hertogh) riots.

Plans were also made by the Director of Operations in Kuala Iumpur if required to withdraw the balance of the lst Queens Battalion from the jungle, together with five more British and Gurkha battalions, to reinforce Singapore at very short notice. (In the event all but one of the '1 ist queens' companies were in Singapore 9 hours after the call, and four other battalions within 11-14 hours - a remarkable achievement considering that two were deployed in the jungle over 100 miles away). ${ }^{72}$

It was decided that, on the threat of serious trouble, the Brigadier commanding the 18th Infantry Brigade would set up his Command Post in the rooms immediately beside the Police Operations Room in Police HQ, Pearls Hill. An office for the CP and the GOC was also set aside in the same corridor (See figure 6A). All operations would initially be under the direction of the CP. 73

The Government's UItimatum

With these preparations complete, the Government was better equipped to deal firmly with Communist subversion. On 18th and 19th September, the Council of Ministers ordered the banning of two notorious Front Organisations - the Singapore Women's Association and the Chinese Musical Gong Society, and in the following week (24th September) they dissolved the Singapore Chinese Middle School Students' Union on the grounds that it had blatantly flouted its pledge not to take part in political activities. ${ }^{74}$ Special Branch were ready with the draft of the White Paper on the SCMSSU which laid out in detail the subversive activities of the Union as described. 
75. White Paper, SCMSSU, 1956.

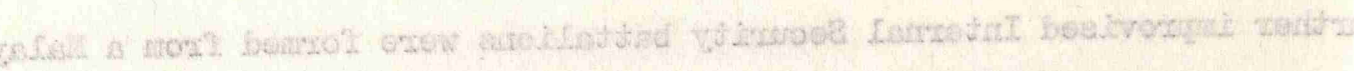

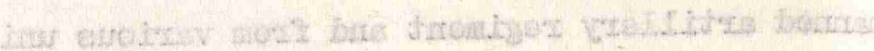

76. Straits Times, 20th October, 1956.

77. Joint Report, p. 3.

78. STAA Debates, 4th October, 1956 Columns 322-323.

79. In the debate following the riots, Lee Kuan Yew, though he accused the government of deliberately provoking the riots at a time of their own choosing, admitted that "once mobs were on the streets, the only, answer was force". SLA Debates, 6th November, 1956 column 584. 
in the previous Chapter. ${ }^{75}$ This was published and distributed on 4 th october.

Meanwhile, on lst October, they had arrested the Secretary General of the SCMSSU, Sun Lo Bun (an over-age student of 23). 15,000 Middle School Students held protest meetings in their classrooms, which coincided with their celebration of Communist China's National Day. ${ }^{76}$ A Civil Rights Convention had also been formed on 28 th September to protest against the dissolution of the two front organisations and the SCMSSU, and this too held meetings at which inflammatory speeches were made. ${ }^{77}$

There was a meeting of the Assembly on 4th October. Lee Kuan Yew proposed a motion "that this house is gravely concerned over the recent arrests of trade union and civic leaders and the dissolution of two societies.." He warned that "repression .. is a habit that grows". First, he said, the Government attacks only those whom Special Branch say are Communists, even though they have no proof other than hearsay; ,next, those, whom Special Branch say are actively helping, although they are not Communists themselves; then, those whom Special Branch say are aiding the Communists by their intransigent opposition to any collaboration with colonialism, thereby encouraging the spirit of revolt and weakening constituted authority; then finally "you attack all those who oppose you". 78 He concluded

"I agree with the Hon Gentleman opposite that if any act is done to overthrow a government by force, that act must be suppressed. 79 But if we say that we believe in democracy, if we say that the fabric of a democracy is one which allows the free play. of ideas, . which avoids revolution by. violence because revolution by peaceful methods of persuasion is allowed, then, in the name of all the gods that we have in this country, give that free play a chance to work within the constitutional framework. If you do not, then you will face outright 
80. ibid, Column 328.

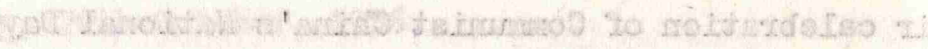

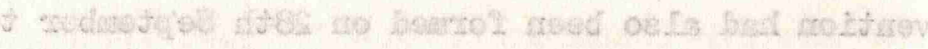

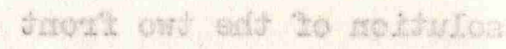

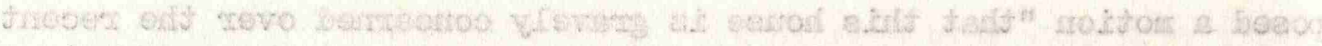

81. ibid, Column 400 .

82. ibid, Column 402. In a later debate after the riots and after the detention of Lim Chin Siong, Lee Kuan Yew said "To fight the Communists, one must understand ..... what they

(6.) are after. Is it evil? I am not convinced myself that Communism is an evil force. In fact, I agree with about $75 \%$ of what they want to do. But it is that $25 \%$ ofhow they do it that I object to and oppose". SLA Debates, 6th November, 1956 Column 581 .

83. SLA Debates, 4th October, 1956 Colum 333. 
opposition, an armed revolt, and eventually an armed

victory. Then the whole social fabric of this

society will collapse." 80

Later in the debate, he expanded further on this theme,

"In Britain, for 400 years, there have been no

violent revolutions because one had this interplay

within a system which allowed changes to take place

by peaceful persuasion .... The theory is that if

the British Communist Party could put up a

sufficient number of candidates and be able either

by political persuasion or propaganda or other

constitutional means of political leadership to get

the majority of the people to vote for them, then

they would become the lawfully constituted and

elected government of the people." 81

He suggested that it was immaterial whether Special Branch were right or wrong about the guilt of the six men detained.

"Even if, in fact, these six men believe in

Communism - the question remains whether they are

prepared to compete constitutionally and peacefully.

If they have never done anything which is not

peaceful or constitutional, then you are negating your

whole political philosophy when you say "I will arrest

you because I think you are propagating an idea which

I consider pernicious"...." 82

Lim Chin Siong, seconding the motion, challenged the government to try the detained men in open court, and questioned Lim Yew Hock's authority

"The Chief Minister proudly talks about "My

Government"! Whom is he trying to bluff? Everybody

knows that under the Rendel Constitution the Colonial

Office controls all the key positions and retains 


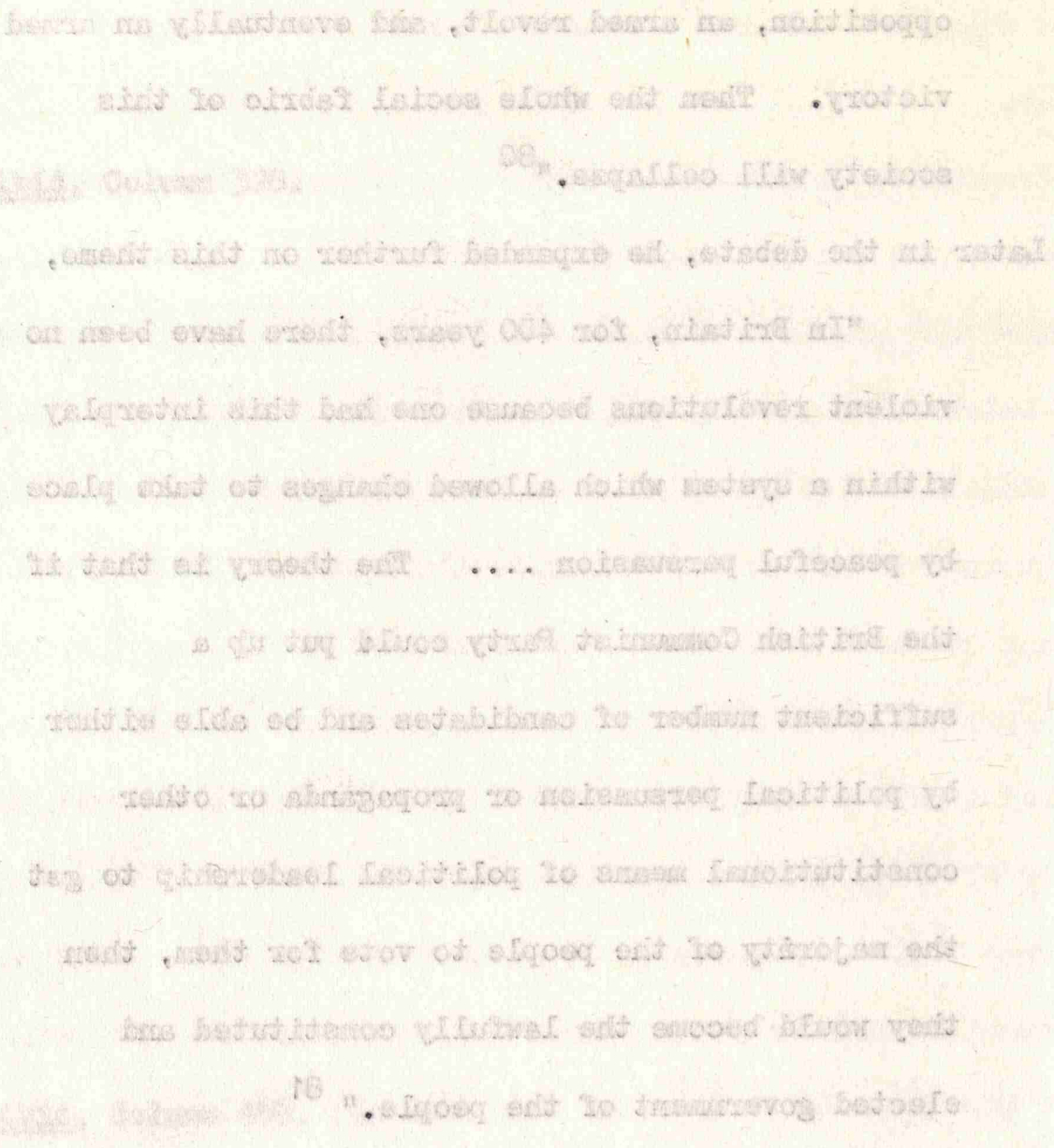

84. ibid, Columns 331-332

85. Straits Times, 11 th October, 1956 and Joint Report, pp. 3 and 4 .

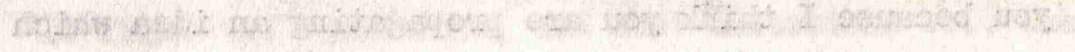

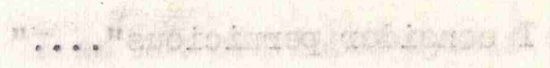

86. Joint Report, p. 5.

87. Straits Times, 11 th October, 1956. 
He criticised the government's "anti-Communist hysteria", but at no time in his speech did he directly reject Communism or dissociate himself from subversion or violence. The difference between the philosophies of the two wings of the PAP comes out very very clearly in the two speeches, and Lim Chin Siong even made a back handed reference to draw attention to Lee Kuan Yew's Westernised, bourgeois habits.

"According to our Minister for Education, the collective study groups among Chinese students are Communists because the Communists also have such study groups. By this logic study group movements throughout the world must be Communist... Englishmen prefer their tea at 4 p.m.. Asians who drink their tea at 4 p.m. are therefore Englishmen! Americans drive about in American cars. Harry Lee also drives an American car. Therefore Harry Lee is an American!" 84

It was an unimpressive and rather immature speech and it proved to be the last he would make in the Assembly.

Meanwhile, however, trouble was building up in the schools and the government continued to act firmly. On 10th 0ctober, 4 student ringleaders from the Chinese High School and the Chung Cheng High School were detained, and 142 others expelled by the Committee of Management on the order of the Government. 854,000 students gathered at the two schools and set themselves up for a siege - 1,000 at the Chinese High School and 3,000 at the Chung Cheng. These comprised the majority - indeed at Chung Cheng the overwhelming majority - of the students. 86 The principals and most of the teachers went away, leaving the students in complete control. 87

On 12th October, the Government closed the two schools, upon which the busmen supplied the barricaded students with food and other comforts, repaying the support which they had earlier received from the students in the Hock Lee strike. 


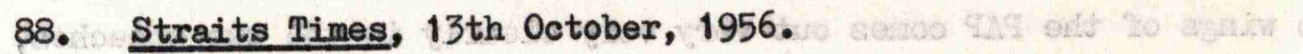

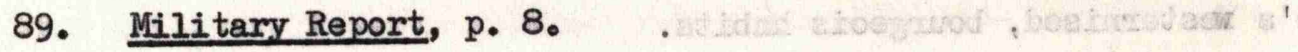

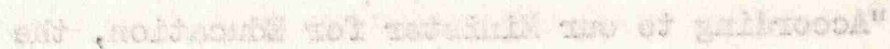

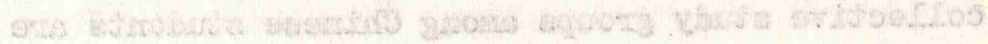

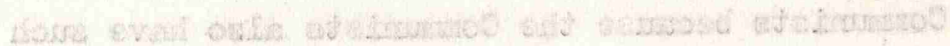

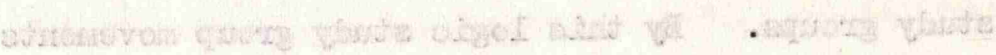

90. Joint Report, p. 5 .

:

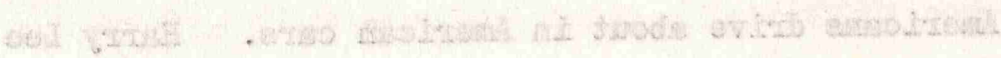

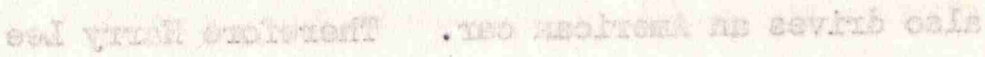

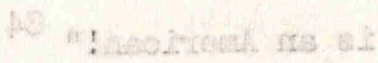

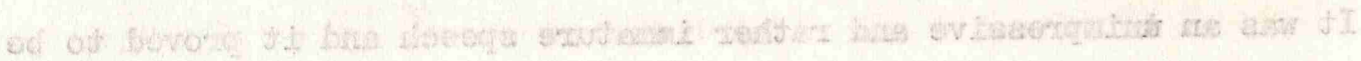

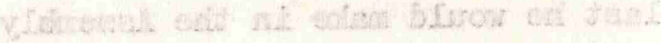

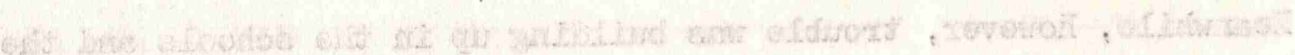

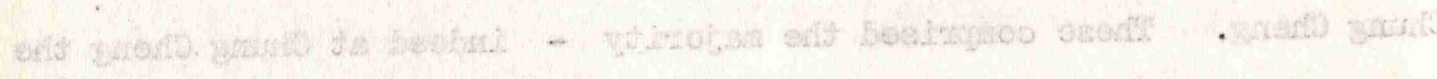

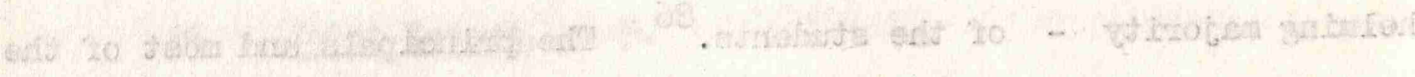

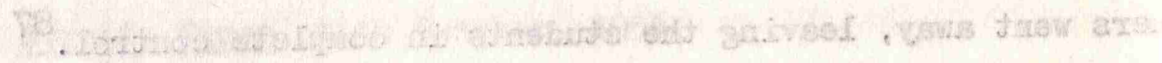

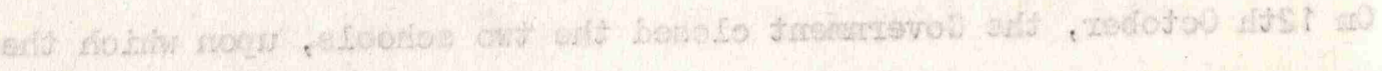

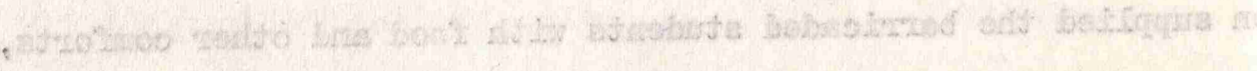

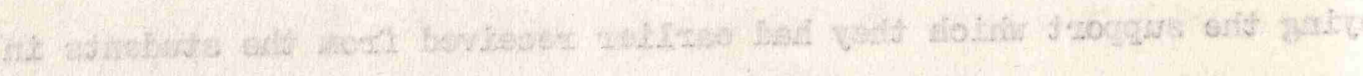


Meanwhile a minority of students defied the SCMSSU, and on 12th 0ctober, 6 boys from the Chung Cheng High School called on the Minister of Education and presented him with the signatures of 725 students supporting the government action. 88 Next day the government announced that two temporary schools would be opened on 16th 0ctober, and began re-registration of students for these schools. 89

On 22nd October, students from the Chung Cheng and Chinese High Schools picketed the other Chinese Middle Schools, and it became clear that the trouble would bex spread unless firm action was taken. The Government therefore gave warning to parents on 24th October that, unless they removed their offspring from the two barricaded schools by 8 p.m. on 25th October, they would be removed by force. 90

H-hour for the October, 1956 riots had been set. 
130 
Lee Kuan Yew, as Prime Minister, some years later criticised Lim Yew Hock's government for allowing themselves to reach this situation in which they had to use force to pluck out thousands of nonCommunist Chinese educated students in order to immobilise the handful who were responsible for the stay-in strikes. He regarded this as a Communist trap to get them to be presented as anti-Chinese culture and anti-Chinese education, and as stooges, and that this in the end resulted in their downfall.

See his Battle for Merger, pp 69-70 and Blades para 19.

2 Joint Report $\mathrm{p} 6$.

3 SLA Debates 5 November 1956, Column 417 and 6 November 1956 column 501) In the debate, the Minister for Education (Chew Swee Kee) said that Iim Chin Siong urged the crowd at Bukit Timah that instead of shouting "Merdeka"(Freedom) they should now shout "Pah Mata" (Bash the Police). 


\section{Clearing the Schools.}

On the morning of the 25 th October parents began to gather outside the two schools, and the police removed the outer barricades. Government attempts to address the students by loudspeaker vans outside were drowned by clapping and singing, while the SCMSSU organisation used their own public address system to keep up the students' morale, and set up an effective organisation to deter any of them from leaving. It was clear that force was going to be necessary. ${ }^{1}$ All police and army units were therefore alerted and briefed, though none were moved at this stage, and preparations were confined to those which were not visible to the public. ${ }^{2}$

At $5 \mathrm{p} . \mathrm{m}$. Lim Chin Siong ran a protest meeting in Bukit Timah village, in the centre of the constituency which had elected him to the Assembly. It lies in the middle of one of the main factory areas, and is on the Bukit Timah Road which is the dual carriageway trunk road from the city to the causeway linking Singapore to the mainland. The village is about 6 miles from the city centre, and the Chinese High School is only 2 miles away, closer in along the main road (see Figure 7A).

This meeting was held under the auspices of the Civil Rights Convention which had originally been formed on 28 September to protest against the dissolution of the SCMSSU and of the two front organisations. Inflammatory speeches were made by Lim Chin Siong and others, and when the meeting ended at about $7 \mathrm{p} . \mathrm{m}$. some of those present moved off down the Bukit Timah road to join the crowds assembling outside the Chinese High School. 3 
4 Report on Singapore Riots October 1956

by Singapore Police, 3 November 1956

Appdx J p.3.

5 Blades, para 20

6 "Seng" (SB) Interview 1966

7 Police Report Appdx H p.2.

$8 \quad$ Police Report Appdx J p.3.

9 Lee Kuan Yew subsequently accused the Government of deliberately provoking the riots in order to carry out a purge, at a time to suit themselves, initially by their acting against the SCMSSU and other front organisations, and finally by the calculated action of the police in allowing the crowd to build up and get out of hand outside the Chinese High School on 25th Octobser, SIA Debates 5 November 1956 Column 479. Also 6 November 1956 Column 576. 
Lim Chin Siong's plan was to present a crowd big enough to be beyond normal control, so that the Government would be forced either to capitulate or to be the first to use force. 4

Lim Chin Siong had buillt up a strong Students/Parents Association to cement his United Front, and this introduced powerful emotions. 5 The "cause" was one with a good deal of popular sympathy, and had no obvious connection with Communism. If the situation could be used to bring about the use of violence by big policemen against small schoolboys with a large audience lined up along the Bukit Timah road, the Communists would have scored a major tactical victory. 6

Though this was the overt purpose of the Bukit Timah protest meeting, it was also used to brief, on the sidelines, the Trade Union branch leaders of the Middle Road Group, with orders to engineer "spontaneous" strikes at all the Bukit Timah factory gates at 8 a.m next morning, and to lead the strikers later in the day to the centre of the city for a mass demonstration of strikers and students from all over the Island.?

By 8 p.m the crowd outside the Chinese High School had grown to 3000, (parents, busmen, workers and other students) many of them, including the ringleaders, fresh from the Bukit Timah protest meeting $A$ large traffic jam was building up on the Bukit Timah Road.

The Police were there in force, but the CP had shrewdly ordered them to take no action to remove the students until 6 a.m the following morning. As he expected, the hotheads amongst the crowd were unable to restrain themselves, and began overturning and burning cars and stoning police vehicles. Violence had begun, but it had been started - and publicly seen to be started - by the revolutionaries. 8 . So the first tactical point went to the Police. 9 
10 Joint Report p.?.

11 Military Report p.27.

12 Blades para. 21.

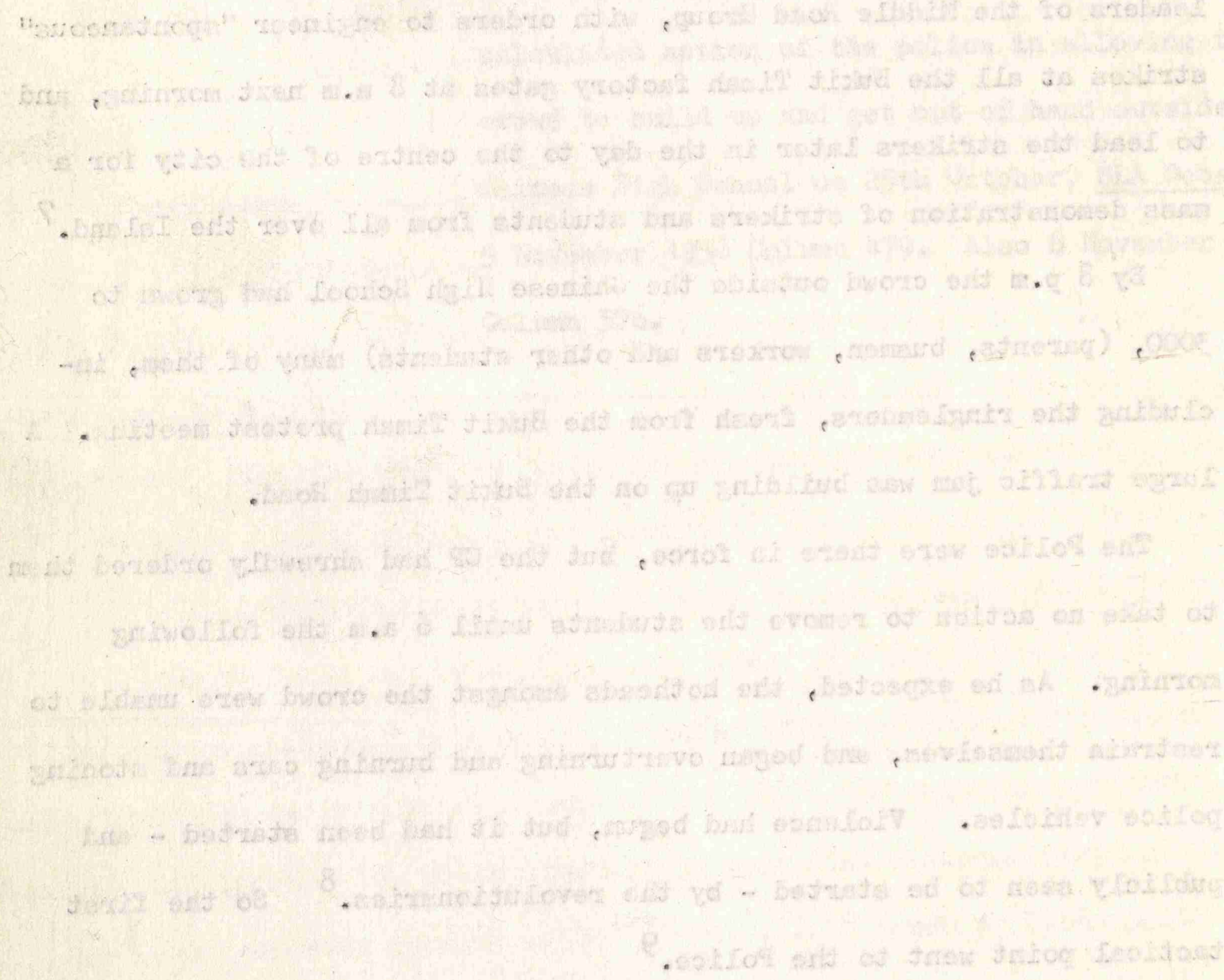


Meanwhile, now that it was dark, more positive action was being taken by the Security Forces to prepare for what was clearly going to be a day of violence. At 9 p.m the CP requested that the army units should move discreetly to their vantage points as planned in operation PHOTO (see Chapter 6) At $10 \mathrm{p} \cdot \mathrm{m}$ the Brigade Commander established his Command Post in the Police HQ in Pearls.Hill. 10

Although all was. now quiet on the Bukit Timah Road, sporadic outbreaks of violence continued elsewhere in the city, with crowds up to 300 strong. In the Kallang area (near the Chung Cheng High School) the crowd bogan to attack Police and European cars, and just before $11 \mathrm{p} \cdot \mathrm{m}$, a police radio car had to open fire in its own defence firing the first shots of the riots.

At this stage, the CP and GOC decided to ask for some of the reinforcement battalions to start extracting themselves from the jungle, and soon after $11 \mathrm{p} \cdot \mathrm{m}$ the orders went out to the balance of three companies from the 1st Queens, to one other battalion and to two squadrons of armoured cars. 11

Just after midnight, the CP used his existing powers to clamp down a curfew until $6 \mathrm{a} \cdot \mathrm{m}$ the time at which he planned to clear the two schools, and at $3.30 \mathrm{a.m}$. the Chief Secretary declared an "Immediate Threat to Public Peace" under the Preservation of Public Security Ordinance, which, among other things, empowered the police to disperse any assembly of more than 10 people - including assemblies in private, such as school grounds - an important feature. 12

At 6 a.m on the 26th, the police broke down the barriers and flushed the students out of the Chung Cheng and Chinese High Schools with tear gas. In the grey dawn, with no crowds, no audience, the 
13 Joint Report p.8, and Police Report p.5

- 14 Miritary Report p.16

15 ibid p.53

16 Mr Samuel Dhoraisingham - Interview 1968

17 Joint Report p.8.

18 G. G. Thomson, para 22. Thomson considers that the Communists made a blunder here. Had they persuaded the students to go home they would have scored a propaganda victory, and could then have put the government on the defensive by peaceful agitation in the Chinese press, which they controlled. The government would eventually have had to give way or initiate the use of force. As it was, by encouraging the students to use violence they provoked a test of arms which the government was bound to win, and bound to emerge with a favourable image as restorers of the peace. This, of course, is just what did happen. Dominic Puthucheary, the younger brother of one of the Middle Road leaders, stated (in an interview in 1969) that both his brother (James) and Iim Chin Siong realised this and did their best to discourage violence, but all other sources consulted confirmed Thomson's view. 
the students put up little resistance. At the Chinese High School there were no serious casualties at all. At the Chung Cheng, three were injured, one dying later from a fractured skull, either from a blow or a fall. Both schools were clear in 20 minutes. 13 Keeping the Crowds down to Manageable Size

By this time, the curfew had ended and parents were beginning to arrive outside the schools. The majority of the students, separated from their ringleader's; were glad enough to go home for a good meal, a wash and a rest after their 16 day sit-in. 14

The more militant ones, however, headed towards the city, mainly in small gangs of about 2 dozen, ${ }^{15}$ throwing stones and bottles, overturning cars, and smashing up trafic lights, islands, and anything else that was obviously government property. One citizen's impression was that these bands of students had no particular aim or guidance, but that individuals were trying to show off to each other. As they made their riotous way along the streets, others were drawn by the noise and excitement, and joined in the fun of smashing and shouting. 16 Shortly before 8 a.m. the student gangs from the Chinese High School, joined by a number of strikers from the factories, starting setting up road blocks by sitting with arms linked across the road at Newton Circus, about a mile from the centre of the city, but they dispersed on the threat of force by a Police Riot Squad. ${ }^{17}$ They continued towards the city centre, and some of them called in at the SFSWU Headquarters about half a mile on where they were met and encouraged to carry on by Lim Chin Siong, Fong Swee Suan and other Union leaders, and were provided with sticks, bottles and missiles. ${ }^{18}$

Some gangs of students, however were already penetrating to the city centre, and three foci of activity were beginning to form, as envisaged in the Police/Military plan prepared in July - first in China Town (South of the Singapore River), second around Victoria Street/Middle Road (North of the River) and third in the Geylang/Katong 


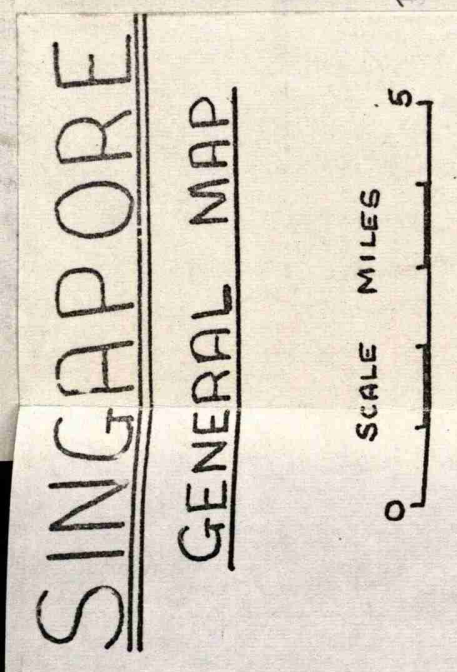


district near the Cheng Chung High School. (See figure 7A).

By 8 a.m. a crowd of students had barricaded themselves into the Hokkien Association in Telok Ayer Street (China Town) and others were beginning to converge on Victoria Street via the Bukit Timah Road and also from the Cheng Chung High School. All public transport was at a standstill.

By this time, large crowds of workers were gathering outside the factory gates around Bukit Timah, where they had been met by pickets who informed them that there was to be a "spontaneous strike". The plan was that there should be protest meetings to whip up support during the morning, but that the demonstrators should not march on the city centre until $2.30 \mathrm{p} . \mathrm{m}$. This would give the Middle Road Headquarters time to coordinate the convergance of huge crowds simultaneously from all quarters into the city, presenting the police again with the alternatives of giving way or using force.

As before, however, the hotheads could not wait, and set off in somewhat disorganised columns down the road soon after 8 a.m. joining up with gangs of students on the Bukit Timah Road. 19

At this stage the Commissioner of Police decided to put the full joint plan into operation.

The Brigade Commander had notified him at 7 a.m. that all the Army roadblock teams were standing by in the immediate vicinity of their tasks. Thus far they had remained out of sight to avoid provoking the crowds; they were, however, reporting the crowds streaming through towards the city. At the same time, the Police radio cars were reporting increasing and widespread violence by the roving gangs of students. A crowd was collecting outside the barricaded Hokkien 


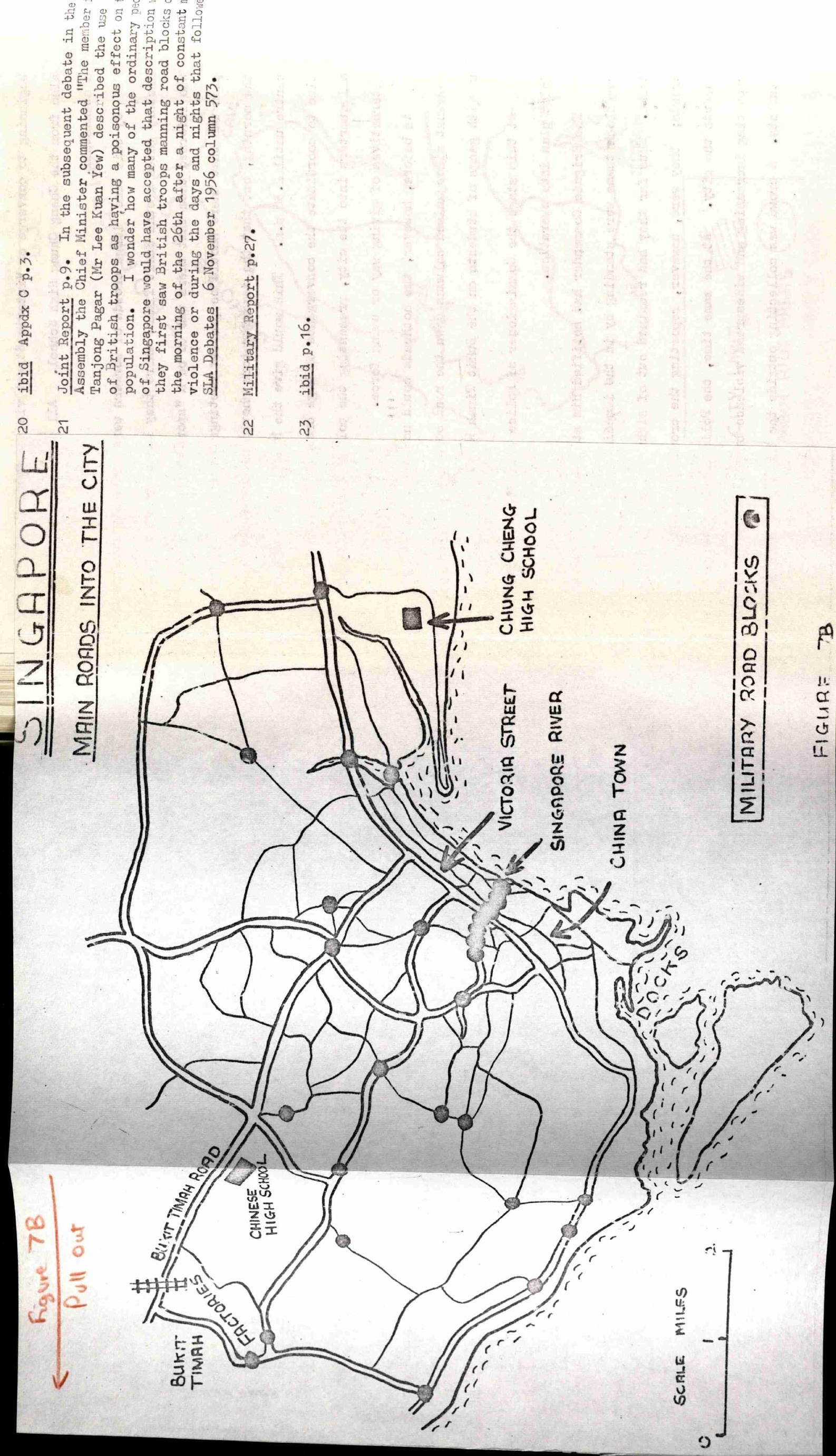


Association in China Town and two crowds, one of 400 and one of 200, were stoning vehicles and erecting barricades in the Victoria Street 20 area.

At 8.15 a.m, the CP therefore made a formal request for military assistance, and handed the Brigade Commander (in the next room at Police HQ) a written requisition for troops to disperse unlawful assemblies. By 8.20 the orders had gone out by radio, and by 8.30 all 29 road blocks were established and manned. ${ }^{21}$ (Figure 7B)

This must be one of the quickest military responses on record to a request for aid to the civil power. Meanwhile, two of the extra companies of the 1st Queens had arrived from the jungle, and a second battalion was not far behind. Orders were at the same time put in motion to call in the other four battalions and an additional Brigade HQ. 22

The roadblocks were manned by teams varying from $2 \mathrm{NCO}$ s and 8 privates up to a full platoon. Each was accompanied by a Police Constable. All had radio or telephone communication to their Company $\mathrm{HQ}$, and thence to Battalion and to Brigade $\mathrm{HQ}$ in the joint Command Post at Pearls Hill. Thus from 8.30 , every road into the city, and every bridge across the river between the China Town and Victoria Street areas was blocked and in radio contact. ${ }^{23}$

At this stage, due to the failure of the revolutionaries to hold back their demonstration marches until they could be co-ordinated, the sizes of individual crowds did not exceed 400 . Thanks to the excellent 2 observation and reporting, the police were quick to appear. Rapid strong action by armed mobile police patrols proved most effective, and 
$24 \quad$ Military Report p.17.

25 Joint Report Appdx C

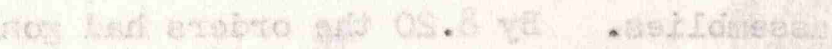

. 26 Military Report p.48 and Joint Report 11

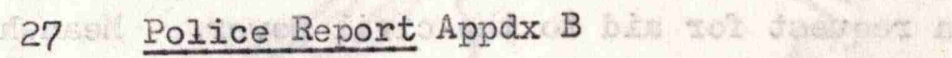

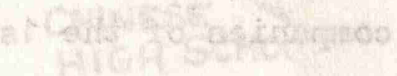

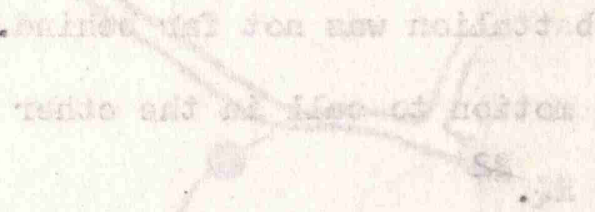

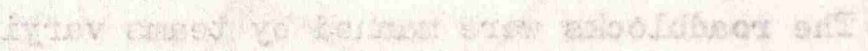

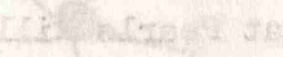

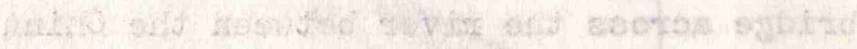
¿.s.

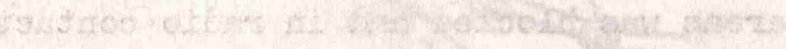

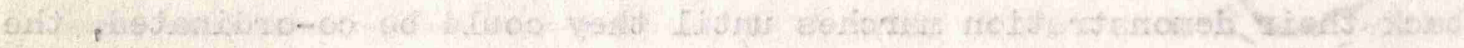

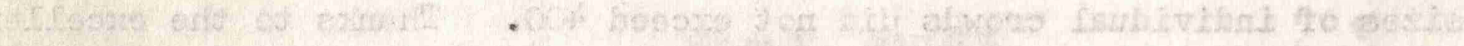

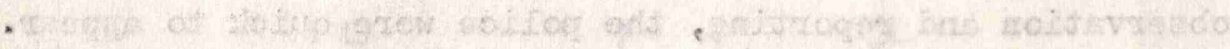

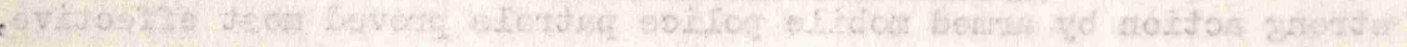


when attacked, these relatively small crowds generally melted into sidestreets and reappeared elsewhere. ${ }^{24}$ It was not until 10 a.m. that a crowd estimated at 2-3000 had assernbled in Telok Ayer Street in China Town. 25 This crowd remained in the area for the next 3 hours or so, throwing stones and bottles at the police, turning over and burning vehicles. The army joined the police in attacking it, and by $1 \mathrm{p} . \mathrm{m}$. it had been broken up without the need to open fire. It split into crowds of not more than 500, one of which moved off towards the Katong area.

The military roadblocks were not attacked, but they served their purpose, and at no time did the crowds in China Town, Victoria Street and Katong link up to form dangerous mobs of $20-25,000$. If crowds of that size had made concerted attacks against key points, they could only have been cleared by drastic action to induce mass panic and flight. It is this kind of action which dramatises the situation, creates public martyrs and builds up bitterness between the crowds and the police," which was the most important Communist aim at this stage. The police and the army defeated it by keeping the crowds apart. .

Nevertheless, during the morning and afternoon, violence by relatively small crowds of $200-500$ built up. Six more of the police radio vehicles were attacked during the morning. In one of these attacks, an 11 year old boy amongst the crowd was killed by an over shot, and another man was killed by a blow from a baton in a police charge on the China Town crowd at 12 noon. During the next 2 hours, another boy, aged 15, was killed by an overshot, and three more rioters were shot dead whilst charging small police patrols of 4 or 5 men in roads and alleys around Victoria Street. This brought the total death roll thus far to 7. 27 
28 Joint Report Appdx C

29 ibid p.11

30 Police Report Appdx B

31 Police Report Appdx B 
This, the early afternoon, was the peak period of violence. Between 12 noon and 4 p.m there were 34 attacks on persons, vehicles and government property, 13 of them by crowds of over 100.28

Observed from roving helicopters, harried by promptly directed patrols and diverted by roadblocks, many began to range back into the outlying areas. 200 students stoning vehicles on the Bukit Timah Road were spotted by a helicopter which itself dispersed them by dropping tear gas grenades, at the same time 'drenching them with dye. 29

At about $2.30 \mathrm{p} . \mathrm{m}$ a crowd of about 1000 had built up on the main crossroads by the airport, about six miles from the city centre, and were attacking vehicles. A police patrol of 3 men saw a car carrying 4 Europeans heading for this crossroads and, realising that this would lead to trouble, set off in pursuit. When they arrived the car was being attacked. The three policemen, led by a Chinese inspector, went in, and the mob turned its attention to them. Armed only with revolvers the three policemen stood their ground until the car had extricated itself. Charged by the crowd, they fired 17 revolver shots, killing one and wounding one, before they withdrew 30

The rioters in fact only killed one civilian. This was at $3.30 \mathrm{p.m}$, in Victoria Street, when they attacked a City Council vehicle. The driver, a Malay, tried to defend himself with his starting handle, and was pursued by the Chinese crowd into a sidestreet and battered to death. 31 The racial implications of the incident created a wave of anxiety, and appeals by leaders of the Malay community for calm and restraint were broadcast by Radio Singapore at frequent intervals throughout the rest of the day. The 1964 riots were later to demonstrate how explosive such an incident might have been. 
33 Alan Blades commented as follows:

"I think that it was recognised later that so long as the Police Force was still a going conoern, this was the way it must be - joint control, each service under its own officers, the Police in the front line and doing the ferreting, the military backing up; supplying Cordons and Control Points and filling in wherever the Police might be otherwise engaged. ..... the request for aid was never, even remotely, in the nature of a cry of distress when almost all was lost. It was part of a well practised plan of prudence - to present tan overwhelming deterrent at the earliest tactical juncture ..... the civil authority ... would have hesitated to ask for aid if it meant the immediate handover of control to a military command." Blades "para 22.

34 Joint Report p.17

35 Police Report Appdx B 
At $3.15 \mathrm{p} . \mathrm{m}$ the curfew was reimposed, and promulgated by public address vehicles and by low flying aircraft with loudspeakers. There was no appreciable decrease in the number of incidents, but more of them were in rural areas. 32

By the evening of 26 th October, the first five of the six battalions extracted from the jungle on the mainland had crossed the causeway into Singapore, and the military outnumbered the police on the ground. There was some discussion as to whether the GOC or the CP should have overall responsibility. The traditional practice laid down in the manuals was that, once the army had been called out the military commander should assume responsibility, which he would discharge mainly with the use of his soldiers, with the police in a supporting role. In the Singapore riots, however, the police and soldiers were all widely dispersed and operating in small parties each under radio control through its own channels. Sensibly, therefore, it was decided not to disrupt these chains of command. Though the Governor authorised the GOC to assume full responsibility, the police retained independent powers under the $\mathrm{CP}$, whose own powers remained unimpaired. 33 Thanks to having" a joint $H Q$ from the start, a joint plan, and excellent liaison built up over the riots of the previous years, this worked well, ${ }^{34}$ though in different circumstances or with different personalities it might have been unsound.

Between dusk (about 6.30) and $8 \mathrm{p} . \mathrm{m}$ there were two more kills, one in China Town, where a police patrol used a pistol when they were charged by a crowd of 200, and the other at the Naval Base 15 miles out of the city, by a Royal Naval patrol which fired in support of police who were stoned when they attempted to remove a barricade. 35 


\section{Joint Report Appdx C}

37 So smoothly that Blades (then Head of Special Branch), looking back, wonders whether it wasn't part of Iim Chin Siong's "martyr" policy. He obviously expected it, as he had withdrawn and salted away all the Unions' funds which were considerable". Blades para 23. 
Thereafter during the first part of the night, the number of incidents actually increased, though they were perpetrated by smaller crowds. Between $8 \mathrm{p} \cdot \mathrm{m}$ and midnight, 12 barricades were erected. After midnight, there were only a handful of incidents by small gangs of curfew breakers, who attacked vehicles and erected one more barricade. Apart from this the night was generally quiet. 36 so, at least, it seemed to be on the surface. Behind the scenes, however, the night $26 / 27$ October was the most active and the most decisive - of the year.

\section{The Special Branch Swoop}

Special Branch cover of the Middle Road Unions and Schools was excellent. This was partly because the MCP in Singapore was operating almost entirely through Open Front activities at this stage. At any rate, Special Branch knew who the leaders were, and where and when they met.

On the night of $26 / 27$ October, the leaders of all the main branches of the SFSWU and of the other Middle Road Unions met together for a Conference at the headquarters in Middle Road. 74 were present, including Lim Chin Siong.

At the same time, 343 of the factory members and students were meeting at the SFSWU 4th Branch HQ in Bukit Timah Road. There were meetings at two other SFSWU Branches, at the Hock Lee Branch of the Singapore Bus Workers Union and at the Singapore Farmers Association in Jurong.

These six meetings, widely distributed over the island, were all raided by Special Branch during the early hours of the morning, with the approval of the Council of Ministers. The raid on the Middle Road HQ went smoothly. 37 All the 74 present were detained, including Lim Chin Siong, ${ }^{38}$ who was to remain in detention for the nest three years. 
The 4th Branch HQ on the Bukit Timah Road, however, was strongly defended. There was a barricade of bicycles over which entry was resisted by men with iron bars, sticks and bottles of acid. 39 Eventually the police broke down the door after using tear gas and firing some shots, wounding three rioters. Inside, they found blackboards marked up with the current riot situation, stacks of food, medical supplies, and other signs that the building was prepared for use as a strong point. The 343 occupants (who included many Chinese High School students) were screened and 70 detained. 40

The other four branches were also raided. In all, 618 people were found inside the six headquarters, of whom 234 were detained. ${ }^{41}$ At the same time, the police found and detained 82 known Secret Society members who were "believed to be connected with the riots". 42

\section{The Riots Subside}

As news of the arrests spread on the morning of 27 th October, there was a revival of public confidence. On the other side, with the simultaneous removal of the entire top level of the Open Front leadership, and of a large number of its subordinate leaders and activists, there was a marked lack of organised activity. Though 11 people had been killed, or mortally wounded, on 26th October, there were no "martyrs funerals" or other organised demonstrations on the 27th. 43

Sporadic incidents did, however, continue during the day, though on a much smaller scale. The curfew was lifted at 6 a.m and by 8.30 crowds of 200 had collected both in Victoria Street and 
China Town, erecting barricades and attacking vehicles, and just before $10 \mathrm{a} . \mathrm{m}$ there was another attack on a police radio van by a crowd of $500 .^{44}$ Generally, however, the crowds were dispersed even more quickly than on the previous day, partly due to an additional technique in which the army, the RAF and the police, all took part. A network of rooftop observation posts was manned by parties of soldiers, each accompanied by a police constable. These overlooked the main riot areas of China Town and Victoria Street. As soon as a crowd formed, they would either descend and deal with it themselves, or notify a helicopter, which would swoop on the crowd with tear gas and dye grenades. 45.

There was only one fatal incident during the day - the last of the riots. The crew of a pfidice radio car were attempting to remove a barricade when they were charged by a crowd of 300 . They opened fire and killed a 17 year old boy who was leading the charge. 4

At $4.30 \mathrm{p} \cdot \mathrm{m}$ the curfew was reimposed until $8 \mathrm{a} \cdot \mathrm{m}$ on the 28 th. Thereafter there were minor incidents only. The curfew was kept on for three more nights. Of the six infantry battalions brought into Singapore from the mainland, two returned to the jungle war on 1st November, and the other four the next day. 47 They had to play little direct part in the riots - indeed only one was deployed at all - but their rapid appearance in such strength (they amounted in fact to $30 \%$ of the infantry deployed in Malaya) undoubtedly played a part in the rapid subsidence of the riots. Alan Blades, the Head of Special Branch, states that -

"It was Lee Kuan Yew's opinion, later on; that it was the sight of tanks and military force, rather than the arrest of the ring leaders, that caused the trouble to subside and he, and Goh Keng Swee in particular 
48 Blades, para 22.

49 Joint Report p. 15.

50 ibid p.14.

51 Military Report p.32. 
were all for the earliest show of bayonets etc when they took over responsibility for internal security after June 1959". 48

\section{Summary of Events}

These riots had the greatest significance and effect of any in the history of Singapore, and indeed had the makings of being the bloodiest. In the event, they were over very quickly, with relatively little bloodshed and damage. This was due to some extent to bad timing and control by the rioters' leaders, but predominantly to good planning and bold and rapid action by the military and the police.

There were in all 13 deaths - only one inflicted by the rioters. No policemen or soldiers were killed, though 5 were detained in hospital, as were 42 of the rioters. 49 Chief credit for this must go to the strict prohibition at pain of death of unauthorised possession of arms and ammunition, which had been enforced under the Emergency Regulations for the previous 8 years. Throughout the riots, there were no cases of the rioters using firearms.

Because the rioters were unarmed, the police and soldiers used their weapons with great restraint. They opened fire 114 times, firing 761 rounds - an average of less than 7 rounds per incident. Most of the occasions when the police fired (108) were when radio cars or small patrols fired in self defence, and they caused 11 deaths - 3 of them by overshots amongst the bystanders. 50 A naval patrol fired once killing one man. The Army fired 5 times - twice in support of police against rioters throwing bottles from houses, and 3 times when isolated vehicles were attacked whilst carrying despatches at night. In all, the soldiers fired only 14 rounds and killed no one - a really astonishing record considering their widespread deployment and the number of incidents. ${ }^{51}$ 
EAt

52 Figures estimated from Map a tacked to Joint Report

wi na

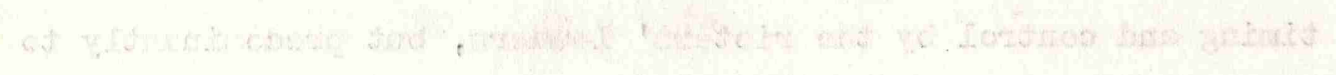

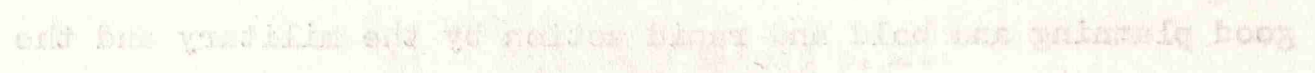

- $2 x^{2} f x$

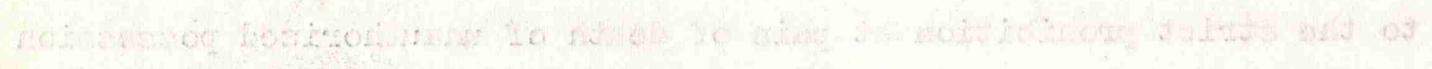

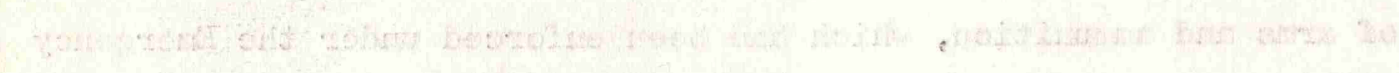

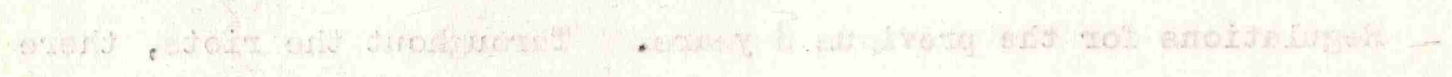

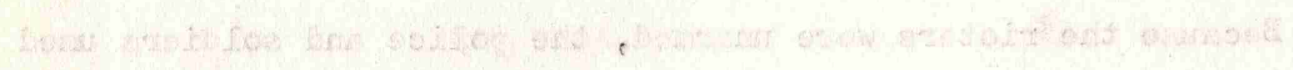

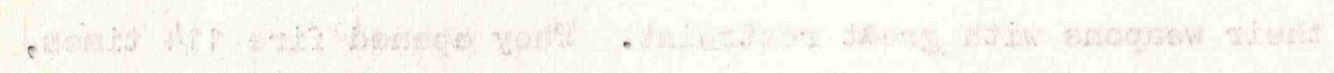

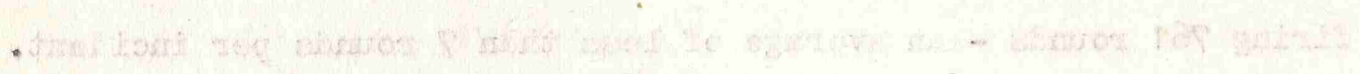

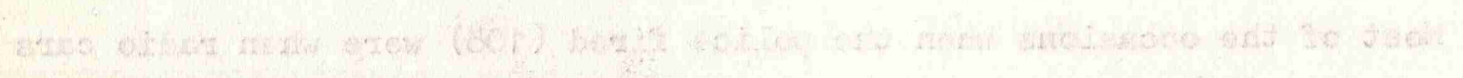

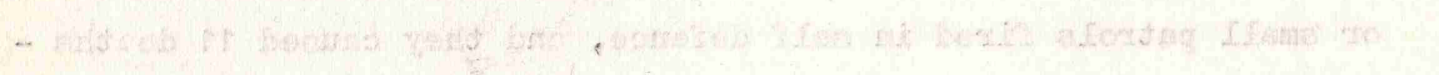

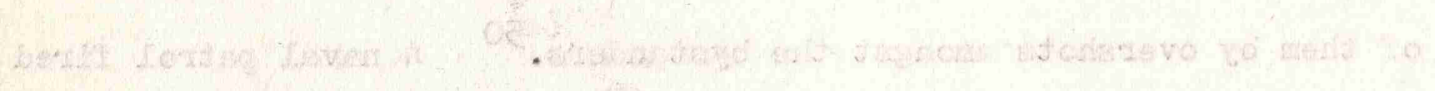

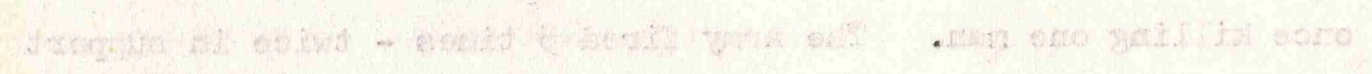

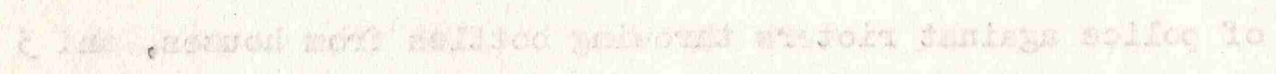

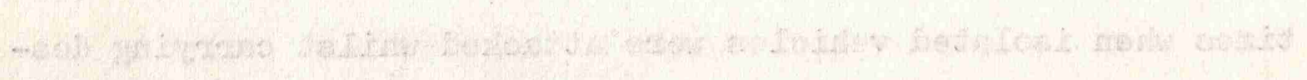

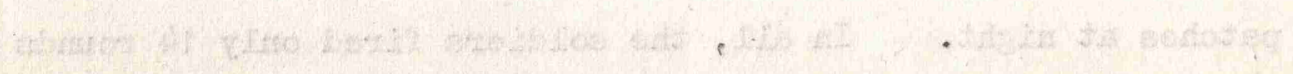

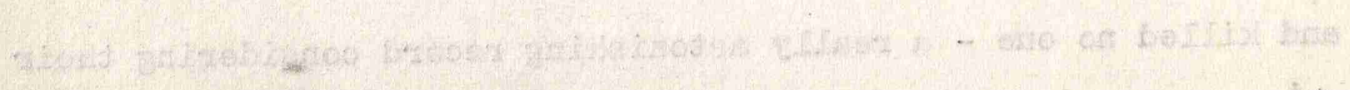


31 vehicles were burned, and another 101 damaged. Three buildings were burned, and two others damaged. Of the total of 150 events classed by the police as "incidents" the great majority were on 26 th October. Most of them (79) consisted of attacks on persons and property, chiefly private cars. $\quad 32$ were against individual police and military vehicles. 107 of them were concentrated within the two areas, each about one square mile, of China Town and Victoria Street (see Map 7A). 52 These were the main housing areas of the poorer urban Chinese - dock labourers, street traders etc. It is significant that on no occasion were the crowds able to converge into the vast open space of the padang facing the City Hall and other main public buildings. Had they done so they would have presented the traditional pattern. of a huge unmanageable assembly threatening a key point and faced by a line of soldiers, who would have eventually had no recourse but to open fire and shed blood in full view of a highly charged audience. . Iet the City Hall and the padang were located between China Town and Victoria Street and within a mile of the main rioting areas on either side, and were the declared target of the demonstration marches. That they never attacked it was because the joint police/military plan was especially designed to prevent the crowds from converging, by means of its combination of roadblocks, patrol cars and mobile riot squads, served by helicopters and, later, by rooftop patrols.

The Performance of the Government Forces

Helicopters were used in these riots for the first time on record and proved an outstanding success. The five helicopters flew 136 sorties in all, totalling 90 flying hours. They were able to keep a 


53 Joint Report p.18.
Also G.G. Thomson para 24
54 Military Report p.75. The rooftop
patrols, being a last-minute im-
provisation, were not equipped with
radio. They used yellow flags to
signal for action. 0 ften the heli-
copter crew saw and acted on these
signals. If not, the HQ of the infantry
company providing the patrols could see
and interpret their signals, and call for
action by radio.


continuous watch on the worst areas, usually carrying a senior police officer on board, and in direct radio contact with a Combined Police/Army HQ. They provided a platform, immune from retaliation, from which tear gas, dye grenades and leaflets could be launched, and they were often able to spot and disperse crowds and prevent them from reforming without calling other forces at all. They thereby established an awesome respect for the ubiquity of the Security Forces. At the same time, they cooperated with rooftop patrols in directing police and army radio vehicles to deal quickly with other assemblies.

The pilots of the three reinforcing helicopters were at some disadvantage in lacking intimate knowledge of the city, but this was partly overcome by the inclusion of police officers in the crew. 53

The rpoftop patrols introduced on the second day also proved most successful. They were concentrated on the areas where most of the potential rioters lived, and where there were many of the foci (such as the Middle Road $\mathrm{HQ}$ and the. Hokkien Association) where crowds collected. They were able to watch the crowds forming up, especially in the narrow alleys, and either take action to disperse them themselves, or notify their Company $\mathrm{HQ}$ who could call in helicopters patrol cars or riot squads by radio. 54

The success of the 40 police radio cars and of the riot squads has already been described. They key was to be on the scene quickly and act boldly - once again creating an image of ubiquity and strength. Great gallantry was shewn by small numbers of policemen against large crowds, of which a few examples only have been quoted.

Apart from providing eyes and ears, the main function of the army was to provide a framework within which the police could operate freely and flexibly - a reversal of normal practice. On this occasion it was the police who provided the striking force - and who did most of the shooting. With an armed police force, this has many advantages, for 
55 Unarmed police forces are, however, rare outside the British Commonwealth.

56 Alan Blades, who by 1958 had become Commissioner of Police, comments "I held this view strongly, and in preparation for the next stage of constitutional development in 1958 in Singapore, ordered the cessation of the use of the rifle as a police weapon, except in the Gurkha and Reserve units, and had them stored in armouries for emergencies only. But Lee Kuan Iew and his Ministers held quite the opposite view....." Blades para 25.

57 Joint Report Annex G 
they are the best judges of how demonstrators and hooligans react, and the use of police against crowds is less emotive than the use of soldiers. Had members of the crowd been armed, or the police unarmed, their small patrols could not have done what they did. In the face of the MCP "armed struggle", the arming of the police throughout Malaya. was essential. In more normal times, the fact of a police force being unarmed 55 contributes so much better to law and order that it should be armed only with reluctance. 56 'There is, therefore, a risk of drawing false lessons from this departure from the normal British police and military roles, though it proved right in Singapore in 1956.

The main elements of the army's framework were the 29 roadblocks, and the road patrols in outlying areas. One of the army's functions was to relieve as many policemen as possible from duty at night, so as to leave them fresh for the main battles of the day.

The army, for example, took on the great majority of the curfew patrols - which, though the taskwas a routine chore, were responsible for nearly half the arrests (1034 out of 2346). 57 They moved in behicles, slowly, concentrating on minor roads, and dismounting to investigate the narrow alleys on foot. To keep down the number of arrests, and to maintain good relations with ordinary citizens, they were instructed to apply the rules sensibly, accepting that many people had not heard the announcement of the curfew, or that they might be out on reasonable errands such as seeking medical aid. Each army curfew patrol was accompanied by a policeman, who did the questioning of curfew breakers. 58

The good communications between HQ, patrols and helicopters gave the police and army a tremendous advantage over the rioters. Now that cheap "walkie-talkies" are available to anyone, this advantage may be 
59 Military Report p.77. See also G.G. Thomson para 22. $\mathrm{H}_{\mathrm{e}}$ was at that time in charge of the Singapore Government Information Service. World cover was scanty, as world news was dominated by the Russian action in Hungary. The British intervention in the Suez war, forfuitously, did not occur until a few days after the riots. Had this been the other way round, the revolutionaries would have had a magnificent propaganda point, and the appearance of British troops in Singapore might have been greeted very differently. The British action in Suez was certainly the subject of some pointed comment in the debate after the riots. See, for example, SLA Debates 5 November 1956, Column 480 .

60 Military Report p.49.

61 See footnote 37 above 


\section{7}

reduced in future riots.

Government handling of Public Relations was also excellent. The Police Secretary acted as spokesman for all services, and the radio was used most effectively. Conducted tours were provided for correspondents, who were well and frankly briefed, and photo cover was extensive. The result was a highly favourable local press. 59

This led in turn to a favourable reaction by the public. Attendance at work remained throughout at a high level despite transport difficulties, and after, the riots there was a marked swing away from the Middle Road Unions to the Tư. 60 of a city people, faced with violence and the threat of chaos, rallying to the side which gave the best promise of restoring law and order.

The really decisive stroke, however, was the series of raids by Special Branch on the nights $26 / 27$ October, which scooped up almost the entire Open Front leadership. Whether or not Lim Chin Siong deliberately allowed it to happen as part of his "martyr" policy," this was a dramatic manifestation of the intelligence cover enjoyed by the police, which in fact enabled them to hold the initiative throughout the whole campaign, from the original action against the SCMSSU in September, through to the restoration of tranquility in the city at the end of October.

In the long run, these arrests also proved to be of major advantage to Lee Kuan Yew and the moderate wing of the PAP, who were able during the next 3 years to build up the party to a position of political dominance (which it holds to this day) with themselves as unchallenged leaders, unmolested by manoeuvres by Lim Chin Siong and his first team. In 1957, an unsuccessful bid to capture the leadership of the PAP by the Communist second team led to their joining Lim and the others in detention. Lee Kuan Yew was to play this advantage 
62 G. G. Thomson para 23.

63 Here they were following the Communist philosophy that it is not necessary to wait for a revolutionary situation. One should be created. This has been well set out by Che Guevara (Guerilla Warfare London $1961 \mathrm{p}$ 111) who writes that the people must be shewn that social wrongs will not be redressed by civil means alone; that it is desirable to have the oppressor break the peace first, willingly or unwillingly; and that under these conditions, popular discontent assumes increasingly positive forms, creating a state of resistance that, provoked by the attitude of authority, can lead to the outbreak of fighting. 
with great skill, retaining the support of Lim's followers by making their release a condition of his taking office in 1959, but watching that the 1959 election ordinance was so drafted that the ex-detainees could not themselves stand for election. The ex-detainees did thereafter make an attempt to capture powers (in 1961-62) but Lee Kuan Yew, was by then just secure enough to defeat the challenge. If it had not been for the October 1956 riots and these resulting arrests, the story might have been different. So in this respect too the riots proved to be a critical point in the history of Singapore. 62

\section{Performance of the Revolutionaries}

The riots were intensely disappointing to the Communists. The achievements of their Open Front leadership over the previous 2 years had been impressive. They controlled an important sector of the trade unions, and a majority of the students at the Chinese schools. They had developed an issue - Chinese education, and particularly the helping of younger students by older ones in their academic work - which evoked widespread sympathy amongst the predominantly Chinese population, who could be rallied under the banner of the Civil Rights Convention in patriotic protest against the "oppression" of the Chinese speaking community by a Colonial Governor and a Council of Ministers who were virtually all English-educated and by a predominantly Malay Police Force, and Malay, Gurkha and British soldiers. 63

They had an excellent open and semi-secret chain of command and control - to every bus garage, to most taxi-drivers and trishaw riders, to most dockworkers to a large number of factory branches and small farmers and to virtually every class in every Chinese High School both for boys and for girls; also to many of their parents through the Parents' Friendly Association, and through many other Front

Organisations. As Lee Kuan Yew recorded later, by working and manifestly appearing to work selflessly and ceaselessly

".... the Communists, although they had only a few

hundred active cadres, could muster and rally 
64 In "The Battle for Merger, p. 21.

65 G.G. Thomson, para 25.

66 Blades, para 27.

¿. 
thousands of people in the Unions, cultural

organisations and student societies". 64

Their secret cell structure was weak, but this was probably not a factor in the failure of the riots, because even a strong secret structure would not have had the channels to take-over the open leadership in time to maintain the momentum after Iim Chin Siong and his colleagues were arrested. Nor indeed should party cell members have exposed themselves in attempting to do so. They might, however, have enabled the MCP in Singapore to have recovered from the setback in the longer term which, to this day, it has failed to do.

The real failure must inevitably lie with the Open Frontleadership, and particularly with Iim Chin Siong himself, who G.G. Thomson considers to have failed primarily as a tactician. He had come to the top at school as an organiser rather than as a thinker. His organisation provided him with a locus vivendi and an opportunity in classical Leninist style, but these proved to be of no avail as he misread the tactical signs, which were more skillfully read by Lee Kuan Yew, who kept out of trouble in the riots and later outmanoeuvred the Communists at their own game. 65 On the other hand, Lee Kuan Yew has retained the highest regard for Lim's capabilities and has not written him off as a long term threat. 66

Lim himself subsequently admitted to Douglas Hyde, in the course of their long discussions in Lim's cell in Changi gaol in the middle 1960s, that he had completely misread the mood of the Chinese workers in 195456. During his speeches they had cheered his references to sympathetic issues, such as his calling for an end to Colonialism, referring with pride to mainland China, or calling on them to strike for better conditions. But, he said, they were cheering the issues in themselves and not their ideological implications, to which he thought they were 


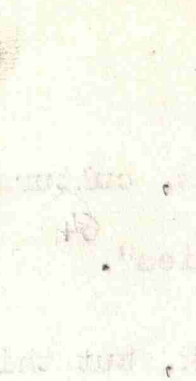

67

Douglas Hyde, Interview 1969.

See also his article "The Star that Fell", published in the Far Eastern Economic

Review just after Lim's release from detention in July 1969.

68

"Seng" (SB) Interview 1966 
committed when in fact they were not. They were pro-Chinese rather than pro-Communist. 67

Along with uncertain leadership, the Communists' tactics were weak. The crowds were launched with high passion by the Civil Rights Committee, but the aim seemed only to be to provoke violence, and (apart from a plan to present a protest to the Minister of Education) they had no clear targets, such as the threatening or seizure of key points. No particular individual clashes were planned. Leaders and agents did not seem to be charged with specific tasks. It was assumed that their training in ABL, Hsueh Hsih and sympathiser cells would provide sufficient guidance for them to exploit opportunities as they arose. $^{68}$

\section{A Comparison with the Hong Kong Riots of 1967}

It is interesting to contrast these riots with the riots in Hong Kong in 1967, which continued with varying intensity for 8 months and are briefly described in Appendix A. There were some similarities in the settings - Singapore and Hong Kong were both island colonies, predominantly Chinese, and Communist middle schools play an open and important part in Hong K⿺辶ng's education system. The trade unions in both cases were fairly evenly split between a Communist Federation and a TUC. The Communist Party in Hong Kong operates openly and legally, with the gigantic moral support of China on the frontier a few miles away. The 1967 riots in Hong Kong were more militant than those in Singapore in 1956, but they both failed for the same basic reason, that the city people proved to be more concerned about stability than about ideology.

If the government had given way in Hong Kong, the result - as demonstrated in Macao - is not hard to guess. In Singapore, the 1956 riots gave each of the four sides (the British, Lim Yew Hock's 
government, Lee Kuan Yew's moderate wing of the RAP, and the Communists) and the public an idea of where each of them stood and how far each was prepared to go. Above all, the success and consequent prestige of the police kept the battle off the streets for the next $?$ years, enabling Lee Kuan Yew to establish his political position and conduct the political struggle with his rivals in the Assembly, in Party Committees and in private meetings without coercion by mob violence.

The riots of 1955 and 1956, however, had left their mark. The Communists realised that unless they had reasonable scope for conducting subversion and intimidation in the schools and trade unions, and could weaken the power and decisiveness of the security forces in dealing with violence on the streets they could not hope to oust the existing government. The Singapore government, on their side, recognised that a solid internal security structure, not too vulnerable to passing political whims, was essential if they were to persuade the British to allow them to progress to full independence, and the Malayans to accept them into the Federation. As a result, the burning issue throughout the political struggle of the next 7 years was to be Internal Security. 
1. Milton E Osborne Singapore and Malaysia, Cornell University New York USA 1964 p 4

2. Report of the Singapore Constitutional Conference, London HMSO April 1957 (Cmnd 147) p 16. In the event the Consti. tution did not come into force until 1959

3. Lee Kuan Yew disowned the "moderate" label in the Singapore Legislative Assembly Debate on 8 October 1958 (Column 808)

4. $\quad$ Singapore Cmd 33 of 23 August 1957 


\section{Constitutional-Conference in London 1957}

If the effect of the 1956 riots was to convince the Singapore Government that it must maintain internal security in order to gain independence from Britain and admittance into the Federation, their - effect in London and Kuala Lumpur was the natural complement - a more cautious approach by the British Government towards independence, and hostility in the Federation Government towards any kind of merger with Singapore. 1

In March 1957 while the Federation was in the final stages of preparing for complete independence (due on 31 August 1957), an all party delegation from Sinfapore was invited to London for a Conference on a Constitution which was still to give no more than limited self-government and which was not to be brought into force until "a date after 1st January 1958". 2 All the same, because of the prestige he had gained in London as a result of the riots in October 1956, Lim Yew Hock was able to negotiate a more favourable Constitution than many would have expected or, indeed, that many thought desirable at the time. Even this might never have been granted if there had seemed to be any serious likelihood of the PAP being elected to form the first government under the Constitution (remembering that at this time they had only 3 out of the 25 selected member in the Assembly. Indeed, Lee Kuan Yew himself and his fellow "moderates" 3 in the PAP were regarded with considerable apprehension, both in London and in Kuala Lumpur, because of the willingness of the PAP to accept people whom Special Branch knew were Communists. Past experience suggested that once a political party accepted Communists in its ranks, they were virtually certain to take control of it in the end. 4 
5. SLA Debates, 12 September 1957 Column 2629 - 30

6. The inclusion of the Borneo territories in the merger was not at this time part of the plan.

7. The writer was based in Kuala Lumpur from $1956-58$, and recalls a widespread feeling amongst British and Malayan officials that Singapore was a cesspit of Communism and must be kept out of the Federation at all costs.

8. G.G. Thomson, para 26

9. Cand 147 p 5

10. ibid $p 6$

11. ibid $p$ ? 
Some thought that Lee Kuan Yew himself was watching which way the cat was going to jump, and would be ready to go along with the Commuists if they prevailed, just as Castro was to do four years later in Cuba. The fact that merger with the Federation was a major plank in the PAP platform $^{5}$ was itself regarded in Kuala Lumpur with deep suspicion, not only because it would result in a Chinese majority, but also because, just when the Malayans were snuffing out their own Communist Party in the jungle and attaining independence, they did not want to import another, urban based revolutionary party and start all over again.?

Nevertheless, Lee Kuan Yew was one of Lim Yew Hock's delegation of five Assemblymen who went to London in March 1957, and Lee played a dominating part in the negotiation 8 of the constitutional proposals, which were signed on 11th April. The main features of these proposals were that

(a) Ex officio and nominated members of the Legislative Assembly should be abolished, and its elected Membership increased to 51. The Chief Minister would become Prime Minister, and would preside at meetings of the Council of Ministers, in which the three ex-officio would be replaced by elected Ministers. 9

(b) The British Governor would be replaced by a Malayan-born head of state, to be appointed by the Queen on the advice of the British Governor in consultation with the Singapore Government. 10

(c) The British Government would be represented by a U.K. Commissioner, who would not attend the meetings of the Council of Ministers, but would receive copies of their Agenda and would have the right to see papers which he considered liable to affect the UK responsibility for external affairs and defence. 11 


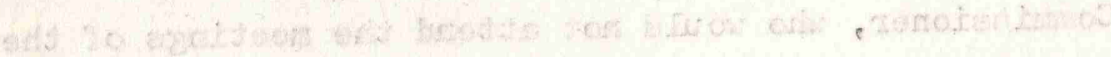

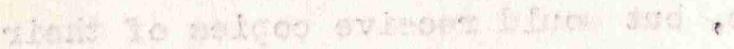

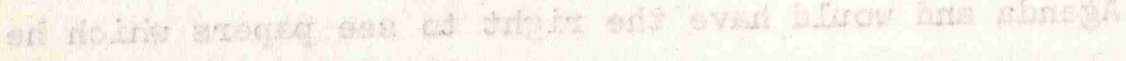

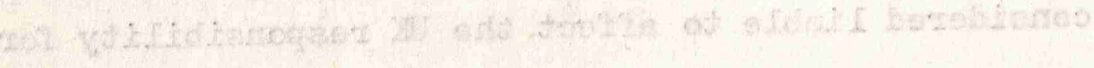

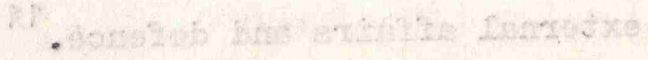


(d) There would be an Internal Security Council composed of three British, three Singaporean and one Federation member - the latter to have the casting vote (see below).

(e) The British Government reserved the right to suspend the Constitution "if in their opinion the internal situation in Singapore had so far deteriorated as to threaten their ability to carry out their responsibilities for external affairs or defence or if the Singapore Government had acted in contravention of the Constitution." In this event the UK Commissioner would assume the government of Singapore. 12

The most controversial argument in the Constitutional proposals was on the provisions for maintaining Internal Security (I.S.). The British Government insisted that "persons known to have been engaged in subversive activity should not be eligible for election to the first Legislative Assembly of the new State of Singapore", though it was accepted that future policy in this respect would be a matter for the Singapore Iegislatire to decide after the first elections. The disagreement of the Singapore Delegation was recorded in the Report as follows:

"The Singapore Delegation expressed their opposition to this departure from normal democratic practice and protested at the unilateral imposition of this condition. They made it clear that they could not accept Her Majesty's Government's proposal. For Her Majesty's Government it was stated that this was a condition precedent to the new Constitution which they would have to impose. It was the view of Her Majesty's 
13 ibid p 10

14 Compare discussion between the Governor and David Marshall in 1955 - see Chapter 6 footnote See also p 718

$15 \quad$ Cmd 147 p 9

16 SLA Debates 26 April 1957 Columns 1707 - 8 
was essential to safeguard the orderly

development of democratic government in Singapore

against the danger of Communist subversion.

Future policy in this respect would be a matter

for the Singapore Legislature to decide after

the first elections. In the circumstances the

Singapore Delegation took note with regret of

the intention of Her Majesty's Government". 13

It is probable that the majority of the Singapore Delegation in fact welcomed this provision, but it was better for their anti-colonial image in Singapore if they were seen publicly to contest it. They might therefore have been somewhat embarrassed if the British Government had not insisted upon it as a precondition of the Constitution, and the British Government will have been well aware of this. 14

Responsibility for Internal Security

The key feature of the provision for IS was the Internal Security Council (ISC). It was agreed by all sides that this would consist of

Three Singaporeans (the Prime Minister and two others)

Three British (the UK Commissioner and two others)

One Minister from the Federation of Malaya.

The UK Commissioner was to be Chairman but in the event of a disagreement between the three Singapore and three UK members, the Minister from the Federation would have the casting vote. To avoid snap votes, it was laid down that, when a vote was to be taken, all members or their duly authorised alternates would attend the meeting and vote. 15

The Constitution was attacked by David Marshall, the ex Chief Minister, who criticised both Lim Yew Hock and the PAP for agreeing to it. In the Assembly on 26th April he issued a challange to fight any member on the issue in a by-election in that member's own constituency. Lee Kuan Yew at once accepted the challenge, ${ }^{16}$ and both he and Marshall resigned their 
17 Lee Kuan Yew, Battle p 51 and pp 58-64

18 Cmd 147 p 9. Before the 1959 elections, Lee Kuan Yew successfully insisted that the existing Public Service Commission be dissolved and the members of its successor selected by the incoming Prime Minister (Blades para 28) p a ? 2

19 Cmd 147 p 10

20 SLA Debates 12 September 1957 Column 2634. Lee also quoted (column 2629) from his election manifesto: "The by-election is to find out if you who elected me as PAP candidate in April 1955 approve of the stand that I, as a member of the PAP and of the recent Constitutional Mission to London took on two issues, which are the constitutional proposals and the anti-subversion clause." 
seats on the 30th. Lee defended the Constitution on the grounds that Singapore, as an important British military base in a predominantly Chinese island, was most unlikely to be granted independence from Britain as a sepacate state, so that the' overriding object of the Singapore people must be a merger with the Federation; and that this would never come about unless the Federation Government had the means to ensure that the MCP was not being allowed to establish a base in Singapore. 17

Amongst the other internal security measures accepted by the Singapore Delegation in London in April 1957 were that the three senior Police Officers - i.e. the Commissioner of Police, his Deputy, and the Director of the Special Branch - would be appointed on the recommendation of the Singapore Public Service Commission - a body formed in 1955 of comminity leaders without political commitment. The Internal Security Council would be informed and could challenge these recommendations once, but thereafter, if confirmed by the Public 'Service Commission, they would stand. 18

It was also agreed that British troops might have to be used to aid the civil power in dealing with internal disorder. The decision to request such aid would rest with the Singapore Minister. ${ }^{19}$ (It must be remembered, however the UK Commissioner retained the right in extremis to suspend the Constitution and govern himself, thereafter reserving the right to call in British troops if he thought it necessary).

The PAP Executive Committee Changes Hands

Lee Kuan Yew was duly returned in his by-election, Mr Marshall having decided after all not to contest it and to "retire from politics". 
21 In the Battle for Merger $p 26$

22 Sing Cmd 33 of 1957 and SIA Debates 12 September 1957 Columns 2597 - 2600. Three of those arrested were later deported to China as proven Communists. It was the Communist "second team" which was arrested, the first team having already been detained since the 1956 riots - see G.G. Thomson, para 23

23 Lee Kuan Yew, Battle, p 26

24 Legislative Assembly Singapore Sessional Paper No. Cmd 33 of 1957, The Communist Threat in Singapore, Singapore, 23 August 1957. 
Lee, however, was now having trouble with the left wing of his own party. In August 1957, supporters of the imprisoned Lim Chin Siong managed to secure 6 of the 12 seats on the Central Executive of the PAP at the annual Party Conference. Lee accused them of rigging the vote by bringing in non-members, 21 and he and his fellow "moderates" refused to take office. For a short while, Lee lost control of the party, but a few days later the Police arrested five out of the six left-wing Committee members for subversive activity in the Trade Union Congress. $^{22}$ Lee resumed the PAP Chairmanship, and acted quickly to prevent a recurrence. To quote his own account:

"After this experience we amended our Party Constitution to make sure that the Party cannot be so easily captured. We instituted two classes of members - ordinary members and cadre members. Ordinary membership is open to all and secret penetration by Communists into this group is easy if they send in their people who are not yet well known. But only those who have proved over a period of time that they are sincerely and honestly with the Party can become cadre members. An election of the Central Executive Committee is only by cadre members". 23

This incident was, however, of considerable embarrassment to Lee Kuan Yew in the Assembly, where Lim Yew Hock naturally claimed to have saved the PAP from itself by these arrests. On 23rd August, the Government tabled a white Paper giving details of MCP aims and activities in Singapore, quoting in detail from recently seized documents dated between April and June. Reaffirming the fundamental aim of the 
25 ibid pp $1-2$

26 ibid p 3

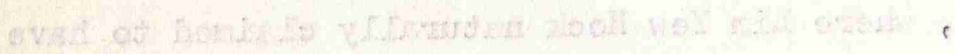

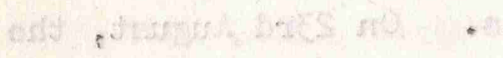

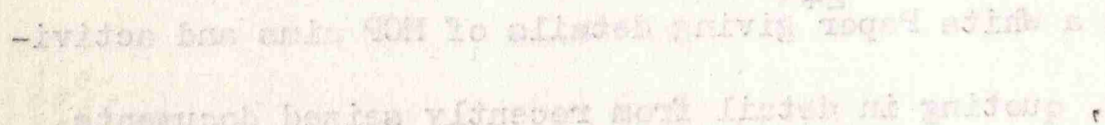

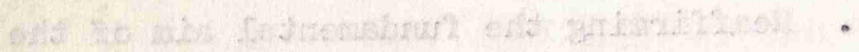


MCP as the establishment of a Communist State, using revolutionary violence if necessary, the White Paper said that, as a preliminary step, or where violence had failed, the Party aimed to join, influence and finally control organisations or groups whose legitimate aims provided a cover for their activities. Party workers infiltrating such legitimate organisations took the greatest care to hide their connection with the MCP. Being trained Communists they did not require frequent directions from the Party, but were able to interpret events and any published statements made by the Party. The organisations often had no idea that they were being penetrated, nor that they were being subconsciously indoctrinated with Communist ideas. 25

The White Paper described the MCP campaign of 1954-56, culminating in the arrest of its leaders in the riots of October 1956. It then quoted from a document seized in a Singapore MCP cell, dated April 1957,

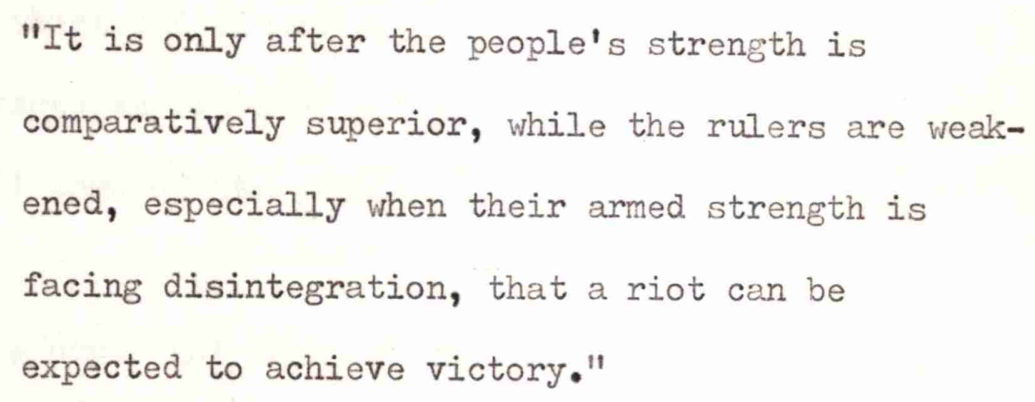

and declared that current policy was to remain under cover, conserve strength, consolidate the United Front, and win over groups or individuals to their cause. 26

A June 1957 document was also quoted, giving details of the technique for gaining control of a farmers union in a rural area of Singapore. It said that

"There must not be deliberate competition for the offices of Chairman and Treasurer at the outset, so as to avoid arousing suspicion" 
27 ibid p 3

28 ibid pp $4-6$

29 ibid p 4

30 ibid pp 6-7 
but it added that the Party aim was to get their men in eventually as Chairman, Treasurer and General Affairs Officer, which in fact in the case quoted they did. 27

Recalling the dissolution of the SFSWU in October 1956, the - White Paper recorded that the Singapore General Employees Union (SGEU) was now operating from the same Middle Road premises, and had revived the Singapore Trade Union Working Committee (STUWC) which had in 1956 claimed to represent 95 Trade Unions, and now claimed 32. They had already revived sufficiently to test their strength against the TUC group of unions in a rival May Day demonstration, and on 18 th July they had held a meeting at Middle Road to discuss tactics for gaining control of the TUC.28

The White Paper described in detail the Communist penetration of the PAP, and particularly of its Cultural and Education Committees, through which it ran picnics and other functions which were used to promulgate blatant Communist propaganda. The White Paper quoted another MCP document dated June 1957 which had described the Party's relationship with the PAP, and had discouraged any idea of splitting the PAP, whose basic policy was correct, even if some of its methods and theories were not. The document had added

\footnotetext{
"We are sure that some of the PAP inclinations can be changed". 29
}

The White Paper recorded that, despite the arrest in October 1956 of 14 office bearers and other important members of the PAP, a number of known members of the secret Communist organisation still held various offices in the PAP and others remained as ordinary members. 30

In the Assembly debate on this White Paper, Lee admitted that his party was not impervious to Communist penetration, but denied that this was confined to the PAP. "The MCP is denied political existence, and must resort to clandestine methods to enter the constitutional political arena", he said, adding that the dissemination of propaganda foreign to the PAP's 
SLA Debates 12 September 1957 Columns $2601-2$ It is interesting that he still referred to the PAP leadership as "non-Communist" and not "antiCommunist".

32

Lee Kuan Yew Battle, p34

33

"Harris" (SB) Interview 1969 
aims was the work of a few individuals and that "the Party leadership ... had consistently stamped out such activities, and that they had been consistently firm and resolute in their non-Communist stand." He challenged the assertion in the White Paper that "from past experience it is quite clear that there is no prospect at all that these legal organisations will be able to purge themselves of Communist influence" and claimed that the PAP, unlike the TUC, were quite capable of looking after themselves. 31 Few people then believed him. The Communists send a Plenipotentiary

In March 1958, according to a later account by Lee Kuan Yew, the MCP tried a bold new tactic with him. They sent a plenipotentiary known by Lee Kuan Yew, and hereafter, as the PLEN - to make secret contact with him. 32 At this time, the secret element of the Singapore Communist Party was based in the Rhios islands - a rash of tiny islands about 12 miles from Singapore which are part of Indonesia. A great many small boats regularly crossed these waters in the process of fishing or carrying merchandise, and with forged identity documents it was not difficult for individuals to pass to and fro. Since these islands were remote from Jakarta and therefore only loosely administered by the Indonesians, they formed a secure santuary for the very small secret element of the Party. 33

The approach was made to Lee Kuan Yew by an intermediary whom he knew to be connected with the Communist organisation, and Lee agreed to meet the PLEN in Singapore, and to respect his confidence.

Lee first decided to test the PLEN's credentials by checking whether he really did have control over the open frontcadres still operating in the Singapore unions and political parties, and asked him to prove his good faith by ordering one Chang Yuen Tong to resign from the City Council and from the Executive Committee of the Workers Party formed by David Marshall since his resignation. Sure enough, a few weeks later, Chang did indeed resign from both bodies, and Lee was satisfied. 
34 Lee Kuan Yew, Battle p 37

35 Blades paras 29-33. 'This recovery was led by Ong Eng Guan, who became the City's first and only Mayor, but broke with Lee Kuan Yew in 1960. 
The first of their clandestine meetings took place just before Lee left for the London Constitutionaltalks in March 1958, and there were three more between then and the elections in June 1959. The PLEN's main concern was to find out whether the PAP was really willing to work with the Communists in a united anti-colonial front. Lee drew attention to the errors which Lim Chin Sjiong had made in 1956, which had resulted in him and others being detained, and to the attempts which the Communists had made to seize the leadership of the PAP in August 1957. The PLEN explained that these errors were the result of difficulty in communicating instructions to Lim Chin Siong and the other open front leaders in time; that now, however, Lee was dealing with the top, with the men who decided the policy and gave the orders, and that they would keep their word on any agreement made with him. Lee, however, declined to commit the PAP. 34 34

Lee Kuan Yew's actions and attitudes at this time must be judged in the light of three things

(a) As a shrewd politician, he was aware of a quite remarkable swing of public opinion in his favour, and he was confident that the PAP would gain a majority at the next election. There had been a clear pointer to this in the City Council elections in December 1957 when the PAP won 14 of the 15 seats a very quick recovery after the troubles of August 1957.35

(b) He was prepared to go quite a long way in risking the "stooge" label in order to ensure that the Communists did not get control of his Party.

(c) He was determined to achieve independence through merger with the Federation, as he knew that he could not deal effectively with the MCP without at least the threat of superior force behind him.

His campaign to reassure the Federation Government and people continued throughout 1958. For example, the PAP Journal Petir, in an article on "The Socialist Revolution", said that the Alliance Party 


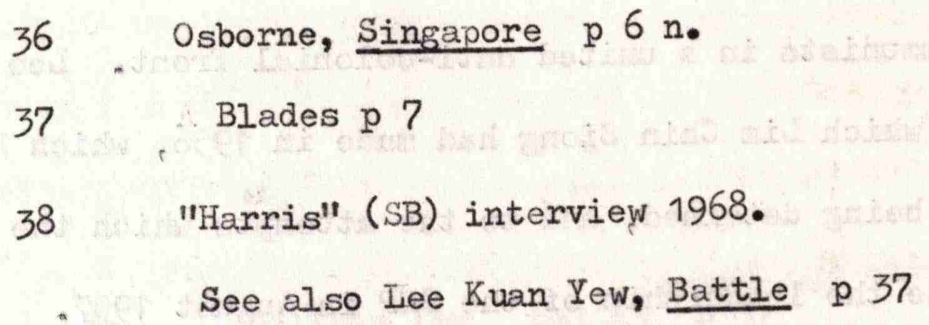

\section{Straits Times}


was anti-merger because

(a) They feared a Chinese majority in their electorate

(the Chinese amounted to $70 \%$ of Singapore's population

and would have added 18\% more Chinese to the Federation's population).

(b) They feared leftists with Chinese support, and did not differentiate between Socialists and Communists.

Petir said that the PAP must allay these fears. 36

At the end of 1958, the government passed new citizenship regulations which extended the franchise to virtually the whole adult population, irrespective of race. This presented little problem in Singapore where unlike the Federation - one race, the Chinese, were predominant both in political and economic strength. The universal franchise did, however, mean that the 1959 elections gave great power and authority to the new government and to the Constitution under which it was elected. 37 The 1959 Elections

By the beginning of 1959, it was becoming clear to everyone, including Special Branch ${ }^{38}$ (which was still in effect under British control) and to the Communists, that the PAP was heading for victory in the forthcoming elections, and Lee Kuan Iew became more confident in his renunciation of the Communists as partners. For example, in an election speech on 26th May 1959, he said

"In this fight the ultimate contestants will be the PAP and the MCP - the PAP for a democratic, non-Communist, socialist Malaya, and the MCP for a Soviet Republic of

Malaya. It is a battle that cannot be won by just bayonets and bullets. It is a battle of ideals and ideas. And the side that recruits more ability and talent will be the side that wins". 39 
Fong Swee Suan, James Puthucheary, S. Woodhull, Chan Chiaw Thor and Devan Nair

42 Alan Blades comments:

"To Lee Kuan Yew, these activists were the "Dynamos" of society. His attitude was"put them somewhere where they will have to show which way they want to bounce; if our way well and good; if not we shall know where we stand and can deal with them accordingly!" A conversion rate of even only 1 in 10 would be worthwhile. Devan Nair was a case in point. He was one of the most virulent Communist sympathisers when first detained with the rest of the University of Malaya group in January 1951". Blades, paras 34 and 35. See also Lee Kuan Yew, Battle, pp 33 and 75 43 "Harris" (SB) Interview 1969 
The election in June 1959 was an even greater landslide than expected. Though the PAP got only $53 \%$ of the votes cast, they won 43 of the 51 seats. Lim Yew Hock, who had gathered the remnants of the Labour Front and others into a new Singapore Peoples' Alliance (SPA) won only 4, the United Malay National Organisation (UMNO) 3, with 1 Independent. 40

This was not as good as it looked for Lee Kuan Yew, however, as there was still a strong Communist element within his own Party. He had cooperated with them to rout the right wing. The battle with the left - already forecast in his election speeches - lay ahead. Lim Chin Siong Released

His first act on attaining power was to honour his promise to release Lim Chin Siong and the other five ${ }^{41}$ left wing PAP leaders arrested during the 1956 riots. They had not, of course, been able to stand in the elections themselves, so they could not sit in the Assembly, but he did appoint some of them as political secretaries in his various ministries - Lim Chin Siong to the Ministry of Finance and Fong Swee Suan to the Ministry of Labour and Law. 42

To many British and Malayan observers at the time this seemed two faced, 43 in the light of his pre-election speeches such as that quoted above, and those he made in the Assembly. It seemed that his public speeches were designed to lull the British into granting him full independence, and the Federation into accepting merger, whilst in private he was bringing the Communists back into the fold of his party.

These criticisms do not hold water. Apart from the political necessity of making their release a part of his election platform in order to win left wing votes, Lee Kuan Yew had from the start insisted that the best way to handle the Communists was to provide them with a 
44 Lee Kuan Yew, Battle p 31

$45 \quad$ ibid $p 4$ and $p 30$.

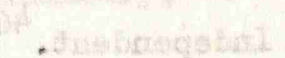

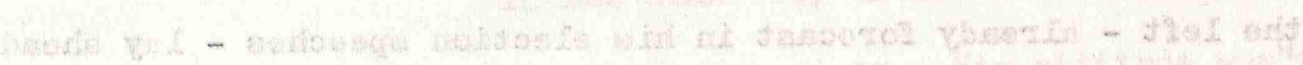

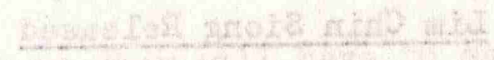

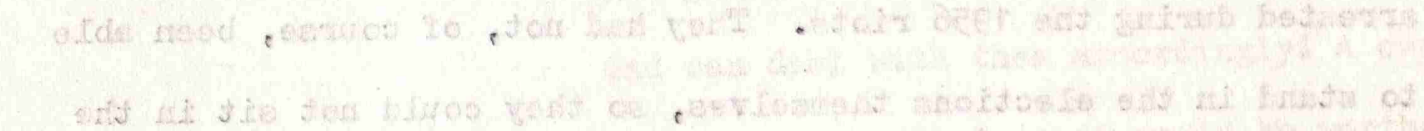

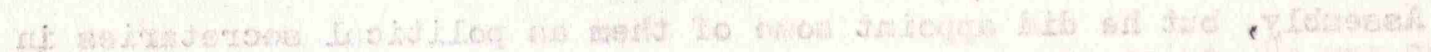
$\operatorname{sis} t a n$

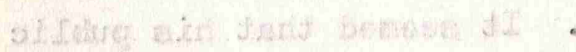

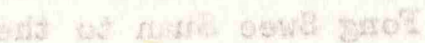

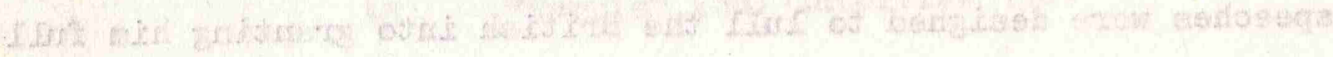

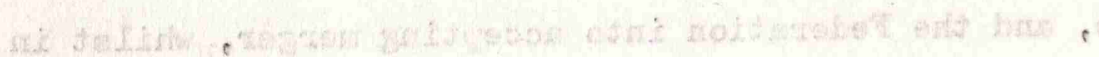


political forum and demolish their case in public debate. He had already taken firm action to prevent them from taking over the Executive Committee of the PAP as described earlier in this chapter. Throughout the detention of the six left wing leaders in Changi gaol, he had visited them regularly and tried to talk them round. During these talks, Lim Chin Siong had offered to go away to Indonesia to "study" (presumably with the PLIN in the Rhios islands) if this would lessen the PAP fears, but Lee Kuan Yew answered that the MCP would merely appoint another open front leader if Lim were not in Singapore. 44 Before thay were released he persuaded all of them except Lim Chin Siong to sign a document declaring that there was no justification whatever for the continuance of the armed insurrection by the MCP. Even Lim signed a document acknowledging that the insurrection had been defeated because the MCP had failed to establish itself as a nationally based movement. Neither of these documents, however, specifically rejected Communism for Singapore, and the most that Lee Kuan Yew could get, even from the other four, was a "solemn declaration" to him that in the event of conflict they would fight with the PAP against the MCP. Because of Lim's refusal to sign the first document or to make this latter declaration, Lee Kuan Yew told the PAP executive committee, in the presence of all five, that, while he was prepared to accept the good faith of the other four, he could not vouch for Lim Chin Siong's sincerity and wanted him to prove it. It is significant that none of the six were allowed to become cadre members of the party (see above), and were therefore barred from voting in the election of the Central Executive Committee of the PAP. 45

A fair summary of the situation is that Lee Kuan Yew believed that he could handle these people out in the open, and was in any case politically committed to releasing them if he were elected. $\mathrm{H}_{e}$ did his best, with only partial success, to convert them to his way of thinking, and meanwhile made sure that their powers were limited, but at no time did he 


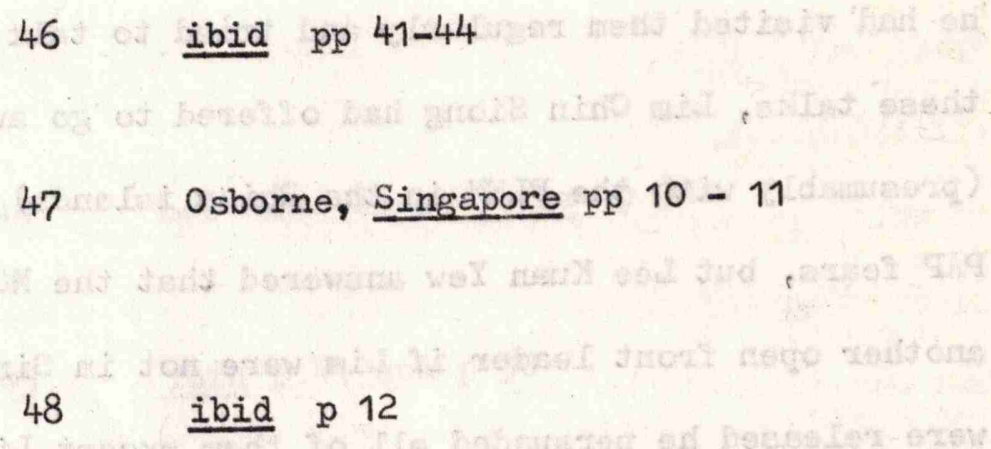

. Jrastov

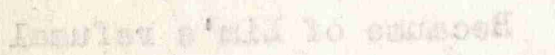

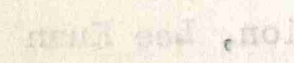

ctority 0

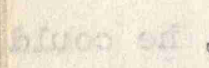

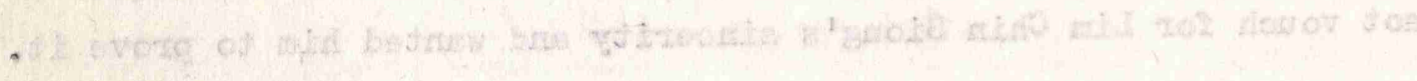

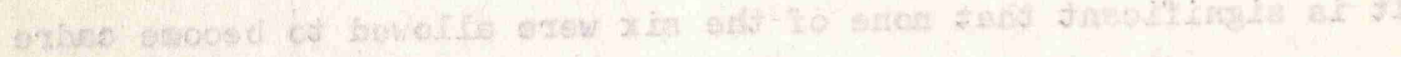

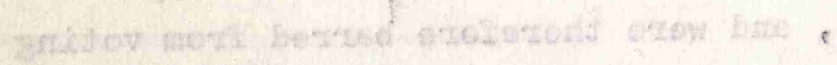

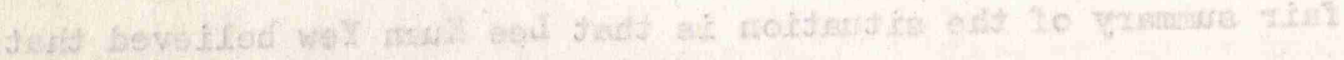

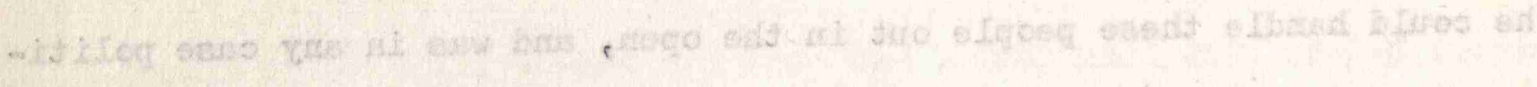

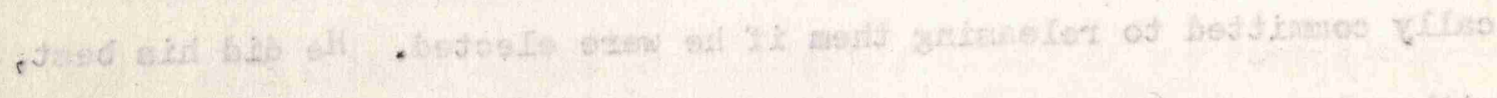

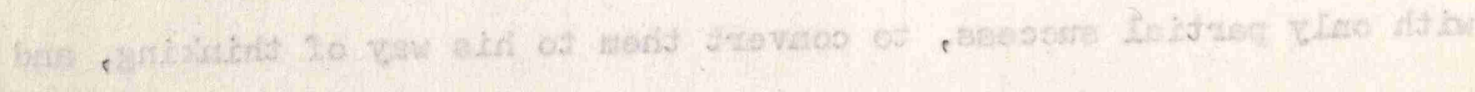

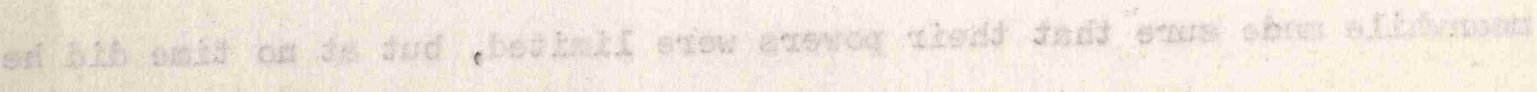


change his own attitude to the problem of dealing with Communism. His public statements in the Assembly and elsewhere remained consistent on this point.

For the first year of the PAP government, Lim Chin Siong showed "sweet reasonableness", no doubt hoping to be accepted back on to the Executive Committee, but. Lee Kuan Yew knew after 9 months (by March 1960) that Lim was working against him within the unions and the rank and file of the workers, and that Fong Swee Suan in the Ministry of Labour was doing the same. 46

\section{The Hong Lim By-Election}

Meanwhile, Lee Kuan Yew was having trouble from another direction. His Minister for National Development, Ong Eng Guan, who had gained notoriety in 1957 by making sensational anti-British gestures as Mayor of the City Council, began in June 1960 to criticise the PAP leadership and demand a "return to the Revolutionary Manifesto of 1954". He was expelled from the PAP in July 1960, and took two other Assemblymen with him into opposition to form the United. Peoples' Party (UPP), thereby reducing the PAP strength to 40 out of 51 . In December 1960, Ong resigned to fight a by-election in his own constituency of Hong Lim, which he had won for the PAP with the largest majority of any candidate in the 1959 elections. 4 ?

The Hong Lim by-election was fought in April 1961, and Ong Eng Guan was returned in triumph with $2 \frac{1}{2}$ times more votes than any other candidate. He achieved this, surprisingly, without the overt support of Lim Chin Siong, or of any of the PAP Assembitymen who were to defect and form the Barisan Sosialis party only a few months later. 48 Nevertheless, Lee Kuan Yew was bitterly hurt by this defeat, which he later put down to discontent over housing, social welfare, and the over-strict control of immigration and of the grant of citizenship. Moreover, he was prepared 
Lee Kuan Yew, Battle p 46 Dominic Puthucheary, in an interview in 1969, identified this relative as the PLWN's sister, Fang Yin Chin, who had been helped by Lee when she suffered injury from burns. Lee also sponsored her for membership of the Assembly, but she later joined his opponents ibid p 47 
to fight the election with his hands tied to some extent by the need not to prejudice his long term aspiration for merger with the

Federation and for the attraction of overseas investment into Singapore. 49 In one of his election speeches, for example, he said "we are not playing to a Singapore audience but we have to play to a pan-Malayan audience." 50

\section{The Plenipotentiary Identified}

'In March 1961, just before the Hong Lim by-election, the PLEN made a further approach through a courier to Lee Kuan Yew. Lee says that by this time knew PLEN's identity, having seen his photograph in a Special Branch file marked "To be arrested on sight" soon after he took over as Prime Minister, in October 1959. He did not tell the Special Branch of his meetings with the PLIN, but he did note the PLEN's true name - Fang Chuang Pi. He did not reveal his name publicly until $1963,{ }^{51}$ but in March 1961 he did indirectly indicate to the PLEN that he knew who he was: the PLEN had from the start operated under the nom de plume of Lee Yek Han (i.e. incorporating Lee's surname) so, when Lee Kuan Yew was asked in March to provide a nom de plume for himself, he in turn incorporated the PLAN's surname and called himself Fang Ping An. At their next meeting on 11 May the PLEN, in true cloak and dagger style, acknowledged Lee's discovery of his identity (and also thereby to some extent his trust) by thanking him for some help he had given to one of his (the PLEN's) relatives. 52

At this meeting ( 11 May) the PLWN urged Lee to insist on the abolition of the Internal Security Council as a target for the 1963 Constitutional talks. Three weeks later, Lim Chin Siong and five others came out with an identical demand, further convincing Iee that they were getting secret instructions from the Communist underground. 53 This public statement by Lim Chin Siong on 2nd June 1961, was the first overt sign of a break between him and Lee Kuan Yew. 54 
Osborne, Singapore p 18

56

ibid pp 18 and 96, and Lee Kuan Yew, Battle p 74

The fact that the defeated PAP candidate was a

Malay drew strong Malay reaction and frustrated

the Communists' hope that the breakaway party

(The Barisan Sosialis) would be multi-racial. G.G. Thomson para 33.

- Coer $57 \quad$ Osborne, Singapore pp 18 and 93

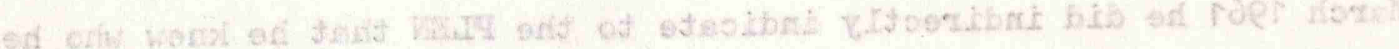

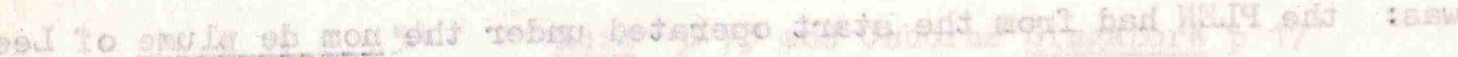

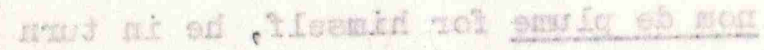

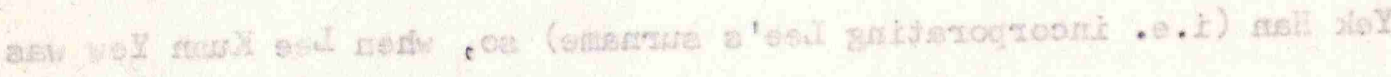

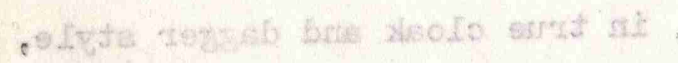

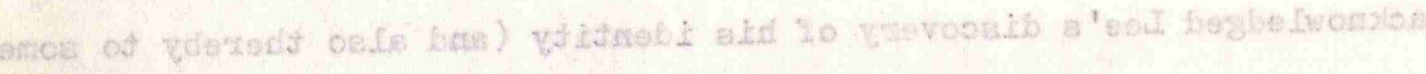

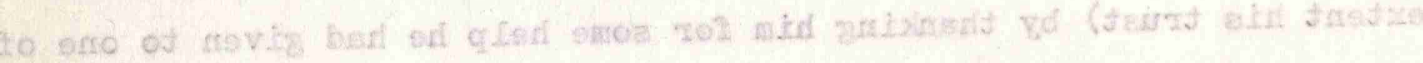

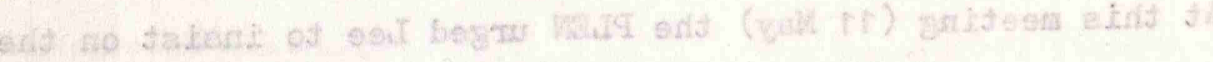

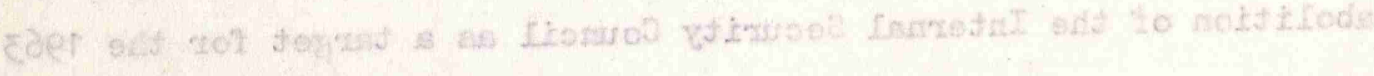

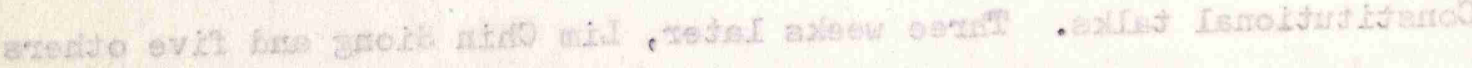

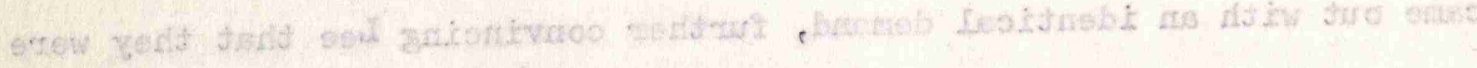
sitith

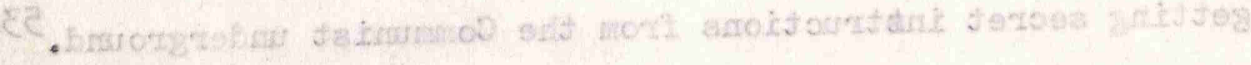

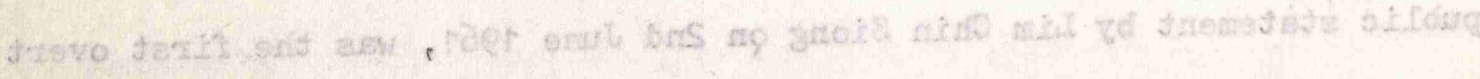

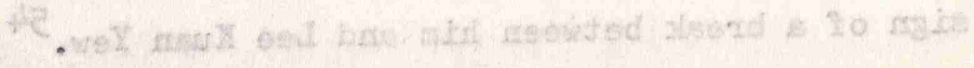




\section{The Formation of the Barisan Sosialis}

The break was starkly confirmed at another by-election in the Anson constituency in July 1961, in which David Marshall had decided to reverse his retirement from politics and stand as a candidate for a new party of his own which he called the Workers Party. Lim Chin Siong stated that he would only support the PAP candidate against Marshall if the party agreed to seek the abolition of the Internal Security Council. Lee - with his eyes firmly on merger refused to do this and, on 11th July, announced that the PAP was prepared to break with its own dissidents if necessary. Two days later, he demanded the resignation of Lim Chin Siong, S. Woodhull and Fong Swee Swan as Political Secretaries. 55 On 15th July, with Lim Chin Siong's support, David Marshall was narrowly returned with a majority of 546 in an electorate of 9000, of whom 1500 abstained. 56

Five days later (20th July) Lee Kuan Yew called for a vote of confidence in the Assembly. 8 PAP members crossed the floor and another 5 abstained. On $26 \mathrm{July}$ these 13 formed the Barisan Sosialis (Socialist Front) Party. Thus, the completion of the Assembly was radically changed. The PAP now had only 26 out of 51 seats. They were opposed by 16 to their left ( 13 Barisan, 2 UPP and David Marshall, who, though previously regarded as right wing, had won his seat with left wing support) and 8 to their right ( 4 SPA, 3 UMNO and one independent). 57

"The British Plot"

At this crucial debate on $20 \mathrm{July}$, Lee Kuan Yew drew attention to the fact that Lim Chin Siong and his friends had been in conference with the UK High Commissioner, Lord Selkirk. He later described these meetings as a cunning British plot to Iull Lim Chin Siong into 
8ar.

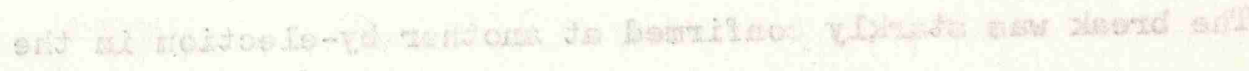

58 Lee Kuan Yew, Battle pp $48-55$

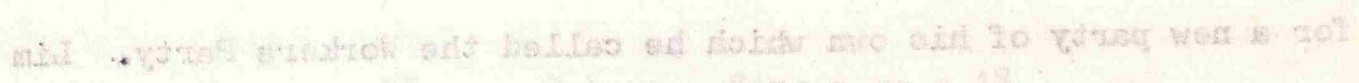

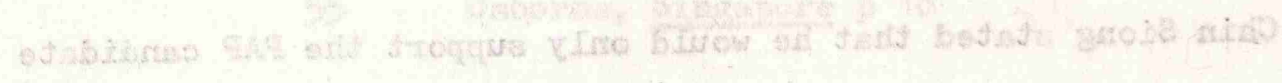

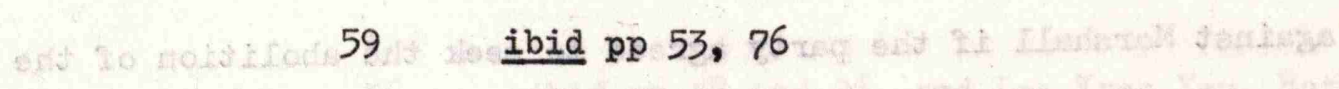

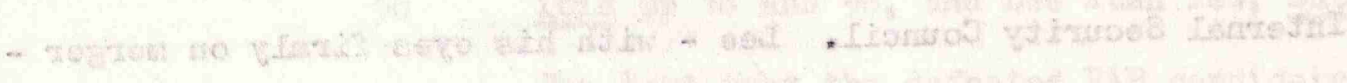

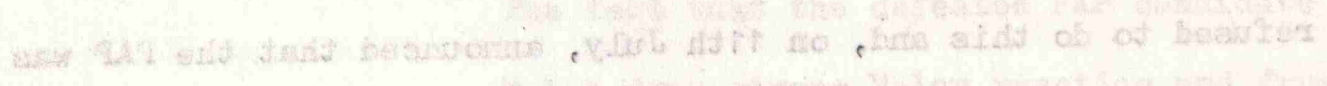

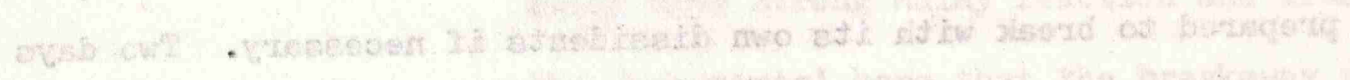

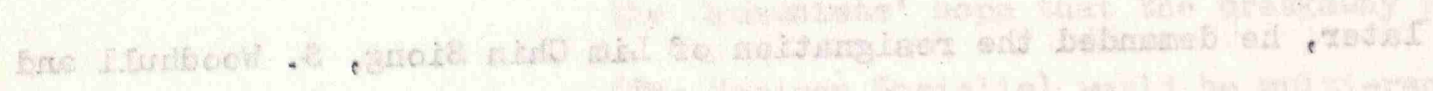

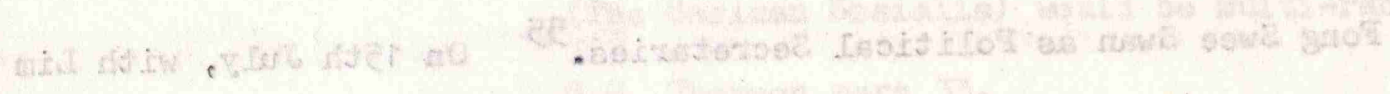

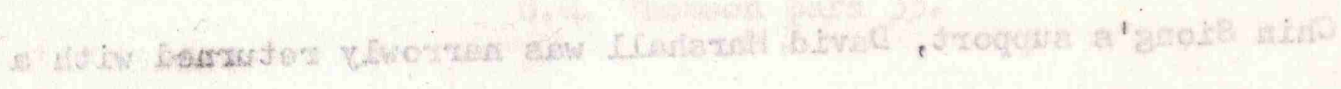

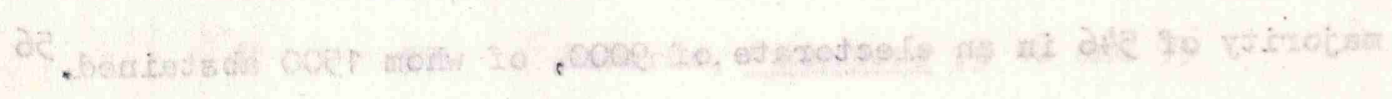

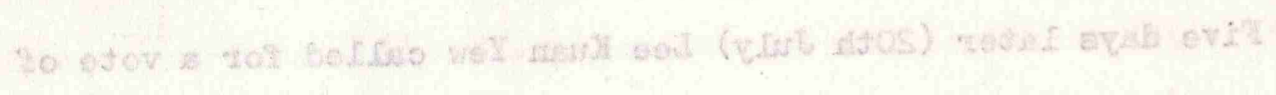

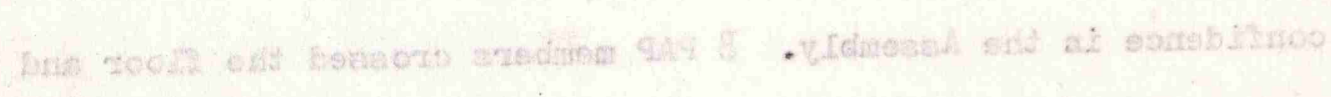

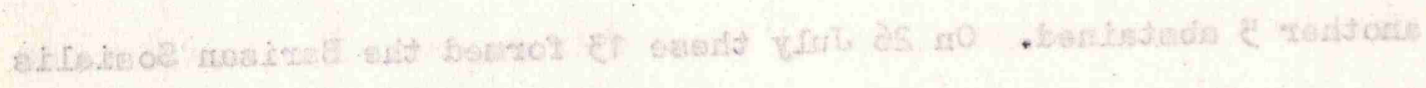

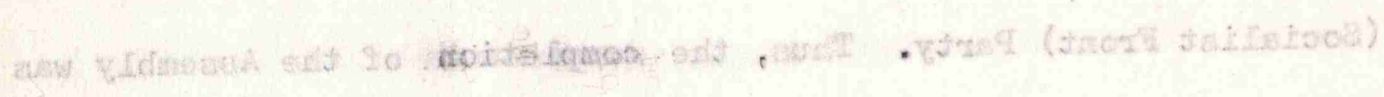

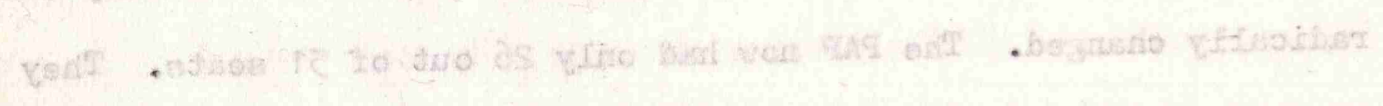

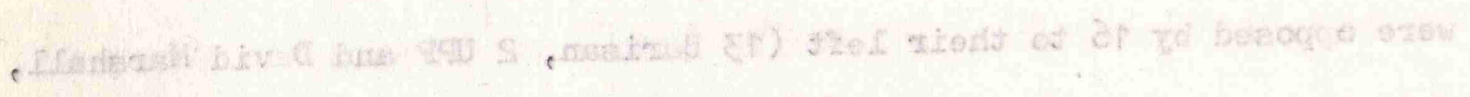

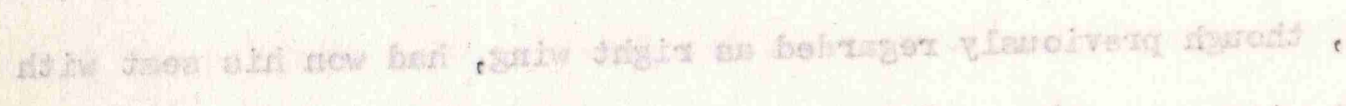

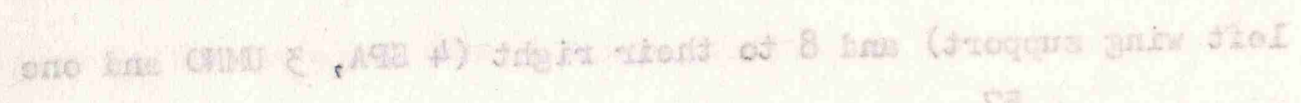

R. (utwomegetini:

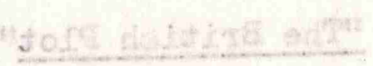

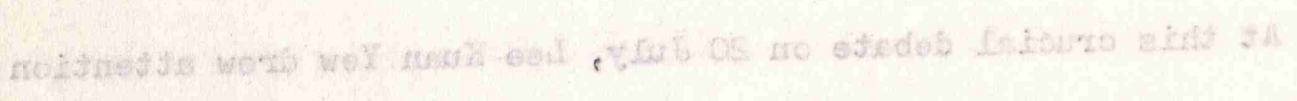

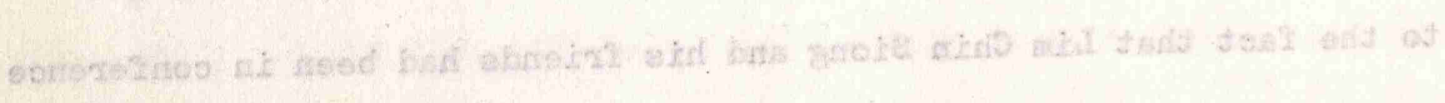

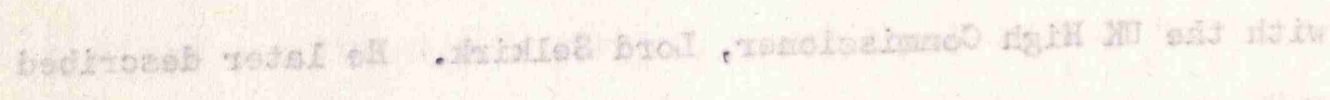

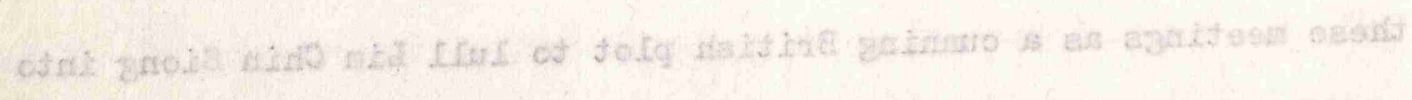


believing that the British would make no difficulties if he and his friends were to attain power by constitutional means. This would encourage them to become more militant, and in turn force the PAP government to curb and contain their subversive activities. This would suit the British, and also do much to reassure the Federation Government, who were reluctant to accept a common market or merger with Singapore so long as they feared that the PAP was giving shelter to the Communists. Lee Kuan Yew said that the British, who had great experience in dealing with such delicate situations, had no comment when he described these meetings with Lim and his interpretation of their meaning.

Given the British green light, he said, the Communists blundered in June into their conflict with the PAP. Following Lim's statement on the ISC on 2 June, they made an angry statement on 12 th June demanding the immediate release of detainees, reunification of the Trade Unions and various relaxations of citizenship and censorship regulations designed to facilitate the revolutionary struggle. 58 This, and the challenge in the Ansen by-election, led on to the open breach and the crossing of Lim's supporters in the Assembly over to the opposition in July.

Lee Kuan Yew said that their plan was not to bring about another general election, but to persuade at least 26 Assemblymen to continue under their leadership still using the PAP label. Dr. Lee Siew Choh would become Prime Minister and Dr. Sheng his Deputy Prime Minister. Both of these men, he said, were politically naive and believed that there was more political future for them if they cooperated with the Communists. 59

Lim Chin Siong's attempt to suborn a majority of Assemblymen to his side appeared on the face of it to fall short by only one seat, 
60 ibid pp $78-79$

61 Lee Kuan Yew himself states that the fight began when the PAP announced their programme on 9 June that in the 1963 Constitutional talks they would seek independence through merger, either with or without the Borneo territories. ibid p 47

\section{Osborne, Singapore p 13}

63 Nangyang Siang Pau (a Singapore Chinese newspaper) 8 May 1961 quoted in Osborne, Singapore p 14 
since the government could only muster 26 out of 51. In theory, since the 25 non-PAP members included 4 SPA and 3 UMNO, who were to the right of both the PAP and the Barisan Sosialis, Lee Kuan Yew should have been able to rely on their voting with him against the Barisan on a decisive issue. In practice, however, some of the right wing members would have gone to great lengths to bring Lee Kuan Yew down, even at risk of landing Singapore with a Communist government - or, perhaps more realistic ally, of landing the British with the problem of sorting out the mess if Lee Kuan Yew were to fall. IIm Chin Siong, for his part, devoted many hours during the next few weeks trying to persuade a number of other PAP members to cross the floor, but without success. 60

The proposal for Merger

On 27th May 1961, the Tunku first publicly mooted the possibility of merger in a speech to foreign journalists in Singapore. This statement probably did much to provoke Lim Chin Siong's demand for the abolition of the ISC on 2nd June, and the Barisan Sosialis eruption in July. 61

The proposal had been under active discussion between the Federation, Singapore and British governments for some time, and there had been a number of meetings between Ministers of the three governments and other senior officers from the territories concerned since January 1961.62 Lee Kuan Yew realised that some form of merger was essential to his political survival and had to carry the Malayans and the British governments with him. In the event, they backed him to the full, and, in parallel with his own activities within Singapore, there were three Constitutional Conferences in November 1961, July 1962 and July 1963 in which the terms of the merger were worked out.

Nevertheless, as late as 4th May 1961, the Tunku had displayed considerable reservations, when he said that Singapore could not be accommodated within the Federation until its people had proved that they were loyal to Malaya as a whole. 63 Lee was therefore probably being quite honest when he told the PLEN on 11th May that there was no immediate likelihood of the Tunku agreeing to a merger, though the PLEN 
64 Lee Kuan Yew, Battle pp 47 and 55

65 Osborne, Singapore, p15. Also SLA Debates 30 July 1963, Column 301.

66 Osborne, Singapore $p$ 19. In terms of population, Singapore should have had 24 seats in the Federal Parliament. In fact they agreed to accept only 15, to be occupied by members of the Singapore Legislative Assembly in proportion to the parties therein. At this time the 15 comprised 12 PAP and 3 Barisan Sosialis.

67 Lee Kuan Yew, Battle, p 80 
no doubt thought he had been deliberately deceived when the Tunku made his announcement on 27th May. 64

Ong Eng Guan's sweeping victory in the Hong Lim by-election in April 1961 may well have been a major factor in bringing the Tunku round to the idea of merger. Though his initial reaction was expressed in his statement of 4th May, he was probably persuaded thereafter by Lee that the economic problems which caused the by-election defeat could only be cured by merger - or at the least by the formation of a common market, and by 27 th May he was presumably convinced that, rather than face the risk of the people of Singapore rallying to the leadership of extremists, he would do better to make a positive public move of support for Lee Kuan Yew. 65

After the split in the Singapore Assembly on $20 \mathrm{July}$, Lee Kuan Yew and the Tunku pushed on fast with plans for merger. On 24 August they announced agreement in principle, under which Singapore would retain control of education and labour in exchange for accepting a lesser number of seats in the Federal Parliament than would be justified by her population. The Central Government would control external affairs, defence and security. 66

On 21st September, Dr。 Goh Keng Swee (the Singapore Minister of Finance) said that there should be a referendum for the people of Singapore to decide whether to accept or reject merger. The Barisan Sosialis opposed this, saying that the issue should be decided by a general election. Lee Kuan Yew interpreted this as a stalling tactic, based on the hope that in a general election no party would gain a clear mandate. ${ }^{67}$ It was over this period that the Prime Minister gave 
In assessing their value as a source, it must be remembered that these broadcasts were made during a crisis in which Lee Kuan Yew was fighting for his political life. Their accuracy, however, and in particular that of his assessment of Lim Chin Siong's Communist affiliation has been confirmed by other sources (eg "Seng" (SB) Interview 1968 and "Harris" (SB) Interview 1969), and no other source has been found to conflict with them - apart from predictable denials by Lim Chin Siong (see Osborne, Singapore p $14 \mathrm{n}$ ). Attempts to get an interviev with Lim Chin Siong in Changi gaol were unsuccessful, but Douglas Hyde (who has done so) was consulted in 1969,

69 Osborne, Singapore $\mathrm{p}$ vi $\mathrm{n}$

70 Singapore Command Paper No. 33 of 1961

71 SLA Debates 20 November 1962 Column $281-328$

72 SLA Debates 16 March 62 Columns 293 - 299

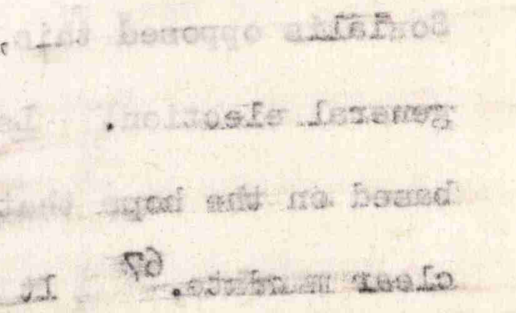


his series of 12 broadcasts over Radio Malaya (from 13 September to 9 October) subsequently published in his pamphlet, The Battle for Merger, ${ }^{68}$ giving his detailed account (frequently quoted above) of his political battle with the Communists and of his meetings with the PLEN.

Opposition members accused Lee Kuan Yew of using the radio with a pro-government bias, and both this 'and his alleged restriction of freedom of the press has been criticised by the Associated Press. 69 Whether or not there was any justification for these complaints, there was probably an element of pique, because Lee Kuan Yew was undoubtedly a more effective radio speaker than his opponents. Complete freedom to criticise the government is in any case unusual in countries whose political institutions are in the early stage of development, and there was probably greater freedom of speech in Singapore than in most of the new democracies - and than in many older ones. As well as time on radio, the opposition were given full rein in the Assembly, whose debates were public, and were published promptly in full in Hansard and freely in the Press.

\section{The Referendum on Merger}

In November 1961, the Tunku and Lee Kuan Yew published their Heads of Agreement for merger, ${ }^{70}$ and it was announced that the Referendum would take place in 1962. In a debate in the Assembly on 20 November, it became clear that all major parties (including the Barisan Sosialis) now accepted the necessity of some kind of merger, ${ }^{71}$ but there was argument over the terms, particularly of citizenship. In a further debate on $16 \mathrm{March}^{72}$ the Assembly voted that, since all parties agreed on merger, the choice in the referendum should not include the option of rejection, but simply a choice of three sets of terms which were finally decided in later debates (in June and July) as follows:- 
73 G.G. Thomson para 34

74 Osborne, Singapore p 25

$75 \quad$ SLA Debates 6 July 1962 Column 1022

76 Osborne, Singapore p 28

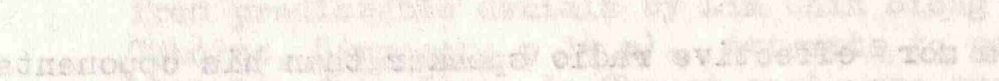


A. Merger based on the Heads of Agreement

B. Merger with the same terms for Singapore as for the ex-British Colonial States of Penang and Malacca

C. Merger on terms no less favourable than for the Borneo States. 73

$B$ was the Barisan proposal, and $\mathrm{C}$ a choice proposed by the ex Chief Minister Lim Yew Hock, on behalf of the SPA. The significance of the choices was complex, and was concerned with issues, such as citizenship, which are not relevant to this study. Their importance lay in their future effect on the balance of parties in the Assembly, because the government at the last minute incorporated a proviso that a blank voting paper would be counted as a vote in favour of the PAP proposal (A). This was because the Barisan had announced that they would canvas for blank papers. Had they had the acumen to conceal this intention until the bill had been passed, it would have been humiliating for the PAP to have passed an amendment adding this clause. 74 Nevertheless the proposal resulted in the defection of a 14th PAP member - Mrs Hoe Puay Choo - who resigned from the Party, later joining the Barisan Sosialis. This left the government with only 25 out of the 51 seats. Nevertheless, with the support of SPA and UMNO members it was able to pass a Bill authorising the Referendum on 6 July. 75

The Referendum took place on 1 September 1962. Of 624,000 eligible voters, 561,000 cast ballots. Of these 397,000 (71\%) were for the PAP's Alternative A, with less than $2 \%$ each for B and C. 144,077 (25\%) were blank. Even excluding the blanks, however, the 397,000 positive voted for Alternative A was well over half the total eligible elector ate of 624000 , so the PAP could fairly claim a victory on any count. 76 Their proviso over the blank votes, in fact, had proved unnecessary. 

"took no evasive action when detention was imminent, ignoring a tacit warning from Lee Kuan Yew who would rather have had him out of the way". Blades para 23 Dominic Puthucheary (Interview 1969). See also Osborne, Singapore, p 32 
Indonesian Confrontation and the Renewed Detention of Lim Chin Siong

The proposal for merger was strongly opposed by the Government of Indonesia, who objected to the inclusion of the Borneo territories. In this President Sukarno was strongly influenced by the powerful Indonesian Communist Party (PKI), who spearheaded the policy of Confrontation against Malaysia.?7

In December 1962, there was a sudden revolt against the government of the Sultan of Brunei - the smallest and richest of the three Borneo states. This was quelled in a few days by British troops flown in from Singapore.. The Brunei revolt (which was a rather pathetically amateurish performance by an underprivileged group with some genuine grievances) was undoubtedly encouraged if not actually sponsored by Indonesia. The PKI had recruited a force in readiness to attack Malaysia before the revolt under the cover name "West Irian Volunteers", and out of the next revolt grew the Confrontation with Malaysia which continued with armed raids and insurgencies on the mainland and in Borneo until after Sukarno's collapse in 1966. By early 1963, consorting with the Indonesians was treated in Kuala Lumpur as treachery.

In their New Year messages, the Barisan Sosialis leaders made statements denouncing the way in which Malaysia was being formed, and referring to the Brunei revolt as a sign of "the peoples will to freedom". 78 On 2nd February 1963, 111 persons were detained by Special Branch in a large scale operation covering both Malaya and Singapore. Those detained included Lim Chin Siong, 79 S. Woodhull, James Puthecheary and his younger brother Dominic. Four days before the Brunei revolt its leader, Azahari, had been in Singapore, where he was in the constant company of Lim Chin Siong. 80 In all, 24 of those arrested in Singapore were members of the Barisan Sosialis, and 7 of the parties associated with it. 11 more were connected with Nanyang 
During the next year, the Barisan Sosialis gained control of most of the Nanyang Uniyersity Students' Societies, and of the Committee of the Students' Union, which was dissolved by the government in 1964. See Federation Government White. Paper. Nanyang University Communist Activities Kuala Lumpur 1964. . Also "Yung" (Interview) 1967.

83

"The Brunei revolt also had the effect of persuading the U K Government, almost overnight, that it must abandon a position which it had taken up over a Kuala Lumpur condition for Merger that Iim Chin Siong and the rest of his associates should again be put in detention before Merger became effective in August 1963 - a condition which suited Lee Kuan Yew so long as he could lay it clearly at the door of the Federation". Blades, para 37. 


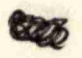

University, ${ }^{81}$ which was becoming a growing centre of subversion. 82

These 111 detentions were decided upon by a meeting of the Internal Security Council which was held in Kuala Lumpur, and was attended by Lee Kuan Yew. He himself clained that he would have preferred to leave these arrests until after merger. ${ }^{83}$ (which was timed to take place on the 6th anniversary of the Federation's Independence in August 1963).

The climax was now approaching in the Singapore Legislature, when the finely balanced Assembly would be taking its final vote for Independence through merger, and there would be a new general election. This political activity was somewhat hampered for the opposition when, on 22nd April, Dr. Lee Siew Choh led a march on the Prime Minister's office to protest against the detentions of Lim Chin Siong and the others. 5 were arrested on the spot, and 7 more later. They were not tried until 29 August, when 8 were convicted on a charge of rioting, the other 4 (including $\mathrm{Dr}$. Lee) being acquitted. Though some had been released on bail while awaiting trial, committal proceedings and the preparation of their cases had considerably harassed the Barisan leaders during this critical electoral period. 84

Independence and the 1963 Elections

Meanwhile, on 1 August, the Assembly voted for Lee Kuan Yew's plah for merger, now slightly revised to increase its attraction as regards citizenship, ${ }^{85}$ and was adjourned sine die.

Intensive delaying action by Indonesia in the United Nations had resulted in the merger being put off until 16th September. A general eloction was held in Singapore (now part of the new Federation of Malaysia and wholly independent of the UK) on 21 September. The PAP term of office could in fact have run until June 1964, but Lee Kuah Yew announced a snap election, at the minimum notice, in the first week of September 1963. This was a shrewd political move because he was able to exploit his success in the referendum, and gain a clear 
Blades explains the comparatively high strength of Communist supporters in the rural areas of Singapore as follows:

a. Opposition to the Japanese had been easier in rural areas, where Communist leadership and sentiment had survived the occupation.

b. During the Emergency, many Chinese peasants moved from the Federation to Singapore to evade resettlement - some of them specifically to organise supplies for the guerillas

c. Most peasants were China-born and Chinese educated, and therefore more influenced by propaganda from China than were the locally born Chinese in urban areas. Chinese rural villages in Singapore retained the feeling of "living in China".

d. In the city there were many other influences, including money-making and rubbing shoulders with a wide variety of people. Even in the intensely Chinese China Town area of the city, the Secret Societies were very strongly entrenched, and regarded the Communist Party as a hated rival. Blades, para 39 
mandate quickly before opposition had time to develop in the event of merger working out favourably for Singapore. 86

This was the first election in Singapore in which Television had been available for use by the political leaders. Lee Kuan Yew, already a successful radio speaker, proved to have a flair for television, and emerged as a clear vinner. The composition of the new Assembly was: PAP 37 seats ( $47 \%$ of the vote), Barisan Sosialis 13 (33\%). The other parties were totally eliminated except for the UPP, Ong Ing Guan retaining Hong Lim, though with a greatly reduced majority, UPP candidates in all polled $7 \%$ of the total popular vote, while the Alliance Party (incorporating UMNO) polled $8 \%$ without winning a single seat. It is significant that Malay PAP candidates captured all the seats previously held by the UMNO for the Alliance Party in predominantIy Malay constituendes. The PAP enjoyed sweet revenge at Anson, where David Marshall (this time standing as an Independent) polled only 416 out of 8436 votes, 87 the PAP candidate winning the seat in a fairly close battle with the Barisan candidate. It is significant that the Barisan Sosialis successes were largely confined to rural areas, where the PAP had done less to improve the peoples' lot than in the urban areas, in which PAP won all but 3 seats. 88

The End of the Merger, and Lee Kuan Yew's Consolidation

Immediately after the elections, on 26 September, 20 preventive arrests were made at Nanyang University, including 3 graduates who had stood as Barisan candidates in the election. An abortive general strike on 8 October was followed by the arrest of the strike leaders of the Barisan - dominated Singapore Association of Trade Unions (SATU). Those arrested included three Barisan Assembly members. All this was made easier for Lee Kuan Yew by the fact that the arrests were made by the 
89 Straits Times. 27 September and $8-9$ October 1963

90 G.G. Thomson para 36

91 Osborne, Singapore p 84

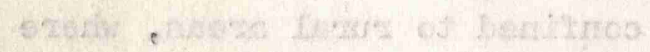

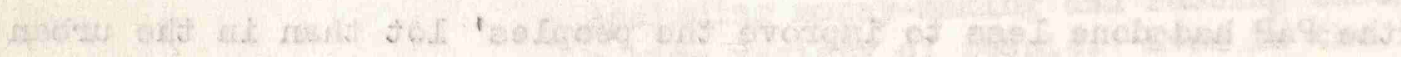

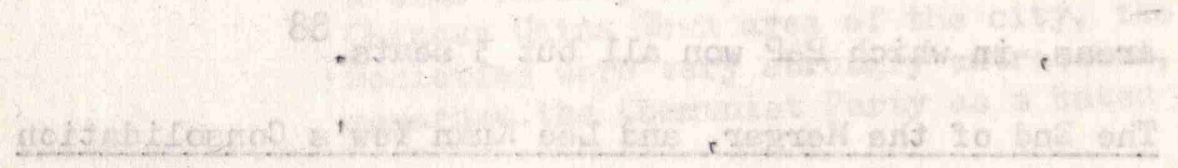

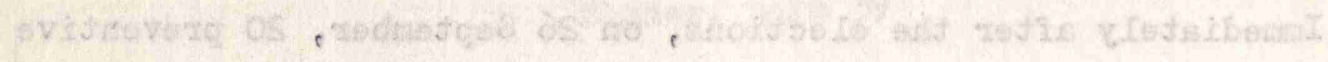

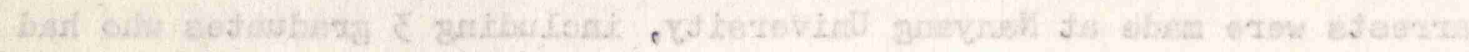

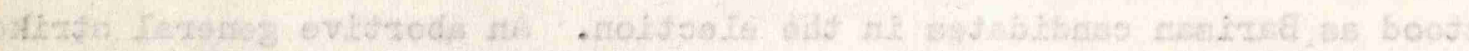

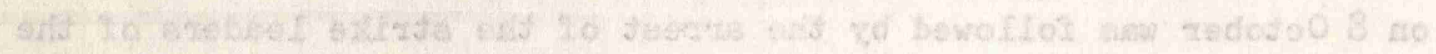

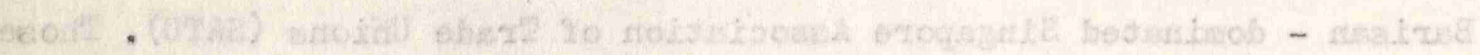

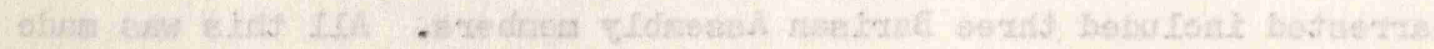


Federal Government which had now assumed responsibility for internal security in Singapore under the Malaysia agreement. 89

Subsequent events had little direct relevance to this study, but will be outlined briefly to put the period described into perspective. There were serious riots in 1964, with some loss of life, but these resulted from racial conflict between Malays and Chinese, caused by a rift between the PAP and racially extremist Malays in the Federation, and were not part of a revolutionary process in the sense of trying to seize political power by illegal means. 90 They no doubt contributed to the deteriorating relations between the predominantly Chinese government of Singapore and the predominantly Malay central government in Kuala Lumpur. The break between them, however, resulted more directly from a bid by Lee Kuan Yew to get a wider political foothold for the PAP by putting up PAP candidates in 9 of the constituencies on the mainland of Malaya in the 1964 elections. Although the attempt was a failure in that only one PAP candidate was returned, 91 many Malay politicians interpreted it as a bid by Lee Kuan Yew for eventual premiership in Kuala Lumpur. After months of vituperation, Singapore was expelled from the Federation in August 1965, and became a wholly independent state. Sukarno was overthrown soon afterwards and Confrontation ended in August 1966. Through all this, Lee Kuan Yew's political strength and popularity grew in Singapore, as his efficient administration - especially in the fields of housing and education - bore fruit. Alan Blades regards this as the biggest factor in the PAP success against Communism, ie, the

"... tremendous drive of Lee Kuan Yew and his chief associates to provide an honest administration and the huge housing, education and industrial opportunities needed so quickly in order to show the people, even including many of his wealthy rightwing opponents, where success lay. Success has followø success, which happens more markedly 
$92 \quad$ Blades, para 40

93 G.G. Thomson para 1, and covering letter to the author, June 1969

94 "Seng" (SB) interview 1968 and "Harris" (SB) interview 1969 
with the Chinese than it does everywhere else and, most important of all, he has been able to do this, or at least to get it under way patent for all to see, before the end of his period of dangerous flirtation with the Communists within his own Party. In this process he has had reason to be grateful to the Tunku both as a longstop and as a contrast" 92

G.G. Thomson comments in similar vein:"While the Communists were acting and organising the political process was developing, and it is only in relation to that process that the Communists can be set in a perspective of contingency rather than in the perspective of inevitability of success in which they are often set. The success of Communism is always someone else's failure to find an alternative solution to the problems to which anybody politic is heir". 93

In March 1968, Lee Kuan Yew called another general election and Dr. Lee Siew Choh announced that no Barisan Socialis candidates would stand as the election was "a fraud". The Communist threat in Singapore is now in almost total abeyance. 94 Singapore's economy grows apace, with the PAP supreme (though some effective opposition might be better for their political health) and Lee Kuan Yew is emerging as one of the Commonwealth's leading statesmen - a development by no means unknown in the lives of other leaders who have been regarded as dangerous firebrands during their countries" advance to independence. 
PART II

RURAI GUERTIIA REVOIUTION

THE : EMMERGENCY IN MATAYA

CHAPTTER 9

THE FIRST YEARS OF THE ENMERG NNCY 
1. This conference was followed by similar outbreaks of violence in other South East Asian countries, but it is an exaggeration to say that "orders" were given for these uprisings at the conference, as part of some coordinated plan conceived for South East Asia in Moscow, as is sometimes suggested. See Ruth McVey, The Calcutta Conference and the South East Asian Uprisings, Cornell University, Ithaca, New York, 1958.

2. Charles Gamba, The Origins of Trade Unionism in Malava, Eastern Universities Press, Singapore, 1962 p. 335.

3. Alex Josey, Trade Unionism in Malava, Singapore, Donald Moore 1954 p. 17. In June 1948 there were 302 Unions in the Federation of Malaya, with a membership of 150,000. Of these, 129 Unions with a membership of roughly 82,000 were controlled by the Communist led PVIFTU.

4. This was probably planned at the PMFTU meeting in Singapore in April, and endorsed by a meeting next day of the MCP Supreme Executive, which was in the next building. During this Open Front period, PMIPTU leaders made no effort to conceal their membership of the MCP. See Gamba p. 334. Also C.C. Too (Gov) - Interview 1967.

5. Victor Purcell, The Chinese in South East Asia, London, Oxford University Press, 1965 p. 330. See also Edgar 0'Ballance Malaya - The Communist Insurgency 1948-60, London, 1966 pp. 77-79.

6. Gamba, p. 333.

7. Straits Times, 9th June, 1948. 


\section{CHAPTER 9}

THE FIRST YEARS OF THE EMERGEHNCY

\section{Launching the Armed Struggile}

We now revert to the situstion described at the end of Chapter 2, when Chin Peng decided to switch the emphasis from the cities to the rural areas and launch the armed struggle. This decision followed the return of MCP delegates from a Communist Youth Conference in Calcutta in February 1948, Which may have had some influence, though the decision was primarily the result of frustration of the attempt at an urban revolution.

The call to mobilize was made in March. Of the 10,000 ex-MPAJA members on the books, only 3,000 took to the jungle in the next 3 months, calling themselves "The Malayan People's Anti-British Army" (MPABA). The Police and the Army, who knew a lot about the camps the guerillas planned to use, launched an operation against them in April, and captured documents which proved that they had an organised military structure. ${ }^{2}$ The GHQ was in the jungle about 12 miles South of Kuala Lumpur.

While the MPABA went through the administrative processes of mobilizing and training in the jungle, the PNFTU, which controlled over half the Trade Union Members in the Federation, ${ }^{3}$ planned a series of militant strikes aimed to convince the British that there was no stable future for their industries。 4 One source suggests that they planned to declare a Communist Republic in Malaya in August 1948, by which time it was hoped that the British would have decided to write off their losses and abandon the country. 5

Incidents in the rubber estates and tin mines from May until mid-June took on a new and more violent character. ${ }^{6}$ From 17 th May to 7 th June, there was a wave of arson and destruction of machinery, most of it (though not all) tied to plausible labour disputes. 12 managers and foremen (11 of them Asians and only one European) were murdered. During the same period the police killed 7 and injured 23 more in fights with strikers. 7 
8. See Chapter 2.

9. Lam Swee (Com) - Interview 1966.

10. Miller, p. 83. He in fact described it as the 8th Regiment, but this regiment was in Kedah, so presumably this is a slip or a misprint. The Perak Regiment was the 5 th.

11. John Davis, - Interview 1966.

12. Gamba, pp. $342-3$.

13. The Emergency Regulations Ordinance 1948 (amended up to 31 st Narch, 1953) Kuala Lumpur, Government Press, 1953.

14. P.B.G. Waller, A Study of the Fmergency Regulations in Malaya 1948-1960 (Draft) Stanford Research Institute, Bangkok, 1967, and R.D. Rhenick Jnr., The Emergency Regulations of Malava, Masters Thesis, Tulane University, U.S.A. 1964. 
On 12th June the new Trade Union Ordinance 8 became law, and the PMIFTU, along with 86 others in the Federation, became illegal. The leaders of the PIITU, who included a number of experienced ex-MPAJA commanders, took to the jungle. 9

Up till now, it appeared that the MPABA, busy with its mobilisation, had played little part in the violence in the estates and mines, but on 16th June there were 5 more murders, 4 of them (in the Sungei Siput district of Perak) being later ascribed to the killer squad of the 5 th Regiment MPABA. 10 Three of the victims this time were British planters -. which Chin Peng later admitted to have been a mistake as it aroused many of the British officials who had until then been rather complacent. ${ }^{11}$

\section{A State of Emergency}

On 19th June, after several more murders, the High Commissioner (Sir Edward Gent) declared a State of Emergency in the Federation, and Singapore followed suit on 23 rd June. ${ }^{12}$

This was the first step in the development of a comprehensive system of Emergency Regulations which have now become a model for controlling the population in the face of a widespread and organized revolutionary movement which uses violence and the threat of violence as well as propaganda. These Regulations were amended and improved and by 1953, after eight years of urban and guerilla insurgency they had reached a peak of effectiveness. ${ }^{13}$ They speak for themselves, but they have also been fully analysed in two excellent monographs. 14

Sir Robert Thompson, who had much to do with the development and enforcement of the Bmergency Regulations in Malaya and thereafter tried vainly for four years to persuade the Government in South Vietnam to introduce similar measures, stresses the importance of emergency legislation being wide enough and strict enough to ensure that police, soldiers and all other government officials can do what they need to do to maintain or restore order without having to act outside the law. The public, he says, will accept remarkably tough measures provided that they are taken under a law of the land that has 
15. Sir Robert Thompson, Defeating Communist Insurgency, London 1966, pp. 53-54.

16. Blades, paras. 2 and 3.

17. P.B.G. Waller, Working Papers, Stanford Research Institute, Bangkok, 1967.

18. Gamba, p. 350.

19. Gamba, p. 363. Also High Commissioner, Despatch No. 5, - 30th May, 1949.

20 This contrasts with Vietnam where it was estimated that there were a million weapons at large and unaccounted for by 1965 . Sir Robert Thompson, - Interview 1965; also his Defeating Communist Insurgency, Iondon, 1966 p. 52.

21. Emergency Regulations Ordinance. 
been duly and publicly enacted, and warns that a government whose officials and security forces act outside its own laws cannot hope in the long run to earn the willing support and respect of its people. ${ }^{15}$

The most urgent and effective Bmergency Regulations were those giving power to arrest and detain without trial - an unavoidable suspension of liberty when witnesses are repeatedly intimidated. ${ }^{16}$ The police at once arrested nearly 1,000 known Communist Party Members or sympathisers, though many others had already taken to the jungle. ${ }^{17}$ By the end of 1948, 1,779 were held in detention and another 637 (together with 3,148 families) deported. $^{18}$ During the next 9 years, (i.e. until the Federation became independent) 33,992 were detained for varying periods, and another 14,907 deported. Bach detention was subject to review every 6 months.

Even more important, in the long term, were the regulations requiring the registration of the entire adult population (over 12), and other measures such as Tenants Registration, to enable the police to spot strangers in a village. Every person over 12 was photographed, thumbprinted and issued with a National Registration and Identity Card (NRIC). This massive processbegan in July 1948 and was completed in 8 months. The MCP reacted violently, killing photographers, destroying NRICs and killing or maiming those who concealed them from the guerillas. 19

Other Regulations, mainly introduced later, gave the government and their security forces the power to remove squatters from land to which they had no title and to resettle them in villages in which they could be protected and controlled.

Another fundamental measure was the strict control of firearms, ammunition or explosives, unauthorised possession of which was punishable by death. 20 Other regulations gave the police the power of search and seizure, the enforcement of curfews and the dispersal of assemblies. ${ }^{21}$ The MCP itself was declared illegal on $23 \mathrm{rd}$ July.

On 29th June the High Commissioner, Sir Edward Gent, was recalled to 



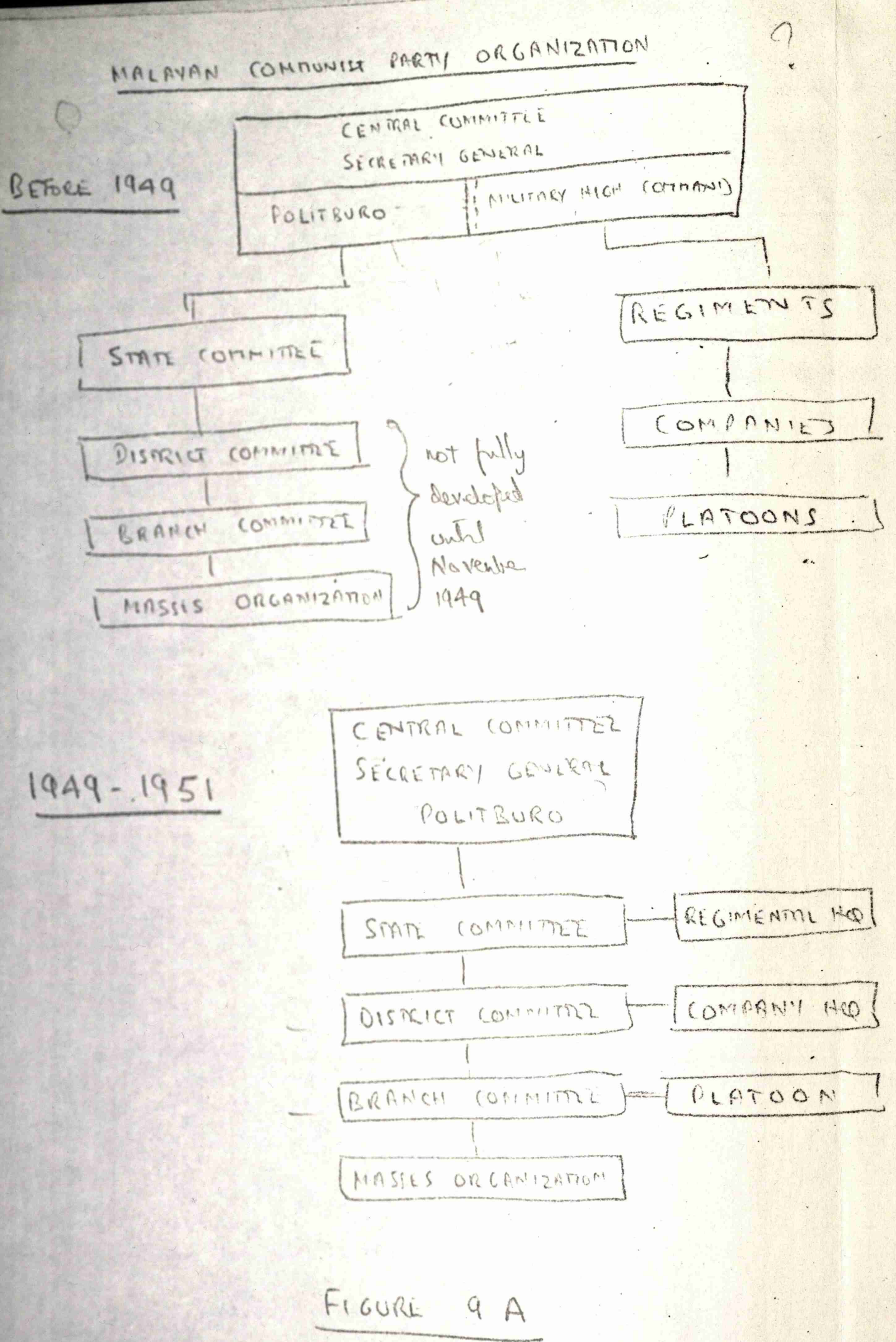

22. Miller, p. 91.

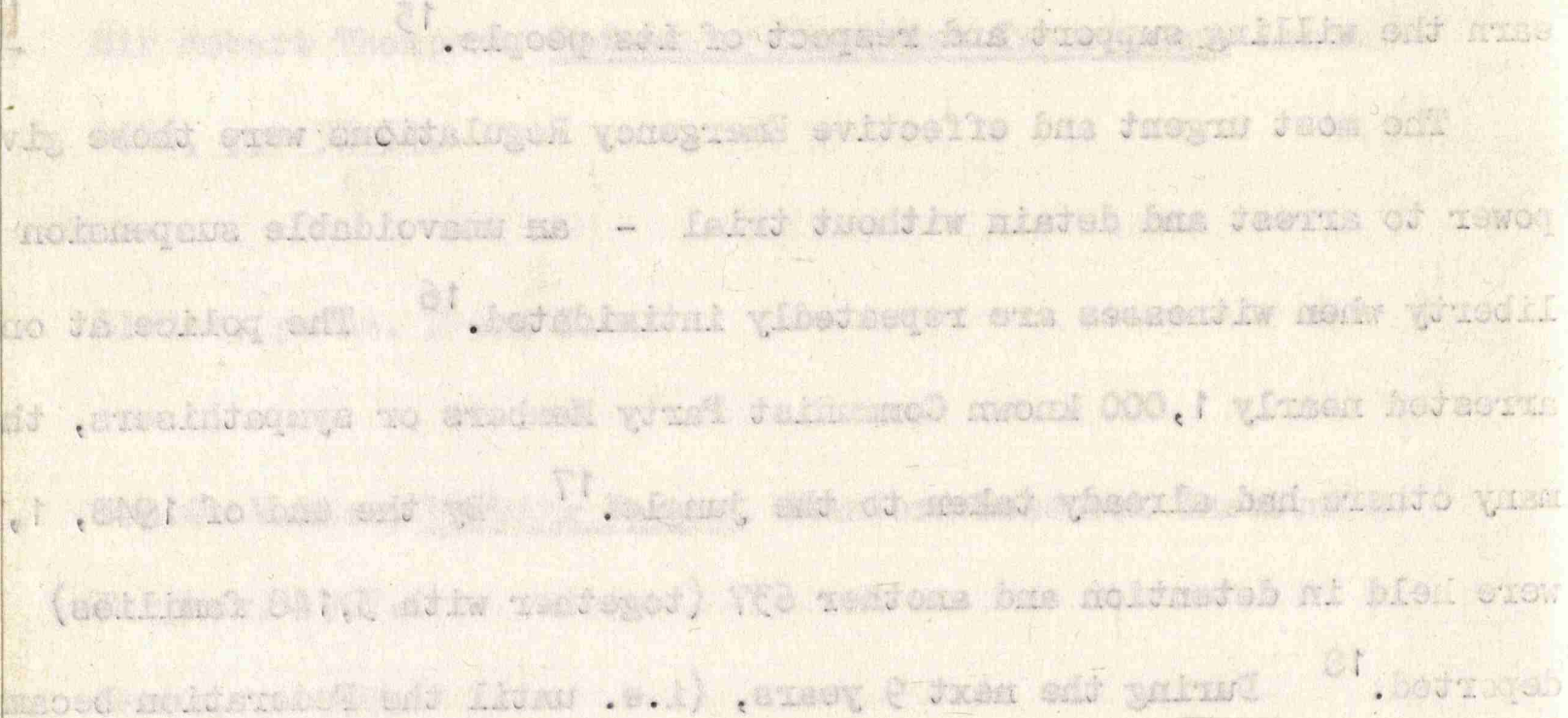

23. P.B.G. Waller, Notes on the Malavan Mmergency Strategies and Organisation of the Opposing Forces, Stanford Research . Institute, California, U.S.A., 1967 p. 21. Also Miller p. 93.

24. Waller, Working Papers, p. 6.

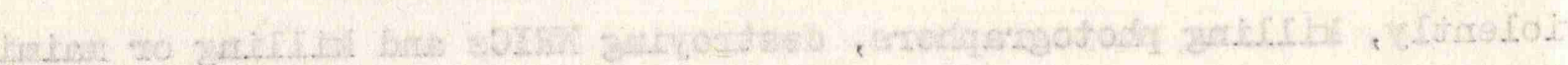

25. Based on Waller, Notes, p. 17 and Interview 1970

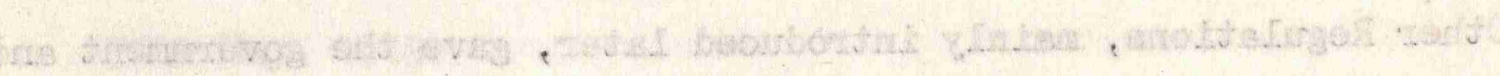

26. Lam Swee (Com) - Interview 1966 and "Fu" (SB) - Interview 1967.

27. Purcell, Chinese, p. 332. 
London for consultation and was killed four days later in an air crash. In September, Sir Henry Gurney was appointed to succeed him. ${ }^{22}$

\section{Guerilla Strategy and Tactics 1948}

The MPABA, with its heroic image from the Japanese war, enjoyed wide popular support amongst the rural Chinese and especially amongst the squatters. Their plan followed Mao's strategy of working inwards - to seize selected areas adjacent to the jungle, while estates and mines were seized by strikers, these later being linked and expanded as "liberated areas". They were, however, surprised by the quick and determined reaction of the police and the army. They were able to seize very few populated areas, and even from these they were driven out within a few hours. 23

The MPABA initially mobilized 8 regiments, later increasing to 10 . Generally, in 1948-49, they lived in large camps of up to 300 guerillas, with parade grounds and lecture huts concealed under the canopy of giant trees. About 3,000 guerillas in all lived in these jungle units, and some 7-8,000 more lived in the open, serving as part time guerillas in an organisation known as the Self Protection Corps. During 1949 they also built up a political organisation of State, District and Branch Committees, partly in the jungle and partly outside, whose chain of command was separate from that of the Regiments. ${ }^{24}$ See Figure 9A. ${ }^{25}$

The underground organisation outside the jungle was at this time rather informal and undeveloped. The MCP assumed that the Chinese rural population would rise spontaneously in support of the guerillas. ${ }^{26}$,

Guerilla operations - mainly carried out by units of 50 or so - were aimed at terrorising waverers and informers amongst the villagers, and paralysing the economy by slashing rubber trees so that they bled to death, smashing mine machinery, and ambushing buses, trucks and trains. From June until October 1948, they killed 223 civilians of whom the great majority were Chinese, (only 17 being European), but in doing so they lost 343 guerillas, 27 and while they undoubtedly had the moral support of much of the Chinese rural population, there was no sign of the active popular rising against the 


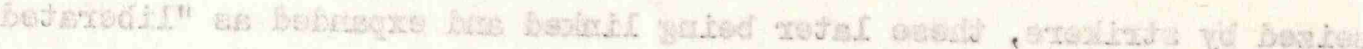
$120 .+20$

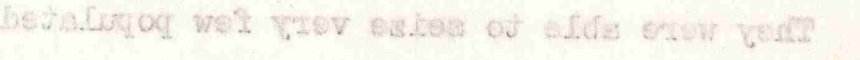

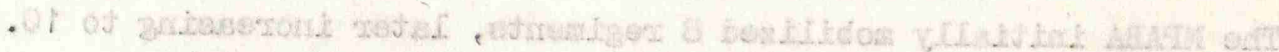

28. Malayan Communist Party, Strategic Problems of the Malayan

Revolutionary War, December 1.948, published in GZ Hanrahan, The

Communist Struggle in Malaya, New York, 1954, pp. 102-115.

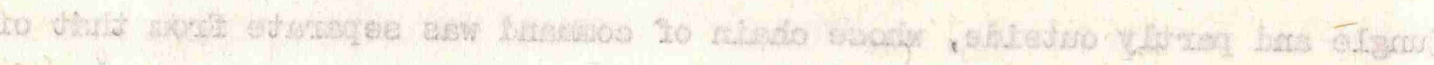

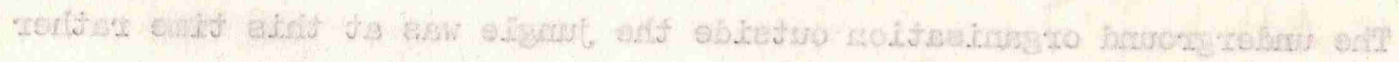

29. Director of Operations, Progress Report on the Emergency in

Malaya, Kuala Iumpur, 15th October, 1951.

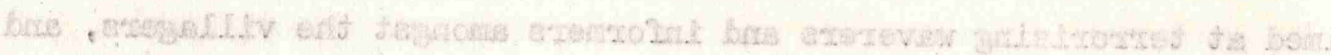

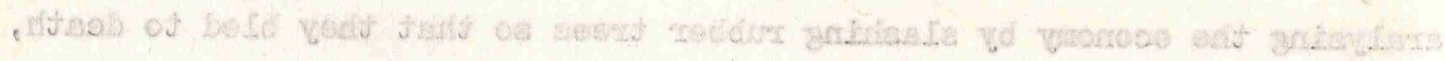

30. "Kim Cheng" (Com) "Harris" (SB) and Waller Interview 1967. 
government for which they had hoped.

Meanwhile, the MCP had been at work on a comprehensive Directive, which was completed in December 1948. This recognised that a quick decision was now out of the question, and that they must settle down to a protracted war, for which permanent jungle bases would be required. Two thirds of the MPABA were to withdraw into the deep jungle, uninhabited except by a handful of aborigines to train and reorganise. The remaining third were to remain as independent companies in camps on the jungle fringe, continuing reduced operations amongst the squatters and in the rubber estates and tin mines. The MPABA was renamed the "Malayan Races Liberation Army" (MRIA).

At the same time, there was a reorganisation and integration of the political organisation with that of the regiments. Instead of having separate chains of command, each MCP Branch Committee was to be given control of a platoon of the MRIA as its striking force. The $\mathrm{HQ}$ of the company to whom these platoons belonged was to be responsible to the District Committee which controlled the Branches and the Regimental HQ to the State Committee. 28 This organisation is shewn in Figure 9A.

In April 1949 this new Directive was put into force. Terrorist incidents fell to less than half. In the meantime, however, the Government had also been taking urgent action. By the end of 1949, the police force had been expanded from 9,000 to 43,000 and the 10 army battalions increased to 18.29 This, coupled with the sudden decline in terrorist incidents, gave the impression that the first crisis had been weathered, and there was a wave of government optimism. Though this optimism proved somewhat premature, the MCP had missed what may have been one of its best chances of victory, and it never regained the initiative, nor did it ever again have the spontaneous support of such a large part of the Chinese rural population. 30

\section{Controversy in the MCP}

At this time, a violent controversy broke out in the higher ranks of the MCP, between Siew Lau, the State Secretary of MMlalacia, and the Politburo. It was conducted in a series of strongly worded theses and directives, 
31. This was later recognised by the government in their resettlement policy. Waller, Interview 1970.

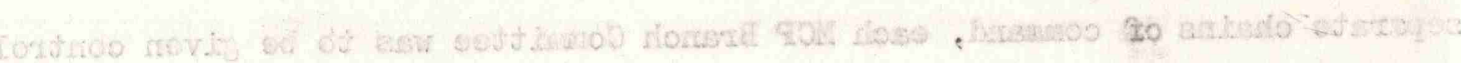

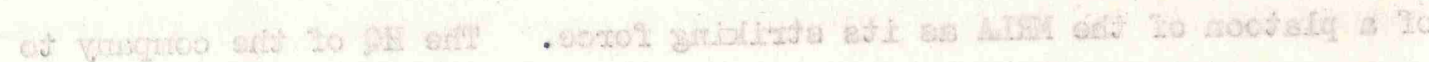

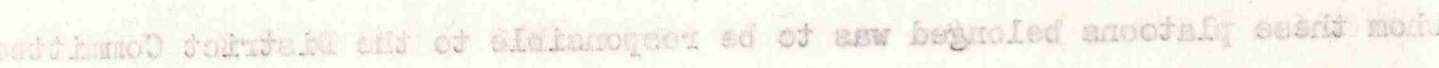

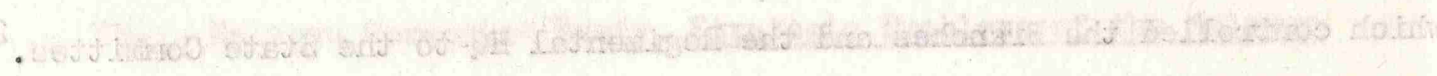

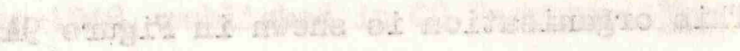

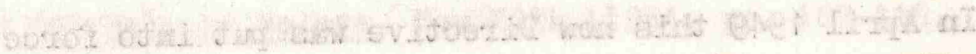

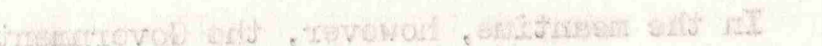

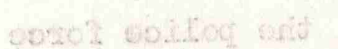

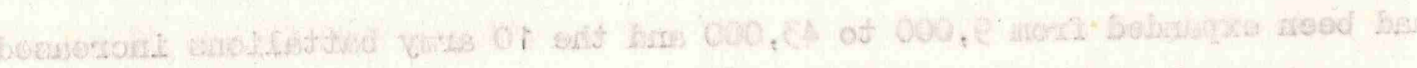
evinge

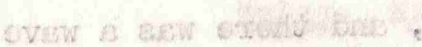

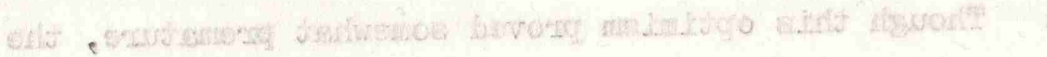

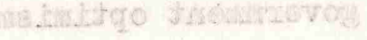
fl bussos.

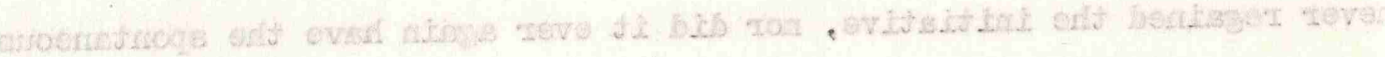

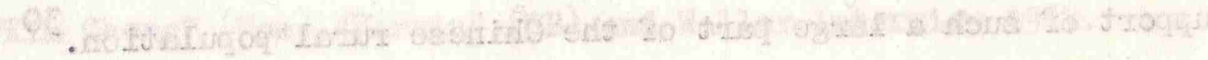


reminiscent of the Bolshevik-Menshevik conflict in the early 1900's. Early in 1949, Siew Lau wrote three theses criticising the December 1948 Directive. While accepting that armed revolution was the only way of dislodging an enemy as powerful as the British, he said that the first objective must be the outlying villages where the British were weakest. Nevertheless, he felt that it would be fatal to pursue this struggle until multi-rącial support had been created. Malay support must be attracted, since without it success was an "idle dream". Since $70 \%$ of the population worked on the land, support must be founded on the economic interests of the land workers, whose outstanding demand was to own the piece of land on which they worked. ${ }^{31}$ Thus, Malaya could not become a Socialist State until after the revolution which must be a gradual process, in which the big capitalists and landlords were dispossessed, and production begun by individuals owning their own land and small enterprises, which should then be expanded into medium sized estates and light industries and eventually be nationalized.

The Politburo replied with a furious directive, distributed throughout the party, denouncing Siew Lau as a "deviationist". He was accused of a fatal error in categorising rubber workers as "agricultural", and thereby deducing that they were entitled to equal shares of the rubber estates. From the social and economic standpoints, rubber and tin must be regarded as industries, and the party must nationalise the big estates in the interests of the people.

The controversy continued, and Siew Lau wrote more letters and pamphlets, criticising the stealing of identity cards and the slashing of rubber trees, and the aggressive use of guerillas at the expense of the people, and describing the Party Executive as "Buffalo Communists".

Many of Siew Lau's ideas were later to be incorporated in the MCP Directive of October 1951, but he paid the inevitable price of being premature. In August 1949 he was demoted, and expelled from the Party in November. In May 1950, he and his wife were executed by an MCP killer squad. 32 
33. Lam Swee formed an "SEP Brains Trust" with Special Branch at Police HQ, Kuala Lumpur, which continued to operate through and after the Emergency. This Brains Mrust, assisted by three Special Branch Officers, was an important source of information for this thesis in 1966-67.

34. This is probably correct. See also Clutterbuck, The Long Long War, Chapter 18. Casualties inflicted by bombing were negligable until 1956, when the RAF began precision bombing on targets fixed accurately by intelligence agents on the ground or by secret radio beacons concealed in radio sets surreptitiously introduced into guerilla camps by Soecial Branch agents in the supply chain. Waller, Interview, 1970. 
A few weeks later, on 27th June, 1950, another leading Communist came out of the jungle to surrender - Lam Swee, who had been Secretary General of the Pan-Malayan Federation of Trade Unions before taking to the jungle on 16th June, 1948. Like Siew Lau he was under a cloud for criticising party policy, but he wisely did not wait for events to take their course. Some months after his surrender he published his views in a pamphlet, My Accusation. These views, which represent a Trade Unionist's views, have been well set out by Alex Josey in his "Trade Unionism in Malaya." 33

Despite its sharp treatment of dissenters, the MCP had realized by the end of 1949 that it was losing ground, and issued a fresh directive, though it did not at this stage reflect the views of Siew Lau and Lam Swee. On the contrary, it was more militant in its attitude to the rural population. For reasons of face-saving and confidence, the new,directive (dated 12th November, 1949) was described as "Supplementary Views" on the previous directive, which, it claimed, had after a year's experience been proved correct but suffered from lack of detail. Even deep jungle bases were precarious, it said, as government troops from Kuala Iumpur could get almost anywhere within.a day. There was practically no such thing as an isolated spot in Malaya. "Relative dispersion" was therefore necessary. The guerillas must operate on the jungle fringe, in smaller units, since heavy concentrations were disadvantageous for withdrawal.

The directive then analysed the government's strength. Since there were no weak links in the administrative system it would be hard to wipe out, but it derided British Troops and air attacks in particular which, it said, had killed only one guerilla in $1 \frac{1}{2}$ years. 34

The directive admitted that it had been a mistake to abandon the major part of the peasant organisation after the Japanese war. The development of the strength of the masses, it said, was never spontaneous, but required organisation, indoctrination and mobilization. The masses still lacked the determination to sacrifice their jobs, homes, families and personal safety. 
35. - Supplementary Views of the Central Politburo of the Malayan Communist Party on "Strategic Problems of the Nalayan

Revolutionary War", 12th November, 1949 Cited Hanrahan pp. 117-129. 38

36. In his Report to the Secretary of State for the Colonies on 8th January, 1949, The High Commissioner asked London for support in developing a proper Police Special Branch, taking in as many Chinese as possible, and warning that the current rate of pay would have to be considerably increased to obtain the right material. In May he added that "Without information the large sums spent on the police and troops will be useless. Information generally may not flow until there has been a success and there is unlikely to. be success without information. It is wise, therefore, to pay for information (i.e. adequate staff and agents) at the beginning". High Commissioner, Despatch No. 5 , 30th May, 1949.

37. Miller, p. 119. See also Chapter 11 and 12. 
It said that the 1948 Directive was wrong in saying that protracted war could not be conducted without permanent bases. It was true that it would eventually be necessary to form permanent bases, since without them it would not be possible to develop People's Governments, or to drive the British out of Malaya. For the time being, however, temporary bases would suffice, and the essential feature of the new plan was to turn the squatter areas into temporary bases, in which the Masses Organisation (Min Yuen) would operate along the lines of a governing body. As each area was abandoned by the security force, the Min Yuen would assume governmental powers, leading to the establishment of permanent bases in which the guerillas could reform into "Guerilla Army Corps" to engage and defeat the government forces. 35

\section{Sir Harold Briggs}

Meanwhile the government had begun to realise that, even if they could contain the guerillas by military action, they could never eliminate them without a better intelligence organisation. The CID, geared for normal crime, was quite inadequate to cope with a large scale $\mid$ rebellion supported by an organişed underground movement. 36

On 6th September, 1949, the government announced generous surrender terms which in effect amounted to an amnesty for all except those found guilty of murder. 116 guerillas surrendered within 4 months, and "Surrendered Enemy Personnel" (SEP) began to play a major part in intelligence operations. 37

These 116, however, were mostly waverers and the surrender rate quickly fell away. At the end of 1949, the MCP offensive was resumed with greater ferocity and greater skill. Concerned with the deteriorating situation, the British government in April 1950 appointed a Director of Operations (a retired General - Sir Harold Briggs) with wide powers of coordination over the police, the army and the civilian departments concerned with the Emergency. Up till this time the army had been called out in aid of the civil power for what had been regarded as a temporary disturbance and, though it had operated under its own officers it did so under the overall 


80. Figure 9B


38. Waller, Working Papers, p. 18.

\section{SIZE OF NEW VILLAGES}

Size

(People)

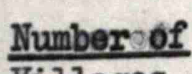

Total in

Villages

their villages

\section{Percentage}

of villages

Percentage of People in these villages

$\begin{array}{lr}\text { Under } 100 & 12 \\ 100-500 & 169 \\ 500-1,000 & 116 \\ 1000-5000 & 169 \\ 5000-10000 & 10 \\ \text { Over } 10,000 & 2 \\ \text { Unknown } & 2 \\ \end{array}$

$$
\begin{array}{r}
769 \\
51,874 \\
79,886 \\
340,710 \\
73,405 \\
26,273
\end{array}
$$

3
35
24
35
2
1
-

$$
572,917
$$$$
\text { (say } 573,000 \text { ) }
$$

100

100
59

13

$-$

\section{PERCENITAGE BY RACE IN NEW VILIAGES} $86 \%$ Chinese
$(493,000)$ $9 \%$ Malay
$(52,000)$ $4 \%$ Indian $1 \%$ others $(23,000)$ $(5,000)$

\section{DEGREE TO WHICH NEW VILTAGGES WHRE NEW} "New Suburbs" (separate, but near towns Unclassified

$$
\begin{aligned}
& 32 \% \\
& 16 \% \\
& 24 \% \\
& 28 \%
\end{aligned}
$$

\section{LABOUR REGROUPNIBNI}

$$
1951-53
$$

Population

$$
\% \text { Chinese }
$$

\%Malay

20.0
68.7
71.8

\%Indian

510,000
80,000

60,000

71.8

$\begin{array}{ll}16.0 & 50.0 \\ 17.6 & 13.6 \\ 14.0 & 14.0\end{array}$

\%others

Mines

Others

Total

$246,000 \quad 104,000 \quad 274,000 \quad 26,000$

* Mainly Rubber, Pineapple and Oil Palm of this size

On new and isolated sites Built around existing small villages

39. Director of Operations, Review of the Emergency in Malava from June 1948 to August 1957, Kuala Lumpur Sept. 1957, pp. 13-14.

40. Kernial Singh Sandhu, "Emergency Resettlement in Malaya", Journal of Tropical Geography, University of Malaya in Singapore, August 1964, which provides a comprehensive study of resettlement, so the subject is therefore only outlined briefly in this thesis.

41. Director of Operations, Review, 1957, p. 17.

42. Sandhu, passim. A summary of the categories and sizes of villages is in Figure 9B. The majority were in a village of between 1,000 and 5,000 people, since this was found to give the best balance between economy, control and defence.

43. Very few of the Resettlement Officers - either British or Chinese - were murdered, though they lived in the New Villages. An important factor here was that they were not charged with 'unpopular' duties such as collecting taxes, registering young men for conscription or making overt repprts of people's movements. For the villagers, they provided the only source of alleviation of their hardships, and the guerillas knew that their murder would be unpopular. This situation contrasted with Vietnam, where Village Chiefs do collect taxes, register draftees etc. are often murdered and in fact seldom dare to sleep in their villages. "Harris" (SB) Interview 1967, and Thompson, Defeating Communist Insurgency, pp. 103 and 210. 
direction of the Commissioner of Police (CP). Because the CP had neither the experience nor the staff to control the widespread military operations which had developed, there was a good deal of inefficiency and friction. 38 .

Briggs' first act was therefore to set up a Federal War Council and War Executive Committees at State and District levels (generally known by their abbreviated titles of SWECs and.DWECs). In these committees, the responsible civilian official was Chairman, with the local. police and army commanders taking joint decisions with him. 39

\section{Resettlement}

Briggs next set about resettlement of the Chinese squatters on the jungle fringe. Originally driven to fend for themselves by unemployment during the 1932 slump, the squatters' numbers had been swelled by others escaping from Japanese ruthlessness in the villages in 1942-43, when their only help, leadership and indoctrination had come from the Communist guerillas, to whom they remained solidly loyal. Owing nothing to the government, independent, scattered, unprotected and uncontrolled, they provided an ideal base for the guerillas. 40

Various unsuccessful attempts had previously been made to resettle some of them, and Briggs implemented the recommendations of a committee which had been formed in December 1948. In June 1950, with terrorist incidents at five times their 1949 level, and with over 100 civilians (mainly Chinese) being murdered every month, a crash programme of resettlement was begun. By 1952, 423,000 Chinese squatters had been resettled in 410 New Villages at a cost of $\$ 41$ million. ${ }^{41}$ Counting other existing villages into which some squatters were absorbed, and labour lines concentrated under government orders on the estates, 740,000 rural Chinese - almost all of them, in fact, - were gathered into wired and defended perimeters. ${ }^{42}$ See Figure 9B

Despite inflammatory efforts by the MCP, there was surprisingly little opposition to this programme, or even evasion, and very little violence used against the government officials responsible for its execution. 43 
44. Waller, Interview 1970.

45. The price of rubber rose from 38 cents per $1 \mathrm{~b}$ in 1949 to 108 cents in 1950, and averaged 169 cents per $1 \mathrm{~b}$ in 1951, during which it once reached a peak of 237 cents per 1b. Ooi Jin Bee, Land People and Economy in. Malaya, London 1963 p. 206 and Dunlop Malaya Estates Ltd., The Story of a Rubber Tree (mimeograph) Malacca 1965.

46. Davis, Interview 1966. The limitations on the ability of an insurgent movement to absorb recruits are described. by Sir Robert Thompson in Defeating Communist Insurgency p. 66 and in his forward to Clutterbuck, The Long Long War, London edition, Cassell 1967.

47. Chinese Advisory Board, Malacca, Minutes, 24th August, 1951. This contrasts with Vietnam, where there was, at any rate up till 1968, no village police force; and the locally enlisted auxiliary army units, where provided, generally lived in. separate defended compounds outside the villages. Authors observation in Vietnam, November 1967.

48. Emergency (Tenants Registration) Regulations, Kuala Iumpur 1951.

49. Surrendered Enemy Personnel Brains Trust, Interview, Kuala Iumpur 1966. 
Amongst the reasons for this were that resettlement was carried out by soldiers in frightening strength but with a consideration which contrasted with the ruthlessness of both the Japanese and the Communist guerillas; squatters were given Temporary Occupation Licences both for their houses and agricultural smallholdings which greatly increased their feeling of security, bearing in mind that they had previously had no legal title whatever to their land; ${ }^{44}$ there was also an unprecedented opportunity for work for the displaced squatters on the rubber estates due to the demands for rubber arising from the Korean war; ${ }^{45}$ and the MCP could not in any case have accepted any large influx of squatters into the jungle due to shortage of weapons and supplies. 46

Protection was a vital element of resettlement. The squatters were not moved into a New Village until a police post could be provided. 47

Tenants Registration was also introduced, whereby the householder maintained a list of all occupants, duplicated in the Police Post, and was obliged by law to notify any arrivals and departures within a day. ${ }^{48}$ Food was also controlled, and this was effective since most Malayan acreage is devoted to inedible commodities such as rubber and tin, and the guerillas could only get rice through their contacts with the people. Because large units were difficult to feed, they split into smaller ones, and these were more within the power of the village police posts to hold off until help came. 49

Starvation became a spectre, and an increasing amount of the guerillas efforts were devoted to acquiring food. Since rice was the staple diet without which their health and morals would quickly collapse, they were prepared to take great risks to get it, and it was this which was to provide the Police with their greatest opportunity for intelligence projects. Special Branch

In May 1950, a month after his arrival, Briggs had appointed a study group to investigate the Intelligence Services, as it was evident that the CID, designed for the detection of crime, was not staffed or trained to cope with the flood of tactical intelligence which could be acquired from the 
50. Waller, Working Papers, p. 22 .

51. Thompson, p. 85. Malcolm Browne, in The New Face of War, London, not to mention 5 or 6 Vietnamese agencies. Michael Clark, im Algeria in Turmoil, London, 1960, p. 9, listed 6 in Algeria.

52. Waller, in a letter to the author, 13th February, 1970.

53. The Police Circle was a group of districts, an intermediate level to ease the span of command of the State Chief Police Officer (CPO). Major operations (see Chapter 11) normally straddled the boundaries of two or more districts, and were therefore handled on the police side by one Officer Superintending the Police Circle (OSPC) and the Circle Special Branch Officer (CSBO), serving whichever DWEC was nominated to run the operation. There were sometimes MIO's in the large independent districts (such as the city of Ipoh) whose police officers had the same ranks as those in the Police Circles in rural areas. 
people in the New Villages. In August 1950, a separate Special Branch of the Police was formed with responsibility for all tactical intelligence and counter-subversion, and the CID hereafter dealt only with the investigation of crime. 50

Briggs realised, also, that it was essential to have a single intelligence organisation. Rival intelligence services tend to spy on each other, and to conceal information from each other. A single informer will, if he can, collect rewards from several intelligence organisations for the same information, which may well be unreliable but will appear at the centre to be "confirmed" by several sources as has happened in Vietnam. 51

An important aspect of intelligence work in Malaya was the evolution of a comprehensive Special Branch registry which correlated all forms of intelligence into a detailed and up-to-date picture of guerilla units and personalities. This enabled every district Special Branch office to be issued with guerilla Orders of Battle and Wanted Lists of individuals, usually accompanied by photographs, so that the DWEC could set about the systematic elimination of the Communist jungle organisation, unit by unit and man by man. Thus, if, say, 6 guerillas were killed in an ambush and were identified as members of a particular branch, the DWEC had a fairly accurate idea of the number of survivors and the quality of their remaining leadership, so that they could judge how much further trouble they could expect from that branch, and the priority of effort they needed to devote to completing its destruction. The complexities of setting up such a registry, particularly in view of the bewildering variability of Chinese names, were considerable, but its value was immense. It would have been quite impossible unless all intelligence agencies had been subordinated to a single head. 52

Much of the work of compiling the registry and the Orders of Battle was done by Military Intelligence Qfficers (MIO), but they were all placed under command of the Head of Special Branch (HSTB) in each State, and of the Circle 53 Special Branch Officer (CSBO) where operations were in progress. 


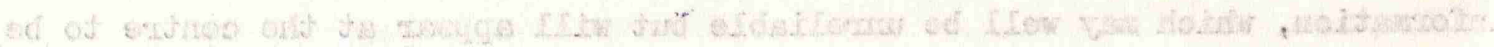

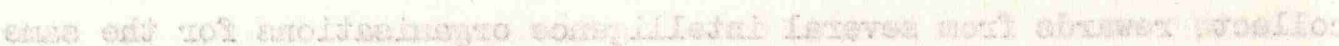

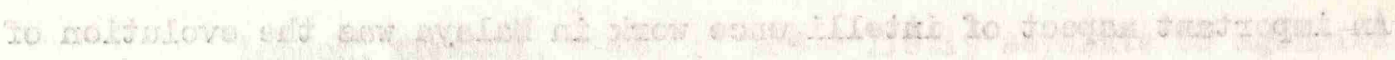

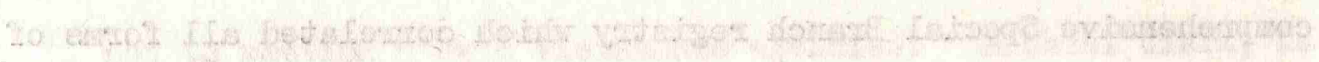

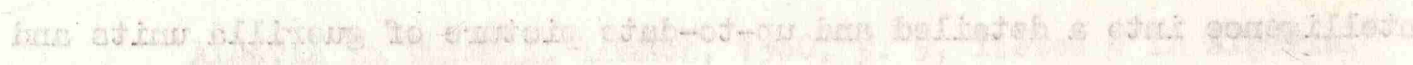

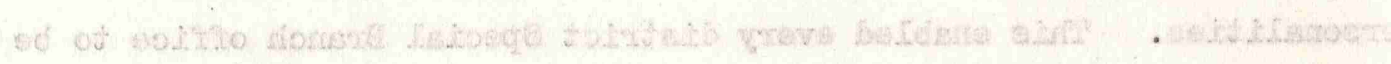

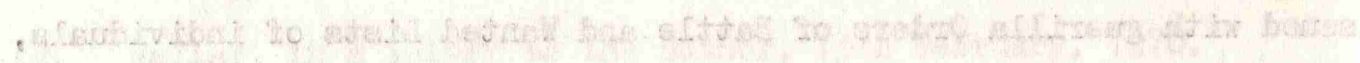

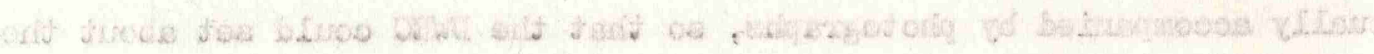

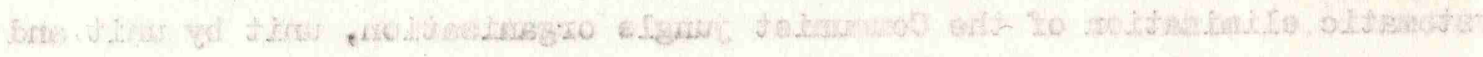

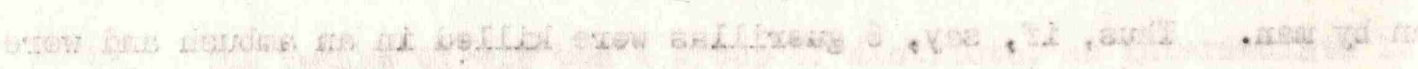

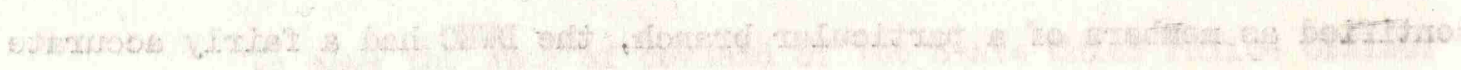

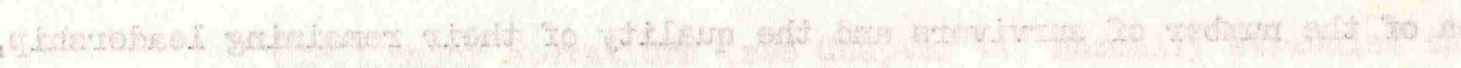

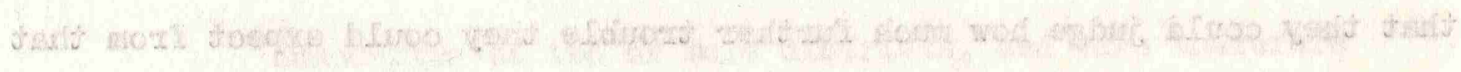

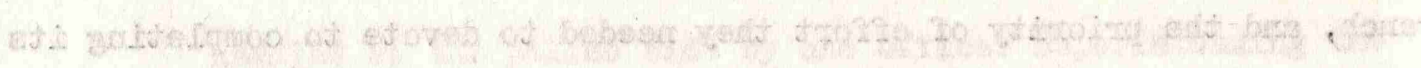

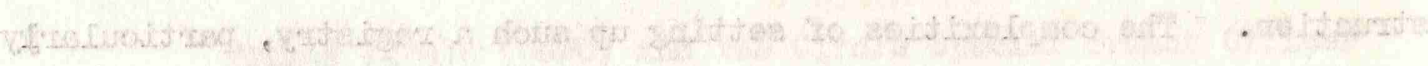
54. Waller, Notes p. 67-69.

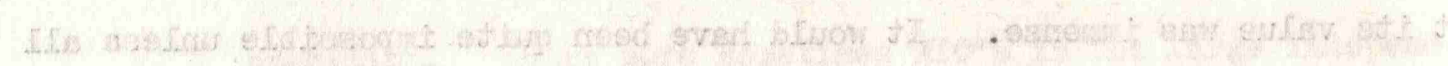

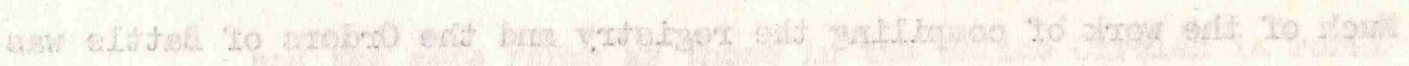

55. SEP Brains Trust, Interview 1966.

56. Waller, Interview 1970.

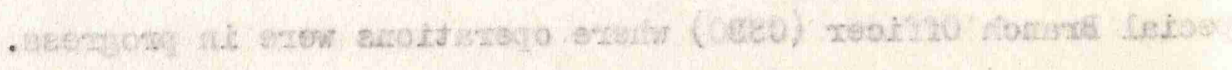


Intelligence information from all sources was fed into Special Branch, and all agents and informers were handled by them. MIOs collated and disseminated tactical intelligence in a form in which army units could use it, but they could only disseminate such information as the HSB or CSBO authorised. In particular, the identity of agents and informers was known to the minimum possible number of people.

The CSBO was normally a Deputy Superintendent of Police (DSP). equating roughly to an Army Major. A District level was an Assistant Superintendent of Police (ASP) with about two Inspectors who equated roughly to Army Warrant Officers. In 1950-51 most of the DSPs and ASPs were still British, though from 1955 onwards they were gradually replaced by Asians. The Inspectors were almost invariably Chinese or Indian, and handled most of the agents.

At the bottom level, there were one or two detectives (Chinese) in most New Villages. They lived in the security of the Village Police Post compound, and worked in civilian clothes. They were known by sight to most of the villagers, though, like their Communist opposite numbers, they made much use of cut-outs (e.g. shopkeepers, taxi-drivers etc.) to avoid compromising their informers. Though they seldom handled delicate intelligence projects, their presence gave confidence to favourably inclined villagers, and made it easier for them to give casual information, for which rewards were paid.

Sources of information included agents, informers, reports from patrols, air reconnaissance, captured documents, dead bodies, and captured and surrendered enemy personnel (CEP and SEP). 54

On occasions, Min Yuen executives were identified by parading the villagers past lorries from which SEPs and informers watched unseen through holes in the canopy. Such informers were particularly hated, and were killed without mercy if suspected by the Min Yuen. 55 Anonymous questionnaires were also used, but with limited results. ${ }^{56}$ Both of these methods were subject to abuse by malicious villagers who wished to settle old scores. 
57. "Ramathan" (SB) Interview 1966.

58. "Harris" (SB) Interview 1967.

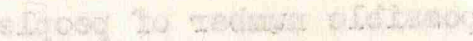

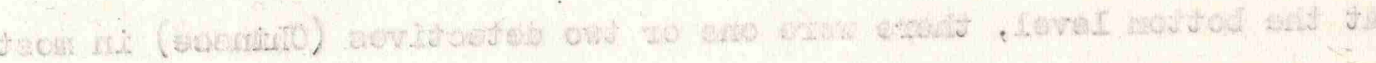

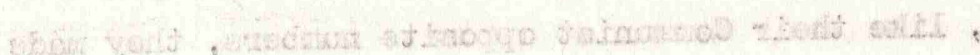

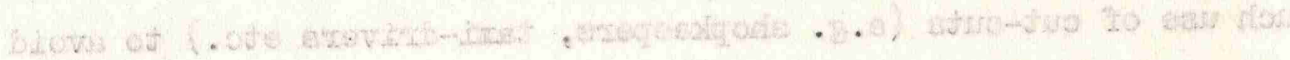

59. Waller, Interview 1970.

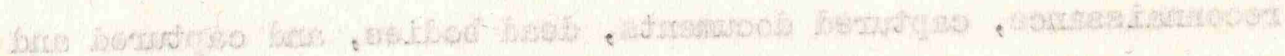

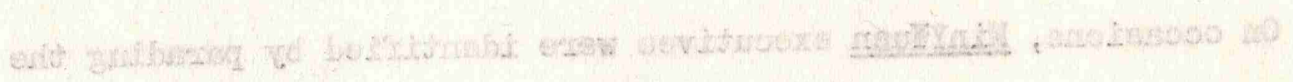

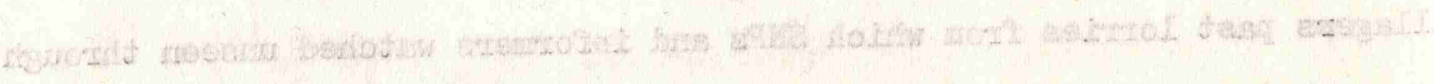

60. ibid. See also Chapter 10 and 13.

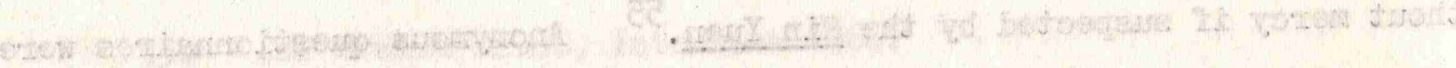

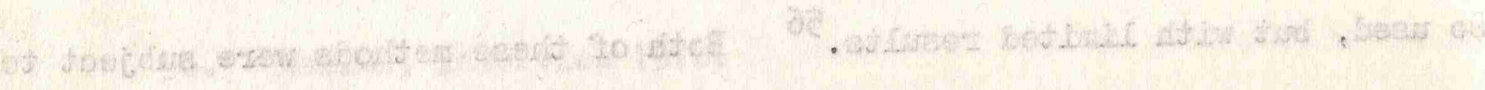


From the start, the aim of Special Branch was to penetrate the MCP organisation. This was seldom achieved on any substantial scale until later in the Emergency, ${ }^{57}$ when a sophisticated technique was developed for acquiring agents (see Chapters 11 and 12). Penetration was, however, easier to achieve in urban areas, and especially in small towns, where Special Branch sometimes had 2 out of 5 members of the MCP Town Committee, and often wrote the directives. 58 This, together with the relative ease of shadowing suspected individuals, was a partial explanation of the failure of the Communists to provide more effective support for the guerillas from the towns - particularly food supplies. Otherwise, this would have been very hard to stop due to the virtual impossibility of wiring and patrolling a long city perimeter, and of preventing the smuggling of food in the profusion of lorries, taxis and cars which emerged from it every day.

At the other end of the scale, the smallest villages, though expensive in manpower to defend, were the easiest for Special Branch activities, because people knew each other, and strangers were easier to spot.

The Malay constables could provide little intelligence as they had neither friends nor relations amongst the Chinese villagers. The Chinese Home Guards, however, were most valuable to Special Branch, both because of their local relationships and also because of the fact that government officials and police could speak to them in the course of duty without arousing suspicion. 59

The most difficult for Special Branch - and consequently the best Communist bases - were the larger villages, such as Yong Peng $(6,000)$, in Central Johore which is described in Chapter 10; also Kulai, in South Johore, and Sungei Siput in Perak. All of these maintained powerful MCP branches which were among the last to crack. 60

The MCP courier systems were particularly vulnerable to penetration by Special Branch, especially in 1950-52, when many messages between jungle units were carried·by "open" iㅡ Yuen couriers using public transport. Special Branch, in fact, often knew the contents of MCP orders and reports 
61. Wallex, Working Papers, p. 22。

62. "Ramathan" (SB) Interview 1960.

63. Guarding against corruption in the payment of these huge rewards engaged much attention from senior Special Branch officers. The dealings between an agent and the Special Branch inspector handling him were necessarily secret, undocumented and known to as few other officers as possible. The actual disbursement of rewards was done by State and Circle Special Branch Officers (at this time almost $100 \%$ British) but there was considerable opportunity for private deals to be done between the inspector and the recipient of the reward. If there were such cases, none came to light, and the successful prevention of this dangerous form of corruption was a creditable achievement. "Harrị" (SB) Interview 1967.

64. Fedẹral War Council, Minutes, 27th April, 1951.

65. Miller p. 101.

66. Federal War Council, Minutes, 9th July, 1951. 
before the guerilla units to whom they were addressed. 61

The best casual informers were often the shopkeepers, who could tell the Special Branch detectives the names of people who had bought extra food. The Army could then ambush the rubber lots in which these people worked, of ten with success. 62

\section{Rewards}

For casual information of value, the police were authorised to pay fairly small rewards - perhaps $\$ 50$ to $\$ 100$ (two weeks or a month's earnings)

- enough to encourage more, but not enough to make the risks of wholesale fraud worthwhile.

If, however, the information led directly to the killing or capture of a proven guerilla, the rewards were very generous indeed. 63

In 1951, the scale of rewards was as follows:- 64

Secretary General (Chin Peng).

State or Town Committee Secretary

$\$ 60,000$

" " " Member

District Committee Secretary

District Committee Member or MRIA

$$
\text { Company Commander }
$$

$$
10,000
$$

MRLA Platoon Commander

$$
6,000
$$

District Committee Member or MRLA

\section{Section Commander}

Cell Leader

5,000

Others

$$
3,000
$$

2,000

Later, these figures were doubled, and for some of the higher ranks quadrupled, ${ }^{65}$ and a $30 \%$ bonus added if the quarry was taken alive. There was, however, a serious grievance. The regular soldier and the policeman, since this was regarded as his normal duty, did not qualify for these rewards while the Home Guard, being technically a civilian, did. This was particularly awkward when they were together on operations - for example in a village perimeter ambush on the Home Guard information. 66 
67. Waller, Interview 1970.

68. See Lucian Pye, Guerilla Communism in Malaya, Princeton, 1956, p. 339. This book consists of an analysis of Interviewswith 60 SEPs in $1952-53$. 
There was no equitable solution, however, as the reward was not for the kill but for information leading to it, which seldom came into the hands of anyone not in or on the fringes of the Min Yuen - and certainly not of a British, Gurkha or Malay soldier or policeman. It would have been even more unfair, and indeed counter productive, to have denied the reward to a Chinese villager just because he had been conscripted into the Home Guard. The risks he took in betraying the Communists were the same as for any other Chinese villager.

The rationale for these fantastic rewards lay, of course, in this risk. In the early years, agents who took the risk were often moved to new districts or even new countries where they had to start a new life under a new name.

Surprisingly, however, many who had received this blood money subsequently came back to their own area with impunity, and later on they often did not even bother to move. 67

Surrendered Enemy Personnel (SEPs)

No less surprising was the behaviour of the Surrendered Enemy Personnel (SEPs). They were almost invariably ready to give information, and would often lead out an army patrol at once, and help to kill the men who had been their comrades in adversity for months or years, within hours of deserting them. 68 Some, showing courage as well as treachery, would reassure the night sentry by giving the password and advance as a friend, silently disable him, and then creep into the sleeping camp with an army or police patrol, pick out the leader and kill him as he slept before the turmoil of capturing or killing the rest began.

The treachery was sometimes compounded or delayed. In 1954, for example, a guerilla was wounded and captured. As he lay dying in hospital an SEP, who had been out for a year, questioned him and pinpointed the deep jungle camp of a Regional Committee Member (Ah Kwang) in the deep jungle. The SEP, who had previously been Ah Kwang's body guard, led out a patrol just before dusk, and surrounded the camp. The patrol killed Ah Kwang and his 5 companions as they sat eating a meal, for they had taken a chance on the 
69. "Fu" (SB) Interview 1967.

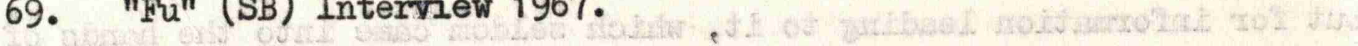

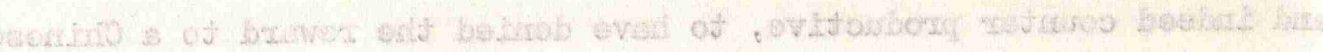

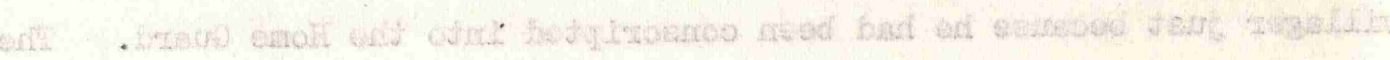

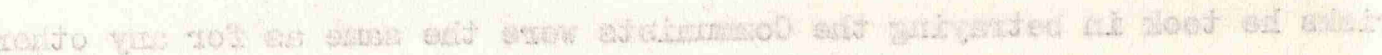

70. Chapman, p. 156.

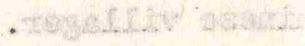

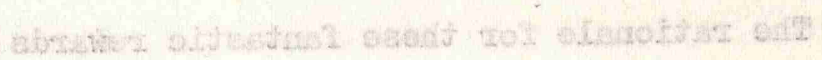

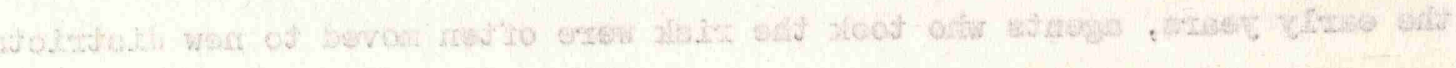

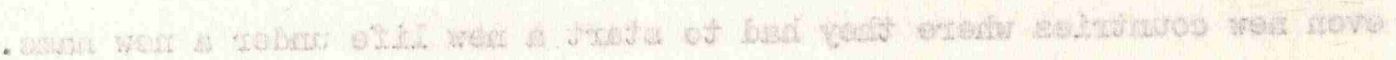

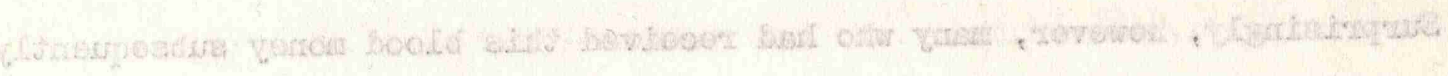

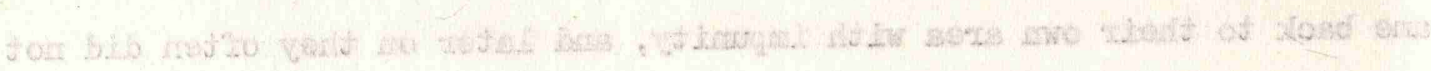

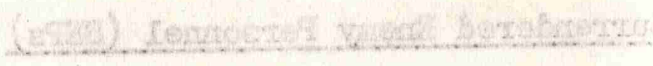

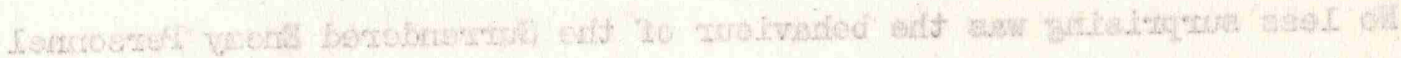

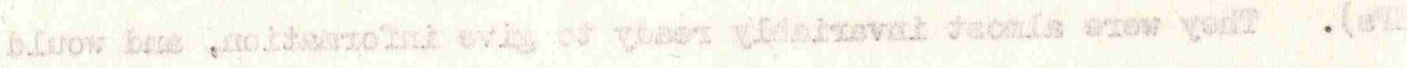

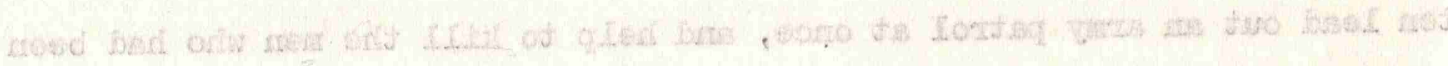

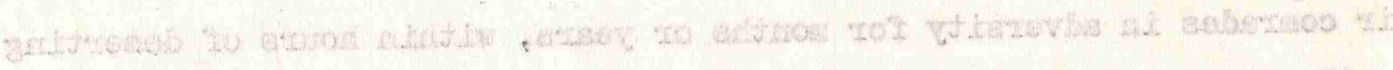

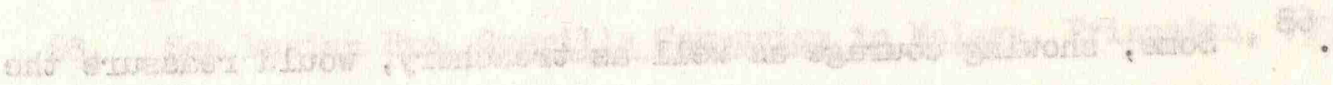

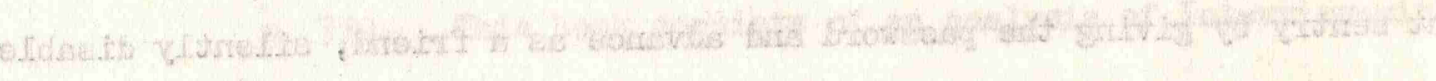

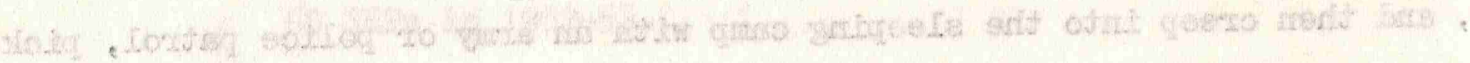

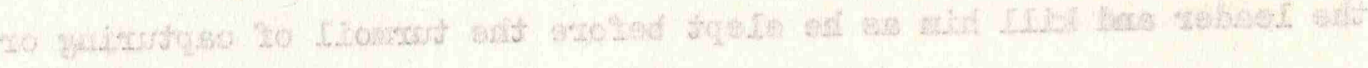

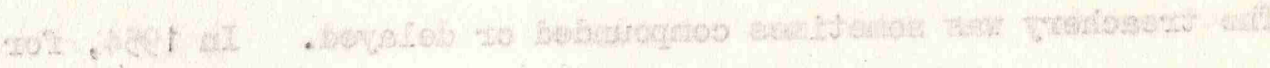

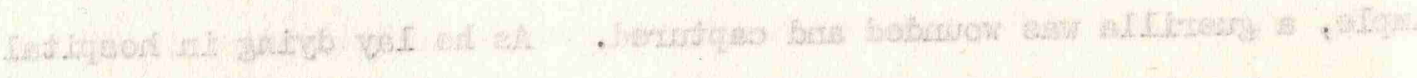
71. Blades, in his covering letter to comments on first draft,

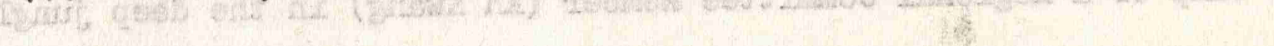

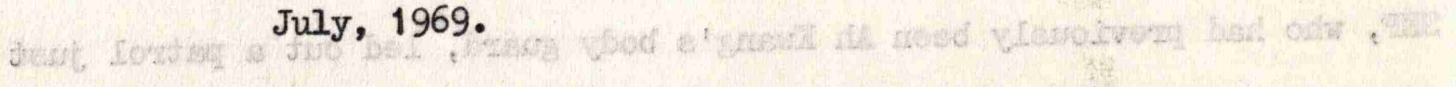

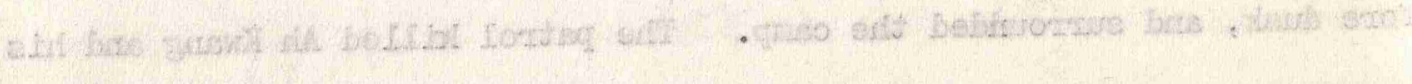


assumption that army patrols were almost always setting up camp for the night at this time, and they had put out no sentries. 69

More often, however, the SEPs would carry out their treachery within hours or days of surrender. British soldiers were constantly amazed by their coldblooded and savage duplicity. One explanation, undoubtedly, was a powerful capacity for pique. Whilst he was with the MCP guerillas during the Japanese occupation, Spencer Chapman observed that a Chinese would do anything, even at the expense of his own life, to get his own back on someone who had humiliated him. 70 The SEP realised that he would lose much face amongst his family and neighbours by having to admit his error in joining the Communists. During the months in which he was brooding on the question of whether to make the break, this prospect would engender a bitter hatred of the Party that had trapped him into this unbearable situation. This hatred would be focused on his immediate Communist boss - fanned by the awareness that this boss would show him no mercy if for one moment he suspected his thoughts of desertion.

At the same time, he perhaps feared that, so long as any of the men in his gang remgined alive, a chance encounter in a back alley, even in 10 or 20 years time, could prove more than embarrassing. He would sleep more soundly if they were dead.

Then, for a man faced with frighteningly uncertain prospects of employment in his new life outside, the reward was a real lure. An SEP qualified for only half rates, but nevertheless, if he were instrumental in the death or capture of his leader (say, a Branch Committee Secretary) and 4 or 5 others, he might expect a reward of up to $\$ 15,000$ - that is, more than 12 years normal working wage.

Another factor, pointed out by Alan Blades, is a positive need in the Chinese character to participate in secret activities. ${ }^{71}$

It usually took a potential SEP many months of heart searching before he made up his mind. Operational research carried out on a sample of SEPs in 
72. The sample was divided into three categories based on their attitude as recruits - A (convinced), B (hesițant) and C (reluctant). The findings were as follows:-

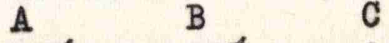
doubts arose within 6 months amongst $\quad 50 \% \quad 80 \% \quad 94 \%$ $50 \%$ decided to surrender within 2 yrs. 17 mths. 9 mths. Time to surrender after decision $-50 \% 15$ dys. 22 days 29 days. 100\% 6 mths. 6 mths. 12 mths.

HQ Malaya Operational Research Paper No. 10 of 1953.

75. Hor Lung and "Kek Yong" (Com) both did this, and were interviewed together with "Fu" (SB) in 1967. See Chapter 13, and see also Clutterbuck, The Long Long War pp. 168-9. This book contains a fuller account of the SEP phenomenon on pp. 101-111. See also Pye, passim.

74. Op GINGER, Military Diebriefing. 
1953 revealed that even those who had joined hesitantly and had soon felt doubts took an average of more than a year to deoide to surrender. . The weakest characters - i.e. those who had been most reluctant to join or coerced into joining - were, not surprisingly, the quickest to decide to surrender but, having made the decision, the most hesitant in carrying it out。 72

Not all SEPs were traitors. Some simply surrendered and returned to civil life, after a period of rehabilitation, having betrayed no one. Others - especially senior ones late in the Emergency - came out realising that the war was lost and with the humane intention of bringing out their scattered commands with the minimum loss of life. Some cooperated with Special Branch over a period of several months, keeping their own defection strictly secret, and going out to lead in their branches and platoons, one by one. They found them by appearing in full uniform at their courier meeting point on the appropriate day (which only they and the courier knew) and getting the courier to lead them to the guerillas, whom they then persuaded to come out with them. They faced considerable risks, which increased with each unit they visited, but they earned huge rewards. ${ }^{73}$

Surrenders were sometimes induced or negotiated. In Perak, for example, Special Branch identified and contacted an open courier and through him sent a message to a Branch Committee member to meet a senior Communist at a rendezvous. The BCI came, and was captured, with two couriers. The two couriers were sent back to fetch a DCM, who surrendered and told of a forthcoming meeting due with two others. Special Branch awaited these two in due course, and, in all, four ranking Committee members and 10 other guerillas were captured or surrendered. ${ }^{74}$

As with agents, fears of retribution - even of those who had helped to kill their ex-comrades - proved unfounded. Many SEPs live openly and without fear in Malaya to this day. One, for example, earned nearly \$250,000 in rewards and is a prosperous business man. Another, earning $\$ 50,000$, used it to buy a small rubber estate, on which his four employees are also SEPs. 
75. Hor Iung and "Km Cheng" (Com) and "Fu" (SB) Interviews 1967.

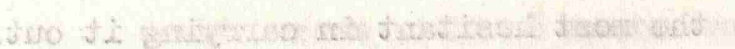

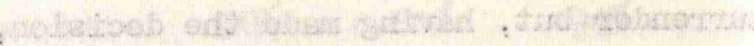

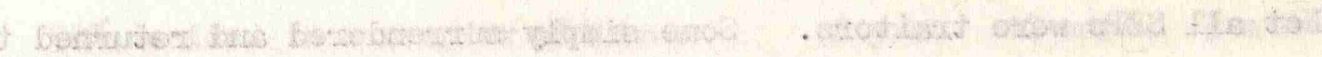

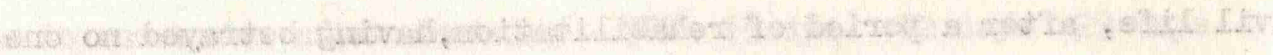

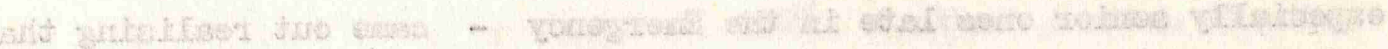

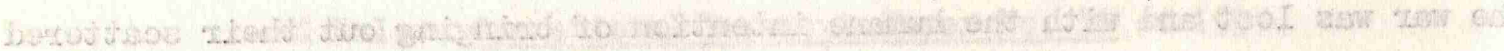

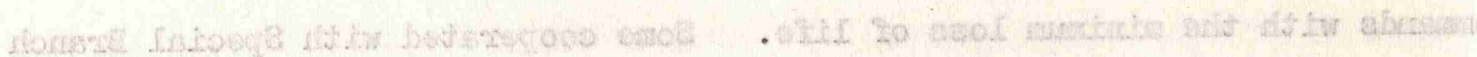

76. Director of Operations Tactical Directive No. 1, 6th October, .1950.

77. Based on Director of Operations, Review, 1957, Appendix B,

78. See, for example, Director of Operations Report on the Emergency Situation 1 st December, 1950.

79. Director of Operations, Directive No. 15, 7th August, 1951. 
None seem to be sensitive about their past, and they live happily with their families in houses on the estate. ${ }^{75}$

Another New Communist Directive - October 1951

It was in the latter part of 1950 that government fortunes began to turn, as resettlement got into its stride and the intelligence activities of the new Special Branch began to take effect. Government tactics also changed. From October 1950, all operations were directed towards the security of the villages and of the places where the people worked. The task of the police was to protect the population and break up the Communist cadres amongst them (the Masses Executive of the Min Yuen). The army was to dominate the jungle fringe, and not to be drawn away into operations in the deep jungle. 76

The effect of these measures is shown in Figure 9c. 77 During 1950 and 1951, fighting on and around the jungle fringe reached the peak of its violence but, while the Security Force casualties remained much the same, their monthly rate of contact with the guerillas was doubled between mid 1950 and early 1951, and the number of guerillas killed each month was doubled too. By August 1951, the previously gloomy tons of government assessments of the situation ${ }^{78}$ had been replaced by much greater confidence, and a growing number of guerillas were being killed on the jungle fringe and in the estates as a result of information from the people. ${ }^{79}$

Discouraged by their waning popalar support and alarmed by their casualties, the MCP Central Committee issued a Directive in October 1951 which radically changed the focus of their compaign. They realised what Siew Lau had pointed out two years earlier - that terror and economic disruption were alienating the people, whose support was essential if they were to win the war. They therefore ordered members to stop destroying rubber trees, tin mines, factories, reservoirs and other public services, derailing civilian trains and burning New Villages. Certain people should still be killed, such as reactionaries, traitors, unpopular nonCommunist Trade Union leaders, senior civil servants, police officers, any 
80. Malayan Communist Party Directive of 1st October, 1951 English translation published in the London Times on 1st

. December, 1952.

81. Miller, p. 225 .

82. His escort had been left behind due to a breakdown. The MRLA platoon diary, captured later, gives no indication that they were awaiting him, or that they knew who he was afterwards. They were on a mountainous road used by many VIP cars, and they seized the chance when one approached unescorted. Miller, p. 225.

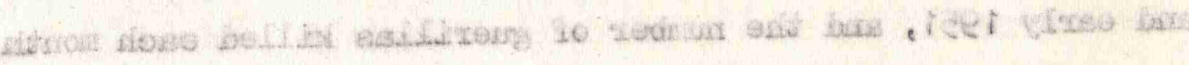

83. Waller, Interview 1968.

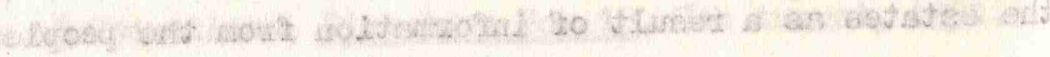

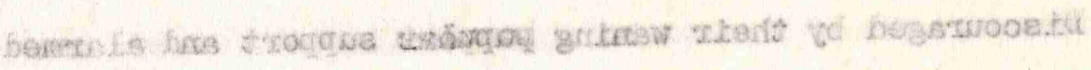

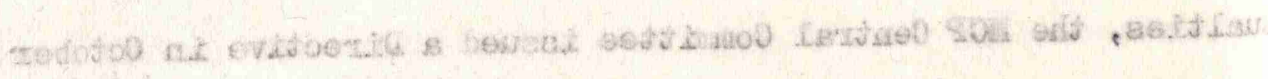

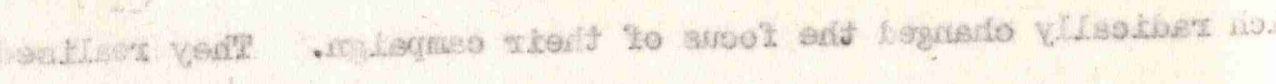

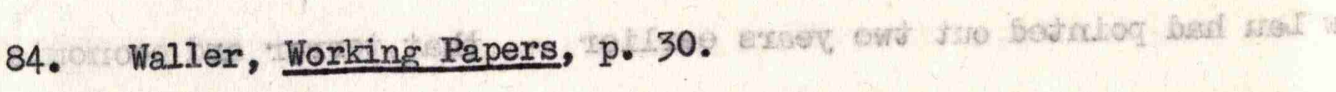
85. ibid, p. 29 .

86. Sir Robert Thompson, in Defeating Communist Insurgeney p. 52-55, stresses the importance of all government officials, police and soldiers acting within the law, and says that the public will accept the most ruthless action provided that it is covered by published law. 
captured British or Gurkha soldiers, and British officials and managers (but not British health officers or engineers). They were however, to beware of injuring the masses with grenades and stray bullets and to avoid all violent actions of a kind which antagonised peasants and workers. 80

Because of disruption of the MCP courier system, this directive took many months - in some cases up to a year - to reach the outlying branches on the jungle fringe. 81 It was ironical that on 6th October, 1951, within a week of its being issued, the MRLA achieved its greatest aggressive triumph - the ambushing and killing of the British High Commissioner, Sir Henry Gurney. The fact that he was the victim was almost certainly a piece of luck. 82

The ambush had a double irony. It gave the impression of a peak of guerilla aggressiveness just as the MCP had decided to abandon terror as its prime weapon (though a senior government official remained fair game even under the new Directive). It also accelerated the Party's defeat by jerking both the Federation and British governments into taking more drastic action, and shocked the public, including the rural Chinese, into accepting such action as inevitable. 83

\section{Sir Gerald Templer}

The British Goverment's answer - in February 1952 - was to despatch General Sir Gerald Templer as combined High Commissioner, $\mathrm{C}$ in $\mathrm{C}$ and Director of Operations, with far wider powers than those granted to Gurney or Briggs. For the first time, the prosecution of the war and the running of the country became a single process under a single head. ${ }^{84}$ Briggs had already left, exhausted, and died within a few months, and the Commissioner of Police was replaced by Colonel A.E. (now Sir Arthur) Young as Templer took over. 85

Templer had full powers and used them. He also had the machinery to amend the Emergency Regulations if they proved inadequate. 86 In fact, however, he accepted the Briggs Plan and implemented it with fresh vigour and determination. During his two years of office (1952-54) two thirds of the guerillas were wiped out, the incident rate fell from 500 to less than 100 


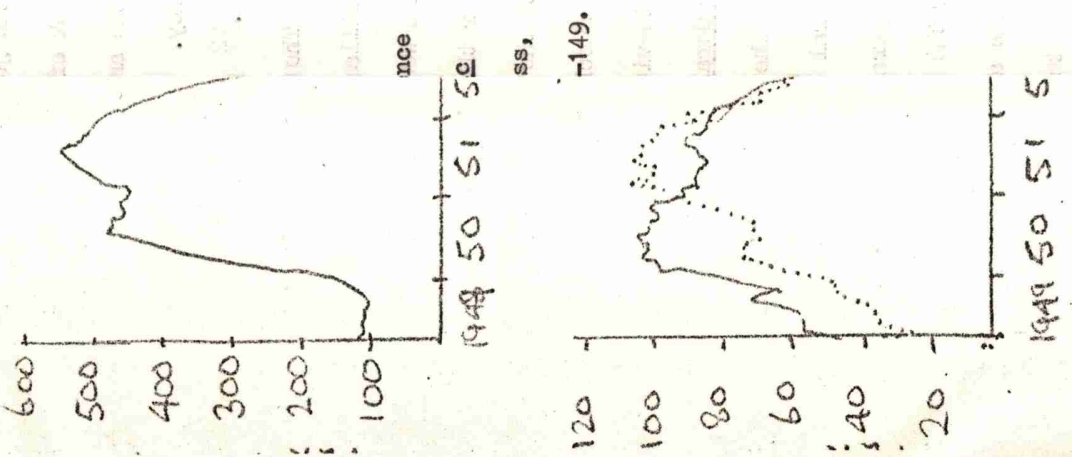

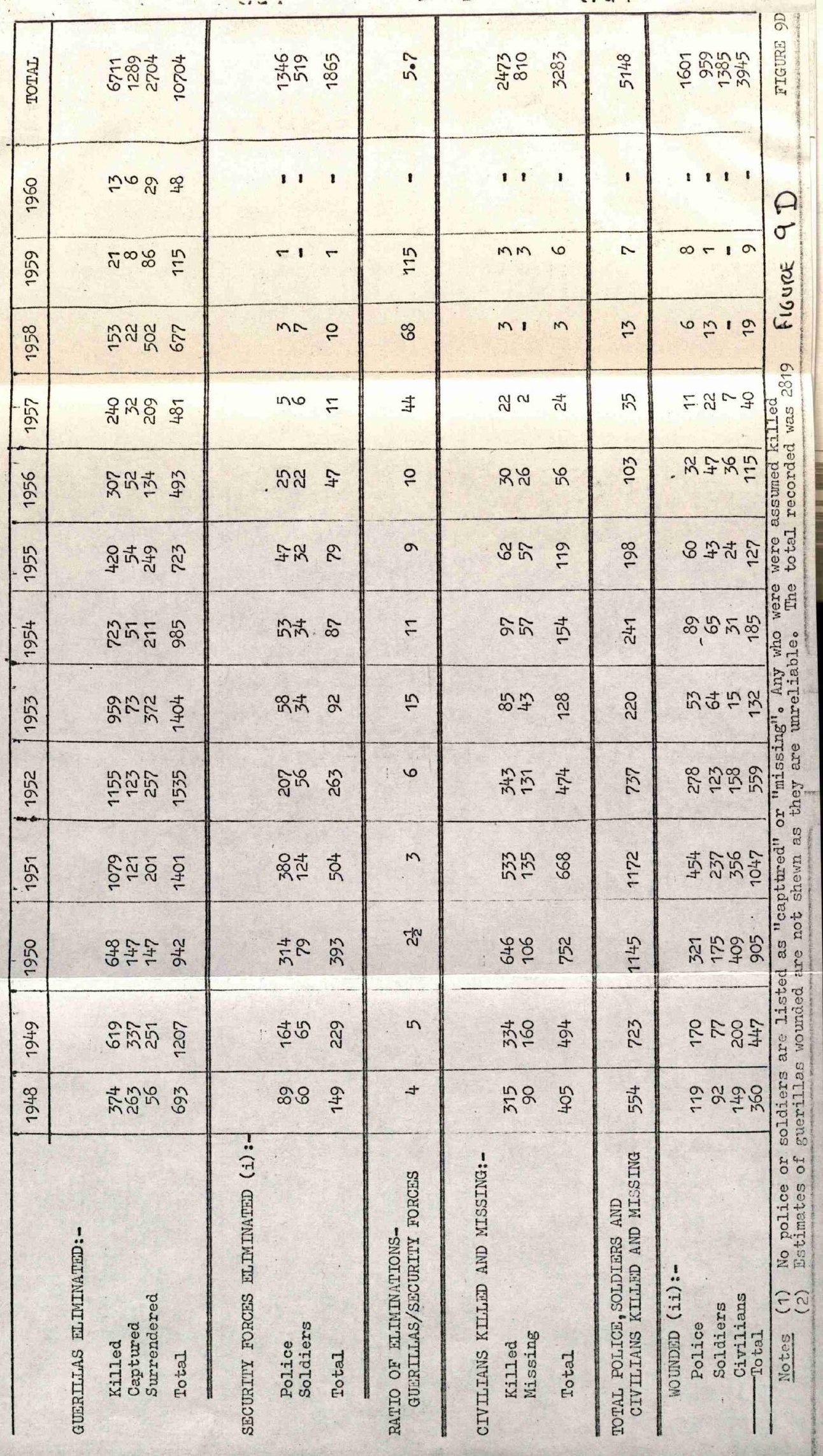


per month, and the civilian and security force casualties from 200 to less than 40. See Figures $9 \mathrm{C}$ and $9 \mathrm{D}$. $^{87}$

This aspect of Templer's dynamism and leadership is well known and well reported. His other achievements, however, were no less important - notably a major advance in self-government at every level from Kuala Lumpur down to the villages, and outstanding progress in rural development, both of which played a big part in winning the support of the people. By the time Templer left, most villages had elected Village Councils, and the strong multi-racial Alliance Party under Tunku Abdul Rahman had emerged as the leading political party, with a firm guarantee of self-government to come. In 1955 the Tunku was to be elected to power with a majority of 51 out of 52 seats, and has to date been re-elected three times. Though currently (1969) the Federation is having political and racial troubles, it has in fact been one of the stablest countries in South East Asia in the 15 years since the Tunku was elected. 88 Village Government

In Malaya, unlike Vietnam, there had been a fabric of government from the centre to the villages for a very long time. This had been ruefully admitted by the MCP in its first directive in December 1948:

"The British have already created a totalitarian, complete, penetrating system of administration, from the Federal Government down to small towns and Malay Kampongs... We have nothing like Federal provincialism to exploit... nor'is there any weak link in the enemy's administrative system for us to exploit ...our hope of wiping out the enemy's rule in a certain region and thereby setting up a permanent base still faces many objective difficulties and obstacles" 19

By contrast, Sir Robert Thompson, speaking in 1966 on Vietnam, said "The real problem with South Vietnam has been to have a Government at all, whether democratic or not. It does not matter to me very much what the political top is. If there is 'no 
90. Sir Robert Thompson, in a talk to the Royal Commonwealth Society in London on 8th November, 1966, reported in The Commonwealth Journal, February 1967, p. 14.

91. "Tong" (Assistant Resettlement Officer) Interview 1966.

92. Sandhu, p. 168 .

93. "Tong" (ARO), Michael Gorrie (DO) and "Fu" (SB) Interviews 1966 and 1967. This again contrasts with Vietnam, where underpaid local officials had to collect taxes and register men for drafting, and were often suspected of corruption, so their assassination by the Vietcong was frequent and often popular. See Browne pp. 103-4.

94. O'Ballance, pp. 119 and 129.

95. Thompson, Defeating Communist Insurgency, p. 135.

96. Viller, p. 218.

97. ibid. 
machinery underneath it to carry out a single instruction of the government, a government is not going to get very far, whatever aims and high ideals it may have." 90

There was, however, no fabric of government amongst the 400,000 Chinese squatters in 1948-49. After resettlement in 1950/51, Village Committees were appointed by the British District Officer (DO) in consultation with community leaders. After Templer's arrival, the government passed the Local Council Ordinance (1952), under which, when the DO was satisfied that they were ready, Council Areas were gazetted in which villages elected their own Village Councils by adult suffrage. 91 These Councils collected rates and licence fees, supplemented by government grants, for specific facilities such as dispensaries, schools and community halls. ${ }^{92}$ They collected no general taxes, and enlightened DOs ensured that they were seen to achieve a. fail number of successes on the people's behalf. As a result, few were murdered, as the MCP realised that this would react against them 93 .

The first Village Councils were elected in May 1952 and by March 1953 one third of the Chinese New Villages had elected Councils. ${ }^{94}$

In the competition for "The hearts and minds of the people", crystallized in the MCP October 1951 Directive and Templer's campaign in the villages, the government had one overwhelming advantage: they were able to offer engineering improvements such as roads, water and electricity which the guerillas could never match. 95 In a White Paper, Templer said that

"The foundations of a better life in the New Villages will be not only freedom from fear but also water supplies and satitation, schools and dispensaries, the growth of civic sensibility and pride in communal as well as individual achievements." 96

A government official was reported as saying "The degree of cooperation we get from a village is in almost exact proportion to what we have put into it." 97 
98. "Security in development; without development there can be no security" Robert S. MeNamara, The Essence of Security, London 1968.

99. Templer's achievement was all the greater because the price of rubber - inflated by the Korean War during the critical years of resettlement - fell from an average of 169 cents per lb in 1951 to 67 cents in 1953. Ooi Jin Bee, p. 206.

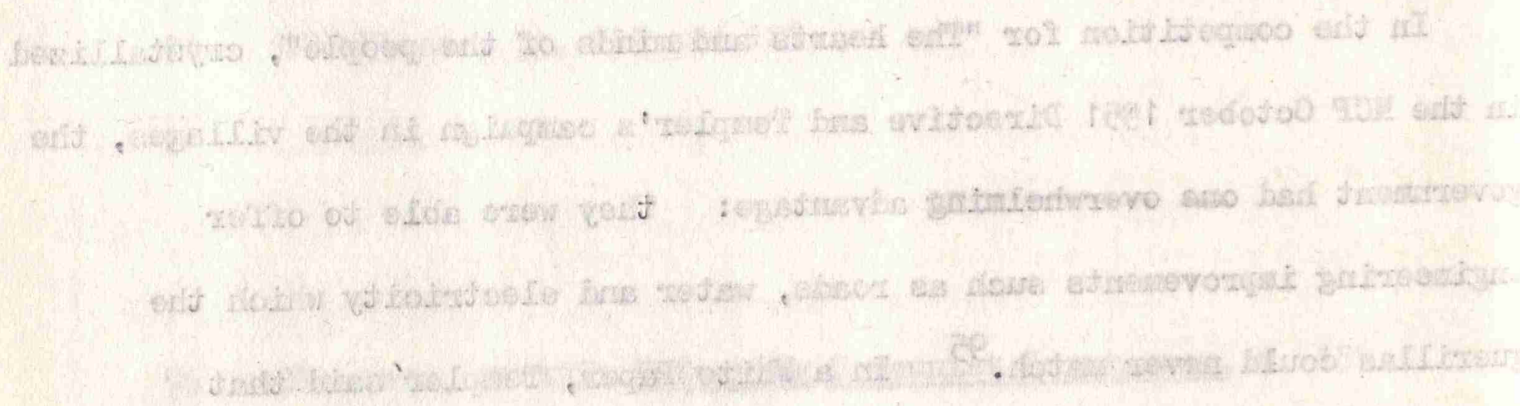

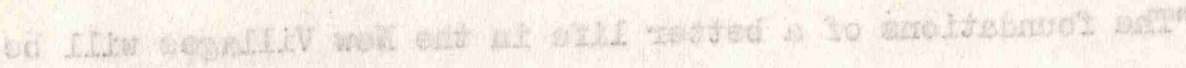

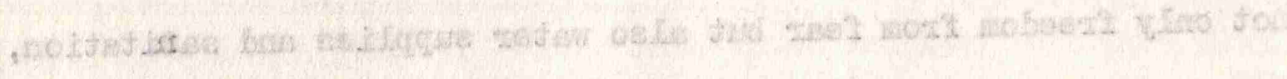

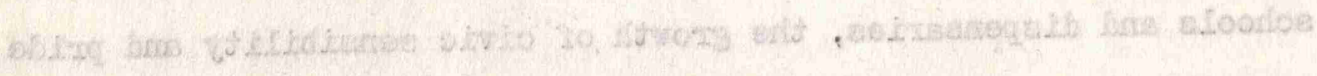

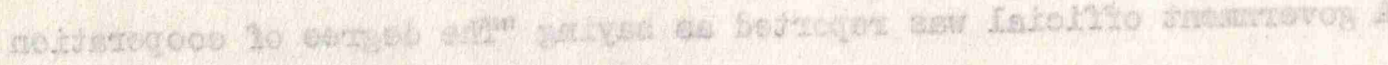

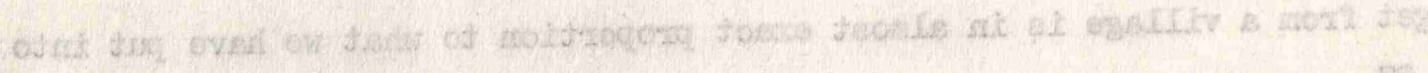

100. Director of Operations, Review, 1957, p. 16. 


\section{Psychological Warfare and the Information Services}

The battle for the hearts and minds of the people was won by Templer and his successors, and by Tunku Abdul Rahman, not so much by propaganda as by visible progress in security and development, which led to confidence and contentment in the prospect of a government vidtory and of the end of strife. Most important was security inside the villages by night which depended on the integrity of the village police post, and the patrolling of the village streets by the policemen while the people slept. Coupled with this security was development. 98 The development of opportunities for education and higher earnings, 99 of housing, water supply and electricity, and of a village government to further these things and to redress grievances.

Nevertheless, these alone would not have succeeded without good Information Services to tell the public what was happening, and by a good Psychological Warfare Service to tell the guerillas too, and to underinine their morale.

These two activities were divided for most of the Malayan Mmergency, but initially a service to cover both functions was formed in June 1950 under Hugh Carleton Greene, (who later became Director-General of the BBC). Initially it was part of the staff of the newly created Director of Operations, but in October 1952, as part of Templer's policy of integrating the war with the routine functioning of the government, it was placed under the Director-General of Information Services. In March 1954 the Psychological Warfare Section was separated, under that title, and .transferred back to the Director of Operations Staff, which was located at Federal Police HQ. Here it remained until the end of the Emergency. From 1954 .onwards, therefore, Psychological Warfare was conducted in close collaboration with the police Special Branch. 100

Carleton Greene, who stayed only until September 1951 to get the Service into its stride, drew attention to its shortcomings in a report on his departure. He said that there had been too much exhortation and not enough 


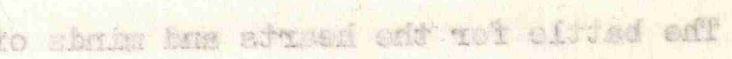

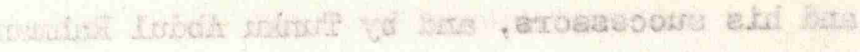

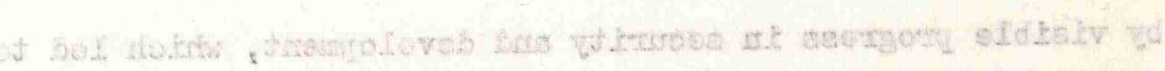

101. H. Carleton Greene, Report on the Information Services from September 1950 to September 1951, Kuala Lumpur 1951. september 1950. Se Septemer

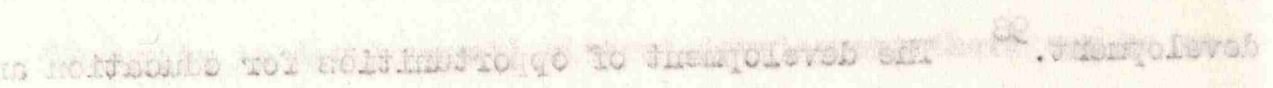

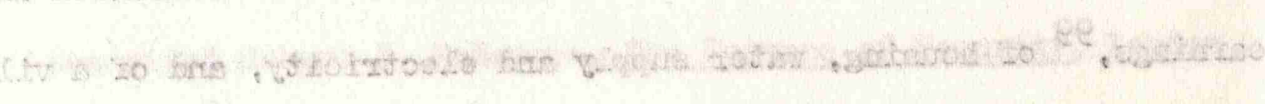

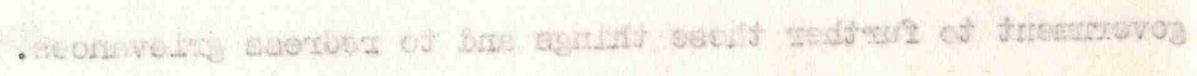

102. Joint Intelligence Advisory Committee Report 24th October, 1950. Lam Swee (Com) said much the same in an interview in 1967.

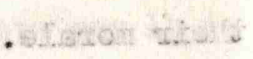

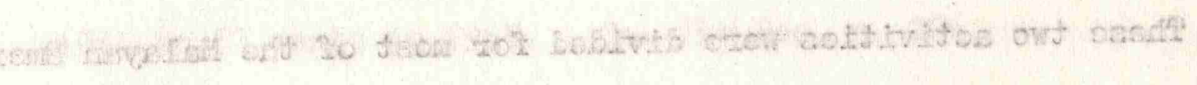

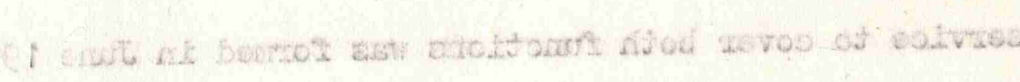

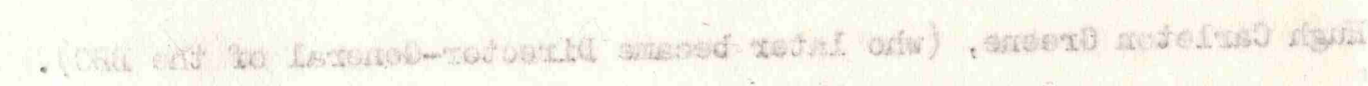

103. Thompson, Defeating Communist Insurgency, pp. 60-68. .errolistis

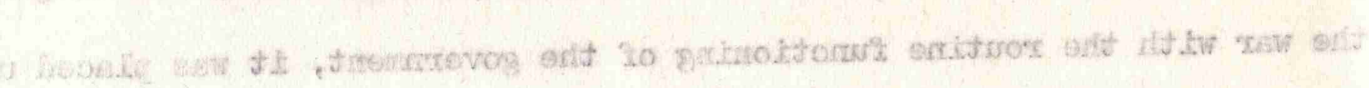

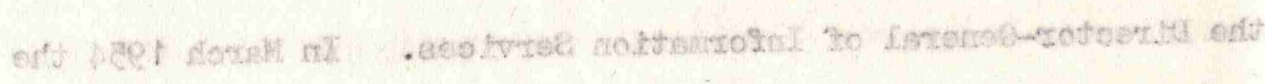

104. O'Ballance, p. 119.

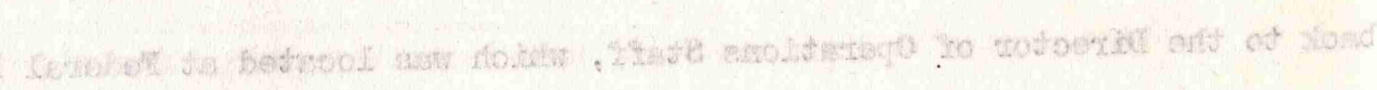

105. Sandhu, p. 180.

106. Waller, Interview, 1967. Ud .

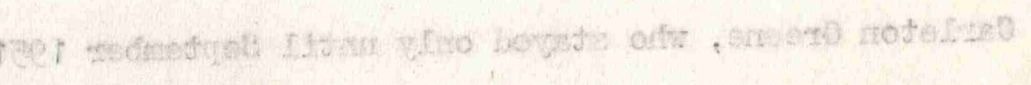

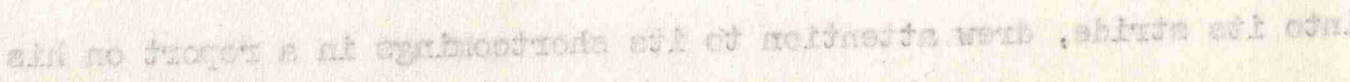


detailed factual information; that it had been a mistake to highlight Communist terrorism, as this made the people more frightened of it and therefore more ready to succumb to the threat; there had been too little exploitation of enemy weaknesses and not enough use of SEPs. He concluded (rightly, as it proved) that the strongest weapons in the hands of the government were SEPs and rewards. 101

His criticisms were reinforced by the Joint Intelligence Advisory Committee, which reported that propaganda had as yet had no real effect either on guerilla morale or on public morale in the Communist-infested areas, and that it was unlikely to do so until there was a clear, precise and convincing surrender policy, and until resettlement had been completed, giving people better security. At present they were impressed by guns rather than words. 102

When Templer had arrived, he had underlined the links between the attitude of the soldiers and police ("Operation Service"), propaganda and rural development. Unless the government forces acted decently and within the law, "civic action" was "eyewash". As later expressed by Sir Robert Thompison, one of the strongest government cards was to draw attention to the contrast between the Communists "Illegality, Destruction and Promises" and the Government's "Legality; Construction and Results". 103

In September 1952, Templer brought citizenship rights to 1,200,000 Chinese and 180,000 Indians by legislation to confer federal citizenship on anyone borm in the Federation. 104

This, coupled with the concentration of money on providing amenities for the Chinese New Villages, ${ }^{105}$ led to accusations that Templer was pro-Chinese. 106 Indignant Malays, and some of the British officials who supported them, complained that priority for development was being given to ex-squatters who had been supporting a vicious rebellion, whereas the Malay Kampong dwellers who had loyally supported the government, were left to struggle on at subsistence level. There was, of course, much truth in this allegation, but 
107. An attempt was made in August 1950 to counter Malay resentment against the spending of money on the Chinese, by setting up the Rural and Industrial Development Authority (RIDA), designed to develop rural areas, particularly for the Malay farmers. In his Report on RIDA (Kuala Lumpur, Government Printing Office, 1957) D.E.M. Fiennes criticised the three watertight compartments into which the rural community was divided - plantations, Chinese smallholders and Malay farmers. He said that almost every educated Malay went into government service, and virtually none into organising the development of the productive economy of the Malay people. For this reason, RIDA achieved little success. After the Emergency ended (1960) priority for expenditure on rural development was, not unreasonably, given to the Malays. This is now (1969) being used by anti-government propagandists against the Malay dominated Alliance government. Arguments will inevitably continue, no matter how the money is spent, but the pendulum has swung rather much to extremes, and it would be healthier if it could settle nearer the middle. Waller, Interview 1970.

108. Bmergency Chinese Advisory Committee, Minutes, 5th April, 1949. This Committee was called together by the government on that date to help to alleviate this dilemma. 'It consisted of 23 prominent Chinese, 14 of whom were magistrates. At this first meeting, the Committee recommended an amnesty for businessmen who paid "protection money under duress and then reported it." This Committee also acted as a channel whereby the small Chinese businessman could get redress if faced with corruption which, they said, was "rife in the lower ranks of the police".

109. Waller, Notes, p. 52.

110. Clutterbuck, The Long Long War, pp. 59-60.

111. Operation GINGER, Notes by Mr P.B.G. Waller.

112. R.J.W. Craig, A Short Account of the Malayan Emergency,

(Typescript held by the author). 
such a policy was essential if the war was to be won quickly, which in the long run was the most important of all things to the Malays. 107

Other communities also felt that they had reason for complaint against the impact of the Emergency on their communities. The dilemma of Chinese businessmen, smallhollers and shopkeepers; subject to extortion of protection money, death if they refused to pay it and imprisonment if they did, was a difficult one. 108 The Indian community had religious problems: rubber planters and tin-miners had views about curfew times. In order to explain and discuss these problems and, where possible, to resolve them and secure better cooperation, community leaders were invited to become unofficial members of the SWECs and DWECs - up to a maximum of 6 on each SWEC and normally 3 on each DWEC. The State and District Information Officers also attended. 109 These "unofficials" and the Information Officer only attended the full SWEC and DWEC meetings, i.e. once every week or fortnight, and not the day to day "Operations SWEC/DWEC" and they were not given access to the more secret papers and directives, but their participation in the full meetings undoubtedly did much to improve cooperation by the public. ${ }^{110}$

In addition to this participation of community leaders in policy-making, they were regularly briefed on the progress of the war and so were. Village Council and Committee Members, local politicians, planters, mịners, selected trade union leaders and headmen. ${ }^{111}$

Good Citizens' Committees were formed, which held public rallies to denounce Communism and even - on occasions - led the entire population of villages to the jungle fringe to shout "surrender" to the supposed guerillas inside. 112

This probably had little effect on the guerillas or on their hardcore supporters, but it did have an influence on public opinion as a whole.

The methods of propagation of information were developed as the Emergency progressed, and described in more detail in Chapter 12, which also gives examples of the "Talking Points" which were found by experience to 
113. Thompson, Defeating Communist Insurgency, pp. 94-97.

114. "Harris" (SB) Interview 1968.

115. See Chapter 13 and Thompson, Defeating Communist Insurgency, p. 100 . 
be effective for use by Information Officers in discussions with New Villagers.

The government recognised that polemics and exaggerated reports of successes did not pay. It was essential for the Government Information Service to establish a reputation for truth. It was better not to conceal mistakes, but to admit them and announce the remedy. They also took care not to promote hatred - especially between the Malay police and the Chinese villagers. They realised that it would be necessary to live with the after effects of their propaganda. ${ }^{113}$

As the Emergency progressed, the Press was taken more and more into the confidence of the government. For example, Harry Miller, of the Straits Times, was kept fully briefed by the Director of Operations, and by the Police in Kuala Lumpur, and was also given every facility in visiting Special Branch Officers and troops on the ground. ${ }^{114}$ Later, the editors of all newspapers were briefed regularly on major operations, with time embargoes, or requests to respect their secrecy for an indefinite period. This policy proved itself in some very delicate Special Branch projects with far reaching results, when the editors of all leading papers in all languages were taken into the government's confidence for several months, and the secret was never betrayed. $^{115}$

Within a few months of its formation, Carleton Greene's Emergency Information Service was joined by a senior Communist defector, Lam Swee, as described earlier in this chapter. Shortly afterwards (in February 1951), a brilliant young Chinese graduate of Raffles College, C.C. Too, was appointed to the staff as Chinese Assistant. He later became head of the Psychological Warfare Section.

From these early months onwards, psychological warfare leaflets, broadcasts etc., were composed by Chinese, who had either been in the jungle themselves or had worked closely with others who had. The propaganda was practical rather than ideological. General promises of good treatment after surrender proved less effective than accounts by SEPs of what had actually 
116. Carleton Greene, Report.

117. Thompson, Defeating Communist Insurgency, p. 93.

118. Carleton Greene Report, and C.C. Too (Gov) Interview 1967.

119. O'Ballance, p. 105.

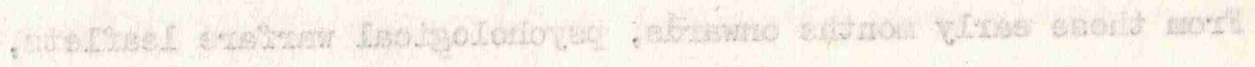

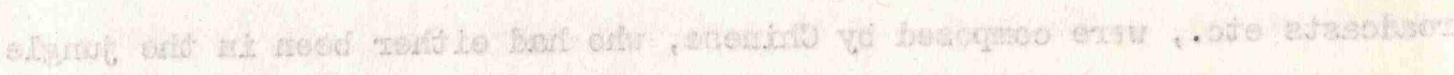

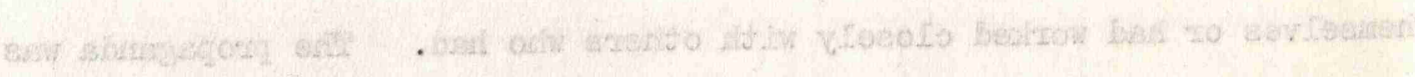

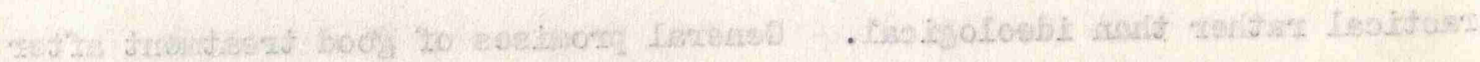

120. Miller, p. 223. Also Waller, Interview 1970. 
happened to them. These were where possible given personally in public in villages where the SEP was known by the Min Yuen, or printed in the SEP's handwriting on leaflets bearing his photograph. These included recent photographs of SEPs who had surrendered some time ago, to show that they had not been maltreated or killed. ${ }^{116}$

Sir Robert Thompson has suggested that surrendered or captured guerillas should be treated according to a categorisation. Some were harmless but useless and should be sent home. Others were of immediate use to Special Branch. Of those captured unwillingly, some would be worth attempting to rehabilitate, while others were recalcitrant and (if they had been captured and not surrendered) should be tried for their crimes. 117

The Psychological Warfare Section had to decide which of those still in the jungle were worth trying to suborn, and which were to be discredited by "smearing". Black propaganda - i.e. statements purporting to come from MCP leaders, and which were calculated to rebound against them - was also used. $^{118}$

C.C. Too and his staff worked very closely with Special Branch. They spent many hours studying captured documents and letters, which both guided their propaganda and gave valuable intelligence clues.

The success of the Psychological Warfare campaign can be judged by the fact that the MCP later imposed a death penalty for reading government leaflets. ${ }^{119}$

\section{White Areas}

In the Autumn of 1953, Templer tried a bold experiment in Malacca, where Special Branch were satisfied that MRLA was ineffective and the MCP organisation had been disrupted over a number of districts. These districts were declared a "White Area", and virtually all Bmergency Restrictions were lifted other than the continued registration of the population. A generous rice ration was allowed and shops remained open day and night. The tappers could take a mid-day meal with them to work. There were no curfews, and there was free movement of people and goods. ${ }^{120}$ 


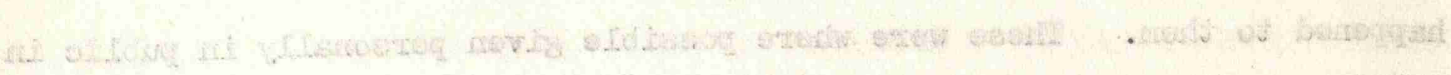

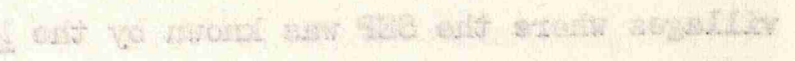

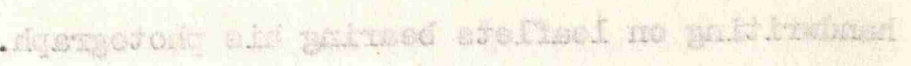

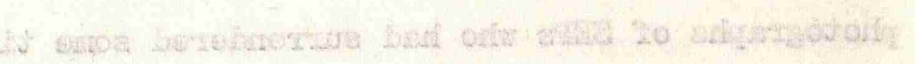
at

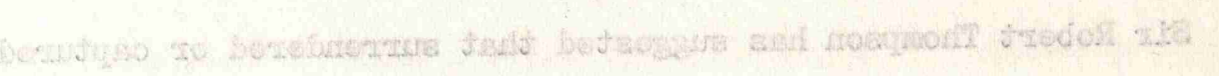

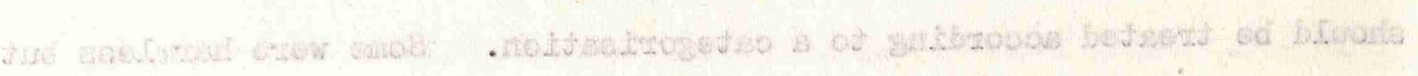

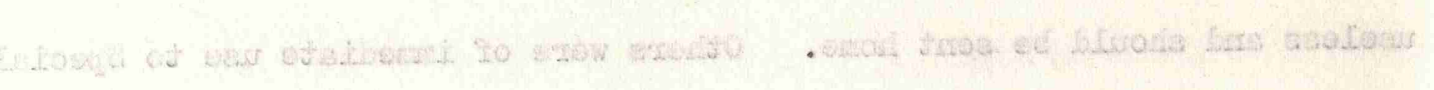

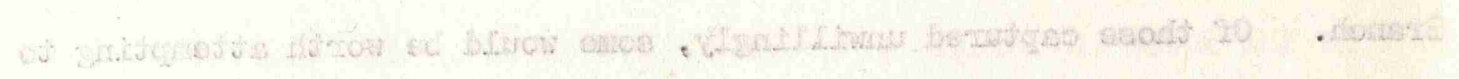

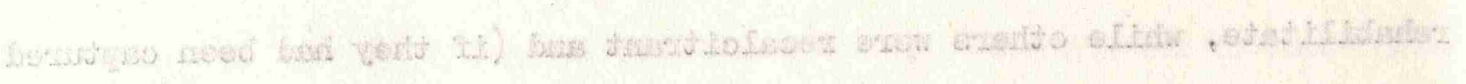

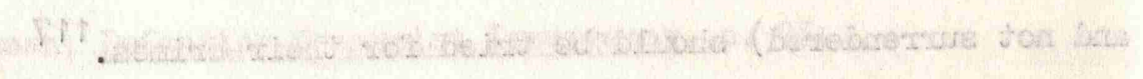

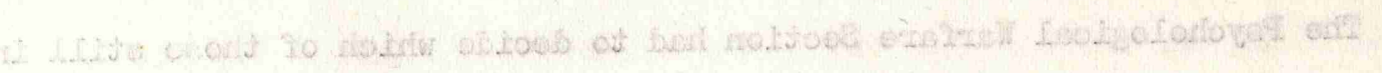

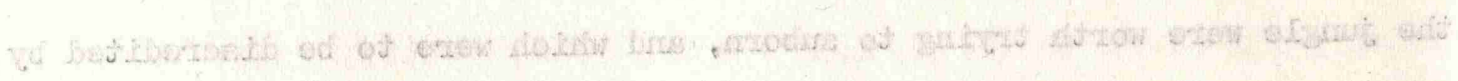

121. Clutterbuck, The Long Long.War, p. 131.

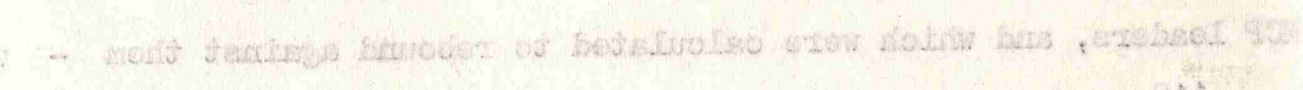
ait

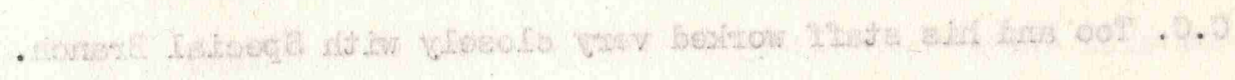

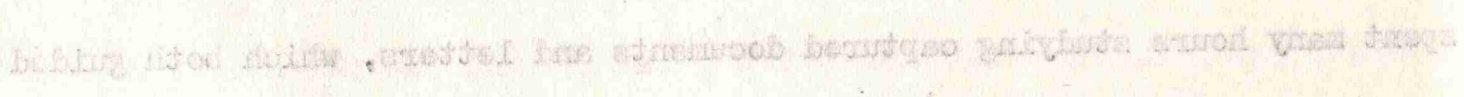

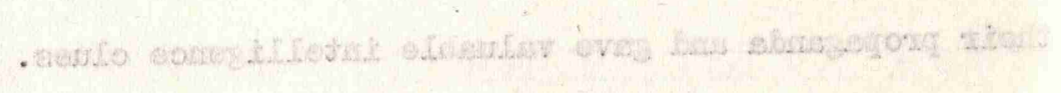

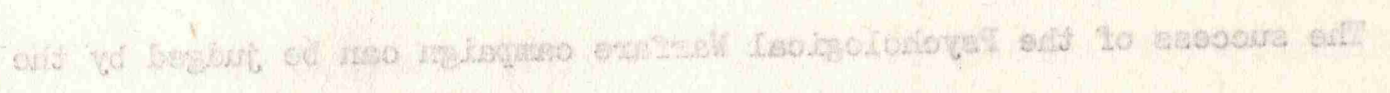

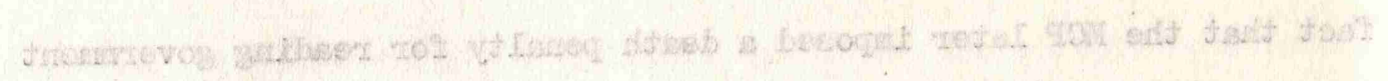
Q:

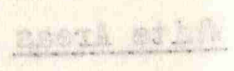

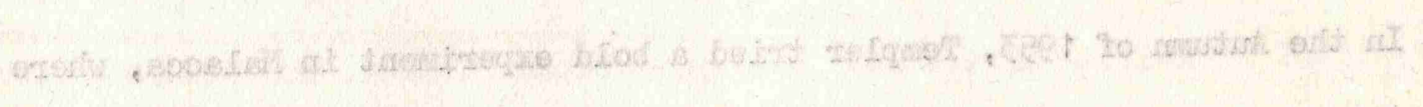

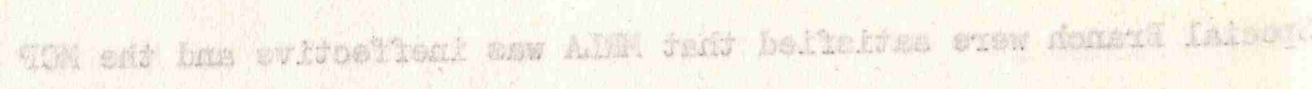

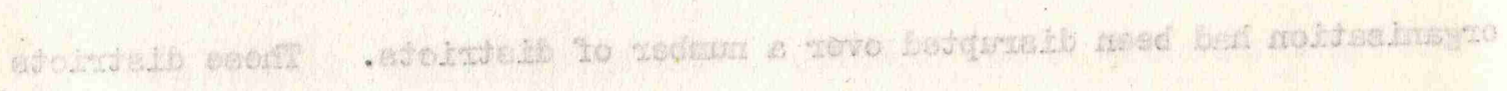

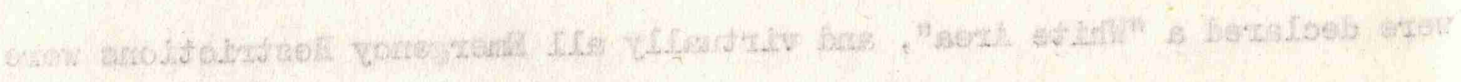

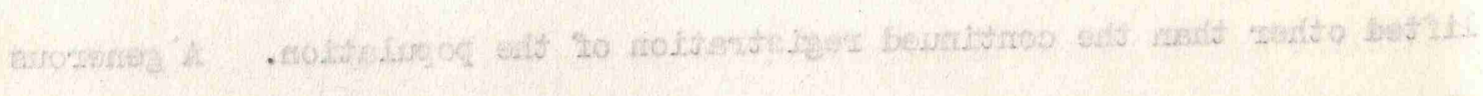

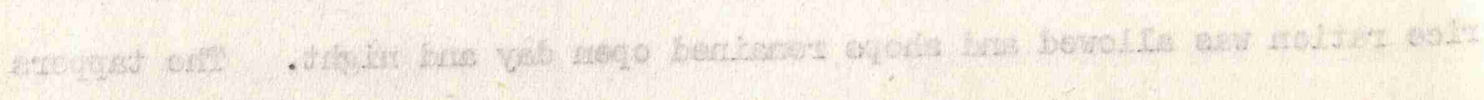

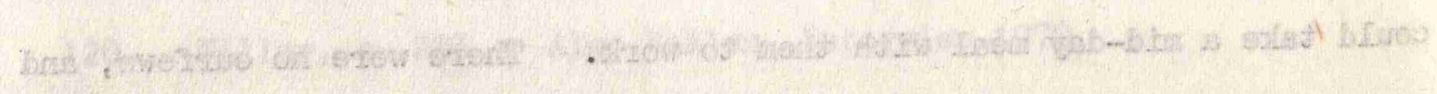

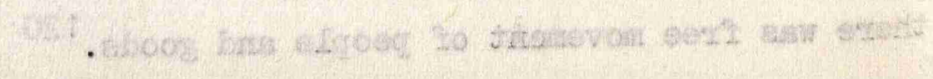


The people were warned that the restrictions would be reinforced at once if there were a resumption of Communist activity or terror in the area. Templer calculated, however, that the public relief at the end of restrictions was so great that he could be sure that any attempt by the Min Yuen to reactivate their organisation would quickly be betrayed to Special Branch. This was a considerable risk, and each time a new White Area was proposed there were powerful voices - often including Special Branch warning against it, lestt the Min Yuen organisation that had taken years to root out might revive and regain its grip of the people within a few months. It was argued that the guerillas would only need a very few loyal supporters to provide their essential needs and that the bulk of the population would be able to give no information because they had no contact.

In the event, however, Templer proved right. No White Area even in fact had to revert to black. ${ }^{121}$ The competition for the hearts and minds of the people was well on the way to being won by the government in 1954 . 


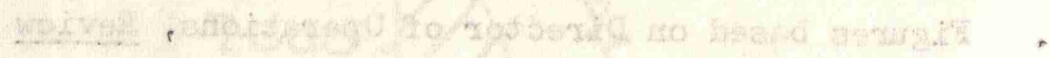

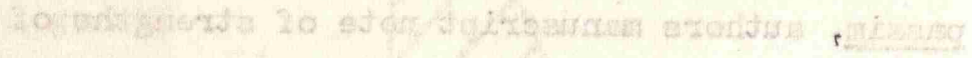

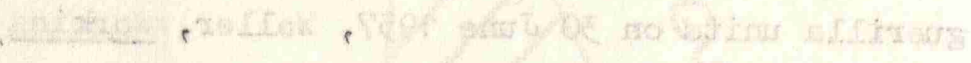

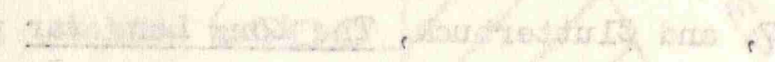

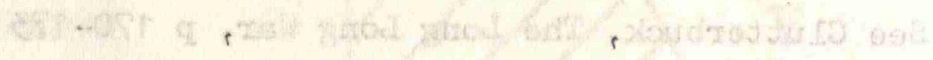

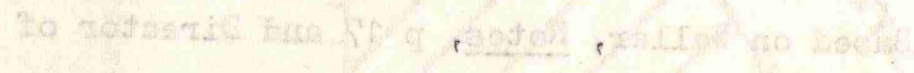


MAYAYAN COMMONIST PARTY ORGANTIATTON 1952-1958

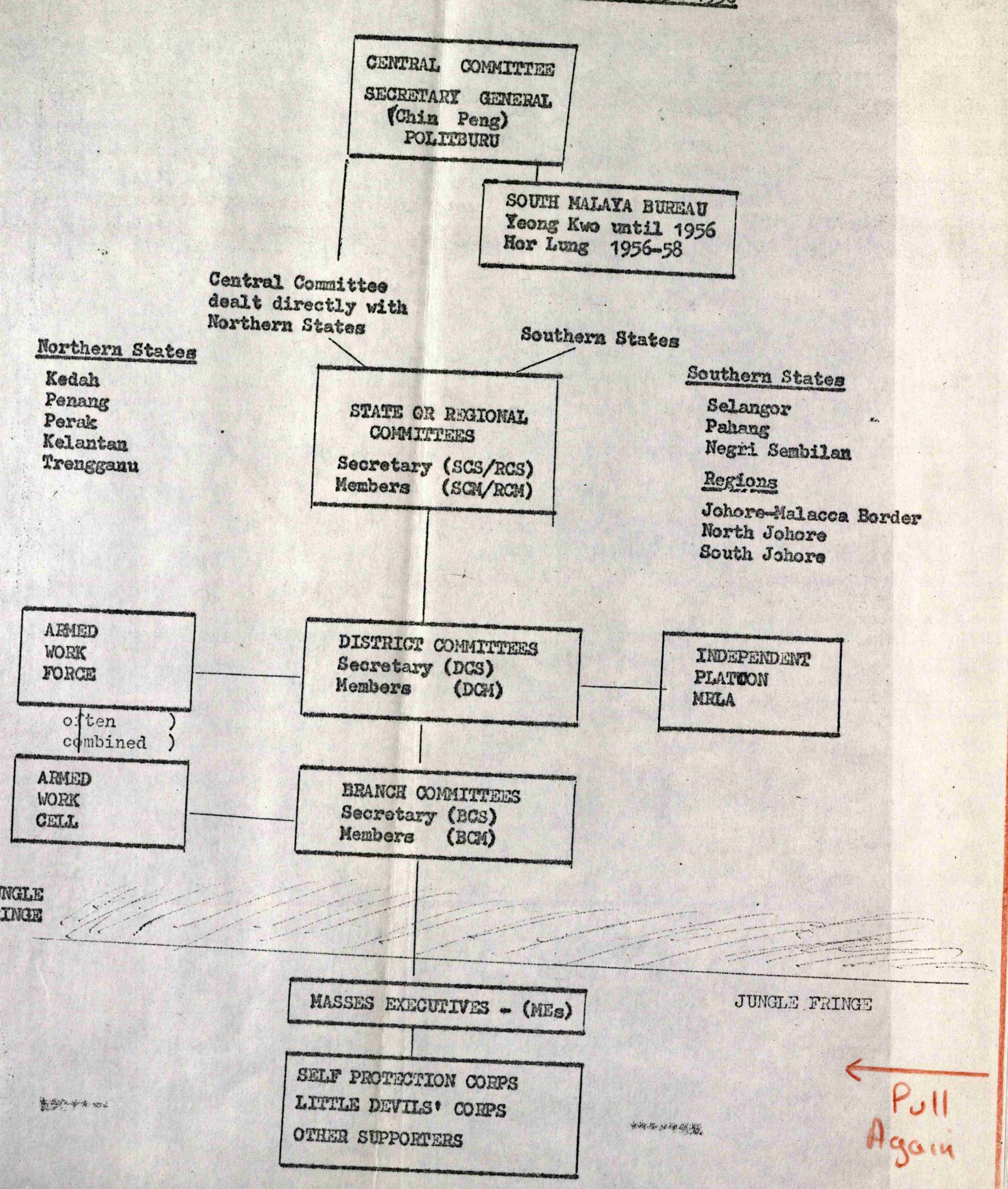

Figure $10 B$
MCP POLITICAL AND LOGISTIC

ORGANIZATION AND FIGHTING UMITS $1951-57$

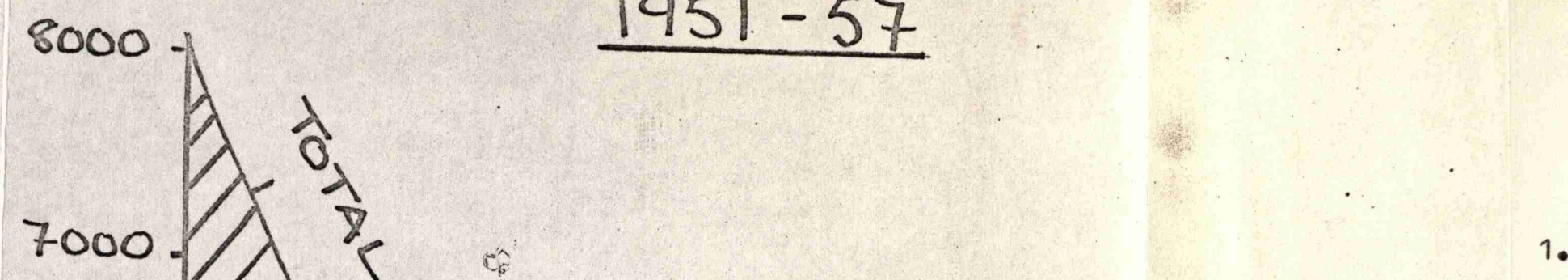

Figures based on Director of Operations, Review 1957 passim, authors manuscript note of strengths of guerilla units on 30 June 1957, Waller, Working Papers p 27, and Clutterbuck, The Long Long War p 87

2 See Clutterbuck, The Long Long War, p 170-173

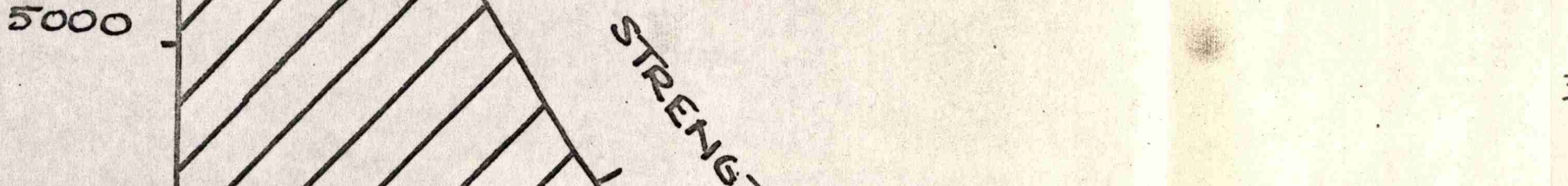

Based on Waller, Notes, p 17 and Director of Operations Review, passim 


\section{ORGANISATION FOR SURVIVAI}

\section{The MCP Reorganisation, 1952-53}

In the two years of Templer's rule, (1952-54), two thirds of the guerilla force was eliminated. Since the raison d'etre of the MCP jungle organisation was to organise andindootrinate the people (and, unlike some guerilla armies, they never lost sight of this fact) the bulk of these losses had to be borne by the MRLA - the fighting units which were milked to keep the political and supply organisation adequately manned.

They continued to lose heavily. During the period 1951-1957, their total casualties (9000) far outnumbered their recruits (3000) and their strength fell from 8000 to 2000. Yet still they kept their branch and district organisation largely intact - except in the white areas. The number employed in it remained much the same though the proportion was much higher, and the MRLA strength fell very low. See figure 10A.

The reorganisation carried out after the issue of the MCP Directive of October 1951 was designed for survival and political manoevre, not for offensive military action. Despite the dwindling of the fighting force, the political and supply organisation did survive more or less intact and fully active until 1957, and was not completely eradicated until 1960. Even then a nucleus remained (and still remains) in the Thai border area. As an example of tenacity, this, in a smaller way, parallels the achievement of Mav Tse Tung after the Long March. 2 The MCP organisation from 1952 to 1958 is shown in figure 10B. 3 
4. Hor Lung (Com) Interview 1967. This bears out the insistence of every ex-Communist or Special Branch officer consulted that MCP Committees did not need, nor often receive, specific orders or instructions, either from outside the country or from their own superior headquarters, but that they were nevertheless able to operate effectively because they knew their aim, understood the well-tried Communist techniques for achieving it and were prepared to apply on their own initiative, whichever of these techniques seemed most appropriate to exploit any opportunity that arose. (Hor Lung (Com) "Fu" and "Harris" (SB) Interview 1967 and others). 


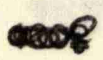

In 1953, to escape harrassment, Chin Peng moved his Central

Committee from Pahang (Central Malaya) Northwards across the border to a secure base in South Thailand, where there was a strong Chinese minority of 30,000 , which had not been resettled into villages where it can be protected or controlled, and was unrestricted by Emergency Regulations. Here, he was able to keep some 400 guerillas under training in large camps, with lecture rooms and parade grounds, as he had in the Malayan jungle in 1948-49.

This meant that his communications with Southern States and Regions became even more difficult, so he left his Vice Secretary General, Yeong Kwo, in Selangor at the head of the South Malaya Bureau. In 1956 , Yeong Kwo was killed in an ambush, and Hor Iung became head of the South Malaya Bureau, thereafter located near the Johore/Pahang border, were it remained until Hor Lung surrendered in May 1958. During these two years (1956-58) no orders or communications of any kind reached Hor Iung from the Central Committee. 4

The State and Regional Committees and branch structure remained unchanged through till 1957, but the command structure of the MRTA was changed for the third time in 1952. It will be recalled (see Chapter 9) that the MRLA in 1948 had an independent chain of command to the top, but that from 1949 (figure 9A) each regiment, company and platoon was placed under the direction of, respectively, a State (or Region), District and Branch Committee.

From 1952, the regiment and company HQ ceased to exist. Their functions were carried out by State and District Committees and the MRLA was reorganised wholly into Independent Platoons. Some of these were nearly 100 strong, though the normal strength was about 30. Bach platoon was allocated to a District and the District Committee launched it in support of the branches for specific operations. These were sometimes on a quota basis, under which the platoon was required to carry out a specified number of, say, railway ambushes, over a 



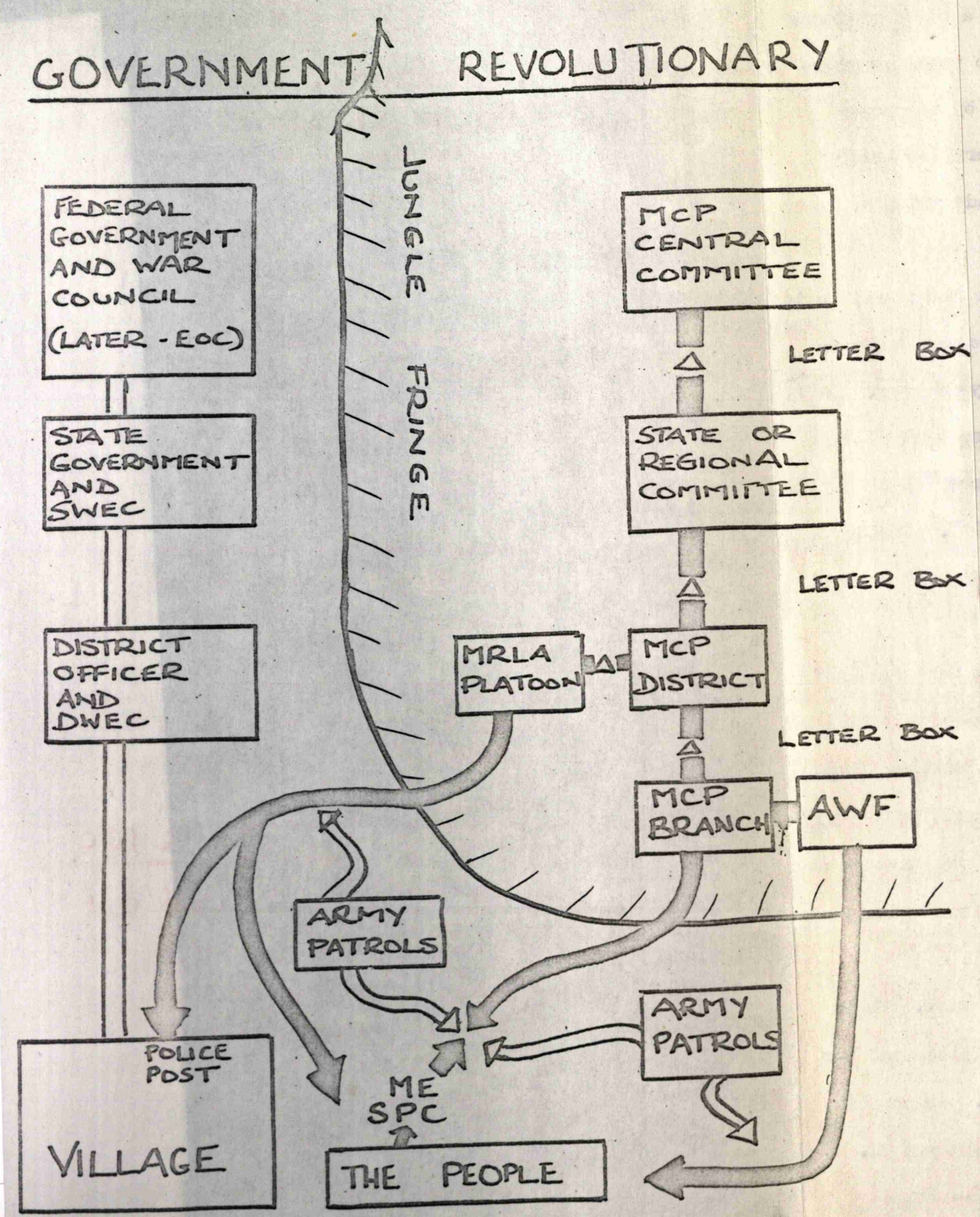

5. "Harris" (SB) Interview 1967

6. Joint Intelligence Advisory' Committee Report 24 October 1950.

7. Waller Notes p 19 and Working Papers p 12

8. Based on Clutterbuck, The Long Long War p 88

9. "Fu" (SB) Interview, $1967^{\circ}$

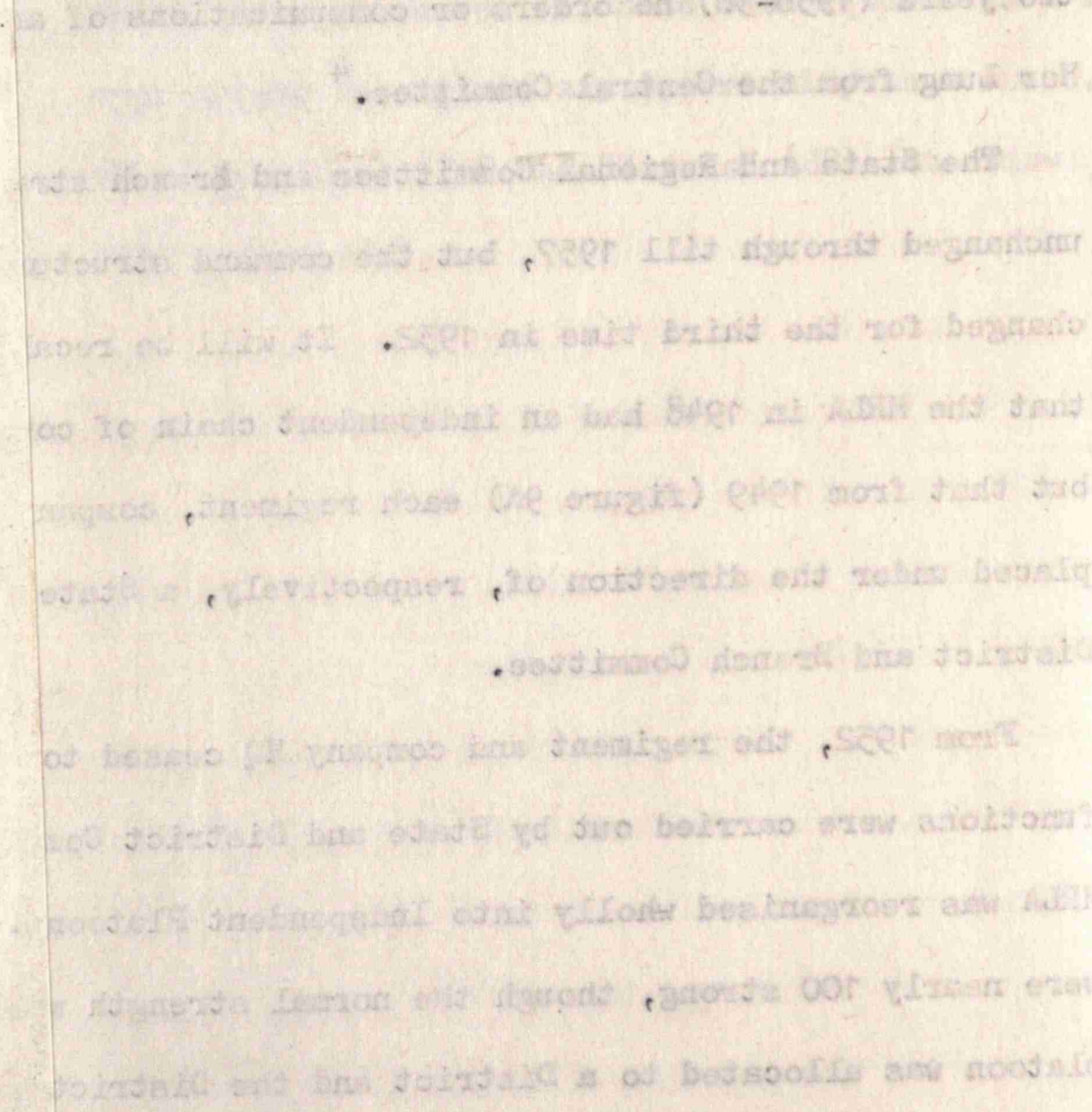

FIGURE $10 \mathrm{C}$ 
period. On other occasions, operations were requested by the branch, for such purposes as acquiring weapons, intimidating a shaky police post or home guard platoon, or disciplining a section of the population. 5

For the local protection of District and Branch Committees, a number of Armed Work Forces (AWFs) and Armed Work Cells (AWCs) were formed from 1950 onwards. They were a development partly from the original killer squads, and partly from the assimilation into the jungle of members of the Self Protection Corps (the part-time village guerillas) for whom life in the villages had become too insecure. 6 The AWFs and AWCs normally worked in civilian clothing, and took on much of the work of sabotage and elimination of government informers. As the guerilla strength dwindled, they were gradually absorbed into the branches, and the Branch Committee and the AWF or AWC became indistinguishable.?

\section{The Parallel Hierarchy}

With their new organisation, despite their losses, the MCP succeeded in maintaining a viable hierarchy of secret government, paralleling the Federation Government, with its SWECs, DWECs, and Village Councils, right through until 1958. See Figure 10c. 8

Outside the jungle, the activities of the people were increasingly focussed around the trusted Masses Executives (MEs), who were generally the only ones who had direct contact with the guerillas. Fewer and fewer people were involved, and the MEs often dealt entirely with relatives who they knew would not betray them. Many of the MEs were themselves related to the guerillas in their branches - a further example of the strength of Chinese family ties, and of their reliance on them in times of stress. 9

The Self Protection Corps continued to function, consisting mainly of boys and girls between 18 and 20 years old. In Yong Peng 



\section{MCP BRANCH ORGANISATION}

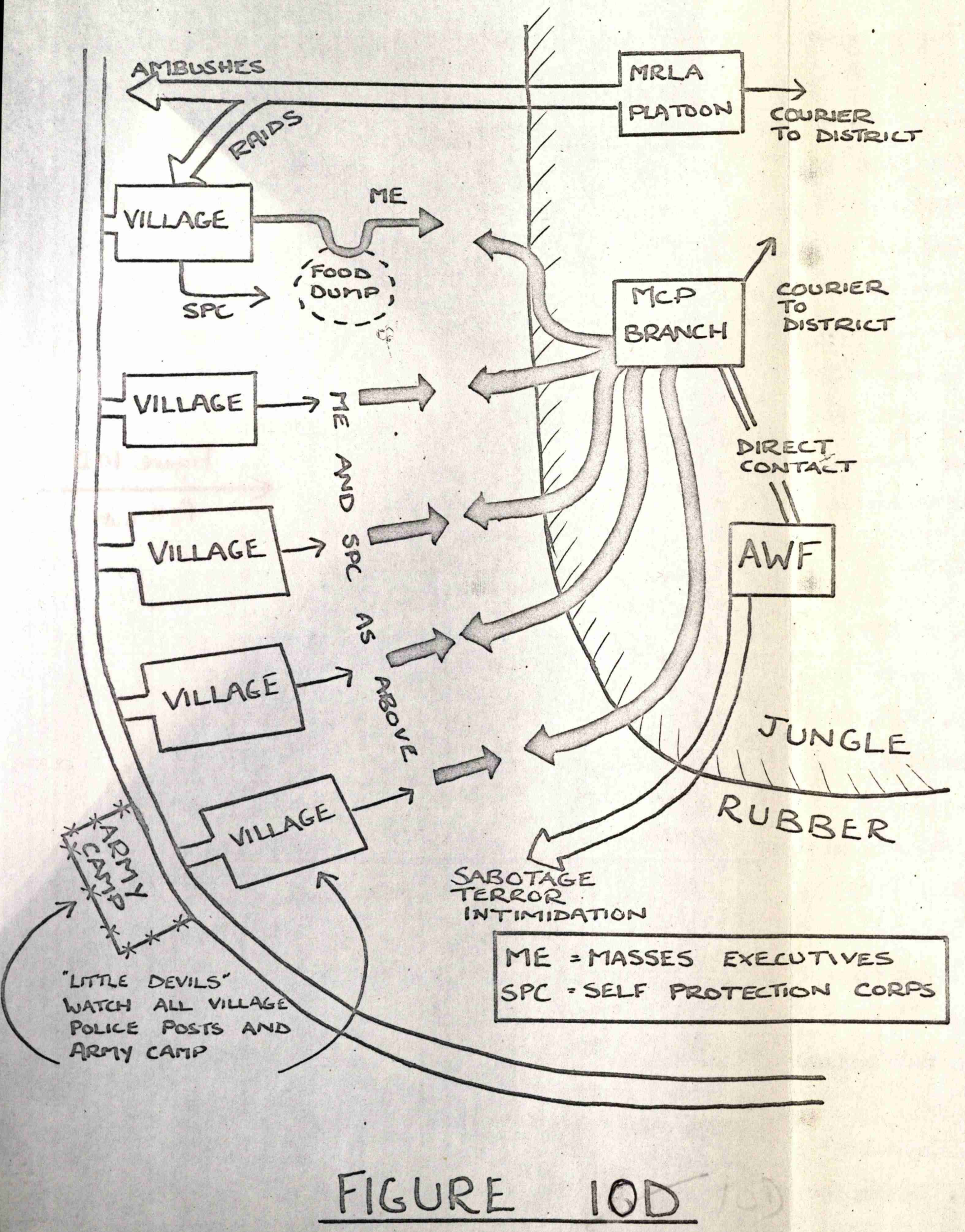

"Kim Cheng" (Com) Interview 1967

"Fu" (SB) Interview 1967

Compiled principally from Waller, Notes and Working Papers, from interviews, with "Fu" (SB) and "Kim Cheng" (Com) in 1967 and from Clutterbuck, The Long Long War $\mathrm{p} 12$ 
(Johore), for example, they continued to report for jungle training once a week until 1953. Thereafter their duties, like those of the majority of their comrades in the jungle, became mainly logistic. They bought or collected the rice and smuggled it out of the gates in order to protect the MEs from the risk of being compromised at the gatecheck. The MEs picked it up from pre-arranged dumps outside, and took it on to dumps or meeting places where it was collected by the branch guerillas. 10

In villages where popular sentiment still supported the guerillas (especially in Perak and Johore) the children still ran errands and formed an intelligence screen as members of the "Little Devils' Corps"11

A branch might be responsible for some 5 or 10 villages and labour $\leftarrow$ lines, containing up to 10,000 people. Figure $10 \mathrm{D} 12$ shows in diagramatic form some typical functions of the various elements in the MCP structure around some of these villages and one of the estates in which their inhabitants worked. In the jungle are the MRLA platoon, the AWF and the branch, with its courier links to higher authority. Outside are the Masses Executives, the Self Protection Corps and the Little Devils' Corps. Precise tasks and organisations varied of course and there are a number of case studies later in this chapter and in Appendix B. MCP Security

From 1954 onwards, MCP security was intense. The guerillas relied utterly on their MEs, and went to great lengths to protect them, and to maintain their popularity amongst the people. Here there was an interesting parallel with the government's concern about the public image of its ROs and AROs (see Chapter 9). MEs were, for example, not expected to carry out assassinations, which were done by men from the jungle - 


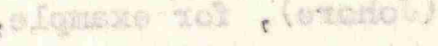

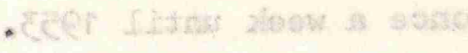

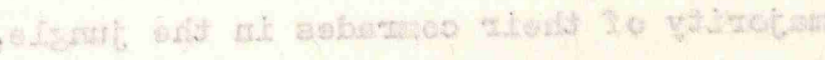

13 "Fu" (SB) and "Kim Cheng" (Com) Interview 1967

14 "Harris" (SB) Interview 1967

15 "Fu" (SB) Interview 1967

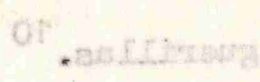

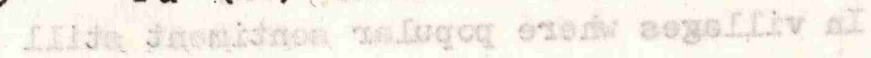

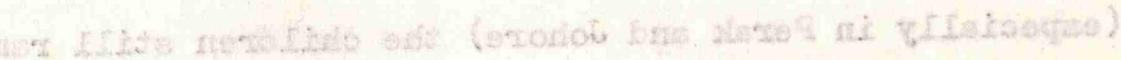

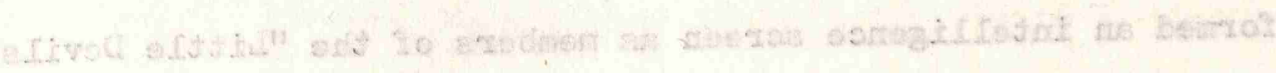

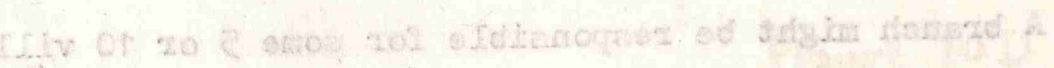

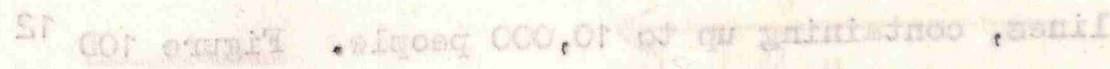

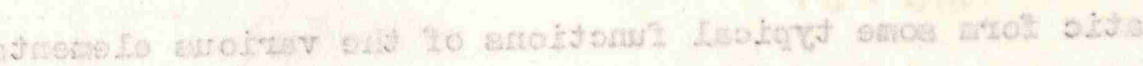

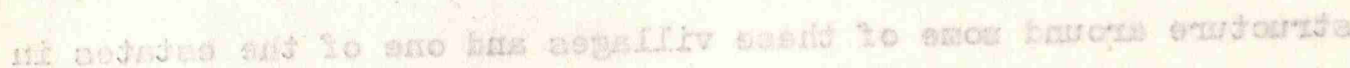

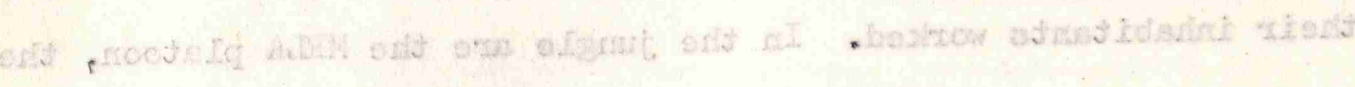

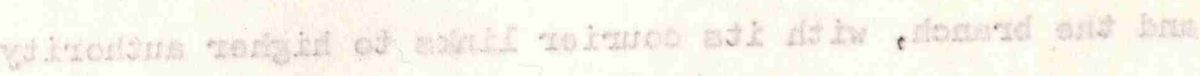

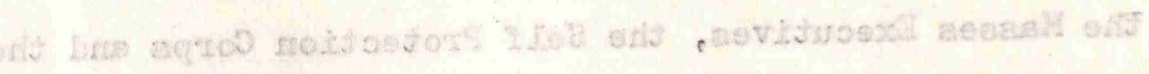

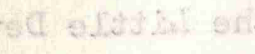

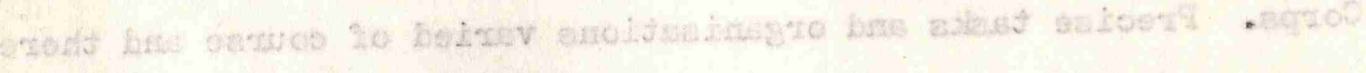

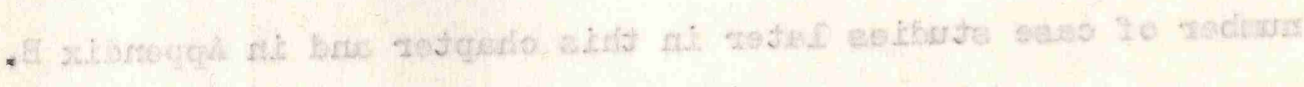

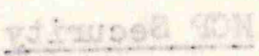

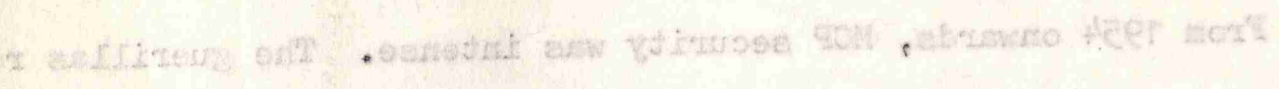

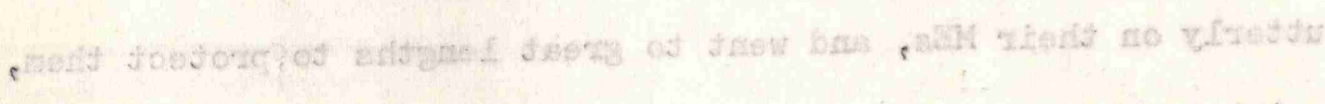

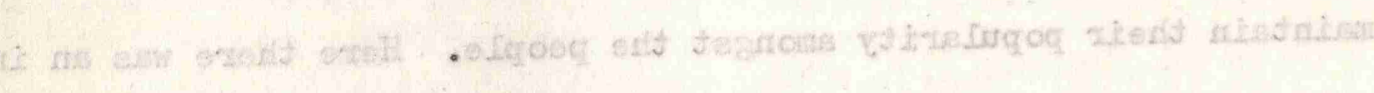

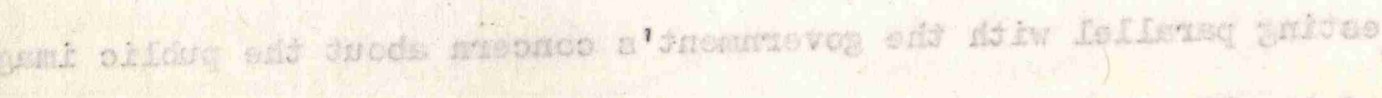

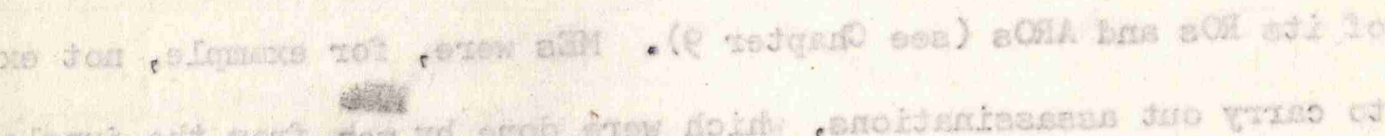

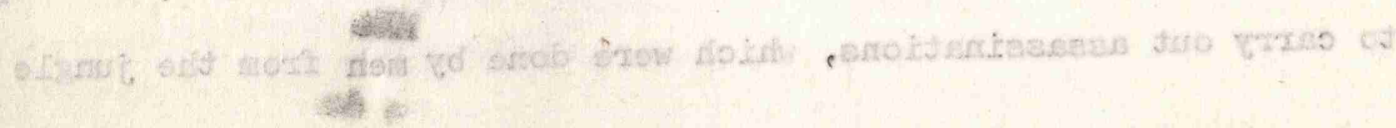


MRLA or AWF. The MEs did not know each other by sight, and they were referred to only by code names. Each BCM knew only one or two $\mathrm{N}$ MEs, and each $M E$ dealt with only one or two supporters in the Self Protection Corps each of whom dealt with a small cell, whose members only met him individually and seldom if ever met each other. ${ }^{13}$ Their knowledge of the organisation was so restricted that the individuals themselves often did not realise that they were "MEs" or "Members of the Self Protection Corps" at all. They merely did what the next man up in the chain told them, either because he was a relative or friend, or because they were vaguely loyal to the movement, or because they had reason to be frightened of disobeying. Special Branch knew far more about the organisation, and of each individuals place in this organisation, than most of the individuals knew themselves. 14

The MCP were generally loyal to their MEs. If, for example, an ME had given information leading to a successful ambush of the police or soldiers by the MRLA, the ME was normally called into the jungle to avoid risk of capture.

One penalty of the very tight security was that, if an $\mathrm{ME}$ was arrested, his part of the organisation melted away because no-one else knew the supporters with whom he dealt, and they were usually glad enough to be off the hook. 15

This inability to reconstitute an interrupted cell system contrasts with the effective arrangements for doing so in Singapore (see Chapter 3). This was partly because of deteriorating morale in rural areas and partly because, at this time, security in the rural organisation had to be more strict than in Singapore for a number of reasons. First, because contacts had to be far more frequent - every pound of rice, every pair of shoes or trousers, every torch battery, pencil or bottle of aspirin for the jungle had to be smuggled by the organisation, whereas the urban revolutionary 
16 "Harris" (SB) Interview 1966. See also Emergency Regulation No. 4C, atitcoss of os

17 "Sin Fai" (Com) Interview 1966, and Clutterbuck, The Long Long War pp 89-90

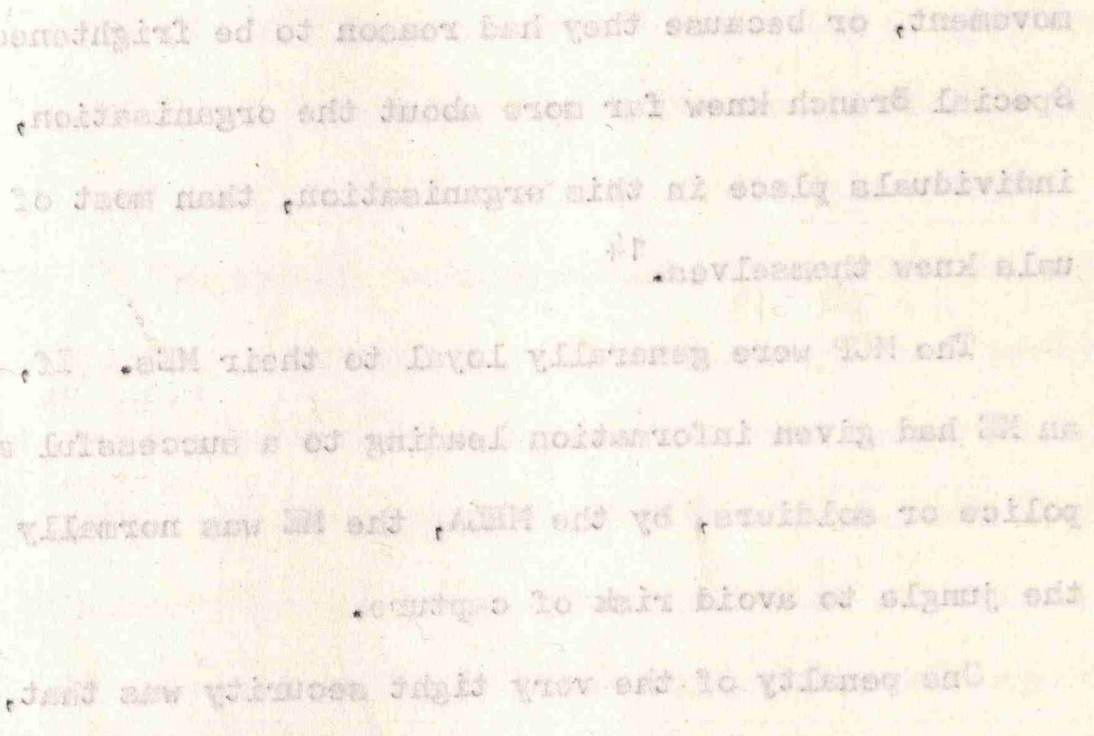

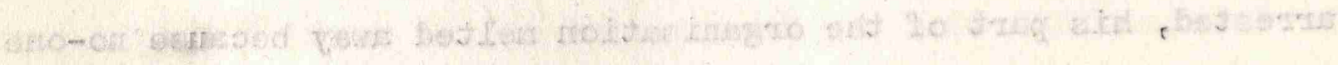

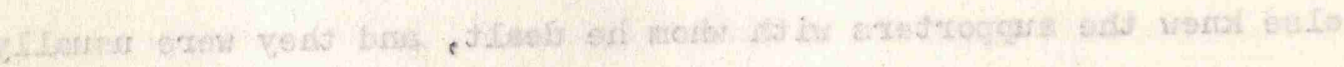

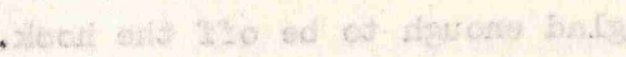

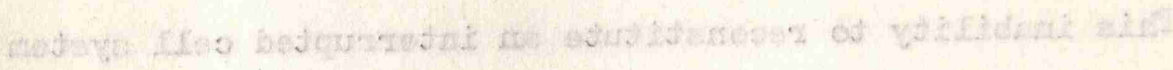

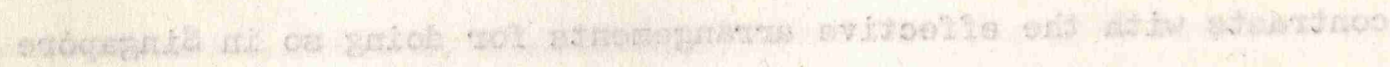

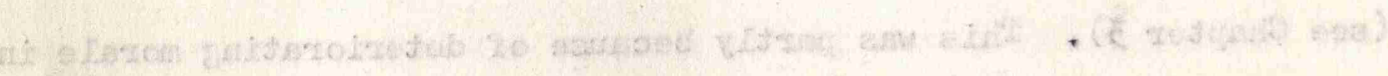

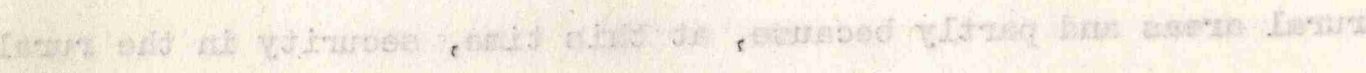

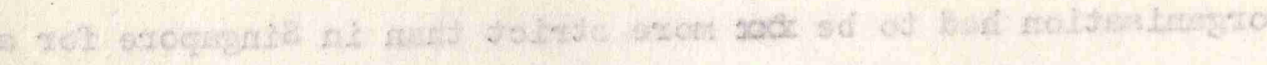

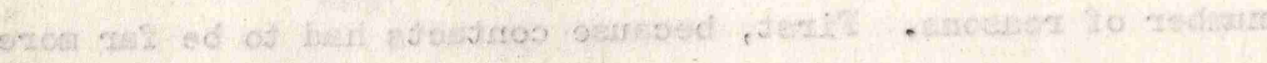

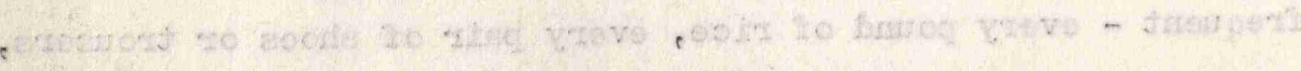

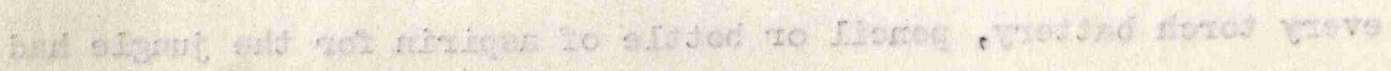

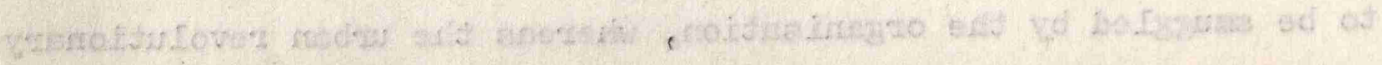


could buy his requirements in a shop. Secondly, whereas an underground worker in the city risked only detention, an $\mathrm{ME}$ who organised food collection faced the death penalty if he were caught. 16

Security of courier communication was also tightened up. There would be one jungle letter box in use between the district and each of its branches, known to the courier from the branch and the courier from the district. They would call there on pre-arranged days of the week, or every other week, to drop and pick up messages. The two couriers called on different days, and neither normally knew the days on which the other one called. There was an alternative letter box for each branch-district link, known to both couriers, which was put into use immediately either suspected that the Security Forces might have detected the original one. Later in the Emergency the alternative was sometimes known only to the District Committee Secretary until he decided that the time had come for a change. This security was effective, but at a heavy cost in delay and dislocation if a courier defected, or was shadowed by the soldiers or by Special Branch or killed. Once broken, the link was often never re-opened, as the district and the branch never found each other in the jungle again. ${ }^{17}$ Examples of the Operation of MCP Branches in 1953

To show the change in the situation and operation of the guerillas and their supporters in the estates and villages, five cases were studied with the help of the SEP Brains Trust and a group of Special Branch officers in Kuala Lumpur in 1966. In three cases, SEPs who had operated in these areas in the period 1950-53 described the changes that took place over these years. In the other two, a Special Branch officer described the way in which the MCP operated in a rubber area and a tin 
mining area in which he had worked during 1952-53.

\section{Case 1. Inner Tenang Road Branch (North Johore)}

The Inner Tenang Road Branch of the MCP operated in North Johore, some 10 miles south east of Segamat, in an area which was also the scene of the operation ("COBBLI") which has been selected for detailed study of the later stages of the Emergency. (See Appendix Bd

The area for which the branch was responsible contained 800 to 900 people, in 200 families. About 60 of them worked in a large 1000 acre rubber estate - the Chuan Moh Estate - and the remainder on a number of smallholdings, mainly of 8 to 10 acres each.

In 1950 , up to $90 \%$ of the people had paid subscriptions to the branch. The underground organisation at this time was strong and well organised. There had been some 200 cells, each of 4 to 5 members, operating amongst the people in their places of work, three of them being on the Chuan Moh Estate, and the Inner Tenang Branch guerillas had moved freely amongst them, dressed as rubber-tappers, and carrying only pistols. The gudrillas had sometimes held indoctrination meetings in houses in the villages. There had been little attempt at security, because everyone knew everyone else.

By 1953 things were very different, because of the heavy guerilla losses and the development of Special Branch methods. The MRLA company in the District had had to split up into AWFs. The Inner Tenang Road Branch was supported by an AWF of 5 or 6 men, armed with rifles, and wearing civilian clothing, which made most of the contacts with the Easses Executives in the rubber, to protect the branch. There were 5 Masses Executive Cormittees, each based on one rubber estate, and each 


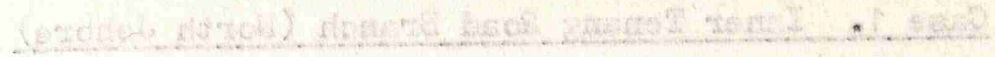

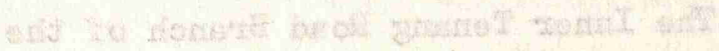

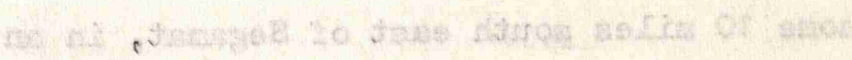

18 SEP Brains Trust 1966

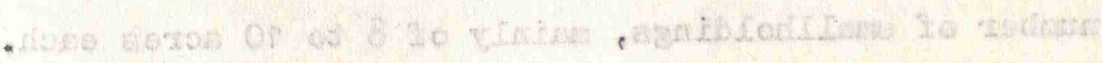

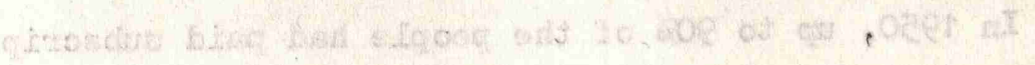

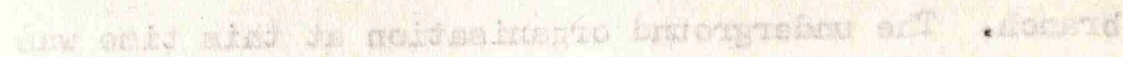

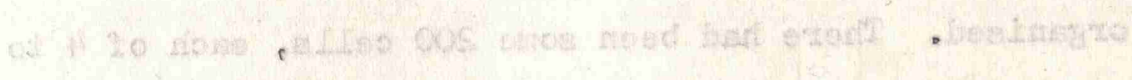

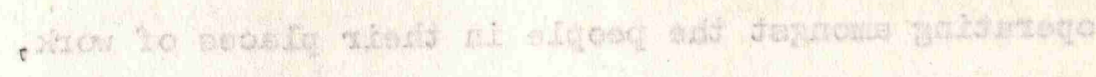

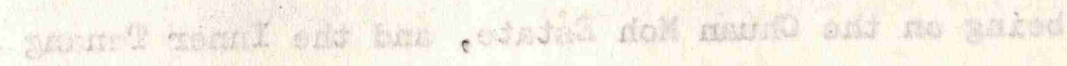

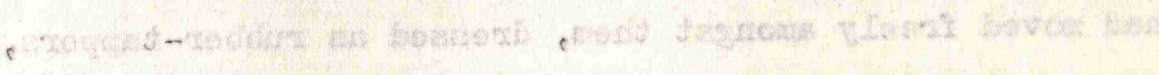

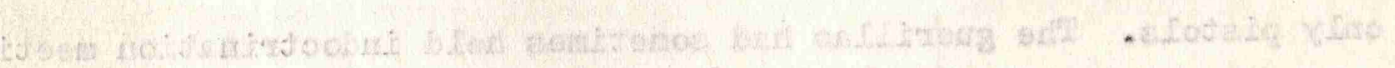

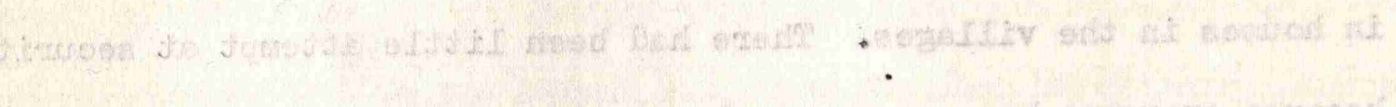

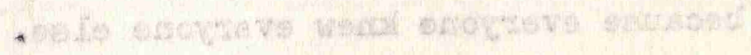

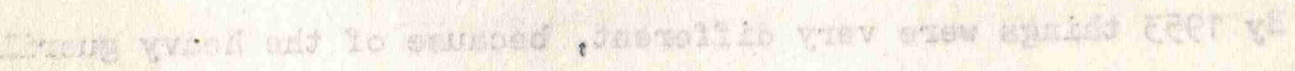

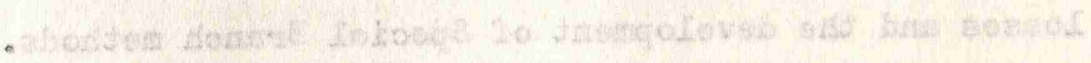

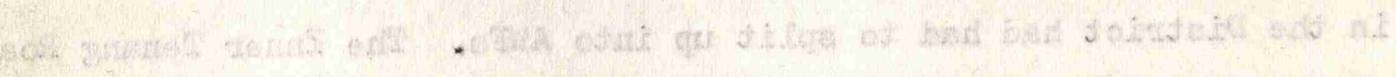

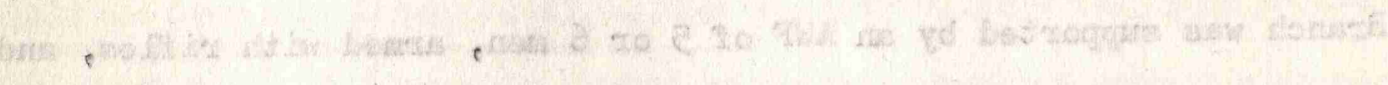

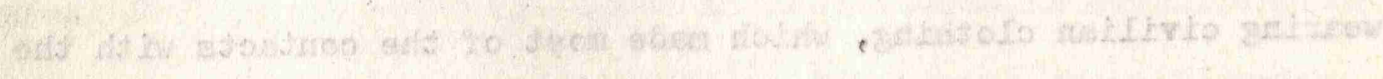

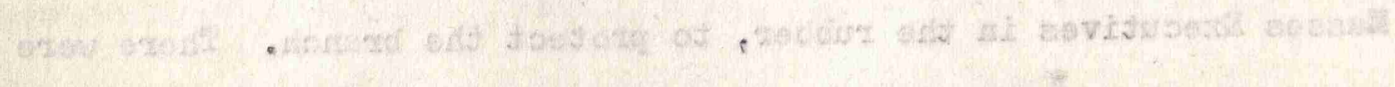

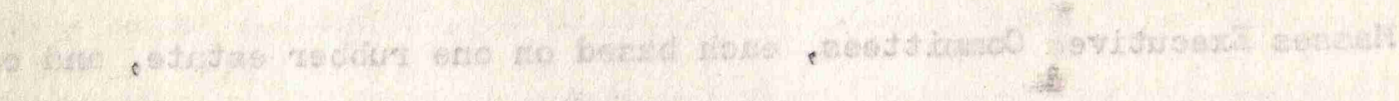


had a cell system under it.

The branch was mainly preoccupied with security and food supply. They were responsible for finding food for some 50-60 guerillas in the district. Food control was initially lax. The AWF guerillas still sometimes came into the villages to collect at night, and on other occasions the MEs dumped food near the fence and cut the wire. Most of it, however, was smuggled out when a "friendly" Special Constable or Home Guard was on gate duty.

Subversion of Special Constables and Home Guards was an importany activity. Home Guards were particularly vulnerable to coercion because their families lived in the town, but each did only 4 hours duty a week. A few Malay Special Constables were subverted by Chinese girls, and the government tried to counter this by moving them fairly often. There was no known case of regular policemen or soldiers being subverted. 18

\section{Case 2. Sabak Estate (Pahang)}

The 4000 acre Sabak Estate had 180 workers, all Chinese, who lived in two Kongsis (ie, villages organised on a community basis). The Sabak MCP Branch consisted of 7 guerillas. In 1949 they had moved freely and, (unlike the Inner Tenang Road Branch) they had not found it necessary to organise cells amongst the people, who gave them virtually 100\% support, and each subscribed 50 cents per month. The branch guerillas used to gather the tappers together for mass meetings on one of three hills on the estate during the period between tapping the trees in the morning and collecting the latex in the afternoon. At these meetings they indoctrinated the people, collected subscriptions and give orders for food and other supplies. The people would then buy the food in the shops (there was no rationing early in the Emergency) and either keep it in their houses for the guerillas to collect, or take it to dumps (known to all) on the jungle fringe. 
In 1950, security was tightened. The branch guerillas would take the supplies from these dumps to branch depots, known only to those who needed to know, and from there the MRLA would send men to transfer them to MRLA platoon dumps which were not known to the branch at all. There was thus a complete cut-off between the MRLA and the people. Dumps were moved as soon as footprints began to give them away (usually about 3 months).

In 1951, they added a further cut-off, between the branch and the people, by appointing 7 Masses Executives.

By 1953, their situation had deteriorated considerably. There were only $3 \mathrm{MEs}$, and they had contact with only $20 \%$ of the people in the Kongsis. They were most apprehensive about betrayal within the Kongsis, and urged their supporters where possible to buy food in the big towns and smuggle it out by bus or lorry. ${ }^{19}$

\section{Case 3. Tras (Pahang)}

The district of Tras had a particular reputation for violence, and it was here that the High Commissioner, Sir Henry Gurney, was ambushed and killed in 1951, after which all the 2000 inhabitants of Tras village were collectively detained under a rarely used Imergency Regulation (ER $17 \mathrm{DA}$ ) and the village burned to the ground.

The MCP leadership in this district was particularly militant and its leader, who later surrendered, was personally credited with a large number of violent incidents.

The district contained two villages. The inhabitants of these, and the squatters, provided 500 workers on 8 estates. The workers were organised by the MCP on a family basis, each group of five families forming one cell. During 1949-50, the guerillas would often spend nights in houses, but in 1951, when the squatters were resettled into wired and guarded villages, this became too big a risk. It was 
then also found better to base the cells on groups of workers in the estates rather than on their families and places of domicile which came too much under the eyes of the police.

By 1952, there was one cell on each of 10 estates, and four of the cell leaders formed a Masses Executive Committee. Each estate was worked by 50 to 60 tappers, most of whom remained loyal. They knew their cell members by şight and handed over food and subscriptions to them. In 1953, however, they became less ready to do so without coersion, and, as the MCP 1951 Directive discouraged such coercion, subscriptions tailed off. It was at this point that the leader surrendered, and thereafter Tras was a relatively peaceful district. 20

\section{Case 4 - Ayer Kuning (North Johore)}

Ayer Kuning was a rubber growing area in North Johore. In 1953 the MCP guerilla organisation was about 20 strong including 3 AWCs each of 5 or 6. They worked amongst a predominantly Chinese population of 3000 , of whom about 1000 were prepared to give some support.

There were a total of 100 to $150 \mathrm{MEs}$ amongst these 1000 - some 7 or 8 working on each of the bigger estates (100 or more tappers) and a single $\mathrm{ME}$ on each of the smaller ones (10-15 tappers). These MEs were always responsible for dealing with a group of people from whom they obtained all that the branch needed - eg food, money, clothing, medicines etc - and never with any particular function, as this would have involved contact with more people. Each ME dealt with 10 to 15 people.

The Branch had to feed some 50 guerillas, including itself and its AWCs. At $5 \mathrm{lbs}$ each, this needed $250 \mathrm{lbs}$ of rice per week. Each ME built up his own small cache of dry rice, in a tin or jar, somewhere in his rubber lot, together with any clothing, medicines, stationery etc. which the branch had asked for. The AWC guerillas would contact him at work in the rubber, and he would lead them to his cache. This gave obvious 8pporttanities for an ambush if any one of the MEs were tempted 


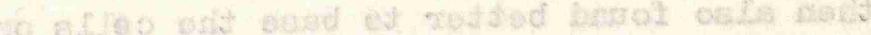

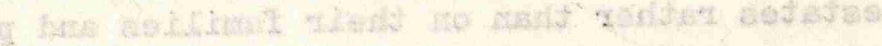

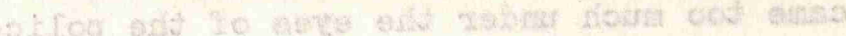

21

"Ramathan" (SB) Interview 1966

22

John Davis, (Gov) Interview 1966

23

"Ramathan" (SB) Interview 1966

$t$

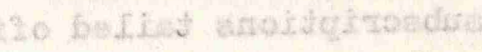

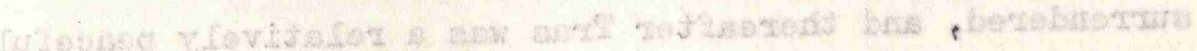

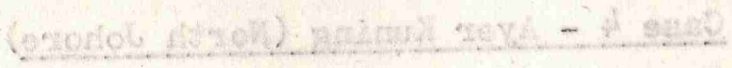

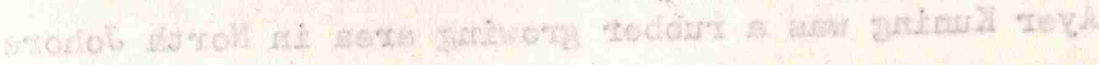

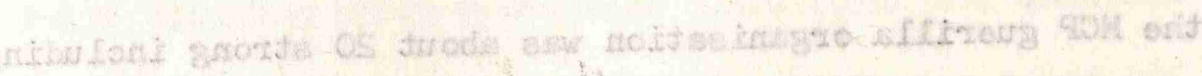

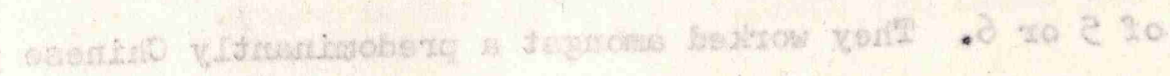

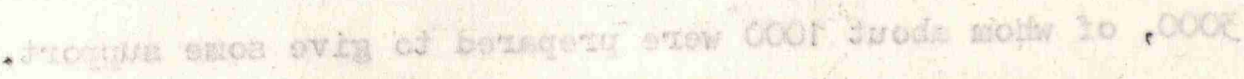

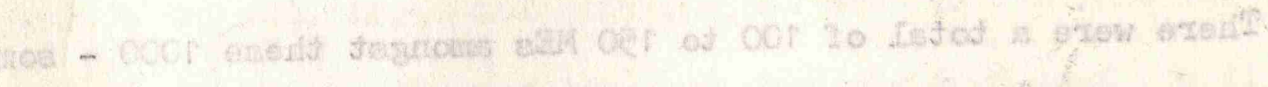

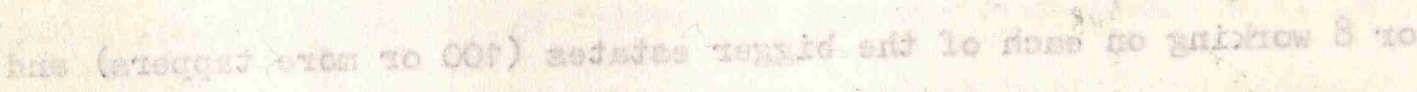

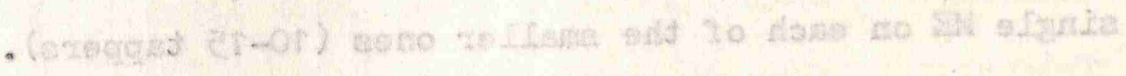

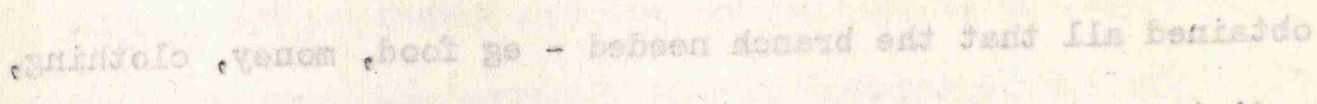

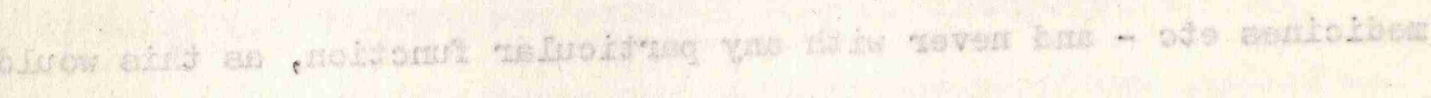

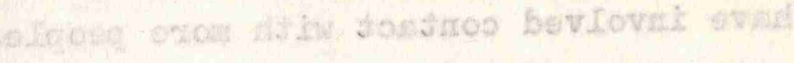
* eftroser

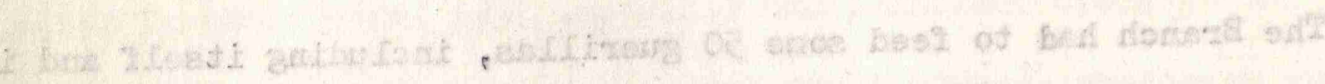

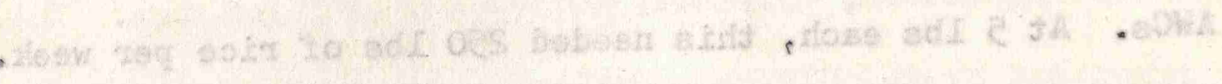

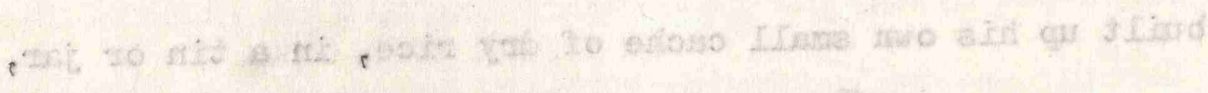

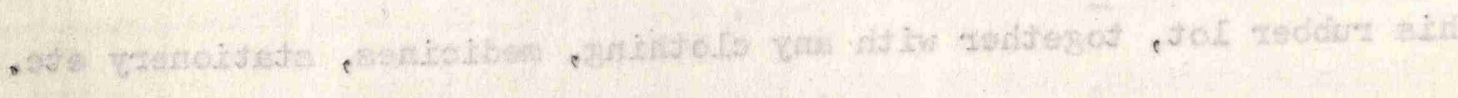

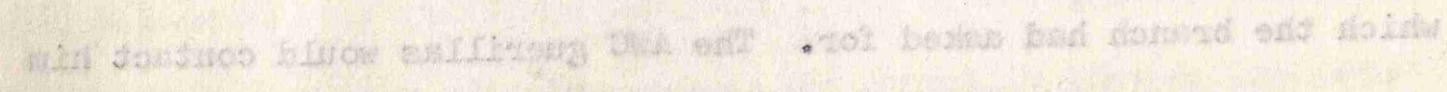

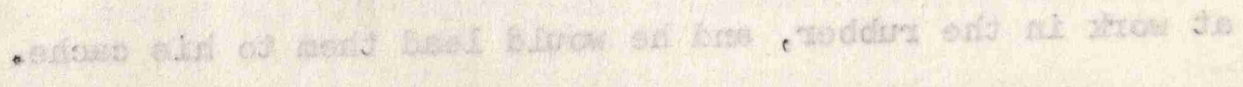


by the reward or induced to become a Special Branch agent, and these opportunities were exploited from 1954 onwards, as will be described in the next chapter.

The Branch raised some $\$ 3000$ a month, $\$ 1000$ of which came from tappers' subscriptions. About 30 smallholders and shopkeepers had to subscribe $\$ 50$ a month each, and the balance of $\$ 500$ came from other business men. Out of this, the branch paid for its rice at 15 cents per Ib (\$150 per month).21

\section{Case 5 Bidor (Perak)}

Bidor was a tin mining area. Tin mines produced a great deal of money for the MCP but not much food, as the workers had less direct contact with the guerillas. The MCP was perhaps unduly cautious about this because mines often worked through the night, and workers could easily have met the guerillas to hand over supplies by prior arrangement in the dark, but they ldom did. ${ }^{22}$ In Bidor district the Chinese owners of small mines had to pay a subscription based on output - usually $2-5 \%$ of its value. Even a small mine could produce \$50,000 worth of tin per month, and might therefore yield \$1000 to \$2000 to the MCP, and if the owner refused he faced the threat of having his mine machinery destroyed, if not a worse fate. 23

Target for 1954-56 - A Typical MCP District (Yong Peng)

As the Emergency progressed, the MCP District became the most important guerilla grouping. With its own MRLA platoon, it became the lowest formation to possess independent striking power. Having several branches it could survive the loss of, or the loss of contacts with, any , one of them - or even of all but one.

One of the most militant hardcore MCP Districts was Yong Peng. In 1952 this district contained about 200 of the 1000 guerillas in Johore, and held out against continuous pressure until ordered to surrender 


\section{9}

by Hor Lung after his defection with the South Malaya Bureau in 1958. 24 The remarkable tenacity of the guerillas in this district, and their success in maintaining a strong measure of popular support to the last, makes it worthy of particular study. See Fisure 10E.

When North Johore was finally declared a White Area in August 1958, the Defence Minister of the newly independent Federation of Malaya, Dato Abdul Razak, visited Yong Peng tó make the announcement. Only 100 of the 6300 villagers turned out to hear it. Razak said "Although we are making this place white, it is not because of any help from you", and sent a telegram from Yong Peng Post Office to Templer (by then Chief of the Imperial General Staff in London), for whom Yong Peng had been a bete noir, saying that they had made "his village" white. The Straits Times headline recording these events must have given some grim satisfaction to Communist die hards - "NO THANKS TO YOU - DATO RAZAK LASHES OUT AT YONG PENG" 25 Such was the character of the guerillas and their supporters in what had been regarded by the Japanese, by Templer and now by Razak as one of the toughest Communist districts in Malaya.

Yong Peng MCP District ${ }^{26}$ contained over 40,000 people, and included the large town and coastal port of Batu Pahat in its extreme South West corner, This town was set in a Malay hinterland. Its Communist organisation had had a strong Malay element, but this had been smashed in 1950. 27 From 1952 onwards, the MCP organisation in Batu Pahat consisted of only two underground workers, and will therefore not be further considered.

of the 27,000 who lived in the rural areas of the district, about 11,500 were Chinese. ${ }^{28}$ Many of the estates had Indian labourers, and the land in the South and West of the district was occupied largely by Malays. The pull-out map (Figure 10F) shows the contrast between the pattern of housing in the rubber estates North and East of the town of Yong Peng, Pull out Map Figure to F at end of Chafler 


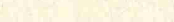

cic

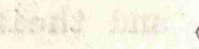

29 K.S. Sandhu, Working Papers made available to the author at Singapore University in 1966

30 Police, Op SHOE Annex A to Appendix E

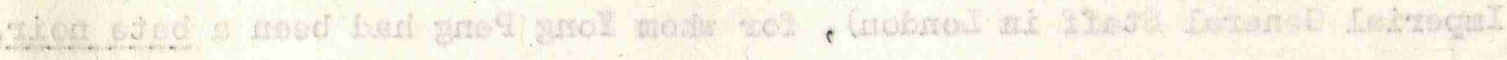

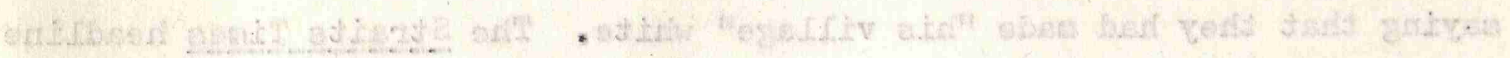

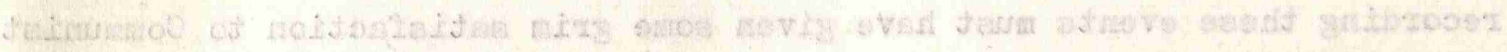
Hesside

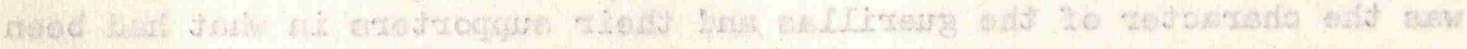

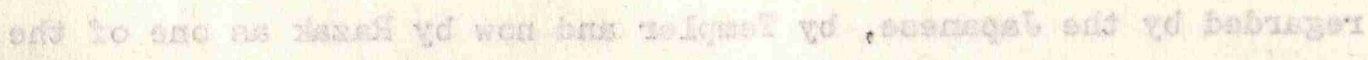

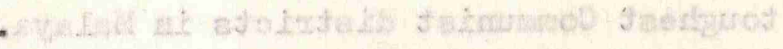

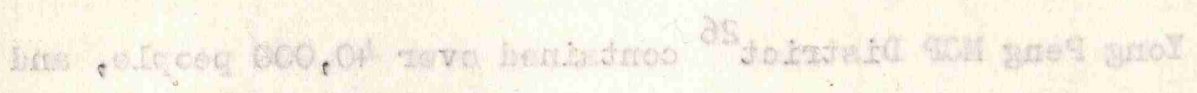

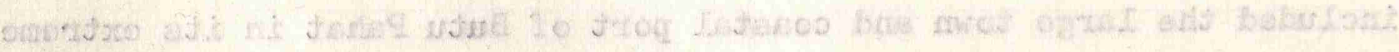

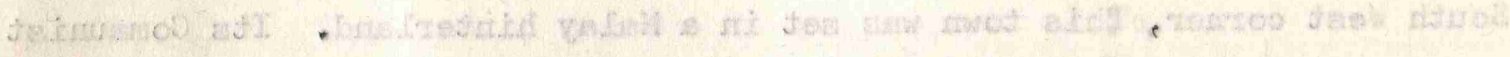

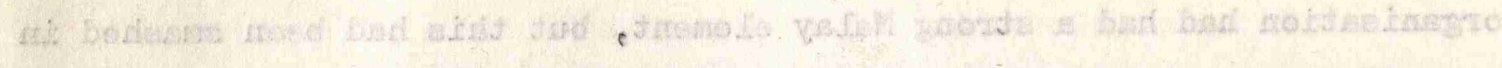

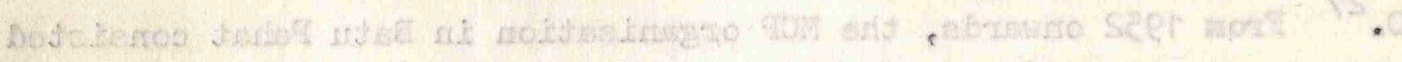

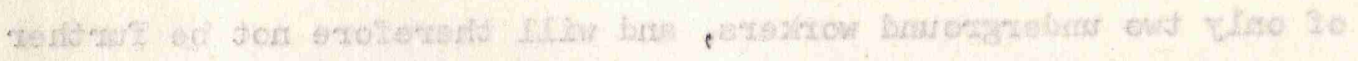

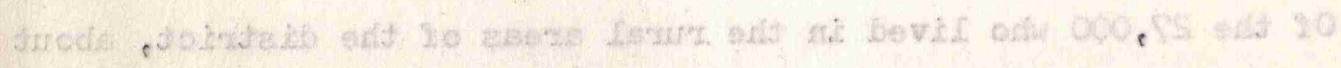

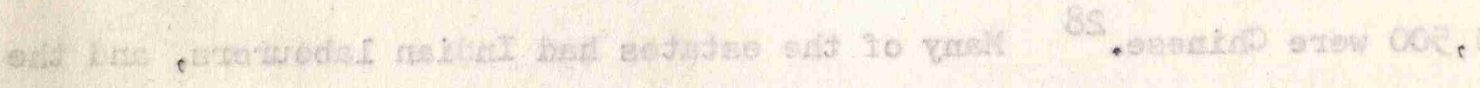

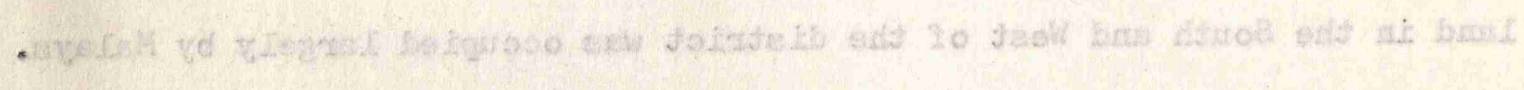

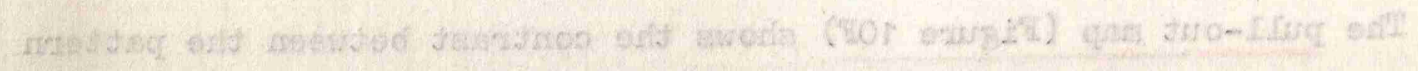

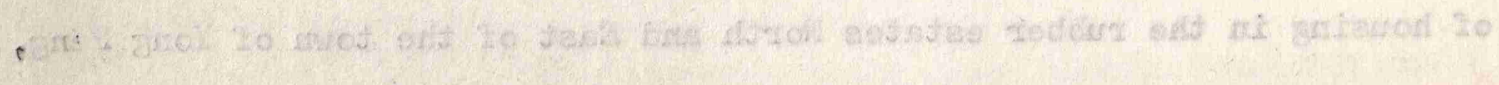


Hnd in the Malay areas, in which there had been no resettlement. The individual Malay houses are shown, spread along the tracks and irrigation ditches, about 15 in every cultivated kilometre square. At an average of 5.7 per Malay household, 29 this works out at 85 men, women and children in each kilometre square of the map, evenly distributed and unprotected.

By contrast, in the rubber estates North and East of Yong Peng, there are about 122 kilometre squares under cultivation. The total population listed in police records for these areas (including Yong Peng itself) was 10,682 . This gives a very similar average - 88 per cultivated square kilometre. But in this case they were concentrated in 9 villages, each of which was defended.

Apart from Batu Pahat and the Malay areas in the South and West, Yong Peng MCP District contained two main cultivated and resettled areas in the North around Chaah and in the Centre near Yong Peng. The Chaah area consisted of a concentrated oil palm estate of about 120 square kilometres, with a population recorded as 10089 of whom 3987 were Chinese.

The central area near Yong Peng contained 7552 Chinese, of whom just over 2000 lived in wired villages within the Malay areas. The village population figures on the map show the Chinese in red and total population of the village in green. Apart from one Iron Mine at Sri Medan (about 12 $\mathrm{km}$ West of Yong Peng), and individual peasant smallholdings, all the cultivated land was planted with rubber.

To organise this district, the MCP had approximately 200 guerillas in 1952-53. They were split as follows:-

District $\mathrm{HQ}$

No. 7 Independent MRLA Platoon

Branches (including AWFs)

Chaah

Iam Lee

Yong Peng

Sam Kongsi
10

40 


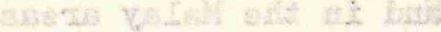

"Kim Cheng" (Com) Interview 1967, with fugures supplemented from Police, Op SHOE Annex A to Appx E and Johore Special Branch Intelligence Appreciation of 23 November 1956

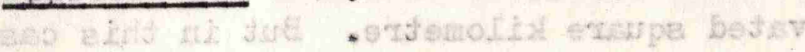

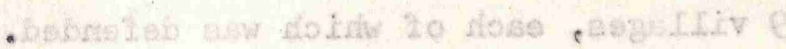

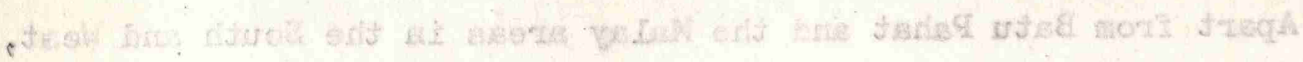

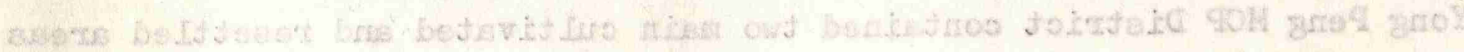

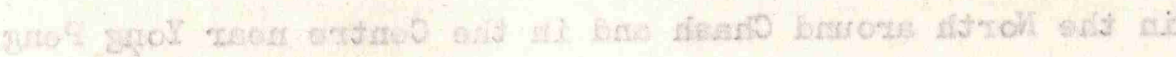

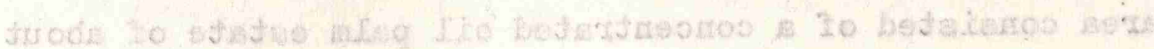

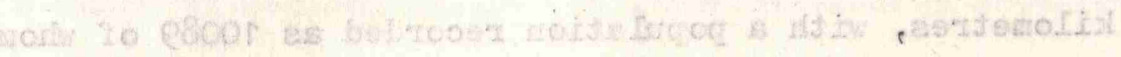

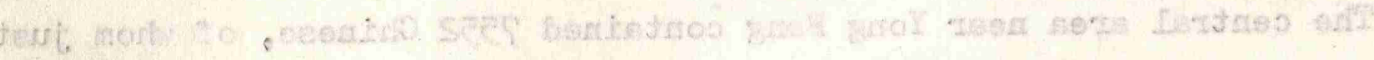

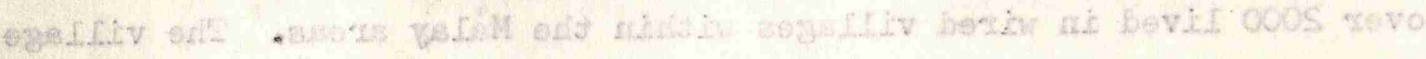

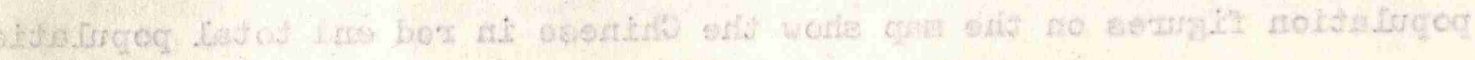

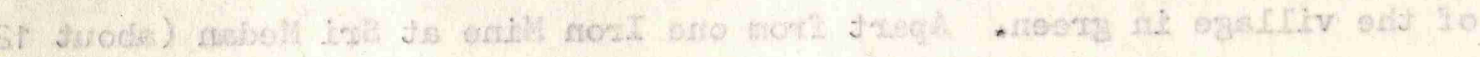

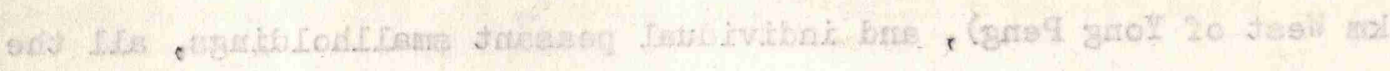

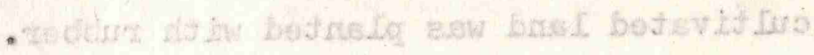

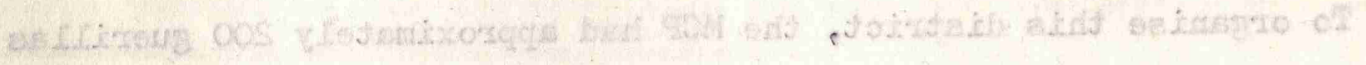

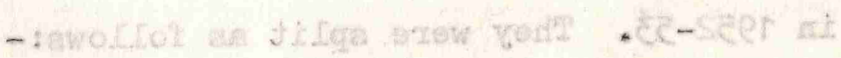
6. QH toxiteic 
Batu Pahat North

Kangkar Bahru

Chia Chu Kang

The branches and their AWFs/AWCs worked as single entities. Their combined strength accounted for 150 of the 200 guerillas in the district.

The branch organisations are shown in Figure 10巴, showing also the number of Masses Executives, who numbered 150-200. 31

Chaah Branch was weakest in relation to the population. This was because the Johore Labis Oil Palm Estate was highly organised, with a network of long straight roads which made patrolling by the Security Forces much easier.

Lam Lee Branch served a small population on two estates, where it had strong support. The branch sometimes in the hills to the East of the estates.

Yong Peng Branch ran the estates astride the main North-South road, 3-4 miles North of Yong Peng. All the labourers lived in Yong Peng New Village. The guerillas usually lived in the jungle to the West, but sometimes camped in the tongue of marshy jungle which cuts across the road immediately North of Yong Peng. This branch was in close touch with the District HQ, which also camped North West of Yong Peng.

The Sam Kongsi Branch was another very strong one, with solid support from the tappers on the Yong Peng River Estate, some of whom lived in the small labour lines on the estate (known as Sam Kongsi), but most of whom came to work from Yong Peng.

The Batu Pahat North Branch drew support from the Sri. Medan Iron Mines and from the workers on the Chingiap Plantation and Chee Hock Huat Estate, who lived in Tongkang Pechah. 


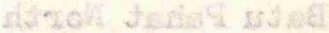

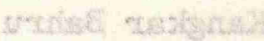

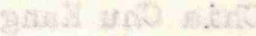

Ooss

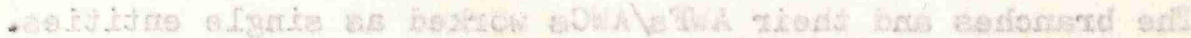

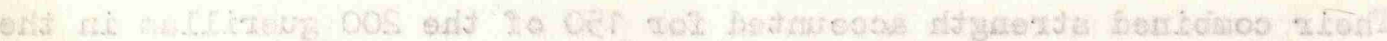
- vistrabas

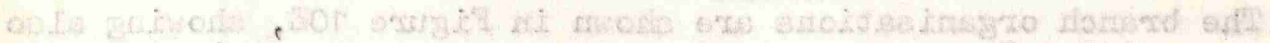

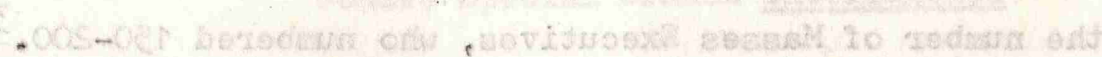

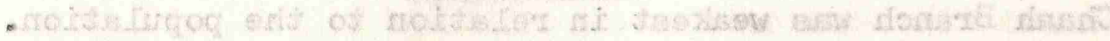

\section{2 "Kim Cheng" (Com) Interview 1967}

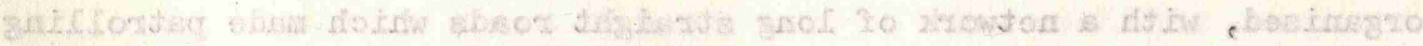

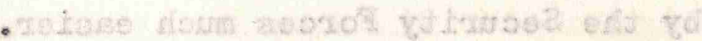

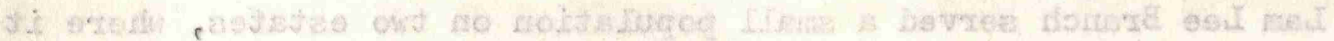

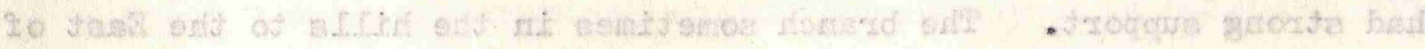

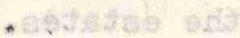

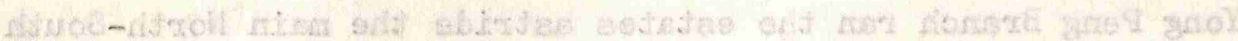

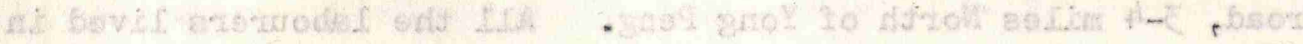

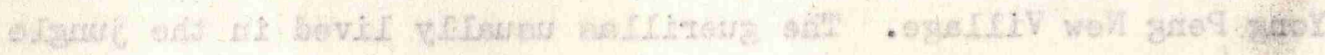

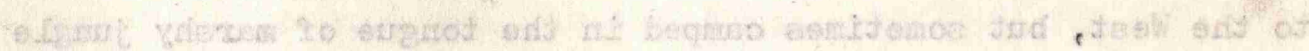

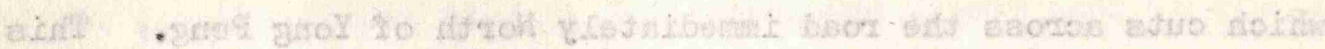

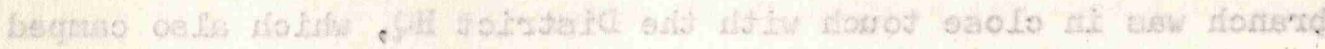

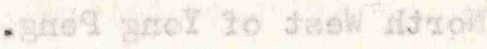

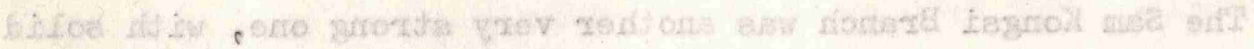

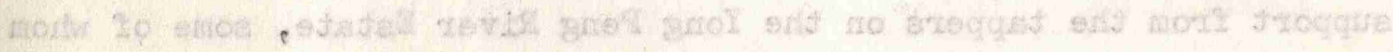

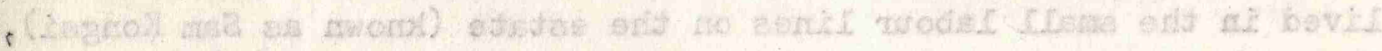

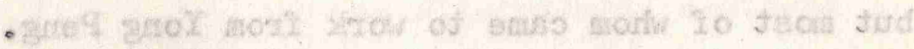

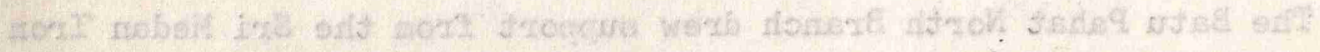

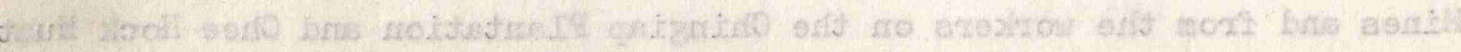

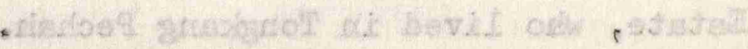


North East of Yong Peng, the Kangkar Bahru Branch operated on the large Yong Peng Estate whose workers lived in five villages and lines as shown in Figures $10 \mathrm{E}$ and $10 \mathrm{~F}$.

Finally, the Chia Chu Kang Branch, another strong one, drew support from the Chinese who worked South East of Yong Peng, all of whom lived in the town except for 108 in the small New Village of Kampong Haji Ghafar. 32

Yong Peng was one of the real hard core of Communist-supporting districts, rivalled only by Kulai in South Johore and Sungei Siput in Perak. All had been strongly Communist during the Japanese occupation and had survived numerous "drives" by the British. They were among the three last districts to succomb. Yong Peng can therefore be regarded as typical of the kind of target which forced the British to evolve the technique of the federal priority operation using food denial as an aid to intelligence. The evolution of this technique is described in the next two chapters. 



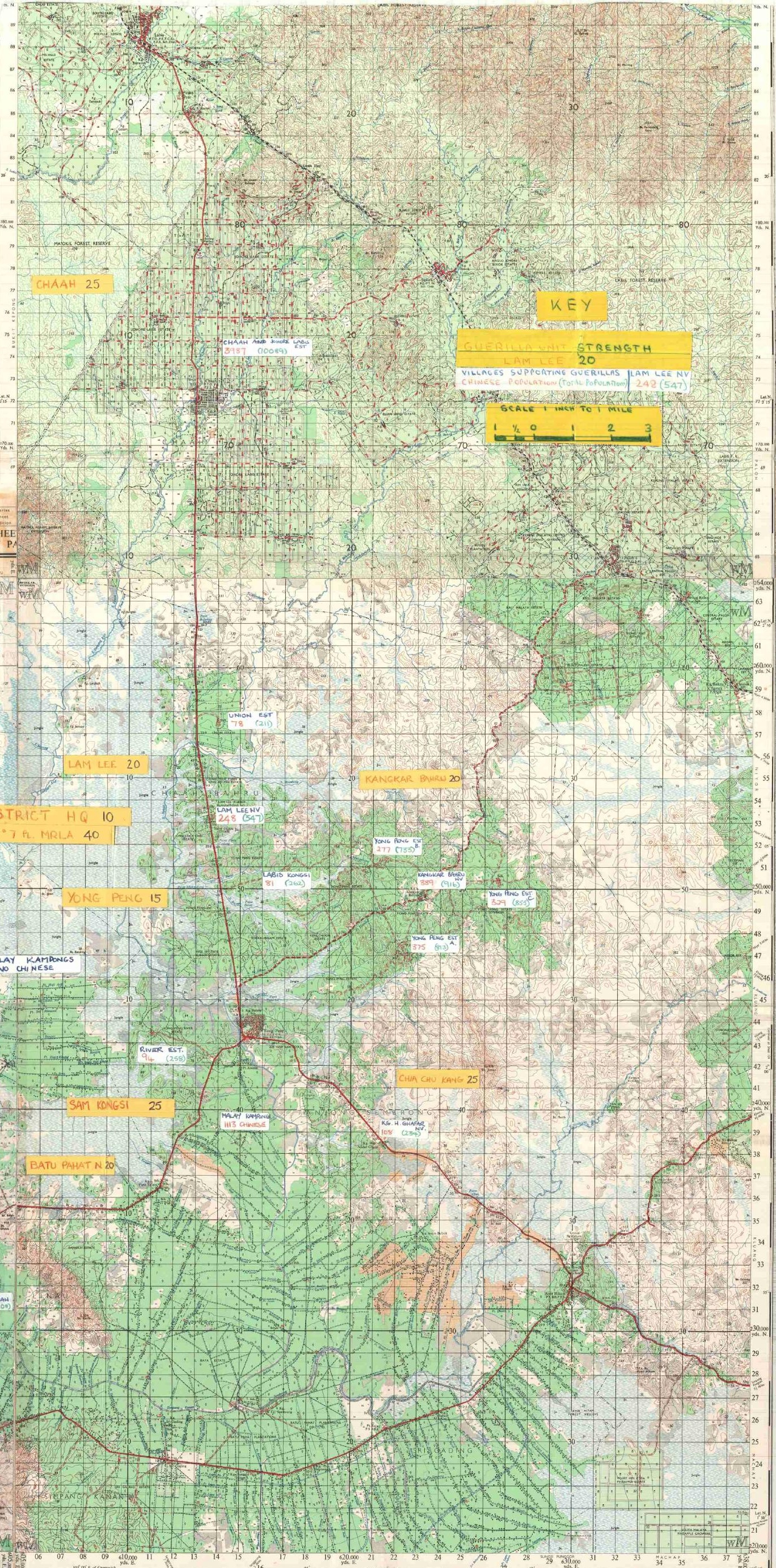


1 Director of Operations, Review 1957, Appx B

2 Director of Operations, Review 1957, p 21

3 SEP Brains Trust 


\section{A Difficult Target}

During 1953, the guerillas were at their least aggressive, and continued to kill less than a fifth of the number of civilians and Security Forces than they had in 1951. Their own losses however, remained very high indeed. The Security Forces were killing or capturing 6 guerillas for every man they lost. 1

During 1954, however, the guerillas became very much harder to find. It was estimated that a soldier might expect to do 1000 hours on patrol or 300 hours in ambush before he encountered a guerilla. ${ }^{2}$ The type of intelligence which had sufficed until then had been more or less the conventional brand of police and military battle intelligence, The soldiers on patrol would follow up tracks and footprints, check the passes of tappers who acted suspiciously or who were away from their accustomed beats, and try to formulate the pattern of movement of the guerillas and of their meetings with the people. The Police Special Branch would watch who talked to whom, discover who was related to whom, and thereby pick on people who knew something. They had also developed the exploitation of SEPs to a fine art. Most of the Special Branch information came from these SEPs and from informers (ie people who could tell them what had happened already, thereby building up the pattern) ${ }^{3}$.

The agent - ie, the man who was a privy to future Communist movements and prepared to betray them in advance - was at this stage a fairly rare bird.

From 1954 onwards, with the guerillas thin on the ground, doing their best to lie low and evade contact, and confiding their secrets only to a chosen few instead of to a mass of friendly villagers, the recruiting of agents became a vital element in the government campaign. Killing guerillas was dependent on this, and went hand in hand with the main task 
ISS

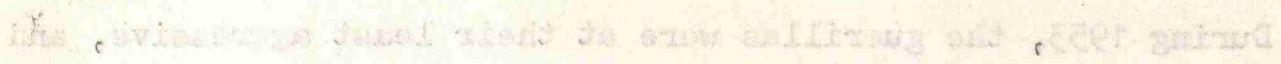

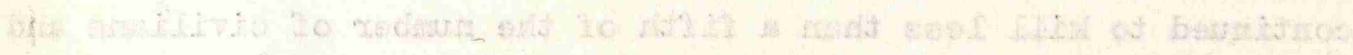

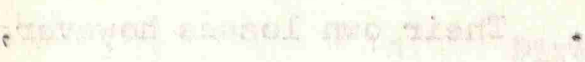

$4 \quad$ "Harris" (SB) Interview 1966

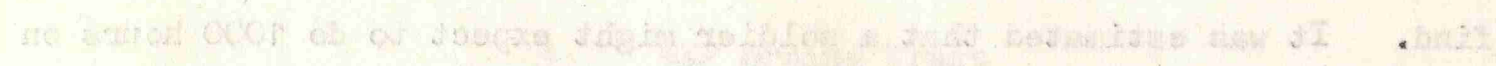

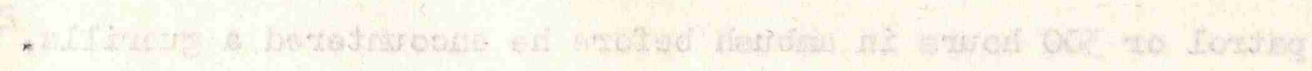

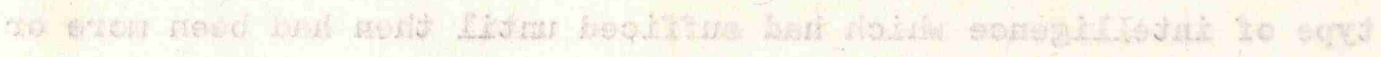

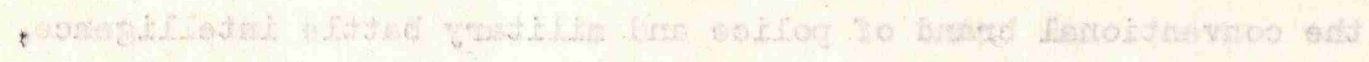

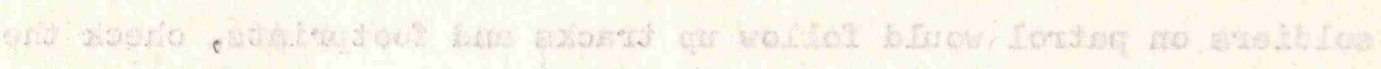

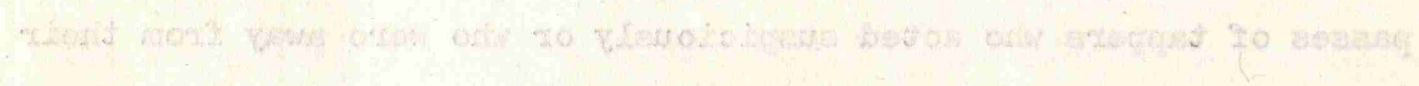

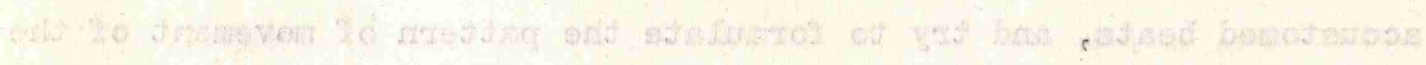

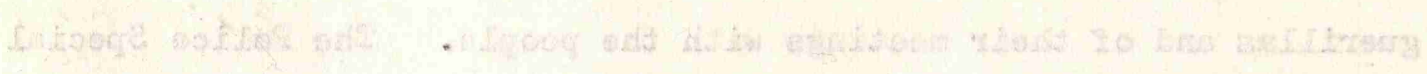

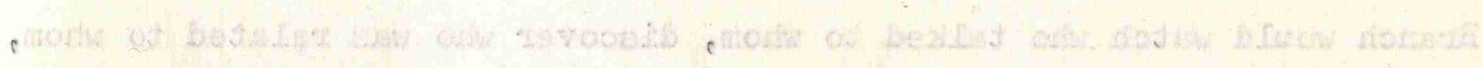

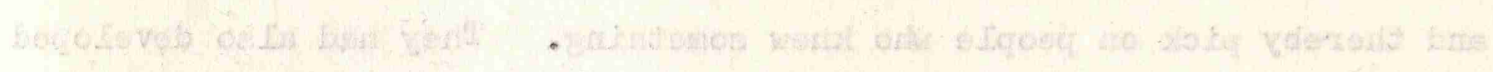

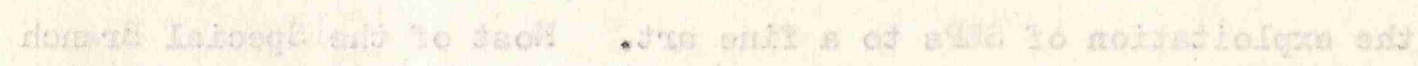

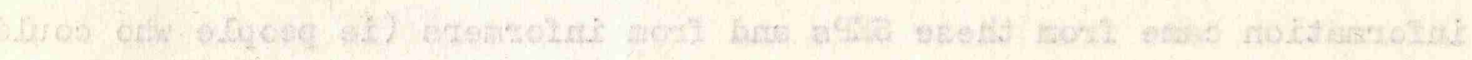

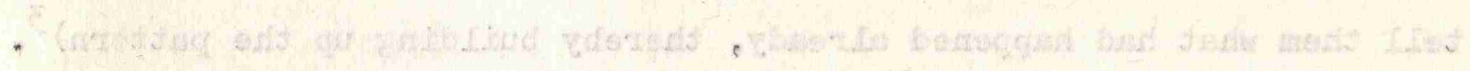

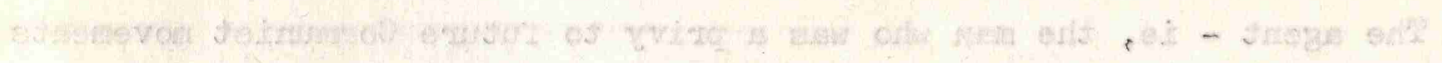

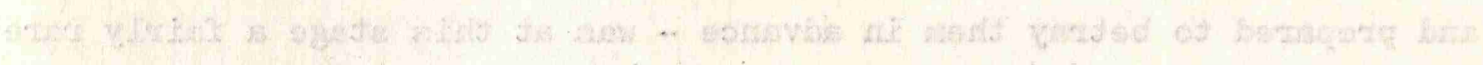

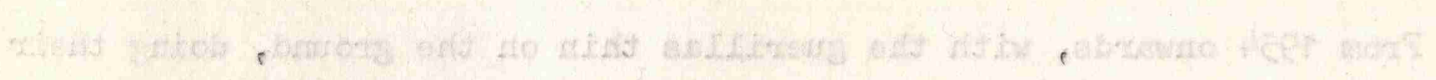

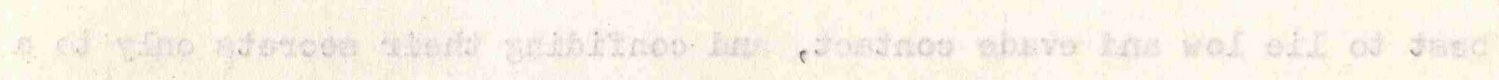

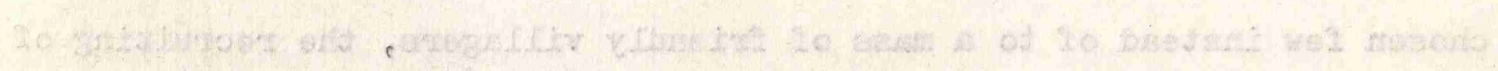

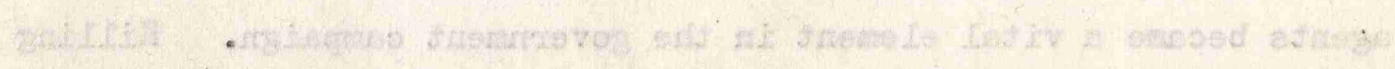

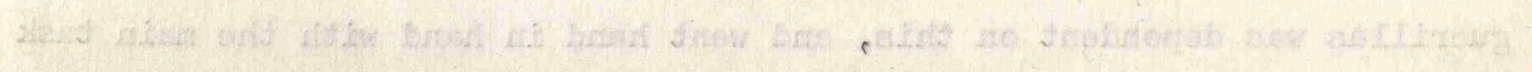


of digging out the Communist roots in the villages. This was to take another 6 years. During these 6 years, both the Communist techniques for survival and the government techniques for acquiring and using intelligence reached a degree of refinement which has probably never been equalled.

\section{Food Denial Operations - Early Attempts}

The method of acquiring and using agents was to spy on the guerillas' contacts with the people, identify those who were in touch with them, persuade a number of these to turn traitor, and so disrupt the rest of the organisation that the guerillas were fairly sure to go on relying on at least some of these people who would in the end betray them by giving "advanee precise information".

Known in intelligence jargon as "turning", this process of suborning people already working for the Communists proved far more effective than attempting to insert police agents from the outside. The latter was sometimes achieved, but it had become less easy than in the earlier days of the Emergency, because the MCP now recruited its guerillas and supporters with greater care, and imposed long probationary periods, in which they were tested and proved before being entrusted with delicate secrets. In any case, newcomers into the system were suspect, since - especially in the later years of the Emergency few people gave active support to the Communists without good reasons eg because they were relatives of guerillas, or because the MCP had some kind of a hold whereby they could be blackmailed. ${ }^{4}$

To select a field for recruitment of agents, Special Branch had to look into the purposes for which the guerillas needed to make contact with the people. In the first years of the Emergency they had dealt 
5 R.J.W. Craig A Short Account of the Malayan

Emergency, unpublished typescript in author's possession, p17, and Special Branch letter Food Control SF/458/2(Y), Kuala Lumpur, 11 May 1954

6 CC Too (Gov) Interview 1968 
with the Chinese rural population in mass, at public propaganda meetings in the rubber estates etc, with no precautions other than the posting of sentries. After 1952, the activities of Special Branch compelled them to confine their contacts to those whose direct support they needed. This support took the form of information, readiness to distribute propaganda, and, above all, supply of food, money, medical equipment, pencils and paper, radios, torches, batteries, clothing etc. And the most vital item of all was rice.

Passive denial of food supplies was not in itself sufficient to bring about, a collapse. Its, value was as a means of creating intelligence. 5 The technique which was evolved over the period 1952-55 was to build up on the general intelligence picture by so restricting and controlling, the flow of supplies - especially of rice - that the suppliers could be identified. Some could then be "turned" and persuaded to give "advance, precise information" such as would enable police and army patrols to be in ambush at, or on the route to, some specific guerilla rendezvous or pick-up point at the right moment.

The restriction of supplies as an operational aid was not itself a new idea. It had been tried as early as July 1949, in Operation SNOW WHITE astride the Pahang-Johore border, when rice was rationed and stocks limited in the shops. The aim at this stage was not to recruit agents, but to supplement normal intelligence by helping the security forces to detect the habits (even if not the identity) of suppliers, so that patrols and ambushes could be better fitted to the likely pattern of their movements. Rationing helped because it gave the timid or reluctant supplier an alibi for not producing anything, so that the hard core had to take greater risks to provide more, and were therefore more likely to be spotted. ${ }^{6}$ This particular operation failed because 
8 See Arthur Campbell, Jungle Green, London 1953

9 Clutterbuck, The Long Long War, pp 51 - 54

10 Brigadier M.C.A. Henniker, Red Shadow over

Malaya, London, Blackwood, 1955, pp 131-2 
rationing only lasted for a month and the guerillas never really felt the pinch. Nevertheless, even at this stage, a number of battalions had begun to appreciate the opportunity offered by the logistic weaknesses of the guerillas and to base their operations on an intelligent assessment of how they, if they were the guerillas would move, eat and camp.? Those who did this were the most isuccessful - notably the Suffolk Regiment. ${ }^{8}$ The pattern of deployment of troops and police which evolved was to allocate most of them to a framework of battalions - mainly split into companies (of about 100 soldiers). Each company was responsible for supporting the police and eliminating the guerillas in the district in . which it lived. Periodically, troops were taken away from their framework operations to take part in larger operations designed to destroy a particular guerilla gang. Up till 1952, however, these big operations had been based on general rather than specific information and had met with little success. 9

The first attempt at a major operation based on the large scale arrest of communist food suppliers was Operation HIVE, in the Seremban District of Negri Sembilan, in the second half of 1952.

It was to some extent fortuitous, in that the newly posted commander of 63 Gurkha Infantry Brigade (Brigadier M.G.A. Henniker) was told that he was to receive a large and temporary reinforcement of troops for two months, and so he and his State War Executive Committee set about deciding how best to use them.

There was at this time a general reaction against big operations in the jungle, and a feeling that it was better to stick to framework operations. $^{10}$ This was a healthy reaction, because troops were generally most effective if left to make steady and unspectacular progress in eliminating guerillas by ambushes and patrols in their own districts, 
C C Too (Gov) Interview 1968.

This predilection for major operations, however persisted amongst some commanders for several more years, see Clutterbuck The Long Long War pp 51-52. It has also been the bane of the life of many regimental soldiers in Vietnam, who have longed to be left to get on uninterrupted with the war around the villages without repeatedly being picked up by the higher staffs and borne away in helicopters to join the throng in some alien area of jungle. (Interviews with It Col G.C. Troy 1967, and interviews and correspondence from Vietnam with It Cols Charles K. Nulsen and Robert B. Osborn,

Director of Operations Tactical Directive No.1 of 6 October 1950, p3. At this period (1950) the strength of the guerillas in Malaya, $(10,000)$ was double that in South Vietnam in 1959-60 $(5,000)$ that is, four times higher in proportion to the population. Had the South Vietnamese Army applied such tactics in its own jungle areas in those early days, the Vietcong main force units might have been cut back, as they were in Malaya, rather than allowed to grow into hundreds of thousands. The fact that the guerillas in Malaya never progressed beyond these early stages was not for lack of trying on their part - Chin Peng's plan was the same as Giap's - but because they were prevented from doing so. See Sir Robert Thompson in his foreword to Clutterbuck, The Long Long War, London, Cassell, 1967, p viii

13 Federal Plan for the Elimination of the Communist Organisation and Armed Forces in Malaya, 24 May 1950, p 1-2, 
where they had got to know the country and the people. Interruption and relaxation of this framework pressure simply allowed the guerillas to make up their losses and reorganise their strained and disrupted supply system, and this had happened all too often when troops were taken away to be thrown into vast sweeps and encirclement operations in the jungle, which killed very few guerillas and did nothing at all to reduce their hold on the people. Indeed, the guerillas were presented with a propaganda point, by being able to claim that the government could not beat them eyen when it turned thousands of troops onto them - the familiar "Paper Tiger" argument. 11

This was appreciated from the start by Briggs, who wrote in a directive at the peak of operations in October 1950.

"A strong section is a match for any bandit gang, especially if it also uses "sting and disappear" tactics. Seldom do more than the first few men get the chance of fire action. Moreover, such section patrols are more controllable, adaptable, less noisy and hence less vulnerable. They are thus more mobile and capable of surprise. ${ }^{12}$

Briggs, as he gained experience as Director of Operations, had begun to get an inkling of the true value of food denial. In his earliest directive, in May 1950, he had spoken of forcing the guerillas to attack the Security Forces on their own ground. 13 This had proved to be a false hope because the guerillas could, and did, lie low for days or weeks on end, provided that they had food dumps in the jungle. In October 1950, therefore, Briggs urged the army to be patient in interdicting the guerilla supply lines, since their dumps must run out before long, and they could then not exist without support from the Min Yuen. This necessitated movement, he said, and it was movement which made them vulnerable to ambush. 15

It was these two tactics - to force the guerillas to make 
Director of Intelligence, Malaya,

Operation HIVE, letter $111 / \mathrm{SF} .46 \mathrm{E}$ of

6 June 1952 p1

$17 \quad$ Henniker, p 132

18 ibid, p 138

19. ibid, pp 134-5

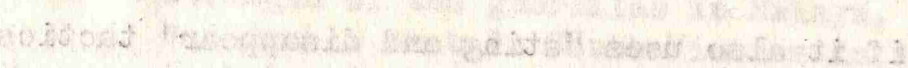


contact with their suppliers and to expose themselves by moving in generally predictable areas - which were at the centre of the plan made by Brigadier Henniker and the Negri Sembilan SWEC to make use of the extra troops they were offered. Operation HIVE was only partially successful, but it did mark a major advance in thought over the conventional military response to the allocation of a temporary reinforcement, and it taught several important lessons.

For the first time, the declared aim of the operation was "to eliminate the armed units (in the MCP District of Seremban) and so to disrupt the MCP Party and Min Yuen structure as to neutralize it for a considerable period". 16

The Seremban MCP District, roughly 25 miles square, was at this time estimated by Special Branch to contain 86 guerillas of whom 31 were in No. 3 Independent MRLA Platoon, and 55 in the District and Branch Organisation. 17

The reinforcement quadrupled the number of troops in the district raising it from the normal framework of three companies to three battalions. $^{18}$

To deceive the enemy during the preparatory stages, a fictitious operation (WHIPCORD) was planned around Bahau, some 40 miles away, for which maps were issued, and a ramp was ordered to be built at Bahau railway station in readiness to unload a large consignment of extra vehicles. 19

Planning for Operation HIVE began in June 1952. Certain areas in the Seremban District were selected as killing grounds, where the army and police patrols and ambushes would concentrate their efforts. There was some discussion as to whether to arrest all known suppliers in the district, or only those outside the killing grounds, in the hope that the guerillas would be drawn into the areas where the ambushes awaited them. 
ibid p $135-6$

21. The SAS was a regiment of hand picked British soldiers, each man selected after a parachute course and intensive tests of physical and mental endurance in the Welsh mountains, and trained to operate independently in enemy territory. They were particularly successful in operating in small. patrols in the remote parts of the jungle.

22 Henniker, pp 142-3

23 ibid p 146

24 ibid pp 147-154 
Eventually, it was decided to arrest all known suppliers which, it was hoped, would force the guerillas to recruit new suppliers in a hurry, whom it would be easier for Special Branch to detect and "turn". 20

Stage 1 of the plan was to establish an outer ring of ambushes to prevent an exodus from the killing ground. Stage II was to ask the normal police informers to advise in which areas the guerillas were operating. Stage III was the arrest of all known suppliers, with the dual aims of obtaining more information and forcing the guerillas to consume their reserve dumps of food in the jungle. This would be followed by a pause Stage IV - in which troops would be rotated for rest while the guerillas were expected to lie low, eating away their dumps. Stage V - the killing stage - would come when their stocks were running low so that they would have to come out of the jungle to seek new sources of food from the villages.

The operation began on 20th August, when one Gurkha battalion with two squadrons of the Special Air Service Regiment (SAS) 21 manned the outer ring of ambushes in the jungle. Intensive searches by patrols discovered 5 or 6 camps, 3 of which were big enough for 30 to 50 men. 22

At the same time, all known suppliers were arrested, 107 of them, including 50 Party members who were Masses Executives. Those arrested also included the ones who were already giving information to the police, as they would otherwise have come under suspicion. As a result, all information dried up, and one battalion was pulled out to rest. 23

On 4th September, the first two guerillas were killed. Soon afterwards a courier was killed carrying documents, and information began to come in from other guerillas who surrendered. In the second month of the operation, as expected, the kill rate rose, and by the time the two months were up and the reinforcing battalions were withdrawn (21 October) total of 25 guerillas had been eliminated - over a quarter of the guerilla strength in the district. 24 
25 ibid pp 137

26 ibid p 187. See also Chapter 12 and Appendix B

27 ibid p 140

28 "Fu" (SB), Interview, 1966 
These were, by any standards, two highly successful months, considering that less than 100 men were being hunted in 600 square miles of jungle. The operation was too short, however, to complete the destruction of the district organisation, which was soon able to recover. It was the solution to this last problem - the destruction of the district organisation beyond recovery - that was to elude the government for 2 or 3 more years.

The operation revealed some loopholes in food control. A good deal of rice was grown in the area, and there had not been the tight control of the harvest that was to be imposed in later operations. Rice dealers were allowed $5 \%$ for wastage - "enough to feed 86 men for a lifetime", and the searching of rubber tappers going out of the village gates to work was not strict enough to prevent the very small leakage required by the Communists. 25

The Malay Special Constables and civilian searchers on these gatechecks were later to be supplemented by British soldiers. 26

Another important lesson from this operation was that, no matter how great the pressure, the guerilla political and logistic organisations (branch Committees, armed work cells etc) did not leave their own areas; first because they dared not abandon their painfully built up food supply lines; and secondly because they were forbidden to do so since their job was to organise and lead the "masses" in their particular area. 27 They could not afford to break the secret and personal links with their masses executives in the villages - which no-one else would be able to take up. Indeed, once "off the hook", most of the supporters used to take good care not to let anyone get them involved again. 28

Operation HIVE was a significant pioneering effort but its intelligence was still largely obtained from informers who knew only of past events and patterns. The operation was not long enough to enable Special Branch to "turn" suppliers into agents, who could give "advance, precise information". 
Capt H.S. Latimer, Notes on Planning Requirements for

Operation HIVE type Operations, 16 January 1953

Waller, Working Papers, p 34

31

It was later found necessary to extend this period to 4 or 6 months 


\section{The Latimer Report}

This weakness was analysed in a brilliant debriefing report on Operation HIVE, by a young Military Intelligence Officer attached to Special Branch, Captain H.S. Latimer. 29 This report was the most important single result of Operation HIVE. It proposed a pattern of operations which was far in advance of its time, and which proved in the end, with only minor improvements, to be the battle winning pattern for the remaining $?$ years of the Emergency. Some of its proposals, however, such as the central cooking of rice in the villages, were not to be introduced for another 3 years. 30

Latimer proposed that Operaptions should be in two phases. In Phase I, to last 2 to 3 months ${ }^{31}$, Special Branch would make a detailed research and analysis of the records of movements and habits of the guerillas and their supporters over the past two years. There would also be a thorough topographical study, and an intense intelligence effort to build up details of the personalities and organisation of the guerillas and their supporters. As the picture took shape, the District War Executive Committee would plan the operations which were to comprise Phase II.

Phase II would begin with a curfew and supply denial scheme, with rationing, restriction of stocks and strict searching of people going out to work. At the same time, food suppliers would be arrested, and, using the mass of information they had built up in Phase I, Special Branch would try to "turn" some of them into agents.

Hereafter, Latimer proposed tactics which were designed to lead the guerillas into killing grounds, which were, in fact, the areas of rubber etc in which prospective agents worked. Everything possible was to be done to drive the guerillas away from the areas outside these killing grounds, by tightening food control and saturating them with patrols and ambushes. Conversely, inside the killing grounds, there was to be judicious relaxation of food control and other regulations, and troops were to be kept out of them. The guerillas would thus be able to move 
Waller, Interview, 1968

33

Waller, Working Papers, p 37

34

Head of Special Branch in Selangor

Notes, 19 June 1953

35

Operation HAMMER, letter S.B. SEL.

TS/GEN/39/18 of 21 March 1953

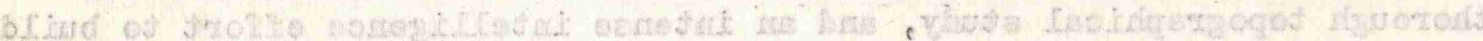

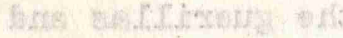

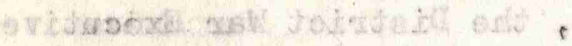

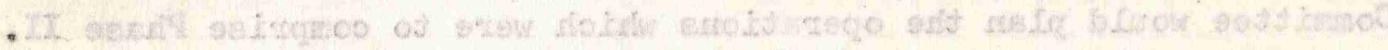

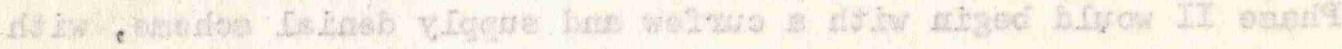

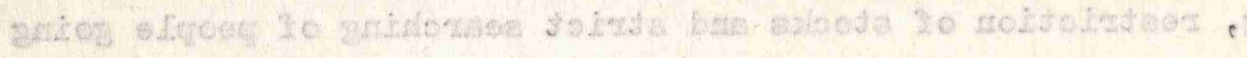
abreses

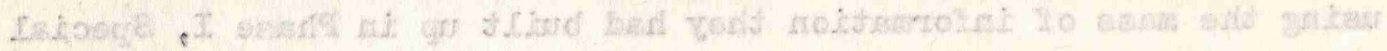

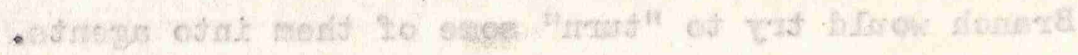

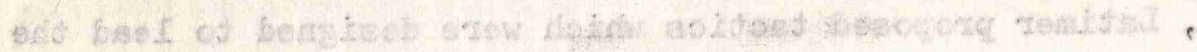

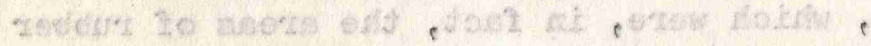

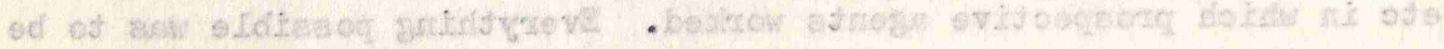

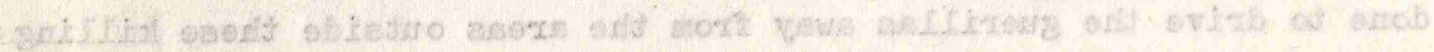

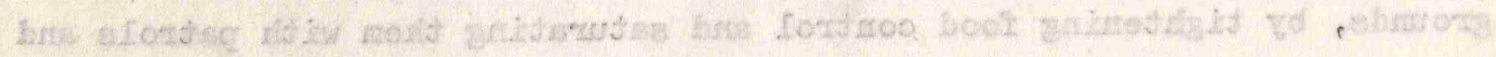

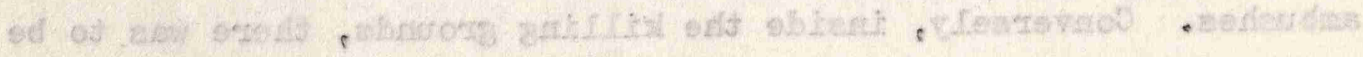

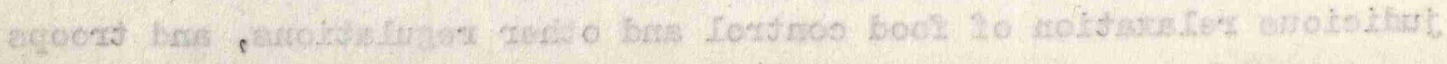

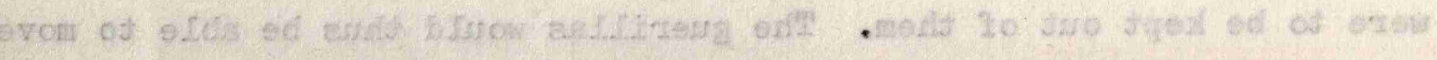


freely and to acquire confidence in the suppliers who operated in the killing grounds, including the ones who had been "turned". This would lead to "advance, precise information" on which individual ambushes could be laid.

Latimer's ideas were not fully understood or applied for some years, but to him must go, the greatest credit for the solution of the problem of "digging out the roots". 32

\section{Impraving the Pattern}

Meanwhile, as Operation HIVE concluded, another operation HAMMER - was launched on similar lines in the State of Selangor. Various improvements were made, and 44 guerillas were eliminated over half of them being SEPs. 33 The District, however, contained five branchęs, of which only two were attacked. Though disrupted, they were not destroyed. The operations proved that it was of little permanent use to attack anything less than a complete district in this way, since the District Committee was able to survive on the support of the branches which had been left intact, under whose cover it could rebuild the others by calling members of the Masses Organisation into the jungle to become guerillas. This is precisely what happened within a few months after Operation HAMMER. 34

Another conclusion was that, since the guerillas normally stockpiled at least one month's food, operations would have to last for at least three months if food denial was to be really effective. (It was later found that even three months was not long enough).

The post-mortem on Operation HAMMER also underlined importance of civil police and military cooperation, and concluded that the army must be prepared to go for weeks without a contact by operating in areas where there was no information simply to keep the guerillas out of them so they would make touch with their supporters in other areas where Special Branch wanted them. 35 


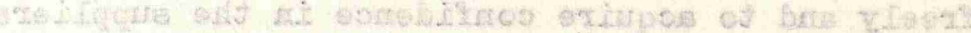

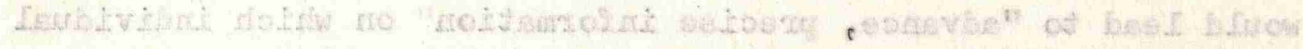

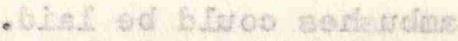

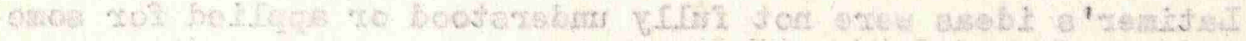

36 Waller, Working Papers p 41

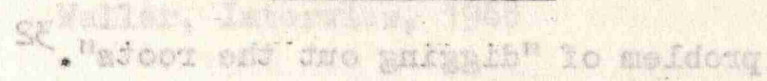

37 High Commissioner Minute No. 2516 of 5 January

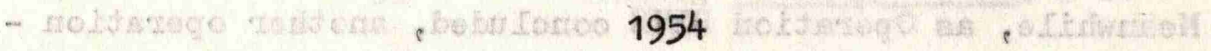

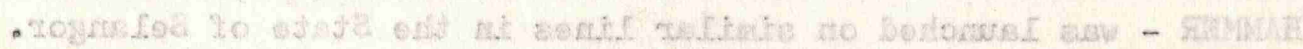

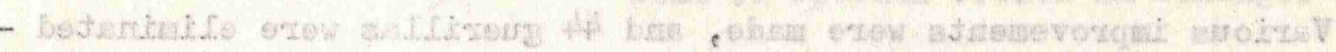

9vic $\quad 38$ Speoial Branch letter, Food Control,

Vetif $\quad$ SF/458/2(Y), Kuala Lumpur, 5 Feb 1954

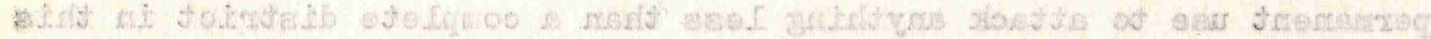

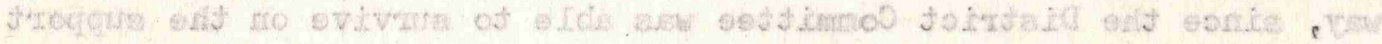

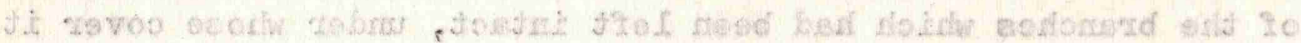

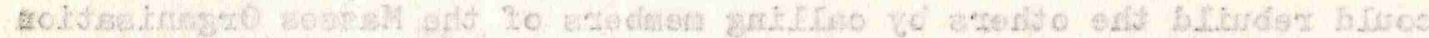

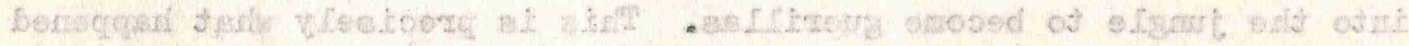

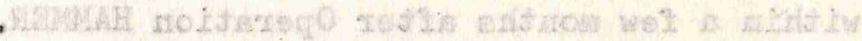

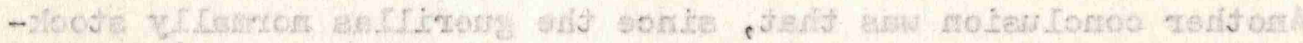

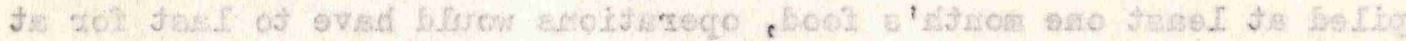

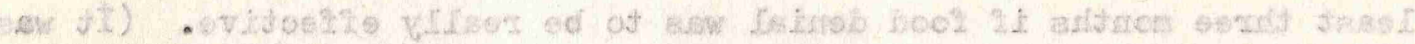

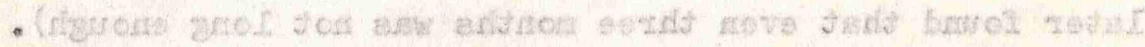

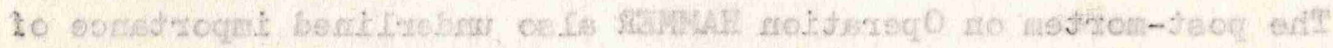

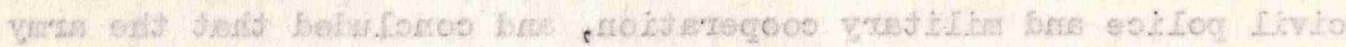

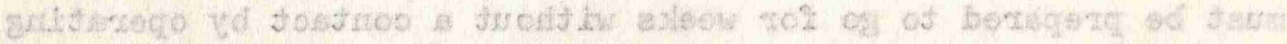

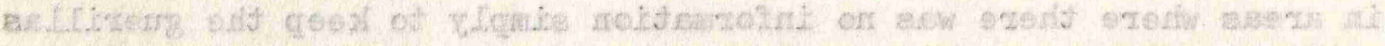

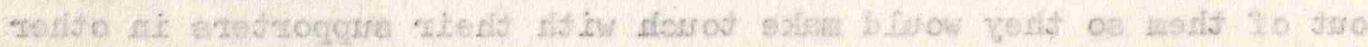


With the experience of Operations HIVE and HAMMER, and of three other concurrent operations in the State of Pahang, General Templer issued two instructions. The first dated 6th August 1953, was Director of Operations Instruction No. 28, The Coordination of Special Branch Projects with Security Force Operations. It laid down that the MCP District should be the normal target, but dealt largely with detailed procedures, without mentioning operational phases. The second, No. 29, Food Denial Operations, also dealt with procedures, but visualised the primary purpose of food denial as starving out the guerillas, and largely overlooked the more important dividend of intelligence. 36 Both were far behind Latimer's report in their thinking.

Meanwhile, it appeared that Templer himself was not as yet convinced of the value of operations aimed primarily at the MCP District. In January 1954 he wrote.

"The penetration that really matters is on the state level and above. A simple food supplier will never lead us higher than Branch Committee level, except in very exceptional cases when we might be lucky enough to get to District Committee level ... Most, though not all, of the people thus eliminated will be comparative chicken feed. 37

The Head of Special Branch commented as follows: "Elimination of what H.E. has referred to as "chicken feed" are thoroughly worthwhile. They are the early dividends of a well directed D of Os I. No 28 operation. When the "chicken feed" has been eliminated, the ranking CTs have to do their own food collecting. This should force them to expose themselves in our chosen killing groundso" 38

and a senior officer in his headquarters wrote a few months later "Food denial is a means to an end (to get at the Min Yuen operatives with a view to eliminating them)... 
39 Special Branch letter, Food Control, SF/458/2(Y), Kuala Lumpur 11 May 1954

40 Waller, Working Papers, p 40, supplemented by Interview 1968

41 The first White Area had been declared in Malacca by General Templer in 1953 - See Chapter 9 
the MCP, and we ourselves, both know that the MCP control

of the masses is the key to the Emergency". 39

But this was by no means the whole story. The real lead into the higher guerilla headquarters and MRLA platoons came not so much through their having to collect their own food as through betrayal by surrendered guerillas from the Districts and Branches who had been responsible for obtaining their supplies from the people and passing them back into the jungle, and by couriers who knew the way to the State, District and MRLA camps. In the operations described, the troops had found it a waste of time to lie in ambush for these tiny HQs and platoons in the deep jungle, using only guess work and without "advance precise information". There was little hope of getting such information from the arrested village suppliers, simply because they never met the higher HQs and MRdA units. Special Branch HQ in Kuala Lumpur was therefore beginning to think in terms of an exploitation Phase - a Phase III - in which the SEPs who had come in during Latimer's Phase II would give "advance precise information" about the movements of the higher HQs and MRLA platoons. 40

This hope was realised with devastating effect between 1953 and 1955 in a series of highly successful operations in Pahang, which eliminated $80 \%$ of the guerillas in the State, enabling Emergency restrictions to be lifted over a large part of it, which was declared a "White Area". 41

It was during these years that the pattern conceived by Latimer was refined and proved. 


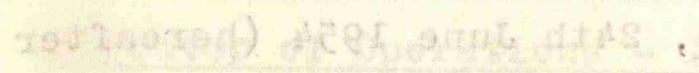

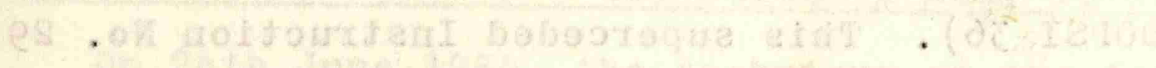

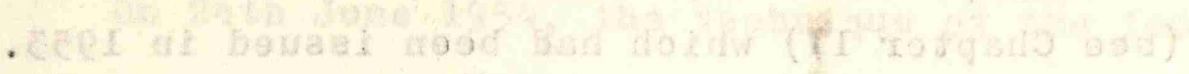

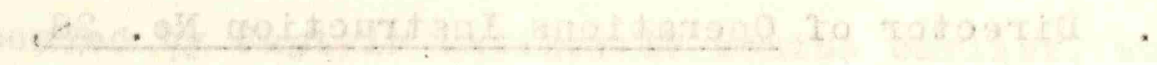

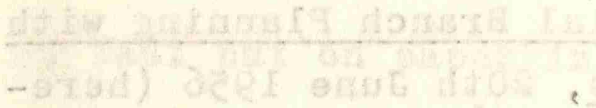

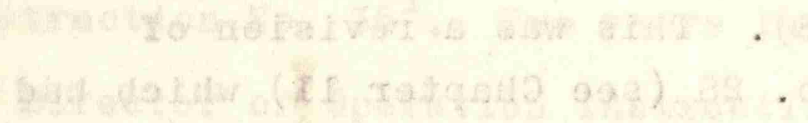

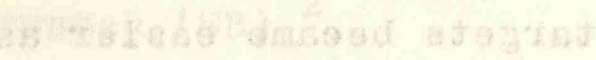

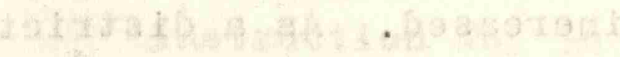

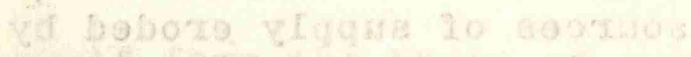

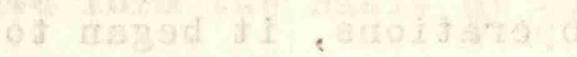

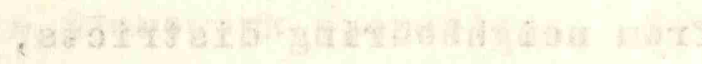

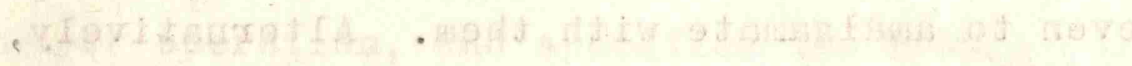

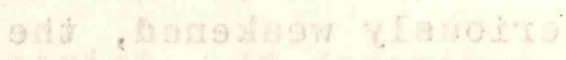

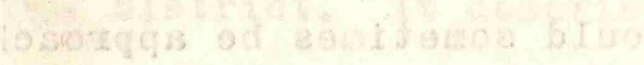

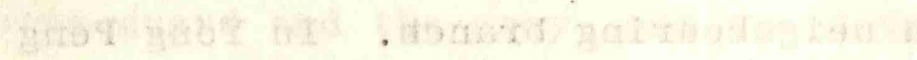

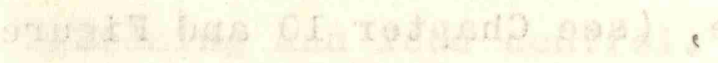

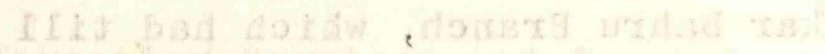

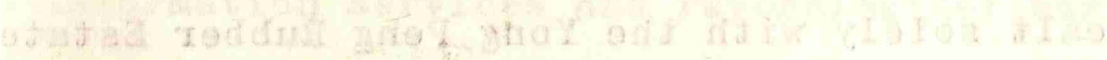

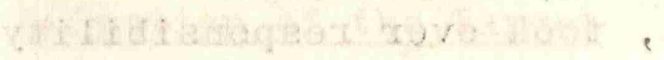

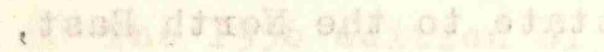

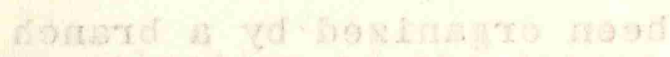

- Lmoo 
1. Director of 0perations Instruction No. 36, Food Denial Operations, 24th June 1954 (hereafter DOPSI 36). This superceded Instruction No. 29 ( see Chapter 17) which had been issued in 1953.

2. Director of Operations Instruction No. 28, The Coordination of Special Branch Planning with Security Force Operations, 20th June 1956 (hereafter DOPSI 28). This was a revision of Instruction No. 28 (see Chapter 11) which had been issued on $6 \mathrm{th}$ August 1953.

3. Leads into neighbouring targets became easier as the pressure on the MCP increased. As a district or branch found its sources of supply eroded by successful framework operations, it began to seek fresh sources from neighbouring districts, or even to amalgamate with them. Alternatively, if one branch were seriously weakened, the Min Yuen in its area would sometimes be approached and led by a neighbouring branch. In Yong Peng District, for example, (see Chapter 10 and Figure 10F) the Kangkar Bahru Branch, which had till then dealt solely with the Yong Peng Rubber Estate to the South West of it, took over responsibility in 1956 for the Paloh Estate to the North East, which had previously been organized by a branch in a neighbouring district. "Kim Cheng" (Com). Interview 1967. 


\section{CHAPTER 12}

\section{THE FINAL PATTERN}

\section{Director of Operations - Instructions Nos. 28 and 36}

On 24th June 1954, the technique of the federal priority operation, incorporating all of the ideas. propounded byy Captain Latimer 18 mọnths earlier, was at last put on paper in Director of Operations Instruction No. $36^{1}$. Two years later, a revised edition of Director of Operation Instruction No. 28 was issued, describing the pattern and techniques used by Special Branch (SB) ${ }^{2}$.

Instruction No. 36 laid down that food control should form the basis of operations both in priority and in framework operations. It outlined the phases of a major operation, and specified the normal target as one MCP District. It described the tasks of the police, the home guard and the army, and the detailed procedures for rationing and food control. It also defined tasks of the Information Services and Psychological Warfare Section.

\section{Selection of the Target}

The 1956 edition of Instruction No. 28 began with the selection of the target. It stressed that it must be a district in which the MCP had contact with the masses, so that SB penetration of these masses could lead back to the guerrillas. It said that the destruction of the district must provide leads towards another important target, and that, if possible, it should be one whose discuption would assist a penetration project. ${ }^{3}$ 
4. Police Operátion Instruction No. 1 (OP SHOE) Ist July 1957, Annex A to Appendix E.

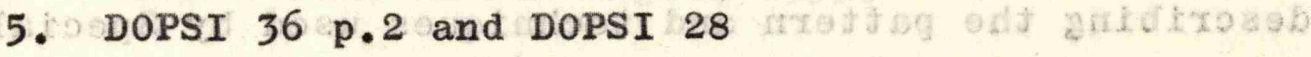

6. In practice this was more often 4-6 months see, for example, Operation COBBLE in Appendix B. Also Craig, p.18. 
This sometimes necessitated more complete operations, overlapping several districts. In the final operation against Yong Peng District, for example, two other districts, both somewhat disrupted, were also incorporated in the target. ${ }^{4}$

Normally, however, a single MCP district remained the target.

\section{Outlines of Phases}

Phases were described as follows. 5

Phase I: A preliminary period of one to three months in which intelligence is built up. 6

Phase II: The beginning of the operation itself, with an intensification of food control and Security Force (SF) pressure。

Phase III:The exploitation of the enemy's loss of morale and increased flow of intelligence by SF ambushes, patrolling and attacks on camps. Food control, hawever, is not. relaxed.

\section{Phase I - Acquiring Agents}

The SB plan began with an area sürvey. The first part listed the estates, inhabited localities, village populations (broken down into races) communications and topographical features. The second part listed the record of MCP activity, with all available data about guerrilla units, camp sites, habits, contacts with the people and terrorist incidents over the past year. 


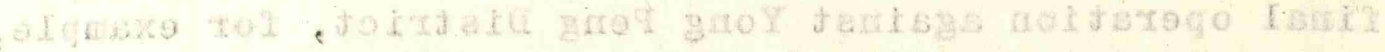

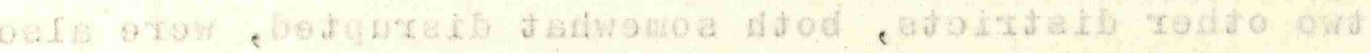

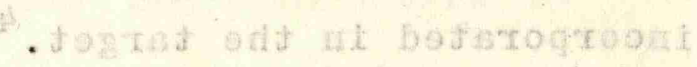

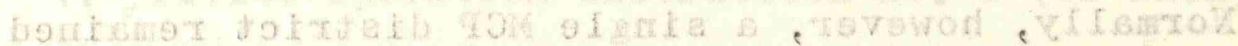

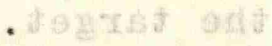

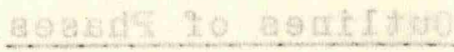

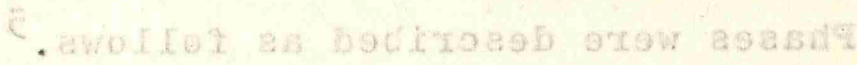

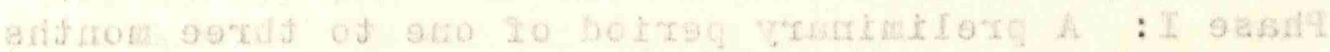

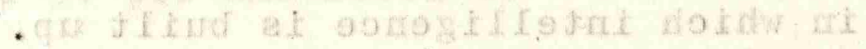

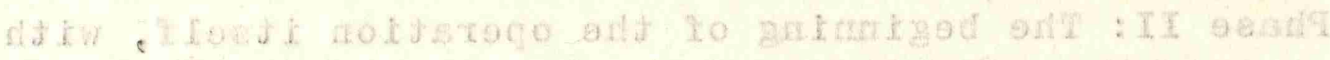

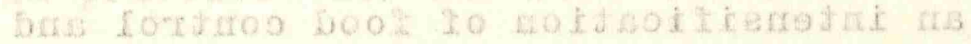

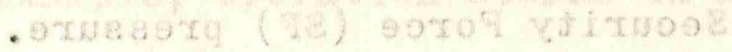

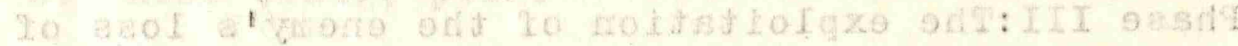

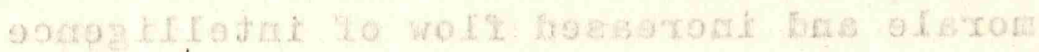

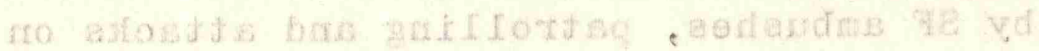

7. Working Papers, Waller, pp. 66-71, .59285152

8. DOPSI 28 p.3

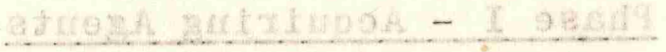

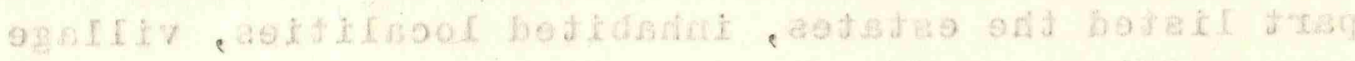

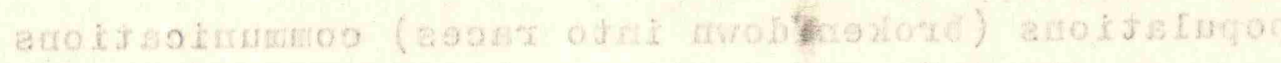

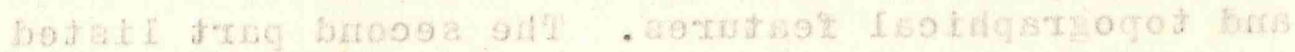

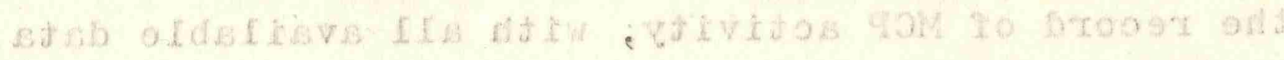

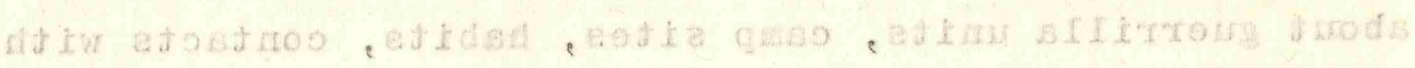

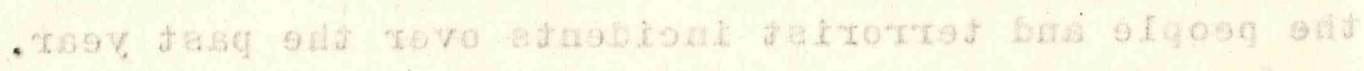


This was followed by a list of all guerrilla personalities and a study of their relatives and friends. A special search was made for any avenues which might provide the basis for an intelligence project against an individual - e.g. particular tastes in tobacco or drugs or links with girl friends.

A similar study was made of the Masses organization, looking for clues as to the pattern of the cells, their contacts and their responsibilities. Leads to individuals were again particularly sought. Sources of the materials needed by the guerrillas were also analysed - e.g. food, medicine, stationery, clothing, rädiós, watches and - oddly important - DóM Benedictine, which was very popular in the jungle.

A "Black Register" was prepared listing the names of suspected waverers, and of any of their relatives whom SB might approach and persuade to induce a surrender. 7

During this phase, the Security Forces had the task of provoking intelligence where SB knowledge and intelligence were inadequate. 8 Their operations were generally designed to force the guerrillas to resort to areas in which SB hoped to acquire agents. Military activity was excluded from certain "Frozen Areas" to allow the guerrillas unmolested contact with supporters who were either already in touch with SB, or whom SB thought that they could "turn" later. These were the potential killing grounds for Phase II. 
9. Craig, p.18

10. "Harris" (SB), Interview 1967.

11. Craig, p.18 and Waller, Working Papers, pp.72-73

12. Waller, Working Papers, p.73 
At the same time, the troops patrolled other areas intensively (often with no hope of contacts) to help to ensure that the guerrillas used the Frozen Areas. 9 Thrusting military commanders, seeking more fruitful action to boost the morale of their soldiers, were firmly restrained from precipitate action in Frozen Areas, which could compromise an agent who was likely to yield much greater dividends later. 10

As the pattern of study and patrolling gave indications of promise, SB made a number of selective arrests of persons with suspected Communist connections, in fairly small numbers, usually about 30 at a time and conforming to no apparent pattern. These arrests included some who were already SB agents, as they would otherwise have come under suspicion. Some of those arrested were quickly "turned" and released; others, who could not be turned, were kept in detention. 11

In some cases, a suspect who could not be arrested because of insufficient evidence was "blackened" instead. This was done by frequent overt enquiries about him by the detectives in the village, and by summoning him at intervals to the police station. This had the effect either of making the guerrillas or MEs frightened of using him, or making them so suspicious of him that he had to flee the area. 12

Victims for arrest were selected on two main considerations - evidence that they were in touch with the guerrillas, and evidence of their vulnerability to 


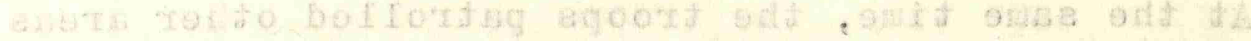

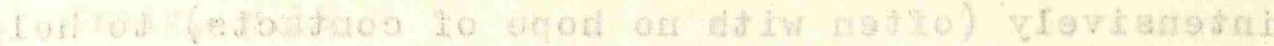

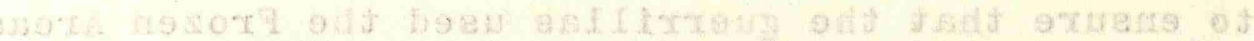

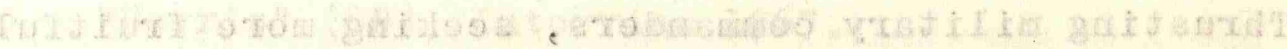

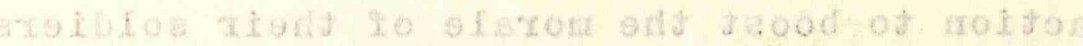

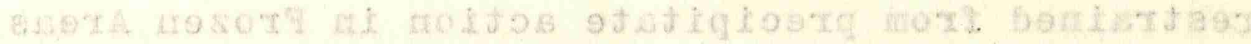

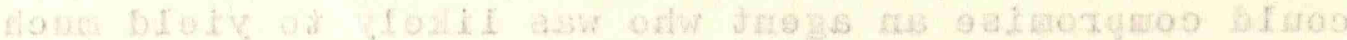

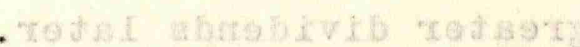

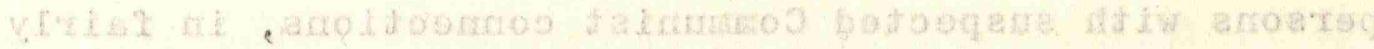

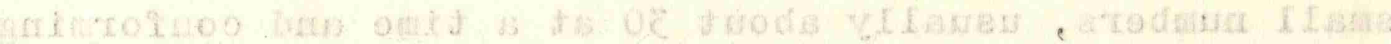

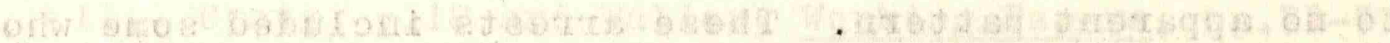

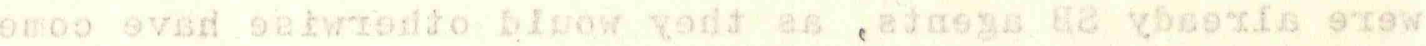

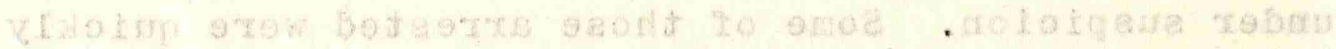

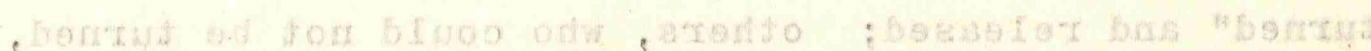

13. "Fu" (SB) Interview, 1967.

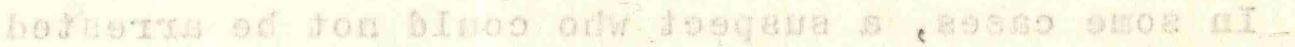

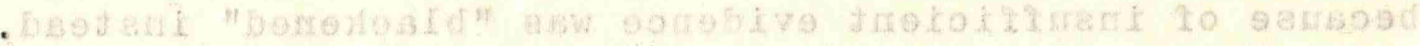

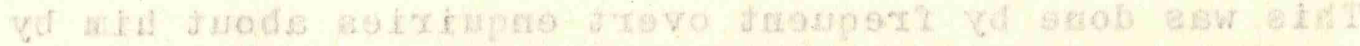

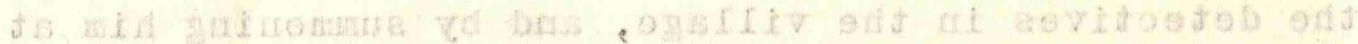
14. "Ramathan" (SB) Interview, 1966.

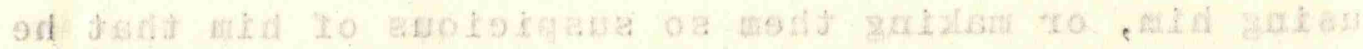

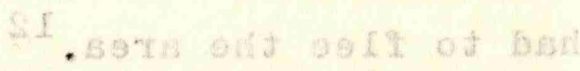

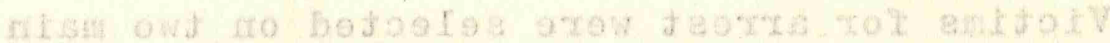

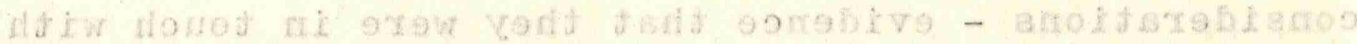

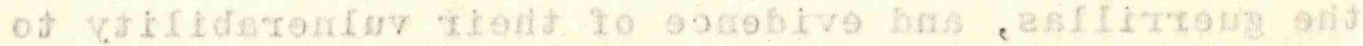


persuasion. The evidence of involvement was often gained only after the hardcore MEs had been detained or compromised, so that the guerrillas were forced to rely on their weaker supporters, often having to coerce them to take risks which they were reluctant to take. Many of the best leads came through relatives, some of whom could be persuaded that the best way of getting their sons or nieces or cousins off the hook was to put them into the hands of the SB Inspector, who could promise that if all went well there would be a big reward, whereas to continue to be mixed up with the guerrillas could lead only to imprisonment or death in the end. Another useful lead was for the SB detective in the village to make friends with the shopkeepers to see which families bought extra food. While rice was rationed, some of more perishable cereals. (such as biscuits or Quaker 0ats) were not, and the family might be passing its rice into the jungle and living on the more perishable substitutes at home. 13

The process of "turning" was usually a mixture of blackmail and bribery (though some of those arrested were so relieved at the prospect of getting off the hook that they needed little persuasion). The likeliest victims were those "in a spot" - for example, who had embezzled party subscriptions or were in love with a girl whose father was a guerrilla ${ }^{14}$ Sometimes, a more refined form of blackmail was used; instead of the supplier himself, one or two of his close relatives, his wife or his sweetheart were arrested. When he came to plead for them he was blackmailed into co-operating with Special Branch - 


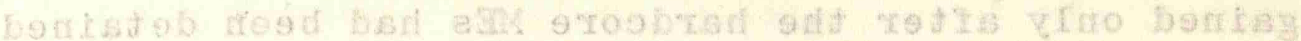

15. Waller, Working Papers, p.35. A number of detailed examplés of the recruitment of agents, are given in Clutterbuck's The Long, Long War, pp. $95-100$.

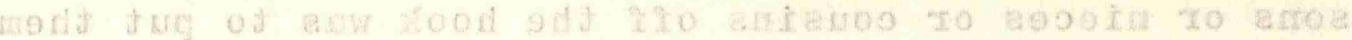

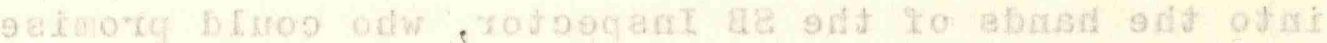

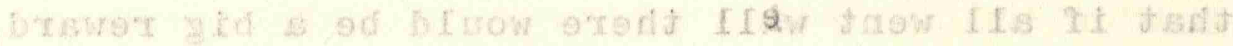

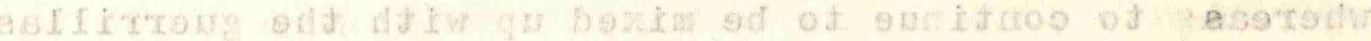

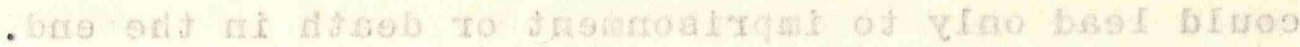

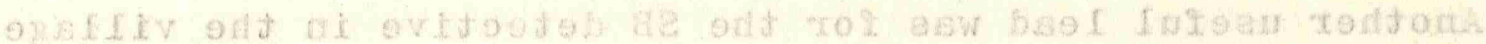

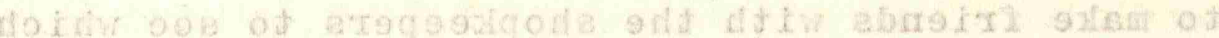

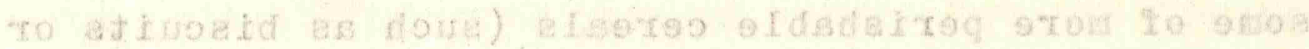

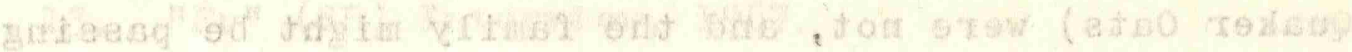

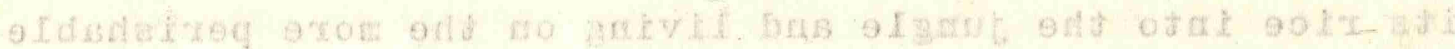

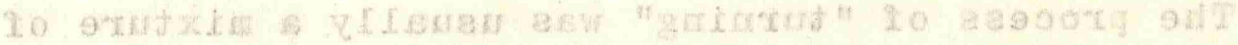

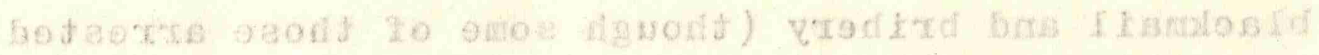

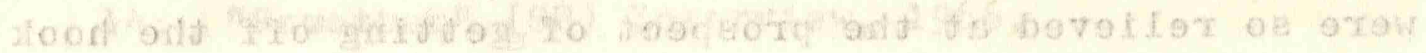

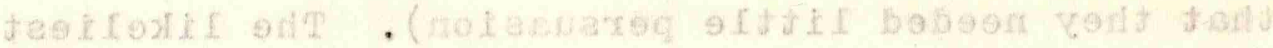

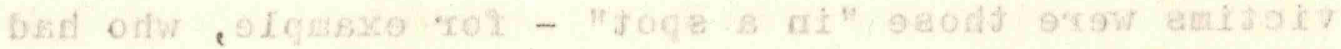

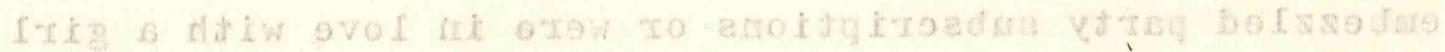

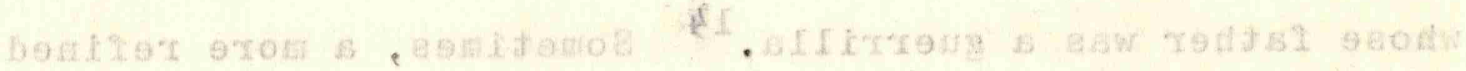

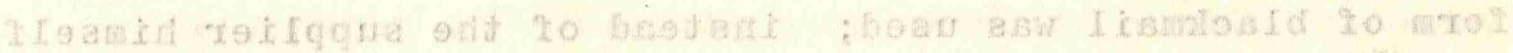

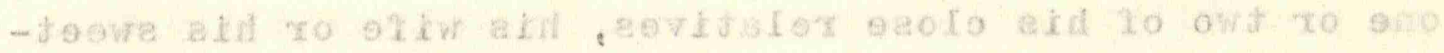

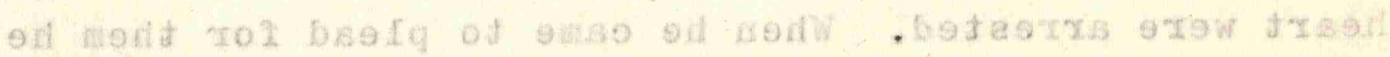


a nasty strategem, but not as nasty as some of the methods of coercion used by the MCP. 15

As a result of all this activity, the SB Appreciation classified the various estates and villages in two respects :

a) The degree of development and activity of the Masses Organization:-

R. Red Areas (much activity)

G. Grey Areas (little activity)

W. White Areas (no activity)

b) Special Branch cover:-

1. Sources in direct contact with SB.

2. Other cover

3. Cover undeveloped

Based on these assessments, they planned in Phase II to impose food denial in varying degrees of severity:

A. Normal, but with special relaxations at $S B$ request (i.e. to exploit or develop sources)

B. Normal

C. Maximum - with central cooking, strict denial of contact between guerrillas and people, and a food search programme.

Thus, the most promising areas would be designated "Rl.A" (i.e. much underground activity, agents in direct contact with SB, and flexible food denial) and these were the potential killing grounds.

In some cases, during Phase I, killing grounds were divided into "Short Term" (where current SB projects were in progress, Security Force action was frozen, and food denial discreetly relaxed) and "Long Term", (planned as 


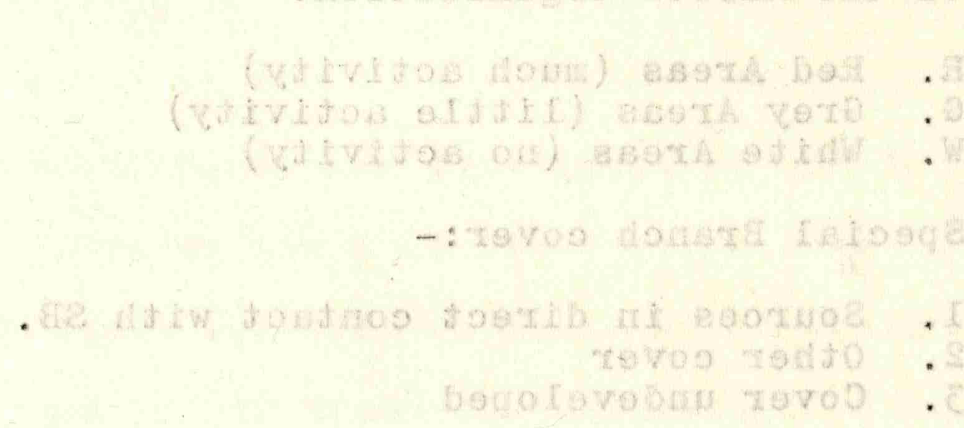

: Wf

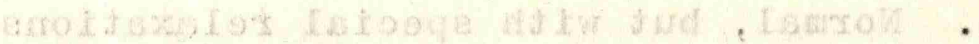

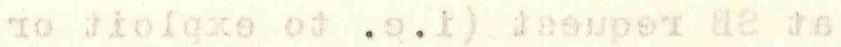

16. Special Branch Appreciation for Phase 2, Operation TIGER Johore Bahru, April 1958 
potential killing grounds in Phase II). The exploitation of a short term killing ground during Phase I of a typical operation ( $C O B B L E$ ) is described in Appendix $B$. An example of the degree of cover achieved by Special Branch when this type of operation had reached its peak of efficiency can be taken from Operation TIGER in the hard core Pontian MCP District of South Johore, in April 1958. At the end of Phase I, Special Branch had agents in direct contact with the guerrillas in 8 of the 9 villages and estates with which the guerrillas dealt. Penetration was so good that it was decided that no security force action would be needed in Phase II other than the provision of ambush or raiding parties when specifically required for an SB project. This, however, was exceptionally good cover. At the same period, first-grade cover was available in only 3 of the 10 villages and estates serving the neighbouring branch Senai Branch. 16

Towards the end of Phase I, SB made a detailed appreciation of the guerrilla and masses organization and finally selected the killing grounds. They then confirmed the plans for Phase II, including details of the mass arrests to be made on D Day.

Phase II - D Day

As D Day for Phase II approached, extra troops and police reinforcements began to move into the area, and there was noticeable activity in the repair of village perimeter fences, the installation of perimeter lighting and clearance of undergrowth around villages and along 
17. In preparation for Phase II of operation TIGER, $\$ 130,000$ was spent on improving perimeter fences and lighting.

18. Craig, p.19. An example of such a deception plan was given in the account of operation HIVE in Chapter 11. 
the sides of roads. 17 Though wherever possible only preparatory work was doen before D Day, some increase in activity was inevitable and could not fail to be noticed, so a deception plan was essential to confuse the guerrillas and their supporters as to the timing, the geographical focus and the extent of the forthcoming operation. 18

On D Day, the first event, usually before dawn, was the simultaneous arrest by SB of all known members of the Masses Organization in every village serving the target MCP District - excluding only those who had. already been established as agents, and certain others who did not know that they were suspected but whom SB believed might become agents if they were left on the ground. Deprived of the majority of their working supporters, the guerrillas would eventually come to rely more and more on these agents or potential agents.as suppliers or be forced to recruit new ones, many of whom would be reluctant and unreliable.

Some agents and informers were arrested at the same time, usually at their own request, in order to reinforce their cover stories when they were later released. A number of other people, who were in fact known to be innocent, might also be arrested and later released as part of the cover plan for the agents. Others were arrested for "turning", others for interrogation and release with a view to "turning" later if they resumed contact with the guerrillas, others released and "blackened" and others held for prolonged detention - just as has 


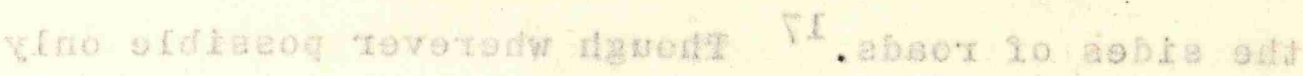

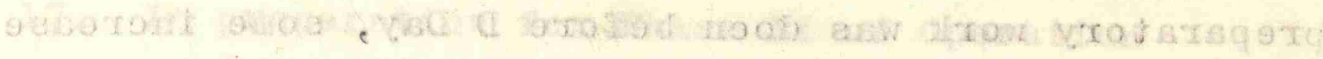

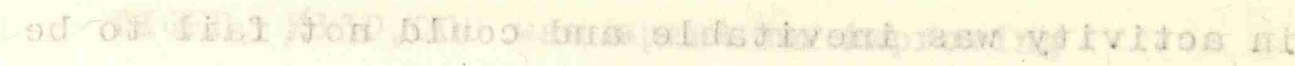

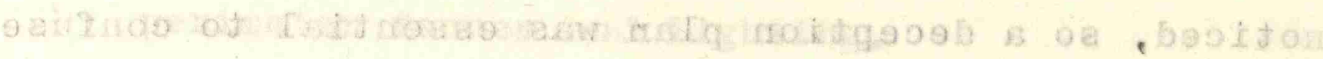

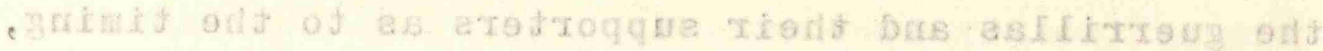

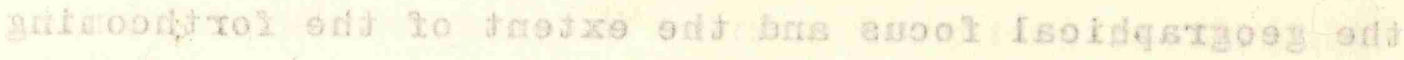

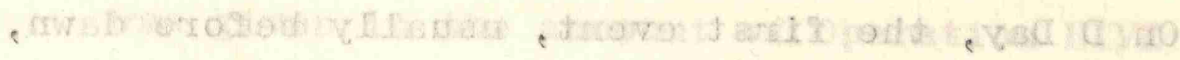

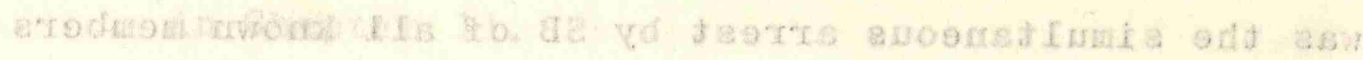

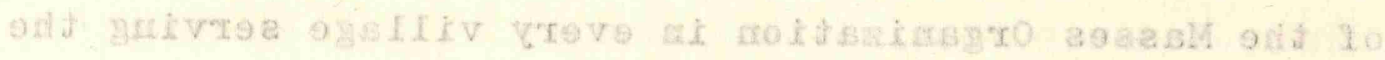
19. Waller, Interview 1970 - toivdeid 907 jog

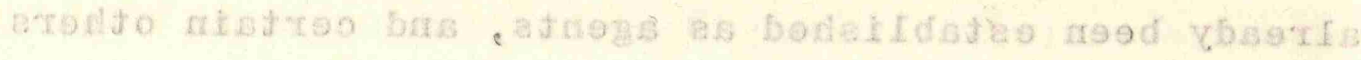

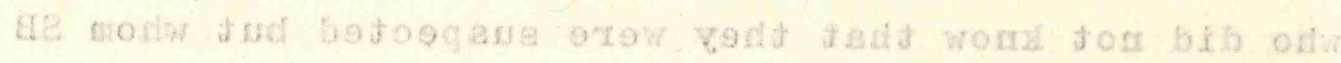

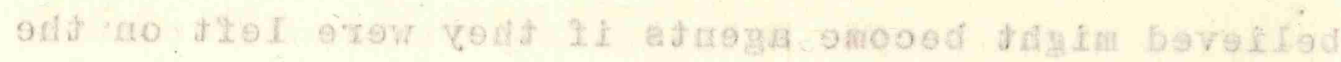

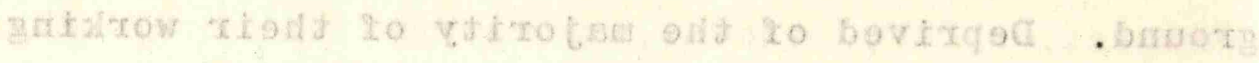

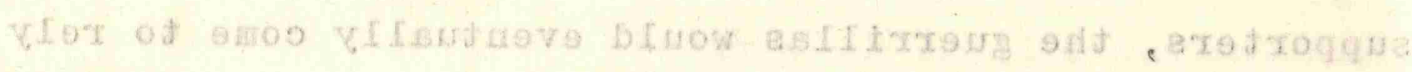

20. 99 Gurkha Infantry Brigade Operation Instruction No. 48, Johore Bahru April 9, 1958

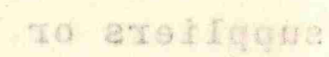

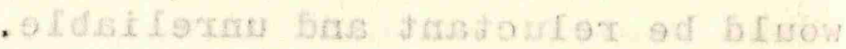

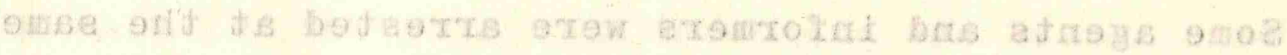

21. Police, OP SHOE, Appendix C.

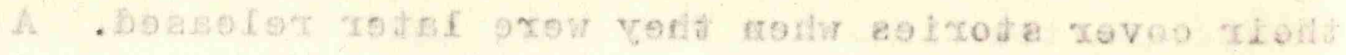

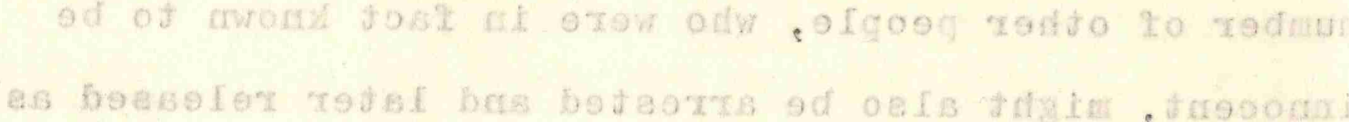

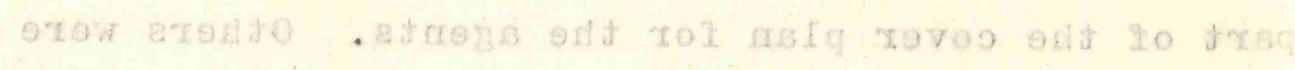

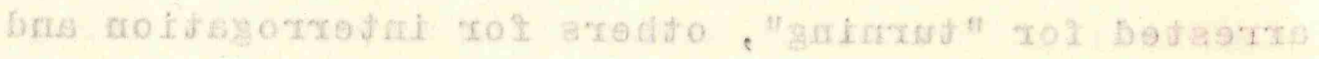

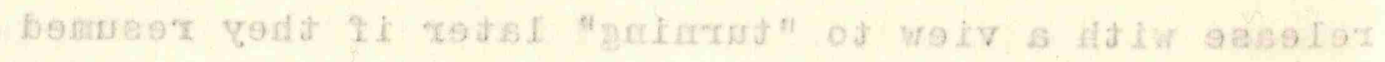

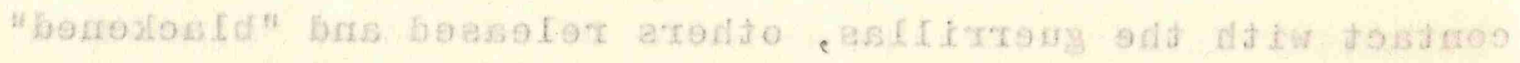

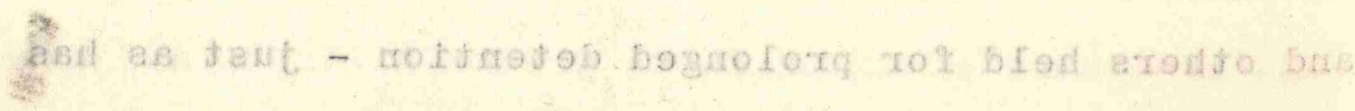


already been described during Phase I.

At the same time, strict food denial was imposed on the whole area except for specific and discreet relaxations required by SB. Every house was searched for surplus stocks, and the stocks in food shops reduced to the permitted level. The rice ration was reduced to the bare minimum, normally 3 or $3 \frac{1}{2}$ katties ( 5 lbs) per week per adult male and less for women and children. Alternatively, in some villages, no rice was allowed at all except that cooked in communal kitchens. This was perishable and the people could therefore buy as much as they liked, so central cooking eventually became quite popular. 19

Reinforced search parties were placed on every village gate. In operation TIGER (South Johore), for example, 341 gates were manned, requiring a reinforcement of 1100 police and six platoons of Home Guards in addition to the 2300 police who were already there. 20 In operation SHOE (Yong Peng, Labis, Paloh Districts), 1473 police (including 218 women) manned 109 gates in 47 viflages - an average of 13 to 14 pe $r$ gate. ${ }^{21}$ They operated at full strength in the early mornings and afternoons when the people went out to work and came back, and on a shift system of 2 or 3 men in between. On D Day, or within a few days afterwards, every village was visited by an Information Services Team, to announce the operation, explain about food rationing and other restrictions, and to urge co-operation in 


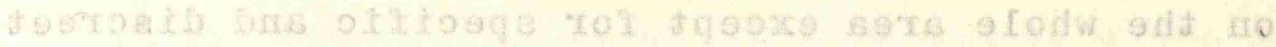

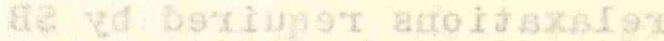

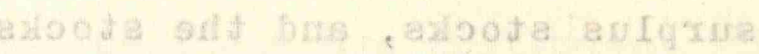

22. Perak State War Executive Committee Operation Order No. 1 Op GINGER, Ipoh, 13 December, 1957

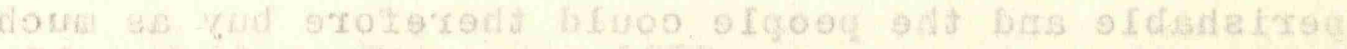

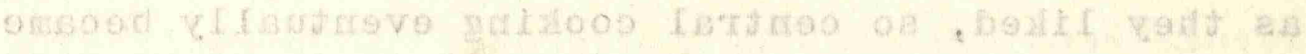
- xs lisuog gitup

23. Waller, Interview 1970 .

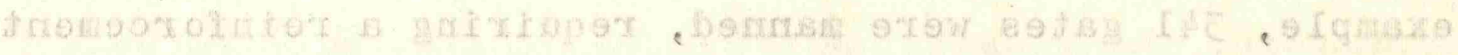

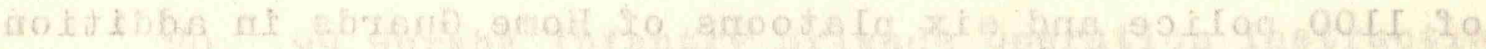

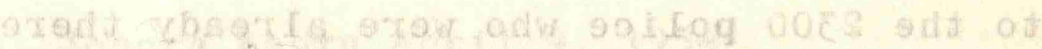

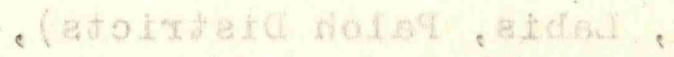

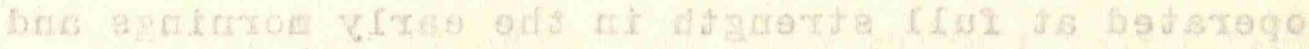

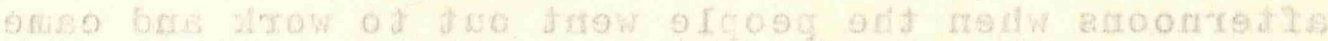

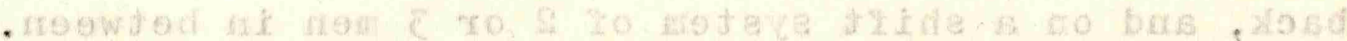
$Z^{2}+589$, $0 \neq$ e 10502

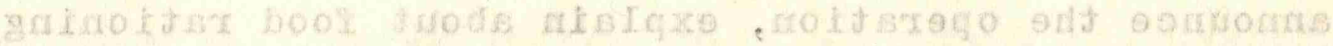

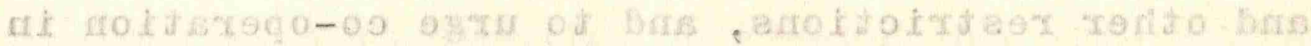


order to complete the operation as soon as posible. In Operation GINGER in Perak in 1948, for example, where there was a rural population of $125,000,2$ Information officers and 6 mobile loudspeaker vans were allocated for the operation as a whole, but 26 additional mobile vans were allocated for the first week of Phase II. In addition, there was widespread use of leaflets, posters, film shows, SEP tours, drama troops and prominent speakers. 22

Visiting speakers and information officers were given talking points, which were also used in the form of scripts for the loudspeaker vans. These scripts outlined the purpose of food denial, and stressed that it would continue until the $\mathrm{MCP}$ in the district was destroyed; promised immunity from prosecution for those who gave information quickly; explained how to give information discreetly and listed the rewards for doing so. After Malaya became self-governing, (1955) and then independent (1957) the scripts stressed that the MCP was now fighting a government elected by the people, and gave convincing proof of the general hopelessness of the Communist cause - a telling point with the pragmatic Chinese. 23

Psychological warfare was also stepped up, in co-operation with SB. Leaflets were dropped in the jungle, and voice aircraft flew over it broadcasting personal messages from SEP's, and from the relatives of guerrillas. People were persuaded to forward letters to friends and relations in the jungle, guaranteeing good treatment, and giving details (with photographs) of the 
24. Perak SWEC, Psychological Warfare, Draft operational Plan, Op GINGER, I poh, December 1957.

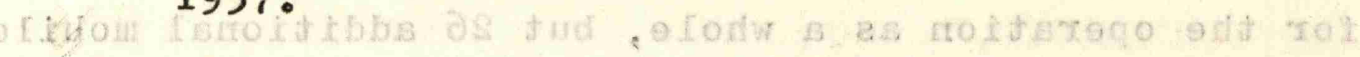

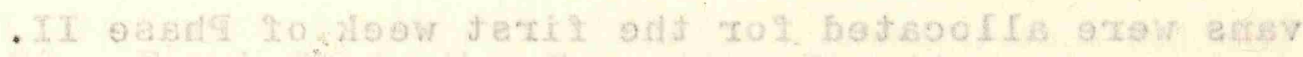

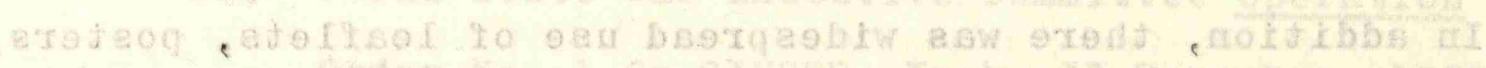

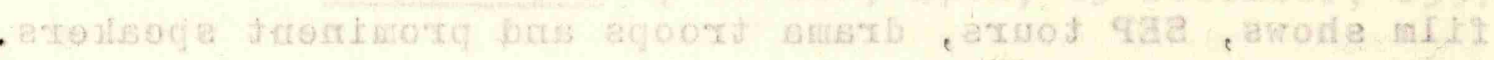

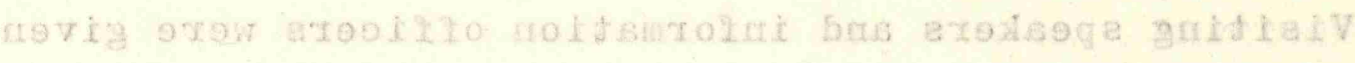

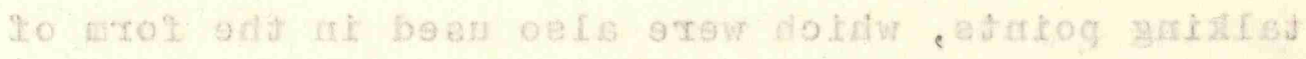

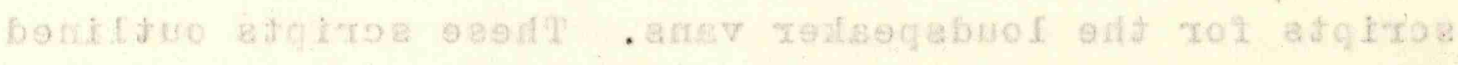

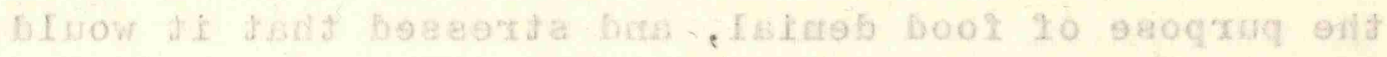

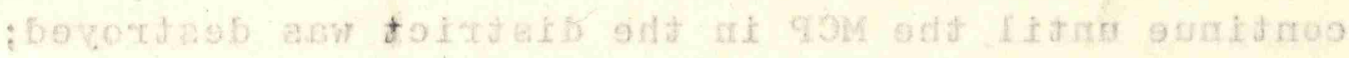

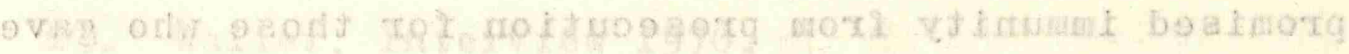

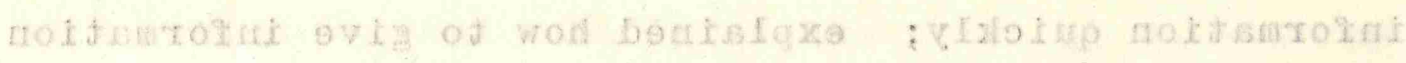

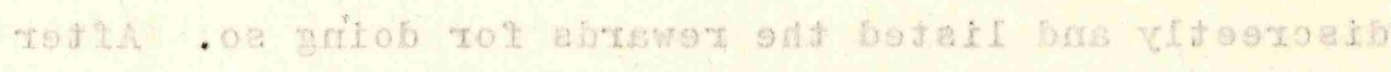

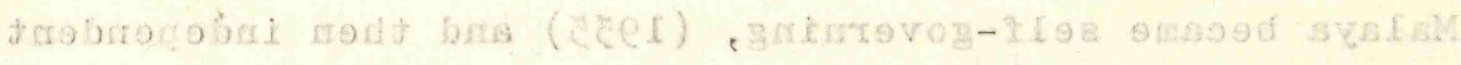

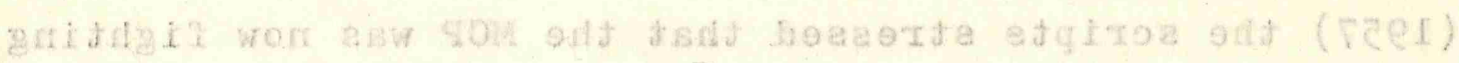

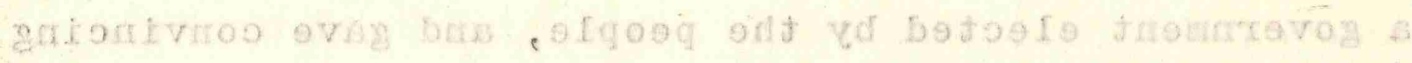

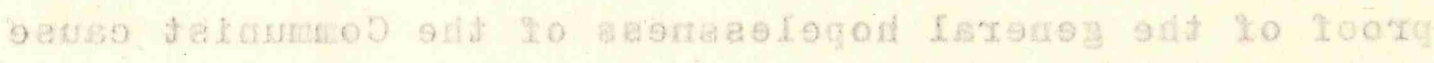

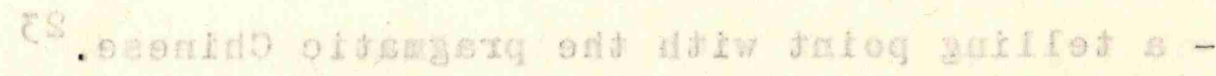

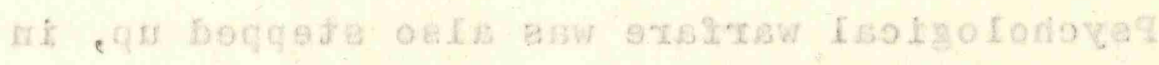

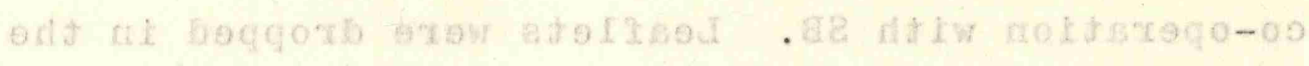

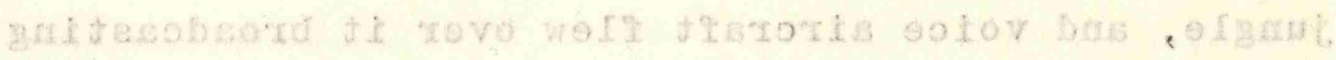

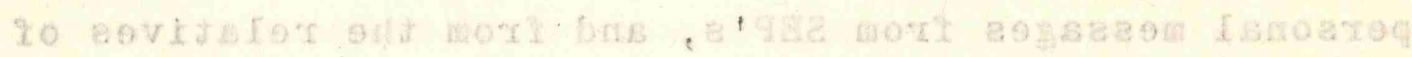

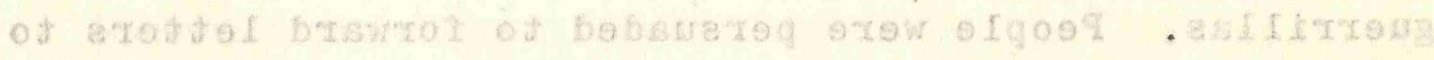

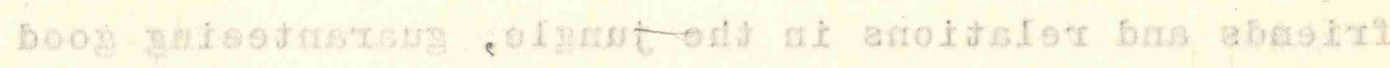

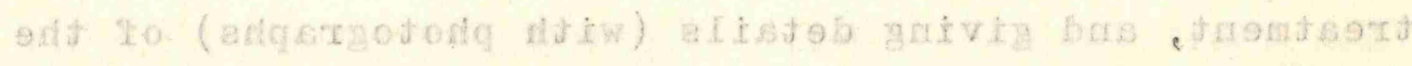


freedom and prosperity of others who had surrendered. Care was taken not to boast of successes which had not yet been achieved. 24

\section{Phase II}

For about two months after D Day, SB could expect a lull in information. Realizing that the operation had begun, the guerrillas would lie low, living on their dumped stocks of food. Meanwhile, they tried to find out all they could about the pattern of food denial, where it was strictest, and which of their suppliers had been arrested. During this period, the Security Forces concentrated mainly on supporting food control, frequently reinforcing the morning gate checks, establishing, road blocks and patrolling outside village perimeters at night. Patrolling was concentrated away from the killing grounds, and in particular in areas where SB cover was poor, to ensure that the guerrillas were prevented from replenishing their food stocks from these areas.

As their stocks were consumed, they had to renew their contacts with the Min Yuen, and operations entered a second sub-phase, during which SB played a game of bluff and double bluff to induce them to make these contacts in the killing grounds. The army still had to keep clear of the killing grounds until the relationships had been re-established with confidence.

After a further period, operations gradually moved into their third sub-phase. Ambushes were laid in the killing grounds on advance precise information. Hungry and 
25. Waller, Working Papers, pp. 77-78

I.

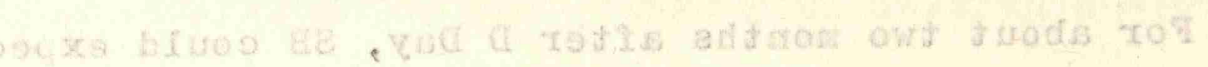

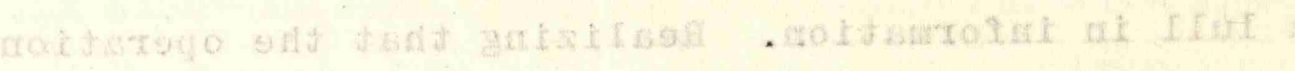

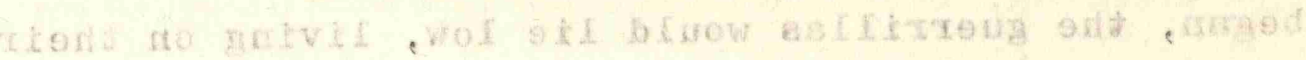

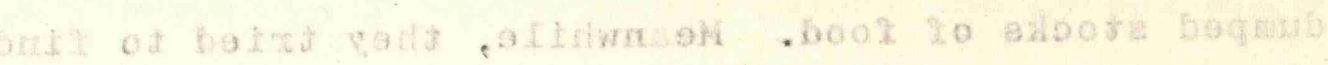

26. Clutterbuck, The Long, Long War, p. 122

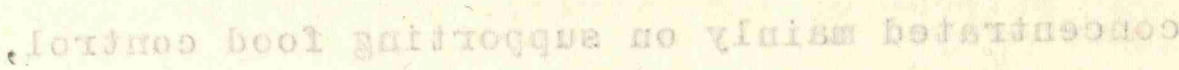

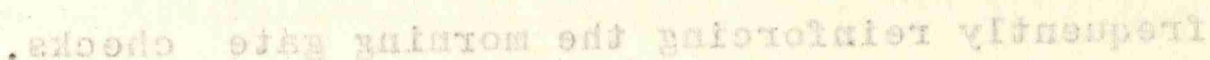

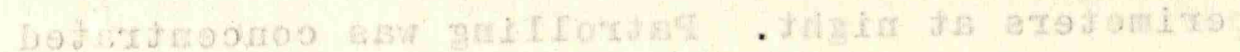

27. Craig, p.20. See also Chapter 13 for examples of this.

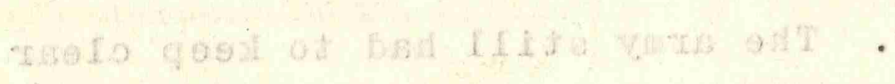


harrassed, guerrillas began to surrender. The SEP's produced more information and the cracks in the MCP Branch and Masses Organizations began to spread. 25

There were no big battles, and eliminations were generally in twos and threes:

"The battles, even in the killing stage, were still not spectacular - nothing like the set-piece affairs in North Vietnam in the $1950^{\prime} \mathrm{s}$, or South Vietnam in the $1960^{\prime} \mathrm{s}$ with whole battalions lying in wait for each other. If we had lost the battles of 1950 and 1951, this is what our war would have been like; but we did not lose them. Although 250 guerrillas might be in the district of a major operation, we seldom met them after 1952 in parties of more than 30; most often, they numbered a dozen or less ...... A major operation was, in fact, a host of minor operations". 26

\section{Phase III}

Phase II merged into Phase III as the branch organization ceased to function. The MRLA units and the higher HQ's in the deep jungle began to become desperate for food. Sometimes they came to the jungle fringe and fell into the clutches of agents. Otherwise, SEP's from the branches, or ex-couriers, used the letter box system to find them, and either talked them into surrender or led them into ambushes. Once their pattern of communications was known, their destruction was fairly quick. 27 


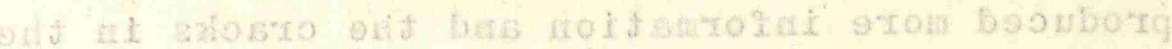

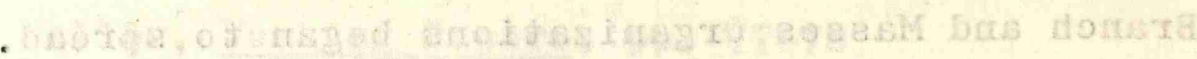

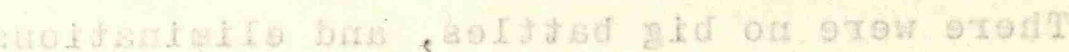

\section{: eognald bus eovit at pif istomo}

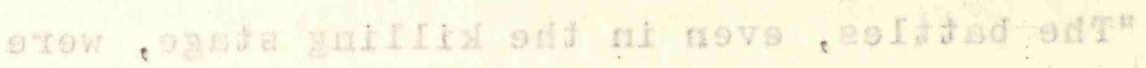

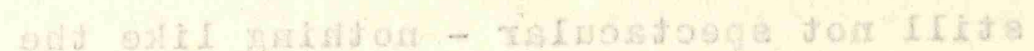

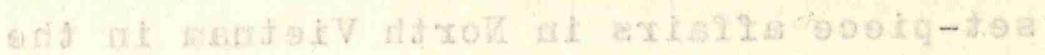
28. "Fu" (SB) Interview 1967.

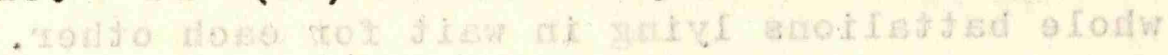

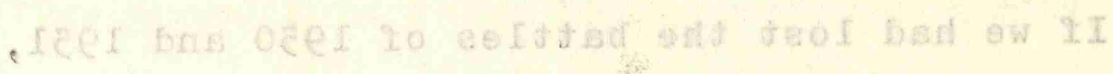

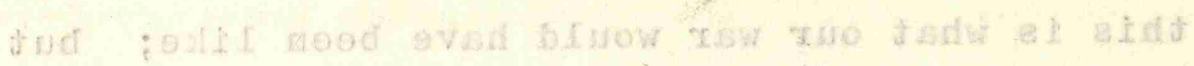

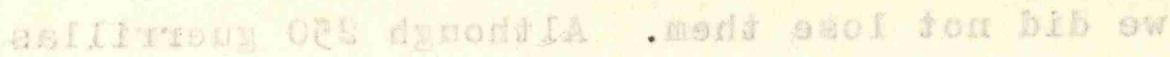

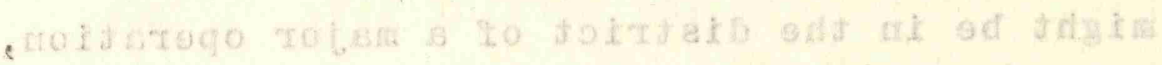

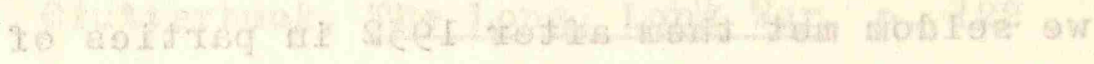

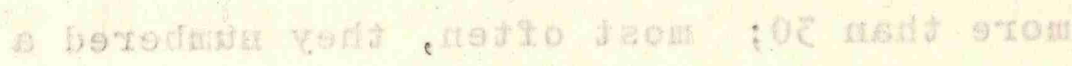

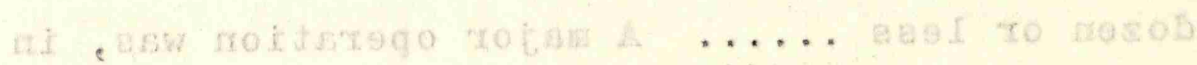

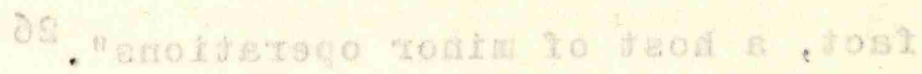

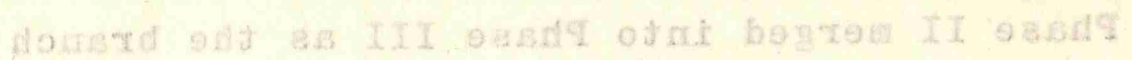

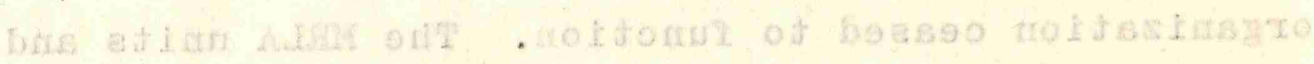

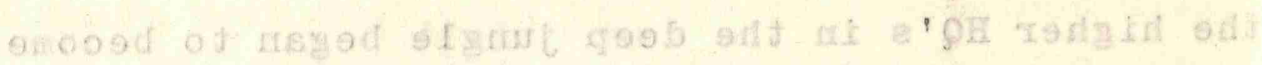

29. See Chapter 10.

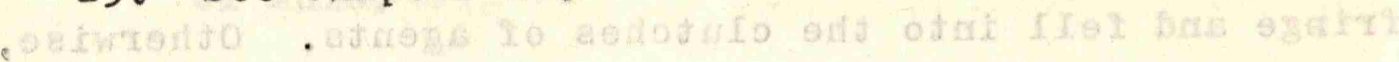

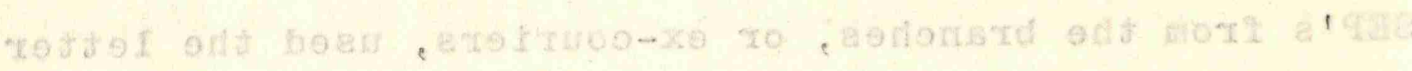

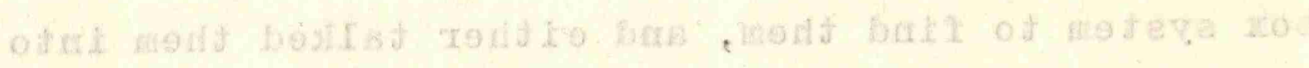

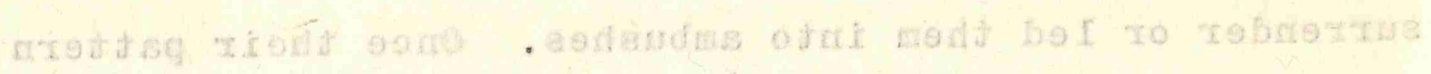

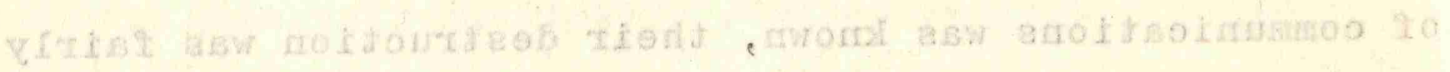
13.7010 
Provided that there was little risk of reactivation by neighbouring MCP District or Branch Committees, the area could then be declared White and the troops, police reinforcements, food denial and information staffs moved on to fresh fields, leaving only the normal police and home guards, together with one or two trusted agents, ex-ME's or even ex-guerrillas, to let Special Branch know if the Min Yuen showed signs of revival. 28

A Strategy to Finish the War

Until 1955, faute de mieux, the government strategy had been to roll up the Communists from the South, starting with Johore. This had a certain logic, as the Federation's only land frontier was with Thailand at the Northern end of the peninsula. Chin Peng had used this same logic in 1953, when he had moved his Central Committee from Pahang across the Thai border.

The strategy of rolling up from the South, however, never began to work, as the State of Johore (along with Perak which adjoined the Thai frontier) had historically one of the two strongest Communist organisations in the country, which proved to be the last to crack, and the MCP's popular support remained until their men had finally come out of the jungle - as was vividly shown at the time Yong Peng was declared a White Area. 29

By 1955, the spectacular successes in Pahang, and the achievement of self government by the Federation, with the imminent promise of full independence, had convinced Chin Peng that he must seek a political solution. 


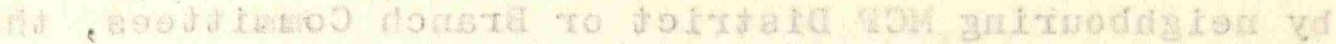

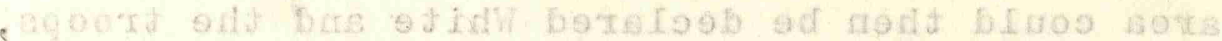

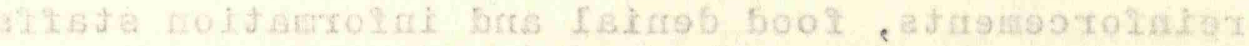

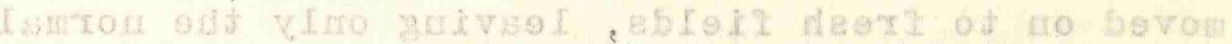

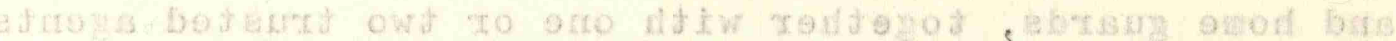

30. Craig, p.22

31. See Chapters 5 to 7 .

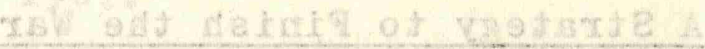

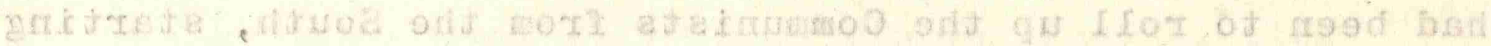

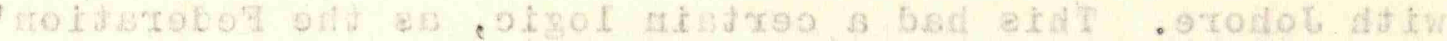

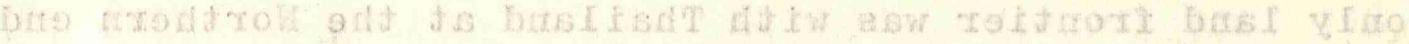

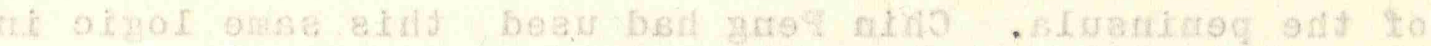

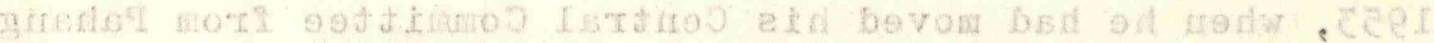

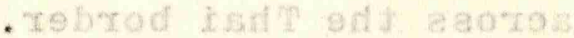

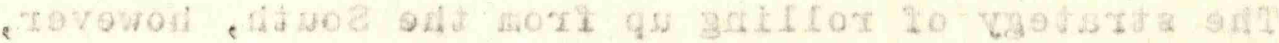

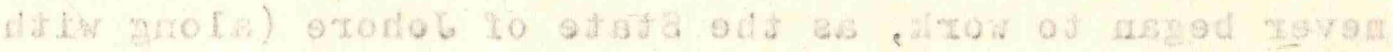

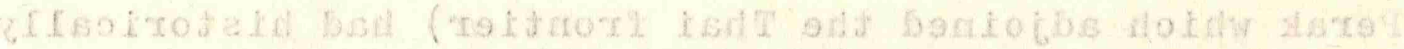

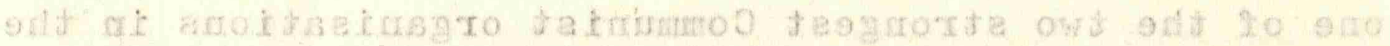

32. Director of operations, Review of the Emergency Situation in Malaya at the end of 1955, 31 January 1956

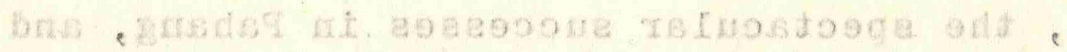

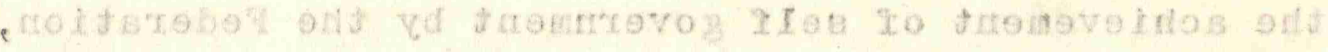

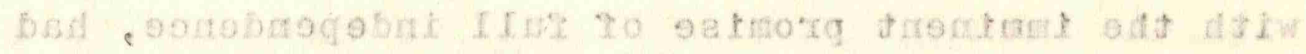

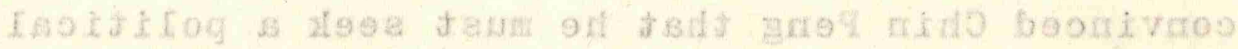


In June 1955, by means of a letter signed with a pseudonym ( $\mathrm{Ng}$ Heng), the MCP suggested truce talks, and Chin Peng met the Chief Ministers of the Federation and Singapore (Tunku Abdul Rahman and David Marshal1) at Baling, near the frontier of Thailand. Chin Peng offered to lay down his arms in exchange for political recognition of the MCP. This was firmly refused by the Tunku, and Chin Peng returned to the jungle. He sent out the word to concentrate on subversion in the large towns. 30 This, of course, was already in hand, and the MCP campaign in Singapore was to reach its peak on the streets in the following year. 31 Meanwhile, the battle for survival of the guerrillas in the jungle and of the Masses organisation in the villages continued. It was still to take more than 4 more years to dig out the roots of it. The Latimer technique, perfected and accepted at last, was to have its long hard winning run.

General Bourne had in 1954 succeeded Templer as Director of Operations (though there was once more a civilian High Commissioner, Sir Donald McGillivray, over him). In January 1956 he issued a fresh review of the situation and a fresh strategy. Exploiting the success in Pahang, priority was to be given to

"driving a White Area belt right across the Federation from coast to coast; when success has been achieved in these operations, to make a decision whether to extend the breach northwards into Perak or southwards into Johore". 32 


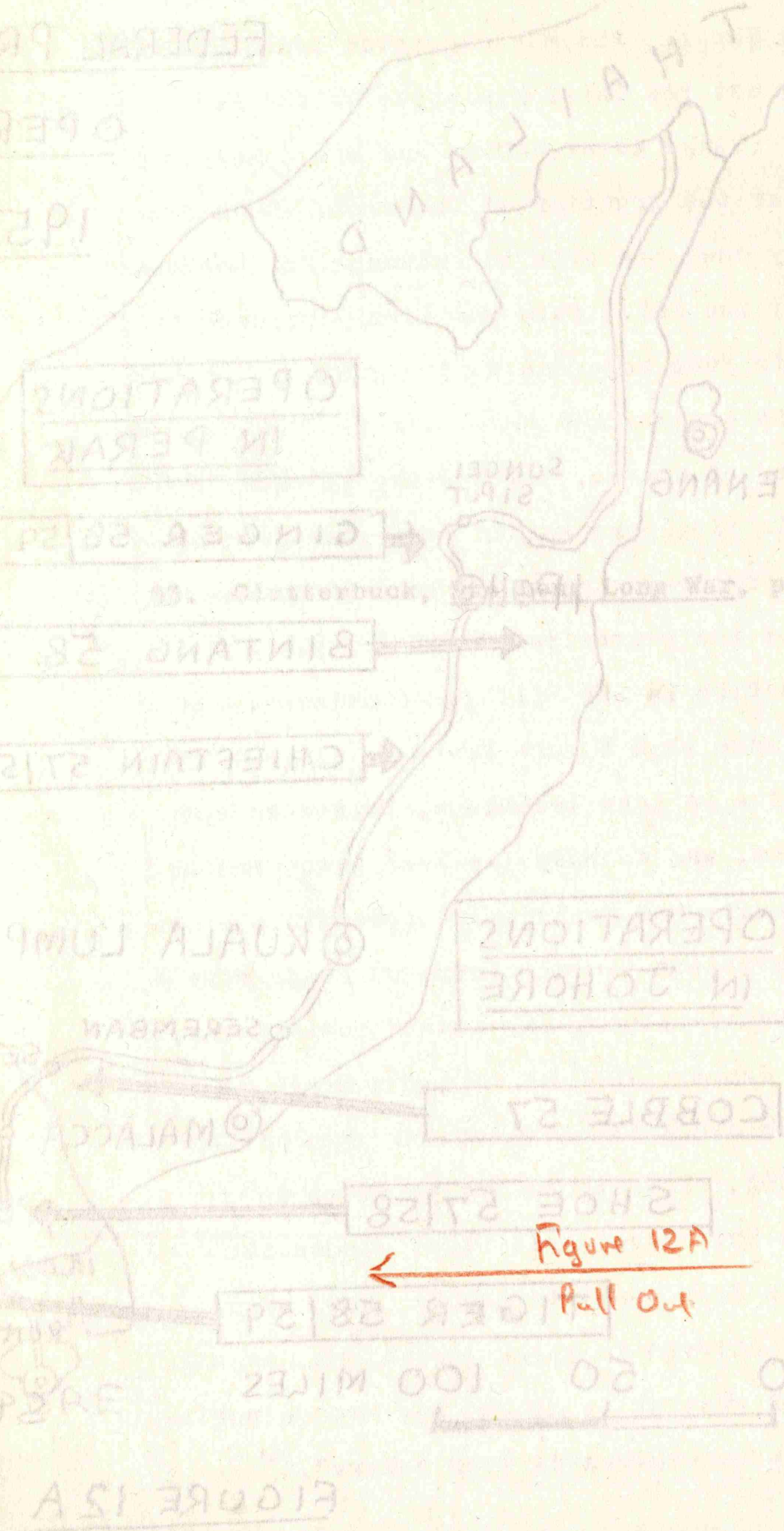

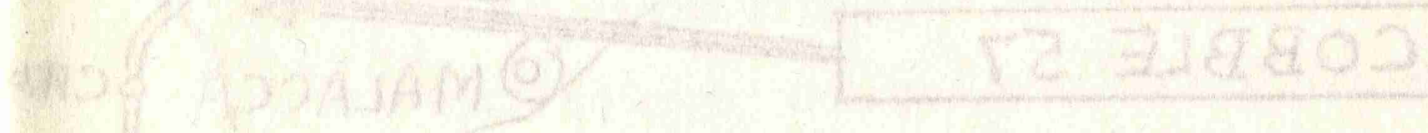

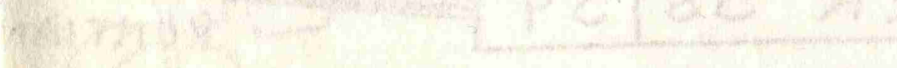


This strategy followed the principle of dealing with the weakest areas first and working outwards to the strongest. This was logical because in a target adjacent to a White Area, the people would be aware of the good fortune of their neighbours and be looking forward to similar relaxations themselves. Moreover, as the target MCP district was weakened, it could expect no help from the flank where the organisation had been smashed. And, most important of all, as it became possible to withdraw troops and police from the weaker areas, the government was able to concentrate greater and greater strength, until, in the end, overwhelming force could be (and was) concentrated on the hard nuts to be cracked in Perak and Johore. 33

Early in 1956, operations in Selangor and Negri Sembilan were making good progress, and planning began on Phase I of operation LAUNCH, later renamed COBBLE, in the Segamat District of North Johore, the first of a series of major operations including SHOE in the Yong Peng District of Central Johore and TIGER in the Kulai and Pontian Districts of South Johore, which was to clear the Federation Southwards to the causeway across the Straits to Singapore by the end of 1958. At the same time, a similar series was being planned to work northwards through Perak to the Thai Frontier (See Fig. 12A). 
34. Operation COBBLE, Johore Special Branch Appreciation, 7th August 1956 (COBBLE SB $7 / 8 / 56)$

Operation SHOE, Johore Special Branch Planning Committee Minutes of Meeting 16 December 1956 (SB SHOE $16 / 12 / 56$ )

Operation TIGER, 99 Gurkha Infantry Brigade Operation Order No. 48 Johore Bahru April 1958 (TIGER 99 Bde 4/58)

35. See Chapter 10. 
The timing of the Johore Operations, in the event, was as follows: -34

$\begin{array}{ll}\text { July } 1956 & \text { Op COBBLE - Phase I (Segamat) } \\ \text { January } 1957 & \text { Op COBBLE - Phase II } \\ \text { January } 1957 & \text { Op SHOE } \text { - Phase I (Yong Peng/Labis) } \\ \text { June } 1957 & \text { Op SHOE - Phase II } \\ \text { December 1957 } & \text { Op TIGER - Phase I (Kulai/Pontian) } \\ \text { April } 1958 & \text { Op TIGER - Phase II }\end{array}$

At this point, April 1958, there was a dramatic development when Hor Lung, head of the MCP South Malaya Bureau, came in to surrender. His surrender, which will be described in the next chapter, was followed by a rapid crumbling of most of the remaining guerrilla units and Masses organisations in Johore. Thus, the targets of Operations SHOE and TIGER disintegrated before the operations had run their normal course, and a study of them could therefore be misleading.

Operation COBBLE, however, was all over before this except for Phase III, of which Hor Lung's surrender was the decisive dividend - though a somewhat delayed one. Phases I and II of operation COBBLE can therefore be studied as a model of the process of digging out the roots of a hard core district in the latter stages of the Emergency. Segamat MCP District enjoyed strong traditional support from the Masses. Its situation in 1956, however, differed from that described for Yong Peng in 1953, 35 
in that the total number of guerrillas to be fed in the jungle had become considerably smaller. Nevertheless, although the MRLA strength was very low, one at least of the branches in Operation COBBLE in 1956/57 was still of roughly the same size (15-20) as those around Yong Peng in 1952/53.

Operation COBBLE is therefore described for reference in Appendix B. It can be regarded as the final pattern of Captain Latimer's conception applied against a small, tough, elusive and very difficult target。 
254 
1. F. E. Kitson, Gangs and Counter-gangs, London, 1966 


\section{CHAPTER 13}

\section{THE CRUMBLE AND THE HARD CORE}

\section{A Successful Framework Operation}

Through 1957 and 1958, the cavalcade of federal priority operations moved Northwards and Southwards from the centre, demolishing on the average two or three hard core MCP districts every six months. There were, however, some 30 other MCP Districts, still not white, in which framework operations continued. The branch organisation in these districts was often just as strong as that described in Yong Peng and Segamat, but the Min Yuen was weaker so it was possible to break them without such a concentration of effort.

When the Selumpur and Bukit Siput Branches collapsed under the pressure of three battalions and a thousand police and home guards in September 1957, two companies of the Rifle Brigade were starting a framework operation against 50 guerillas to the Southwest of Segamat - the survivors of the one-time 200 strong Johore Malacca Border Committee's command.

One of the two company commanders, Major F.E. Kitson, had a genius for intelligence, which he had already revealed two years previously against the Mau-Mau in Kenya. ${ }^{1}$

Finding on his arrival that there was no intelligence cover in the district, he turned his whole company onto creating it. He divided intelligence in his own mind into "background information" about the guerilla gangs and their habits, and "contact information", which enabled soldiers to find or ambush the guerillas. There was no. 
federal priority operation in the area, and Kitson was convinced that he would never get enough contact information unless he created it himself. He therefore set about developing the background information first. He distributed his men in twos and threes around the rubber and logging tracks to watch the faces of the people going to work until they could recognise any strangers who appeared. After a few weeks, they had provided enough background information, in conjunction with that he received in the normal way from Special Branch, to deduce the area of jungle in which one of the gangs (the Kebun Bahru Branch) was living, and that they were likely to visit one of two or three villages on one of two or three nights.

These villages were on the opposite side of the road from the guerilla camp, and a careful study of the ground revealed that there were only six of the many tracks debouching from the road into the adjacent rubber estate which led right through into the jungle where the camp was. He therefore ambushed these six tracks until the gang came - which eventually they did. By good fortune and good shooting his ambush party killed the leader - the District Committee Secretary. This disconcerted another of the gang so much that he surrendered next day and led Kitson's men to the camp. It was empty when they arrived, but the soldiers ambushed it and killed another when the gang returned. This led to another surrender, and the gang got really jittery. A fifth man tried to surrender and killed a sixth who tried to stop him. At this the branch disintegrated completely and the remnants fled to other gangs 。 


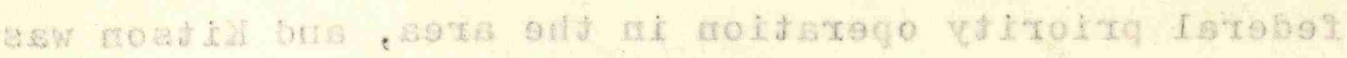

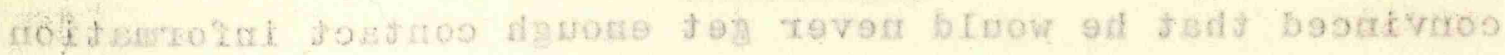

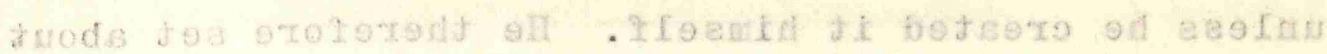

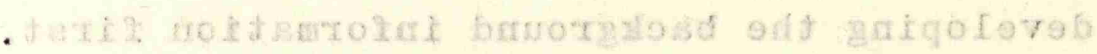

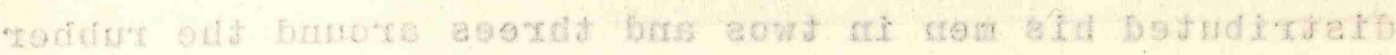

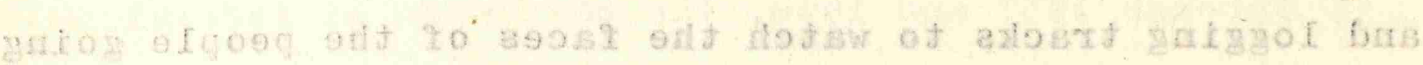

2. Kitson, Interview, 1969, and author's wor of Hawe recollection of spending four days with al Kitson's company at the, time of the brworgyoso operation. See ałso Nalay Mail, 27 August 1958

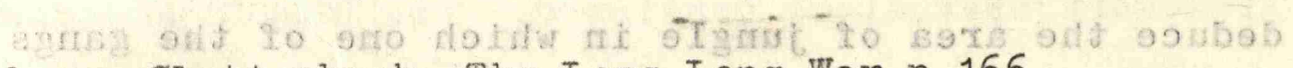
3. Clutterbuck, The Iong Long War p 166

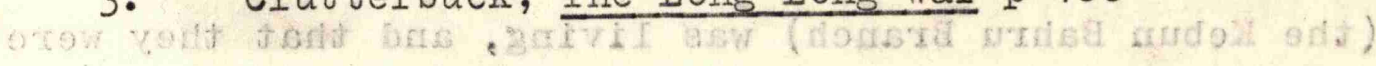

To 4. IS See Appendix B to ont qo gato jialv of vfextil

5. Tunku Abdul Rahman, Press Conference

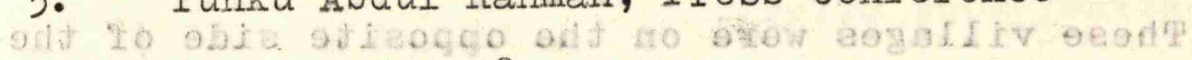
26 August 1958

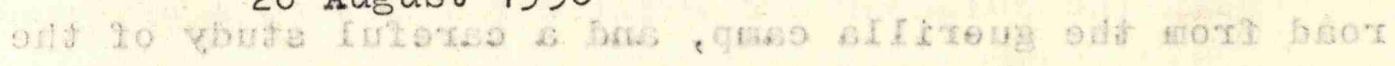

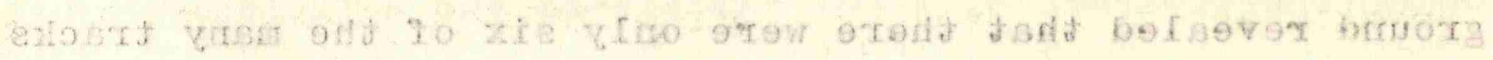

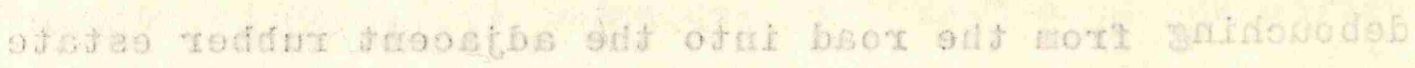

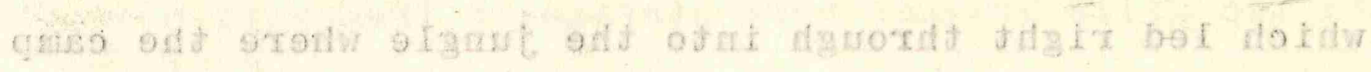

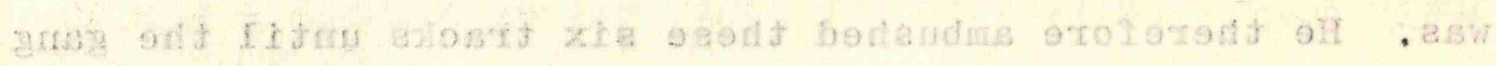

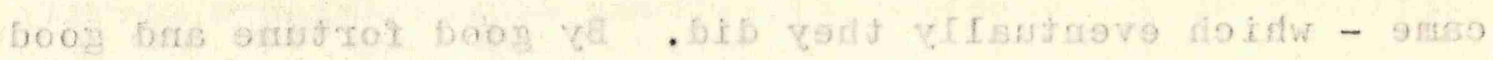

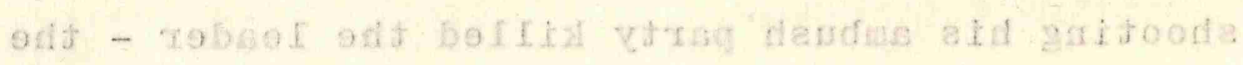

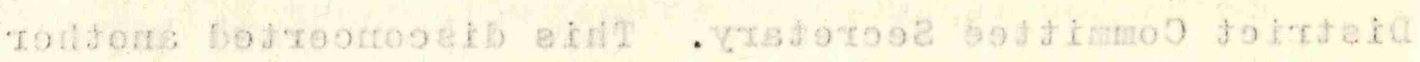

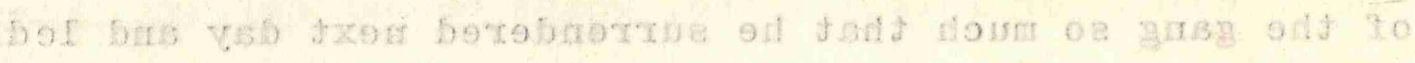

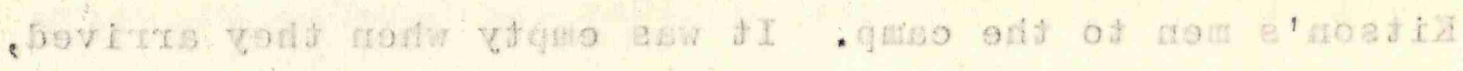

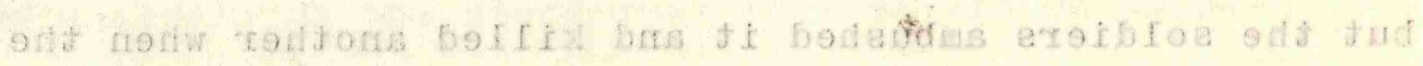

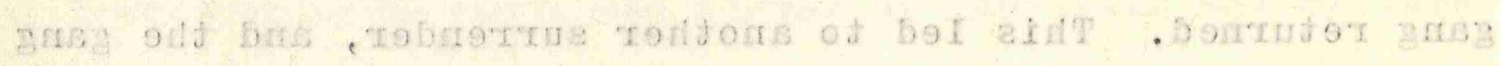

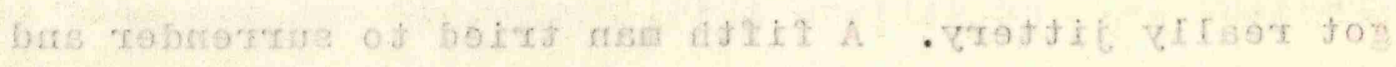

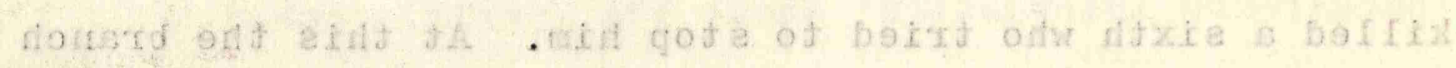

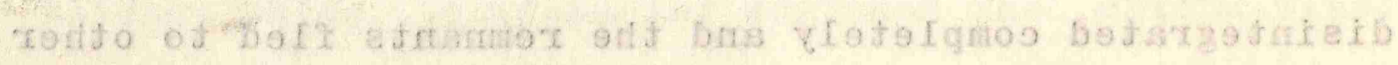


Kitson then turned his attention to another gang the Grisek Branch. Starting once more by building up background information, his men contacted the branch three times in three weeks and killed four of them. Two more then surrendered, and, after a night of interrogation they were persuaded to join a patrol the next day. To show his confidence Kitson armed them and placed them in the ambush party. More kills and more surrenders led to mounting pressure, and the Grisek branch and the other branches and districts collapsed one by one. Soon only the Regional Committee Secretary (RCS) remained, with his staff of 7 and with no districts, branches or Min Yuen with whom to maintain contact with the people in the villages. In January 1958, six months after the operation began, they too came in to surrender. ${ }^{2}$ Hor Lung and the Collapse in Johore

By April 1958, despite the pressure of priority operations, only the Malay coastal districts and the Johore/Malacca Border Region cleared by Kitson's framework operation had become White Areas. The remainder of Johore, and indeed most of Negri Sembilan, was still black. Even the Segamat District, where operation $\mathrm{COBBLE}^{4}$ had virtually destroyed the branch organization, was still black, because Hor Lung and his South Malaya Bureau HQ were intact and believed to be living in the deep jungles North of Segamat. Intensive Phase III operations had found camp sites and evidence that food was still coming from the masses in the Segamat District, and from a small supply group operating further north into Negri Sembilan. 5 


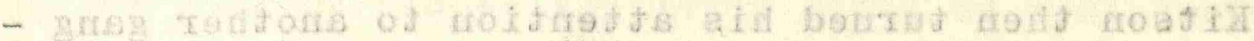

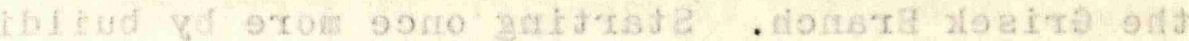

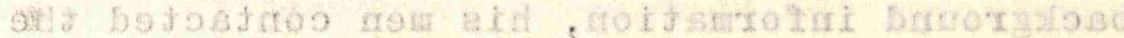

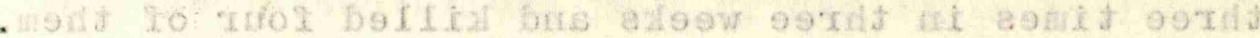

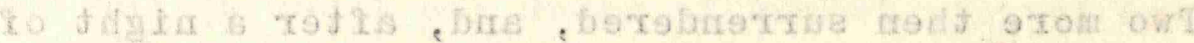

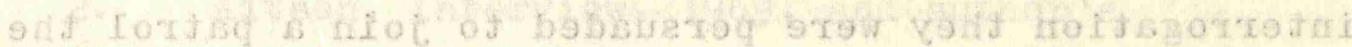

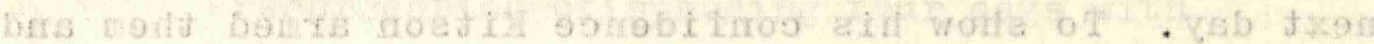

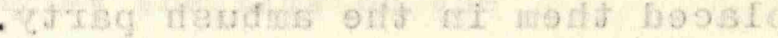

\section{Straits Times, 27 August, 1958}

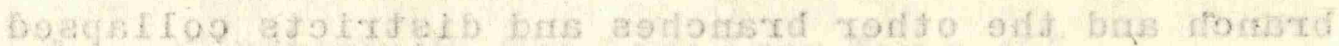

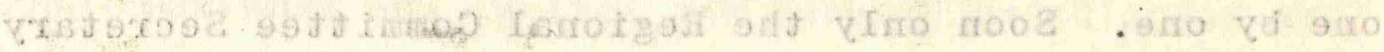

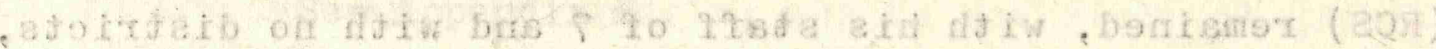

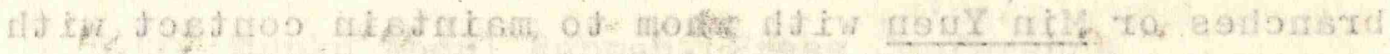

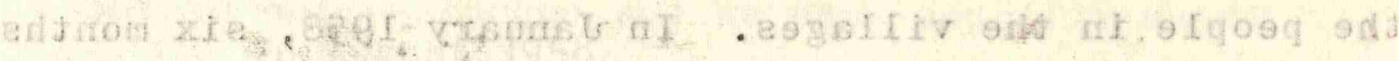

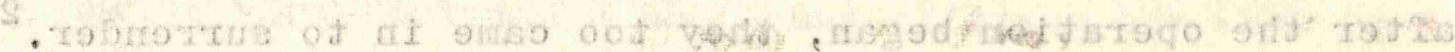

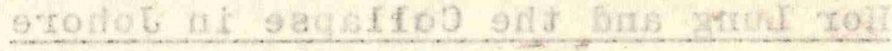

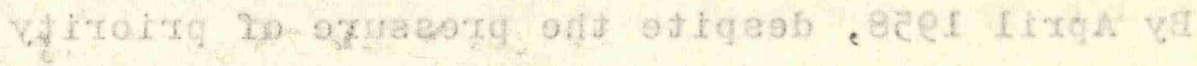

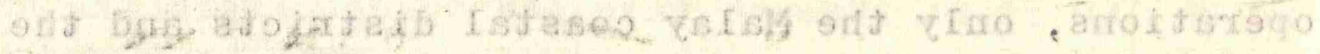

7. Hor Lung (Com) Statement published in the Malay Mail 27 August 1958

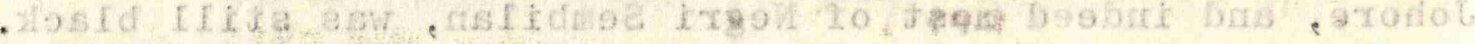

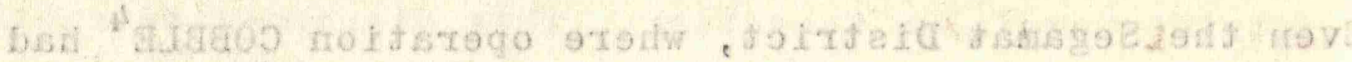

If

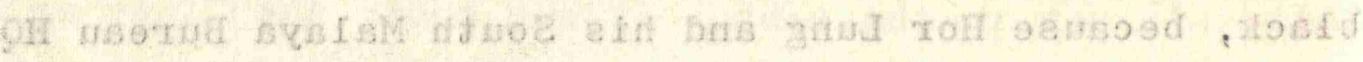

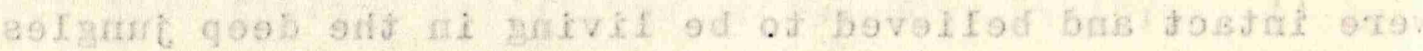

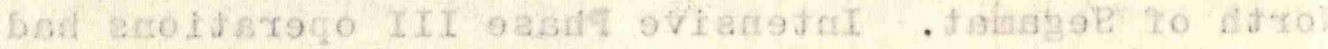

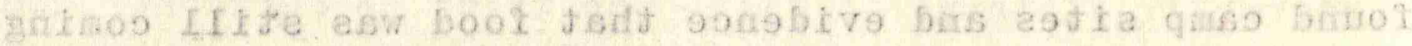

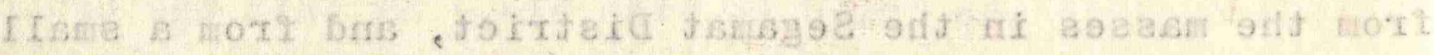

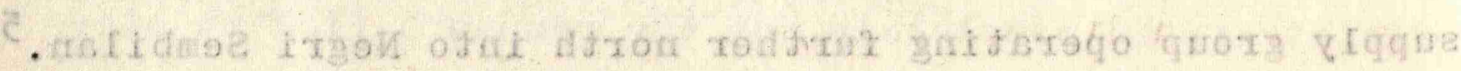


In February 1958, four guerillas from this supply group surrendered and, on their information, the chase became hotter. On 5th April 1958, quite unexpectedly, Hor Lung himself, alone and having discarded his uniform, walked into the enquiry office of the Police Post at Kampong Tengah, 2 miles from Segamat.

He did not at once announce his identity, but did so a few hours later in the seclusion of the special Branch office in Segamat. It was quickly checked from police photographs. 6

In a signed statement in his own handwriting, later published in facsimile in the press, he declared his reasons. He recognised that Malaya's independence, granted on 31st August 1957, was a "glorious page" in her history, even though it fell short of what the MCP regarded as ideal and that the Alliance Government, though its policy differed from that of the MCP, was legally elected and recognised. He accepted that the people wanted peace to improve their living conditions.

"We therefore determined to consult the government on this matter and as a result of this we accepted the reasonable terms laid down by the government". 7

During the next four months, working in the strictest secrecy and living in the houses of a number of Special Branch officers in turn, Hor Lung went back into the jungle in uniform, contacted the various couriers on their appointed days at the letter boxes, and got them to lead him back to his units, one by one. There he set himself the task 


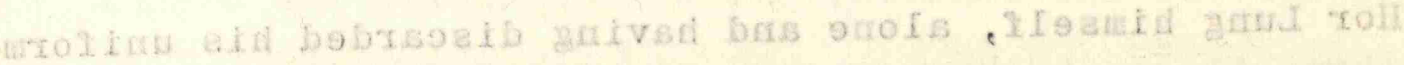

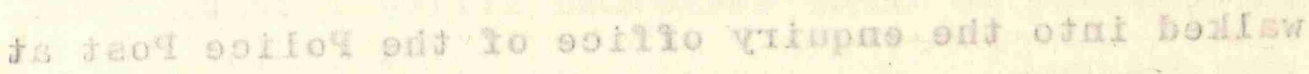

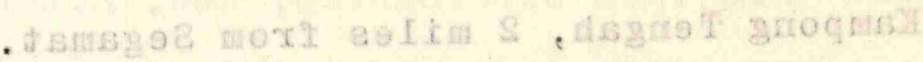

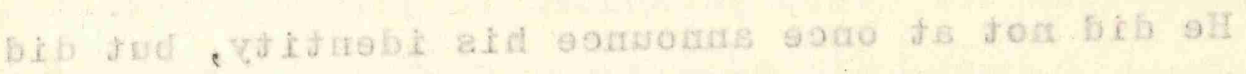

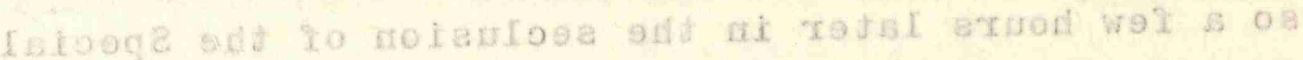

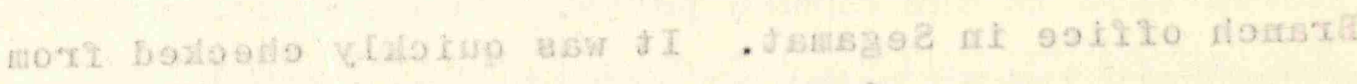
. Edicsigotorid $90 \mathrm{fog}$

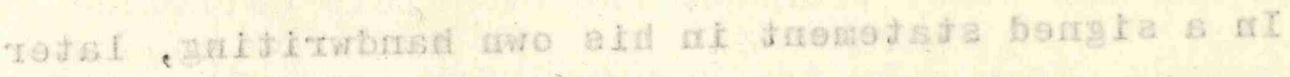

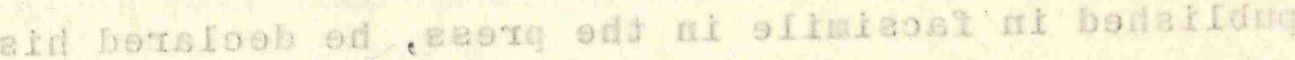

\section{Ibid}

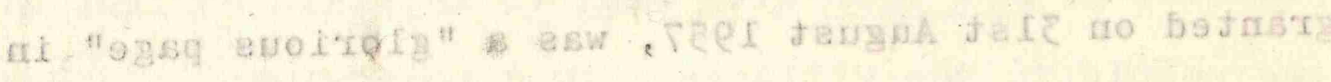

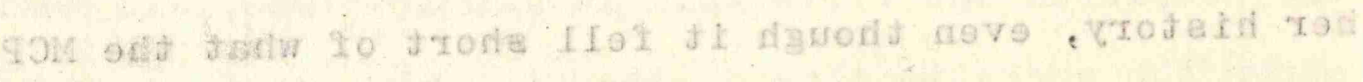

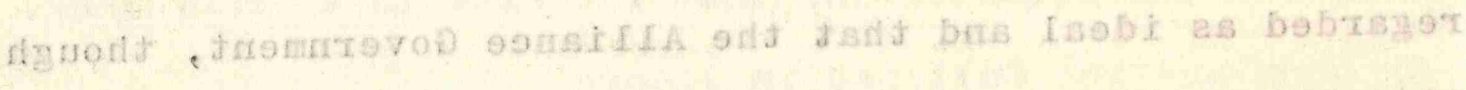

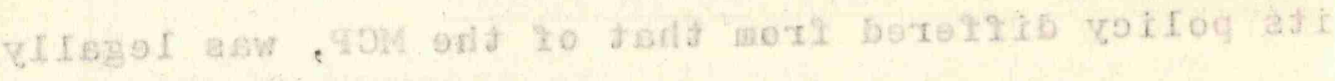

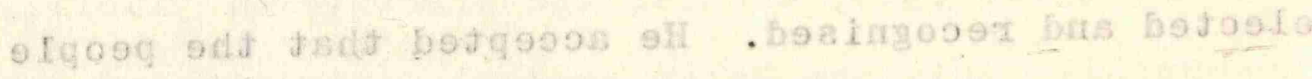

9. Hor Lung (Com) Interview 1967.

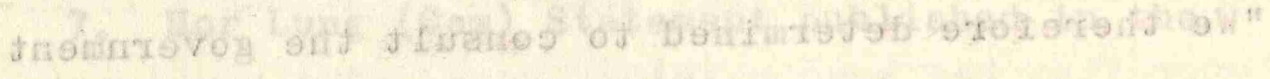

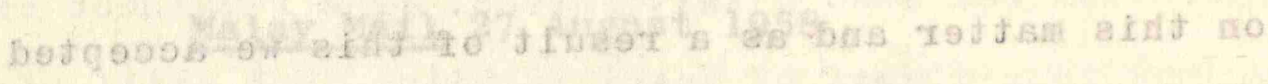

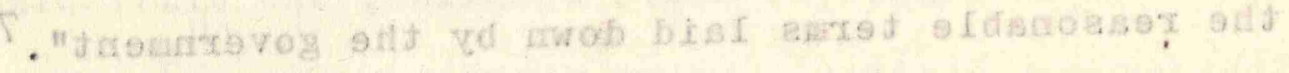

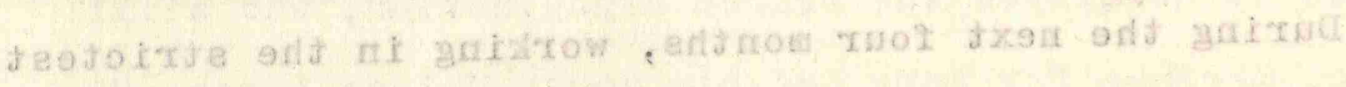

10. Tunku Abdul Rahman, Press Conference,

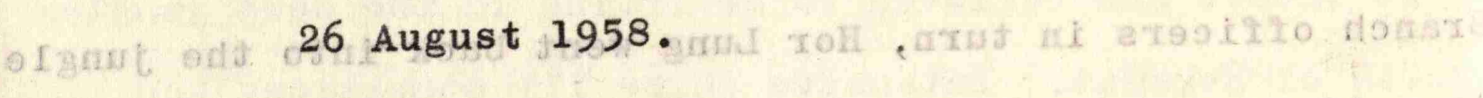

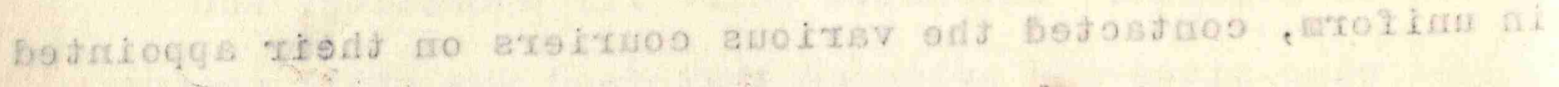

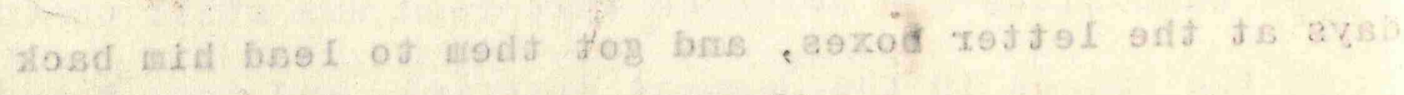
11. "Fu" (SB) Interview 1967, vo gao , at lam aid of 


\section{(2)}

of persuading them to come out. He is reticient about

how he did it, but it is clear from his published.

statement that he still regarded himself a Communist, and had not renounced his ideals. He presumably based his persuasion on the proposition that his comrades could better achieve these ideals from outside the jungle rather than from inside. He gave a further hint of this in his statement:

"Starting from the end of May up to the present moment, all the comrades in North Johore and in other States in South Malaya who could be contacted have accepted these terms and left the jungle one after another to come out and live a life of peace. For the past two or three months the government has firmly carried on its promises and accorded us fair, equitable and reasonable treatment." 8

He probably varied his line to suit what he knew of the character of the particular leader of the branch or platoon concerned. No doubt they all realized; as he did, that the armed struggle was lost in any case, and were glad of a chance to get out with their lives and with the approval of their commander. 9

He brought out 160 guerillas in all, and qualified for a huge reward, even at the half rates due to an SEP. In al1, $\$ 469,000$ was paid out, ${ }^{10}$ of which Hor Lung's share was $\$ 247,000^{11}$. He now lives prosperously, still 
12. Hor Lung (Com) Interview 1967 , th th ad wo

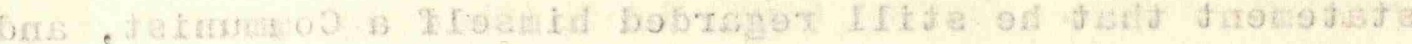

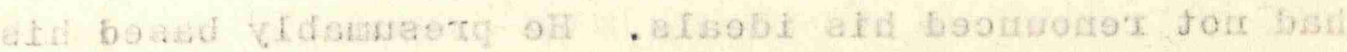

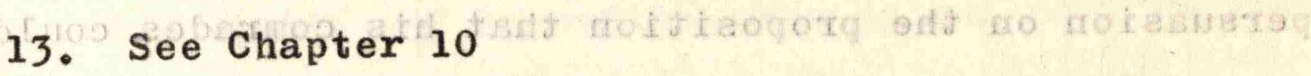

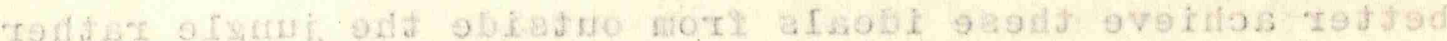

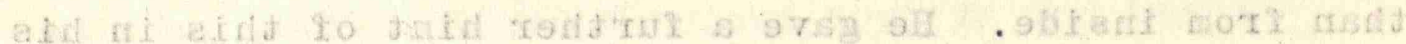

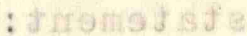

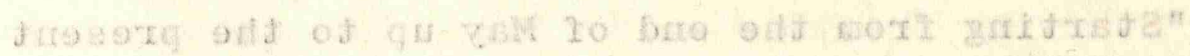

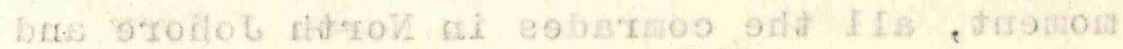

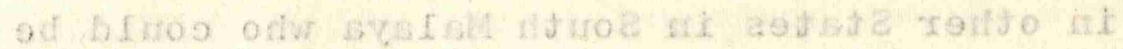

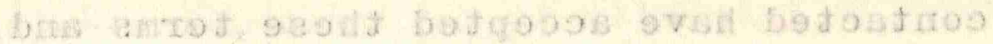

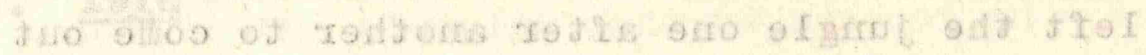

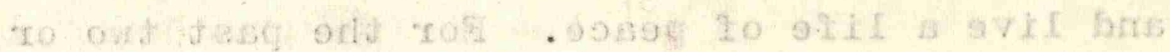

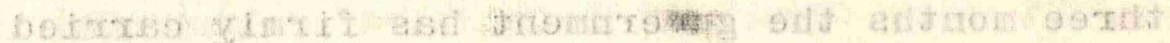

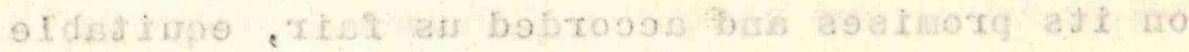
14. "Fu" (SB) Interview 1967

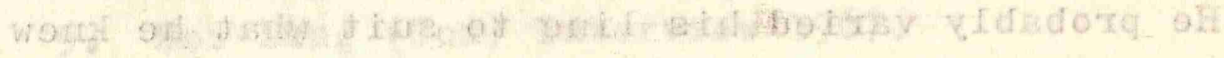

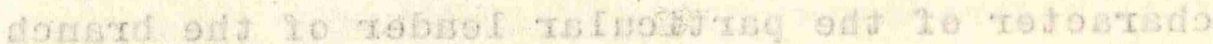

\section{See Appendix B}

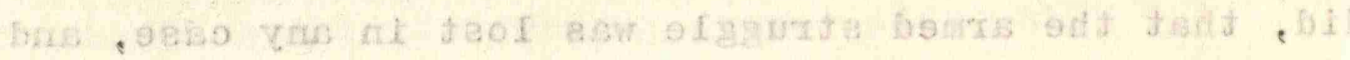

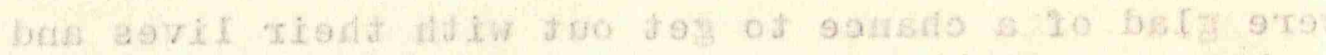

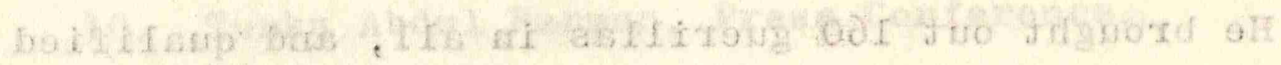

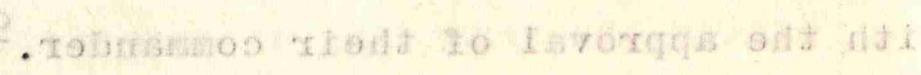

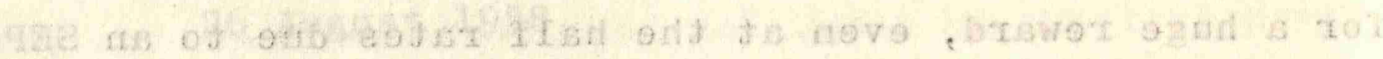

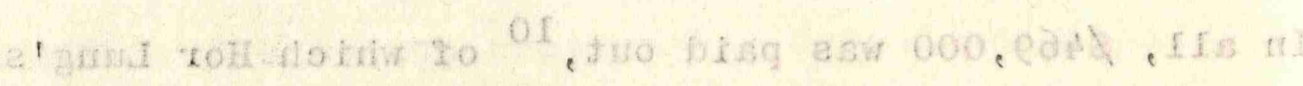

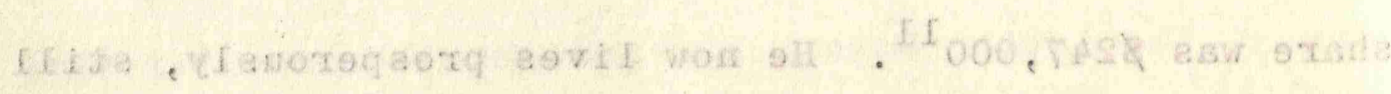


in Johore, and in no apparent fear of retribution. 12

Amongst those he brought out was "Kim Cheng", who

had run Yong Peng District with such success for the past 10 years. 13 "Kim Cheng" in turn brought out the militant No 7 Platoon MRLA, which Hor Lung said would not accept his order to surrender. "Kim Cheng" donned his uniform and went alone into their camp, at considerable personal risk, with a Police Special Branch officer hovering in the jungle nearby. The Platoon agreed to accompany him on condition that they marched out fully armed and thereafter negotiated their own terms with weapons in hand. The police officers agreed, and the 20 armed uniformed guerillas sat down in the home of the British Special Branch Officer and argued it out. They demanded, among other things, that the government should provide $\$ 2,500$ which was due in arrears of pay to, the Masses Executives for their work. Special Branch agreed, on condition that each $M E$ came forward with detailed evidence of the activities for which payment was due! There were, of course, no takers, but No 7 Platoon had made their point and, honour satisfied, they handed in their arms. 14

For his part in this bizarre and hazardous negotiation, "Kim. Cheng" earned, a reward of \$50,000. He and his wife (who had also been in the jungle since 1948) used it to buy a small rubber estate in Johore, on which he employs a staff of four, all SEP's, including an ex-member of the Selumpur Branch Committee. 15 "Kim Cheng", who now has 
16. "Kim Cheng" (Com) Interview 1967

17. Free passages to China had been offered as early as January 1952 to those refusing resettlement, and 700 had applied for it. (see Federal War Council, Minutes, 8 February 1952). Detained persions (including SEP's) could be deported at their own consent or request which came to the same thing. The offer of repatriation without interrogation: was part of the Merdeka surrender terms published on lst September 1957. See Director of Operations, Review 1957, p.17

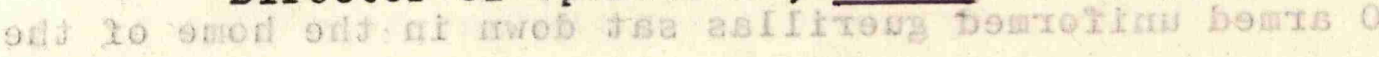

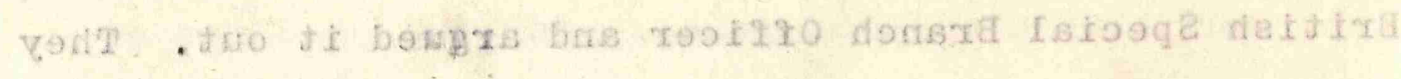

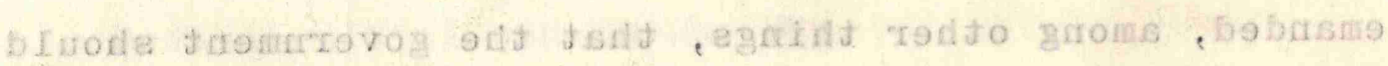

18. See Chapter 4. mi guh esw foldw OOC.

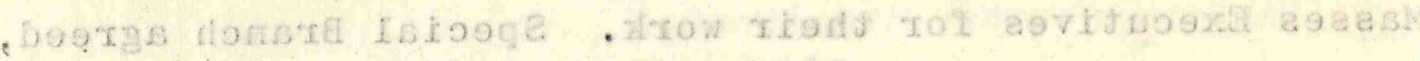

19. Op TIGER - JBSB

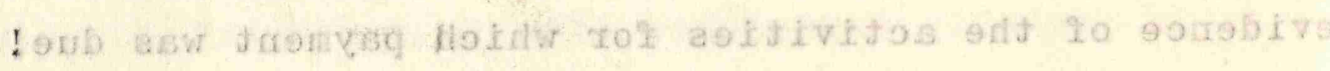

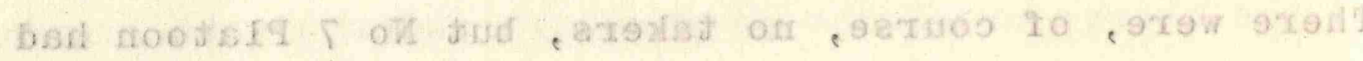

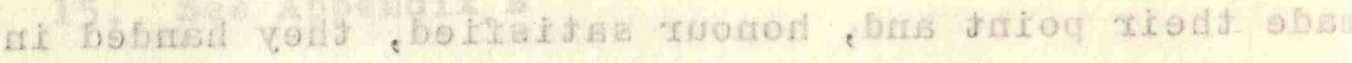

20. "Fu" (SB) Interview 1967

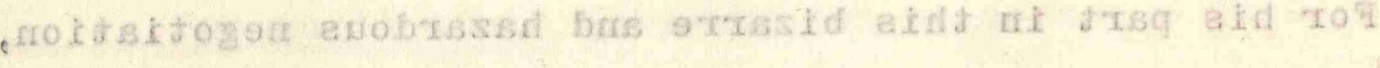

91. 21. Director. of pperations Staff, Kuala Lumpur,

Letter to author, 16 september 1958.

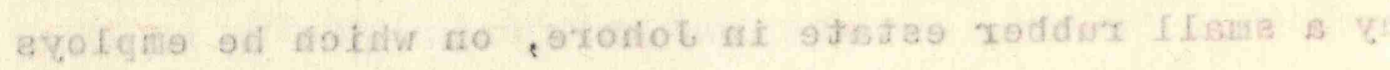

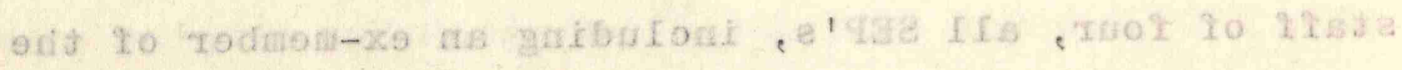

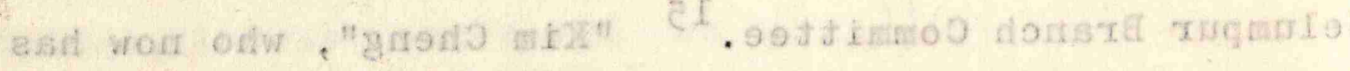


five young children, lives a happy and comfortable life, in close friendship with one of his ex-enemies from Special Branch. He is a man of great natural charm and dignity, and is proving as successful as a small captialist as he did as a Communist. 16

Not all of Hor Lung's 160 SEPs elected to settle in the new Malaya. Some chose instead to accept the government's alternative offer of free repatriation to China, without interrogation. 17 Amongst these was Ah Chiau, the District Committee Secretary of Pontian MCP District, who appeared much earlier in this'story in connection with the subversive activities amongst the Chinese school children of Ayer Baloi. 18 In the latter stages of the Emergency, she ran a district as hard to crack as Yong Peng, with only 5 surviving guerillas and 400 active supporters. In their "Appreciation of the Situation" for Operation TIGER, Special Branch somewhat ruefully described her as:

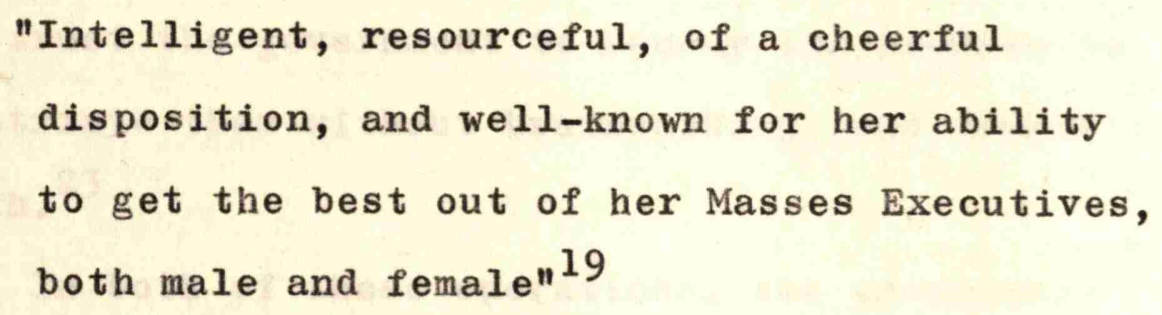

She was still only 35 when she decided to accept the surrender terms and carry her Communist convictions back to China. She, too, impressed Special Branch with her dignity and charm. She would have been a good leader in any sphere. 20

By September 1958, there were still 1000 guerillas left in the Federation, mainly in Perak and across the Thai Border, but only 70 of them now remained in Johore, 21 and these were all eliminated by early 1959. 


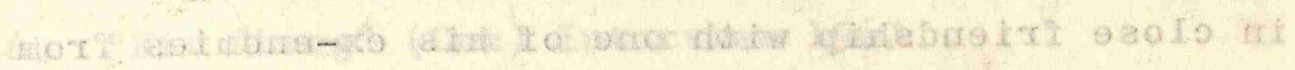

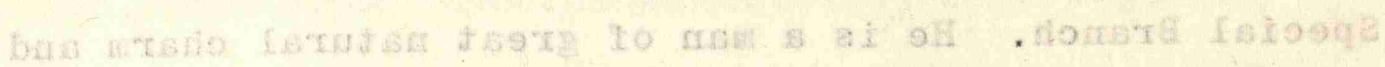

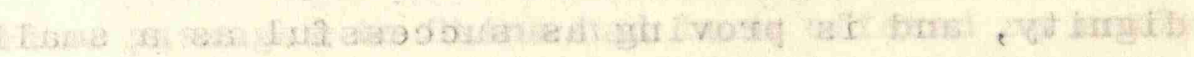

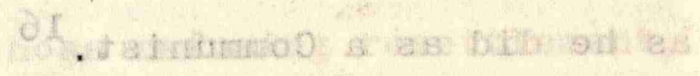

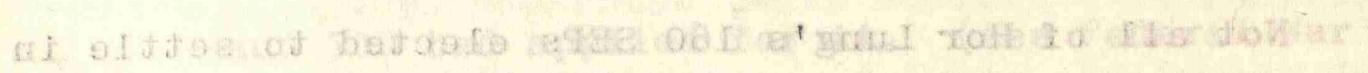

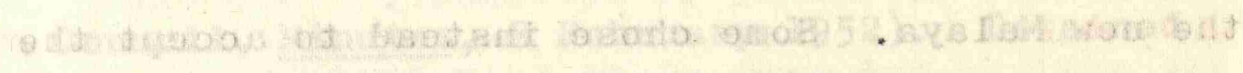

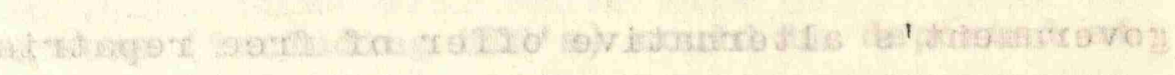

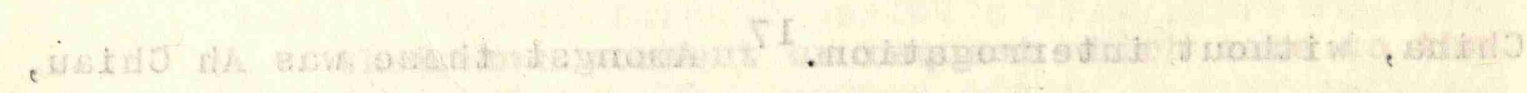

22. Straits Times, 27 August 1958

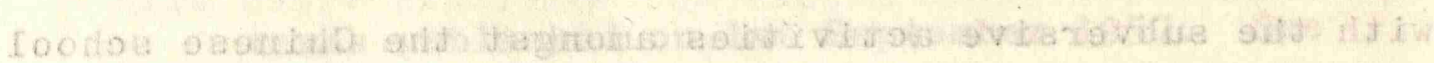

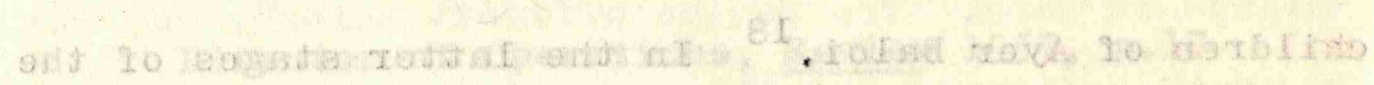

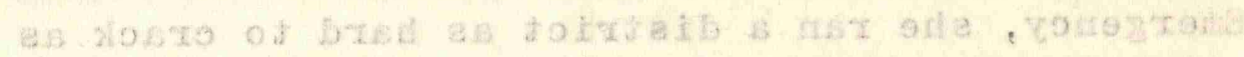

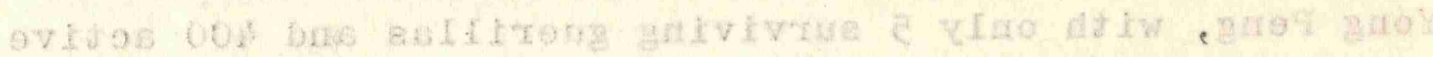

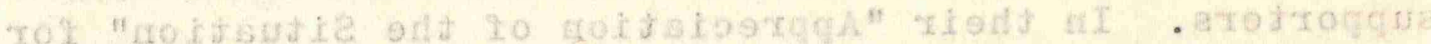

23 - The ambush of one of these is described in

\section{Clutterbuck's The Long Long War, p.171}

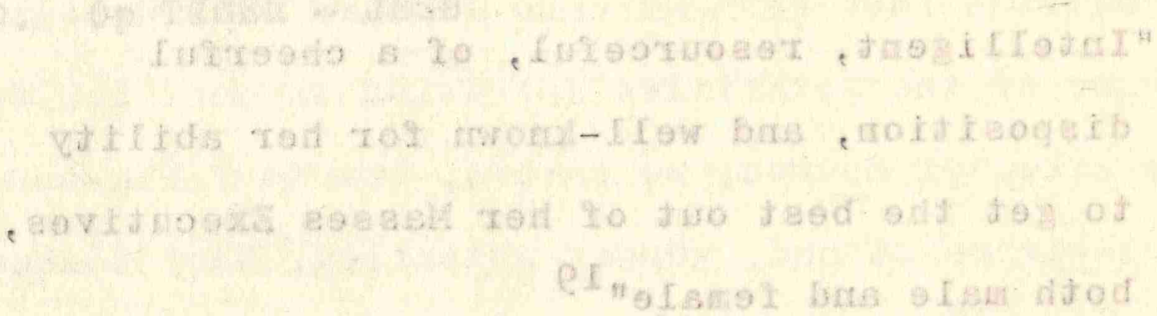

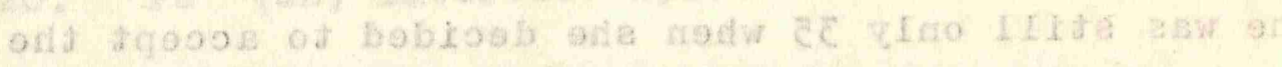

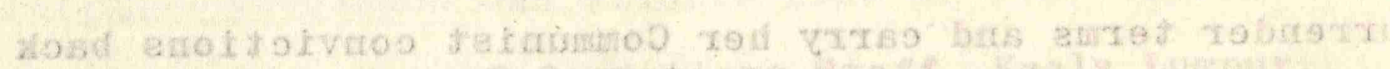

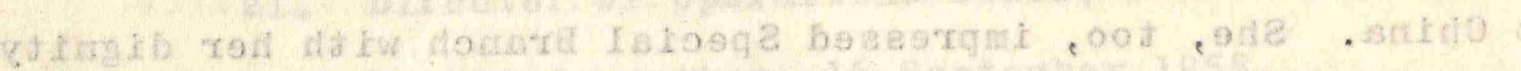

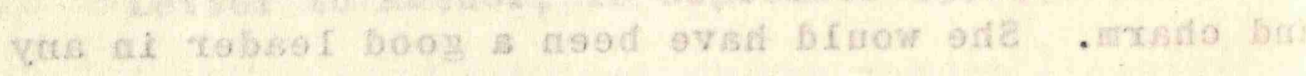

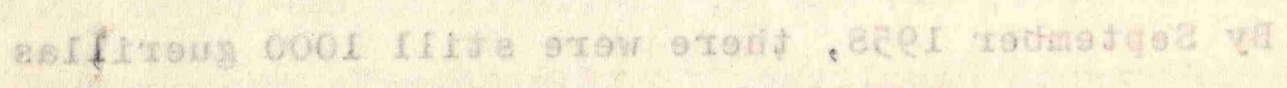

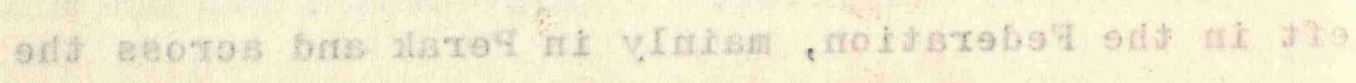

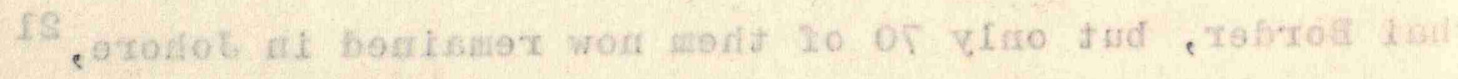

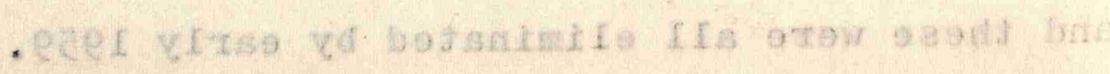


The final battle in the other hard core state Perak - was a tougher one, but was also successfully concluded in 1959. As it happened, the crumble in Perak started earlier than in Johore, and also began with a "Super SEP" - though he was not quite as senior as Hor Lung .

He was a Regional Political Commissar, and he surrendered in October 1957. An exceptionally shrewd young British Special Branch officer conceived the plan for him to do precisely as has been described for Hor Lung and indeed, this operation was the model on which Hor Lung's was based. The Political Commissar, over the next six months, brought out 118 guerillas - virtually the entire organisation of South Perak. ${ }^{2}$ There were a few of these who he was convinced would not answer his call, and these were ambushed and killed instead. They were the toughest of them all, who, unlike Ah Chiau, would not trust the government to honour its promise to repatriate them without brainwashing, and fought to the death. 23

In both of these operations, the principals (the Political Commissar in 1957 and Hor Lung in 1958) lived in seclusion in the homes of British Special Branch Officers. So, for a time, did the guerillas they brought out. As the number grew, however, it became more and more difficult to prevent something leaking out, yet the smallest hint would have alerted that tiny core of dedicated Communists who would have gone to any lengths to trap the "traitor", and would have in any case 


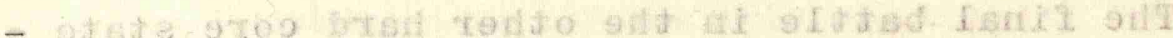

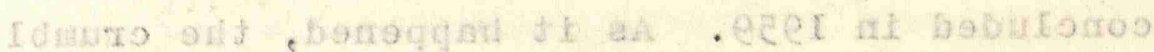

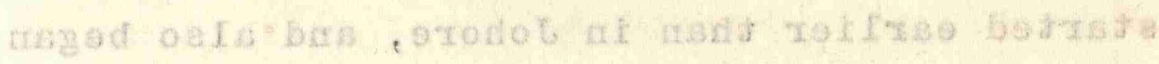

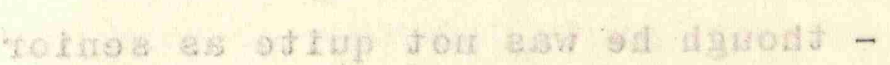

24. Straits Times, 27 August 1958

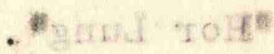

25. Malay Mail, 27 August 1958

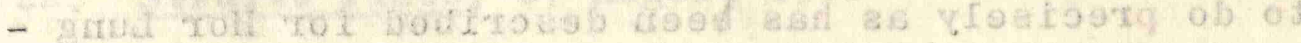

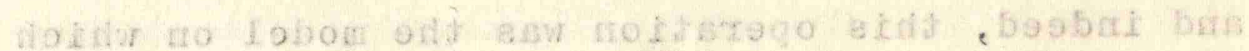

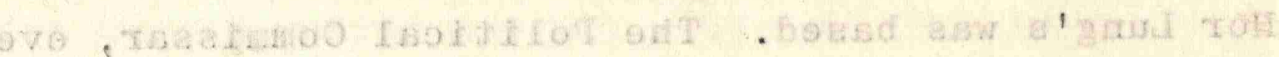
26. See Chapter 9

27. During the previous 4 years only 83 guerillas had been eliminated, of whom at least 42 had been from the MRLA platoons. Operation GINGER, Special Branch Debriefing 1959, and Director of operations, Review, 1957.

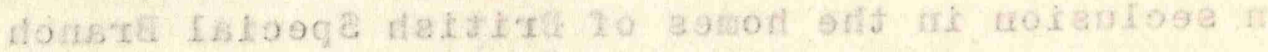

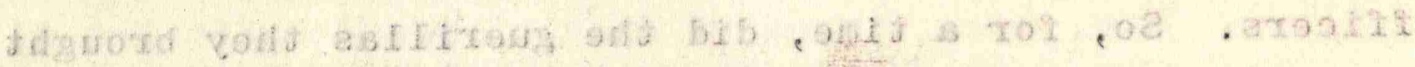

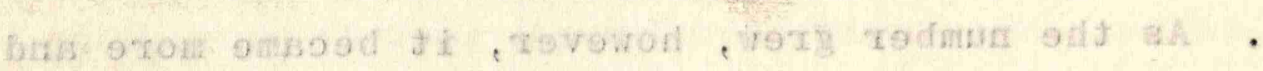

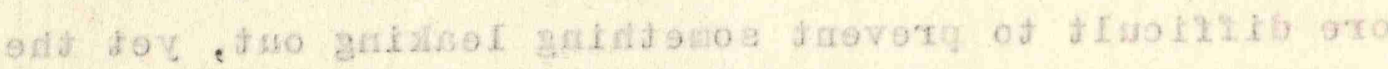

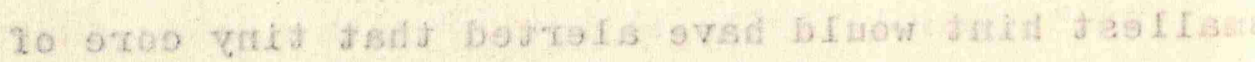

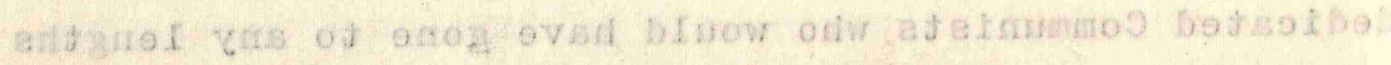

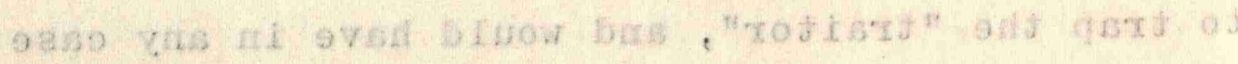


nullified his activities by applying a complete emergency. change of courier routes and jungle letter boxes. At an early stage, therefore, the Director of operations advised the Prime Minister to allow the editors of the leading newspapers to be given the outline of the operations, and to ask them to quell unwitting initiative by their reporters. This confidence was fully respected and no hint whatever leaked out until the news was released - of the 118 in Perak in June 1958, and of Hor Lung and his 160, as already described, in August. 24 The Press was publicly thanked for its discretion by the Prime Minister when he gave his Press Conference. 25

The hard core in Perak was in the North, in the tin mines, around Ipoh, and in the tapioca fields and rubber estates in the Sungei Siput District, which had been Chin Peng's stamping ground in the Japanese occupation, and where the Emergency had begun in 1948.26

In January 1958, there were still 170 guerillas in these two districts of whom only 19 were in the single surviving MRLA Unit (No. $13 / 15$ Platoon), and 161 were in the district and branch organization, which was almost as strong as it had ever been. 27 Its pattern was similar to that described in the Yong Peng District of Johore (see Chapter 10). Excluding the city of Ipoh $(150,000)$, the population in the small towns and villages numbered 125,000. Special Branch estimated that "the vast majority of the Chinese" in the area supported the MCP. They operated an elaborate intelligence system, and it was almost impossible for Security Forces to enter the area without the guerillas being informed. This was particularly effective in the tapioca areas, in which the crop stands roughly chest high, enabling the Communist supporters 
28. Operation GINGER, Ipoh District Special Branch Appreciation, 31 January 1958. This type of terrain was unusual in Malaya but is common in the Philippines and Vietnam, where the guerillas have used a similar system of signalling. Interviews, Colonel Napoleon Valeriano 1963 and Colonel Charles K. Nulsen 1968.

29. Operation GINGER, Military Debriefing, Ipoh 1959

30. Operation GINGER, Special Branch Debriefing, Ipoh 1959

31. Waller, Interview, 1967. Mr. Waller was officer Commanding the Police District of Ipoh during the planning of operation GINGER.

32. GINGER SB Debriefing. 
to watch unobserved, and then, when necessary, to stand up and "adjust" their highly coloured head-scarves with a flourish, as a signal to the guerillas overlooking the fields from the jungle covered hillsides. Most of the cultivated areas north of Ipoh were planted with tapioca. 28

15th January 1958 was D-Day for Phase II of Operation GINGER directed against these 170 guerillas and their Min Yuen. It was the last federal priority operation of the Emergency, and followed the pattern described in Chapter 12. With an initial strength of 1900 Police, 9 platoons of Home Guard and 4 Infantry battalions, the process of clearing the weaker areas first enabled the unprecedented total of 7 battalions to be concentrated on the operation from September 1958.29

Phase II lasted 15 months - i.e. until April 1959. By this time 156 of the 170 guerillas had been accounted for. 30 It was later found that 7 had escaped to Thailand in 1958, and another 6 surrendered after the operation, leaving only one unaccounted for. 31

of the 156 eliminated during the operation, 40 were killed in battle and 5 were hanged after capture and trial for their crimes, having refused the chance to accept SEP status. 5 died in the jungle or were executed by the guerillas. There were 106 surrenders, of which 60 were induced or negotiated, on similar lines to those induced by Hor Lung in Johore, ${ }^{32}$ and described earlier in this chapter.

As was often the case there were no kills in the first two months of Phase II, (though 3 guerillas were 


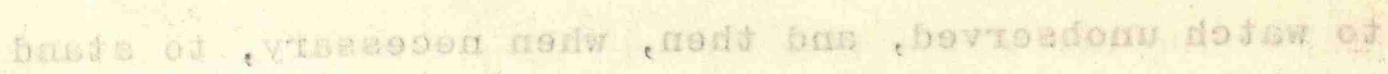

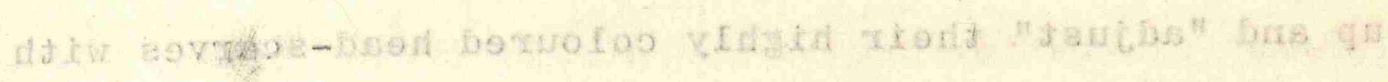

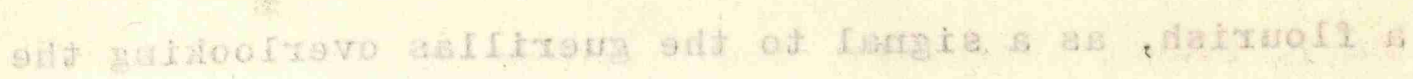

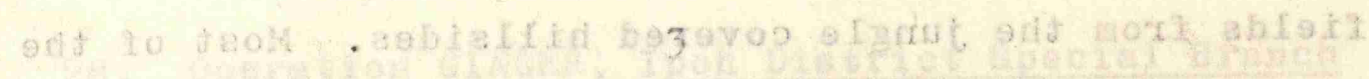

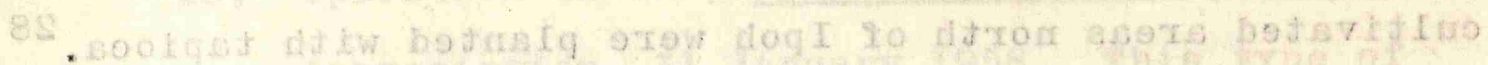

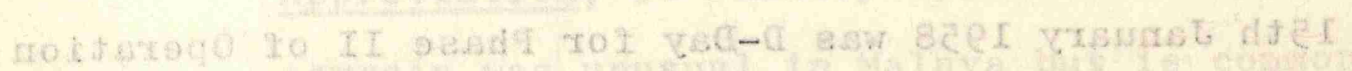

33. Waller, Interview, 1967

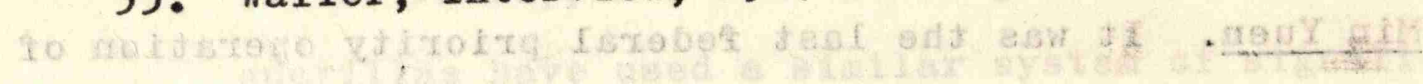

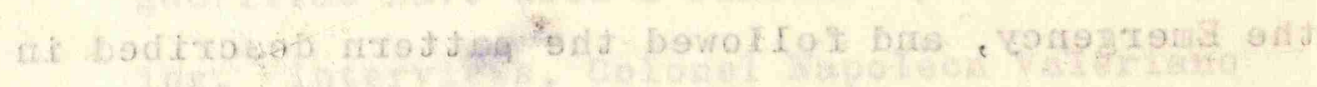

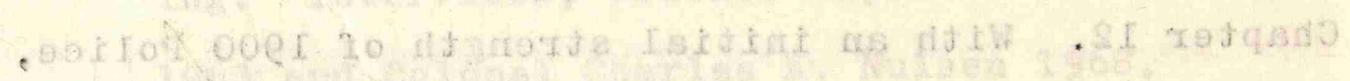

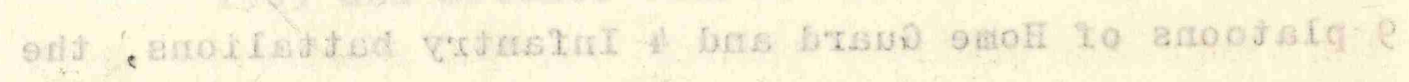

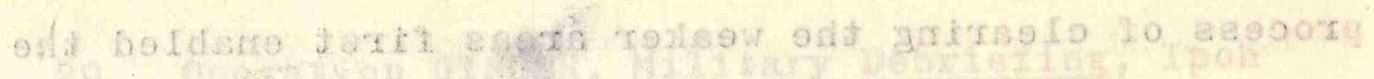

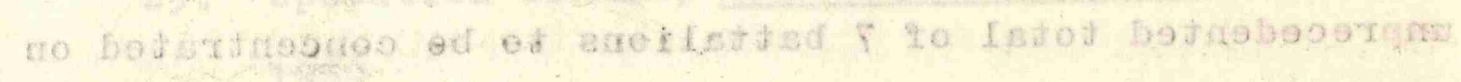

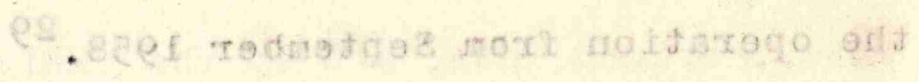

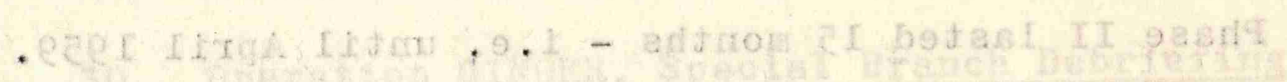

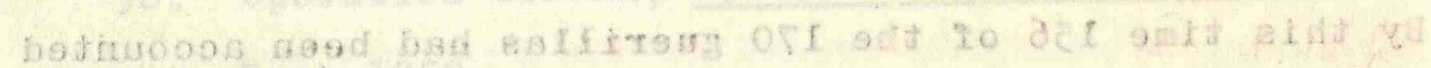

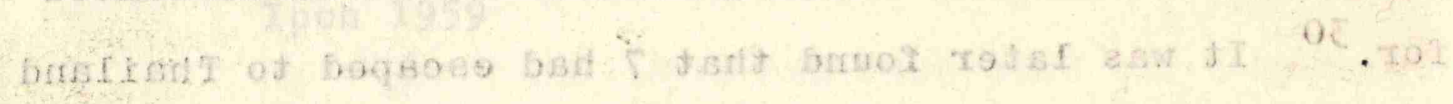

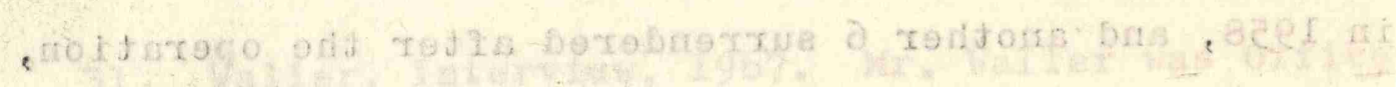

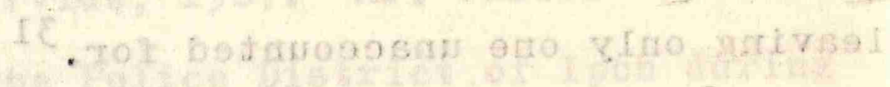

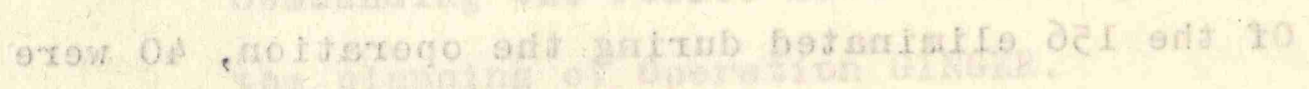

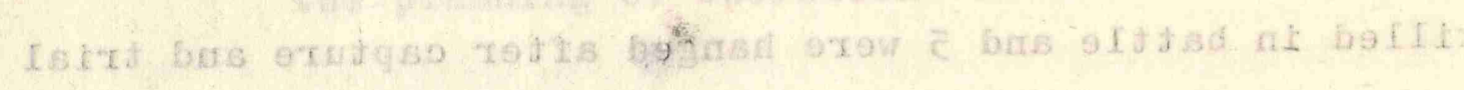

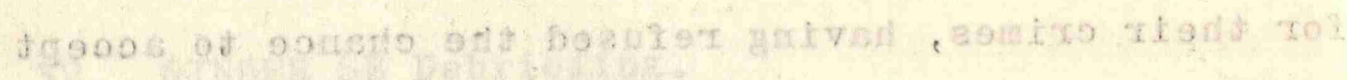

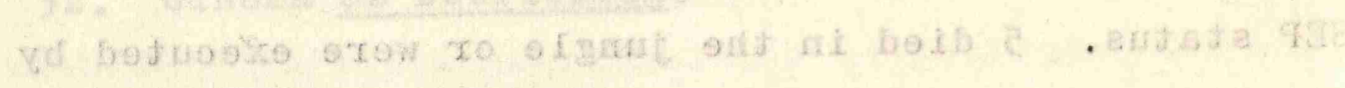

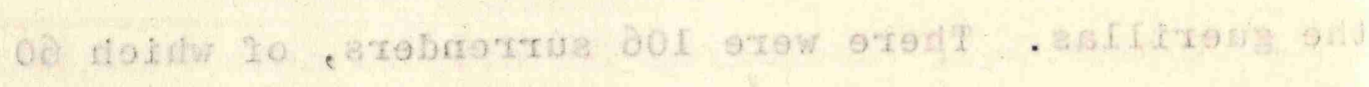

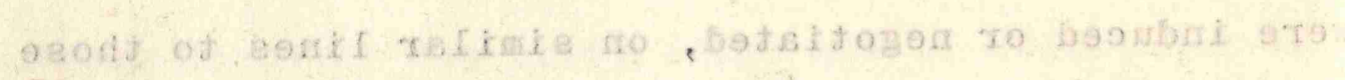

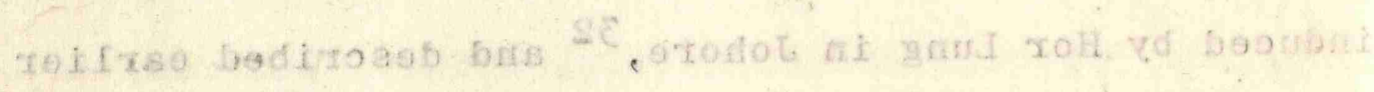
- xomasilo atilt

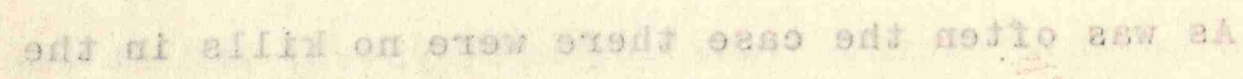

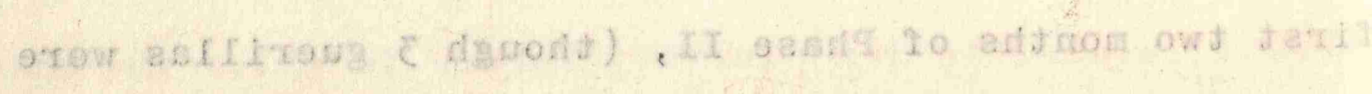


captured or surrendered). The first kills came in the $3 \mathrm{rd}$ and $4 \mathrm{th}$ months ( 4 in each), and over $60 \%$ (25) in the 5 th, $6 \mathrm{th}$ and $7 \mathrm{th}$ months. During the first 6 months there were only 16 surrenders. During the second 6 months, there were 79 including 31 induced. 33 Thus the last MCP stronghold on Federation soil was destroyed - leaving only Chin Peng and his remaining force across the Thai Border.

Kedah - A Different Approach

Before considering the Thai Border situation, it is worth examining an entirely different approach - neither framework nor priority operation - which was used to neutralize the guerillas on the Malayan side of the Border in the Northern state of Kedah.

This was a typical watershed frontier; it had only two road crossings, one at each end, with a 100 mile strip of mountainous jungle, 20 miles deep, between them. It was to Baling, on the southern of these two roads, that Chin Peng crossed for the abortive truce talks in 1955.

Between these crossings there were only two minor road systems, splitting into fingers and petering out altogether as they reached the jungle about 20 miles from the frontier.

In this strip of jungle there were a number of tiny but fertile valleys, cultivated by families or small communities of a semi-nomadic mixed Thai-Malay breed known as Sam-Sams. They were wholly non-political, and knew nothing of Malaya, or Thailand, or Communism, or 


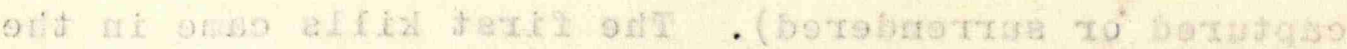

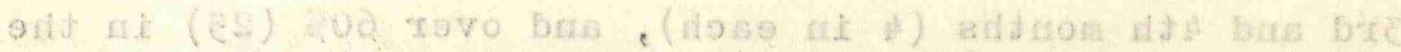

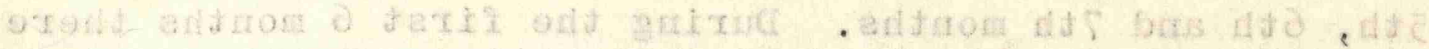

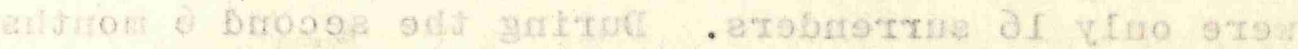

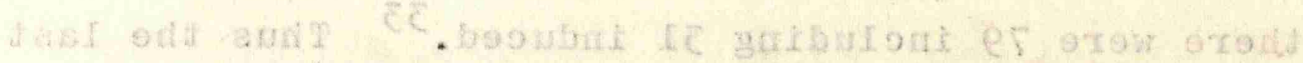

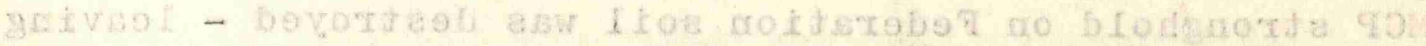

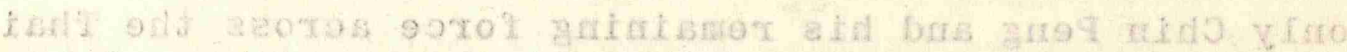
.296709

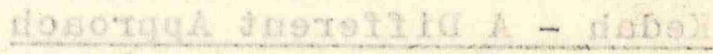

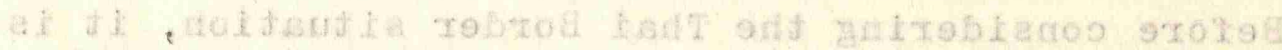

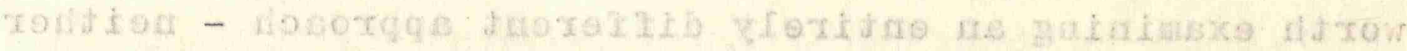

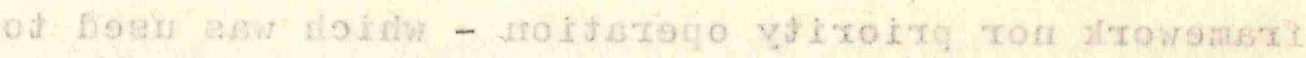

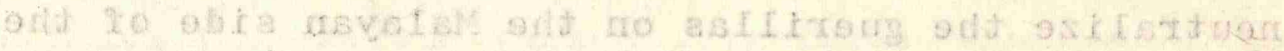

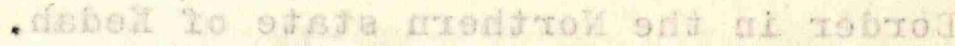

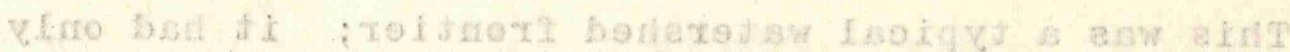

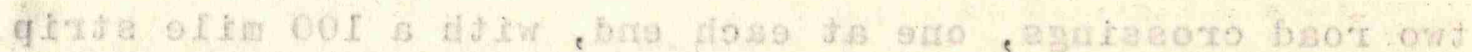

34. This pattern applies over much of Vietnam, where food denial has also been ineffective.

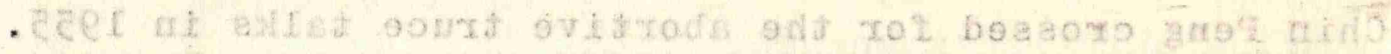

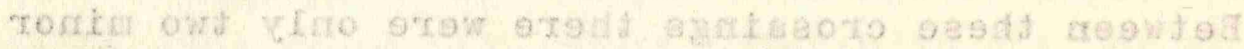

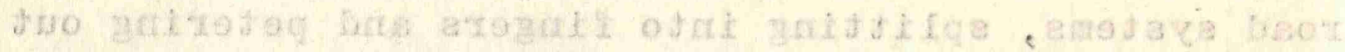

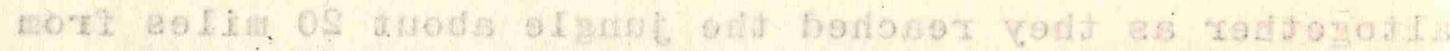

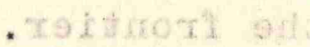

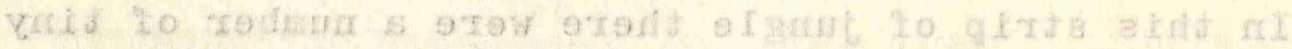

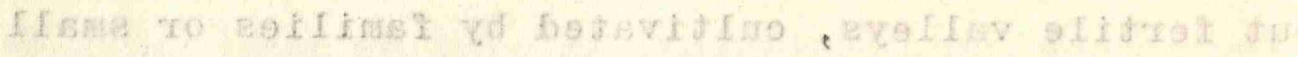

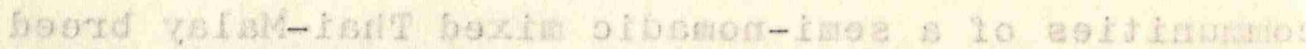

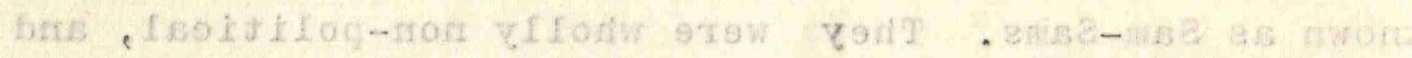

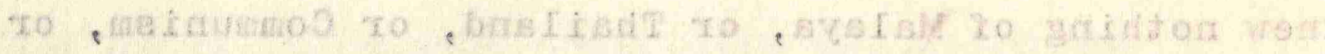




\section{2}

democracy, or indeed of government of any kind. They lived at subsistence level, growing padi in the wet fields beside the streams, which also provided their fish. To get to a market, or to a doctor or a school, meant a 15 or 20 mile walk along a jungle trail, and they did not find this worthwhile. Nor did the government find it practicable to bring any of these services to them until 1957.

Meanwhile, however, the guerillas found them most useful. The branches and platoons whose main work lay amongst the rubber estates in the cultivated plains of Kedah lived in these jungles, and obtained ample food from the Sam-Sams, for which they paid in full from the funds they gathered from their Chinese supporters on the estates. They provided the Sam-Sams with tools for building their houses and for tilling their land, with medical supplies and clothing, all of which they brought in from the plains. They also gave them and their children a certain amount of education.

In such circumstances the standard food denial operation - or framework based on food denial - would have been useless. This was more so because the plains of Kedah contain large rice growing areas. Though grown by Malays, this rice was in such profusion that it could not be wholly denied to the guerillas. 34 The Sam-Sams were not amenable to resettlement in a strange environment and when previous attempts had been made to resettle them they had melted away again into their jungle valleys. 


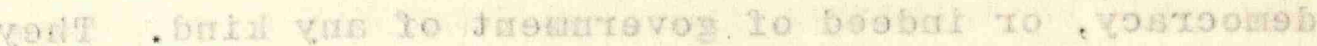

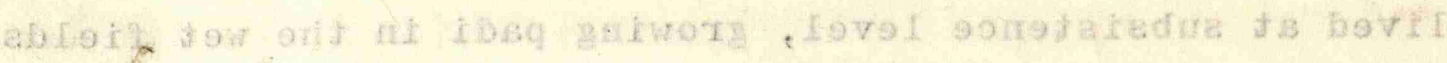

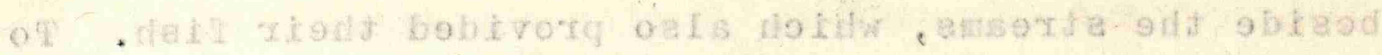

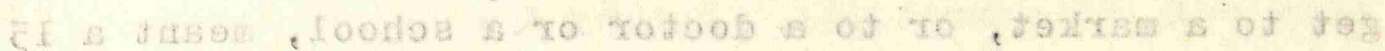

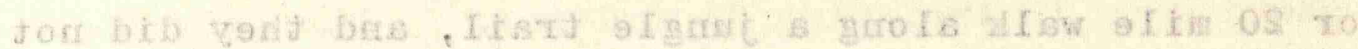

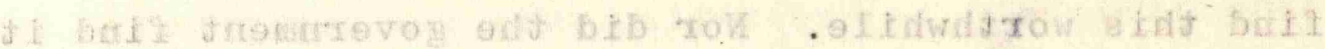

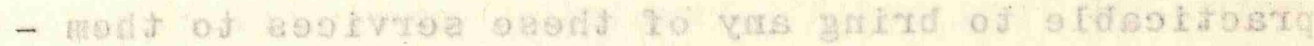
- TEQI II:ET:

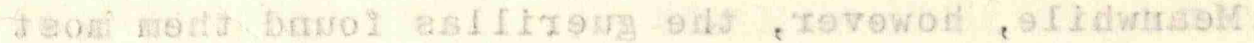

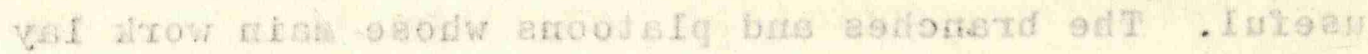

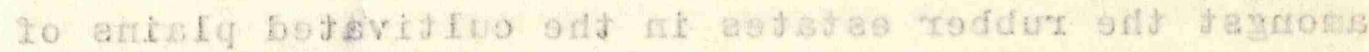

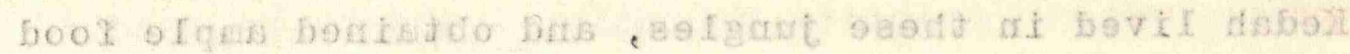

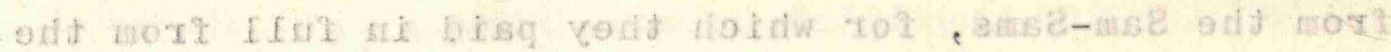

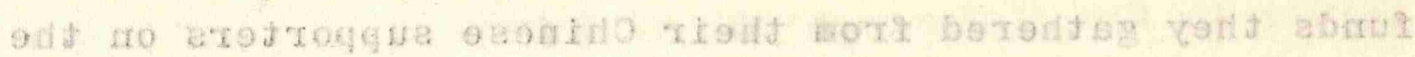

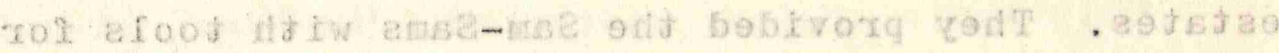

35. Clutterbuck, "Military Engineering as a Weapon Jala in the Cold War" in the Military Engineer, xi Washington, July-August 1963, pp.231-2 and Clutterbuck, The Long Long War, pp.153-5

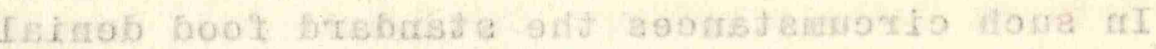

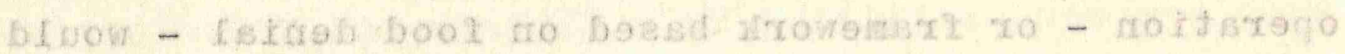

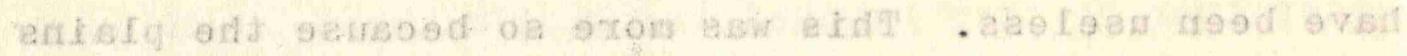

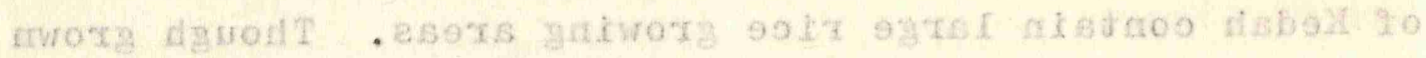

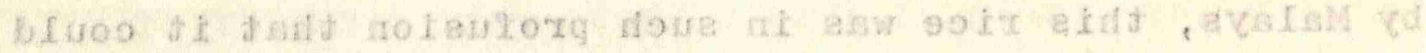

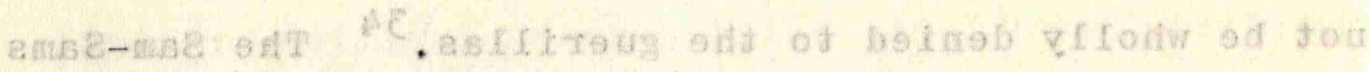

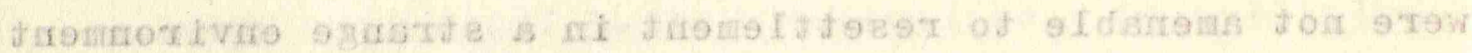

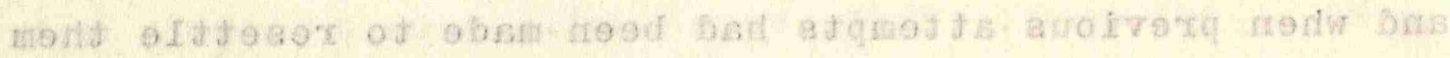

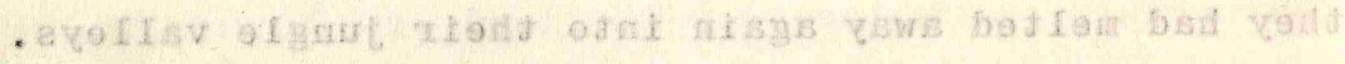


The solution was to link up the existing fingers of road with a 64 mile arc of new road embracing the Sam-Sam communities. This was done by military engineers Malayan, British and Gurkha - concurrently with the major operations in Perak and Johore from 1957-59. Trucks thereafter plied regularly along this road to take produce to market and to bring in agricultural equipment and fertilizer. Schools and clinicswere established, doctors paid visits and ambulances took the sick and injured to hospital. The Sam-Sams at last had a' stake in government, and helped the police and army in ousting the guerillas from their valleys.

The Min Yuen in the plains of Kedah was not as strong as in Perak or Johore, and, deprived of their sarictuary among the Sam-Sams, the guerillas either succumbed to framework operations or crossed into Thailand. 35 .

The Aborigines

A similar approach had been made to the problems of deep jungle bases for the guerillas amongst the even more remote aborigine areas in the mountain spine of Malaya. The aborigines were averse to normal village life and, if resettled, melted away to resume their semi-nomadic life of "shifting cultivation" in the jungle, usually several days walk away from civilisation. The solution was the establishment of jungle forts - really little more than defended camps occupied by between 30 and 100 men of the Police Field Force - in areas attractive to aborigines. These forts became trading posts; offering air-transported tools, clothing etc. to the aborigines 
36. Clutterbuck, Military Engineering, pp.229-231 and The Long Long War pp.150-2. Also Waller, Interview, 1970.

37. Director of 0perations, Review 1957 Appendix D.

38. See Chapter 10

39. Waller, Marginal Comments on Clutterbuck's The Long Long War 1968

40. Author's observation during a reconnaissance flight over the Thai/Malayan Border area in. 1957.

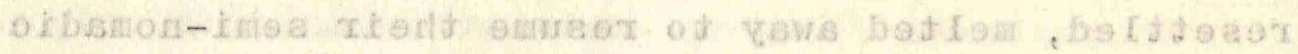

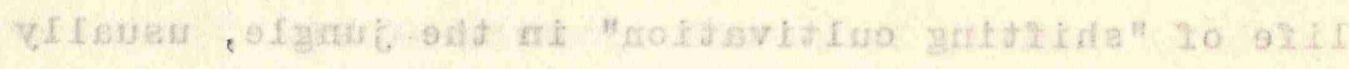

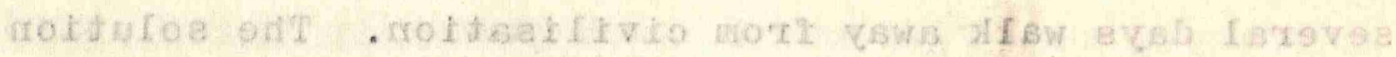

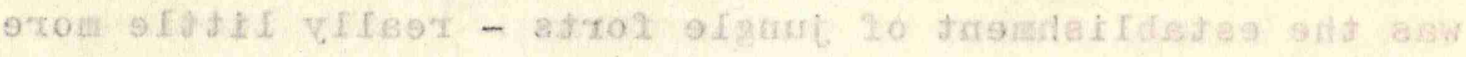

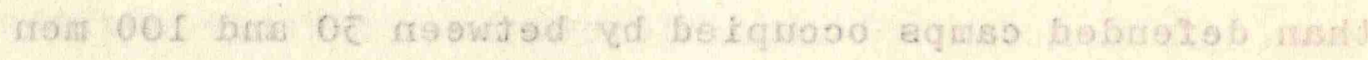

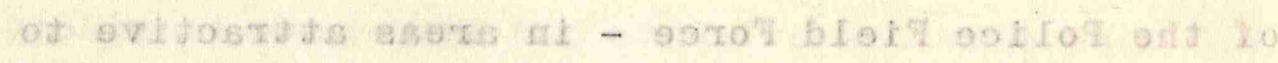

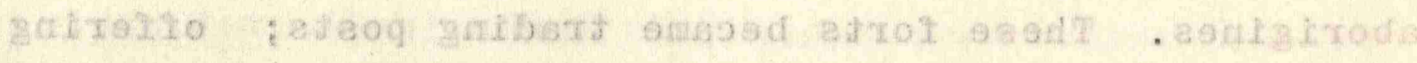

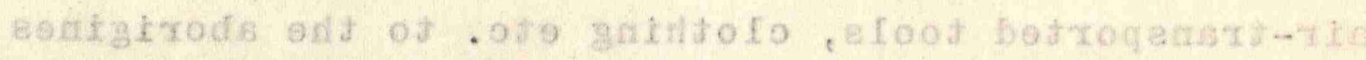


in exchange for their jungle-grown rice and tapioca, and as wages in kind for work or for service with jungle patrols. They were also medical posts, with a weekly visit from the doctor, and provided primary education. Drawn by the availability of these advantages, without the need to change their way of life, the aborigines shifted their cultivations to these areas, and, co-operated with the police in eliminating the guerilla bases. 36

\section{The Thai Border}

There remained - and still remains - Chin Peng's active sanctuary across the Thai Border, where on 1st September 1957 it was estimated that he had 467 guerillas, mainly living in large training camps in the $1948-49$ style. 37

Chin Peng's decision in 1953 to move his Central Committee and Training Base from Pahang to South Thailand has already been described. ${ }^{38}$ The population in South Thailand included some 30,000 Chinese, 39 mainly working in rubber, and living dispersed, each family close by the rubber lot on which it earned its living. 40 There had been no resettlement, so they were subject to neither protection nor control. Food was unrationed, and there were no other restrictions like those in Malaya. Most of these Chinese probably had little objection, and in any case no alternative, to providing the very small support in terms of food, money and information that was needed to maintain 450-500 of their fellow Chinese as guerillas in the neighbouring jungles. As early as April 1954, Special 


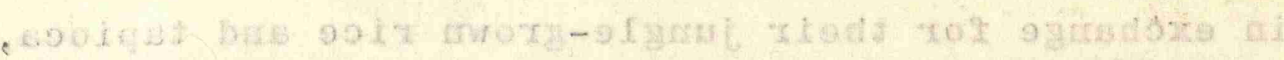

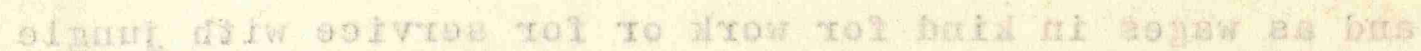

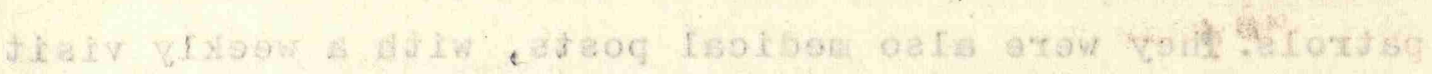

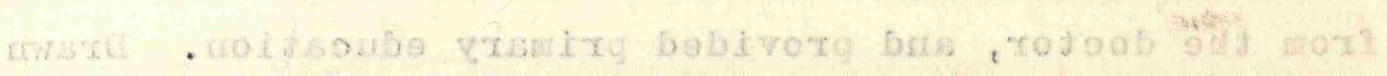

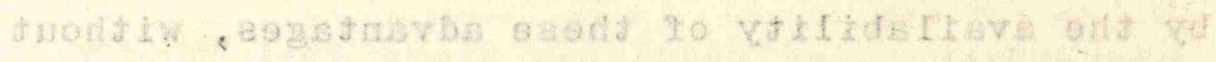

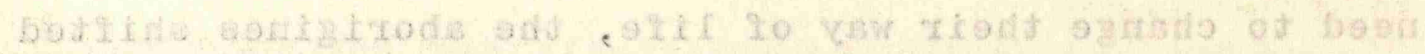

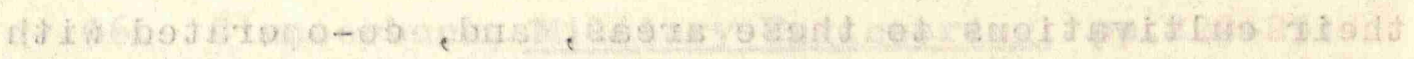

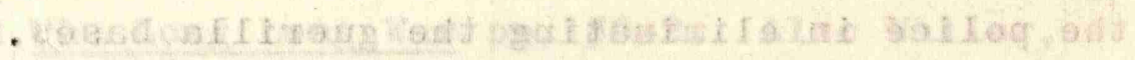

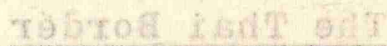

\section{Intelligence Appreciation for Operational}

\section{Planning for the Second Half of 1954 ,}

27 April 1954, p.17

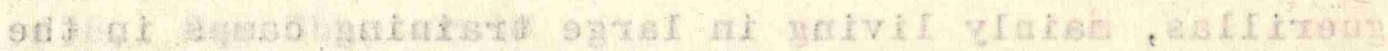

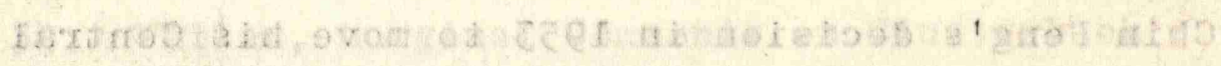

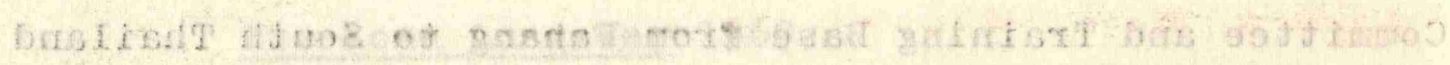

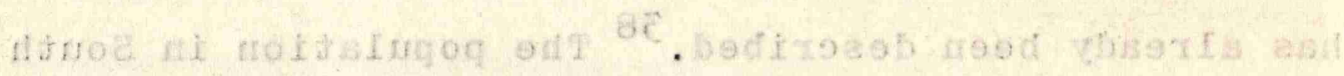

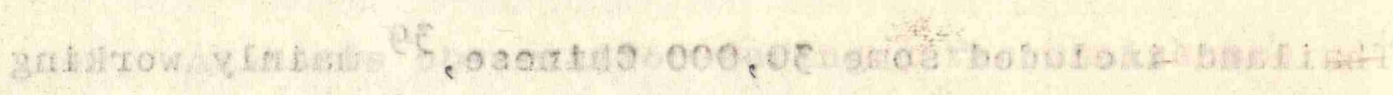

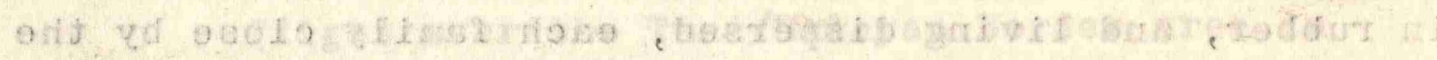

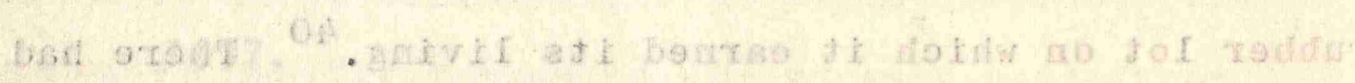

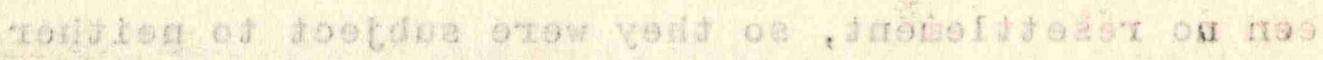

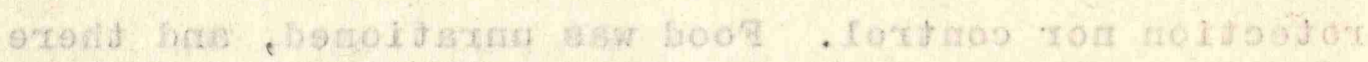

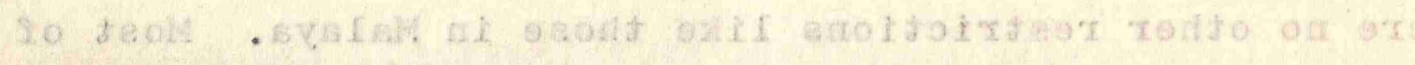

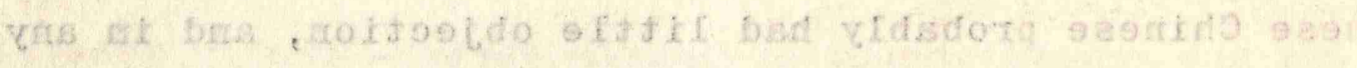

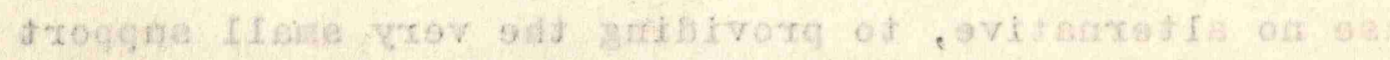

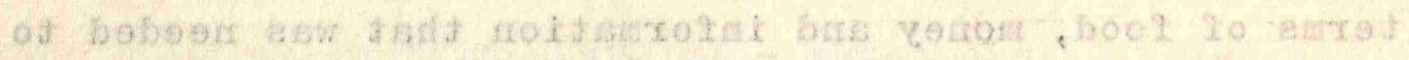

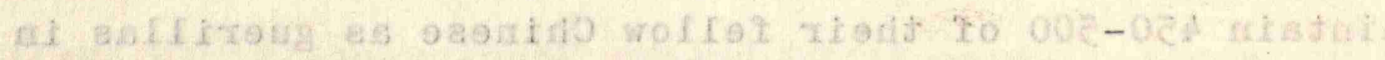

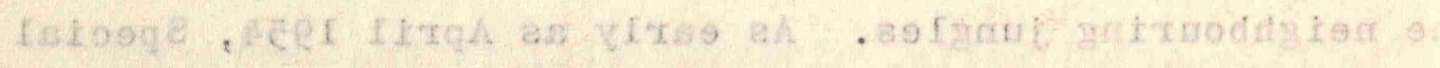


Branch in Kuala Lumpur had realized that this guerilla community was unlikely to be eliminated. They wrote:-

"Some headway has been made in improving both intelligence and co-operation with the Thais, but it is likely that the terrorists in the border area will remain a constant threat". 41

The situation remained the same for the next three years, and more. In September 1957 the departing British Director of Operations in his final report forecast the MCP collapse (which was, in the event, to begin a month later with the defection of the Regional Political Commissar in Perak and then of Hor Lung in Johore) but added:-

\footnotetext{
"There would still remain, however, several hundred (guerillas) firmly established in the undeveloped country astride and beyond the Thai Border. It would be wrong to divert much effort to this area until the main inhabited areas (of Malaya) are cleared. Even then, successful operations would depend on the enforcement of unpopular civil measures, such as resettlement and food denial. The Thai Government is being approached about this, but it is unlikely to be politically strong enough to enforce really effective Emergency Regulations or to mount major military operations in South Thailand. We should, therefore
} 


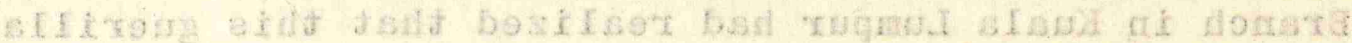

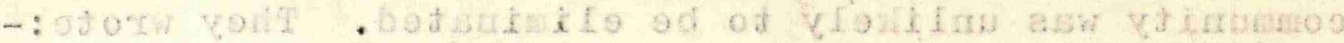

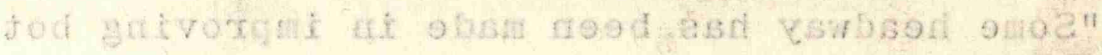

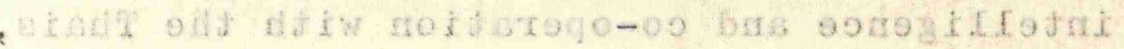

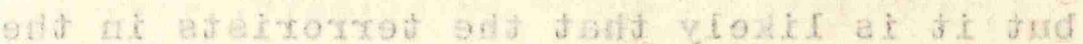

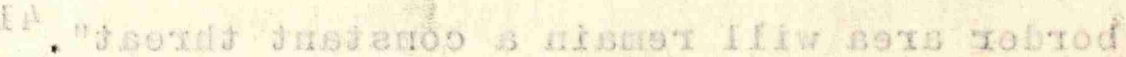

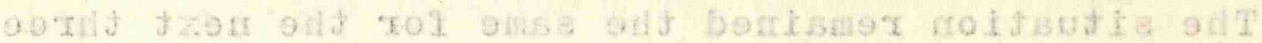

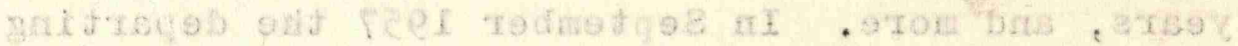

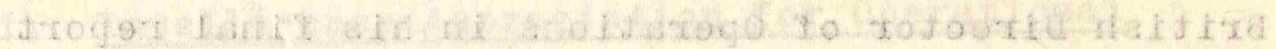

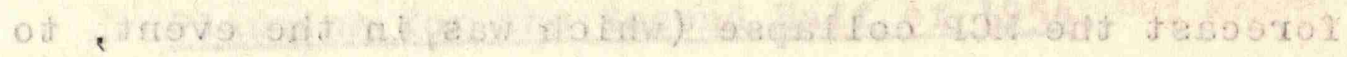

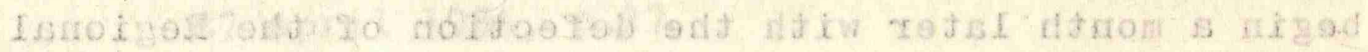

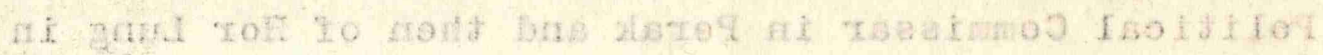

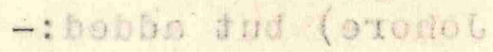

42. Director of Operations, Review 1957, p.24

This passage was in fact drafted by the author, then on his staff.

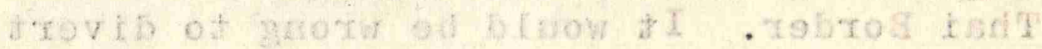

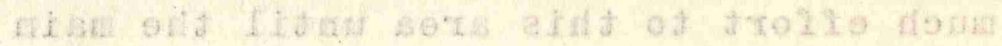

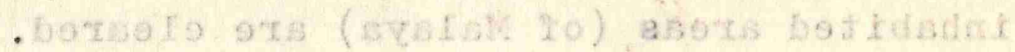

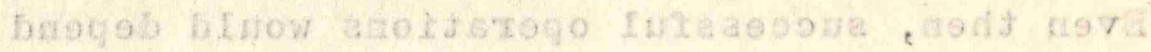

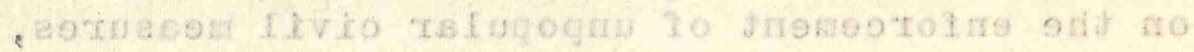

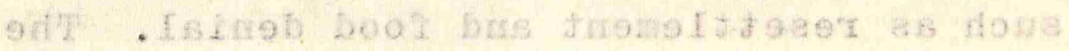

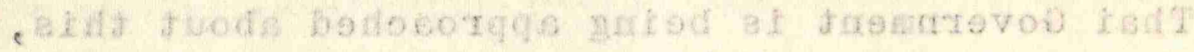

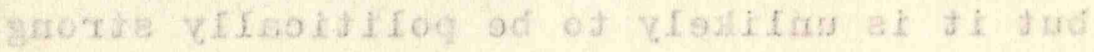

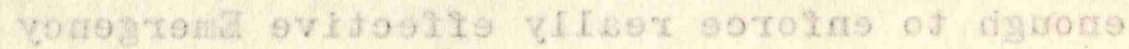

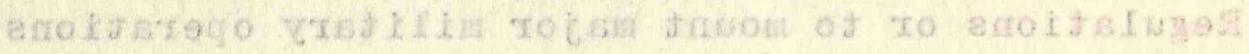

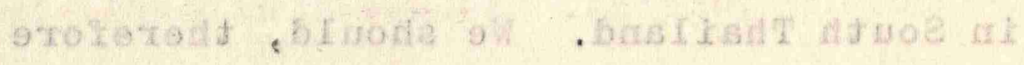


base our future strategic thought on the assumption that Chin Peng will retain an army of at least 500 in South Thailand, and may well draw in more from the Federation. This Army will be able to live in relative security, to train and to expand and to wait, as the Communists waited in China, in the hope that political and racial difficulties and the progress of subversion will create the conditions suitable for renewal of their intervention in the Federation or Singapore. The best guarantee against this will be growing prosperity and a strong, efficient and enlightened Government. These will best be ensured by losing no time in shaking off the load of the Emergency from the wealth producing areas and by weakening the Communist potential for subversion in the villages and the towns." 42

The threat remains today (1969) in precisely the same form, though it is stronger. The guerilla strength is now estimated at over 1000 , most of which consists of young Chinese undergoing training who return home after their course. The number trained and available is therefore probably very much greater. Some of these have come from the Federation and returned there after 


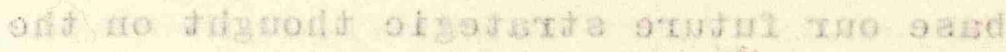

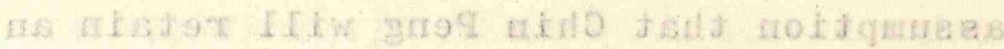

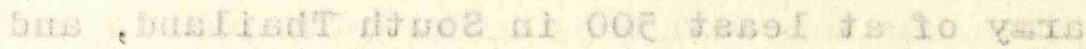

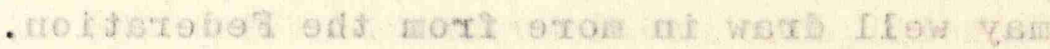

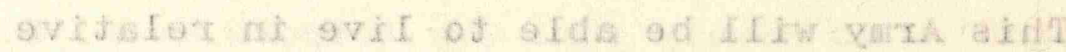

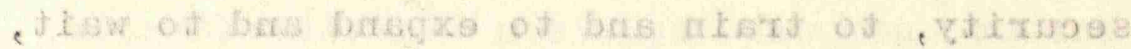

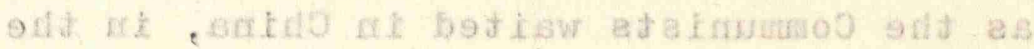

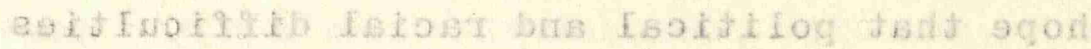
9d

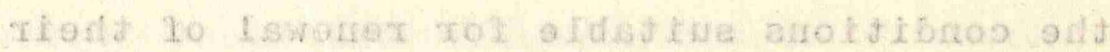

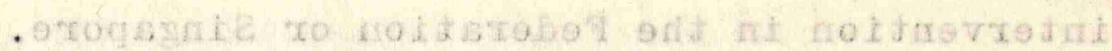

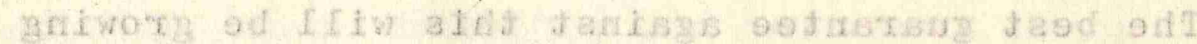

43. A copy of prints from this film is in the author's possession. Otherwise, this description is based on interviews with "Harris" (SB) and with Waller in 1967.

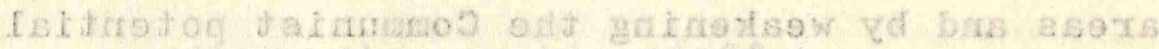

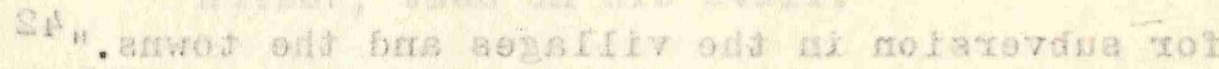

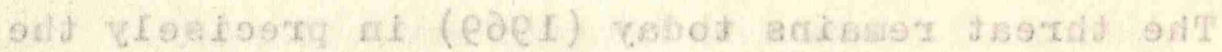

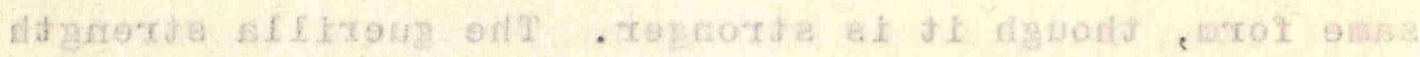

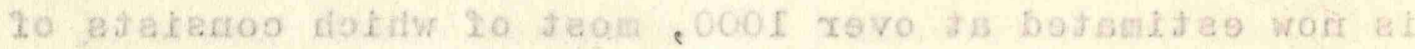

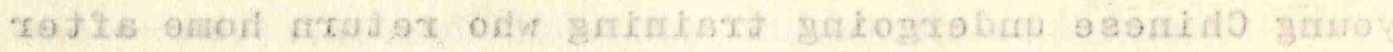

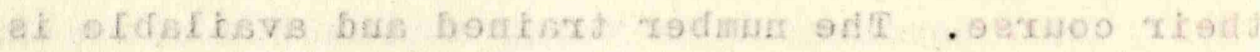

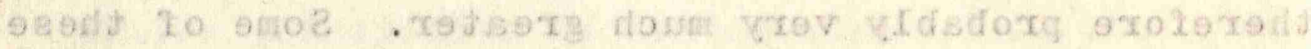

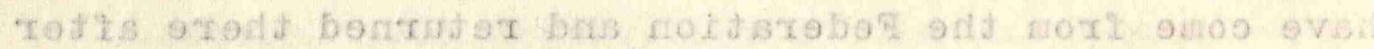


training, though most come from the 30,000 Chinese who live in South Thailand.

The guerilla camps remain, large, permanent and well found. One was discovered (hastily abandoned) by a joint Thai-Malay patrol, scarcely 100 yards in from the edge of the jungle, late in 1966. In it the patrol picked up a roll of film which recorded the events of a recent "Open Day". Over 90 armed guerillas in uniform had marched past a row of senior officers, in Moscow May-Day style, on an impressive balcony (found intact) under a huge Hammer and Sickle. There were pictures of propaganda plays, showing mock-up tanks and guns ("Paper Tigers") and an impersonation of President Johnson; of singing, dancing and games; of a large audience of civilians, mainly young, attending a lecture; and of a gay and festive children's tea party. 43

Though the "load of the Emergency" was shaken off in 1960, "conditions suitable for renewal of their intervention" in the Federation seem no further off. Malaya survived Indonesian Confrontation in 1963-66, and in doing so brought about the destruction of a very strong Communist threat from the South. "Racial difficulties", however, have become greater rather than less. The failure of merger with Singapore in 1965 had a strong racial flavour. Though Tunku Abdul Rahman and the multi-racial Alliance Party remain in power, the 1969 elections showed rising support for opposition parties mainly supported by Chinese and Indians. In 
9asmiglo 000,

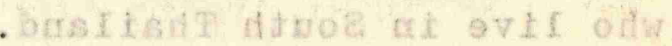

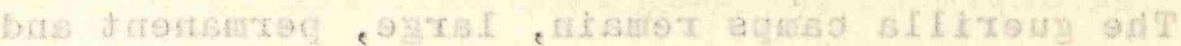

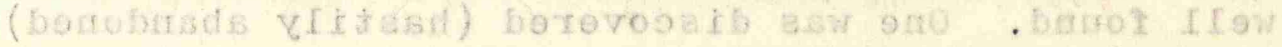

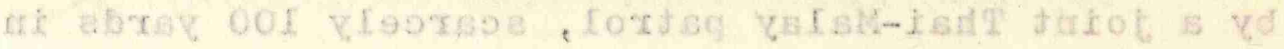

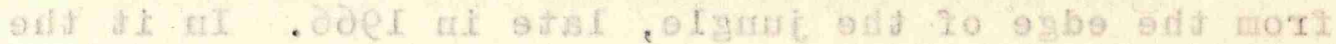

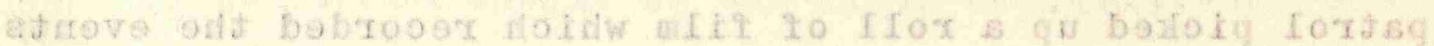

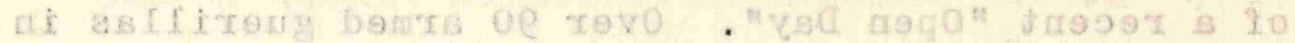
44. The Times, 8 November 1969.

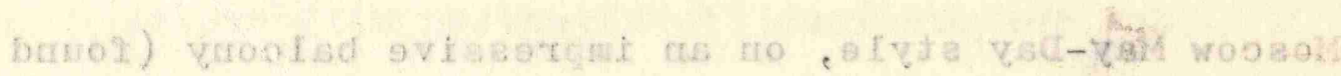

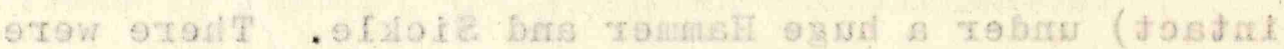
45. "Seng" (SB) Interview 1968

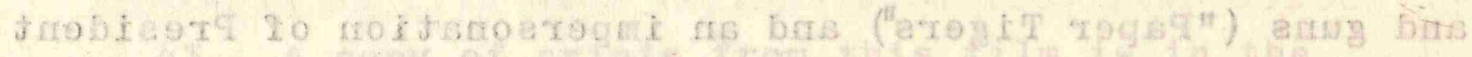
46. Douglas Hyde, Interview, 1969.

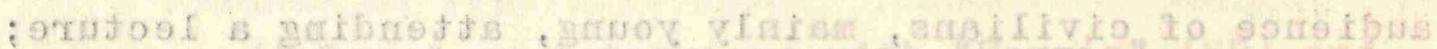

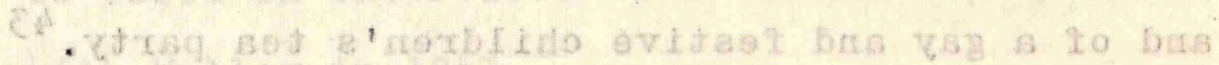

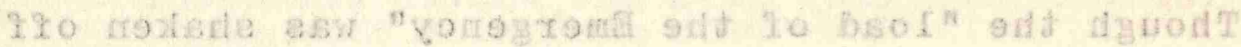

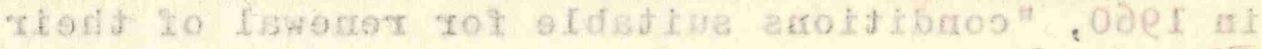

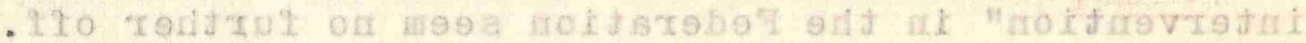

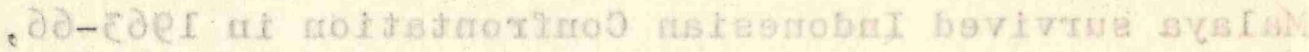

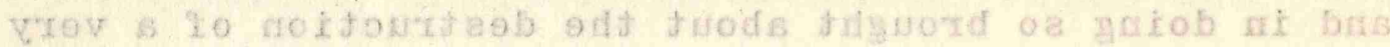

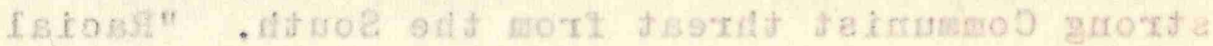

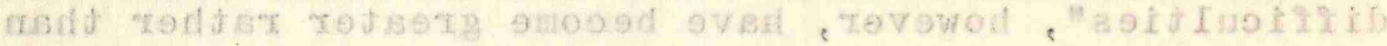

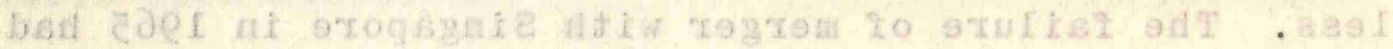

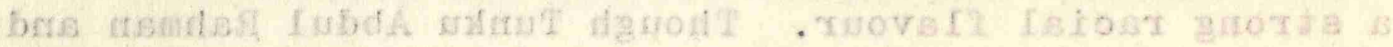

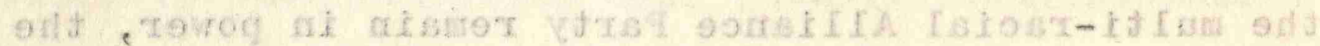

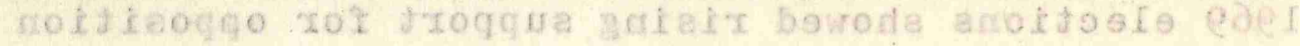

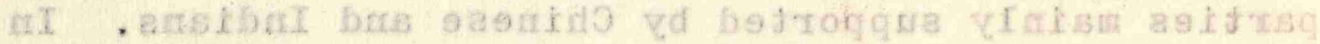




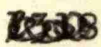

ensuing demonstrations by supporters of these opposition parties, Malay soldiers and police were called out to fire on the crowds and communal rioting was only checked after considerable loss of life. Less than 10 years after the end of "The Emergency" another State of Emergency was declared and remains in force. Parliament is suspended and the situation remains tense. 44

The MCP is banned both in Malaya and Singapore, and the legal political parties with which it might hope to form a United Front are weak and disunited. ${ }^{45}$ Relative prosperity and economic growth in both countries offers poor grounds for Communism, but Chinese frustration, or resentment of what they consider to be unjust discrimination or suppression, has an explosive potential in the Federation (though not in Singapore). Should they feel that legal political leadership is being denied them, the number of Chinese responding to clandestine MCP leadership could increase. If it does, Chin Peng is well placed to exploit the opportunity. 46 
CHAPTEER 14

CONCLUSIONS 


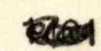

\section{CHAPTER 14}

\section{City versus Guerilla Revolution}

The progress of events in Singapore and Malaya underlined the contrast between the techniques of city and guerilla revolution. In Singapore the revolution was run by a very small cadre of party members, with a larger proportion of the people openly involved, but with very small loss of life. In the cities of the Federation, although most contained an overwhelming majority of Chinese, the revolution failed to get any appreciable hold at all, but in the Chinese villages and in the jungles around them there was a far bigger party organisation, with many fewer of the public openly involved, thaigh with far more of them being killed than in Singapore.

This reflects the contrasting fears and aspirations of city and rural people mentioned in Chapter 1. City people fear a collapse of order, of being without work, wages, food, water and other public utilities, and tend to rally to the government in face of excessive violence or dismuption unless that government is manifestly less likely to be able to restore order than the revolutionaries - a stage never approached in Singapore.

By contrast, the isolated mural Chinese, such as the squatters and the rubber tappers at work, had little answer and little hope of protection against the threat of murder, abduction and looting of their food stocks. To acquire support, therefore, the revolutionaries made these threats very real by killing those who resisted them. At the peak of the Emergency they killed many more civilians than soldiers, and of the civilians killed the overwhelming majority were Chinese.

Although they remained separate until 1963, Singapore and the Federation would probably have stood or fallen together. Neither the British nor the Communists could for long have governed one without the other. The revolutionary efforts in both therefore proceeded concurrently, though 


\section{0}

with varying intensity and success.

These variations were not laid down in any MCP Master Plan. The Communists in all areas worked towards standard aims as opportunity arose. Where they succeeded, like ants seeking a way over a belt of puddles, they exploited their success. Their members and supporters were less often motivated by specific instructions emanating from the Central Committee (whose communications were appallingly difficult and slow) as by the study of dogma which made up the greater part of the work of the cells, and which told them how best to act in any given situation.

The MCP did, however, influence the priority of effort in city and countryside by switching more of its best members from one to the other, notably in 1945 and 1948. It must be asked whether this paid them and which field gave greater promise.

The first change, in 1945, was probably wrong. Had the MCP maintained its thriving anti-Japanese guerilla army, with its loyal mural Chinese support, faced by weak and discredited Malay local administrations, the British would have found it remarkably difficult to have revived the tin and rubber industries and, had they failed, they would have probably been glad to abandon the Federation and Singapore. The factors which guided the MCP away from this choice were their lack of thought and preparation resulting from the sudden surprise ending of the war by the atomic bombs; the British "penetration" of their jungle army which they had accepted to help them fight the Japanese (though they could quickly have liquidated the men of Force 136 if they had planned to do so); the obvious delight of the great majority of the people of all races at the defeat of the Japanese and the end of the war, which was reflected in a joyful welcome for the British, with the hope they offered of a return to a better life; and the predominance in Communist theory at this time (before Mao Tse-Tung's success) of the urban revolutionary strategy. With the reestablishment of British authority and of the British- 
1 Patrick Seale and Haureen HoConville, In

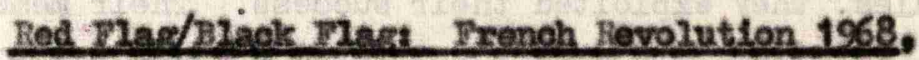

New York 1968, elve a renarkable pletuxe of the chaotic lack of organisation and of the Ineffectiveness of the many anateurish revolutionary movements attempting to rally populax support and provoke oonfrontation with the police, In Parls in 1968. The end of the story the rally of the mass of the people to the government speaks for itself.

2 See also The Denesi and Fhere It Kles, Infomation Services, Tederation of Malaya, Ktala Iuxpux, 1957 p 57-63 for an aocount of Communiat Trade Inion taotios in the Federation of Halays. 
managed tin and rubber industry, it may be that the MCP's cause was already lost by 1948 . They had by that time been effectively blocked in Singapore. Had they kept their rural organisation intact from the war, and had they concentrated from 1945-48 on weakening the tin and rubber industries and strengthening their hold on the workers in these industries instead of putting their effort into Singapore, the rural rebellion might have succeeded - particularly in view of the mistakes in military tactics made by the British up till 1952, and the initial weakness of the Police intelligence service.

\section{The MCP Organisation in Singapore}

The MCP in Singapore certainly put its money on a Leninist type of organisation. More modern revolutionaries, particularly in Europe, have a great deal to learn from it, for their organisations in 1970 are greatly inferior to that of the Singapore Communists from 1947-56. ${ }^{1}$

The control of about half the Trade Unions by the SFTU, with its open and legal link with the MCP, was a strong start towards a parallel hierarchy, or Trotsky's "dual power". So was the emergence of the SFSWU (for the unions) and the SCMSSU (for the students) in 1955-56.

The revolutionary organisation in the Trade Unions in 1947 was a model of how such things should be run. The three prongs - the open leaders and members of the legal Communist Party: the Party Groups of secretly Communist members holding key posts in legal Trade Union committees and the wholly secret party cell system, fostering and exploiting grievances on the shop floor - were screened from each other but were all controlled by the Town Committee. Strikes, as a result, were well timed and well coordinated with each other and with the political situation. ${ }^{2}$

The organisation for growth of the cell system downwards was also greatly strengthened and made more secure by the intermediate level of the Anti-British League. The sympathiser cells, which carried out the function 
of screening potential recruits, were always liable to contain turncoats or agents planted (or turned) by Special Branch. The Party cells themselves, however, were fully insulated from betrayal by these people because of the intermediate cells of ABL members who had proved their reliability by previous service in sympathiser cells.

The student organisation in the Chinese language schools, as well as incorporating the $\mathrm{ABL}$ and sympathiser cell structure, also had an open structure greatly superior to that of most contemporary student organisations. In the open, there was a central and legal Committee in secret touch with a Party representative outside the school. This was the School Committee which, through its Standard Committee for each age group, ensured that boys sympathetic to its ideas were elected to most of the Class Monitor posts. At the grass roots, the open and seemingly laudable Tuition Cells fed promising boys across to be exposed to more direct indoctrination in the secret Hsueh Hsih cells, which in turn formed a source of members for sympathisers and ABL cells, which in turn had their link with the Party outside.

The MCP in the Chinese language schools had one great advantage not enjoyed by the schools and universities in the USA, Latin America, Europe and Japan - nor indeed by the present schools and universities in Singapore: because of the emotional appeal of Chinese culture, the starvation of Chinese-language schools in comparison with English-language schools, and the bias in favour of the English-educated in searching for jobs, the SCHSSU enjoyed the support of the great majority of the students in its schools, and those who did not want to support it had little option but to do so in face of this weight of public opinion, which took an aggressive form.

This favourable public opinion, however, was created and developed by the organisation as well as supporting it. 
The ability of the Party and its supporting organisations to attract and foster genuine idealism - particularly amongst the young-should not be under-rated, and this was publicly conceded by Lee Kuan Yew at the crucial moment of his fight against Communism. A most convincing example of this idealism was the work of "Hong", the Communist teacher at Ayer Baloi, described in Chapter 4.

The weakness of the organisation lay in its own extremely tight security. Gaps in the organisation were concealed from higher authority in order to safeguard reputations, and from subordinate cells in order to maintain confidence. In addition, the information reaching members was scanty and slow due to the complex system of couriers and cut out men. This resulted in members working in great obscurity, and was a major cause, for example, of the fatal tactical errors made in the October 1956 riots and the events leading up to them. These contrast with the tactical successes of the Governor, the police and the army, whose officers were fully informed of what was happening. Achievements and Failures of the MCP in Singapore

The aim of the MCP in Singapore up till 1955 was to oust the British colonial government and substitute a Communist one, in conjunction with a similar aim in the Federation of Malaya. During the transition stage to independence (1955-63) when the British were clearly on the way out, their aim became to capture control of the elected Singapore govermment, either by constitutional or revolutionary means.

Both of those aims were perfectly feasible. The most promising years for the first were 1945-47; for the second, they were 1956-57 (to coincide with Malayan independence) and 1962 (to coincide with the end of British responsibility and reserve powers of intervention).

The Party failed in both aims, and achieved little in the way even of erosion of authority; so far from accelerating the British withdrawal and 
the final attainment of independence, it almost certainly retarded them.

Its achievements were therefore no more than those of a football team which trains for a number of championship matches but loses every one. Yet that team might come within a single goal of winning, and the achievement of their preparation can be assessed by whether they can keep within striking range of victory, whether they can seize the chance of the vital goal if it comes, and whether they can hold the championship after they have won it.

On this assessment the MCP organisation in the Trade Unions in 1947 and 1956 and in the Chinese schools in 1955-56 were of championship standard. The political organisation was probably not, even when it seemed to be within a single vote of capturing power in 1962.

But the MCP lost. It is therefore fair to ask whether they might have done better with wholly different training and tactics - and in particular whether they could have succeeded with a "New Left" philosophy of bringing about a popular rising by continuous demonstration, violence and dislocation, without the delays involved in building up an organisation and fostering a revolutionary situation. In theory, such violence and dislocation, leading to bloody confrontation with foreign soldiers and foreign-officered police, could have resulted in such chaos that neither the Port of Singapore nor the British Military Base have functioned. An intermediate stage might have been the granting of concessions to strikers, leading to a growing attraction of new members to the MCP controlled union federations - the GLU, the SFTU and the SFSWU in turn which would have enabled the Party to withold labour wholly and at will from the Port and the Base. In their other overseas bases, once such facilities had ceased to be able to fulfil their function economically, the British had shewn realism in getting out - as they had in 1948 from Palestine, and in 1954 from the Suez canal - both times abandoning huge 
assets and supposedly vital strategic advantages. Had there been an abandonment of Singapore to the Communists in the 1940s or the 1950s, this would have carried with it a British abandonment of Malaya.

The evidence suggests, however, that confrontation without organisation would not have brought things to this stage in Singapore. First, because the army and the police were very strong, with ample reinforcements quickly available from the Federation (as was proved in the riots in October 1956, when six battalions were withdrawn from the Malayan jungle and appeared in Singapore within two days); secondly because neither the army nor the police could be penetrated or disaffected, since they were mainly manned by British, Gurkhas and Malays, none of whom had any reason to support a Chinese Communist revolution; thirdly because, with so much at stake in Malaya and in the port and military base in Singapore, the British would have fought far harder than they had fought in the Middle East, where many of the assets (notably the oil installations) were largely unaffected by the withdrawals; and fourthly because the majority of the Singapore Chinese, sensing all these things, and not wishing to throw away either British capital or law and order, would have rallied to the government rather than to the MCP in the face of a real threat of chaos, because the government always appeared the likelier of the two to be able to restore order. Premature violence and confrontation would have accelerated the arrest of the leaders and, without its organisation behind it, the Party would have passed beyond hope of recovery. Returning to the football analogy, instead of losing 3-2 they would have lost 10-nil. The Singapore Govermment's Handling of Violence and Coercion

The govermment's most cost-effective and its most decisive weapon was its intelligence arm - the Police Special Branch. Its arrests in 1932 and its (supposed) planting of Lai Tek in 1934 weakened and poisoned the MCP almost from its birth. The arrest of the complete Singapore Town Committee in 1950 made the urban end of the revolution ineffective during 


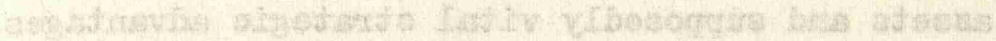

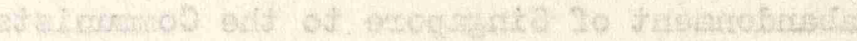

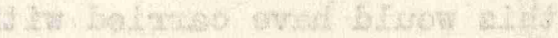

3. G. G. Thomson, Letter to author, June 1969

t.

4. Many of these techniques developed in the

Singapore riots of 1956 were clearly recognizable

in the British Army's handling of the disturbances

in Northern Ireland in 1969-70. 
the critical years of the guerilla conflict in Malaya, and for some time afterwards. The intelligence cover in the Chinese schools in 1955 proved to be an adequate counter to a dangerous and powerfully united organisation with tremendous potential for sympathetic confrontation. And the Special Branch swoop on the SFSWU was the decisive stroke in defeating the rioters in October 1956.

The government's choice and timing of counter revolutionary legislation were also sensible. The 1948 Trade Union Ordinance, the State of Emergency in 1948 and the action against the SCMSSU and the SFSWU in 195556 were all good examples of this.

Police organisation and techniques - after the failures in the 1950 Hertogh riots - provided a model that has been studied by many other police forces. ${ }^{3}$ The far-sighted contingency planning in 1956 for "Operation PHOTO" ("Failure of Talks Operation") paid big dividends, and in the execution of the Operation the joint Police/Army Control, the Police Radio Car system, the timely deployment of military roadblocks and roof top observation posts, the use of helicopters and the handling of Public Regulations were all excellent. 4

The image of the soldiers as peacekeepers rather than as killers was remarkable in the circumstances but it was founded on fact. The deployment of the army in the Hertogh riots in 1950 quickly ended the bloodshed. Thereafter, the army did not kill or lose a single man (though the Navy killed one) in Singapore. Their appearance on the streets in October 1956 was undoubtedly greeted with relief by the majority of the population. The government's timing in the riot situations themselves was also good. A notable example was the dispersal of the crowd outside the Chinese High School on the night of the 25th October and the clearance of the schools without an audience at dawn next day.

With such a high standard of play on the day the govermment deserved to win, but this excellence has undeservedly overshadowed the performance 
of the MCP.

Lee Kuan Yew

Lee Kuan Yew has a place in history as one of the only politicians who marched to power arm in arm with Communists, and managed to discard them. He also inherited the British peacekeeping (or, some would say, suppressive) apparatus and techniques and has continued to use them to good effect. Since he has had independent power, there has been no country in South East Asia with such a proportionately low rate of death and damage in riots and disturbances. He has now consolidated his position and his prospects with an equally high record of administrative achievement, in housing, education and economic development. Though there are some stirrings amongst his intellectuals, there is no doubt that the majority of Singaporeans are with him in heart and mind.

The Communists' Balance Sheet in the Village War

Like their comrades in Singapore, the guerillas and their supporters in the jungles and the villages of the Federation were defeated, though they salvaged a good deal from their defeat - enough to revive their campaign if circumstances became propitious. They would not be the first remnant of a beaten army to survive and come back to win.

About the ir dedication and faith in final victory there can be no doubt. The fottitude of the tiny bands of guerillas, such as those in Yong Peng (Chapter 10) and Segamat (Appendix B) which held out for 6 or 12 months against the concentrated efforts of 20 or even 60 times their strength of soldiers, when to all appearances the war was lost, must rank high in the annals of human endurance.

The biggest achievement of the MCP in the Federation, therefore, was their refinement of the art of survival in the latter years of the Emergency - 1954-60. Though they were much inspired by the example of Mao Tse-Tung, who had recovered from the agonies of 1934 to rule China in 


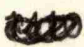

1949, their circumstances were very different. After the long march, Mao's republic in Yenan was well populated but out of range of effective interference by the Kuomintang forces. The MCP guerillas, on the other hand, were in virtually unpopulated jungle, but within a few miles of strong govermment forces. In China, the armies on both sides and all the population were Chinese. In Malaya, there was a strong inter-racial flavour and, though this helped the MCP to rally the Chinese population against the British Gurkha and Malay security forces, it did deny them the chance of penetrating and suborning the army and the police - as was done so effectively in China, and as it was earlier in Russia and later in Cuba.

Chin Peng's guerillas, having at first tried to apply Mao's theories too rigidly to their very different environment, later devised their own techniques for survival. They made best use of the dense jungle to remain intact within easy walking range of their supporters, and developed the most intensive security discipline to avoid detection and betrayal.

After 1954 they shewed a rare understanding of the real function of the guerilla revolutionary which was to indoctrinated the people and organise their support, and they judged this to be more important than destroying the govermment forces - the reverse of Debray's philosophy. As their jungle strength was eroded, the combat units were milked to keep the political organisation up to strength.

Unlike their comrades in Vietnam, the MCP guerillas had no "active sanctuary" on their borders - such as China provided for the Vietminh and North Vietnam for the Vietcong. The Thai Border offered reasonable immunity for Chin Peng's command and training base, but it was not a practical channel for weapons and supplies. Nor, (because of the distance from China) was coastal shipping. The MCP had therefore to rely on local sources - captured weapons from the army and police and supplies from the villagers. This, in fact, was a blessing in disguise, because there were always plenty of guns, with ammunition to fit, within range of their 
8.85

atis

sritiou the

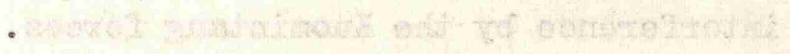

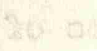

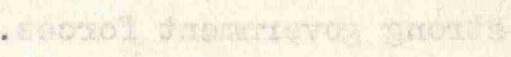

5 Cluttexbuek, The lone Jons - Ilas, o 74

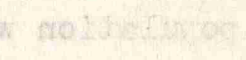

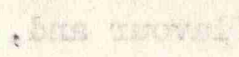

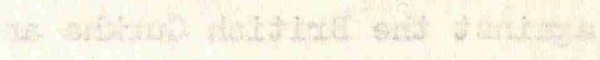


raiding parties, and because the people who were persuaded to give them food and other supplies were committed and involved. It is significant that, until the North Vietnamese Army entered South Vietnam in force in 1964, the Vietcong relied on similar sources for $90 \%$ of their equipment. Did the MCP miss a chance of victory in 1948? Perhaps they did. They had certainly missed one in 1945-46, when they weakoned their mural organisation to concentrate on the cities. In 1948, they belatedly attempted to disrupt the rubber and tin industries, but they paid the price paid by so many revolutionaries before them of having an inadequate organisation for popular support. The popular rising they hoped for never came.

Perhaps they could have driven out the British by other means. Their violence was directed against Chinese "collaborators" rather than against the British themselves - from June till October 1948 almost all the 223 civilians they killed were Chinese, and only 17 were Europeans. They no doubt calculated that widespread murders of British rubber planters and tin miners would have provoked more violent British reaction and reinforcement. They may well have been right, but it is doubtful whether the rubber and tin industries could have survived unrestricted attacks on its British managers, the nature of whose work made them extremely vulnerable. With the managers decimated or unable to supervise their industries, the financial losses might have been so great that the companies - and then the British government - might have decided that Malaya would never again provide a sound economic investment, and that some kind of political solution leading to a withdrawal would be wise.

This is by no means certain. The British have historically been stubborm in the face of this kind of personal violence; more so than against other tactics such as sabotage or withdrawal of labour - which the 
MCP could have organised successfully in the tin and rubber industries in 1945-46 had they tried to do so. Having failed to do this, they may have missed their only other chance of outright victory by their forebearance from wholesale murder of Europeans in 1948. By 1949, the six-fold crash expansion of the Police and the pouring of more British troops into Malaya had taken away this last chance, however slender, of quick success.

The wholesale murder of Chinese, however, did not show any similar promise of victory, and the MCP were wise to turn away from it in October 1951. Though they never looked like building up the support they needed from the public except by violence, their relative forebearance probably helped them to survive without inflicting scars on the rural Chinese which would have been held against them in the 1960s and 1970s and beyond. If, one day, Malaya, including Singapore, becomes a Communist-oriented Chinese dominated country, history may credit Chin Peng's success in surviving on the borders of Malaya, leaving little bittermess behind him in the Chinese villages, as a decisive factor.

\section{The Government's Counter Revolution}

The government's achievements are easier to perceive, since they defeated their enemy and drove him right out of the country, even if they did not leave him quite dead; and they did this with astonishingly little loss of life and little damage to the country.

One of their most important contributions to the art of counterinsurgency is recorded in the comprehensive 150 page system of Fmergency Regulations, as finally amended in 1953. This book contains the essence of the legal provisions which five years of experience had proved necessary in order to prevent the guerillas from obtaining effective support from the people in the villages - a bible of population control. The regulations for registering the village population and the resettlement of the squatters were of special importance and were implemented with determina- 
tion, sense and skill.

Though the public acceptance of resettlement was greatly assisted by the boom in the price of rubber arising from the Korean War, a more important factor was the decision not to move the settlers into any New Village until enough constables had been trained to man a police post inside the village, day and night. This was not done in Vietnam, where in many villages people who actively helped the government had no protection from the Vietcong's "man with a knife" at night, with obvious results.

Village security was the firm base on which the government campaign was built in Malaya. It depended upon the integrity of each small police post, which was in turn dependent on the army to ensure that it was not attacked with overwhelming force.

Also dependent on this security was the establishment and integrity of the elected village government and rural and community development. Village security and village development were vital planks in the government's propaganda platform which eventually convinced the rural Chinese that it could win, and that it was in their interest for it to do so.

Also worthy of note is the system of command and control which the government developed in 1950. After nearly two years of weak and divided command, General Briggs arrived as Director of Operations and introduced the State and District War Executive Committees, on which the responsible civil official, police and military commanders conducted operations jointly under the chairmanship of the civilian. It was a further two years before the Director of Operations (in the person of General Templer) was given full power over all these resources at the top. In the later stages, after Independence, a British Director of Operations and a British Army Commander worked under the direction of the elected Malayan ministers.

If the decisive defensive element was village security, the decisive offensive element was intelligence. The Police Special Branch was 
British led but employed Chinese officers to handle Chinese agents, and was probably the most efficient of its kind in the world. By the mid 1950 's, the great majority of guerillas were known by name, and special Branch had acquired photographs of most of them from others who had been captured, or from their relatives in the villages. The handling of agents and surrendred guerillas was outstandingly successful. The generous systems of rewards - paid only for information which led to the death or capture of a wanted mann - was an important factor here, but equally important was the psychological treatment of the Chinese defectors (whether guerillas or their supporters) which successfully induced them to betray their comrades.

The govermment technique for acquiring intelligence reached a degree of complexity and refinement which offers a useful example for future governments trying to dig out the roots of a guerilla insurgency, though it must be viewed in the context of the particular circumstances prevailing in Nalaya. Important amongst these were the juxtaposition of the jungle and the tin-mines and rubber estates, the fact that the rural economy was mainly based on cash crops and not on food, and that such rice as grew locally was almost entirely grown by Malays, who were hostile to the rebellion.

This technique, which depended on exploiting the reliance of the guerillas on rice which had to be smuggled out of the Chinese villages and turning a proportion of the smugglers into police agents, was described in Chapters 11 and 12 and Appendix B. A significant point was the very small number of food smugglers who needed to be turned into agents to bring success. For example, in the Segamat District before operation COBBLE, there were only 4 registered Special Branch agents who were able to betray the guerillas by giving advanced information about them. The process of arresting and turning food supplies yielded another 11, bringing the total 
to only 15. This in a district containing some 38,000 people of whom 21,000 were Chinese, in which over 500 police and 1200 soldiers were concentrated in an attempt to root out about 30 guerillas in a "federal priority operation".

Such federal priority operations were like sledge-hammers cracking nuts - but they did crack them. Nevertheless, some nuts were cracked by less ponderous weapons in "framework operations" like the one described in Chapter 13. In these too, however, the decisive factor was intelligence.

Praise is also due to the government's strategy of dealing first with the areas in which the MCP were weakest, so that these could then be lightly policed while overwhelming strength could be concentrated on the really hard nuts at the end. Coupled with this was the "White Area" policy, under which risks were taken in lifting restrictions from areas which had been dealt with, so that the population felt that they were rewarded for their cooperation, and trusted; also so that the people of neighbouring districts, envying their freedom, were encouraged to emulate them.

But the real key to the government's success was that it concentrated its attention on the people in the villages rather than on the guerillas, whom they regarded as clandestine political organizers rather than soldiers. This is just how the MCP regarded them, as do most Communist parties - but not all governments.

\section{Leninism or the New Left?}

As in Singapore, the Communist guerillas in Malaya lost their battle. Would they have done better if they had followed the guerilla philosophy of Regis Debray? If instead of tying themselves to a support organisation based on particular villages, the guerillas had operated as mobile focos; buzzing like bees, cohesive around the swarm but with the swarm moving to evade the swipes of soldiers; hoping that the other insects 
(ie, the rural Chinese) would have been inspired by the activity of the bees to buzz spontaneously around the foco, wherever it moved? And would the government and its soldiers and police have been stung to death?

As in Singapore, all the evidence suggests otherwise. Whenever a guerilla branch under intense military pressure shifted from its area and broke its links with its known supporters in the villages, Communist support in that area never revived. The faithful lost heart, and the reluctant were thankful to be off the hook. If the guerillas came back, one of these people would usually betray them. If they tried to create links with other villages they got little response, became hungry and dispirited, and eventually dissipated - the weaker ones to surrender (if not forestalled by execution) and the stronger ones to join other branches. Had the MCP followed the theories of the New Left, they would not have won, nor would they have held on for 12 years.

How far is evidence from Malaya valid in general? Probably considerably more so than that from Cuba (the sole success on which Debray's theories are based) and certainly more so than that put forward by other theorists who can claim no basis of success at all. The MCP were not badly placed in 1948. The government forces were weak and ill-prepared, with little previous experience of fighting against guerillas in the jungle. The Nalays, though hostile to a Chinese takeover, were weakly organized and shamed by the Japanese occupation. The MCP had three years of wartime experience, and tremendous prestige. The rural Chinese were generally prepared to support them, and many of them dedicated to doing so. The Chinese are a tough and brave people - some of the toughest and bravest in the world. It would be hard to find better material for a popular rising, but they failed to rise in 1948 because the MCP had allowed their rural organisation to lapse.

Debray's claim that the Cuban people rose spontaneously to Castros 
tiny foco in the Sierra Maestra without any cadre organisation amongst them is itself suspect. They did not give effective support to Castro until the morale of the government officials and soldiers in the provinces was withering on the vine as a result of the rotting of its roots in Havana. The people responded to Castro's leadership when they acquired a sense of impunity, when their fears and dislike of the officials and soldiers had turmed into contempt. But the rotting of the roots of Batista's regime was primarily due, not to Communist acivity but to the radical liberal movement in Havana. 6

Though the NCP failed both in Singapore and in the Federation of Nalaya, the conclusion is that their excellent organisation brought them nearer to victory than if they had tried to operate without it, by violence and confrontation in the cities and with mobile guerilla focos, not linked to villages, in the jungle.

Their relatively narrow defeat was due more to the skill of the governments and their forces than to MCP shortcomings. Their defeat may prove more short-lived than expected, as their surviving rump in South Thailand is gaining strength, and the racial troubles which flared up in Malaya in 1969 may help them to revive their campaign there in more favourable circumstances than in 1948. But for the 14 years after it was first elected in 1955 the Alliance Government in Kuala Lumpur enjoyed a stability unrivalled in South East Asia, and some at least of this they owed to their success (albeit initially under British control and later with strong British support) against the Communist insurgency. And in Singapore, Lee Kuan Yew's success in overcoming a more personal and political Communist challenge has placed him and his People's Action Party, after 11 years in office, in an even stronger position than the Alliance, and one which has been strengthened at each election since 1963.

The MCP will continue the struggle, both in the Federation and in Singapore. It is likely that they will continue their Leninist style of 
organisation, as they are doing in South Thailand. Whether they, or the govermments which were so much strengthened by defeating their previous challenge, will prevail in the end will be a matter for study by future historians. 
292 
1. Waller Interview 1968. Hong Kong provides about $50 \%$ of Communist Chinats foreign exchange. 


\section{2 \\ APPFNDIX A \\ THE 9667 RIOTS IN HONG KONG}

From May to December 1967 Hong Kong was, torn by serlous and well organised riots, both inside the cities of Victoria and Kowloon, and by mobs crossing the Frontier from Communist China. This confrontation was clearly a by-product of the Cultural Revolution in China, though there was subsequent evidence that it was initiated without the approval of Mao ise Tung or of his Foreign Minister, and ended In a complete climb down by the Conmunists, the "five demands" which they made publicly and militantly at the start being ienored and then quietly forgatten,

Hong Kong had a population of about 4 million, roughly half of whom wer refugees from Communtst China who had entered during the 17 years since liao Tse Fung seized power. Though the Colony had achieved miracles in housing and creating employment for these refugees, there were obvious difficulties in both fields.

The immediate excuse for the outbreak of rioting was an industrial dispute in an artificial flower factory, During the next 8 months, about 50 poople were kiled in riots and in bomb explosions. There were, in all, over 1,500 bombs which either exploded or vere neutralised by the army and the police.

The 4 million people in Hong Kong live mainly in the two principal citles, Victoria (on Hong Kong Island) and Kowloon (on the mainland), which have amongst the highest population densities in the world. The Colony Boundary runs through what is now the middle of Kowloon, and there is a hinterland of 365 square miles, the New Territories, which are leased to Britain until 1997. There is a 22 mile frontier between the New Territories and Communist China, and under the Ireaty people are free to cross both ways at authorised points to cultivate land on the other. 31 de of the frontier. Wach agricultural produce is also wheeled (or driven on the hoof) across the one main road bridge from China at Man Kan To for sale in the Colony, and there is also much traffic aoross the one railway Bridge at Lo Wh. These two points vere the scenes of much of the frontier rioting, and so was the fishing village of Sha Tau Kok which is split by the frontier - the market again being on the British side. 


\section{The Zconomist 27 Hiay 1967}

3. A J Shephaxd, "The Communist Falluxe in Hong Kong" in The Comnonmealth Joumal, Apxtl 1968 p 98

4. \$सK $500=230$, and is a reasonably high nonthly wage in Hong Konge

5. Denis Bloodworth, in the Singapore Sunday Mines 30 September 1967

6. Some militant Communists were contemptuous of this mercenary technique as "killing the spirit of revolution", as "capitalist enterprise" and as "attracting money-grubbers, not militants". (Denis Bloodworth in the Singapore Sundesy Iimes 15 ootober 1967.

7. The Bconomist 27 Way 1967 
The Communist Party in Hong Kong is legal, and has its headquarters in the Bank of China Bullaing, which is bullt like a fortress. As in Singapore, some of the Trade Unions (63) forfliated to the Comninist Federation of Trade Unions (FTU), and about the same number (62) to the TUC, with 115 unattached, Whe clu controlled. Public Utilities and the dockyard ${ }^{2}$.

The Communist Party in Hong Kong also muns a number of middle schools which play a large part in secondary education in the Colony ${ }^{3}$.

The Cormunist techniques used in the Hong Kong Riots were more militant than those used in Singapore. Strikes were encouraged, despite the strong government warning that striking public utllity workers would lose their jobs. The riTU paid strike pay of $\$ F F K 500$ per month ${ }^{4}$. When the man lost his jol he was asked to "earm". his $\$ 500$ by painting slogans and sticking up posters. The Communists photographed him doing this, and then showed him the photograph, saying that it had been "filched from the police". They used this to persvade him to go underground, reduced his pay till he was desperate, and then forced him to earn his keep by violence - including the plarting of bombs. 5 There was a stendard rate for planting bombs - $\$ 40$ for a hoax, \$ 200 for a live one, \$ 300 if it exploded, \$ 400 if it killed someone, and $\$ 500$ if the perpetrator went to prison. 6

The riots were organised on similar lines. Police observers amongst the crowds estimated that stone-throwers earned 10/- to $\$ 1$ per day - a reasonable Hong Kong wage. Histrionic collapses by "injured" rloters were carefully rehearsed, with "blood" smeared on their faces (from chickens or ketchup bottles). Bandages wero held ready for spurious application - with nore "blood". Above all, trained leaders were switched from one area to another during the riots, 7 


\section{The Beonomist 27 Ney 1967}

9. Denis Bloodworth in the Singapose Sundey Times 15 octobex 1967

10. A J shephaxd pp $85-86$ 
The organisation and execution vere first-class, and yet these riots falled in their object as dismally as those in Singapore, The reason, again, was good police work, coupled with rapld but not unnecesisarily ageressive military action. The Commuists were taken aback by the astonishing and immediate popular reaction against rioting. Public meetin ws were held to support firmer counter - action. The police suddenly became the colony's heroes, and a fund for improved educational opportunities foi policomens' children had risen to $\$ 62,000$ within 10 days of the outbreak of violence. Television coverage of the riots caused public discust, and the dislocation of vital examinations did not help the Communist cause amongst an educationconscious Chinese community. ${ }^{8}$ A series of highly aggressive attacks were then made from Communist China on the frontier police posts, but these too stood firm with army support. Violence continued in the form of bomb incidents. Between Nay and September, the Bank of China spent HHK 1 million on rewards to bombers, but at this stage they stopped further payment. 9 A significant and paradoxical factor here was a quarrel between the AntiPersecution Struesle Committee, representing the workers, and the official representatives of the Peking Govermment, which was concerned to keep up the foreign exchange earnings from Hong Kong, backed by the Chinese Communist business men in Hong Kong, who did not wish to see their volume of business curtailed by continuous strikes. ${ }^{10}$ By the end of 1967, the entire campaign had subsided, and the militant and unusually specific demands which had been made by Communist China were quietly abandoned unfulfilled.

The riots in Hong Kong in 1967 were far better led than those in Singapore In 1956, but both failed because the leaders underestimated the peoplea' instinctive desire for law and order, which caused them to rally to the government the moment it became clear that the security forces were standing firm without the use of undue violence. 
296 
Figuren 16A and $16 B$

Pull out 


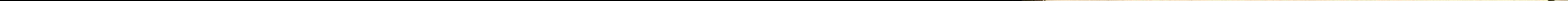




$$
\begin{array}{r}
\text { Figure } 16 \mathrm{~A} \\
\text { and } 16 \mathrm{~B} \\
\text { Pull out }
\end{array}
$$


 \\ \begin{tabular}{l} 
APPENDIX B \\
OPERATION COBBLE - 1956-57 \\
\hline
\end{tabular}}

\section{An Example of a Federal Priority Operation based on Food Denial}

\section{Operation COBBLE - The Setting}

The Target of Operation COBBLE was the single MCP District of Segamat, which contained some 20 predominately Chinese villages and estate labour lines. The total population of the District was about 38,000 of whom just over half $(21,000)$ were Chinese. About 8,000 lived in the 34 Malay Kampongs in the district, and these were largely unaffected by the operations. 18,000 (12,000 Chinese) lived in Segamat Town. The real battle ground, however, was around those 20 villages and labour lines, whose population of some 12,000 contained about 9,000 Chinese (see Figure 16A).

The guerillas were organised into a District HQ, three branches and an independent platoon. The branches were very small. The Selumpur branch, ran its "parallel hierarchy" amongst 5,000 Chinese who worked mainly on small holdings in the Western part of the district and consisted of 20 guerillas. 1 The other two branches were much smaller. The Bukit Siput Branch (8 guerillas) worked amongst the rubber tappers on the large estates in the centre of the district, while the Tenang Branch (2 guerillas) worked amongst the many loggers in the Forest Reserve in the North East corner, though it too had some rubber - tappers in its area. (See Pull out map - 16E). The 32nd Independent Platoon MRIA had one section detached to a neighbouring district; the remainder, under its commander Kin Fai shared its operations between the Selumpur and Bukit Siput Branches. 2

\section{The Selumpur Branch}

The Selumpur Branch (Figure 16B) had an almost ideal area for working॰ The Branch Committee was in dense jungle some 10 miles North of Segamat Town. Between the jungle and the town lay 100 square miles of small holdings (mainly 

rubber and coffee) interspersed with tongues and corridors of swamp and abandoned holdings now overgrown with head-high lalling and blukar (secondary jungle), which offered perfect cover for moving and lying in wait for the people when they came to work on their land.

There were no less than 1,500 of these small holdings, worked by the 4,500 Chinese men, women and children in the area, which made the task of government administration very difficult - far more difficult than on the big estates, since there was no central authority which could be ordered to operate curfews for its workers, or to clear undergrowth at pain of a fine. Each family was generally self-employed and aggressively independent. The incoming troops found them hostile and sullen - even the children. They had, for the past 8 years, been subjected to a series of "operations" by hundreds of soldiers, all of which had left their local guerilla branch intact. Its tough and wily leader - Ming Lee - was credited by many with supernatural power. ${ }^{3}$

The smallholders lived mainly in four New Villages (NV), one of which (Tambang 7th Mile) was the other side of Muar River which marked the boundary of the government administrative district of Segamat. These four villages were:

Buloh Kasap - containing the largest number, 2,627 Chinese.

Tambang 7th Mile - 405 Chinese, who came across the river to work, and also carried supplies from another village (Batu Anam NV 1,168 Chinese) outside the district.

Pekan Jabi - with the best Communist organisation, supported by the majority of its 613 Chinese.

Kampong Tengah - where the majority of the 932 Chinese also supported the guerillas. (It was here that Hor Lung eventually surrendered).

In addition, supplies were delivered from Segamat Town by supporters in pirate taxis, who dropped them or handed them to smallholders at the roadside in the Kampong Kawah area (Figure 16C). ${ }^{4}$ 


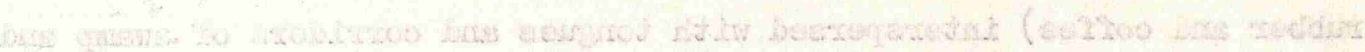

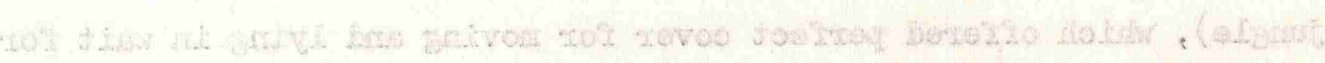

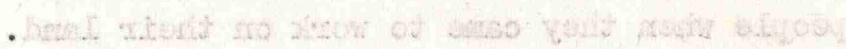

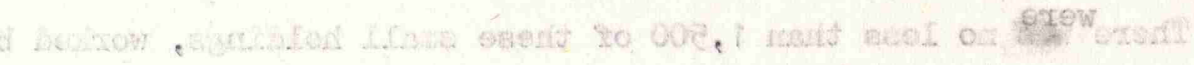

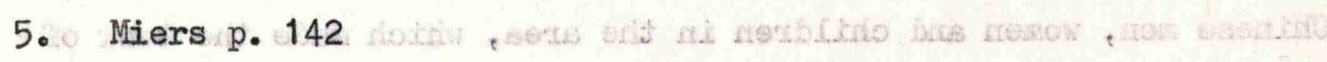

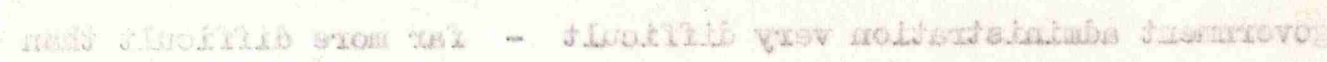

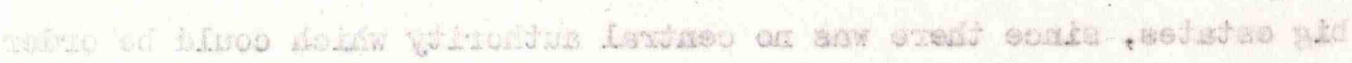

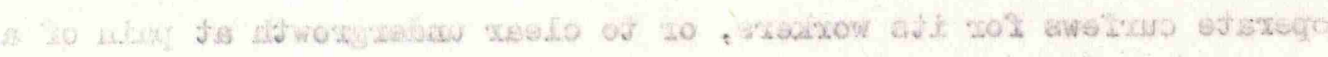

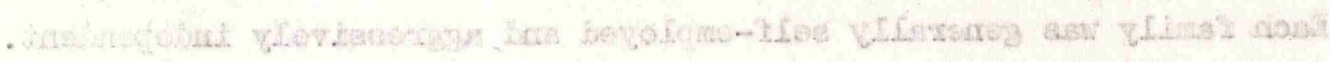

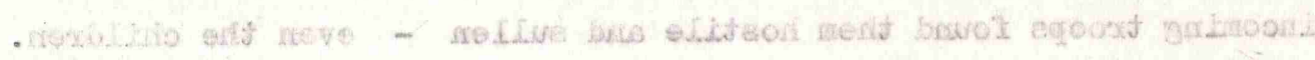

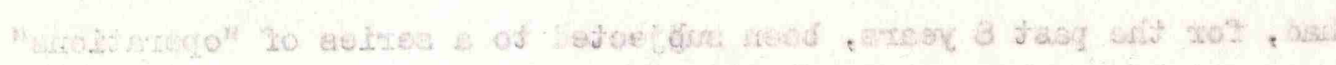

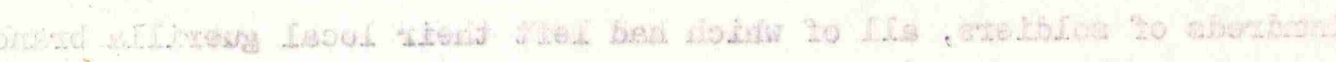

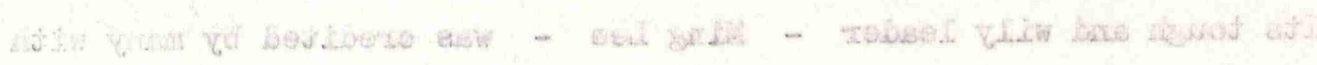

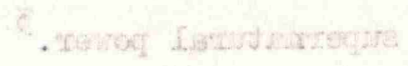

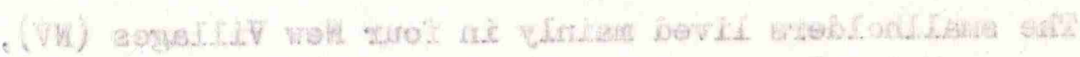

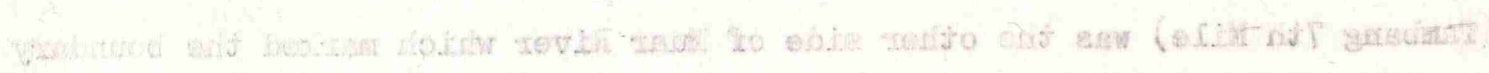

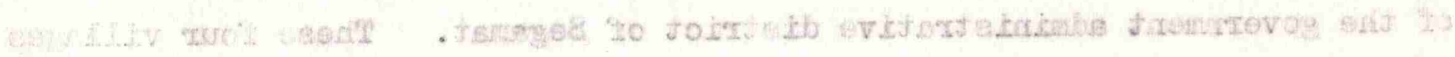

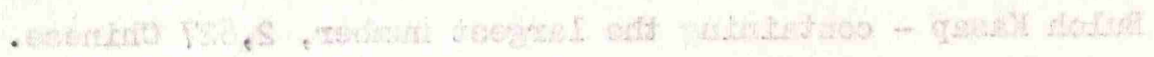

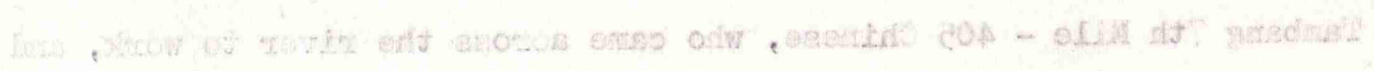

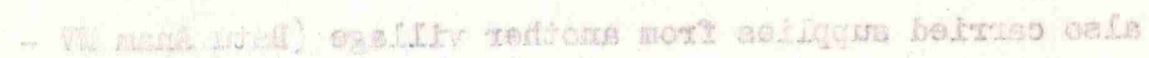

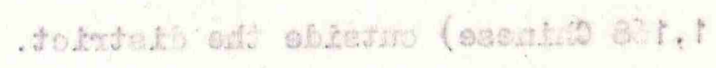

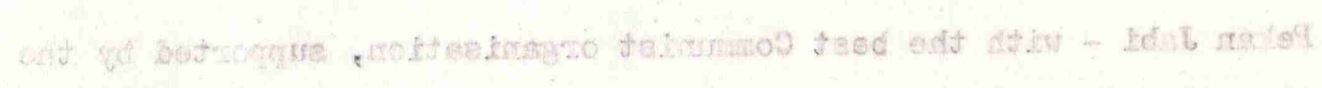

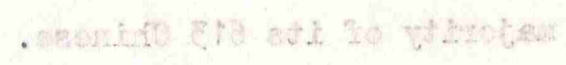

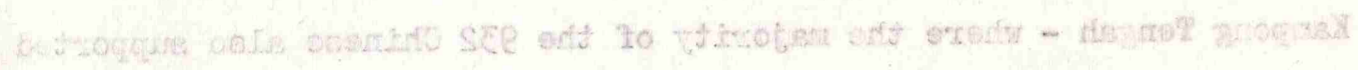

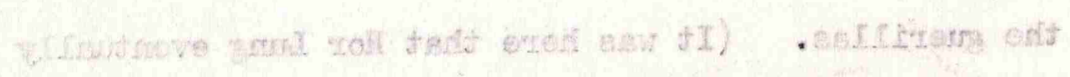

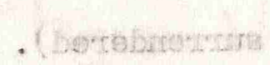

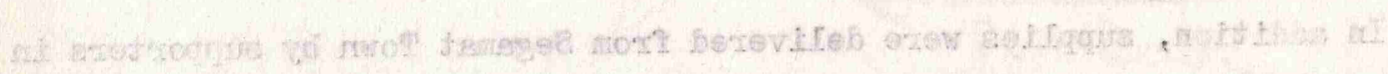

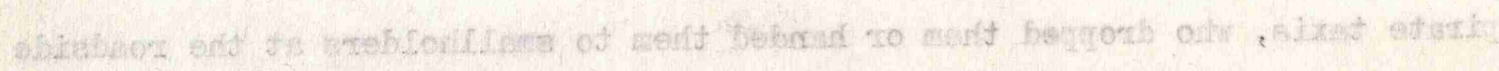

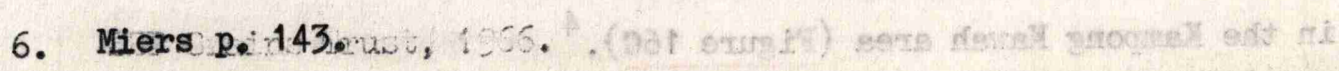


The tasks of the Selumpur Branch were: first, to indoctrinate the people with Communism, preaching faith in ultimate victory, and obtaining recruits for the masses organisation or for the jungle army; secondly, to collect intelligence, supplies and money for the branch, for 32 nd Independent Platoon and for the District and higher HQs; and thirdly, to provide targets, guides and a launching base for terrorist raids by 32 Platoon. ${ }^{5}$

Its leader, Ming Lee, acted more confidently than was normal at this stage of the emergency, as is borme out by the police log of his activities in a typical period of 3 weeks early in 1956.

18th February. Ming Lee, with three others, distributed propaganda pamphlets to the workers on the Hup Heng Estate, and ordered them to provide $\$ 500$ within a week.

21st February. Ming Lee, with two others, gave a lecture to the workers on the Chuang Nam Estate, urging them to join the organisation and drive the British out of Malaya. He took away 3 bags of fresh fruit.

27th February. Ming Lee, with 14 others, came out of the jungle on to the Field 33 Estate, and summoned all the workers together. He told them to smuggle food out of their villages and dump it in a certain spot near the jungle fringe next day. He warned them not to inform the police.

8th March. Two guerillas, one believed to be Ming Lee, visited the Ban Joo Sin Estate, and warmed the owner that no rubber collection would be allowed until he had paid $\$ 400$ arrears in his subscriptions.

11th March. A strong party with Bren guns and other weapons, led by Ming Lee, distributed copies of The People's Awakening News, and conducted a preliminary inquiry into the killing of a guerilla by the Security Forces during the previous week. 6 





It was relatively rare for guerilla leaders to make personal contact at meetings of workers in the estates in 1956, when most of them were protected by two echelons of cut-out men (armed work forces and masses executives) from the risk of betrayal by individual members of the public. ${ }^{7}$ Ming Lee was clearly confident that his support amongst the rural Chinese was still so strong that such individuals would not dare to betray him.

\section{The Bukit Siput and Tenang Branches}

The Bukit Siput Branch, which at the start of Phase I of Operation COBBLE was 7 or 8 strong, was well-knewn and held in much respect by the population。 Its terrain was very different from that of the Selumpur Branch, though more typical of Malaya. For the 10 miles South of Segamat, the main Kuala Lumpur - Singapore road passed through European-owned rubber astates, which butted onto the jungle only one or two miles away on the North East side of the road, and 3 to 5 miles away on the South West. The Bukit Siput Branch was thus able to live in relative security only 2 or 3 miles North East of the road, within a mile of the clearly defined jungle fringe, from which they could quickly spot the tappers in the tidy rows of trees which were characteristic of European-owned estates. (see Figure 16D).

Bukit Siput New Village, on the main road about 3 miles East of Sagamat, contained a very strong Communist organisation. All but 3 of its 2,147 inhabitants 'were Chinese. The other main source of support was the small labour lines of the Siding Division of the Segamat Estate, containing 63 Chinese and 77 Indians, about a mile North of Bukit Siput village.. There was also considerable support amongst the tappers on the Chuan Moh San Estate, on the South side of the road, and specialist commodities were smuggled out along the main road by individuals from Segamat Town. 8

The Tenang Branch, by the time Operation COBBLE began, was down to only two guerillas, who worked jointly with the Bukit Siput Branch and were combined with them later in the operation. Their geographical situation was similar to that of the Bukit Siput Branch (rubber estates astride the road). 


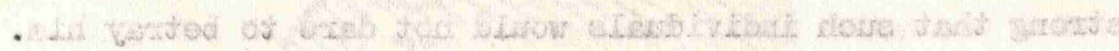

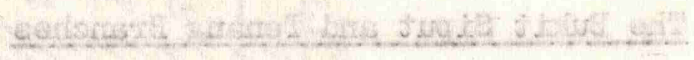

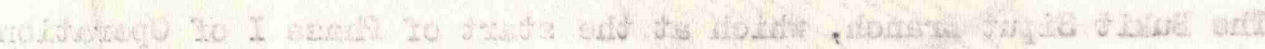

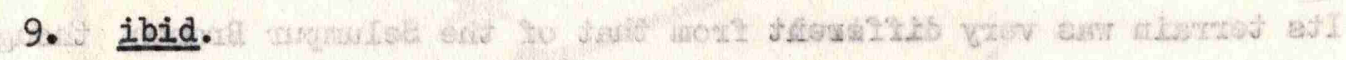

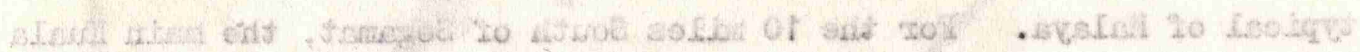

10. 1956 Census. Also, Operation COBBLE, Segamat District War Executive Committee Operation Instruction No. 1, Op COBBLE Phase II, 21dt December, 1956 (COBBLE DWEC 21/12/56).

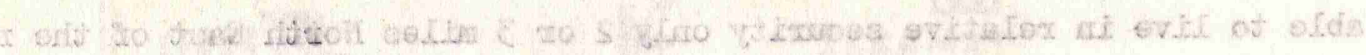

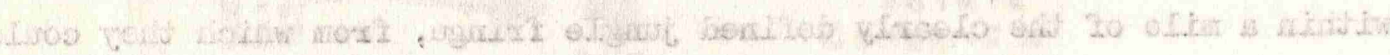

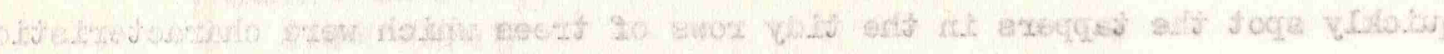

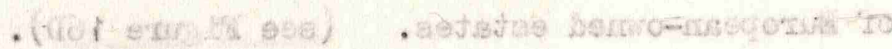

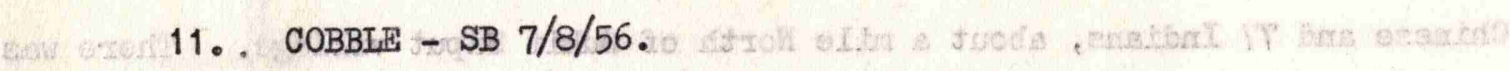

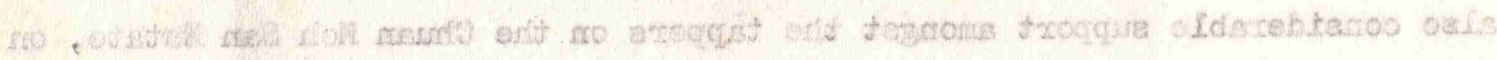

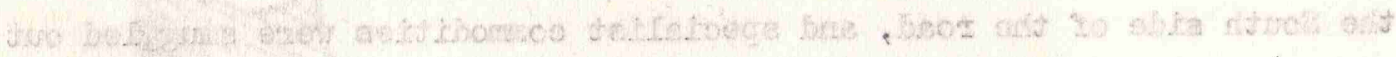

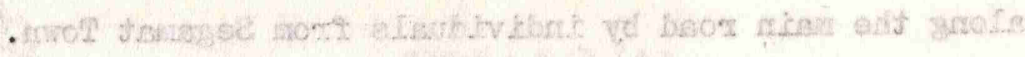

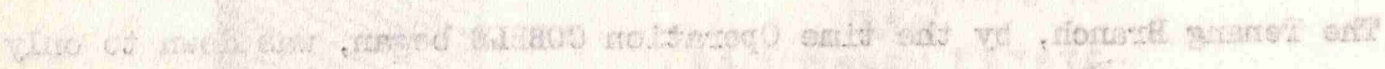

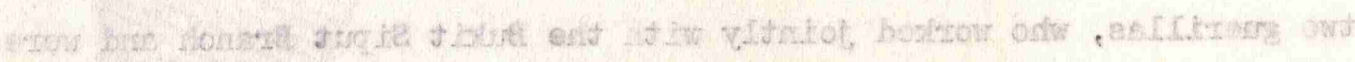

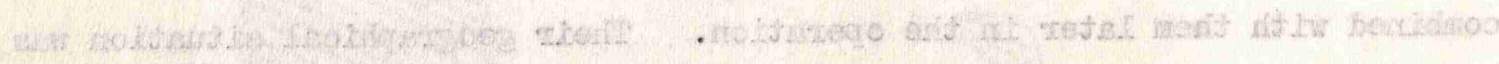

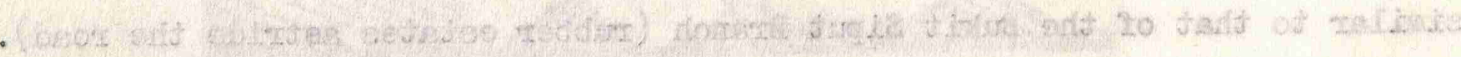


They received bulk deliveries by vehicle along the main road from Segamat, about 8 miles away, which were smuggled to the jungle fringe by workers on the Pogoh Estate (see Figure 16D). The main task of the branch, however, was to collect subscriptions from the loggers who worked in the jungle which butted onto the Pogoh Estate, and which was a Forest Reserve. A number of timber tracks penetrated into this jungle, and the Tenang guerillas took a toll of $\$ 80$ to $\$ 100$ a month from each timber lorry. In all, from lorry tolls and loggers subscriptions, these two guerillas collected about $\$ 35,000$ a quarter, most of which went to the higher HQ of the North Johore Regional Committee and the South Malaya Bureau. ${ }^{9}$

In all, the population in the combined areas of the Bukit Siput and Tenang Branches was under 7,000, of whom 3,876 were Chinese. ${ }^{10}$ Their contribution to the Communist cause - especially the money collected by the Tenang Branch - is a striking example of what a very small underground organisation can achieve in a fairly prosperous rural area of South. East Asia. Operation COBBLE Phase I - Intelligence Activity

After some months of preliminary study and planning, Phase I of Operation COBBLE began in July 1956 with the first of a series of apparently disconnected arrests of suspected food suppliers for interrogation. These were staggered, first to avoid giving the impression that this was anything more than a normal framework operation, and secondly because there was a limit to the number who could be interrogated at any one time.

The plan was as follows. 11

$\begin{array}{lll}\text { 24-25th July } & \text { BUKIT SIPUT Branch } & \text { Arrest 27 } \\ \text { 25th August } & \text { SELUMPUR Branch } & \text { Arrest 30 } \\ \text { 25th September } & \text { TEHANG Branch } & \text { Arrest 28 } \\ \text { 1st January, 1957 D Day for Phase II } & \end{array}$

In the event, on the night $24 / 25 \mathrm{July}, 24$ suspects were arrested in the Bukit Siput area. Of these

2 were already informers, but were arrested to avoid compromise 6 more agreed to cooperate and were released as "turned" 
12. ibid.

i.

13. Operation COBBLE, Contingent Special Branch Johore letter dated 24th September, 1956 (COBBLBis) SB, 24/9/56).

14. Operation COBBLE, Minutes of Johore Contingent Planning Committee 9th December, 1956 (COBBLE SB 9/12/56).

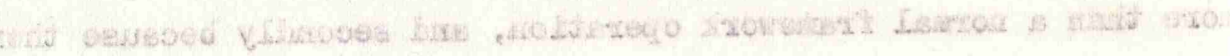


9 made admissions, and were released to avoid compromising the 6

3 were detained under Bmergency Regulations

4 were not interrogated. ${ }^{12}$

Next month, on 25th August, the 30 arrests were made in the Selumpur area, from the four main villages - Tambang 7th Mile, Buloh Kasap, Pekan Jabi and Kampong Tengah. Of these, 11 were "turned", of whom only 7 in the event proved useful. Most of the successful ones were in Buloh Kasap, and Special Branch had little success with those from Pekan Jabi.

The 30 Selumpur arrests had fully extended all the available interrogators in Johore, and 10 of them had had to be interrogated at the Eederal Police Holding Centre. The pressure was such that the 28 arrests in the Tengah Branch area, planned for 25th September, had to be delayed until the night $2 / 3$ october. Of these, 3 were interrogated in Segamat itself, the remainder being split, as before, between the State and Federal holding centres. 13

Before Operation COBBLE began, Special Branch had only 4 regiștered agents in the District. As a result of the interrogations, 11 were recruited, bringing the total to 15. Altogether, the intelligence dividends from Phase I were as follows: ${ }^{14}$

New agents able to give advance precise information 11

New informers for secondhand or historical information 13

New casual informers

Phase I - Operations in Support of Special Branch

Meanwhile, additional troops were being moved into Segamat District. The framework battalion already/was a Gurkha battalion, which in Phase II was to concentrate on the Bukit Siput Branch. Another battalion - The Rhodesian African Rifles - was already in a neighbouring district, from which it could operate in Segamat. In July, a third battalion - the 1st South Wales Borderers ( 1 SWB) - moved up from South Johore and established its $H Q$ and one company in Segamat itself, with thrẹe other companies in operational camps close to (but not inside) three of the hard core New 
15. Notes on visit by author to 1 SWB January 1957.

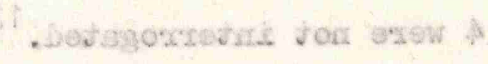

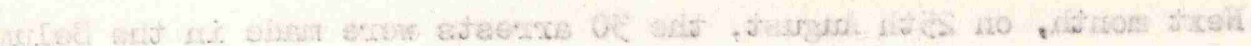

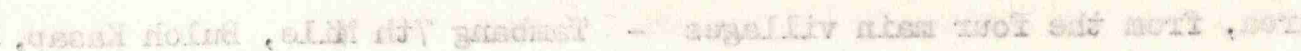

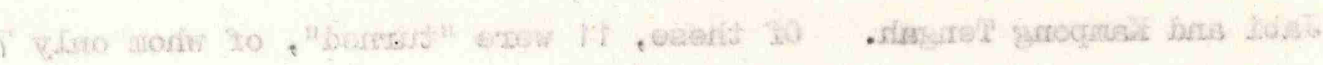

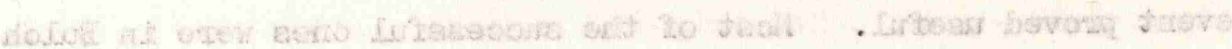

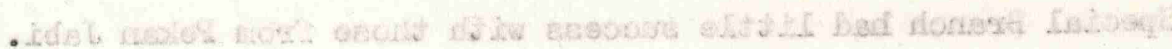

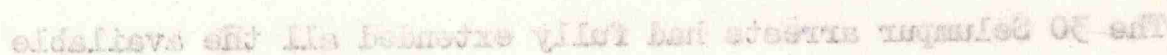

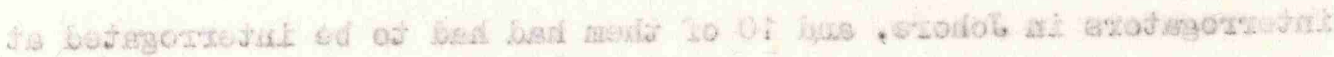

16. COBBLE SB $7 / 8 / 56$.

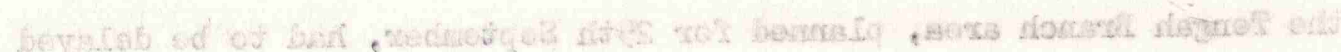

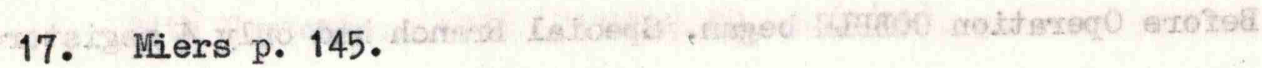

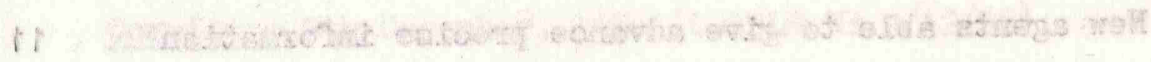

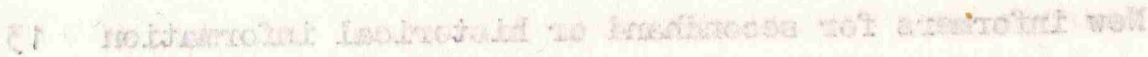

18. Operation COBBLE - Contingent Special Branch HQ Johore letter $\mathrm{SBJ} / \mathrm{SF} 32 / \mathrm{A} / 1(\mathrm{~V})$ of 31 st July 1956, Food Denial Operation in Segamat LAUNCH/COBBLE (COBBLE SB 31/7/56).

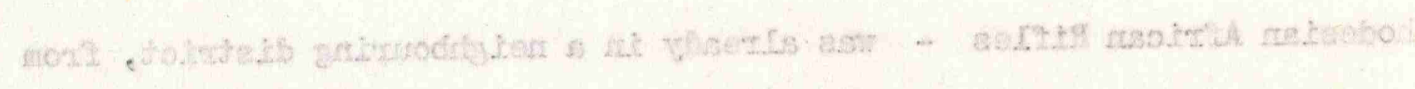

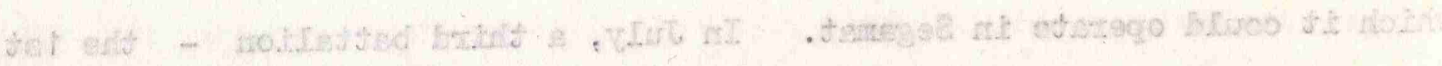

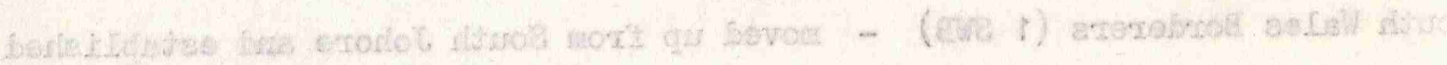


Villages - Buloh Kasap, Pekan Jabi and Kampong Tengah. ${ }^{15}$

The eventrial target of 1 SWB was to be the Selumpur Branch. Initially, however - presumably to give the impression that it had come as a routine relief for the Gurkha framework battalion, it operated in the Bukit Siput area as well, until the start of Phase II.

Before the Phase I arrests were made, the troops patrolled the cultivated areas, to deny contact (so that the guerillas would be less likely to be told of the arrests) and to put the suppliers in the right frame of mind to talk. Once the suppliers had been released after interrogation, the troops were kept out of the cultivated areas, in order to encourage the guerillas to re-establish contact. ${ }^{16}$

Thus, throughout the month of August, 1 SWB were allowed to patrol the estates and smallholdings in the Selumpur area, in order to promote intelligence, soften up the less determined suppliers and to enable the soldiers to learn their way around the maze of trails, cultivation and secondary jungle. ${ }^{17}$

The regimental officers and soldiers were naturally keen to get into areas in which they were likely to meet guerillas, but Special Branch were insistent that they should not go into Phase II prematurely and "blow the gaff". There was also much donkey work to be done in preparing the detailed plans for food denial, estimating and obtaining the funds to strengthen fences etc. $^{18}$

Nevertheless, a close understanding was built up between the CO of 1 SWB (It Col Miers), the District Officer, and the Special Branch Officer. During August, when the interrogation of Bukit Siput suppliers was well under way the Special Branch officer decided that it would be worth the risk to 'blow' one of his agents before Phase II began. This would be quite consistent with a framework operation, and might aid deception by using the battalion destined for the main target - the Selumpur Branch - in the Bukit Siput area.

This agent, whom Colonel Miers nicknamed "Henry" in his book, ${ }^{19}$ was a 


\section{Les}

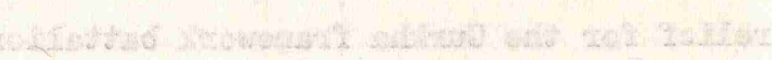

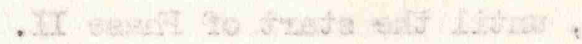

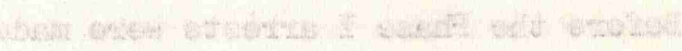

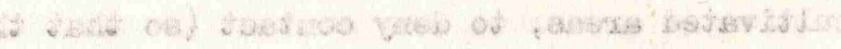

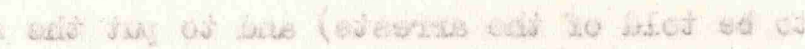

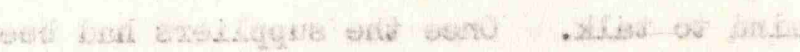

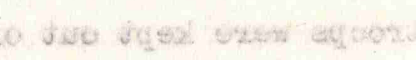

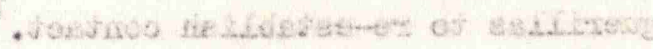

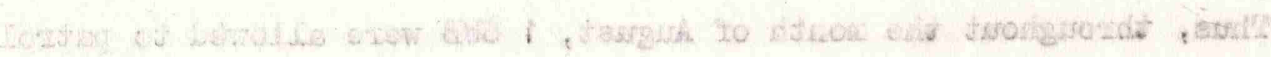

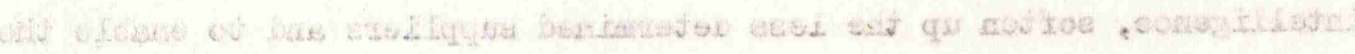

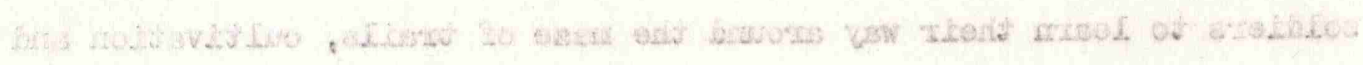

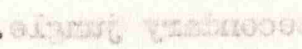

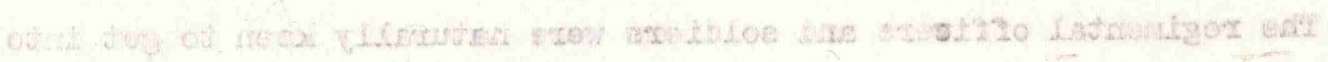

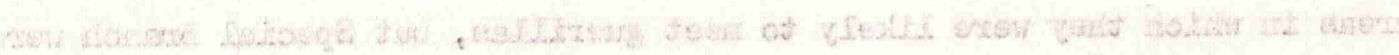

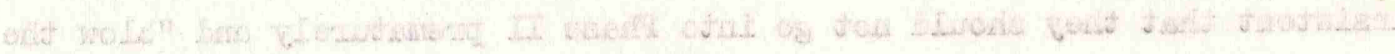

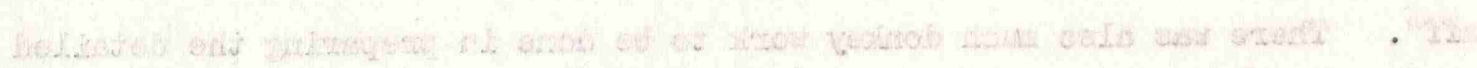

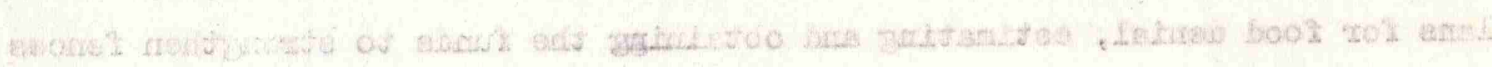

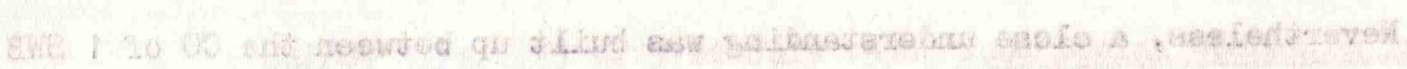

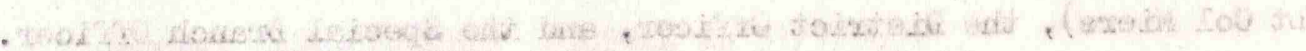

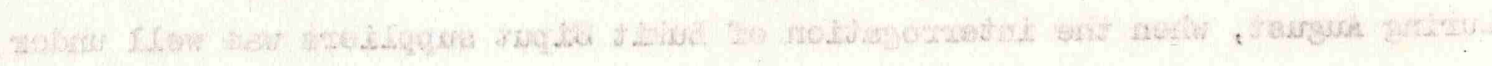

20. This seems both dangerous and naive, but it was certainly safer for a Chinese to invite a "British Tommy" to come to the cinema than to send a message to the police.

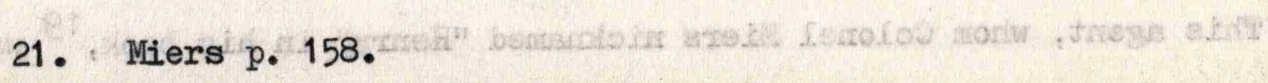


regular supplier of the Bukit Siput Branch. The Special Branch officer brought "Henry" into his house after dark and there - in armchairs behind drawn curtains - the Colonel was invited to come and meet him. The three of them discussed their plans with remarkable frankness, the Special Branch officer being confident that "Henry" would not double-cross them at this stage, first because he had already given away more than the Communists would forgive, and secondly because there was a large reward at stake.

"Henry" told them that the guerillas never gave him advanced warning of what they wanted him to do, but normally waylaid him on his way to work in the rubber. Alternatively, they would send another tapper to fetch him, and he would be led to meet them on the jungle fringe, approaching across open ground which they could watch to ensure that he was not followed. Sometimes they sent him straight away into the villages to buy small items, such as medicine or an electric torch. More commonly, however, he would be asked to bring out a larger consignment of food (presumably thrown over the village fence at night and picked up later, or smuggled out of Segamat in a lorry) in a sack on his bicycle and dump it in a patch of undergrowth in the rubber estate whence the guerillas would come and collect it at night.

"Henry" reluctantly accompanied a moonlit night patrol, dressed as a soldier with an oversized jungle hat flopping over his face, and showed them this dumping area. It was clearly unsuitable for a successful ambush, particularly at night.

To reach this dump from the jungle fringe however, the guerillas had to pass over a belt of swamp, crossed by only two causeways. "Henry" agreed to telephone the battalion next time he put food in the dump, saying - as a simple code - that there was a good picture on at the cinema that night, and asking the soldier who answered the telephone to come and see it. 20

In due course the message came. Ambushes were mounted on both the marsh crossings with electrically operated flares in the trees. The best shots in the battalion - intensively trained to shoot at night - manned the ambushes. Four guerillas came and three were killed. 21 "Henry" 
22. The three dead guerillas included a District Committee Member $(\$ 12,000$ reward $)$ and two others $(\$ 4,000$ each $)$ - total $\$ 20,000$ (about $£ 2,300$ ). This represented about 17 years pay at the average rubber tapper's earnings of $\$ 100$ a month, and there are now many owners of small businesses or estates in Malaya who bought them with rewards obtained in this way. The author interviewed a number of these (but not "Henry") in 1967.

23. COBBLE SB $24 / 9 / 56$.

24. COBBLE DWEC $21 / 12 / 56$ - Annex A SB Plan. 
collected his reward. 22

Though this successful ambush could plausibly be represented as framework, the Special Branch Officer nevertheless decided that he must deter other potential agents from blowing their information too soon. He had a promising collaborator in the Siding Division who looked likely to be able to give another lead into the Bukit Siput Branch, and he decided to conserve him. He had no cover at all, however, in Bukit Siput New Village itself, from which regular foods lifts were still being made by the guerillas themselves. He therefore decided to make some further arrests in September 1956, some of them by means of clandestine pick-ups. 23

Meanwhile 1 SWB were concentrating their patrols in the Selumpur area again, and in the final month of Phase I (on 1st December) they killed two guerillas - the first to be eliminated in the Selumpur Branch for 12 months. ${ }^{24}$ This was the result not of "advance precise information", but of deduction by Special Branch after the detailed study of the pattern of Ming Lee's movements over a long period. At a remote part of a rubber estate was a store for liquid latex. Supplies would be hidden in this shed, and Ming Lee would leave a concealed "shopping list" for his local masses executive to pick up when he collected the supplies. Ming Lee gave no warning of these visits, but Special Branch deduced that such a visit was due in the first 7 days of December. The battalion mounted an ambush in the only available cover some bushes about 5 yards from the shed, and only a few feet from trees which were regularly worked by tappers. Thus, perfect concealment and absolute stillness were essential, and the five men in the ambush party had to eat, drink and perform bodily functions where they lay, throughout tapping hours 10 hours on end from 6 a.m. to 4 p.m. Since the ambush was planned to be in position for 10 days if necessary, the party was to be relieved each night during the silent hours of the curfew.

In the event, they did not have to wait long. At 11.30 on the first morning, the ambush commander, Major Alfun Gwynne Jones ${ }^{25}$ saw tappers converging on the shed, at the door of which they were received by two 


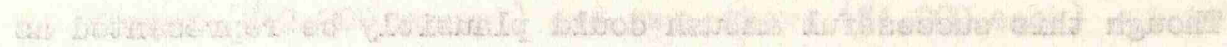

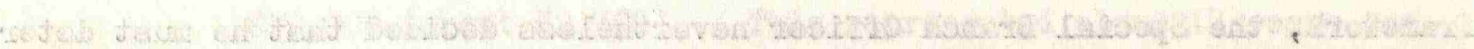

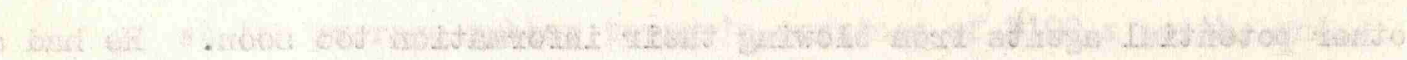

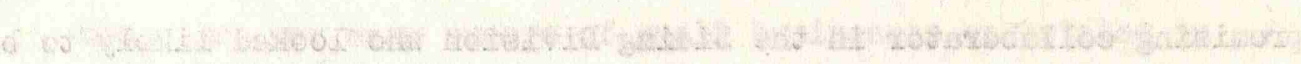

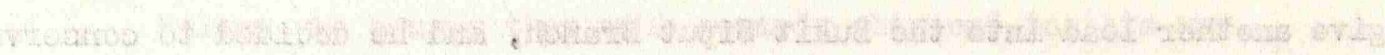

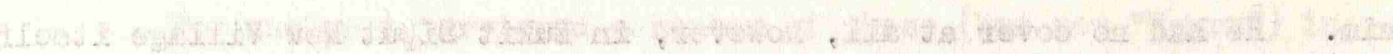

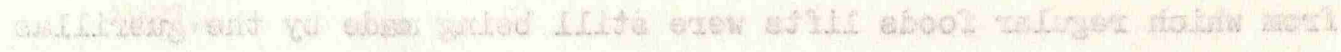

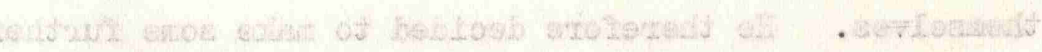

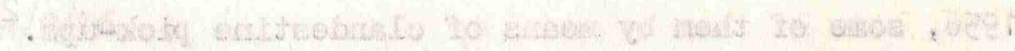

26. Miers pp. 177-9.

27. COBBLE DWEC $21 / 12 / 56$ - A SB.

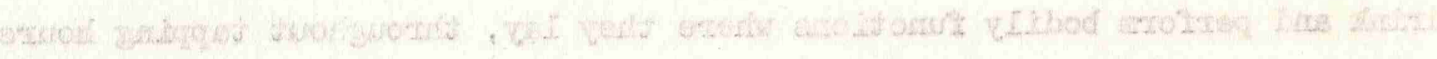


guerillas in smart uniforms with Red Star caps. Neither of them was Ming Lee, who Gwynne Jones still hoped would come, so he held his fire. The meeting lasted an hour, after which the guerillas were clearly preparing to leave, so Gwynne Jones sprang to his feet and shot the leader dead. The second guerilla dodged into the trees but was pursued and shot down by the soldiers. He was not quite dead when Gwynne Jones came up on him, and he tried unsuccessfully to hide some documents under the grass. He used his last breath to spit in Gwynne Jones' face.

It transpired that Ming Lee had intended to come to the meeting himself, but had injured his foot, and the two dead guerillas were members of his bodyguard. 26

Meanwhile, two more guerillas from the Bukit Siput and Tenang Branches had been eliminated, bringing the combined strength of the two branches, which were then amalgamated, to 5 men. Thus in all, during Phase I, 7 of the 40 or so guerillas believed to be in the District had been eliminated. Several food dumps had been discovered, though the guerillas were still judged to have some 3-months supply in stock. Above all, the Special Branch had greatly increased their coverage of agents and informers. 27

Based on the prospects offered by these agents, Special Branch in December selected their killing grounds (see Figures 16C and 16D). . These were based on agents in

Tambang 7th Mile NV (Selumpur Branch)

Bukit Siput NV

Siding Div Labour tines

Chuan Mah San Estate Labour Lines )

Bukit Siput and

Tenang Branch

In the Selumpur Branch the aim was to plan ambushes on advance precise information in the smallholdings, into which the Tambang people crossed the river to work. In the other cases, the aim was to draw the guerillas in as close as possible to the villages themselves to be ambushed on the perimeter. ${ }^{28}$ 


\section{9. ibid.}

30. COBBLE DWEC $21 / 12 / 56$.

31. ibid.

32. Many of those charted for the Selumpur Branch had, unknown to Special Branch, already been eliminated in various ways - see Miers p. 211. 


\section{Operation COBBLE Phase II}

Phase II began on 1st January 1957 with the simultaneous arrest of 60 more suspected suppliers ( 92 had been planned, but 32 of these had been frightened out of the area during Phase I). ${ }^{29}$

At the same time, strict rationing was imposed. Villages in turn were cordoned at darm and searched for hidden food in the houses. Food inspectors checked stocks in shops and removed surpluses. Tighter curfews were imposed. All the logging areas in the Tenang area were closed for 6 months from 1 st January. Police, reinforced by women searchers and troops, manned 54 gates through which villagers went out to work from Segamat Town and from the 20 villages and labour lines which contained a significant proportion of Chinese. 30

This required considerable reinforcement of police. The number of police required to man the gates is shown on Figure 16A. In all, 308 of the 527 Police in the District were on gate checks at peak periods. These figures do not include 6 platoons of Chinese Home Guards in the three main villages in the Selumpur area, nor the Malay Home Guards in 15 of the 34 Malay Kampongs. 31

In relation to the small number of guerillas (believed to be 33 at this stage, but in fact nearer $25^{32}$ ), and bearing in mind that there were also three battalions in the district, the ratio of Security Forces to guerillas was extremely high. On the other hand, the police were not employed against the guerillas at all, but in controlling the population. In the villages about which the operation was conducted, there was an average of about one policeman or home guards to every 50 people. Even these figures, however, do underline the immense effort which had to be concentrated to dig out the Communist roots in hard core areas.

The peak periods for searching at the village gates were when the bulk of the rubber tappers went out to work $(6.0$ to 7.0 a.m.) and when they returned $(1.30$ to $2.30 \mathrm{p} . \mathrm{m}$.$) . It was not possible in these periods to$ search every tapper meticulously, and the aim was to search $20 \%$ thoroughly 
33. COBBLE DWEC 31/10/56 Appendix E - Food Denial - (E.Food).

34. A Kattie is $1 \frac{1 / 3}{3} \mathrm{bs}$, so the male ration was 4 lbs per week.

35. These included some not predominately Chinese, and therefore not listed in Figure 16A。

36. Miers p. 185. 
each morning. 33 British troops helped in these searches, and became adept at sensing whom to search. The smallholders, in particular, were smuggling out rice in small quantities - concealed at intimate places on their bodies, in the tubular frames of bicycles, in bicycle pumps, in tins concealed in night soil buckets, and in the hollow bamboo poles which the villagers used as yokes to carry these buckets.

The rice ration was severe. Adult males received 3 Katties $^{34}$ per week, while females and children under 12 had only $2 \frac{1}{2}$. No individual was allowed to hold more than one week's ration, and no retailer more than two weeks'. On 31 estate labour lines ${ }^{35}$ all rice was cooked in central kitchens, and the people were not allowed to hold any dry rice at all, but they could buy as much cooked rice as they liked at meal times.

In all, 17 types of food were restricted, including salt and all dried and tinned foods. On the other hand fresh meat, fresh fruit, live poultry, vegetables and root tapioca were not resticted, provided that the possessor could, if called upon, satisfy a magistrates court that he was holding them for lawful purposes.

There were very severe restrictions on what a person could take out of the gate to work - one bottle of tea, coffee or rice gruel, and an ice cream or beverage containing not more than 15\% sugar. Except for those from labour lines with central kitchens, the tappers would start the day hungry from their tightly rationed daily diet, and in a long days work in the field, they suffered real hardship. But this harshness achieved its object, for large numbers of workers were able to claim the alibi that it was impossible to smuggle out food, and there wase growing evidence that the guerillas were suffering from a severe shortage of nutrition ${ }^{36}$ And, of course, the narrowing number of suppliers was a major factor in helping Special Branch to recruit and exploit agents.

Other restricted articles (clothing, stationery, medicines etc.) were as described in Chapter 12. 


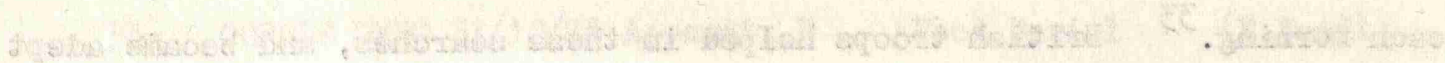

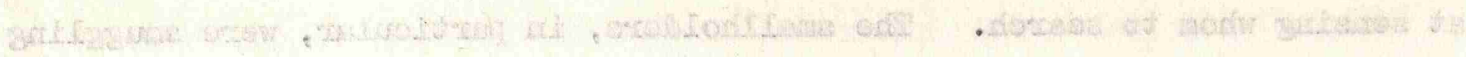

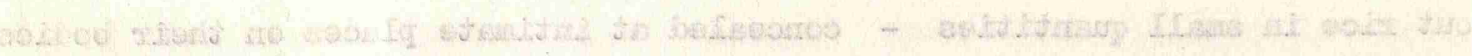

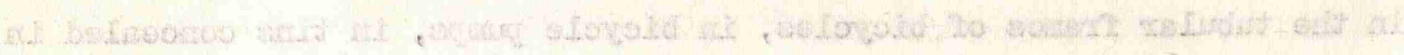

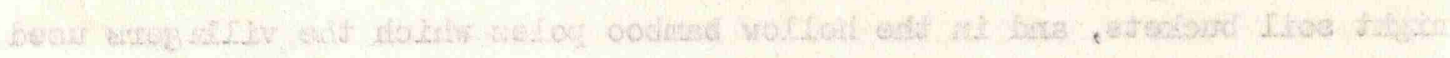

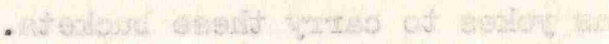

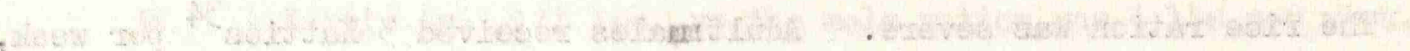

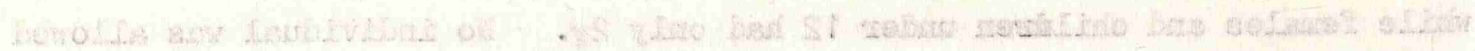

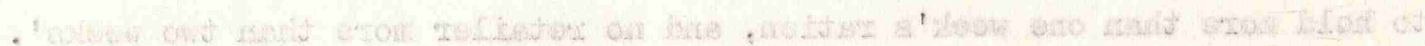

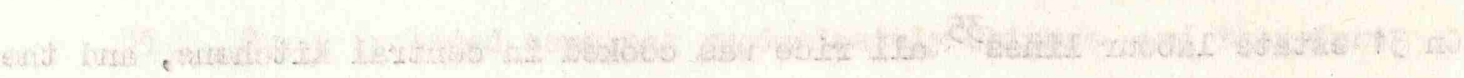

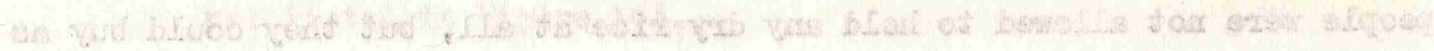

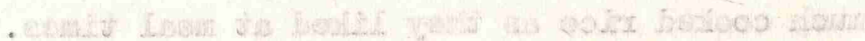

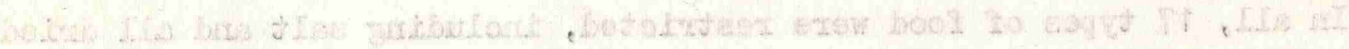

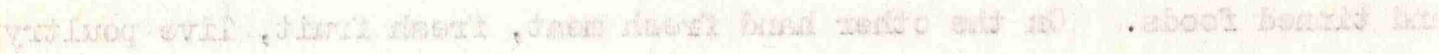

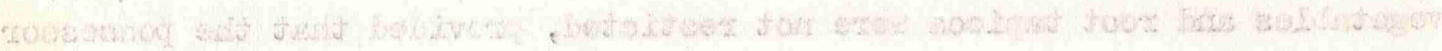

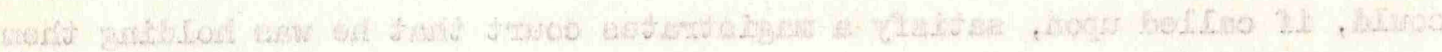
-

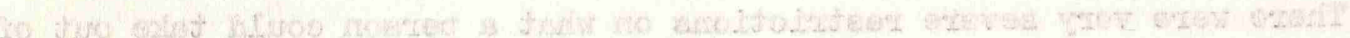

37. COBBLE DWEC $21 / 12 / 56$.

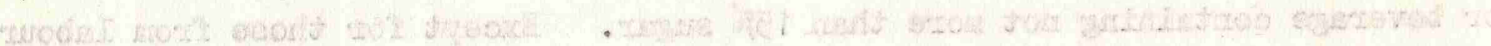

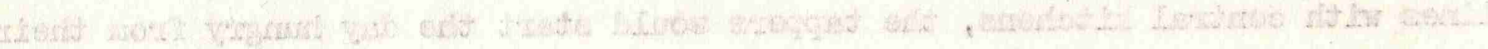

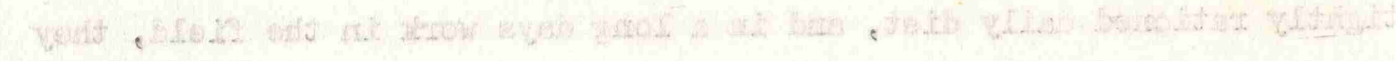

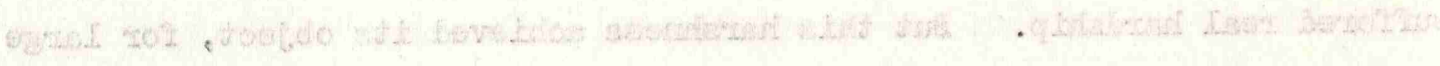

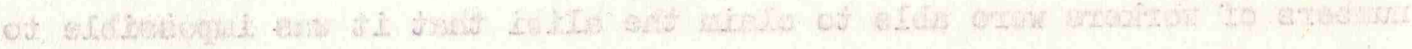

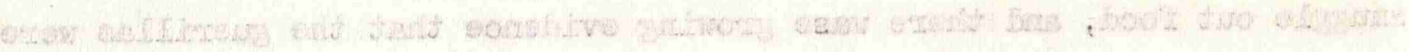

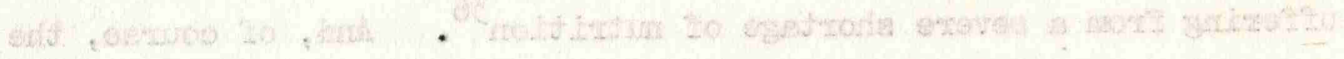

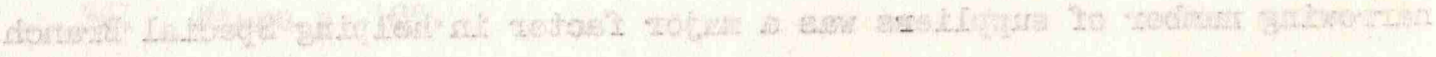

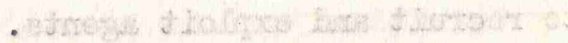

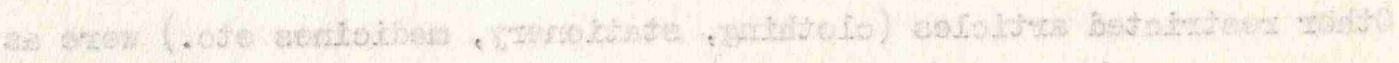


Preventing smuggling in vehicles was a difficult problem, as the main road cut through the centre of the district, and passed through many towns and villages with strong Communist organisations - notably Segamat.

Vehicles carrying restricted articles had to be covered by tarpaulins securely laced down, and to carry a written manifest of their contents. They were forbidden to leave the main road without a police escort, or to move between dusk and dawn. Nevertheless, a single sack of rice, dropped into the ditch for later collection on a quiet stretch of road could feed the Selumpur branch guerillas for a fortnight, and no doubt of ten did.

Apart from Police and military road blocks, searches etc., food control was enforced by 2 food inspectors, each accompanied by 2 policemen and 2 soldiers, who inspected dealers stocks, and checked their books against ration cards.

Curfew times were as follows:-

$$
\begin{aligned}
& 4.15 \text { p.m. Rubber curfew - all to be out of rubber estates } \\
& 7.00 \text { p.m. Perimeter curfew - all to be inside their villages } \\
& 11.00 \text { p.m. House curfew - no one on the streets (except in Segamat) } \\
& 5.00 \text { a.m. House curfew lifted } \\
& 6.15 \text { a.m. Other curfews lifted }
\end{aligned}
$$

The life of a rubber tapping family in the New Villages ran to a pattern governed by these curfews. From 4 a.m. onwards, they would be up, feeding babies and cooking a fair sized meal of rice and fish, or perhaps an egg from the chickens scrabbling in the yard. This meal had to last most of the day.

By 5 a.m. many of the tappers, impatient to be out in the cool of the day when the latex flows best, would be queuing at the search barriers. In some villages, when it was practicable and safe to hold a "cushion" of people between the search barriers and the village gates, the search would begin soon after 5 a.m. under floodlights. Generally, however, searching was concentrated between 6 and 7 a.m.

Complete families would go out into the rubber - father and mother and the older children with bicycles, carrying the younger children on the 
38. Latex tins with false bottoms were a common device for smuggling rice.

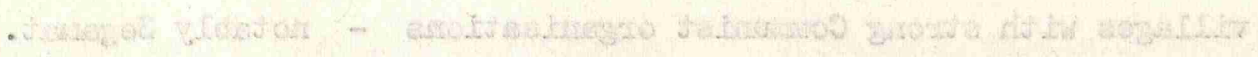

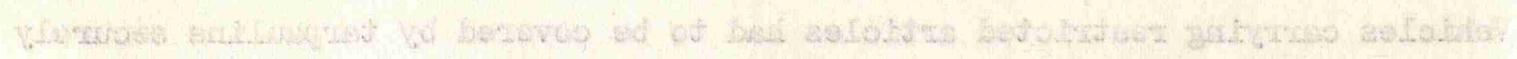

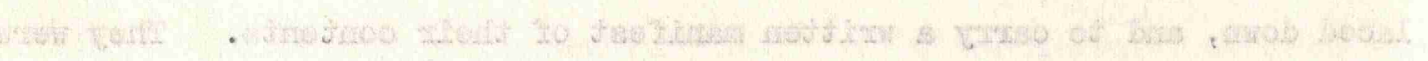

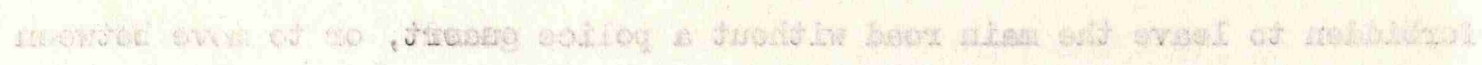

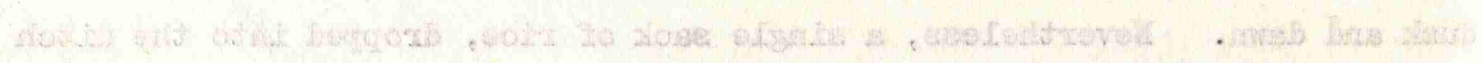

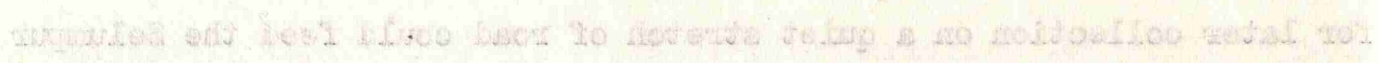

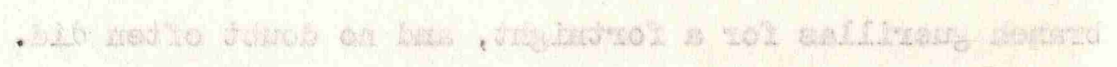

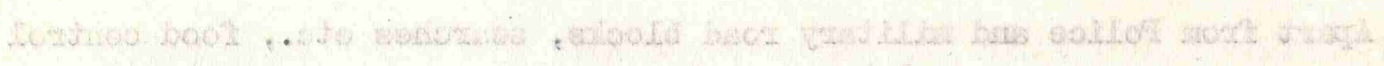

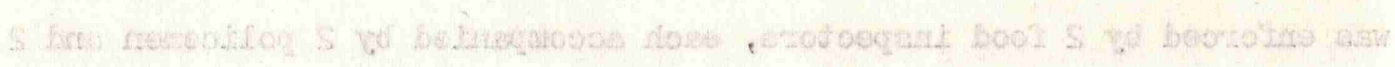

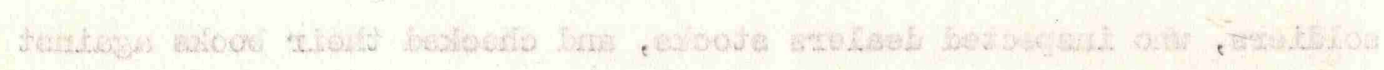

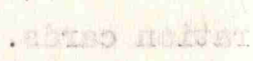

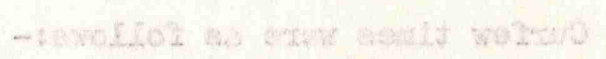

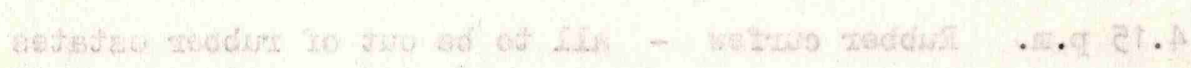

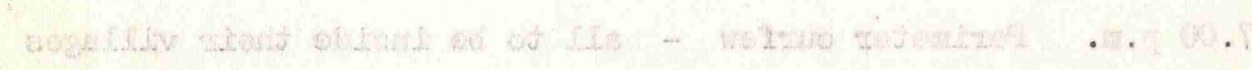

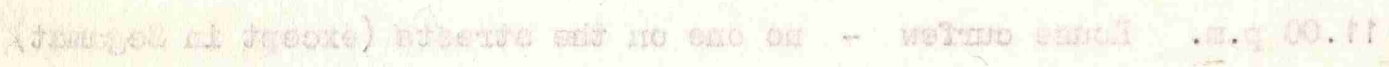

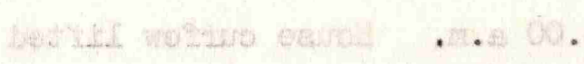

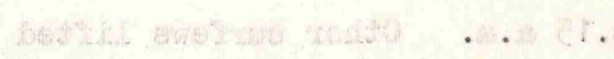

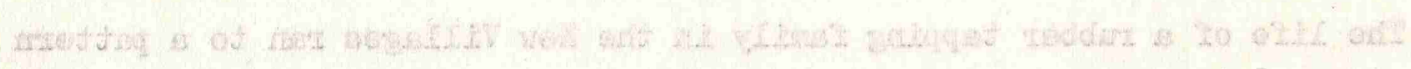

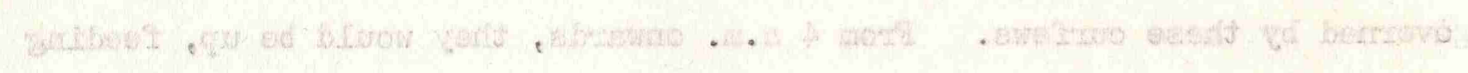

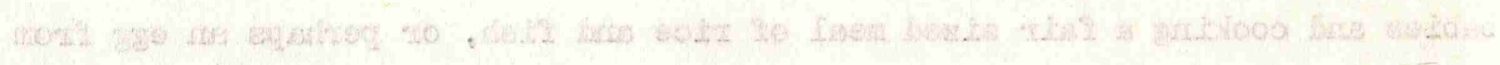

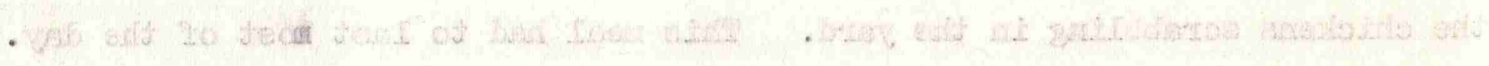

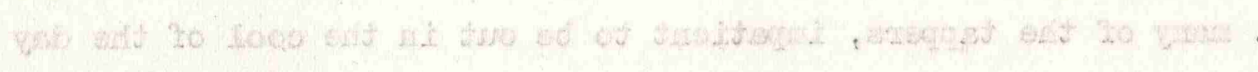

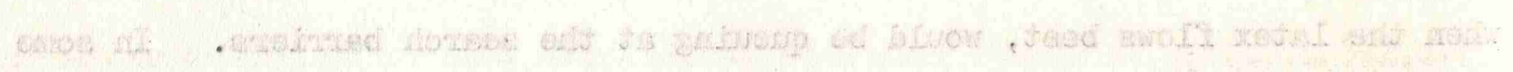

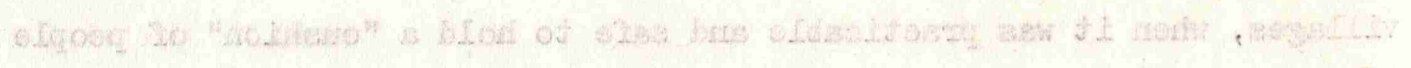

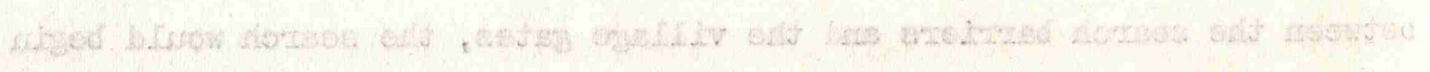

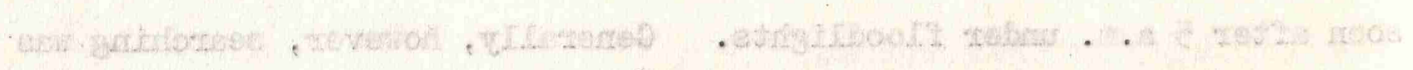

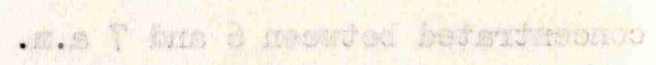

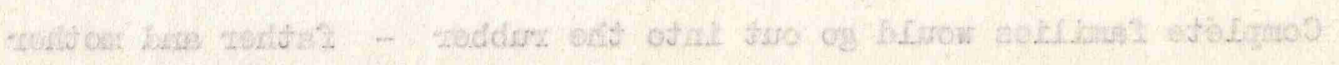

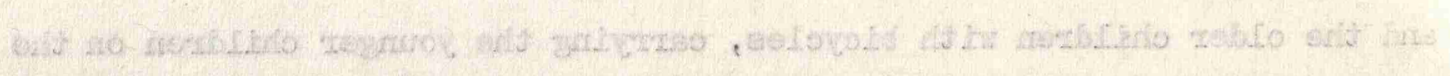


handlebars, with latex tins and tapping knives strapped on the back. ${ }^{38}$ Only the babies and the very old grandparents would be left at home to keep each other company. Even a 6 year old child was useful in the rubber - he would go ahead of his father or his older sister, darting from tree to tree stripping off the congealed latex from the previous cut. By these means, each adult or teenager could tap some 500 trees a day and, if the latex flowed well, could hope to earn $\$ 100$ to $\$ 120$ a month. If a family could bring in 4 or 5 such incomes, life became reasonable for them, and they could spare some of their older children - especially the boys - to go and be educated at the High School in Segamat. It was hard to connect these boys, in their spotless white shorts and shits and polished bicycles, with the parents in their dusty black cotton trousers, stained with latex, as they all waited together to be searched by the Malay constables and the British soldiers at the village 'gates.

They usually waited with patient resignation, but sometimes the teenage girls would giggle and try to provoke the Malay constables and occasionally, with several hundred Chinese pressing at the barriers, the atmosphere would. become uglier. The constables - scarcely more than boys, and fresh from their kampongs with only a few weeks training - would be sorely tempted to skimp the search and release the pressure, and it was here that the moral support of a British corporal with half a dozen men could be decisive.

By the middle of the day the latex would have ceased to flow, and the tapper would complete the round of emptying the cups into their tins and taking them to the weighing sheds. This is where they would of ten be contacted by the masses executives or by the guerillas themselves, and, if the guerillas were confident, they would hold propaganda meetings and call for public votes of solidarity. In a district like Segamat it was not easy to swim against the stream, so the high police rewards for informers were really necessary.

By $4.15 \mathrm{p} . \mathrm{m}$. the rubber estates had to be clear. This was to allow patrols and ambushes to get into position before dark, near suspected dumps, 
39. This lack of "policemen on the beat" has been the biggest single weakness in Vietnam up till 1969. There was no real equivalent to a police force in the hamlets. Security was in the hands of the Popular Force - an equivalent of the Home Guard - which generally lived with its families in a separate wired compound well outside the hamlet. Even the hamlet and village chiefs saldom dared sleep in the hamlets, but came in by the day. Any ordinary villager who had failed to obey Vietcong orders, or, even more daringly, had given information to the government, had no protection at night from "the man with the Knife", of whom the villagers were far more frightened than of the Vietcong units in the jungles outside. (Interviews with three Vietnamese Colonels visiting Singapore, 1966, confirmed on a visit to Vietnam by the author, 1967).

40. The above description is based upon a 4 day visit by the author to 1 SWB in Segamat in January 1957, in which he went through a complete cycle of gate-checks, street patrols and perimeter patrols in Pekan Jabi; also the initial cordon and search of Buloh Kasap, a rubber patrol and an ambush. 
or on guerilla approach tracks through the rubber or the jungle fringe.

During the afternoon and evening, schoolteachers would run primary school classes in the villages for the children back from tapping, and parents would do their shopping if this had not already been done by "granny" during the morning.

By 7 p.m. all were inside the perimeter fence, on which the floodlights played, and which was patrolled throughout the night. If a guerilla raid or food lift was expected, an army ambush would just have time to get into position outside the fence before the last of the light had gone.

7 to 11 p.m. were the sociable hours of the day. The families would eat their main meal, and would call on each other. The coffee shops would be busy, and the Mah Jong pieces would clatter on the tables as the men gambled with their earnings. Some. would seek comfort in opium. These occasions, like the mid-day gatherings at the weighing sheds, were when the masses executives did much of their work, and the Special Branch detective and his agents would be on the prowl, watching from the shadows to see who talked to whom, and who called at whose house.

By 11 p.m. all were confined to their homes. Police and home guards would patrol the streets to guard against the man with the knife creeping around to deal with "traitors to the people". 39

There were, however, inevitably a few loopholes in the house curfew. Most houses, for example, had outside privies between the house and the perimeter fence. These provided an alibi for villagers who were seen moving outside - possibly hoping to toss bags of rice over the fence into patches of long grass for collection later, or to signal to raiders outside, or to cut gaps for them to come in. Even a small village, with a population of 1,000 or so, would have a perimeter over a mile long, and it was not easy for patrols inside or outside them to make them $100 \%$ watertight. 40

By 4 a.m. the village would come alive, with many lights bobbing down to the privies, and the daily cycle would begin again. 
41. $\quad$ pp. 167-213.

42. A big glass acid jar, buried beside a track so. that the only thing above the ground (and concealed by loose leaves) was the neck, into which the tappers poured their contributions of rice as. they passed. Miers p. 184. 
Operation COBBLE - The Fnd of Phase II

The story of the final destruction of the Selumpur in Phase II is well told in Miers' book. ${ }^{41}$ When it began it was quickly over.

First, an agent led Miers and Gwynne Jones to a camp containing 5 guerillas. In daylight it was not possible for them to get close enough to shoot effectively, and the Colonel and his company commander watched fascinated as the 5 guerillas played a child's game of "tag" for exercise. That night the camp was raided. Three happened to be away from it, one more escaped and one was killed. Later, two others came in to surrender.

The next guerilla was killed in the ambush of a small rice dump, ${ }^{42}$ and his condition left no doubt that the guerillas were very short of food. Another was shot in an ambush of a shed regularly used as a pick up point. Two Chinese police inspectors dressed as coffee plantation workers acted as a decoy to lure in a guerilla known to be separated from his gang and dsperate to get food. Two more were killed in an ambush based on clever deduction from the now very detailed information of the pattern of guerilla movement, and another surrendered in the same ambush. Then Ming Lee himself walked. into two ambushes, in one of which one of his companions was killed, but he escaped both times. This brought the number of eliminations in the Selumpur Branch to 11 - 2 in Phase I and 9 so far in Phase II.

Ming Lee himself seemed indestructable, and Special Branch charts showed 7 others at large with him.

The day after his second narrow escape, however, Ming Lee had had enough, and asked an ancient Indian rubber tapper to lead him to the police station. The old Indian was so flabbergasted with his reward that he fainted. Like most surrendered guerillas Ming Lee was ready to cooperate to the full, and talked freely. He said that his greatest problem was food. As dumps ran low, and his trusted suppliers were detained or, worse still, became informers, he had to take more and more risks to get food, and casualties mounted in a vicious circle. He asked the MCP District Committee for permission to move temporarily to a new area, but was told to stay. Finally, he realised that 


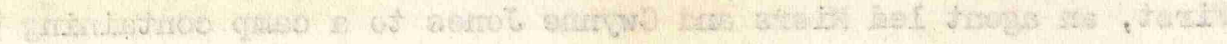

43. Miers p. 213.

44. This account is based on author's recollections at the time.

45. Tunku Abdul Rahman, at a Press Conference in Kuala Lumpur on 26th August, 1958, reported in the Malav Mail 27th August, 1946. 
the battle was lost. Special Branch were pleasantly surprised to hear that, of the 7 they thought remained, one had died of wounds, one had been killed by a buffalo, and two others had disappeared in the jungle without trace. This left only 3. Ming Lee agreed at once to go out with a patrol to try to lure these 3 survivors into an ambush, but they did not come. Nevertheless, the Selumpur Branch was finished as an effective force and never revived. Ming Lee, after a brief spell in the Rehabilitation Centre, became groundsman at the Segamat Cricket Club. 43

The end of the Bukit Siput/Tenang Branch was more sudden and spectacular. Special Branch at last got a good agent in Bukit Siput New Village, who said that the gang, bold to the last, were coming to a certain spot' on the village perimeter, at night, to pick up sacks of food passed over the fence by the villagers. The Gurkhas laid an ambush and shot well. All the 5 remaining members of the branch were killed outright.

The bullets cracked through the village and penetrated the thin walls of the tappers' houses, but on-one stirred. When dawn came, the police went round to check for casualties, and to question the people in the houses which had been hit. All said that they had heard nothing - even some who had been sleeping in beds beside which the wall was peppered with bullet holes.

Meanwhile, the police had laid down the 5 bodies outside the police post. The people filed past. As they counted the bodies and recognised their faces, their attidude changed. Every guerilla was dead, and the threat was gone - and they knew which was the winning side. They began to talk freely, and all that remained of the Bukit Siput Masses Organisation was quickly rounded up. 44

Remnants of the Segamat MCP District HQ, however, still existed, and there was evidence that Hor Lung and the South Malaya Bureau were still receiving supplies from the masses organisation in the Selumpur area. 45 It was therefore still not safe to declare this a White area, and Operation COBBLE moved into what proved to be a prolonged Phase III, the final dividends of which are described in Chapter 13. 


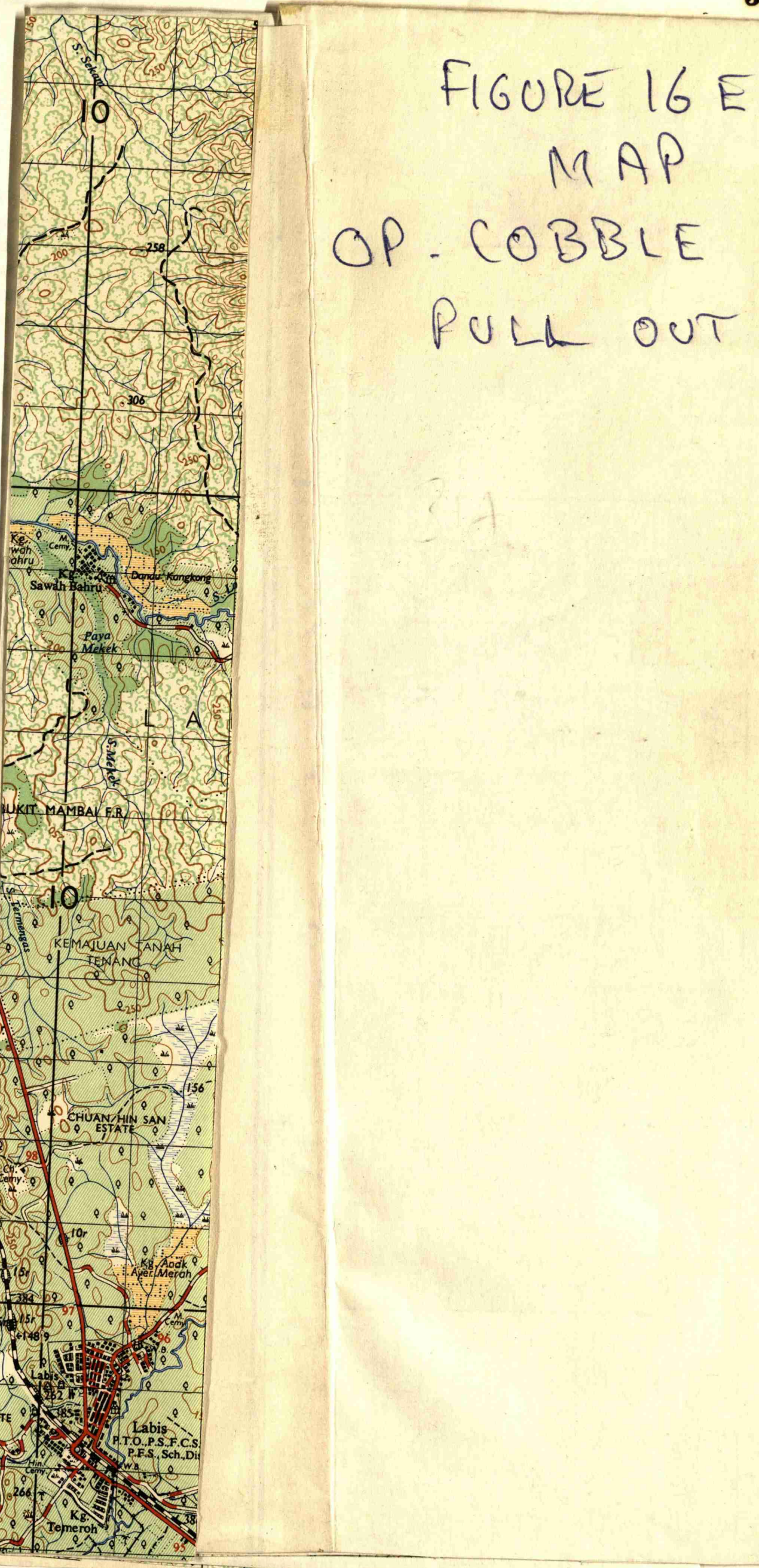









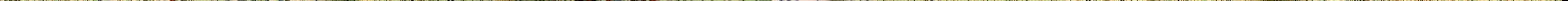


My aim in this thesis has been to study the organisation and techniques of revolution and counter revolution in Singapore and the Federation of Malaya from 1945-1963 before the memories of those who took part have dimmed and before too many of the unpublished documents have been destroyed. They are rare in that an urban and a rural revolution were attempted simultaneously by the same Communist Party.

I have studied them as contemporary history, in the context of revolution as a subject rather than of the development of the two countries concerned; and I have tried to look back from the viewpoint of today rather then to project forward from the past. ${ }^{2}$ Though I have drawn some attention to earlier revolutions in so far as they influenced the actions of my players, I have tried rather more to see how events in Singapore and Malaya in the $1940 \mathrm{~s}, 50 \mathrm{~s}$ and early 60 s may throw light on contemporary controversies about revolutionary and counter revolutionary techniques.

I did most of the primary research from 1966-68, while stationed with the army in Singapore, and as a part-time $\mathrm{PhD}$ candidate at Singapore University. From 1968-1970 I transferred my candidature to London University, concentrating on secondary sources, but supplementing information from primary sources by correspondence, and during two short visits to South East Asia in 1968 and 1970.

In both Singapore and the Federation I received generous assistance from government departments, and both governments authorised officers of their Police Special Branches to help me. Many of these officers gave me repeated interviews, and arranged for me to meet ex-members or supporters of the Malayan Communist Party. I was also given access to large numbers of unpublished reports, appreciations, instructions, letters etc from which I have quoted freely.

I have referred to Special Branch officers by pseudonyms; also those ex members of the revolutionary organisation whom I interviewed, with the exception of two whose views have been published under their own names. I have also used pseudonyms for a number of others when asked to do so.

I have listed a small number of books, by authors who played an active part in the events described, as primary sources. For convenience I have repeated these in the main alphabetical list of books under secondary sources.

The Bibliography is arranged as follows:

\section{PART 1 - PRIMARY SOURCES}

A - Interviews

B - Documents - Unpublished

C - Documents - Published

D - Books (Primary Sources only)

PART II - SECONDARY SOURCES

E - Books

F - Articles and Monographs

G - Newspapers and Periodicals

1 See Geoffrey Barraclough, An Introduction to Contemporary History

London (Pelican) 1969 pp 17-20

2 See E H Carr, What is History? London (Pelican) $1964 \mathrm{pp}$ 20-30 
I - PRIMARY SOURCES

A - INTERVIEWS

"AH TUK"

BLADES A.E.G.

"CHING"

DAVIS, John

DHORAISINGHAM, Samuel

"PT"

WOH KENG SWEE

Michael
Communist TCS (Town Committee Secretary) of the Communist Party in Singapore,. Captured in 1950. Had earlier run the Secret Party organisation in one of the larger Trade Unions.

Singapore Police Officer from 1945-1964, Director of Special Branch up to and during the 1954-56 riots, and then Commissioner of Police. Gave interviews and also commented in detail on first draft of Singapore section of thesis (see Documents, Unpublished).

Born 1941, son of a small contractor in Johore. Was involved with the Communist Movement at Chinese High School in Johore Bahru, 1956-1959. Arrested 1959 and released. Later at Nanyang University (1963-1968).

Commanded Force 136, the British mission with the Communists in the jungle (1943-45). Then served in the Malayan Civil Service till 1960. A Chinese speaker, he frequently talked to surrendered guerillas and Chinese villagers during the Emergency•

Citizen during Singapore Riots 1956.

A Chinese officer with some 20 years experience in Special Branch, who was concerned with many surrenders. He took a major part in Operation TIGER.

French army officer who fought in Indochina and Algeria.

Leading member of Singapore Peoples Action Party (PAP) and later Finance Minister and Defence Minister.

District officer in Selangor during resettlement. Has served in Malaya and Singapore for 20 years. 
"HARRIS" (SB)

HOR LONG (Com)

HYDE, Douglas

"KIM CHENG" (Com)

KITSON, FE

LAM SWEE (Com)

MARSHALL, David

NULSEN,

Lieut Colonel Charles $\mathrm{K}$

ONG BAN CHAI
A British Special Branch Officer who served in most parts of Malaya during and after the Emergency. When the author served in the Director of Operations staff in Police HQ, Kuala Lumpur, "Harris" was in charge of the anti-Terrorist Wing of Special Branch in the same HQ, and they worked closely together. Since then, they have had many discussions, before and during the research for this thesis.

Communist SCS (State Committee Secretary). Was in the jungle throughout the Japanese occupation, and again from 1948-1958. From 1956 to 1958, due to breakdown in the chain of command, he ran a large group of States and Regions independently. After his own surrender, he negotiated the surrender of most of the groups in his command without bloodshed over a period of 6 months.

Ex-member of the British Communist Party and News Editor of the Daily Worker. Author of I Believed and other books on Communism. Has interviewed many Communists in detention, including Lim Chin Siong in Singapore.

Communist RCM (Regional Committee Member) responsible for running one of the most staunch Communist districts in Johore. Served throughout the Japanese occupation. Surrendered in 1958.

A British army officer with experience in counterinsurgency operations in Kenya and Malaya.

Communist RCM and Regimental Commander. Served throughout the Japanese occupation. Surrendered in 1950 after a disagreement over policy with the Central Committee.

Singapore's first Chief Minister in 1955.

Served with US Army in Vietnam, 1961-62 and 1966-67.

Was schoolboy in Singapore in 1954, and thereafter at Singapore University.

Served with US Army in Vietnam 1964-65.
OSBORN, Lieut Colonel Robert B. 
PUTHUCHEARY, Dominic

"RAMANTHAN" (SB)

"SENG" (SB)

"SHAMSUDIN" (SB)

SHORT, Anthony

"SIN FAI" (Com)

SURRENDERED ENEMY PERSONNEL BRAINS TRUST (SEP Brains Trust)

THOMPSON, Sir Robert

THOMSON, G.G.
Brother of James Puthucheary, one of the leaders of the Peoples Action Party in Singapore in 1956. Dominic was a supporter, and was later arrested and detained in 1962.

A Special Branch officer at District and Circle level during the Emergency in Perak and Johore, and later in Police HQ. An experienced Chinese Special Branch officer in
Singapore.

A senior Malay police officer who was in Special Branch during the Emergency. Played key part in eliminating Malay guerillas in Pahang, and later in Batu Pahat.

Former Lecturer in History at the University of Malaya, and author of The Communist Insurrection in Malaya, now in manuscript form awaiting publication by the Malaysian government.

Communist BCS (Branch Committee Secretary) in a strong Communist area. Surrendered early 1950 .

A group of five ex-Communists, including a Central Committee Member, two State Committee Members, a District Committee Secretary and a Branch Committee Secretary. They took part in a discussion with the author, and subsequently (with the aid of Special Branch) compiled a written report in answer to a questionnaire.

Secretary for Defence, Malaya 1957-60 and Head of British Mission, Vietnam 1960-64. Author of several books on revolutionary war.

Director, Political Study Centre, Singapore. Was on Lord Mountbatten's Intelligence Staff in 1945, and was in charge of Information Services in Singapore in 1956. He has lived in Singapore for over 20 years and is now a Singapore citizen. Gave interviews and also commented in detail on first draft of Singapore section of thesis. (See Documents, Unpublished). 
"TONG"

TOO, C.C.

TROY

Lieut Colonel Guy C.

VAIERIANO Colonel Napoleon

WALLER, P.B.G.

"YUNG"
An assistant resettlement officer during the Emergency.

Head Psychological Warfare Section, Federation of Malaysia. Has served in section since 1952.

Served with US Army in Vietnam in 1967-68.

- Army of the Philippines.

A British officer who served with the Malaysian Police from 1950 to 1966. He was Personal Staff Officer to Colonel GRAY, Commissioner of Police in 1950-51. Later he commanded Police Field Force Units in Pahang, and was OC District Police, Ipoh for the planning and launching of Operation GINGER. Now with the Stanford Research Institute, Bangkok.

Born 1942 of poor Hokkien parents (father unemployed, mother a street hawker). Was on the fringe of the Communist movement at the Chinese High School, but later changed sides and took part in the attempt to defeat its control of the Students Union at Nanyang University, 1960-65. 
B - DOCUMENTS - UNPUBLISHED

Blades, A.E.G, comments on 1st draft of Part 1 of Thesis 29 July 1969

Blades

Carleton-Greene, Hugh, Report on the Information Services from September 1950 to September 1951 Kuala Lumpur 1951.

Carleton-Greene Report

Chinese Advisory Board Malacca - Minutes 1950-53

Chinese A B M Minutes

Commissioner of Police and General Officer Commanding, A Paper on the Security Situation in The Federation of Malaya, Kuala Lumpur, 5 April 1949.

CP and GOC 5 April 149

Craig, R J W. A short Account of the Malayan Emergency Craig Mr Craig was a Special Branch officer during the Emergency and in 1969 he loaned this manuscript to the author who now holds a typescript of it.

Director of Intelligence Malaya, Operation HIVE Letter $111 / \mathrm{SF}$.46 of 6 June 1952.

Operation HIVE 6 June 1952

D of Ops Directive No. 15

DOPSI 28

Director of Operations Instruction No. 28, The Co-ordination of Special Branch Planning with Security Force Operations (Revised) 20 June 1956

Director of Operations Instruction No. 36 Food Denial Operations 24 June 1954

Director of Operations, Progress Report on the Emergency in Malaya, Kuala Lumpur 15 October 1951.
$D$ of Ops Report 15 Oct 1951

$D$ of Ops Report 1 Dec 1950

DOPSI 36

Director of Operation (or D of Ops) Review 1957

Director of Operation (or D of Ops) Review 1956 
Director of Operations Staff Letter to Author 16 Sep 1958

Director of Operations, Tactical Directive No. 1, 6 October 1950

Emergency Chinese Advisory Committee - Minutes 1950-53

Federal Plan for the Elimination of the Communist Organisation and Armed Forces in Malaya Kuala Lumpur 24 May 1950

Federal War Council - Minutes 1950-52

Head Special Branch Selanger Notes 19 June 1953

High Commissioner Dispatch No. 5, 30 May 1949

High Commissioner Minute No. 251615 Jan 1954

High Commissioner, Report to the Secretary of State for the Colonies, 8 Jan 1949

Intelligence Appreciation for Operational Planning for the Second half of 1954, 27 April 1954

Joint Intelligence Advisory Committee Report 24 October 1950

Latimer, Captain H S Notes on Planning Requirements for Operation HIVE type Operations 16 January 1953

Operation COBBLE - Contingent Special Branch Johore letter SBJ/SF32/A/1(V) of 31 July 1956 to Federal Police HQ, Food Denial Operation in Segamat - LAUNCH/COBBLE

Operation COBBLE - Johore Special Branch Appreciation 7th August 1956

Operation COBBLE - Johore Special Branch Letter SBJ/SF32/A1(Y) of 19 July 1956
Latimer

D of Ops Tac Directive No. 1

ECAC Minutes

Federal Plan

24 May 1950

Federal War Council, Minutes

HSB Notes $19 \mathrm{June} 1953$

High Commissioner

Dispatch No. 5

High Commissioner

Minute No. 2516

High Commissioner Report, 8 Jan 1949

Intelligence Appreciation 1954

JIAC Report 24 Oct 1950 COBBLE - SB 31/7/56 COBBLT - SB $7 / 8 / 56$ 
Operation COBBLE - Contingent Special Branch Johore Letter of 24 September 1956

Operation COBBLE - Minutes of Johore Contingent Planning Committee, 9 December 1956

Operation COBBLE - Segamat District War Executive Committee Operation Instruction No. 1 Op COBBLE Phase 2, 21 December 1956

Operation COBBLE - Segamat District War Executive Committee Operation Order 31 October 1956

Operation GINGER - Ipoh District Special Branch Appreciation, 31 January 1958

Operation GINGER - Military Debriefing, 1959

Operation GINGER - Notes by Mr P B G Waller, at that time Officer Commanding Police District IPOH

Operation GINGER - Perak State War Executive Committee, Operation Order No. 1 of 1957, 13 December 1957

Operation GINGER - Psychological Warfare Draft Operational Plan Ipoh, December 1957

Operation GINGER - Special Branch Debriefing, 1959

Operation GINGER - Talking Points (scripts issued for loud hailer vans) (in possession of PBG Waller)

Operation HAMMER Letter SB SEI TS/GEN/39/18 of 21 March 1953

Operation SHOE - Johore SB Intelligence Appreciation 23 November 1956

Operation SHOE - Johore Special Branch Planning Committee Minutes 16 December 1956

Operation SHOE - Police Operation Instruction No. 1 Op SHOE 1 July 1957
COBBLE SB $24 / 9 / 56$

COBBLE - SB 9/12/56

COBBLE DWEC 21/12/56

COBBLE DWEC 31/10/56

GINGER - SB 31/1/58

GINGER - MiI

Debriefing

GINGER - Waller

GINGER - SWEC

$13 / 12 / 57$

GINGER - Psy War

\section{GINGER - SB}

Debriefing

GINGER - Talking Points

Operation HAMMER 21 March 1953

JSB Appreciation $23 / 11 / 56$

SB SHOE $16 / 12 / 56$

Police Op SHOE 
Operation TIGER - Johore Bahru Special Branch
Appreciation for Phase 2, Johore Bahru April 1958

TIGER - JBSB

Operation TIGER - 99 Gurkha Infantry Brigade Operation TIGER - 99 Bde
Instruction No. 48 Johore Bahru 9 April 1958

Operational Research Papers, HQ Malaya Command 1951-53 ORS

$\frac{\text { Report on Military Action in Singapore Riots }}{25 \text { Oct } 56 \text { - } 2 \text { Nov } 56 \text { by HQ Singapore Base }}$

District - undated - presumed late 1956

$\frac{\text { Report on Singapore Riots October } 1956}{\text { Police }-3 \text { Nov } 56}$ by Singapore

Police Report

$\frac{\text { Singapore Riots October } 1956}{\text { Singapore by GOC Singapore }}$ - Report to Governor of Singapore by GOC Singapore District and Commissioner
of Police 27 March 1957

Joint Report

Special Branch Letter, Food Control SF/458/2(Y)

Kuala Lumpur 5 February 1954

Military Report

Special Branch Letter, Food Control SF/458/2(Y)

Kuala Lumpur 11 May 1954

SB Letter 11 May 1954

Statistical Information Concerning New Villages in the Federation of Malaya CS $6527 / 52$, Kuala

Stats NV

Thomson, G G Comments on 1st Draft of Part 1 of Thesis, July 1969

G.G. Thomson

Waller P B G, Working Papers, made available to author at the Stanford Research Institute,

Waller, Working Papers 
Chief Stastistician,

Singapore

Monthly Digest of Statistics,

Commonwealth Relations Office Cmnd 620 of 1958 Exchange of letters with Federation of Malaya on $\frac{\text { Constitutional Commission, Singapore. Report by }}{\text { Sir George Rendel, } 22 \text { Feb } 1954}$

Department of Statis

the Federation of 1957 Population Census of the Malaya, Report No. 14, Kuala Iumpur

Emergency Regulations Ordinance 1948 (amended up to 31st March 1953) Kuala Lumpur, Government Press 1953

Emergency (Tenants Registration) Regulations, Kuala
Lumpur 1951

Household Budget Survey 1957-58, Kuala Lumpur

* Malayan Communist Party (MCP)

* MCP Directive, 11 June 1956, quoted in White Paper * MCP Political Bureau, Party Directive of 1st October
1951

* MCP Record of Decisions, 13 June 1940

* MCP Strategic Problem of the Malayan Revolutionary War,

- MCP Supplemen

Malayan Central Politburo of the Malayan Revolutionary War, 12th November 1949

* These MCP documents were published as Appendices in Hanrahan, GZ, The Communist Struggle in Malaya, New York 1954
Abbreviation

Stats, Singapore

CRO Cmnd 620 of 1956

Rendel Report

Census 1957

\section{gula- or ERs}

ERs (Tenants Reg)

Household Survey MCP, Const 1934

MCP, 1951

MCP, 1940

MCP, Directive of December 1948

MCP, 1949 
Malayan Union and Singapore, Summary of Proposed Constitutional Arrangements, Colonial Office, Cmd 6749 of March 1946

Minutes and Council Papers of the Legislative Council, Federation of Malaya (First Session) August 1955 - Sept 1956. Paper No. 21 of 1956, Wednesday 16th May 1956, Report of the Education Committee 1956

$\frac{\text { Monthly Statistical Bulletin of West Malaysia, }}{\text { Kuala Lumpur }}$

Report of Rural and Industrial Development Authority (RIDA) 1950 - 1955 - Kuala Lumpur 1956

Report of Singapore Constitutional Conference $\frac{\text { London, }}{1957}$ (S of S for Colonies - Cmnd 147) HMSO London

\section{$\frac{\text { Report of the Singapore Riots Commission } 1951}{\text { London } 1951}$ \\ $\frac{\text { Singapore Legislative Assembly Debates (Official Report) }}{\text { Government Printing Office, Singapore }}$}

\section{Bound Volumes:-}

Vol I, 22 Apr 1955 - 7 Jun 1956

Vol 2, 29 Aug 1956 - 6 Dec 1956

Vol 3, 9 Jan $1957-30$ Jul 1957

Vol 4, 21 Aug 1957 - 8 Jan 1958

Vol 7, 13 Aug 1958 - 5 Nov 1958

Vol 11 (Nos 1 to 19) 1 Jul 1959 - 20 Dec 1959

Vol 12 (Nos 1 to 13) 13 Jan 1960 - 1 Jun 1960 )

Vol 13 (Nos 1 to 11) $20 \mathrm{Jul} 1960$ - $16 \mathrm{Nov} 1960$ )

Vol 14 (Nos 1 to 14) 29 Nov $1960-14$ Jun 1961)

Unbound and Un-numbered - Individual Days

16 March 1962

6 July 1962

20 November 1962

$30 \mathrm{July} 1963$
Colonial Office

Cmd 6749 of 1946

Razak Report 1956

Stats, KI

RIDA 1956

Cmnd 147
SLA Debates

(with date) 
Singapore Legislative Assembly, Sessional Papers

Sing Misc 2 of 1956

No Misc 2 of 1956. Correspondence between the

Chief Minister and the Secretary of State for the

Colonies on the subject of Re-opening the Constitutional Conference

No Cmd 15 of 1956 - White Paper on Educational Policy

No Cmd 31 of 1956 - Report on Singapore Al1-Party Mission to London Apr/May 1956

No Cmd 53 of 1956 - Singapore Chinese Middle School Students' Union Singapore 1956

No Cmd 33 of 1957 - The Communist Threat in Singapore

Cmd 33 of 1961 - Memorandum Setting out Heads of Agreement for a Merger between the Federation of Malaya and Singapore

Singapore Paper No. 34 of 1954

Constitutional Commission, text of Governor's Despatch 11 March 1954

S of S for Colonies' Reply 23 Apr 1954

Statesman's Yearbook 1947-1957

Trade Union (Amendments) Ordinance 1948 Kuala Lumpur 12 June 1948

Trade Union (Amendments No. 2) Ordinance 1948 Kuala Lumpur 19 July 1948

Trade Union Registry: Annual Report 1948 Government Press, Kuala Lumpur 1949

United Nations Statistical Year Book 1948-1957

White Paper, Nanyang University Communist Activities Kuala Lumpur
Sing Cmd 15 of 1956

Sing Cmd 31 of 1956

White Paper SCMSSU 1956

Sing Cmd 33 of 1957

Sing Cmd 33 of 1961

Sing Paper 34 of 1954

Statesman's Yearbook

T.U. Ord 12 June 1948

T.U. Ord 19 July 1948

T. U.R. Annual Report 1948

UN Stats

White Paper, Nanyang 1964 
Author and Title

Abbreviation

Campbell

Chapman

Chapman, F. Spencer, The Jungle is Neutral,
London 1949 Clutterbuck, Richard, The Long Long War, New York 1966
and London 1967

Clutterbuck, The Long Long War

Crawford, Oliver, The Door Marked Malaya, London 1958 Crawford

Giap, Vo Nguyen, Peoples' Army, Peoples' War, Nlew Youk 1962 Giap

Guevara, Che, Guerilla Warfare (Cassell), London 1962 Che Guevara

Henniker, M.C.A., Red Shadow Over Malaya, London 1955 Henniker

Hyde, Douglas, I Believed, London 1951

Lee Kuan Yew, The Battle for Merger, Singapore 1961 Lee Kuan Yew Battle

Mao Tse-Tung, Guerilla Warfare (Cassell) London 1962 Mao Tse-Tung, Guerilla Warfare

Mao Tse-Tung, Quotations from Chairman Mao Tse-Tung Peking 1966 ("The Little Red Book")

Mao Tse-Tung, Quotations

Miers, R.C.H., Shoot to Kill, London 1959

Miers

Oldfield, J.B., The Green Howards in Malaya,

Oldfield

Trotsky, L•, The Russian Revolution, New York 1959 Trotsky 
Arendt, Hannah, On Violence, London 1970

Awberry, SS and Dalley FW, Labour and Trade Union Organisation in the Federation of Malaya and Singapore, Government Press, Kuala Lumpur 1948 Barraclough, Geoffrey An Introduction to Contemporary
History, London (Pelican) 1967

Brimmell J H., Communism in South East Asia, London

Brinton, Crane, The Anatomy of Revolution, New York (Vintage Edition) 1957

Browne, Malcolm, The New Face of War, London 1966

Campbell, A., Jungle Green, London 1953

Carew Hunt, RN, The Theory and Practice of Communism London (Pelican) 1963

Carr, E.H., What is History? London (Pelican) 1964

Chapman, F. Spencer, The Jungle is Neutral, London
1949

Clark, Michael, Algeria in Turmoil, London 1960

Clutterbuck, Richard, The Long Long War, New York 1966 and London 1967

Crawford, Oliver, The Door Marked Malaya, London 1958

Critchley, T.A., The Conquest of Violence, London 1970

Dalley F.W. and Awberry S.S., Labour and Trade Union Organisation in the Federation of Malaya and Singapore

Debray, Regis, Revolution in the Revolution? London (Pelican) 1967

Donnison, F.S.V., British Military Administration in the Far East 1943-46 London 1956
Arendt

Awberry \& Dalley

Barraclough

Brimmell

Brinton

Browne

Campbel1

Carew Hunt

Carr

Chapman

Clark

Clutterbuck, The Long Long War

Crawford

Critchley

Awberry \& Dalley

Debray

Donnison 
Elliott-Bateman, Michael, of Mao Tse Tung on War, London 1967 Last - The Mark

Abbreviation

Engels, Marx, Lenin, The Essential Left, New York 1962

Fall, Bernard B., Street without Joy, London 1964

Fall, Bernard B., The Two Vietnams, London 1963

Fanon, Frantz, The Wretched of the Earth, London
(Penguin) 1967

Fisk E.K., and Silcock T. Independent Malaya, Singopore 1963 Silcock and Fisk

Gamba, Charles, The Origins of Trade Unionism in Malaya, Gamba

Giap, Vo Nguyen, Peoples' Army, Peoples' War, New York Giap

Girling, J.L.S., People's War, London 1969

Guevara, Che, Guerilla Warfare, London (Cassell) 1962

Girling

Hanrahan, G.Z. The Communist Struggle in Malaya,
New York 1954

Che Guevara

Hanrahan

Han Suyin, And the Rain my Drink, London 1956

Henniker, M.C.A., Red Shadow Over Malaya, London 1955

Hosmen, S.T., Counterinsurgency: A Symposium,

Rand Corporation, Santa Monica, California 1963

Hyde, Douglas, Confrontation in the East, Singapore 1965

Hyde, Douglas, I Believed, London 1951

Hyde, Douglas, The Roots of Guerilla Warfare, London 1968 Hyde, Roots

Information Services, Federation of Malaya, The Danger and Where it Lies, Kuala Lumpur 1957

Josey, Alex, Trade Unionism in Malaya, Singapore 1954

Kennedy, J., A History of Malaya, London 1962

Han Suyin

Henniker

Hosmen (Rand)

Hyde, Confrontation

Hyde, I Believed

The Danger and Where
It Lies

Josey

Kennedy

Kitson, F.E., Gangs and Counter-gangs, London 1966

Kitson

Lee Kuan Yew, The Battle for Merger, Singapore 1961

Lenin, Engels, Marx, The Essential Left, New York 1962

Malaparte, Coup d'Etat

Mao Tse Tung, Guerilla Warfare, (Cassell) London 1962

Lee Kuan Yew, Battle.

The Essential Left

Malaparte

Mao Tse Tung, Guerilla

Warfare 

Mao Tse Tung, Quotations from Chairman Mao Tse Tung
Peking 1966

Mao Tse Tung, Selected Works, New York 1954-58,

Marx, Engels, Lenin, The Essential Left, New York 1962

McConville, Maureen and Seale, Patrick, Red Flag/Black Flag: French Revolution 1968

McCuen, John L., The Art of Counter-Revolutionary Warfare London 1966

McNamara, Robert S., The Essence of Security, London 1968

Miers, R.C.H., Shoot to Kill, London 1959

Miller, Harry, Menace in Malaya, London 1954

Mills, Lennox A., Malaya - A Political and Economic Aporaisal, Minneapolis 1958

Moorehead, Alan, The Russian Revolution, New York (Bantam) 1959

Morray, J.P., The Second Revolution in Cuba, New York 1962

O'Ballance, Edgar, Malaya - The Communist Insurgency 1948-60, London 1966

Oldfield, J.B., The Green Howards in Malaya Aldershot 1953

Ooi Jin-Bee, Land, People and Economy in Malaya, London 1963

Purcell, V., Malaya, Communist or Free? Iondon 1954

Purcell, V., "Malayan Politics", in Politics in Southern Asia (Ed Saul Rose) London 1963

Purcell, Victor, The Chinese in South East Asia, London 1965

Pye, Lucian W, Guerilla Communism in Malaya, Princeton USA_1956

Ratnam, K.J., Communalism and the Political Process in Malaya, Singapore 1965

Robinson, J.B., Perry, Transformation in Malaya, London Robinson 1956
Ma.o Tse Tung

Quotations

Mao Tse Tung

Selected Works

The Essential Left

Seale and McConville

McCuen

McNamara

Miers

Miller

Mills

Moorehead

Morray

O'Ballance

Oldfield

Ooi Jin-Bee

Purcell

Purcell Malayan

Politics

Purcell, Chinese

Pye

Ratnam 
Rose, Saul (Ed), Politics in Southern Asia,

Saul Rose London 1953

Scalapino, Robert A (Ed), The Communist Revolution in Scalapino Asia, Prentice Hall, New Jersey, USA, 1965

Seale, Patrick and McConville, Maureen, Red Flag/Black Seale and McConville Flag: French Revolution 1968, New York 1968

Seton Watson, Hugh, The Pattern of Communist Revolution, Seton Watson London 1960

Silcock, T.H., and Fisk, E.K., The Political Economy of Silcock and Fisk Independent Malaya, Singapore 1963

Sorel, Georges, Reflection on Violence, London 1925 Sorel

Special Operations Research Office, The American Soro University, Casebook on Insurgency and Revolutionary Warfare, Washington 1962

Sukhanov, N.N., The Russian Revolution 1917, Sukhanov Iondon 1955

Tanham G.K., Communist Revolutionary Warfare: The Vietminh in Indochina, New York 1961

Thompson, Sir Robert, Repeating Communist Insurgency, London, 1966

Trotsky, L., The Russian Revolution, New York (Doubleday Trotsky Edition) 1959

Wilson, Edmund, To the Finland Station, New York, 1940 Wilson

Wint, Guy, Communist China's Crusade, London 1965 Wint

Wolfe, B.D., Three Who Made a Revolution, Boston (Beacon Press) 1955

Wolfe 
Bloodworth, Denis, Article in the Singapore Sunday

Bloodworth, 30 Sep 67

Times 30 September 1967

Bloodworth, Denis, Article in the Singapore Sunday Times 15 October 1967

Bloodworth, 15 oct 67

Clutterbuck, Richard Military Engineering as a Weapon

Clutterbuck, in the Cold Warl! In the Military Engineer, Washington July-August $19 \overline{63}$

Dobby, E.G.H., "Resettlement Transforms Malaya" in Dobby Economic Development and Cultural Change 1953 pp 163-181

Dudley, C.E.S., "Insurrection from the Jacobins to Mao Tse-Tung" in The Royal United Service Institution Journal, May 1966

Dunlop Malaya Estates Ltd., The Story of a Rubber Tree, Dunlop (mimeograph) Malacca 1965

Goh Keng Swee, reported in The Straits Times, Singapore 17 April 1967

Goh Keng Swee, Apr 1967

Goh Keng Swee, reported in The Sunday Times, Singapore 29 Jun 1967

Heilbrunn, O., "The Algerian Emergency" in The Royal United Service Institution Journal, Iondon August 1966

Goh Keng Swee, Jun 1967

Heilbrunn, 0., "Terrorist Warfare" in British Army Review, August 1966

Hyde, Douglas, "The Star that Fell" in The Far Eastern Economic Review, July 1969

Janos, Andrew C., The Seizure of Power - A Study of

Janos Force and Popular Consent Princeton University USA

Lin Piao, in Peking Review, 3 September 1965 quoted in Iin Piao Current Scene, Hong Kong, 26 September 1966

Marshall, David, The Struggle for Nationhood Talk at St Andrews Cathedral Singapore 12 July 1969

Heilbrunn Terrorist Warfare

Hyde, Star

\section{Heilbrunn Algerian Emergency}

McVey, Ruth T., The Calcutta Conference and The

Marshall Struggle South East Asia Uprising, Cornell University, New York, 1958

Osborne, Milton E., Singapore and Malaysia, Cornell Osborne, Singapore University, New York 1964

Osborne, Milton, Strategic Hamlets in South Vietnam - Osborne Hamlets A Survey and a Comparison (with Malaya) Cornell 
Rhenick, R.D., The Emergency Regulations of Malaya Masters Thesis, Tulane University, USA, 1967

Sandhu, Kernial Singh, "Emergency Resettlement in Malaya" in The Journal of Tropical Geography Vol 18, Augut 1964, University of Malaya in Singapore 1964, pp 157-183

Sandhu, Kernial Singh, Working Papers made available to author at Singapore University 1966

Sandhu Resettlement

Schapiro, Leonard, "Changing Patterns in the Theory of Schapiro Revolution and Insurgency" in the Royal United Service Institute Journal September 1970

Shephard, A.J. "The Communist Failure in Hong Kong" in The Commonwealth Journal, April 1968

Spitzen, Alan B, The Revolutionary Theories of Louis Auguste Blanqui, New York 1957

Sandhu Working Papers

Stewart, Neil, Blanqui, London 1939

Spitzen

Stewart

Thompson, Sir Robert, "The Other War" in The Straits Times, Singapore, 28 January 1967:

Thompson, Othen wor

Thompson, Sir Robert, "Vietnam", lecture to the Royal Commonwealth Society, London on 8th November 1966

Vietnam reported in The Commonwealth Journal, February 1967 p14

US Military Assistance Command, Vietnam, Revolutionary Revolutionary Development" in Command Information Pamphlet No. 4-67, Development

Waller, P.B.G., A Study of the Emergency Regulations of Waller Notes Malaya 1948-1960. (Draft) Stanford Research Institute, Bangkok 1967

Zawodny, J.K., "Soviet Partisans" in Soviet Studies, Zawodny, Soviet
Oxford 1966"

Zawodny, J.K., Organisational Problems and Dynamics of Violent Political Movements. Paper presented to the Eighth World Congress of the International

Zawodny, Organisational Political Science Association, Munich, September 1970 


\section{G NEWSPAPERS AND PERIODICALS}

Commonweal th Joumnal

Current Scene (Hong Kong)

Economist

Far Eastern Economic Review

Journal of Tropical Geography (University of Malaya in Singapore)

Malay Nail (Kuala Iumper)

Military Bngineer (Washington)

Nanyang Siang Pau (Singapore)

\section{Observer}

Royal United Service Institution Joumal

Straits Times

Sunday Times (London)

Sunday Times (Singapore)

The Times 